The Bodhisattvapițaka

Its Doctrines, Practices and their Position in Mahāyāna Literature

\author{
Ulrich Pagel
}

Thesis Submitted for the Award of Doctor of Philosophy at the School of Oriental and African Studies

(University of London)

1992 
ProQuest Number: 10752663

All rights reserved

INFORMATION TO ALL USERS

The quality of this reproduction is dependent upon the quality of the copy submitted.

In the unlikely event that the author did not send a complete manuscript and there are missing pages, these will be noted. Also, if material had to be removed, a note will indicate the deletion.

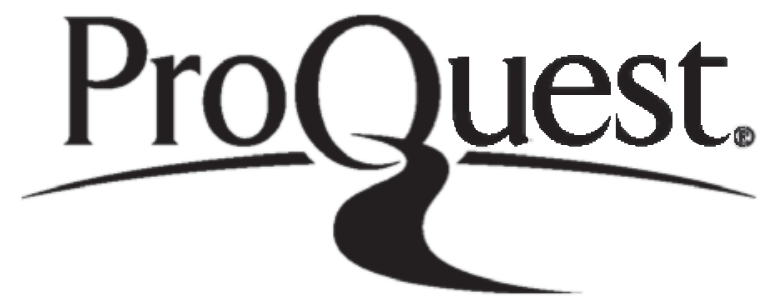

ProQuest 10752663

Published by ProQuest LLC (2018). Copyright of the Dissertation is held by the Author.

All rights reserved.

This work is protected against unauthorized copying under Title 17, United States Code Microform Edition (C) ProQuest LLC.

ProQuest LLC.

789 East Eisenhower Parkway

P.O. Box 1346

Ann Arbor, Ml $48106-1346$ 


\begin{abstract}
This thesis aims to provide a comprehensive study of the Bodhisattvapitaka with specific emphasis on the bodhisattva ideal. The content of the Bodhisattvapitaka indicates that its exposition belongs to the earliest treatises on the bodhisattva. The practices and doctrines that are expounded are invariably rudimentary and show little of the complexities that characterise their discussions in later bodhisattva literature. The Bodhisattvapitaka's inclusion into the Mahäratnakūta rested probably on its pioneering account of the bodhisattvacarya $\bar{a}$. Being by far the longest work on the bodhisattva in the whole collection, it expounds important practices and constitutes the hub for the remaining bodhisattva writings in the Mahäratnaküta.

The study falls into five parts. The first chapter considers the position of the Bodhisattvapitaka in Mahāyāna literature. It investigates the various usages of the term Bodhisattvapitaka, it considers the relationship between the Bodhisattvapitaka and Aksayamatinirdeśa and discusses the scholastic affiliation of the Bodhisattvapitaka. In addition, exploring the contents and evolution of the Mahäratnakutta collection, it establishes the scriptural context in which the Bodhisattvapitaka is placed. The second chapter provides an analysis of the Bodhisattvapitaka. It examines the structural and literary traits of the Bodhisattvapitaka, its chapter organisation and some aspects of the bodhisattva path in the Bodhisattvapitaka. Chapter three discusses the bodhisattva ideal in the Mahäratnaküta collection. It distinguishes between the various categories of bodhisattva sütras in the Mahäratnaküta, it examines the bodhisattva practices and investigates whether there is evidence of a premeditated design that might have influenced the compilation of the Mahäratnaküta sütras into one collection. Chapter four considers the bodhisattva doctrine as it is propounded in the Bodhisattvapitaka within the context of other scriptural traditions. It discusses the evolution of the concepts of the cittotpāda, apramāna, pāramitä and samgrahvastu and assesses the contribution of the Bodhisattvapitaka to that process. Chapter five consists of a translation of the eleventh chapter of the Bodhisattvapitaka.
\end{abstract}




\section{Acknowledgements}

I would like to express my gratitude to the following persons: to Tadeusz Skorupski, my supervisor who provided me throughout my research with unfaltering support, inspiration and guidance-without his patient and exacting supervision this thesis would have never been completed; to Phillip Denwood, Peter Schreiner and Renate Söhnen-Thieme who taught me Tibetan and Sanskrit over many years; to the members of the British Academy for granting financial assistance; to Allan Bloxham and Christopher Lamb who corrected my English; to my father whose continuing and generous financial support throughout the years allowed me to devote all my time to my research; and, last but not least, to my wife and son for their unfailing encouragement and support in times of difficulty when progress was slow and especially for putting up with those times when the thesis took priority over everything else, including family-life. 


\section{A Note on Orthography}

With certain exceptions, all non-English terminology has been italicised. Words that have not been italicised include proper nouns (e.g., Dharma, nikāya), classifications of Buddhist practitioners (e.g., srāvaka, arhant, buddha/pratyekabuddha and bodhisattva) including references to their respective vehicles that have also been capitalised and personal names (including references to the historical Buddha).

Generally, Sanskrit forms have not been pluralised except in the few cases that found their way into standard English vocabulary or where it seemed inevitable out of stylistic considerations. Exceptions are the following words: buddha/pratyekabuddha, bodhisattva/mahāsattva, bhikșu/bhikkhu, sūtra/sutta and sāstra. I have decided to take this approach, because I do not wish to hybridise the Sanskrit word-forms. Although the hybridised forms have become widely accepted, from the linguistic point of view such adaptation is unfortunate since it denies Sanskrit the treatment that is given to Greek and Latin terms whose plural forms are generally not anglicised. 


\section{Table of Contents}

Abstract 3

Acknowledgements 4

A Note on Orthography 5

$\begin{array}{ll}\text { Introduction } & 9\end{array}$

Chapter One: The Bodhisattvapițaka in Mahāyāna Literature

1. The Term Bodhisattvapițaka 15

2. The Bodhisattvapițaka and the Akșayamatinirdeśa 31

3. The Scholastic Affiliation of the Bodhisattvapitaka 39

4. The Mahāratnakūta Collection: 44

a. Topics Included in the Mahāratnakūṭa 46

b. History of the Mahāratnakūṭa: $\quad 50$

1. Chinese Sources 55

2. Indian Sources 59

3. Tibetan Sources 61

4. Miscellaneous Sources 65

5. Conclusion $\quad 67$

Chapter Two: Analysis of the Bodhisattvapitaka

1. Structural and Literary Traits 70

2. The Bodhisattva Path 75

3. Chapter Organisation 78 


\section{Chapter Three: The Bodhisattva Ideal in the Mahāratnakūta Collection}

1. Categories of Bodhisattva Texts $\quad 88$

2. The Bodhisattva Vow and Doctrines 96

3. Literary and Structural Characteristics 107

4. Conclusion 112

Chapter Four: The Bodhisattva Doctrines and Practices in the Bodhisattvapitaka within the Context of other Scriptural Traditions

1. The Thought of Enlightenment 116

2. The Four Immeasurables 125

3. The Perfection of Generosity 138

4. The Perfection of Morality 153

5. The Perfection of Patience 173

6. The Perfection of Vigour 191

7. The Perfection of Meditation 209

8. The Perfection of Wisdom: 230

a. Initial Phases in the Training of Wisdom 231

b. Perfect Wisdom and Skill 244

c. Practices That Conduce to Enlightenment 267

d. Acquisition of Wisdom 283

e. Phases in Perfect Wisdom 284

9. The Means of Conversion 299

10. Conclusion 304

Chapter Five: Translation of Chapter Eleven of the Bodhisattvapițakasūtra

$\begin{array}{ll}\text { Introduction } & 311\end{array}$

1. Accumulation 314

2. Application 323

3. Seeing 325 
4. Emancipation 331

5. Skill: 333

a. Skandha, Dhātu, Āyatana 334

$\begin{array}{ll}\text { b. Satya } & 338\end{array}$

$\begin{array}{ll}\text { c. Pratișamvid } & 340\end{array}$

d. Pratisarana $\quad 345$

e. Punya and Jñānasaṃbhāra 352

f. Smrtyupasthāna 361

g. Bodhyanga $\quad 368$

h. Āryāșțāngamārga $\quad 370$

i. Samatha and Vipaśyanā $\quad 374$

j. Samyakprahāṇa 376

$\begin{array}{ll}\text { k. Indriya } & 378\end{array}$

$\begin{array}{ll}\text { 1. Bala } & 380\end{array}$

m. Ekayänamārga $\quad 381$

n. Pratītyasamutpāda $\quad 382$

o. Dharma 383

6. Prajñā 385

$\begin{array}{ll}\text { 7. Pāramitā } & 387\end{array}$

$\begin{array}{lll}\text { 8. Benefits } & 388\end{array}$

Appendices

1. Forms of Learning in the Bodhisattvapițaka and the Aksayamatinirdeśa 393

2. Samādhi Lists in the Bodhisattvapițaka and the Akșayamatinirdesa 396

3. The Mahāratnakūța Collection (A Bibliographical Guide) 400

4. Tibetan Text of Chapter Eleven of the Bodhisattvapițakasūtra 415

$\begin{array}{ll}\text { List of Abbreviations } & 495\end{array}$

$\begin{array}{ll}\text { Bibliography } & 499\end{array}$ 


\section{Introduction}

The present dissertation aims at providing a wide-ranging study of the Bodhisattvapitaka. In the course of my research two main areas of investigation have emerged as being particularly important. First, there is the content of the Bodhisattvapițaka. Being one of the longest works on the bodhisattva in Mahāyāna literature, it provides a wealth of information on the training and dynamics in which the bodhisattvacaryā unfolds. Second, I have examined the Bodhisattvapițaka's doctrinal propositions in the wider context of Mahãyāna thought. While it is possible to speak of these two aspects of my research as distinct targets, in practice they are closely interwoven and often go hand in hand.

My interest in the Bodhisattvapitaka was aroused by the frequent references in Mahāyāna sources to a text (or collection of texts) called Bodhisattvapitaka. As these references occur in practically all strands of post-nikāya sources, extending from the very earliest Mahāyāna sütras to the latest phase of tantric Buddhism, it occurred to me that the Bodhisattvapitaka must be an important text that was esteemed by generations of Buddhists. Although referred to in various contexts and for different purposes, practically all references to the Bodhisattvapitaka recommend it for its treatment of the bodhisattva ideal.

Of course, I was not the first person to have come across these references. They have been noted and duly recorded by a number of distinguished scholars, including Étienne Lamotte, Jean Przyluski, Alex Wayman and Anthony Warder. However, preoccupied with their own particular research, none of them went beyond making some useful but rather general observations. The first attempts to collate and explore these references in the wider frame of Mahāyāna literature were undertaken by Priscilla Pedersen and Nancy Schuster in 1975/76. Both scholars, working primarily from Chinese sources, have collected a fair amount of material and tentatively propose interpretations of its position and nature. However, as neither of them attempts to produce a systematic study of the Bodhisattvapitaka the results of their investigations are somewhat limited. Not having read through the Bodhisattvapitaka, they differ in their evaluation of the references and disagree on the historical context in that they belong.

The Bodhisattvapitaka is part of the Ratnakuta collection. The majority of the forty-nine works included in the Ratnaküta are only extant in Chinese and Tibetan translations. In its 
present format the Ratnaküta dates back to early eighth-century China. Its compiler, Bodhiruci, was a monk from South India. At the end of the seventh century, Bodhiruci travelled to China where he was commissioned by the T'ang Emperor Chung-tsung to translate the forty-nine sutras into Chinese. It is said that he brought with him a complete Sanskrit copy of the Ratnaküta. After several years of editing and translating, he produced the first complete Chinese version.

Little is known of the history of the collection before Bodhiruci. While we have several fifth and sixth-century accounts mentioning the Ratnaküta in conjunction with other well-known sütra collections, nothing concrete is known about its early contents and structure. Ratnaküta fragments found in Khotan, Tun-huang and Kucha indicate that its texts enjoyed particular popularity in Buddhist circles of Central Asia. We have practically no knowledge about its development in India. Tibetan historians say that it became greatly renowned by the second century $\mathrm{AD}$, but there is no independent evidence supporting this claim. Indeed, I know of no reference to a collection bearing the name Ratnaküta anywhere in Indian literature.

The nucleus of the Ratnakutta collection is probably found in a relatively small body of sütras that were put together sometime between the third and fifth centuries. The Buddhist traditions of India, China and Tibet preserved several sütra lists where ten to fifteen Ratnaküta works constantly appear en bloc. The earliest of these enumerations goes back to third-century China. Although the origin of these lists is not known, their pan-Asian circulation indicates that they might have come into existence with the expansion of Buddhism across Asia. This would explain the complete silence of Indian sources and account for the difficulties in tracing the genesis of the Ratnaküta beyond Bodhiruci to a specific geographical area and a given historical context.

The hypothesis of a gradual formation would also accord with much of the content of the Ratnakutta texts. There is every indication that they were carefully compiled in a process that might have extended over several centuries. Its texts embrace a wide spectrum of Buddhist thought and address practically every aspect of Mahāyāna spirituality. Within this broad area of themes, the most frequently discussed topic is the bodhisattva ideal. Out of the forty-nine texts, roughly one half is concerned specifically with the bodhisattva. The longest and most important bodhisattva sütra of the Ratnaküta is the Bodhisattvapitaka. In volume, it occupies roughly one seventh of the collection and is specifically dedicated to the paramitā practice. Its length and the fact that there is practically no other text in the collection that discourses on 
the pāramitā in detail, place the Bodhisattvapitaka in the centre of the Ratnakūta's discussion of the bodhisattva. The Bodhisattvapitaka's treatment of the pāramitā is supplemented by a variety of material on the bodhisattva in the remaining Ratnaküta sütras that deal specifically with the bodhisattva practice. The thematic complementarity of these works is such that their propositions come close to representing a balanced cross-section of all major ideas in the development of the bodhisattva doctrine.

While it is difficult to establish the precise relationship between the various texts due to the uncertainties of their chronology, it is possible to distinguish several strands of bodhisattva thinking within the Ratnakūta works. The oldest thought on the bodhisattva is contained in sütras such as the Käśyapaparivarta and Ugrapariprcchā. Second-century translations of these texts confirm their antiquity beyond any doubt. Next, we have works that seem to set out to systematise the material that was introduced in these early sütras. The Bodhisattvapitaka belongs to this category. Then, the collection contains several sütras displaying a high degree of organisation in their expositions on the bodhisattva. One characteristic of these texts is the meticulous implementation of the daśabhümika scheme. Examples of this type are the Svapnanirdeśa and Akșayamatipariprcchā. Finally, there are a number of rather advanced sütras. These tend to show less interest in the practical aspects of the bodhisattva training, but focus on doctrinal matters. Quite frequently, they represent the latest strand of Ratnaküta sütras and include such works as the Srimālādevisimhanāda and Pitāputrasamāgama.

The above outline places the Bodhisattvapitaka among the earlier bodhisattva sutras of the Ratnakūta. Its antiquity is supported by an array of internal and external evidence. First, there is the close association between the Bodhisattvapitaka and the second-century Aksayamatinirdeśa. Since the Akșayamatinirdeśa is greatly indebted for its material to the Bodhisattvapitaka, the origin of our sütra must predate that of the Aksayamatinirdeśa. Second, we have a number of references to the pāramitā discussion of the Bodhisattvapitaka in other sütras. While some of these date back to the second century, others are third or fourth-century compositions.

The most persuasive evidence is, however, found in the content of the Bodhisattvapitaka. The relatively undeveloped nature of the practices and their rudimentary organisation point to a period of composition when the thinking on the bodhisattva was still dominated by the spiritual ideal of early Buddhism. Although clearly a Mahāyäna text in orientation, several of the practices show traits that link them to the Srāvakayāna. The fact that in later times many 
of these early elements were modified and adjusted to doctrinal developments further confirms their antiquity.

If we compare the material that is included in the Bodhisattvapitaka with that of later writings on the bodhisattva, we note two things. First, most of what is being said about the bodhisattva in the Bodhisattvapitaka retained its validity and found its way into the scholastic treatises of the fourth and fifth centuries. It is often possible to trace to the Bodhisattvapitaka the individual building blocks of advanced works such as the Bodhisattvabhümi. Second, some of the structures of its bodhisattva practices were adopted in later literature. The internal divisions of the pāramitā, the blueprint of the ten cittotpāda and the outline of the wisdom-practices all had profound bearing on the development of the bodhisattva doctrine.

After consideration of all the evidence, there seems to be a strong case for not only placing the Bodhisattvapitaka among the earliest works on the bodhisattva, but also for looking at it as a text of fundamental importance to the evolution of the bodhisattva doctrine. Its pioneering exposition of the perfections, the lasting influence this exerted on generations of Buddhist thinkers and the frequent references to the Bodhisattvapitaka in a wide spectrum of Mahāyāna works all seem to point in this direction.

In spite of the Bodhisattvapitaka's influence, very little is known about its history and the circumstances in which it was composed. The fact that several of the early Indian schools possessed a collection of texts of this name alongside the traditional Tripitaka led some scholars to surmise that the Bodhisattvapitaka might have sprung from a body of loosely connected, but distinct works on the bodhisattva. Wayman, for example, proposed an association with the Mahāsanghika school by arguing that Mahāsanghika followers "gradually built up the theory of the bodhisattva modelled after the life and theoretical former lives of Gautama Buddha" and thus produced the Bodhisattvapitaka as "the ultimate form of this effort". While it is incorrect to link the origin of the bodhisattva ideal specifically with the Mahāsanghika, he is probably correct in seeing a connection between the Bodhisattvapitaka and the jätakagenre. In the Bodhisattvapitaka itself we find included altogether fourteen accounts of the Buddha's former lives. Moreover, the jātaka-genre probably provided the first impetus to the formulation of the bodhisattva ideal and almost certainly inspired some elements of its practice. Warder went so far as to suggest that the early schools actually included the Jâtaka collection in their Bodhisattvapitaka. While there is no real evidence to support this hypothesis,

1. Wayman, 1991, p. 9 .

2. Warder, 1980, p. 357. 
the importance of the jätaka to the bodhisattva doctrine in general and their presence in the Bodhisattvapitaka in particular might not be coincidental.

Even if we accept the existence of such a link, leading eventually to the composition of the Bodhisattvapitaka (either in the form of one unified text or a collection of independent works on the bodhisattva), it tells us little about the place, time and circumstances in which the Bodhisattvapitaka was conceived. Like Wayman, Warder also ascribes the origin of the Bodhisattvapițaka to Mahāsanghika circles in southern India. As evidence, he cites a pițaka list in the Satyasiddhiśāstra that includes the Bodhisattvapitaka as one of the five sections of the Buddhist canon. Since the Satyasiddhiśāstra is a Bahuśrutiya text, he infers that the Bodhisattvapitaka formed part of the Bahuśrutiya canon. The Bahuśrutiya was of course a sub-sect of the Mahāsanghika that is known to have been widespread around Nāgārjunikoṇ̣a in South India.

This line of argument, although perfectly sound by itself, does not take into consideration either of two factors. First, the Mahāsanghika themselves do not include a Bodhisattvapitaka in their division of the canon. According to Hsüan-tsang, their scriptures consisted of a Sütra-, Vinaya-, Abhidharma-, Samyukta- and Dhäranipitaka. ${ }^{3}$ This alone does not disprove the South Indian Mahāsanghika connection-Hsüan-tsang was given this list at Rājagṛha in the seventh century $\mathrm{AD}$ - but it raises the question whether it is possible to ascribe the Bahuśrutiya division to the Mahāsanghika in general. Second, the only other sect that is recorded to have been in possession of a Bodhisattvapitaka is a non-Mahāsanghika sect, namely the Dharmaguptaka. ${ }^{4}$ This is significant in two respects. On the one hand, it indicates that we cannot speak of an exclusive Mahāsanghika connection for the Bodhisattvapitaka. Quite obviously, the Bodhisattvapițaka was known in Sthaviravāda and Mahäsanghika circles alike. On the other hand, it throws doubt on South India as the place of origin of the Bodhisattvapitaka. The little information we possess about the Dharmaguptaka indicate that their sphere of influence was limited to North-West India, Central Asia and China. Although the Dharmaguptaka might have adopted the Bodhisattvapitaka from the Bahuśrutiya later, the geographical separation makes a regular exchange of ideas (and texts) unlikely. Therefore we have two conflicting scenarios for the origin of the Bodhisattvapitaka. One points to the ancient Buddhist sites in southern India and the other to North-West India and possibly beyond. Apart from a likely jātaka content and a terminus ad quem in possibly the late 3. Beal, 1884, ii, pp. 164-5.

4. Bareau, 1955, p. 296. 
Introduction

second century $\mathrm{AD}$, we know little else about the early history of the Bodhisattvapitaka. 


\section{Chapter One}

\section{The Bodhisattvapițaka in Mahāyāna Literature}

\section{The Term Bodhisattvapiţaka}

Throughout the centuries, in Mahāyāna literature the term Bodhisattvapițaka has been applied in a number of distinct ways. There are indications that it originated in the early, pre-Mahāyāna, schools. In later times, the term Bodhisattvapitaka was taken up by Mahāyāna writers who altered its scope of application and imbued it with new connotations. Yet, even in the later phases no single widely accepted interpretation evolved. In order to distinguish and indicate the various ways of its use and application, I propose to divide our sources into the following four working categories:

1. Treatises in which the term Bodhisattvapitaka is applied to Mahāyāna scriptures as a whole.

2. Sources that identify the term Bodhisattvapitaka as a distinct collection of works on the bodhisattva ideal.

3. Sources that associate the term Bodhisattvapitaka with the traditional six päramita and related practices.

4. Mahāyāna texts that refer to a specific work called Bodhisattvapițakasūtra.

Turning first to the question of its origin, there is no reference by which one could securely date the original formulation of the term Bodhisattvapitaka. It was first employed by members of the Dharmagupta and Bahuśrutiya schools who included a Bodhisattvapitaka in their Pañcapitaka. Here, the Bodhisattvapitaka is thought of as a body of literature and cited along with the Sütra-, Vinaya-, Abhidharma- and Dhäranipitaka. No details have so far emerged as to the contents of their Bodhisattvapitaka. In all likelihood, these consisted of texts that formed part of the early development of the bodhisattva path as an alternative career to that of the arhant. Considering that both schools were part of the net-work of sects which belonged 
to the proto-Mahāyāna movement, it is probable that the texts contained in their Bodhisattvapitaka have served as a foundation for the later developments of the bodhisattva doctrine. Unfortunately, as these texts are no longer extant we can only speculate on the role their thought may have played in the evolution of the bodhisattva ideal.

In Mahāyāna literature, the first occurrence of the term Bodhisattvapițaka is found in Lokakșema's second-century translation of the Käśyapaparivarta $(K p)$. Here, a text called Bodhisattvapitaka is recommended as "a scripture that the bodhisattva should study". ${ }^{1}$ It is not clear, however, whether the expression Bodhisattvapitaka should be taken here to refer to a collection of texts or an individual work. The passage itself is highly ambiguous and does little to clarify this problem since, as Pedersen has observed, the Chinese expression $p$ ' $u$-sats'ang-ching can be read as "sütras of the Bodhisattvapitaka" and as "the" or "a Bodhisattvapitakasütra". ${ }^{2}$ Leaving aside these particular intricacies, this reference clearly shows that the term Bodhisattvapițaka was known already to the earliest Mahāyāna writers.

As I have stated above, the works that are included in the first category view the term Bodhisattvapițaka as an overall designation of Mahäyāna scriptures in general. Six texts, in particular, belong to this category. ${ }^{3}$ They are the Srāvakabhūmi, Bodhisattvabhūmi (Bbh), Mahāyānasamgraha, Sütrālamkāra, Mañjuśrimülakalpa and a work found in the Tun-huang collection but known only through its colophon. The authorship of the first four treatises is traditionally ascribed to one person, Asanga. ${ }^{4}$ Hence, it is not surprising to find in them a far-reaching concurrence of interpretations of the term Bodhisattvapitaka.

In the $B b h$ we learn that the Bodhisattvapitaka corresponds to the vaipulya-genre of the twelve traditional branches of Buddhist scriptures. ${ }^{5}$ It is cited in the Dharma Study Chapter

1. Stael-Holstein, 1926, pp. 13-14, § 6 .

References to the $B d p$ are taken from the twentieth-century reprint of the sTog Palace $h K a h$-hgyur, entitled: The Tog Palace Manuscript of the Tibetan Kanjur, 1979-Leh, Smanrtsis Shesrig Dpemzod. All page/folio references and text specifications (length, chapters, structure etc.) that are drawn to Ratnaküta sütras other than the $B d p$ refer (unless a Sanskrit version is available) to the Tibetan Tripitaka Peking Edition (ed. by DT Suzuki, Otani University, Kyoto, 1956, vol. 22-24).

2. Pedersen, 1976, p. 25

Perhaps, this ambiguity reflects some uncertainty on part of the translator who himself might have been in doubt about the precise nature of the reference.

3. There are a number of other texts that, by implication, could be taken to fall within this category. In the Sgm (Mahäsamnipāta, 5), for instance, "not hearing and not accepting" the Bodhisattvapitaka is cited as one of the four dharma that obstruct the Mahāyāna (T 397 (5), vol. 13, p. 630; ref. Pedersen).

4. This traditional attribution is only a working hypothesis as it involves a whole range of uncertainties that have, as yet, to be resolved. For a discussion of the problematic in this assumption see: J. May, "La Philosophie Bouddhique Idéaliste", Revue de la Société Suisse d'Etudes Asiatiques, xxv, 1971, pp. 279-301, especially, p. 293.

5. $\quad B b h$, p. 96.1-5. 
(dharmaparyeșaka) alongside the Sravakapitaka and non-Buddhist treatises (bähyakäni śästrāni); these include logic, medicine, grammar etc., besides arts and crafts of the world as those areas of learning that the bodhisattva should become acquainted with. The association of the Bodhisattvapitaka with the vaipulya-genre is by no means rare and is found in a number of treatises. ${ }^{6}$ In most of these instances it is used quite cleary as a synonym to the expression Mahāyānapițaka .

In the Srävakabhümi, for instance, the Paramārthagāthā opens with the following sentence: ${ }^{7}$

"Among the [deliberation of the meaning of the Buddha and of the meaning of the versifications of the discourses] in the Vastusamgrahani and in the instruction of the Bodhisattvapitaka I shall set forth extensively the deliberation of the meaning of the discourses."

Wayman remarks in a note to this passage that "it is a reasonable assumption that this method of instruction (avavāda) of this pitaka refers to the various aspects of the Yogäcärabhümi where Asanga has set forth the Mahāyāna, especially the bodhisattva doctrine."

In the Bbh, Asanga adds: "This Bbh is also called Bodhisattvapitaka-mätrka and Mahāyānasamgraha". Then he gives an explanation of the term 'Mahāyanasamgraha', stating that it bears this name because it includes the contents of "all subtle sütras that are included in the Bodhisattvapitaka". Elsewhere in the Bbh he enumerates eight characteristics essential for a text to be called Mahāyannasamgraha. ${ }^{9}$ The first three factors are that (1) the text in question must contain the instructions included in the Bodhisattvapitaka, (2) it has to reveal the real meaning of all dharma included in the Bodhisattvapitaka and (3) it reveals all the inconceivable powers of the buddhas and bodhisattvas that are in this Bodhisattvapitaka.

Asanga's hitherto most explicit statement concerning the expression Bodhisattvapitaka is found in the Sütrālaṃkāra: ${ }^{10}$

6. $\quad A k n-t i \bar{k} k \bar{a}$, TTP, 104, p. $184.2 .7 ;$ Bbh, p. 297.21

According to the Abhidhh-sam (R), p. 139, the reason for this identification is the Bodhisattvapitaka's exhaustive treatment of the päramitā, particularly with regard to their characteristics, order, number and cultivation. In the same text, the adherence to the Bodhisattvapitaka figures among the principal marks of persons who subscribe to the Mahäyāna (op. cit., p. 147).

7. Wayman, 1961, p. 163.

8. $\quad B b h$, p. 298.3-5; cf. pp. 157.4, 180.16, 274.21, 332.23.

9. Bbh, pp. 298.3-8, 409.11-410.1.

10. $M s l$, p. 53.16-18

See also: Przyluski, Le Concile de Rājagrha, 1926-8, pp. 357-9. 


\begin{abstract}
"Three baskets, this is Sütra, Vinaya and Abhidharma. If classed in terms of Hīnayāna and Mahāyāna, the three baskets fall into two, the Srāvakapițaka and Bodhisattvapitaka."
\end{abstract}

On the basis of such passages it becomes clear, I think, that Asanga considers the term Bodhisattvapițaka synonymous with the notion of a Mahāyānapitaka, that is, the Mahāyāna literature in general.

Next, there are references to the Bodhisattvapitaka in the Mañjuśrimülakalpa and in a manuscript fragment found in Tun-huang. In both of them, the term Bodhisattvapitaka is cited in connection with the Avatamsaka collection.

In the Mañjuśrimūlakalpa, the term Bodhisattvapițaka appears in two instances. First, it is part of the overall title that runs, according to Chinese catalogues, as bodhisattvapitakānMañjuśrimülakalpa-mahāvaipulyasūtra. ${ }^{11}$ Second, it is mentioned in the formula that concludes the individual chapters. Curiously, it does not appear in all formulae but figures only in the later chapters. ${ }^{12}$

If we accept the results of Przyluski's text-critical study that chapters one to three predate the other chapters by several centuries, we are led to conclude that in the early phase of the Mahāyāna the application of the term Bodhisattvapitaka was not particularly wide-spread. Quite evidently, in this context, it was introduced to supersede the ancient formula patalavisara -a term virtually identical in meaning. Its association with the Avatamsaka collection indicates, according to Przyluski, that the term Bodhisattvapitaka was interpreted to stand for Mahāyāna scriptures in general. Naturally, the Avatamsaka is part of these.

In the other source that cites the Bodhisattvapitaka in connection with the Avatamsaka, the colophon of the Tun-huang manuscript, we read: "Bodhisattvapitaka buddhāvatamsaka Mahäyānasūtra kramena arvajñā jñānakara nāma daśabhūmi nirdeśa parivarta". ${ }^{13}$ Unfortunately, this colophon is the only fragment extant of the text it names. On the basis of this

11. J. Przyluski, 1923, p. 302.

12. The formula runs as follows: bodhisattva pițaka avatamsakān Mahāyāna sütram mañjuśri müla kalpāc caturthah | prathama pața vidhäna visarah parisamāptah. In chapters one to three, the phrase runs differently: iti bodhisattva patala visaran mañjuśri kumārabhūta müla kalpāt tritiyo mandala vidhāna parivartah̆.

13. Louis de la Vallée Poussin: Catalogue of Tibetan Manuscripts from Tun-huang in the India Office Library, Item Number 132, India Office Library, Oxford, 1962. 
single statement, out of context, one can have no certainty as to the precise application of the term Bodhisattvapitaka.

Nancy Schuster has suggested that it might point to a Bodhisattvapitaka section in the Avatamsaka. ${ }^{14}$ She argues that the title Daśabhüminirdeśa presumably corresponds to the Daśabhümika (Dbh) chapter (twenty-two or twenty-six) of the Avatamsaka and is here to be interpreted literally as the 'basket of bodhisattva practices' in that collection. Her hypothesis receives support from the Bodhisattvagarbhasthasütra; this lists the Bodhisattvapitaka in connection with the $D b h$ in sixth position of an eightfold division of Mahāyāna scriptures. ${ }^{15}$ Apart from this reference, I have not been able to trace any further material in support of her thesis. It may be better to assign it a provisional value until further evidence has come to light in favour of her position, and meanwhile to take the term Bodhisattvapitaka to be a synonym for Mahāyānapitaka as in the case of the Mañjuśrimūlakalpa.

There is one more reference that speaks of the Bodhisattvapitaka in terms of the Mahāyānapitaka. It is found in a text called Nandimitrāvadāna and proposes a kind of catalogue of a Bodhisattvapitaka. ${ }^{16}$ This text contains a list of thirty-seven Mahāyāna sūtras, including, among others, such works as the Prajñāpāramitā, Saddharmapunḍīika, Buddhāvatamsaka, Sukhāvativyūha and Vimalakirtinirdeśa. Having listed these sūtras, it says: ${ }^{17}$

\begin{abstract}
"Pareils sūtras du Grand Véhicule existe par centaines de myriades, distingués par groups et par catégories. En outre, il ya le recueil (pitaka) du Vinaya du Grand Véhicule et la multitude des groupes et des espéces de recueil de l'Abhidharma. Tout celă forme l'ensemble du Recueil des Bodhisattvas (Bodhisattvapitaka)."
\end{abstract}

The second category of references to a Bodhisattvapitaka consists of a number of miscellaneous, apparently unrelated, literary documents. First, there are three works that classify Buddhist scriptures on the basis of the religious practitioners who take recourse to them. In all three, that is the Karunāpuṇ̦arika, Mahākarunāsūtra and Ajatasatrukaukrtyavinodana,

14. Schuster, 1976, n. 110 .

15. Link, 1961, p. 283.

16. For a French transiation of the Nandimitrāvadäna, see: Lévi; Chavannes: "Relation sur la Durée de la loi, Enoncée par le grand Arhat Nandimitra" $(J A, 8,1916, \mathrm{p}$. $5 \mathrm{ff}$.). It is only extant in a Chinese translation entitled Ta a lo han nan t'i mi to lo so shuo fa chu chi (T 2030, 49, pp. 12-15; ref. Pedersen).

17. op. cit., pp. 19-20. 
the term Bodhisattvapitaka is contrasted with the Srāvakapitaka and Pratyekabuddhapitaka. ${ }^{18}$ Second, there are five treatises that cite the term Bodhisattvapitaka in connection with the more traditional threefold classification of Buddhist scriptures. In the Satyasiddhiśastra, it is listed as the fifth division, following the Sütrapițaka, Vinayapițaka, Abhidharmapitaka and Samyuktapițaka. ${ }^{19}$ In the Daśabhūmikavibhāṣāśāstra, the term Bodhisattvapițaka is cited in connection with the traditional Tripitaka and a Matrka. ${ }^{20}$ Paramārtha also places the Bodhisattvapițaka in fifth position, preceded by the Sütra, Vinaya, Abhidharma and Dhärañipițaka. ${ }^{21}$ In the Bodhisattvagarbhasthasütra, the Bodhisattvapitaka is referred to in combination with the Srāvakapitaka and Vinayapitaka. ${ }^{22}$ Curiously, Hsüan-tsang who carried out the earliest translation of the Bodhisattvapitakasütra (Rkt 12) does not mention it in his discussion of the classification of Buddhist scriptures current in Mahāsanghika circles. ${ }^{23}$

Finally, there are two references which set the term Bodhisattvapitaka in the context of the twelvefold classification of Mahāyāna scriptures:

In the Abhidh-sam, the Bodhisattvapitaka is included in the Sütrapitaka as a separate class of scriptures. On the one hand, it distinguishes those sections of the Buddhist canon which have traditionally been associated with early Buddhism, that is the Sütra, Geya, Vyakkarana, Gäthā and Udāna. On the other hand, there are the Vaipulya and Adbhutadharma portions of the canon which the Abhidh-sam considers constituents of the Bodhisattvapitaka. ${ }^{24}$

In the Ratnagotravibhāgaśāstra, a similar classification is employed. ${ }^{25}$ Here, the Bodhisattvapitaka is contrasted with the Sütra, Geya, Vyākarana, Gäthā, Udāna and Nidāna. While these are dismissed because of their association with conventional truth (samvrtisatya), the Bodhisattvapitaka is commended because it contains an exposition of the doctrine of absolute truth (paramārthasatya). To my knowledge, this is the only instance in which a classification

18. Yamada, 1968 , p. 211; T 380, 12, p. 971b; T 626, 15, p. 386 respectively (Taishō ref. Pedersen). In the Karunäp (pp. 14, 15-6), this threefold classification is complemented by the introduction of the Buddhapitaka as the fourth and highest division of Buddhist scripture. A text called Buddhapitaka is extant in both the Chinese Tripitaka (T 653, vol. 15) and in the Tibetan canon (TTP 35, no. 886).

19. Bareau, 1955, p. 296.

20. Pedersen, op. cit., p. 33.

21. Bareau, 1955, p. 296.

22. Link, 1961, p. 282.

23. He cites the traditional Tripitaka, plus a Samyuktapitaka and Dhäranipitaka serving as divisions of the Mahāsanghhika classification of the Buddhist canon (Bareau, 1955, p. 296).

24. Abhidh-sam (R), p. 132

This division is found only in the Sutrapitaka since the type of texts associated with the Vinaya and Abhidharmapitaka, that is the Nidäna, Avadäna, Itivrtaka, Jätaka and Upadeśa, are shared by both śrāvaka and bodhisattvas.

25. Takasaki, 1966, p. 285. 
involving the term Bodhisattvapitaka is explicitly based on doctrino-philosophical issues. ${ }^{26}$

The third category of sources is significant in two respects. First, these sources are the only ones that associate the Bodhisattvapitaka with a well-defined set of spiritual practices. Second, they represent some of the earliest strands of Mahāyāna literature and are therefore particularly helpful in reconstructing the 'original' meaning of the term Bodhisattvapitaka.

As I have mentioned earlier, all texts of this group associate the Bodhisattvapitaka with the bodhisattvacaryā and, in particular, with an exposition on the six traditional pāramitā. Among them the most prominent sütras are the Vkn, Kp, Samdhis, Ug and Prn. Although none of these texts gives explicit information on the actual physical format of the Bodhisattvapitaka, the context implies that it is a title for a collection of works relating to the bodhisattva, rather than an independent treatise.

In the $K p$, the term Bodhisattvapitaka is mentioned in connection with the training of a bodhisattva who is admonished to: ${ }^{27}$

"Seek out the proper Sütra Dharma, the six päramitā and the Bodhisattvapitakasutra and all the vessels of the Buddha, [with a] heart free from anger [and] respectfully serving all the people under heaven in the ten directions, [whether] they are slave or great scholars."

26. There is another reference to a division of Buddhist scriptures featuring the term Bodhisattvapitaka that deserves our attention. It is contained in the Kuśalamülasamparigraha where the author places "this Mahāyāna Dharmapitaka" side by side with "the sütras of the Bodhisattvapitaka" (T 657, 16, p. 138a; ref. Pedersen). To all appearances, this reference is pointing to some undefined, implied distinction between Mahäyāna sütras and texts contained in the Bodhisattvapitaka. Unfortunately, we are left once more with limited information as to its contents and can do little more than guess about its composition and scope. Significantly, like the other references found in this source-category, it too refers to a Bodhisattvapitaka as an autonomous, distinct body of Buddhist scriptures.

27. I adopted Schuster's translation (op. cit., n. 491) which is based on Lokakșema's second-century Han translation. There exist some differences between the various Chinese translations of this passage. Also the Sanskrit and Tibetan versions exhibit differences. The two remaining Chinese translations run as follows:

Chin: "[A bodhisattva] delights in hearing the good Dharma, [and] does not delight in hearing false Dharma, delights in the six päramitā Bodhisattvapitaka. He has humble thoughts without pride towards all beings" (op. cit.).

Ch'in: "[A bodhisattva] renounces evil Dharma [and] seeks the True Sutra Canon, the six päramitã Bodhisattvadharmapitaka, with a heart free from pride towards all beings, entirely humbled" (Kp, p. 15).

Weller's German translation, based on the Tibetan and Sanskrit version is: "Seitdem er sich so daran machte, die Sammlung von Werken fur den bodhisattva als diejenige zu suchen, welche die sechs Vollkommenheiten enhält, sucht er die gute Überlieferung, doch die schlechte Überlieferung sucht er nicht; und da er gegen alle Wesen ohne Überheblichkeit ist, gleicht sein Gemüt dem des Hundes" (Weller, 1962, p. 67). 
In the $V k n$ we meet with the following definition of the term Bodhisattvapitaka: ${ }^{28}$

"The texts which are contained in the Bodhisattvapitaka are profound, of profound aspects, difficult to perceive by the world, ... are marked with the seal of the kings of formulae and texts, reveal the irreversible wheel of the Dharma and originate in the six perfections. They teach the bodhipāksika dharma, compassion and friendliness."

The Samdhis adds that the bodhisattvas "should have courage, faith in and understanding of the subtle doctrines of the true Dharma connected with the pāramitā of the Bodhisattvapitaka."29 In the Vasudharasūtra we are told that "this sütra and other profound sütras are included in the Bodhisattvapitaka and connected with the päramitāa." ${ }^{30}$ In the Prn, a Ratnaküta sütra that itself discusses the bodhisattva training in some detail we find the following definition of the term Bodhisattvapitaka:

"Further, O Pūrṇa, bodhisattvas who do not hear appropriate bodhisattva sütras-which means the sütras of the Bodhisattvapitaka, sütras that generate the bodhicitta, sütras that attract to matters of bodhisattvas, sütras that are linked to the six pāramita - because they do not listen to these, they do not practice as instructed; since they are not instructed correctly, they will renounce the Doctrine." 31

A further reference is contained in the $U g$. It distinguishes between those who "teach the sütras, those who keep the precepts and those who adhere to the Bodhisattvapitaka" and admonishes those who adhere to the Bodhisattvapitaka to seek instruction in the päramitā and skilful means (upāyakauśalya). ${ }^{32}$

28. Lamotte, 1976, p. 259.

It is probably no coincidence that apart from the pāramitä, the bodhipāksika dharma, karunā and maitrī are precisely those practices that figure most prominently in the $B d p$ ( $\mathrm{R}$, folio $649.2-679.5 ; 264.4-278.4$ ).

29. Samdhis (ELa), p. 131.26-28, § 9.3; see also: p. 133.11-12, § 10.2, p. 140.9-12, §18.5.

30. T 482, 14, p. 666a; ref. Pedersen.

31. TTP, 23, p. 239.3.1-3.

32. op. cit.,p. $267.2 .5-6$

There are numerous other references which shed some light on the way in which the term Bodhisattvapitaka is interpreted in Mahāyanna literature. The Lankkāv (p. 66.2-5), for instance, says:

"What is meant by abandoning the roots of virtue? It refers to those who have abandoned the 
At this point let us briefly review the collected evidence. The majority of sources examined so far agree to assign the expression Bodhisattvapitaka the role of a scriptural classification of Buddhist texts. In a number of treatises, it is taken to correspond to a body of sütras comprising the totality of Mahāyāna writings. In others, it is more specifically associated with the bodhisattva ideal, apparently with the aim of demarcating its teachings from those of current orthodoxy. In this context it is probably best understood as a collection of teachings preached to bodhisattvas.

We have practically no information as to the exact structure and content of that classification. The majority of texts investigated correlate the term Bodhisattvapitaka to issues connected with the bodhisattvacaryā. Apart from its association with the six pāramitā, few details have emerged that clarify the nature of the practices included or their position in the evolution of the bodhisattva doctrine. On the basis of the rather vague nature of the evidence available, little can be said about the historical status of a collection of sütras called Bodhisattvapitaka. The numerous references found in almost all strands of Mahāyāna literature suggest that it must have been a widely known classification of scriptures over a fairly long period. However, since none of the references so far examined contains any information as to its structure and exact contents, we cannot exclude the possibility that the expression Bodhisattvapitaka may have stood for the totality of scriptures that, in one way or another, deal with the bodhisattva ideal. In this event, the question of its historicity is most delicate since the expression Bodhisattvapitaka may have existed solely as a vague concept in the minds of a few people.

As already indicated above, my forth working category refers to a number of texts that contain explicit references to a specific, individual text called Bodhisattvapitakasütra. It is to these references that we shall turn next. In view of the heterogeneous nature of the sources included in this fourth category, I propose to divide the material into two subcategories:

First, there is a number of canonical and paracanonical sources that contain citations of a Bodhisattvapitaka. The most prominent texts of this category are the Sikșāsamuccaya (Sikș), Lokadharapariprcchā (Lkdh) and Bodhisattvapițakasütra $(B d p)$ as well as three, as yet uni-

Bodhisattvapitaka, who make wrongful accusations that are not in conformity with the Sütra, Vinaya and liberation."

The Akn mentions the term Bodhisattvapitaka as part of an enumeration citing eighty-four ways of learning. In the middle of that list (no. 39) it differentiates between the way "... of studying the prajñäpäramitä, studying the Bodhisattvapițaka, studying the samgrahavastu, studying the upāyakauśalya" (p. 50.5.5). 
dentified, fragments found in the Tun-huang material. ${ }^{33}$

Second, there are the catalogues and compendia of the indigenous Chinese and Tibetan Buddhist traditions. Here, particular use will be made of Nanjio's catalogue, the Mahãvyutpatti $(M v y)$ and, to a lesser extent, of Seng-yu's Ch'u san tsang chi chi. ${ }^{34}$

The greatest number of references to a specific text entitled Bodhisattvapitaka is found in the Bdp. Here, the term Bodhisattvapitaka is mentioned sixty-four times. The majority of these references refer to the $B d p$ itself. There are, however, instances that contain ambiguity whether the reference in question points to a specific sütra or a vaguely delineated body of texts considered above. ${ }^{35}$ Since such instances are very few indeed and often appear in a context in which it is virtually impossible to decide conclusively on their format, it seems preferable to leave them untreated, at least for a moment.

Four brief quotations will suffice to convey some idea of the way in which the Bodhisattvapitaka sees itself:

"Sitting in that seat, in order to benefit many sentient beings, the Tathägata will explain a sütra (mdo sde) called Bodhisattvapitaka which advances the bodhisattvacary $\bar{a}$ and is commended as benefiting all sentient beings." 36

33. All three citations have been taken from, or are closely related to, the $B d p$ :

1. 705.2 (28) corresponds to $R$, folio $604.2-604.7$

2. 705.2 (688) corresponds to $\mathrm{R}$, folio $81.1,86.1,86.3$

3. 635.32 bears close affinity in contents to chapter eleven of our sūtra. Amongst others, it discusses skill in vijñanna and jinäna, skill in the bodhipäkșika and skill in neyartha and nitartha sütras and would therefore seem to correspond to extracts from $\mathrm{R}$, folio 631.4-673.6. As in many cases the manuscript is almost unreadable, I have not succeeded in pinpointing all of its contents. There is a fourth reference (380.109) that cites a Bodhisattvapitaka. The content of this fragment corresponds loosely in style and topics to our sütra, but again, positive identification has not yet been possible.

34. For an analysis of Seng-yu's writings and his position in the Chinese Buddhist tradition, see: Link, 1957, $1960,1961$.

35. I base my conclusion, in addition to close contextual congruencies, on the following features of the Tibetan text. In the Bdp, the majority of references cite the term Bodhisattvapitaka in conjunction with demonstrative pronouns (Tib. hdi, de) which, in some cases, are reinforced by the reflexive pronoun 'itself' (Tib. ñid). I take this emphatic use of the demonstrative pronoun, which in Tibetan is quite optional, as an indication that the author had a particular text in mind, most probably the Bdp itself, when he refers to 'this Bodhisattvapitaka'. Moreover, the context in which the references appear is always intimately linked to the subject matter discussed in that very passage. In addition, the term Bodhisattvapitaka is often supplemented by the syllables mdo sde whose principal meaning is, according to the compilers of the $M v y$, sütra or sütränta $(350,805,1412,1435)$.

There are, however, instances in which the expression Bodhisattvapitaka appears to refer to a collection of texts. Furthermore, the Tibetan term mdo sde can optionally also carry the meaning 'sütra-class'. As I do not feel confident to resolve this contradiction positively, I wish to draw attention to the possibility that, originally, the Bodhisattvapitakasütra might have been comprised of various texts which, in the course of time, grew into a homogeneous whole.

36. $\mathrm{R}$, folio $76,4-6$. 
"What are the riches of a bodhisattva's teacher? It is the Dharma enunciation of this Bodhisattvapitaka. When his teacher has recognised that the bodhisattva is speaking gently in every respect, he instructs him in the Dharma-enunciation of this Bodhisattvapitaka at great length. He teaches and proclaims it. He establishes him in it and analyses it. He clarifies and propounds it. A bodhisattva who abides securely in this Bodhisattvapitaka understands [how to] cut off poverty forever and quickly realises perfect enlightenment. ${ }^{.37}$

"O Śāriputra, bodhisattvas who desire to attain swiftly their prediction (vyākarana) should listen to the Dharma enunciation of this Bodhisattvapitaka. They should take hold of it and retain it. They should also propound it to others and teach it at great length. ${ }^{\prime 38}$

"If bodhisattvas take hold of this Bodhisattvapitaka and retain it, etc., they will persist in order to perpetuate the lineage of the three jewels and will never be separated from the four immeasurables. They will be training themsevles vigorously in the six perfections and convert all sentient beings by means of the four means of conversion. O Sāriputra, this Dharma enunciation of the Bodhisattvapitaka is the path of enlightenment. And why? Because supreme and perfect enlightenment is connected to the Dharma enunciation of the Bodhisattvapitaka. ${ }^{39}$

The other sütra that unmistakably refers to the expression Bodhisattvapitaka as an individual text is the $L k d h .^{40}$ In his study on the Karunappundarika, Yamada suggests that it refers to the Bdp. ${ }^{41}$ Whilst Schuster argues that there is not sufficient evidence to support such a view, ${ }^{42} \mathrm{I}$ do not know why she asserts this; in my opinion it is beyond any doubt that we are dealing here with citations from the $B d p$. The most conclusive example is found in chapter eleven of the Lkdh that discusses the bodhisattvacarya and its mental concomitants. Here, the title

37. R, folio $338,2-5$.

38. $\mathrm{R}$, folio 717.3-6.

39. $\mathrm{R}$, folio 735.4-736.3.

40. TTP, 34 p. 8.3.7-8; p. 7.46-7 and p. 32.1.3-4.

41. Yamada, 1968, p. 212 n. 3.

42 Schuster, op. cit., n 109. 
Bodhisattvapitaka is quoted in conjunction with an elevenfold enumeration of a bodhisattva's skill. This corresponds closely to the Bodhisattvapitaka's exposition on skill. ${ }^{43}$ The first six and the eleventh type concur verbatim, while the remaining five agree in contents. Moreover, the $L k d h$ reproduces several of the $B d p$ 's organisational irregularities. It cites, for instance, 'skill in mindfulness' when this type of skill is not mentioned in the $B d p$ 's introductory list on skill itself, but then is freely included in the exposition. ${ }^{44}$ It appears, therefore, very likely indeed that we are dealing here with a reference to our sütra. ${ }^{45}$

The above finding has an important bearing on the historical status of the $B d p$. So far, the earliest reference to our sütra that can be dated with any security has been Hsüan-tsang's seventh-century translation. Apart from close textual affinities with the $A k n$, there has been no evidence at all to confirm its existence prior to the seventh century. All this has changed since we know from Chinese sources that the $L k d h$ already existed by the fourth century $\mathrm{AD}^{46}$ Therefore, we may now take the fourth century as the terminus ad quem for the Bodhisattvapitaka's origin.

Next, there is a quotation in the Sikṣ that Santideva (700-750 AD) attributes to a Bodhisattvapitaka. ${ }^{47}$ However, this quotation does not occur anywhere in the $B d p$. This is not surprising, as the devotional flavour of the quotation that details ways of honouring a Tathāgata shrine is stylistically out of kilter with the pragmatic, factual tone of the $B d p$.

This apparent incongruence raises another important issue. If we accept that this citation refers to one specific text (which is probable, considering its context and way of presentation),

43. In the $L k d h$ a bodhisattva's skill is divided into eleven types:

1. Skill in aggregates; 2 . Skill in sensefields; 3 . Skill in elements; 4 . Skill in dependent co-origination; 5. Skill in the bases of mindfulness; 6 . Skill in the faculties; 7. Skill in the eightfold path; 8 . Skill in mundane and supramundane dharma; 9. Skill in conditioned and unconditioned dharma; 10. Skill in investigating the marks of all dharma; 11 . Skill in obtaining the power of recollection and a mind of investigating the sayings of all teachings (34, p. 9.5.4-6).

44. R, folio 615.4-616.1; folio 649.2-662.3.

45. Apart from the list in the $L k d h$ which runs almost parallel, I have not found a single list which matches exactly the $B d p$ 's scheme of skill. Lists of skill are by no means exclusive to the $B d p$. However, in general, they do not match in every respect and include several additional members. For references to several of these enumerations of skill, see: chapter four, note 654 .

46. The $L k d h$ is extant in two Chinese translations. The first was carried out by Dharmarakșa between 265 and $313 \mathrm{AD}$ (T 481); the second by Kumārajīva between 402 and $412 \mathrm{AD}$ (T 482).

47. The quotation runs as follows (Siks, p. 311.13-312.2; trsl. Bendall, p. 278):

"Again, in the holy Bodhisattvapitaka is described a way to increase merit: "He that cleans a shrine of the Tathägata, he attains four purities of aspiration of perfection. And what are these four? Perfect purity of aspiration in form, in steadfast undertaking, in seeing the Tathãgata, in the multitude of lucky marks."

Again, in the same place it is said:

"One who lays a flower on the shrines of the Tathāgatas or anoints them attains eight things without deficiency. And what are these eight? No deficiency in form, enjoyment, surroundings, virtue, tranquillity, knowledge, wisdom and aspiration." 
then there must have been at least one further sütra known under the title of Bodhisattvapitaka. Against this it would have to be assumed that the text known as Bodhisattvapitaka has undergone considerable internal change since the early eighth century. These questions will be investigated next.

Chinese catalogues of the Buddhist canon enumerate five texts with the title Bodhisattvapitaka. Nanjio, following the Ming catalogue, lists three texts in the Mahāyāna Vinaya section which beside the $B d p$ have been known in the past as Bodhisattvapitaka.

1. A text called Bodhisattvapitakasūtra (T 1491, N 1103). Its Chinese translation consists of one fascicule only. This translation was carried out by Sanghabhara during the Liang Dynasty between AD 506 and 524.

2. A sūtra that is listed currently under the title Mahāyānatriräsikșamasūtra (T 1493, N 1090). Alternative titles cited in Nanjio are Karmāvaranapratisarana, Karamāvaranapraticchedana, and Triskandhaka. The Taishō index lists it also under the name Karmāvaraṇapratipraśrabdhisūtra. It was first rendered into Chinese by Jñānagupta and Dharmagupta during the Sui Dynasty ca. AD 590.

3. A text which Nanjio lists as Sāriputraksamasütra (T 1492, N 1106). He adds that this sütra is also known as Triskandhaka and that it is an earlier and shorter version of the translations cited under N 1090 and N 1103. Its Chinese translation is attributed to An Shih-kao who is said to have made it during the Eastern Han Dynasty between AD 148 and 170.

A text entitled Triskandhaka is also mentioned in the $M v y(1384)$ and by Bu-ston. ${ }^{48}$ In the Mvy it is found in the sütra section of the Tibetan Tripitaka. ${ }^{49}$ A work of the same name is further cited in the Siks and $U g .{ }^{50}$ Here, the term Triskandhaka is mentioned primarily in a liturgical context. Schuster has suggested that, like the Bodhisattvapitaka, the expression Triskandhaka might also have had a twofold meaning, viz.; that it might have referred to a particular text bearing that name and to a category of presumably brief treatises describing certain liturgical practices. ${ }^{51}$ Such a liturgical text would seem a likely candidate as the

48. Obermiller, 1931-32, i, p. 171.

49. Mvy 1384, TTP 950.

50. Siks, p. 290.1-2.

51. Schuster, op. cit., n. 99. 
source for Śāntideva's brief citation from a Bodhisattvapițaka on stūpa worship in the Sikș. If the three translations cited in Nanjio's catalogue (N 1090, 1103 and 1106) are approximately identical in content and have a shared interest in liturgical practices we are probably dealing here with texts that have little in common with our sütra.

There is one more text that has been referred to in the past as Bodhisattvapitaka. It is the seventeenth work in the Ratnaküta collection and presently called Purnapariprccha or Pürnaparivarta. ${ }^{52}$ Its alternative title as Bodhisattvapitakasütra is attested in a number of sources. Bodhiruci's translation of the Ratnaküta, for instance, gives Bodhisattvapitaka as its secondary title. Also Kumärajiva who rendered the Prn into Chinese between AD 402 and 409 referred to it under the title of Bodhisattvapitakasütra. His translation is the only Chinese version that survived. Mochizuki, however, has discovered that the T'ang catalogue lists Kumārajiva's translation as the second translation. ${ }^{53}$ According to the same source, the first translation (which also bears the name Bodhisattvapitaka) was made by Dharmaraksa at the end of the third century $\mathrm{AD} .{ }^{54}$ It is recorded as being a comparatively short text comprising only three fasciculi. This earlier version is no longer extant. In the Taishō, the term Bodhisattvapitakasütra is still employed as the secondary name of the Prn. ${ }^{55}$.

In this sütra the Buddha discourses on the bodhisattva path to a monk called Pūrnamaitrayaniputra. In the course of the exposition that culminates in a description of Pūrna's attainment of the stage of irreversibility, the Buddha explains the generation of the thought of enlightenment, the manner in which an aspiring bodhisattva eliminates all enmity directed at him by a hostile world, and how he should cultivate the 'faculty of hearing'. Pūrṇa's personal quest is marred initially by his past exposure to evil influences that cause him to forget the goal of enlightenment. At a later stage, however, after he has overcome his unwholesome disposition he becomes successful in cultivating the four silla dharma that generate in him roots of virtue, the resolve of 'no-turning-back' and finally the state of enlightenment.

Structurally, the exposition of Prn has many features in common with other Ratnaküta texts. It also makes an extensive use of tetrads as a particular means of explaining the complexities of the bodhisattva training. In the Prn, the tetrad section is extraordinarily long and covers roughly a quarter of the whole sütra. Large parts of this section are dominated by

52. TTP, 760.18, T 310. 17.

53. Mochizuki, 1931-36, p. 3441a 5-25; ref. Schuster, op. cit, p. 45, n. 100.

54. See also: Bagchi, 1927, i, pp. 83, 84 who confirms this information.

55. Seng-yu, in his Ch'u san tsang chi chi, gives as its usual title Bodhisattvaptakasütra and cites Pūrnapariprcchā and Mahākarunäcitta as two altemative names (Shih, 1968, p. 76, no. 65). 
enumerative descriptions of the bodhisattva's duties. Conceivably, it is its apparent preoccupation with providing instructions relevant to the bodhisattvacaryä that accounts for its alternative title as Bodhisattvapitakasütra.

If we turn now to comparing the structure and content of the Prn with the references to a Bodhisattvapitaka that are found in the various strands of Mahāyăna literature, a number of important differences become apparent. As we have gathered from the quotations cited above, the Bodhisattvapitaka is associated with the six pāramitā, upäyakausalya, maitri, and with preserving and acquiring the Dharma. In the Prn these characteristics do not stand in the foreground. Most importantly, the Prn does not include a systematic exposition of the pāramitā. Naturally, they do receive some attention but are clearly not the raison d'être of its composition. Hence, it seems improbable that when the sources refer to a Bodhisattvapitaka they actually imply the Prn.

As already concluded above, in most cases the expression Bodhisattvapitaka served as an umbrella title for a group of texts which dealt in one way or another with the bodhisattvacaryā. Judging by the numerous references to the six perfections, the treatment of the paramita must have been the core of many of the sütras that were included in that collection. We cannot exclude the possibility that the Prn was included among the body of such early bodhisattva sütras. It is not probable, however, that the Prn can be indentified as the text such ancient sütras as the $K p$ had in mind when they referred to a Bodhisattvapitaka.

Finally, there is a reference to a Bodhisattvapitaka in the $M v y .{ }^{56}$ Here, a Bodhisattvapitaka is given as the fifth work in a list that enumerates one hundred and four Buddhist texts, between the Avatamsaka and Lalitavistara. The Avatamsaka is a composite work. Its two main recensions are divided into thirty-four and thirty-nine chapters, many of which are in fact separate sütras that have been in circulation as independent texts. The Lalitavistara, in contrast, is a more homogeneous text that narrates the lives of Sākyamuni Buddha. Perhaps, by placing the $B d p$ between these two works, the authors of the $M v y$ intended to point to some affinity in structure or contents between the three works. They may have regarded the Bodhisattvapitaka as being composite in a similar way to the Avatamsaka. Alternatively, they may have considered the presence of jätaka-type stories in the $B d p$ to be a factor that links it to the Lalitavistara. It is also possible of course that the arrangement of sutra titles bears no relation to their respective content. Yet, the sequence of their enumerations seems to indicate 56. ref. Schuster. 
the implementation of a premeditated design. ${ }^{57}$

57. The lists commences with the Satasāhasrikaprajñāpāramitā, Pañcavimisatisāhasrikaprajñāpāramitä and Aștasāhasrikaprajīnāpāramitā, followed by the Buddhāvatamsaka, Bodhisattvapitaka, Lalitavistara and Samädhirāja. Considering the position assumed by these sütras in Mahāyāna literature, the sequence might indicate an arrangement in which the texts are ranked in order of importance. The Ratnakutta is cited in the thirty-ninth position. 
The Bodhisattvapitaka and the Akșayamatinirdeśa

\section{The Bodhisattvapițaka and the Akșayamatinirdeśa}

As part of the discussion of the Bodhisattvapitaka's position in Mahāyāna literature, I shall next explore the relationship between the $B d p$ and $A k n .^{58}$

The main body of the $A k n$ consists of a detailed exposition of eighty inexhaustible (aksaya) faculties and attributes of a bodhisattva. Here, many of the more important practices of the bodhisattvacary $\bar{a}$ are discussed and set into an early Mahāyāna context. ${ }^{59}$ Significantly, only the first ten of the eighty aksaya bear unmistakable marks of Mahāyāna thought. Virtually all

58. The earliest reference to the $A k n$ is found in a Chinese catalogue of the Buddhist Canon where it is listed as an early fourth-century translation and is included as the twelfth section of the Mahäsamnipāta (Li tai san pao ki; 41.2a; Bagchi, i, pp. 90-91). This translation was carried out by Dharmarakșa in AD 307. The work is still extant and catalogued as Taishō no. 397. According to Nanjio (no. 74, 77) it is in fact a co-authoured translation carried out by Chih-yen and Pao-yun soon after $427 \mathrm{AD}$. The $\mathrm{Akn}$ seems to have formed from the very outset a part of the Mahāsamnipāta collection which itself ranks among the earliest collections of Mahāyāna literature (Bagchi, i, p. 90). Bagchi lists the Mahāsamnipãta collection among the early Mahāyāna sūtras that were translated by Lokakșema during the second half of the second century AD (Bagchi, i, p. 43).

In the Tibetan Canon which does not know any collection entitled Mahäsamnipāta, the Akn has been included in the 'sütra section' (TTP 34, no. 842). Judging by the remarks found in the prologue and epilogue of the Tibetan translation, it is clear that by the ninth century, at least, the $A k n$ had become a part of the Indian Mahäsamnipāta collection. Wayman cites some internal evidence which suggest that the $A k n$ was composed by the same circle of monks who composed the Satasāhasrikāprajñāpāramitā, Saptaśatikäprajñäpäramitā, Kuśalamülaparidhara, Buddhapitaka and Saddhp (Wayman, 1980, pp. 212-214). The greatest number of citations from the $A k n$ are contained in $S i k s$. Altogether, it refers twenty-two times to various sections of the $A \mathrm{kn}$. Other citations are found in the Sütrasammuccaya (TTP, 102, p. 85.1.2 ff); in Sthiramati's sub-commentary on the Mahāyānasütrālamkāra, that is the Sütrālamkāravrtti-bhāsya (TTP 109, p. 48.2.2); in Candrakirti's Prasannapada (La Vallée Poussin, 1913, p. 108.1-3) and in the Mppś (iii, pp. 1245-50, 1272, 1716). For a list of $A k n$ quotations in Mahāyāna literature, see: Braavrig, 1989, pp. lvi-1xi.

Despite the $A k n$ 's apparent popularity with the later Mahāyāna writers it seems unlikely that it belonged to the very earliest strand of Mahăyăna sūtras. That is to say, it almost certainly postdates works such as the $A s t a$ and Saddhp, but may have appeared in the second wave of Mahāyana texts alongside the $V k n$ or $S g s$. First, its highly systematised and concise way of dealing with the various aspects of the bodhisattvacarya, its main topic, indicates that it is not an early work. Second, there are some issues which await, as yet, clarification. In the Prajña $\bar{a}$ Chapter (p. 56.2.6), for instance, there is a reference to a Yogäcärabhümi, saying: "Wisdom is attached to all places in the Yogäcärabhümiśästra" (p. 56.2.6). The general nature of this citation does not allow us to infer that it is a reference to Asanga's Yogäcärabhümi or to follow Wayman's suggestion that it is the Yogācārabhümi composed by Sangharakșa. If we take it to be a reference to Asanga's Yogācārabhūmi, then we have to discredit the various entries found in the Chinese catalogues which date the $A k n$ 's first translation to $307 \mathrm{AD}$, since we know that the Yogãcärabhümī in its present form, is at the earliest a late fourth-century work. On the other hand, Chinese sources do mention a partial, late second-century translation of Sangharakșa's Yogäcärabhümi. If we assume that it is this text to which our citation refers, then the possibility of the $A \mathrm{kn}$ belonging to an early literary phase of the Mahāyāna cannot be excluded (Demiéville, 1954, pp. 395-396).

59. As Wayman has demonstrated, it is this list of eighty aksaya that was taken as a basis in the Sütrālamkāra where the $A k n$ is cited as authority for the twenty-two forms of generating the thought of enlightenment. Cast into twenty-two similes in the Süträlamkära, they correspond in number and sequence to the eighty akșaya listed in the $A k n$. The similes themselves, however, did not originate in the $A k n$, but stem from a number of sources, most notably from passages of the early Prajñāpāramitā literature. The list of the similes is, for instance, contained in three kārikā of the Abhisamayālamkāara (Conze, 1954, pp. 9-10). 
other practices cited fall within the scope of pre-Mahāyāna Buddhism and figured, in one way or another, already in the suttas of early Buddhism.

A number of otherwise well-known Mahāyāna concepts are not included in the $A k n$, most notably the theory of gotra, the fivefold path as propounded in the Abhisamayalamkāra and the tenfold scheme of the bodhisattva's career. ${ }^{60}$ Instead, more basic Mahāyāna concepts such as the generation of the thought of enlightenment (bodhicittotpa $\bar{a} d a$ ), the cultivation of the six päramitā and the attainment of the stage of irreversibility (avaivartikabhūmi) stand in the foreground. This preoccupation with ancient elements of Mahāyāna thought seems therefore to endorse the scriptural evidence found in Chinese catalogues that places the $A k n$ in the early, formative period of Mahāyāna thought.

Next, we turn to comparing the issues that are central to the $A k n$ with those found in the $B d p$. In doing so, we note numerous themes which are common to both sütras. In a number of instances, whole passages correspond word by word. Structural affinities are found also in the internal design and logical sequence in which the dialogues are construed. But the overall order of the practices differs in several respects. In the $B d p$ most of the concurrences are found in the Prajña Chapter, while in the $A k n$ they are more evenly spread out over the eighty akșaya. The reason for this lies in the differing concentration of bodhisattva practices. In the $B d p$, most of the practices are allocated to chapter eleven, while in the $A k n$ no such accumulation prevails.

Particularly striking is the frequent recurrence of long, almost identical, abhidharmic-type lists enumerating the various qualities and practices associated with the bodhisattva. Clearly, concurrences of that kind point either to the existence of some commonly accepted patterns of exposition current a the time of their composition, or to a particularly close connection between the $A k n$ and the $B d p$. Further below, I shall show at some examples that the direction of this influence must have flowed from the $B d p$ to the $A k n$ and not vice versa. ${ }^{61}$

When we turn to the practices, we note that in both texts, the pāramitā are treated individually

60. Obermiller, 1932, pp. $14-46$.

In the opening passage of the fourth aksaya, there is however one brief reference to 'stages' of the bodhisattva path. Since these are left undefined and do not seem to be part of the $A k n$ 's overall scheme, we may be dealing here with a later interpolation, attempting to include a reference to the $D b h$ into the structure of the $A k n$ (p. 41.5.3). The $A k n-t i \bar{i} k \bar{a}$ interprets the bodhisattva practices in the $A k n$ in terms of the ancient scheme of the sambhāramārga, prayogamārga, darśanamärga and bhāvanāmārga. This scheme, however, is not explicitly put forward in the root text.

61. For a detailed analysis, see: Pagel. "The Akșayamatinirdeśa and Bodhisattvapitaka". The Buddhist Forum. iii. forthcoming. 
and are not linked to any path structure. Also, the material that is employed under the respective headings of the six perfections corresponds in many points. In the Kșänti Chapter, a practically identical exposition on the nature of 'highest patience' is found. ${ }^{62}$ In their Dhyāna Chapters both texts cite a largely concurring list of about one hundred samädhi. In their Virya Chapters, both sütras underline the importance that mental exertion assumes in the bodhisattva's training and provide an identical way of explication. ${ }^{63}$ However, similarities in contents go well beyond the pāramitā chapters. They are found in about eighty percent of practices which occur in both works. Outstanding examples are provided by the discussions of punya and jñānasambhāra, the treatment of samatha, vipaśyanā, bodhyanga and

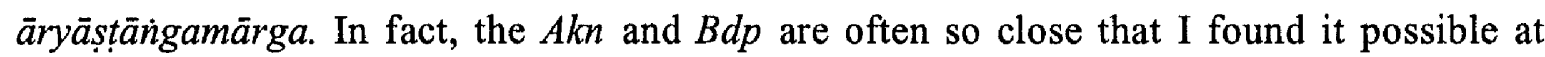
several occasions to draw on the $A k n-t i k \bar{a}$ to clarify obscure passages in the $B d p{ }^{64}$

The first person to point to the textual parallels between the $A k n$ and $B d p$ was Alex Wayman in an article published in $1980 .^{65}$ Noting their association only in passing, he acknowledged their common ground on many topics and correlated a few of their sentences. Taking his article as a point of departure, I investigated the other areas in which the parallels occurred. Leaving aside a handful of uncertain cases, we can distinguish three categories of textual parallelism. First, there is a group of concurring enumerations. Second, there is a large body of formulaic sections of text, so common in suttas of early Buddhism. Third, there are several independent, non-formulaic passages that are shared by both works.

Of the three areas of parallelism, it is easiest to account for are the concurrences that appear in lists. Altogether, I encountered far-reaching agreement in six enumerations. These include a list of types of skill ${ }^{66}$, an enumeration of thirty-two pairs of mental vigour (cittavirya), the samādhi list of the Dhyāna Chapter and a catalogue of forms of learning. In theory, owing to

$62 \quad B d p$, p. $46.4 .2-47.1 .2 ; A k n$, p. 45.3.3-4.8

In order to lend accuracy to the comparison between the relevant sections of the $A k n$ and $B d p$, I adopt for this section of my work the readings in the Peking Tripitaka Edition (Suzuki, Tokyo-1956).

63. $\quad B d p$, p. 55.3.6-5.3; $A k n$, p. 48.1.5.

64. Wayman has drawn our attention to some, in his opinion, significant philosophical shifts in emphasis between the $A k n$ and the $B d p$. However, on close examination of the respective passages in both sütras and the $A k n-t i t k \bar{a}$, these discrepancies seem to be of a rather minor nature. For details, see: Pagel, 1991, pp. 8-12.

65. A. Wayman. "A Report on the Akșayamatinirdeśasūtra". Studies in Indo Asian Art and Culture. 6, New Delhi: 1980, p. 219.

66. In the $B d p$, these include 'skill' in skandha, dhätu, äyatana, satya, pratisamvid, pratisarana, vijñāna and jñāna, bodhipāksika dharma, pratityasamutpada and märga, (pp. 77.2.3-87.5.6). In the $A k n$, the list runs as follows: 'skill' in skandha, dhätu, äyatana, satya, trikäla, yāna, pratityasamutpada and sarvadharma (pp. 52.2.8-56.1.6). The five topics that do not appear in this context in the Akn are 'skill' in pratisamvid, vijñäna and jñäna, bodhipäkșika and 'skill' in the path. They are given elsewhere an independent treatment (pp. 62.2.7-63.48; p. 64.2.4-3.5; pp. 66.4.3-70.4.3 and pp. 70.4.4-71.2.1 respectively). 
the tendency in oral traditions to adopt wholesale listings of any type for mnemonic purposes, it is possible that this concurrence is ascribable to a third source and not to direct borrowing between the $A k n$ and $B d p$. In spite of intensive research in this area, I have not been able to trace any enumeration from which they might have stemmed. ${ }^{67}$

The second category comprises a number of parallel passages that are largely composed of set expressions, turns of phrase and formulae. They prevail, above all, in the exposition of the bodhipäkșika dharma, in skill in aggregates, elements and sensefields and in the section on the unique knowledge. While it was an easy task to identify them, it is virtually impossible to determine the texts from which their particular set phrases were originally taken. Being well acquainted with Buddhist sütras, the authors of the $A k n$ and $B d p$ probably recited them from memory without having in mind any specific work as point of reference. However, a number of interpolations of non-standardised text elements such as connecting phrases in the $A k n$ shows beyond doubt that it was the $A k n$ which drew on the $B d p .^{68}$

Finally, the $A k n$ and $B d p$ share a considerable number of non-formulaic text portions that are kindred in spirit and almost identical in phrasing and hence appear to be unique to the two sütras. As will become clear further on, it is precisely this uniqueness that indicates the $A k n$ 's indebtedness to the $B d p$. The most interesting examples of this category are found in the sections dealing with 'skill' in satya, 'skill' in dharma and 'skill' in pratisarana.

Amongst the six concurring enumerations, the most interesting example is the list detailing the bodhisattva's forms of learning. Wayman, noticing their agreement but not providing any reasons, saw in the list of the $B d p$ a kind of prototype for that of the $A k n$. While, in principle, I agree with his judgment, I wish to add precision to his observations and to corroborate them with additional findings. For one thing, Wayman thought that we are dealing with two, essentially identical lists. This is not the case. The first obvious variation is the difference in

67. See: Wayman. "The Samādhi Lists of the Akșayamatinirdeśasūtra and the Mahāvyutpatti". $A O H, 34$, 1980 , p. 305-318.

In his article on the samädhi lists (op. cit., p. 312) Wayman writes that the samädhi in the $A k n$ were adopted from the list of the $B d p$. Wayman does not give any reasons to susbstantiate his assumption but he is probably correct in proposing this direction of borrowing. Of the total of one hundred and eighteen samädhi in the $A k n$ seventy-two occur also in the $B d p$. For the most part the meditations that are common to both texts appear in clusters of six to ten samädhi each. Perhaps to account for changes in doctrine, we have several cases in which the samädhi titles appear in slightly altered versions in the $A k n$. What puzzles me is the rationale behind the choice by which the $A k n$ adopted samädhi from the $B d p$. Why are of one hundred and one samādhi in the $B d p$ only seventy-two found in the $A k n$ ? What were the reasons for excluding the remaining forty-six samädhi-some of which bear well-known titles such as the Samädhiräja? Neither the order in which they are listed nor the actual wording of their titles appear to hold the key to these questions. I have given a list of both the $A k n$ 's and Bdp's samādhi lists in Appendix ii.

68. Pagel, op. cit., pp. 5-8. 
the length of the lists. The $A k n$ 's enumeration gives eighty-four forms of learning, whereas the $B d p$ knows of only seventy-two.$^{69}$ Furthermore, the $B d p$ contains thirteen items that are not found in the list of the $A k n$, raising the number of variant items to twenty-five-roughly a third of the sum total. This substitution of individual items suggests that one of the lists was carefully edited. The greater length of the $A k n$ 's list alone indicates posterity, because it is doubtful whether the $B d p$ would deliberately reduce its scope. On the contrary, if one's experience with other texts is anything to go by, material is usually added in the process of transmission rather than being taken away.

The majority of discrepancies that exist between the two lists are found in the second half of the enumeration. Up to äkära thirty-three, most items concur closely in both sequence and contents. After that, apart from two codified sets of practice (no. 49-52, 53-55), the items are generally ill-matched and display few parallels. Thus far, I have not managed to identify a rationale behind this process of restructuring. Apart from some well-known standardised groupings $^{70}$, no scheme springs to mind when comparing the organisations of the two lists. ${ }^{71}$ Since both enumerations contain a remarkable comprehensive catalogue of practices, it is tempting to conjecture that their purpose was to gather all known bodhisattva practices in a single Abhidharma-type mätrka list. Their placement before the main thrust of the bodhisattva practice adds weight to this theory.

In the other enumerations the situation is much clearer, since a close accord in number as well as contents is shown. This agreement makes it of course more difficult to determine the direction in which the borrowing took place. In these enumerations, the only clue is the presence of numbering schemes in the $A k n$ that are not found in the $B d p$. While the inclusion of these schemes, taken on its own, is not sufficient to substantiate the view that the lists of

69. It is worth noting here that also Sanntideva's quotation in the Sikss of the $A k n$ enumeration is at variance with the original. I suspect that these divergencies are not the result of a consciously undertaken selection but occurred inadvertently, since the number of items is very close (80) and does not show any new $\bar{a} k \bar{a} r a$ (see: Appendix i).

70. E.g., Bdp item no. 49-52: four hallmarks of Buddhism (bkah rtags kyi phyag rgya bźi ); item no. 53-55: three gateways to liberation (trini vimoksamukhäni); item no. 76-77: reliances (pratisarana); item no. 63-64: bodhipäksika dharma; no. 65-71: buddha-powers (buddhabala) etc.

71. As far as the individual items are concerned, one meets with a few inconsistencies that stand out at once. First, there is the item called "study of the Bodhisattvapitaka" (no. 39, 35). Its position in the list, next to prajñāpāramitā, samgrahavastu and upāyakauśalya, suggests that it was conceived of as a (set of) practice and not as single text (or body of scriptures) as it is interpreted elsewhere. Second, one notes the discrepancy that exists between the title brahmavihära given to item $42 / 38$ in the list and its designation in the text itself where these four practices are invariably referred to as the four apramāna. While it is true that one cannot speak of a standard title for this set of practices, the incongruence in their titles might indicate that the list of learning was implanted in the texts in a prefabricated form and does not stand in any 'organic' relation to the exposition itself. 
the $A k n$ were taken from the $B d p$, a number of unambiguous editorial modifications suggests this.

The most telling examples of this kind are found in the section which details the bodhisattva's accumulation of merit (punya) and pristine cognition (jñana). In the $B d p$ we meet here with the statement that bodhisattvas of pure resolve "appear in all worlds". In the $A k n$ this sentence has been altered to say that purity of resolve endows bodhisattvas with "power over all worlds". 72

Now, it takes little acumen to see that this variation sprang from a shift in perception of the 'model bodhisattva'. In all likelihood, it dates back to the period in which the early characterisation of the bodhisattva as a human being was superseded by a more transcendental concept of bodhisattvahood. Unfortunately, we have little information to indicate when this shift took place. If one follows Harrison's findings-based on the earliest Chinese translations of Mahāyāna sütras-it did not occur before the third century AD. ${ }^{73}$ Other scholars, basing their propositions either on iconographic evidence ${ }^{74}$ or by correlating the final stages of the daśabhümika path with the emergence of mythical bodhisattvas ${ }^{75}$, have suggested the second century $\mathrm{AD} .^{76}$ Today, this view has been seriously challenged by Schopen in his masterly (re)interpretation of the various rock and pillar inscriptions. He shows that in epigraphical sources 'mythical' bodhisattvas are not attested before the 4th to 5 th centuries $\mathrm{AD} .{ }^{77}$ Thus, without entering the intricacies of the controversy (which, in any event, is based on rather slim documentation), there is enough reason to place the emergence of mythical bodhisattvas in a rather later period than commonly assumed. ${ }^{78}$ In principle, this dating fits in with the chronological order that I proposed for the $A k n$ and $B d p$.

Another variant reading that seemingly corroborates my theory is given in a tetrad enumerating the means that aid the bodhisattva to increase his accumulation of knowledge (jñanasambhāra). In the $B d p$, we learn in this connection of the following four paths. 1 . The path of the

72. $\quad B d p$, p. $81.4 .2 ; A k n$, p. 65.3.7.

73. Paul Harrison. JIABS, 10, pp. 67-89.

74. V.S. Agrawala. "Dhyāni Buddhas and Bodhisattvas". JUPHS, 11(2), pp. 1-13.

75. See E. Conze. A Short History of Buddhism. 1982, p. 49.

76. Gregory Schopen's findings about the Kusāna image of Amitäbha has made this early date- by implication-unlikely (Schopen, 1987, pp. 111-125).

77. Schopen, op. cit., p. 119.

78. Epigraphic evidence and iconographic representations point to a considerable discrepancy between the literary forms of Mahāyāna Buddhism (dating back to the beginnings of our era) and their public manifestations. There was virtually no popular support for the Mahäyanna before the 4th/5th century $A D$ that is documented in the various inscriptions, and even then it is chiefly of monastic origin and not by lay-supporters (Schopen, op. cit., p. 124; Schopen, 1985 pp. 9-47; Schopen, 1979, pp. 1-19). 
päramitā; 2. The path of the bodhipäksika dharma; 3. The noble eightfold path; 4 . The path that leads to the pristine cognition of all knowing. ${ }^{79}$

While this list is not particularly remarkable in itself, the $A k n$ reading of this tetrad contains one interesting deviation. It replaces the third limb, the 'noble eightfold path', with the 'path of the stages' ${ }^{80}$ Since the other three paths correspond to those of the $B d p$, preference to the scheme of stages indicates tangible doctrinal progress. It is plausible that the author of the $A k n$ felt compelled to account for this progress and consequently adjusted the $B d p$ reading accordingly. ${ }^{81}$

Another interesting, though somewhat more ambiguous, variant reading is found in the discussions of "reliance on the spirit and not on the letter" (arthapratisaranena bhavitavyah na vyañjanapratisaranena). While, in the $B d p$, we learn that the letter instructs the bodhisattva "not to abandon any sentient being", the $A k n$ says that the letter teaches bodhisattvas "to renounce all possessions". ${ }^{82}$ The $B d p$ 's reading of this phrase is a reference to the bodhisattva's moral obligation to pursue actively universal liberation. Historically, it probably stemmed from the thought contained in several early Mahāyāna scriptures that gives prominence to the ideal of the grhapti bodhisattva over that of the pravrajita bodhisattva. Texts such as the $V k n$ and (the early versions of the) $U g$ provide illustration of this literary strand. In contrast, the reading of the $A k n$, advocating total renunciation of worldly possessions, belongs to a later period. Its message is strongly reminiscent of the later trend that replaces the lay-ideal with that of the pravrajita bodhisattva as 'model bodhisattva'. The dating of Chinese translations of Mahāyāna texts suggests that this reorientation to the mendicant model of early Buddhism was well advanced by the fourth century AD. Again, this would accord with the proposed chronology of the $A k n$ and $B d p$.

There exists, however, a second possibility of interpretation. Mahāyāna sūtras of all ages agree in propounding generosity (dāna) as the cardinal virtue of the lay-bodhisattva. Generosity epitomises his obligations and efforts, and is the principal means by which the grhapti

79. $\quad B d p$, p. 82.3 .1 .

80. $A k n$, p. 66.3.4.

81. Since their expositions of the bodhisattva's training, both in emphasis of practice and structure, have many elements is common, the time gap between the two works cannot have been very great. Both sütras, for instance, do not employ the tenfold path structure although they must have been aware of it, since it is briefly referred to in several places. Had they originated wide apart, one could expect to meet with traces testifying differences in doctrinal views of the period that separated their formulation. But for three sets of new practices and some minor shifts in emphasis this does not seem to be the case.

82. $\quad B d p$, p. $79.5 .7 ; A k n$, p. 63.5 .6 . 
bodhisattva becomes cleansed from the three root defilements. Indeed, pure giving is often set forth on its own as a model for the grhapti bodhisattva's middle way which fares between affection and aversion-the two extremes against which he battles every day. Hence, the $A k n$ 's admonition could also be understood as referring to the grhapti bodhisattva's obligation to practice generosity at all times with the aim of universal liberation. In this event, the $A k n$ and $B d p$ would subscribe to the very same ideal. However, the $A k n$ 's plea for a very severe form of generosity-which in its radicalism is fundamentally incongruous with the wellbalanced middle way that is trodden by lay-bodhisattvas-renders this line of interpretation possibly less convincing. 
The Scholastic Affiliation of the Bodhisattvapitaka

At this stage I wish to offer some thoughts about possible scholastic affiliations of the $B d p$. The first translation into Chinese of the $B d p$ was carried out by Hsüan-tsang in $\mathrm{AD} 645$. He is reported to have undertaken it immediately on his return to China. The initial phase of his translation activity is recorded as follows: ${ }^{83}$

"On the first day of the seventh month [of the year of his return in China], the master started to translate the palm-leaf Sanskrit scriptures. At the beginning he translated the Bodhisattvapițakasütra, Buddhabhūmisütra, Sanmukhadhāranisūutra and Prakarañäryavacaśāstra. He completed the translation of the Sanmukhadhäranisisutra on that same day and finished the translation of the Buddhabhümisūtra on the fifteenth day while the Bodhisattvapitakasütra and the Prakaranāryavacaśästra were done by the end of the year."

The translation of the $B d p$ won Hsüan-tsang great praise from the emperor T'ang T'ai-tsung. In the same source we read: ${ }^{84}$

\footnotetext{
"The emperor also read the Bodhisattvapitakasütra which the master had submitted to him, and he highly praised it and ordered the crown prince to write an epilogue for this sütra."
}

The passage concludes by relating how Hsüan-tsang's translation of the $B d p$ had even helped to bring about a change in the emperor's disposition towards Buddhism which, so far, had been marked by indifference. ${ }^{85}$

It is well known that Hsüan-tsang's motivation for travelling to India was to acquire a copy of the Yogācārabhūmi. He managed to obtain this text and subsequently translated it between $\mathrm{AD} 646$ and 648 together with the Mahāyānābhidharmasamyuktasañgiti, Mahāyānasamgraha,

83. Li-Yung-hsi, 1959, p. 216 (ref. Schuster).

84. op. cit., p. 225.

85. op. cit., pp. 224, 225. 
Mahāyānasamgraha-bhāsya and Pratityasamutpādasūtra. Other texts, translated at a slightly later date, included the Sanmukhadhāraṇi, Prakaraṇāryavaca and Buddhabhūmisūtra.

If we consider the authorship and doctrinal affiliation of the texts that Hsüan-tsang had chosen to translate first along with the Yogācārabhümi, we find that most of these texts are closely associated with Yogācāra thought. The Prakarañāryavaca and the Mahāyānasamgrahabhāsya are attributed to Vasubandhu and so is a commentary on the Sanmukhadhārani ${ }^{86}$ Furthermore, Bu-ston knows of a commentary on the Pratītyasamutpädasütra which he ascribes to Vasubandhu. ${ }^{87}$ Obermiller pointed to a doctrinal affiliation between the Buddhabhümisūtra and certain currents within the Yogācāra school. ${ }^{88}$ The Mahāyānābhidharmasamyuktasangiti is attributed to Asanga while Aśvabhāsa is generally accredited with the composition of the Mahāyānasūtrālamkāra. ${ }^{89}$

In the light of his preoccupation with Yogācāra literature, it seems natural to raise the question about the reasons lying behind Hsüan-tsang's choice to translate first the $B d p$. Does the $B d p$ form a part of the Yogācāra literary tradition? Did Hsüan-tsang know of some evidence that links our sütra doctrinally or historically with the Yogãcāra school? If so, he apparently regarded it as rather unimportant, since he does not mention it in any of his writings. Neither his $S i-y u-k i$ nor his various biographies seem to contain such a reference. ${ }^{90}$

As I shall discuss further below, Sthiramati is reported to have shown much interest in some of the Ratnakitta works. Tibetan historians accredited him with the composition of the Kāsyapaparivartatikā, the only surviving commentary of that text. ${ }^{91}$ The same sources attribute to Vasubandhu two other commentaries on Ratnakūṭa texts, namely, the Amitābhavyūhatikā

86. Obermiller, 1931-32, i, p. 146.

87. op. cit., i, p. 57.

88. op. cit., i, p. 127 and n. $1192-1197$ on p. 178.

89. Warder (1980, p. 553) gives the title of this commentary as Mahāyannasamgrahopanibandhana (TTP 1598).

90. Schuster (op. cit, , p. 55, n. 123) believes that his motive was of a more mundane nature. She proposes that he wanted to have the $B d p$ available as propaganda fide. Knowing in advance that he would be given an opportunity to report about his extensive travels in foreign countries, he may have chosen to prepare an easily intelligible text of imposing dimensions which was previously unknown in China in order to impress the emperor. She argues that Hsüan-tsang must have been well aware that any of the other, more philosophically oriented, texts would have achieved just the contrary.

One wonders, however, why he had chosen a text of such an extraordinary length. He must have suspected that the interest and patience of the indifferent and increasingly ailing emperor would hardly suffice to absorb a text of such length. Other equally imposing but much shorter texts must have been amongst the over six hundred works that he acquired on his travels. Furthermore, it seems improbable that Hsüan-tsang resolved to translate a lengthy text of little interest to himself for mere propaganda purposes at a time when a large number of works of high personal interest were awaiting examination. The prospect of an audience with the emperor may have influenced the sequence in which he decided to translate the Indian manuscripts, but it seems unlikely to have determined the nature of the texts themselves.

91. TTP 1523. 
(T 1524) and the Ratnacū dabhāṣya (T 1526). Paramārtha knows of yet another Ratnakūta commentary whose authorship he ascribes to Vasubandhu, this is, a commentary on the Srimālādevīsimhanāada. ${ }^{92}$

Hsüan-tsang himself is known to have been a strong advocate of Yogācāra thought. Shortly after his return to China, he founded the Fa-hsiang school whose basic tenets are derived from the Yogācārabhümi and other related works. Considering his personal interest in Yogācāra Buddhism, it seems plausible that he should choose to translate first those works which bore closest affinity to Yogācära doctrines. Such a view is further supported when we recall the two instances where the term Bodhisattvapitaka appears in conjunction with the title Avatamsaka, a collection of texts that is traditionally associated with the Yogācāra school. Moreover, if we accept the hypothesis that the list of sütras found in the Mvy is based on some premeditated scheme, the listing of the $B d p$ next to the Avatamsaka could be interpreted to reflect some connection between our sūtra and Yogācāra thinking.

In the absence of any conclusive evidence, it is helpful to turn once more to the $A k n$, or rather, to its commentary, the $A k n-t i \bar{k} \bar{a}$. On reading the $A k n-t i k \bar{i}$, one discovers soon that it interprets the $A k n$ from a Yogācāra standpoint. One meets repeatedly with concepts such as ālayavijñāna, cittamātratā, prajñaptimātratā, trisvabhāva and āśrayaparāvrtti even though these concepts are not found in the sütra itself. ${ }^{93}$ The author of the $A k n-t \underline{i} k \bar{a}$, whether it was Sthiramati or Vasubandhu (an issue that is not as yet resolved), regarded the $A k n$ clearly as a work belonging to Yogācāra thought. In view of the close affiliation of the $B d p$ and $A k n$, this assumption warrants some consideration when discussing the scholastic affiliation of the $B d p$. Furthermore, in chapter one of the $B d p$ we find recurring references to the term $a b$ hütaparikalpa. ${ }^{94}$ The concept of abhütaparikalpa is closely associated with Yogãcāra thought and figures predominantly in works attributed to the advocates of its philosophy.

Finally, I propose to return to the history of the $B d p$ and its position in the formation of the Mahāyāna. It has been argued by several scholars that the $A k n$ belongs to the earliest strands of Mahāyāna literature. ${ }^{95}$ The arguments cited most frequently in support of this view, are

92 The authenticity of this reference is disputed. Wayman thinks that it is apocryphal, saying that it applies to comments in the Buddhagotraśästra which is attributed in Paramārtha's Chinese translation of the Buddhagotraśástra to Vasubandhu (Wayman, 1974, p. 7).

93. In conjunction with 'skill' in the aggregates, we read for instance (p. $194.2 .6 \mathrm{ff}$ ):

"The unwholesome aggregates are overcome by the change of basis (ásrayaparivrtit) in the store-consciousness (älayavijina $\bar{a} n$ ) at the time of reaching enlightenment."

94. R, folio $36.1,43.7,44.1 \mathrm{ff}$.

95. Wayman, op. cit., p. 232. 
based first on the contents of the $A k n$, second on its association with the $V k n^{96}$ (itself a very early text) and third, on its inclusion in the Li tai san pao chi catalogue ${ }^{97}$, as having been translated by Lokakṣema in the second century $\mathrm{AD} .^{98} \mathrm{As} \mathrm{I}$ do not wish to repeat the argument in detail it should suffice to point out that so far no author has been able to bring forth any compelling evidence in support of the antiquity of the $A k n$ other than circumstantial testimony. However, since the inferential grounds put forward are persuasive, I think it justifiable to accept the $A k n$ 's comparatively early date of composition-perhaps in the first or second century $\mathrm{AD}$-as a working hypothesis.

Considering the nature of our findings about the relationship between the $A k n$ and $B d p$, such an early date for the $A k n$ affects, of course, the dating of the $B d p$; until now this has generally been held to be a rather late work. ${ }^{99}$ To some extent this was due to the late date of the $B d p$ 's first Chinese translation, undertaken not before the middle of the seventh century $A D{ }^{100}$ Other factors that were cited in support of this theory range from its alleged systematisation and use of comprehensive enumerations, including the presence of supposedly "fully matured Mahāyāna thinking" in its exposition. ${ }^{101}$ Although my reading of the $B d p$ has left me with a different impression, it is quite unnecessary to subscribe to a discussion of such difficult and subjective terms as 'maturity', 'comprehensiveness' or 'systematisation', since our analysis has provided us now with much more powerful evidence. If we accept the antiquity of the $A k n$, the terminus ad quem for the $B d p$ is pushed back from $645 \mathrm{AD}$ (the date of Hsüan-tsang's translation) and 265-313 AD (the dating of the $L k d h$ 's first translation) to the final quarter of the second century $\mathrm{AD}$, the time when the $A k n$ is reported to have been translated into Chinese.

Such early date of the $B d p$ would in many ways accord much better with the rather ill-organised, inconsistent internal structure of the $B d p$ and account for the rudimentary depiction that it gives of the bodhisattva career. In particular, it would validate my mātrka-theory for the list of seventy-two kinds of learning that I proposed in my paper on the $A k n$ and $B d p$.

96. Lamotte, op. cit., pp. Ixxxvii; pp. 105, 197, 284.

97. Bagchi, 1927, pp. 43, 91 .

98. Alex Wayman (op. cit., pp. 211-214) has further enlisted the rather uncommon use of the name Sāradvatiputra for the usual Santiputra in support of the antiquity of the $A k n$.

99. E.g., Schuster, op. cit., pp. 48, 51 .

100. This argument is rather weak, since we know of several other early and important Buddhist works that came only relatively late to the attention of the Chinese translation teams. The Agama and Vinaya, for instance, were all translated at a very late date (Demiéville, L'Inde Classique, ii, pp. 418-419).

101. Schuster op. cit., pp. 48-51. 
Undoubtedly, enumerations of this kind were particularly susceptible to change and expansion immediately after their compilation when the ideas they epitomised were still fluctuating. This last point applies to the $B d p$ 's exposition as a whole. That is to say, the author of the $A k n$ would surely have shown greater restraint in modifying the wording of the $B d p$ had he seen it to embody an advanced account of the bodhisattva doctrine. It is tempting to deduce-if only by implication-that the $B d p$ stood more at the beginning of this evolution. Assuming that the length of the $B d p$ as it is preserved today reflects its original size, its exposition of the bodhisattva must have served as the foundation to many of the later bodhisattva treatises. I shall demonstrate in chapter four when exploring the practices and doctrines that this assumption is indeed borne out by the $B d p$ 's vision of the bodhisattva-ideal.

What is more, an early date of composition would also provide answers to a series of questions that, so far, have been resolved in an unsatisfactorily manner. It would account, for instance, for the references to a $B d p$ that are found in the $K p, U g$ and $V k n$-themselves amongst the earliest Mahāyāna texts. The physical format of the Bodhisattvapitaka they refer to is uncertain, but the fact that they associate it with the pāramitā, maitri and bodhipākșika dharma-all themes that are discussed at great length in the $B d p$-possibly indicates a references to some early, composite version of the $B d p$. We do not know what exactly happened to the individual component parts, but it is conveivable that at a later stage these were incorporated into the structures of the present $B d p$. As I shall show, its organisation of content and chapter divisions would certainly allow for this possibility. It would also explain Hsüan-tsang's selecting the $B d p$ out of over six hundred texts for immediate translation. He was no doubt aware of its importance to the formulation of the bodhisattva ideal and so decided not only to record the place when he obtained it, but also to give it priority over all other texts in his translation work. 


\section{The Mahāratnakūta Collection}

The Mahāratnakūta (hereafter Ratnakūta) collection comprises forty-nine sūtras of varying doctrinal orientation and literary affiliation. ${ }^{102}$ As a collection of Buddhist texts it is considered to be one of the most popular and important Mahāyāna works, along with the Buddhāvatamsaka and Prajñāpäramitā sütras. As for the date of its compilation there is a certain disagreement among modern scholars of Buddhism. The antiquity of many of the texts it contains, however, has been established beyond any doubt. The collection as it stands today has been preserved in Chinese and Tibetan translations with only a few texts extant in the original Hybrid Sanskrit and Middle Indo-Āryan Prakrit idiom.

The sütras included in the Ratnakūta cover a wide range of Buddhist thought. Most of its forty-nine texts share a common interest in the bodhisattva path. Indeed, it is argueable that this shared concern with the proper execution of the bodhisattva practices occasioned their inclusion into one collection. Although a certain thematic unity is provided by the incorporation of almost all basic Mahāyāna concepts, a tone of heterogeneity prevails. It is this very heterogeneous nature that may reveal the compiler's intention of presenting a cross-section of Mahāyāna thought. One is left with the impression of a deliberatedly arranged overview of Mahāyāna doctrines.

By the time of its initial compilation the principal Mahāyāna tenets were evidently wellestablished in most of the Buddhist communities of northern India. Yet, some of the (earlier) Ratnaküta texts seem to derive their religio-philosophical message from what might be called the phase of transition between the early strata of Buddhist thought (fundamentally based on the teachings of the historical Buddha) and those introduced in later centuries. In many instances these early teachings are skilfully incorporated into the Mahāyāna frame of reference, thereby producing sütras of great literary beauty.

The path and ideal of the bodhisattva are central to many of the works included in this collection. Some sütras are wholly dedicated to the new ideal and provide detailed instructions on the pattern by which an aspiring bodhisattva should pursue his spiritual training. Other

102 As a collection of texts it is also referred to as Ratnakūta, Mahāratnakūta, Mahāratnakūtasūtra, Mahāratnaküta-dharmaparyāya or Mahäratnaküta-dharmaparyāyaśatasahäsrikä-grantha (Stael-Holstein, 1926, pp. vii-x). 
texts integrate the teachings on the bodhisattva in an otherwise more philosophical exposition.

The lay and mendicant ideal are treated in a rather partisan fashion in a number of sütras. In many instances, the respective positions are put forward with great conviction. But judging by my own reading, both ideals are advocated with equal strength. On the one hand, some texts as our $B d p$ unequivocally propose a monastic, celibate environment as the only appropriate framework for the bodhisattvacaryā. On the other hand, there are numerous sütras that place the bodhisattva ideal firmly within the reach of non-celibate layfolk. ${ }^{103}$

The topical references to the bodhisattva path prompted several scholars to conclude with Friedrich Weller that "the ethics of the bodhisattva career is just what all the forty-nine texts of the Ratnakūta sütra have in common"104 or with Schuster, "that it is this (common element), above all, which binds them together and gives them a recognisable identity"105.

In India, the title 'Ratnaküta' was initially associated with the $K p$, a text that at present is included as $R k t$ 43. ${ }^{106}$ The question arises concerning the grounds and the circumstances by which this title came to be applied to the entire collection. Sthiramati, the author of one of the major commentaries on Ratnakūta works ${ }^{107}$ who is cited by both Bu-ston and Tāranātha offers the following explanation: "The title Ratnakutta was bestowed on the sütra because this Dharmaparyāya comprehends all the jewels of the Mahāyāna". Then, Sthiramati lists sixteen Mahāyāna 'jewels' or virtues, for example, right conduct, and points to their presence in the $K p$, calling it Ratnaküta. ${ }^{108}$ The $K p$, as the majority of other Ratnakūta texts, sets these virtues in the context of the bodhisattvacarya and so intrinsically relates them to the bodhisattva training. Similar lists are found in the $B d p, U g, R p$ and Bhadra-vy to mention only a few of the more well-known Ratnaküta works. In many instances, these lists are structured in such a

103. Among the texts that belong to this second category figure most prominently the Sms (Rkt 49), Ug (Rkt 19), Aśokadattāvyākarana (Rkț 32) and Gangottarapariprcchā (Rkț 31).

104. Weller, 1965, p. 19.

105. Schuster, op. cit., p. 36.

106. Chinese catalogues list another text that includes the title Ratnaküta in its name. It is called Ratnakūtasütra and was first translated into Chinese during the Eastern Han Dynasty in the second century $\mathrm{AD}$. In the Taishō Tripitaka it is listed under the name of Buddhasita-ratnakütasamädhi-mañjuśri-bodhisattvapariprcchä-dharmakäyasütra (T 356). It was retranslated at the beginning of the seventh century bearing the title Ratnakütasütra. Although it is not included among the forty-nine Ratnakūta works proper, it is nevertheless contained in the group of texts that the authors of the Taisho apparently considered to be related to the Ratnaküta (Lancaster, 1979, pp. 93-94).

107. He is accredited with the composition of a work that, in the Chinese translations, bears the name Mahäratnakütasūtra-śästra (Stael-Holstein, 1926, p. xv). The Tibetan tradition refers to it as Ārya-mahäratnakütadharmaparyāya-parivarta-śatasāhasrika-käśyapaparivarta-țikā (Schiefner, 1868, p. 131). Stael-Holstein has convincingly shown that this commentary refers only to $R k t+43$ and not to the whole collection (op. cit., pp. xiv-xv).

108. Stael-Holstein, op. cit., pp. 2-7. 
way as to form groups of tetrads. Just as in other, predominantly early, Buddhist writings these tetrads served as mnemonic devices to facilitate the memorisation and recitation of complex texts. In the Ratnaküta the frequency of their reccurrence and their typical association with the bodhisattvacarya $\bar{a}$ suggests that they became also guidelines for a wide range of practical training aspects. It is therefore likely that, as Schuster says, "the name Ratnaküta originally referred to the teaching of the bodhisattva conduct, epitomised in series of tetrads ... for the edification of all those dedicated to the bodhisattva career"109.

In order to convey some general idea of the principal doctrinal issues involved in the Ratnakutta texts, I have drawn up a tabulated list of the most salient points discussed in the collection. ${ }^{110}$ This survey is not intended to provide a comprehensive analysis of all the forty-nine texts included, but aims to show the major interests and themes that are common to many Ratnakūta sūtras.

Topics included in the content of the Ratnakūta literature:

1. Texts that discuss predominantly the nature, training and dangers associated with the lay-bodhisattva path: $R k t+16,18,19,24,27,28,29,30,31,32,33,36,38,45,47,48$.

2. Sütras that propound the monastic environment as the preferable setting for a bodhisattva's training: Rkt 1, 12, 17, 18, 19, 21, 23, 24, 25, 43, 44, 45, 49.

3. Sütras that focus in their discussion of the bodhisattva's training on the distinction between ordinary or worldly and transcendental morality: $R k t+3,18,19,38,41,45,47$, 49.

4. Discourses containing jātaka-type accounts and similar tales: $R k t 12,14,16,17,18,37$, 44.

5. Texts that include into their elaborations miraculous and magical elements such as charms or wonders: $R k t 3,18,21,38,43$.

109. Schuster, op. cit., p. 37.

110. I am indebted to Nancy Schuster for suggestion of this type of tabulation. 
6. Texts that elaborate on mythological buddha-fields and their buddhas: $R k t 1,2,5,6,13$, $14,15,18,47$.

7. Sütras that deal with caitya rituals, veneration of all buddhas or with vision of all buddhas: $R k t ! 1,12,15,18,19,24,25,38,43,44$.

8. Sütras propounding the ideal of the female bodhisattva: $R k t+30,31,32,33,40,48$,

In addition, there are several sütras that merit special attention because they contain important doctrinal discussions:

1. Trisamvaranirdeśaparivarta:

3. Tathägatācintyaguhyanirdeśa:

5. Sukhāvatīvyūha:

6. Akșobhyatathägatasyavyūha:

12. Bodhisattvapitaka:

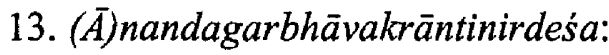

on the affliction of clinging to the belief in the reality of the self.

on self-sacrifice and the impermanence of the body.

on the resolves of the bodhisattva Dharmākara and the formation of his buddha-field.

on Akșobhya's buddha-field, (mental) dispositions required for rebirth there, on stūpa cult and on self-annihilation by one's own fire-element.

the chief bodhisattva text of the entire collection; famous for its treatment of pāramitā, jātaka accounts and āvenika dharma. 
on rebirth, pregnancy and the notion of garbha.

14. Āyuṣmannandagarbhävakrāntinirdeśa:

16. Pitāputrasamāgama:

17. Purnapariprcchā:

18. Rāṣtrapālaparipṛcchā:

19. Ugrapariprcchā:

21. Bhadramāyākäravyākarana:

24. Upālipariprcchā:

25. Adhyāśayasamcodanasūtra:

28. Viradattapariprcchā: on the virtues of meditation, the impermanence of the elements and the 'empty' nature of dharma.

on the cultivation of the bodhicitta, avaivartikacitta, kuśalamūla and abhijñāa.

on the virtues of the monastic (bodhisattva) path, self-sacrifice and aspirations to enlightenment.

on dāna as the foundation of the bodhisattva training, śünyatā, the virtues of grhapti bodhisattvas and caitya worship.

on magic as a vehicle for the upāya of the Buddha and as a valid means for facilitating the comprehension of doctrinal matters.

on serious misdeeds, the liturgy of the thirtyfive buddhas, the code of conduct for (grhapti) bodhisattvas and its disagreements with the code of conduct of śrāvaka.

on proper conduct for mendicant monks and recluses.

a meditation manual for the bodhisattva, contem- 
plation of the body and its vileness, (also known as Yogācārabhümisūtra).

41. Maitreyapariprcchādharmāsta:

43. Kāśyapaparivarta:

44. Ratnarāśisütra:

45. Akșayamatipariprechā:

46. Saptaśatikaprajñāpāramitā:

47. Ratnacūdapariprcchā:

48. Srīmālädevisimhanāia: on the eight 'profound' dharma which are to be realised if bodhi is to be attained; it also deals with the cult of Maitreya.

discussions of bodhisattva ethics, concepts of śūnyatā and āryagotra and bodhisattvacaryā.

elaborations on spirit and observance of monastic conduct, significance of the monastic robe and the spiritual benefits of forest life.

on the significance of proper and genuine motivation for giving, the ten stages of bodhisattva, meditation, dhāraṇi explanations.

a concise discussion on what is essentially prajñāpāramitā thought.

on the significance of mindfulness and the training thereof for both monks and layfollowers; it provides a detailed treatment of the bodhipākșika and pāramitā.

on the tathāgatagarbha doctrine, ekayāna doctrine, the (favourable) position of the lay spirituality in the Buddhist scheme of salvation. (Apparently one of the later sütras in the collection).

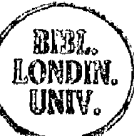




\section{The History of the Mahāratnakūta Collection}

On the whole, rather little is known about the history of the Ratnakūta collection. ${ }^{111}$ Keeping with Buddhist tradition, each of the forty-nine texts is attributed to the Buddha. A brief prologue (nidāna) of the circumstances accompanying the formulation of the discourses is provided in their respective introductory sections. Thirty-five of the forty-nine sütras are said to have been composed on either Mount Gṛhrakūtạ, near Rājagrha, or in the garden of Anāthapiṇạada, in the Jeta Grove in the vicinity of Srāvastī. Both locations are well known in Buddhist accounts and are frequently given as sites for the various sermons of the Buddha.

As for its original compiler, no reference is found in either the sütras themselves or in the Chinese and Tibetan commentarial literature that would point to any specific person. None of the forty-nine texts contains any cross-references to the other texts included except for the unresolved references to the Bdp. Both Chinese and Tibetan sources point to a later date of compilation. ${ }^{112}$ It seems probable that the Ratnaküta collection as it is known to us, represents a rather later development of Buddhist literary activity. Yet, despite the fact that its compilation may have taken place as late as the early eighth century $\mathrm{AD}$, many of the sütras it comprises are of considerable antiquity and belong to the earliest strata of Mahāyanna Buddhism. This is evidenced by the doctrinal orientation of the texts in question and the early date of many of

111. Considering the comprehensive nature of this collection and the antiquity of many of its texts it is rather surprising to discover how little scholarly attention it has so far attracted. Out of the total of forty-nine works only twelve have been the object of academic investigation. These are the Sukhävativyūha, Rāstrapālapariprcchā, Käśsapaparivarta, Saptaśatikaprajñäpäramitā, Ratnarāśs, VinayaviniścayaUpāliparip!cchā, Ugrapariprcchä, Srīmālādevisiṃhanāda, Upāyakauśalyaparivarta, Mañjuśrībuddhaksetragunavyūha and Bhadrakārāvyākarana. For details on the authorship, as well as the date and place of publication of the respective studies, see: Appendix iii. To date, the best discussion of the history of the Ratnaküta collection is found in: Schuster, 1976, pp. 1-42. Other useful material has been collected by Stanton-Pedersen (1980).

112. Otani bKah-hgyur Catalogue, p. 231, n. 1 (folio 123a), where we are told that the (Tibetan translation of the) Ratnakuta collection was compiled on the basis of Indian originals, complemented by Khotanese and Chinese sütras during the second half of the eighth century. In Taishō Daizōkyō (vol. 11, pp. 1b 20-2b 6; see: BTI, no. 28 , p. 6), the early eighth century AD is given as the date of compilation of its Chinese translation. 
their first Chinese translations.

The majority of sütras included in the Ratnaküta collection are designated, according to their Sanskrit titles, questions ( ariprcchā) or elucidations (nirdes'a). Thirty-four of the fortynine texts fall into these two categories. Of the remaining texts, six are called predictions (vyäkarana) or arrays (vyūha). ${ }^{113}$ Many of these texts are comparatively brief and resemble in structure the suttas of the Pãli nikāya. Often they are composed in a stereotyped questionand-answer format and lack the elaborations and grandeur of the more voluminous Mahāyāna vaipulya sūtras. The group of texts that contain the terms pariprcchā and nirdesa in their titles includes most of the sütras translated into Chinese during the second and third centuries AD. ${ }^{114}$

It is noteworthy that some of the works included in the Ratnakutta collection occur also as parts of other vaipulya sütras (in the Chinese canon) or, by virtue of their content, are incorporated into other sections of the Tripitaka. The Saptaśatikaprajñāpāramitā, for instance, is a prajñāpāramitā text that is also found in the Mahāprajñāpāramitā Section of the Chinese canon (T 232). ${ }^{115}$ A translation of the Ratnacüdapariprcchä (Rcd) is also included in the Mahāsamnipāta collection (T 397). Other texts, such as $R k t ̦ 1,23,24$, and 44 bear strong resemblance to Vinaya texts. So, too, $R k t 13$ and 14 exhibit close parallels to a section of the Mūlasarvāstivāda Vinaya. ${ }^{116}$

In the Taishō Tripitaka, the bulk of the forty-nine Ratnaküta sütras is followed by a large number of texts that were apparently considered to be closely related to the collection proper by Taishō compilers who base their opinions on older traditions (Ming, 1368-1644 AD). Among them are five translations of the Sukhāvatīvyüha (T 360-364), nine texts related to the themes found in the Sukhāvatīvyūha, such as the Smaller Sukhāvatīvyūha and the Amitāyurdhyāna (T 365-373), two translations of the Ratnakūta(samādhi)sütra (T 355, 356), three versions of the Sarvabuddhavișayāvatārasütra, as well as a few miscellaneous earlier translations of Ratnaküta works, such as the Akṣobhyatathāgatasyavyūha (T 313), Daśadharmakasūtra (T 314) and Mañjuśribuddhaksetragunavyūha. ${ }^{117}$ It therefore cannot be ruled out

113. Several of its titles contain references to well known personalities from the nikäya. The best known examples are Ugra and Rațhapāla $(R k t, 18,19)$. Others are addressed to figures who were among the very first converts of the Buddha at Vāränasīi $(R k t+17,26,33)$.

114. Bagchi, 1927, pp. 40-44, 86-114.

115. Lancaster, 1979, p. 7.

116. Lalou compares both versions with their corresponding passages found in the Vinaya section of the Tibetan Canon, noting divergencies between the three texts (Lalou, 1927, pp. 240-243).

117. Lancaster, 1979 , pp. 24-27 
that, at some stage, the collection may have comprised more, or at least different, sütras than those which are currently included.

The oldest (Chinese) translations of some of the Ratnakūta sütras, according to the Taishō index, date back to the later years of the Eastern Han Dynasty (202 BC-AD 220). ${ }^{118}$ They are the Sukhāvatīvyūha (Rkt 5), Akșobhyatathāgatasyavyūha (Rkț 6), Ug (Rkt 19), Maitreyapariprcchādharmāsța (Rkt 41) and Kp (Rkt 43). Records show that their translations were done between $\mathrm{AD} 150$ and $\mathrm{AD} 185 . R k t$ 6, 19 and 43 are attested as Han translations by the oldest surviving catalogue of the Chinese Buddhist canon, the Ch'u san tsang chi chi of Seng-yu (T 2145), written in $\mathrm{AD} 515 .{ }^{119}$ A further seventeen to nineteen sütras were rendered into Chinese between the fall of the Han (AD 220) and the fall of the Western Chin Dynasty in $\mathrm{AD} 317 .{ }^{120}$ Considering that three further sütras among those which had already been translated during the Han Dynasty were retranslated within one hundred years, there must have been a sizeable interest among early Chinese translators in several of the Ratnaküta texts. $^{121}$

One of the main protagonists in this early translation period was a monk called Dharmaraksa (AD 230-308). Born in Tun-huang of a Yueh-chih family, he was primarily active in Chang-an between AD 266 and 304. ${ }^{122}$ There, he translated at least thirteen Ratnaküta sütras. ${ }^{123}$ Dharmarakșa is not known to have travelled to India, but most of his translations are based on Sanskrit versions that he acquired in Central Asia. Although in the years following his death various translators continued to engage in the translation of Ratnakutta texts, there can be little doubt that in China the era of greatest interest in the collection was during Dharmarakșa's lifetime. During the fourth and fifth centuries interest in Ratnakūta texts must have waned as

For a complete list of these texts see the respective entries in Appendix iii.

118. Lancaster, 1979, pp. 27-34.

119. Schuster, op. cit., p. 4; Link, 1958, p. 18.

120. According to the Ch'u san tsang chi chi, the number is seventeen while the Taishō Daizōkyō lists nineteen texts whose earliest (Chinese) translations fall within this period (Lancaster, 1979, pp. 24-35).

121. The Sukhävatīyyühasütra was rendered into Chinese at least four more times, the Ug at least twice and the $K p$ once.

122. Dharmaraksa dominated the Buddhist communities of his time at Tun-huang and Chang-an. He is accredited with the translation of over one hundred and fifty Buddhist texts, with the foundation of monasteries and with the propagation of Mahāyāna thought. Although born and educated in Tun-huang, he spent most of his time at Chang-an, the Chinese capital of that period. He remained there at work with a great number of disciples until he was driven out shortly before his death by invasions and warfare at the beginning of the fourth century AD (Demiéville, L'Inde Classique, p. 414; Shih, 1968, pp. 33-37).

123. The Taishō Daizōkyō attributes the following sixteen Ratnaküta translations to Dharmarakșa while others accredit him only with thirteen: $R k t 3,4$ (?), 5 (?), 10, 13, 15, 19, 21, 30, 32, 33, 36, 37 (?), 38, 42 (?) and 47. Those marked with a question mark have been contested. For further details see: Renou, 1953, § 2074; Schuster, op. cit., p. 3, n. 14; Bagchi, 1927, pp. 83-114. 
only a few texts are known to have been translated in that period. In all, twenty-two Ratnaküta had been rendered into Chinese by the end of the fifth century. ${ }^{124}$ No doubt, the frequency of their translation allows for inferences to be drawn about the importance that was assigned to these sūtras during the centuries when Mahāyāna Buddhism made major inroads into Chinese society.

The earliest reference in the Chinese canon to a Ratnakutta collection consisting of forty-nine sütras dates back to the T'ang dynasty (AD 618-907). It gives an account of a South Indian Brahmin called Bodhiruci (AD 571-727) under whose supervision a team of translators edited and partly rendered the Ratnaküta into Chinese. ${ }^{125}$ On his arrival in China in AD 693 , Bodhiruci is said to have been in possession of the Sanskrit originals. ${ }^{126}$ These texts came to form the foundation of the collection as it is known to us. At first, however, Bodhiruci's assistance was sought by Sikșānanda who was then engaged in the translation of the Buddhāvatamsaka ( $\mathrm{AD}$ 695-698). Thus it was only in $\mathrm{AD} 706$ that Bodhiruci set to work on the Ratnakūta. Out of a total of forty-nine sütras Bodhiruci is accredited with the translation of twenty-six texts, apparently considering the remaining twenty-three (then extant) translations as being satisfactorily executed. ${ }^{127}$ The translations which he incorporated into his edition of the Ratnaküta had been translated by a total of fifteen scholars from different backgrounds over a period of more than four hundred years. ${ }^{128}$ Bodhiruci retranslated fifteen texts that had

124. The number of texts cited in the Taisho index is higher. It lists twenty-six Ratnakutta translations that were undertaken in the second to the fifth centuries. However, this list does not seem to take into consideration duplicate translations. We are told of six translations of the $U g$ to have been completed by ca. $\mathrm{AD} 425$, for instance, yet only three are extant and can be accounted for (Bagchi, 1927, p. 391).

125. The Ta pao chi ching (in the Taishō Shinshü Daizōkyō edition of the Chinese Tripitaka, ed. by J. Takakusu et al., no. 310 in vol. 11, p. 1a 1-659a 27) contains an Imperial preface (hsu) by Jui-tsung dated $\mathrm{AD} 713$ (p. 1a 1-b 19). It refers to a collection of forty-nine sütras called Pao chi pu (Ratnaküta section) which have been translated between $\mathrm{AD} 706$ and 713 by a team of translators led by a certain Bodhiruci (BTI, 28, pp. 5-6).

126. There is agreement among Buddhist scholars that by the time Bodhiruci arrived in China a Ratnakuta collection of some form must have been in existence in India. Wayman writes that "Bodhiruci, a native of South India, who arrived in China in AD 693 ... brought with him the Sanskrit text of the Ratnaküta collection of individual Mahāyāna sütras" (Wayman, 1974, p. 9).

Lü Ch'eng (1971) goes even further, stating that "Bodhiruci had brought to China a new (sic.) Sanskrit text of this [Ratnakūta] sütra" and that "he took advantage of the special structure of the Mahāratnakūta sūtra ... making suitable adjustments in compiling and translating it". Unfortunately, Lü Ch'eng does not document such an important statement by referring to his sources. In any event, he seems to be suggesting that on Bodhiruci's arrival in Loyang he was already in possession of a well-structured collection of forty-nine Sanskrit texts which he then improved and rendered into Chinese. He does not say whether at that time the collection already bore the name under which it came to be known or whether it differed significantly from Bodhiruci's edition. He also does not speak about the circumstances of its origin. See: Bagchi, 1938, pp. 541-543.

127. From among the already existing translations he selected the following works which included in his edition: $R k t, 1,2,3,4,8,9,12,14,15,16,17,18,19,23,26,32,33,36,38,39,46,47,44$.

128. For their names and biographical data, see my notes in Appendix iii. 
apparently been badly done or were incomplete, and rendered for the first time into Chinese eleven texts that had so far not been translated. Thus he cast the collection into the form in that it exists today. ${ }^{129} \mathrm{He}$ received the official request to engage in the translation of the Ratnakūta in AD 706 from the Emperor Chung-tsung. Supported by a team of assistant scholars of largely Indian origin, he was able to report on the completion of his task after seven years in $\mathrm{AD} 713$.

The Tibetan Buddhist tradition appears to have modelled its version(s) of the Ratnakūta collection on that of Bodhiruci. The overall arrangement in all Tibetan editions corresponds closely to the structure of the Chinese version. Several of the sütras included in the dKon-brtsegs (Ratnaküta) section appear to have been translated directly from the Chinese, thus giving further testimony to a close relationship between the Sino-Tibetan literary traditions. ${ }^{130}$ The vast majority of the Tibetan translations, however, are based on Sanskrit originals. Many of them had already been translated during the so called 'first diffusion' of the Buddhist faith in Tibet ( $\mathrm{AD}$ 641-838) and were revised and rearranged at a later date into a collection of forty-nine texts.

When we consider the number of sutras included in the various Tibetan editions of the Ratnaküta and their respective listing in the catalogues we find certain minor differences. The Ratnaküta version of sDe-dge edition seems to correspond most closely to the collection as compiled by Bodhiruci. It too lists forty-nine sütras and the sequence of the texts is identical with those of the Chinese Ratnaküta. The Peking and sNar-than editions, by contrast, contain irregularities. Although both of them comprise the forty-nine texts found in Bodhiruci's edition, they do not agree in their sequence. ${ }^{131}$

129. Bodhiruci's translation of the forty-ninth parivarta, the Rsivyasapariprcchā, breaks off abruptly shortly before the end. Roughly three hundred characters $(t z u)$ are missing (ref. Schuster). The missing passages are easily restored from an earlier, still surviving, translation of the text in question (T 354). The question, however, remains whether this omission is simply the result of (accidental) mishandling, or whether it reflects a sudden change of mood in the minds of the royal sponsors. Clearly, after $\mathrm{AD} 716$ the atmosphere at the court became more adverse to the translation efforts of possibly too ambitious monk-scholars. In $\mathrm{AD} 717$, for instance, Subhākarasimnha's request for royal support in his translation of Sanskrit Dhärañi texts was silently rejected by the emperor.

130. At least seven of the forty-nine texts had been transiated directly from the Chinese.

The sNar-than edition of the Tibetan Tripitaka refers to the Varmavyūhanirdes'a (Rkt 7), $(\bar{A})$ nandagarbh $\bar{a}-$ vakräntinirdeśa $(R k t, 13)$ and Därikävimalaśraddhäpariprccha $\bar{a}(R k t+40)$ to have been translated by Chos-grub (Fa-cheng) directly from the Chinese. Recent research has established that the Raśmisamantamuktanirdeśa (Rkt 11), Ayusmannandagarbhāvakrāntinirdeśa (Rkt 14), Pürnapariprchā (Rkt 17) and Vidyut(präpta)pariprcchā (Rkt 20) are also based on Chinese sources (Sakurabe, "Tibetto-yaku Dai-Hoshaku-kyo no Kenkyū", Otani Gakuho, 11, p. 550).

131. Six sütras are in particular affected: the $(\bar{A})$ nandagarbhāvakrāntinirdeśa (Rkt 13), Ayușmannanadagarbhävakrāntinirdeśa (Rkt 14), Pūrnapariprchā (Rkt 17), Rāṣtrapālapariprcchä (Rkt 18), Ratnarāśs (Rkț 44) and $A k$ sayamatipariprccha $(R k t+45)$. In both editions their position in the overall scheme of the collection 
Lalou pointed to three further documents that exhibit irregularities concerning the composition of the Tibetan Ratnakūta. ${ }^{132}$ First, there is the table of contents of the Peking bKah-hgyur which records only forty-four texts as belonging to the Ratnaküta. Second, there is a bKah-hgyur manuscript held in the Königlichen Bibliothek zu Berlin which cites only forty-seven sütras. ${ }^{133}$ Third, there is the catalogue of the 'Lhan-dkar collection' commissioned by Khri-gtsugs-ldebrtsan (815-838 AD). According to its table of contents, as preserved in the Peking edition, the Saptaśatikaprajñāpāramitā (Rkț 46) is not part of the Ratnakūta collection, but belongs to the Prajñāpāramitā Section. ${ }^{134}$ Despite such anomalies, the actual number of texts included in all editions of the Tibetan canon is forty-nine.

The history of the collection prior to Bodhiruci has not been subject to any systematic research. Uncertainty prevails with regard to the date, place and historical circumstances in which the Ratnakutta collection may have been shaped. The source material can be grouped into four major working categories. First, there is a sizeable body of Chinese translations of Indian Buddhist writings, including some indigenous exegical material. Second, there are Buddhist texts of Indian origin, usually in their original Hybrid Sanskrit idiom. Third, there are Tibetan translations of Sanskrit texts, commentarial and historical documents. Finally, there exists a small, but potentially significant, group of (fragmented) miscellaneous works of Khotanese, Singhalese and South Indian origin.

\section{Chinese Sources}

The earliest reference to a collection of sütras bearing the name Mahäratnaküta is contained in the Daśabhūmikavibhāṣāśāstra (Dbh-v), a commentarial work traditionally ascribed to Nāgārjuna. No Sanskrit or Tibetan versions of the text are known to exist. The only Chinese translation extant was done by Kumārajiva between $\mathrm{AD} 402$ and 415, entitled Shih chu p'i

differs. While in the sNar-than edition the $(\bar{A})$ nandagarbhāvakrāntinirdesa follows upon the Ayusmannanadagarbhāvakrāntinirdeśa, the Rästrapālapariprcchā upon the Pürnapariprchā and the Akșayamatipariprccha upon the Ratnaräsisisutra, the reverse order is found in the Peking edition.

132. Lalou, 1927, p. 237.

133. See: Hermann Beckh. "Verzeichnis der Tibetischen Handschriften". Die Handschriften-verzeichnisse der Königlichen Bibliothek zu Berlin, xxiv, 1914, pp. 16-25.

134. TTP, 127, fol. 352a-373a (item no. 25-72; ref. Lalou)

Lalou. "Les texts Bouddhiques au Temps du Roi Khri-sron-lde-bcan". JA, 241, 1953 , pp. 320-21. 
p'o sha lun. ${ }^{135}$ Here a reference is made to a chapter (hui) of the Ratnaküta, called Käśyapaparivarta. ${ }^{136}$ It also cites a text called Akșayamatipariprcchā as belonging to the same collection. Another reference to an Akșayamatipariprcchā as forming a part of a Ratnakūta is found in the Chinese rendering of the Mahāprajñäpäramitāśāstra (Mppś). ${ }^{137}$ Both works are contained in Bodhiruci's edition of the Ratnaküta collection, occupying the forty-third and forty-fifth position respectively. In addition, Japanese scholarship has shown that quotations in the $D b h-v$ from the $U g$ and the Vimaladattapariprccha correspond to texts contained in the Ratnaküta under the same names (Rkț 19 and $R k t+33$ respectively). ${ }^{138}$ Also, the twelfth sütra of the Ratnakutta, the $B d p$, is quoted in the $D b h-v$. All this suggests that Kumārajiva was aware of some Ratnakūta collection. Since both works were produced in Kucha, such a collection was probably available in Central Asia. If we allow some time for the process of transmission, this evidence suggests the existence of a Ratnaküta collection during the fourth century $\mathrm{AD}$. Yet very little can be said about its structure and content, except that it included the $K p$ and Aksayamatipariprcchä and possibly the $B d p, U g$ and Vimaladattapariprcch $\bar{a}^{139}$

135. T 1521.

136. This way of reference to the individual sütras of the Ratnaküta collection was subsequently adopted by Bodhiruci. In the place of sütra (ching), he employed the term hui meaning assembly (or section, chapter), probably because he perceived the individual sütras as forming a part in an overall scheme. This usage contrasts the terminology employed by the authors in the transiations of individual sutras executed in the preceding centuries. Here, as a rule, the term ching meaning sütra is applied. Indeed, Kumārajiva's rather unusual terminology could be taken to indicate that by the late fourth century $\mathrm{AD}$ some of the previously unassociated Ratnaküta sütras had become a part of an overall structure.

137. Mppś, pp. 1245, 1272, 1762.

138. Kajiyama, Y. 1968, p. 197; Hirakawa, A. 1963, p. 98.

139. In the light of its importance for illuminating the earliest known literary form of our collection a closer examination of the history of the $D b h-v$ (T 1526) seems appropriate. It has already been mentioned that its authorship was ascribed to Năgāijuna by Kumãrajīva. Modern scholarship has cast some doubts on its authenticity since the ideas put forward do not seem to correspond to those normally associated with Nāgārjuna.

This fact was for the first time highlighted in an influential article published by A. Hirakawa in 1957 (IBK $5,2, \mathrm{pp} .504 \mathrm{ff}$ ) where he challenges the claim of authenticy. Lamotte, on the other hand, holds the view that it has been composed by the founder of Madhyamaka thought (see: Lamotte, op. cit., p. xcvii). Ruegg, a well-known authority on Madhyamaka literature, takes a more cautious position by pointing to the need of further detailed research on this matter (see: Ruegg, 1982, p. 29, n. 67).

A number of Chinese sources clearly accredit this work to the founder of the Madhyamaka. In the Chinese translation of the Suvikrāntavikrämapariprcchä Prajñāpāramitāsütra, for instance, it is listed among the works attributed to Nāgārjuna (cf. Hikata, R., 1958, pp. lii, sq. Ixxii sq where it is mentioned along with the Mülamadhyamakakärikä, Ta-chi-tu-lun and Bodhisambhāraśästra). Chinese catalogues include it under the title of $P^{\prime} u$ sa hui kuo ching amongst the texts of Nāgarjuna allegedly translated by Dharmarakșa between AD 265 and 313 at Chang-an (Bagchi, 1927, i, p. 100).

Lamotte (op. cit., p. xcvii) points to passages in the Ch'u san tsang chi chi (T 2145, ch. 2, p. 8b 17), a commentarial work composed in the first half of the sixth century, and the Li tai san pao chi (T 2034, ch. 6, p. 63a 23) both of which note the translation and remark: "The colophon says that it is an extract from the Daśabhümikavibhășäsasstra of Nāgāriuna" (trsl. Lamotte). In any event, the fact that one of the translations of the $D b h-v$ is firmly accredited to Dharmaraksa highlights the possibility that it was extant as early as the third, or possibly the second century $\mathrm{AD}$. This suggests a new, as yet hypothetical, terminus ad quem for the existence of our collection. 
The first reference to the Ratnakutta as being established amongst the major Buddhist scriptures is found in the Li tai san pao chi. ${ }^{140}$ Here we read how the Gandharan translator Jñānagupta (arrival in Chang-an in $\mathrm{AD} 559$ ) relates that the following twelvefold division of Buddhist scriptures was established in the south-east of the country of Che-chu-chia (modern day Karghalik): the Mahāsamnipāta, Avatamsaka, Vaipulya, Ratnakūṭa, Lañkāvatāra, Lalitavistara, Sāriputradhāraṇi, Puṣpakūtadhāraṇī, Tuṣāragarbha, Mahāprajñāpāramitā, Prajñāpäramitā in eight sections and Mahämeghasütra. ${ }^{141}$ This division places the Ratnaküta (collection) alongside the titles of other well-known major works. Jñānagupta's account not only suggests a Ratnaküta collection in some form as early as the beginning of the sixth century, but also allows for inferences about its geographical area of circulation.

The first reference before the times of Bodhiruci that points to a Ratnakutta collection of considerable length and popularity is found in the biographies of Hsüan-tsang. ${ }^{142}$ On New Year's Day in AD 664, he is said to have been approached by a group of scholar-monks who requested him to translate the Ratnakutta collection. He declined on the grounds that the collection was as long as the voluminous Mahāprajñāpäramitāsūtra (T 220), whose translation he had just completed. At his advanced age he saw little prospects of mustering the strength required to complete such a formidable task. He eventually opened his manuscript after repeated appeals and began to translate a few lines, only to resign a few minutes later. ${ }^{143}$

Three conclusions can be drawn from this account. First, some forty years before Bodhiruci's

A major problem is the reliability of our sources when they comment on events which took place several centuries before their compilation. The Ch'u san tsang chi chi, composed between AD 502 and 557 by Seng-yu, writes about events which reportedly took place two hundred and fifty years earlier. This time-span is even greater in the case of the Li tai san pao chi which was compiled by Fei Ch'ang-fang in AD 597. See T 2154-537a:27 and T 2154-624:16 respectively (Lancaster, 1979, p. 366).

One cannot assert with certainty whether the version translated by Dharmarakșa in the third century AD was identical with that rendered into Chinese by Kumārajiva one hundred and fifty years later. As Lancaster says, Sanskrit manuscripts had the tendency to undergo considerable changes in the course of their history, reflecting doctrinal shifts in emphasis which mark all living religious traditions (Lancaster, 1975, pp. 32 ff.). Furthermore, Kumärajiva is known to have interpolated his translations frequently with his own thoughts without indicating such course of action (Hikata, 1958, pp. lii-ixxxiii; Link, 1961, p. 89; Lamotte, 1973, pp. 41-49). Therefore to conclude that the references contained in Kumārajīva's translation must have been included already in Dharmarakṣ's version lacks the desired foundation. Nevertheless, interesting possibilities are suggested.

140. T 2034 (ref. Stanton-Pedersen).

141. The titles of the texts have been conjectured from the Chinese sources by Stanton-Pedersen. Nanjio's catalogue contains a work called Śäriputradhāraṇi (N. 353). I have not been able to locate a Puspaküṭadhāraṇi or Tusāragarbha in any of the catalogues.

142. See: Waley, 1952, p. 126; Bagchi, 1927-38, ii, pp. 542-543. Stanton-Pedersen, 1980, p. 64, cites the following Chinese sources as containing the complete account: Ta-t'ang-ku-san-tsang-Hsüan-tsang-fashih-hsing-chuang (T 2052, vol. 50, p. 219a), and Ta-tz'u-en-ssu-san-tsang-fa-shih-ch'uan (T 2053 vol. 50, p. 276c).

143. See Ta-tz'u-en-ssu-san-tsang-fa-shih-ch'uan (T 2053, vol. 50, pp. 236a, 254a and 258a, ref. Schuster, op. cit., p. 22; cf. Mochizuki, 1954, pp. 3418a, 25b, 26). 
translation Chinese scholar-monks knew of the existence of the Ratnaküta collection of a length comparable to that of the Mahäprajñāpäramitāsūtra. This raises the possibility that by then it already comprised many of the texts presently included in the Ratnaküta. Second, the Ratnakūta must have had great renown. Otherwise would such a venerated but aged Tripitaka master have been selected for the task of translating it at a time when other capable translators were at hand? Third, Hsüan-tsang seems to have been in possession of some Sanskrit version of the Ratnakūta, presumably brought from India.

Unfortunately, neither Hsüan-tsang's biographers nor his Si-yu-ki mention the place where Hsüan-tsang might have procured the Ratnaküta texts. Only the acquisition of the $B d p$ is recorded. He received this text in the monastery of Shih-fei-to-pu-lo (Svetapura), located on the river Ganges some eighty to one hundred li south of Vaisāli. About the monastery and its inhabitants he reports that it was inhabited by Mahāyāna monks who paid close allegiance to the spirit and letter of both the Dharma and Vinaya. ${ }^{144}$

Of all six hundred and fifty works he brought home, the $B d p$ is one of the few texts that Hsüan-tsang gave details about the place and circumstances of its acquisition. It was also among the few texts that he chose to translate immediately on his return to China. Clearly, this suggests that he either held the $B d p$ personally in high esteem, or that it must have enjoyed great renown in India or, locally, in Śvetapura monastery. ${ }^{145}$

The texts that Hsüan-tsang brought from India but remained untranslated at his death (AD 664) were deposited in the Tzu-en temple in Chang-an. Their translation was held in abeyance after the master's death. If our sources are correct, a copy of the Ratnaküta collection, or at

144. Li Yung-hsi, 1959, p. 98 and Beal, 1981, pp. 75,76.

145. His travel account, commissioned by the Emperor, does not contain any indications that Hsüan-tsang was aware of the Bodhisattvapitaka as forming a part of an overall collection, although his knowledge of a collection of texts bearing the name Ratnaküta is recorded in his biography, in connection with his translation attempt in $\mathrm{AD} 664$, twenty years after his return from India. The time elapsed between these two events prompted Schuster to speak about the possibility whether "the compilation of the Ratnakuta in forty-nine sections might not have been accomplished in China between AD 645 and 664, by putting together forty-nine texts from among the six hundred odd which Hsüan-tsang had brought with him from India".

She concedes that this leaves us with several other problems. First, the collection's Chinese origin seems irreconcilable with the (Chinese) account of Bodhiruci bringing a complete copy of the Ratnakutta from India in $\mathrm{AD}$ 693. Second, how likely is it that Hsüan-tsang knew of the precise extent of Dharmarakșa's translation activity at Chang-an between AD 265 and 308? Without such knowledge he could have hardly matched up his selection with those thirteen Ratnaküta texts Dharmarakșa had rendered into Chinese four hundred years earlier and leave out those texts he could not correlate with the Indian manuscripts in his possession. Is it really conceivable that the scrupulous Hsüan-tsang, who went to such lengths in order to acquaint himself with genuine Indian Buddhism, conspired to create a new collection of sütras? Acceptance this theory means that one would have to discount the evidence provided by the Tibetan Buddhist tradition that points to an Indian origin of a (basic) Ratnaküta collection. I think that we can thus safely rule out the possibility of Hsüan-tsang's compilership of the Ratnaküț. 
least large parts of it, would have been kept in the Tzu-en temple from $665 \mathrm{AD}$ onwards. ${ }^{146}$ As I already observed, Chinese traditions maintain that on his arrival in China Hsüan-tsang had the entire collection in Sanskrit in his possession. However, no reference is made at any point to its structure or contents, nor are there indications of what happend to his Sanskrit collection after it had been deposited in the Tzu-en temple in our sources. If the Chinese traditions are correct, then by $\mathrm{AD}$ 630-644 (Hsüan-tsang's period of travel) there must have been in some part of India a literary tradition associated with the Ratnakutta collection, perhaps even as it stands today. Schuster says that Bodhiruci's biographer makes it sound as if he might have been requested to bring a full copy with him to the Chinese capital. ${ }^{147}$ If credence is to be given to this account, we may infer that by the late seventh-century Hsüan-tsang's Ratnakūta Sanskrit version was either not available to the court translators, or that it had never been a complete one.

\section{Indian Sources}

The other major category of sources relevant to our research are, of course, the texts belonging to the Indian Buddhist tradition. These consist in the following (fragmented) Sanskrit versions of Ratnakūṭa texts: Sukhāvatī vyūha (Rkț 5), Mañjuśrībuddhakṣetragunavyūha (Rkt 15), Rp (Rkț 18), Vinayaviniścaya-Upālipariprcchā (Rkț 24), Kp (Rkt 43), Ratnarāsisisütra $\left(R k t\right.$ 44) and Saptaśatikaprajñāpāramitā $(R k t+46)^{148}$. Since these works represent but a small fraction of the total body of the collection, by themselves they do not provide much ground to assess the manner of the collection's formation or its date of compilation.

Besides these seven works, a number of quotations of Ratnaküta works have been preserved in later Buddhist literature. Most of them are contained in the Siks and Msl. ${ }^{149}$ Other short

146. There are several other recorded cases where the scriptures of deceased Chinese scholar-travellers were deposited in local temples for safe-keeping. One such account tells of the texts that Wu-ching collected in India towards the end of the seventh century. After his death-he never reached his homeland as he died on the journey from Northern India - these were brought by his disciples to the Hua-yan temple. There, they were taken up in AD 716 by Subhakarasimpha for study. No such resumption of study of Hsüan-tsang's material is known to have taken place (Hodge. The Buddhist Forum. forthcoming, pp. 9-10).

147. Schuster, op. cit., p. 13.

148. Almost all of these texts have already been the object of detailed studies. For the authorship, date and place of publication, see Appendix iii.

149. Seventeen out of the total of forty-nine works are referred to by name and quoted in these two texts. No mentioning, however, is made by either Asanga or Śāntideva of them as belonging to any kind of a collection (Siks, p. 367-371; Msl, p. 165). 
quotations of Ratnakūta texts are contained in the Ratnagotravibhāga, ${ }^{150}$ in Prajñākaramati's commentary on the Bodhicaryāvatāra, ${ }^{151}$ in Candrakīti's Prasannapad $\bar{a}^{152}$ and in the Buddhagotraśāstra attributed to Vasubandhu. ${ }^{153}$ While these quotations are valuable from the philological point of view, they do not reveal any information on the history or structure of the collection as a whole. The exception to this is possibly the Siks. It contains a large number of quotations from the Ratnakūta taken from a total of fifteen texts. Although Santideva does not associate them with any overall collection, the mere fact that they are frequently referred to en bloc in doctrinally related contexts suggests that he was probably aware of their interconnection. However, we must conclude that the Ratnaküta was not widely known in India since he does not refer to them as being part of an established collection.

In the past there has been some confusion with regard to the origin of some of his quotations from the Ratnakutta. In seven instances the Siks says that they were taken from a work called Ratnaküta. ${ }^{154}$ Initially, this reference was taken to mean that Sāntideva was aware of a collection of that name on which he drew for canonical quotations. Baron von Stael-Holstein corrected this misunderstanding at the beginning of the twentieth century. He positively established that all quotations referred to by Sanntideva as belonging to the Ratnakūta were taken from a work which was known already to the Tibetan translators as the $K p^{155}$

Due to Santideva's way of referring to the $K p$, it is up to the present day that it is frequently referred to as the 'old Ratnaküta' ${ }^{156}$ Despite having given rise to some confusion, Sāntideva's usage of the title Ratnakuta throws light on the role played by the $K p$ in the history of the collection. Frequently, the $K p$ is taken to have formed the nucleus of the Ratnakuta collection.

150. The quotations contained in the Ratnagotravibhāga are primarily taken from the Sms. They have been collected, arranged in the order of their appearance and published by Ui, H. in Hoshoron kenkyu, 1959, Tokyo.

151. La Vallée Poussin, 1901-1914, pp. 147, 153-4, 526, 527.

152 La Vallée Poussin, 1913, pp. 53.7-54.4, 121.4-122.2, 155.1-12, 191.2-9, 234.10, 256.12-258.5, $348.14-349.2,408.10-409.6,429.4-430.4,474.7-10$.

153. Stanton-Pedersen, 1980, p. 62.

The text most frequently cited is here the $K p$. For an array of references to the $K p$ in Mahāyāna sources, see: $M p p s$ s, pp. $1845-6$.

154. See, for instance, Siks, pp. 54.11-14, 55.3-5. There we read: “... how this comes to pass is described in the Ratnakuta" or "the way to avoid the loss of the thought of enlightenment is still more clearly set forth in this same work, the Ratnaküta" (other references are found at pp. 52.12, 58.17, 146.4, 148.8, 196.11).

155. Stael-Holstein, 1926, p. xvi.

The Tibetan equivalent of the title Käśyapaparivarta is hphags pa hod sruns kyi lehu żes bya ba theg pa chen pohi mdo.

156. Japanese scholars, in particular, seem to favour this term. In Bodhiruci's edition, this work has been retitled Samantaprabhāsabodhisattvapariprcchā. Apparently this alteration was made in order to avoid confusion with the Mahäkäśyapasañitisimhanāda, Rkt 23 in the Ratnaküța collection. 
Sāntideva's mode of reference (also adapted by the $M s l$ ) seems to support such a view. Starting from such an assumption, the $K p$ would have become already at an early stage a kind of doctrino-literary 'flagship' of the entire collection. In fact, large sections of it give a well-balanced doctrinal cross-section of Ratnaküta thought. ${ }^{157}$ As a literary document it is undoubtedly worthy of the title Ratnaküta ('accumulation of jewels') ${ }^{158}$ A similar development seems to have occurred in other collections. One only needs to reflect on the role of the Asta among the many texts that comprise the Prajñāpāramitā literature. Chronologically, an early version of the $K p$ might well have been among the first texts to be included in the Ratnakuta as it was among the very first texts to be translated into Chinese. ${ }^{159}$

\section{Tibetan Sources}

Tibetan sources are of minor importance for research into the history of the Ratnaküta. Although the meticulously executed translations of the forty-nine sütras are invaluable for determining the respective doctrinal positions, they yield little relevant data on the historical processes that shaped the collection as a whole.

Of far greater interest are the accounts composed by the Tibetan historians Bu-ston and Tāranātha. In his Chos-ḩbyun, Bu-ston observes that though the Ratnakūta consisted originally of one hundred thousand chapters, only forty-nine were still extant at his time. ${ }^{160}$ Since he makes similar remarks on almost all other major Mahāyāna scriptures, claiming that in their present form they represent only a fraction of their 'original' size, caution should be exercised about the historical value of his statement. It seems likely that the motivation behind his statement was a pious wish to exalt Buddhist scriptural heritage rather than scholarly exactitude.

Bu-ston and Tāranātha's descriptions of the circumstances in which the 'one hundred thousand books' came to be known are of greater significance. The books are said to have first appeared at the time of the Third Buddhist Council organised by King Kanișka at around

157. See, in particular, $K p$, pp. 50-68, 92-100.

158. In the Aśokāvadāna, we read of an island called Ratnakūta. The location of this place is of course not known. According to this legend it is reached via the Magadha port of Tāmralipti (Przyluski, 1923, p. 104).

159. Stael-Holstein, 1926, p. iii; Tao-hsüan (Ta t'ang nei tien lu, T 2149-223c: 18) according to whom it was first translated in $\mathrm{AD} 179$ by Lokaksema.

160. Obermiller, 1931-32, p. 169 (ref. Schuster). 
AD 100 in Kashmir. ${ }^{161}$ The same sources inform us that the diminution of the collection to its present forty-nine texts took place in the years between the life-times of Matrceta (second century $\mathrm{AD}$ ) and Asanga (AD 290-350) "in a period when Buddhism endured a general decline in northern India". So far I have not been able to locate any third-party accounts which would confirm these details. Bu-ston and Tāranātha do not cite their sources. Existing archeological evidence and historical accounts contain little to indicate that there was a general decline in the fortunes of the Sangha during the second and fourth centuries. ${ }^{162}$ And yet, if credence is given to their reports, one would have to place the origin of our collection in India, in the early centuries $\mathrm{AD}$.

Elsewhere in the same source Bu-ston relates that "this teacher (Sthiramati) has studied the Ratnaküta up to the forty-ninth chapter and composed a commentary on it." ${ }^{163}$ A similar statement is contained in Tāranātha's account. ${ }^{164}$ The commentary in question has been preserved in both the Tibetan and Chinese Buddhist traditions. ${ }^{165}$ Frauwallner, in his brilliant article "Landmarks in the History of Indian Logic", places the dates of Sthiramati between $\mathrm{AD} 510$ and $570 .{ }^{166} \mathrm{Japanese}$ scholars have suggested even earlier dates, setting his period of activity between $\mathrm{AD} 470$ and $550 .^{167}$ Apparently, we have here a reference that places the dates of an Indian version of our collection as early as the fifth century AD.

Again, a more cautious approach seems to be in order if we consider the following factors. First, as mentioned above, when Sthiramati and other Indian Buddhists mention or quote from the Ratnakutta they usually refer to the $K p$. Second, the compilers of the $M v y$ appear to have been unaware of a collection of texts called Ratnaküta. Although they enumerate as independent sütras fourteen of the texts contained in Bodhiruci's edition, they do not mention them as being part of a collection. ${ }^{168}$ Third, the catalogue of the sDe-dge edition of the Tibetan Tripitaka explicitly states that the Ratnaküta collection, consisting of forty-nine

161. Obermiller, 1931-32, pp. 169, 170; Schiefner, 1868, pp. 63, 98 .

162. La Vallée Poussin. Dynasties et Histoire de l'Inde depuis Kanishka jusquax invasions musulmanes. Paris: 1935, pp. 7-71. Renou; Filliozat. L'Inde Classique. i, pp. 237-256.

163. Obermiller, 1931-32, ii, p. 148.

164. Schiefner, 1868, p. 130 .

165. Chinese: (T 1523), translated by Bodhiruci (the younger) between AD 508 and 535; Tibetan: TTP 5510.

166. WZKSO, 5, 1961, pp. 136-137.

167. WZKSO, 1968-69, pp. 194-199.

168. Mvy 1355 (Rkt 3), 1330 (12), 1381 (15), 1333 (16), 1361 (18), 1396 (19), 1393 (26), 1407 (28), 1394 (37), $1364(43), 1400(45), 1391(46), 1363(47), 1392(49)$.

In the Mvy, a work called Ratnakutta is listed in position thirty-nine (Mvy 1364). There is, however, no evidence indicating that the authors may have associated this sütra with our collection. 
works, was compiled by putting together sütras from India, China and Khotan. ${ }^{169}$ It seems that both Bu-ston and Tãranātha formulated their statements about the Ratnakūta on the grounds of a misinterpretation of Sthiramati's usage of the term Ratnaküta.

The majority of Tibetan texts included in the Ratnakūta were translated during the first half of the ninth century. They were translated by translation teams that often comprised Sanskrit scholars from India, Bactria and Tibet working together, using Indian manuscripts. Apparently they did not hesitate to consult Central Asian or even Chinese copies of the text in questions in the event of doubt. ${ }^{170}$

Many of these scholars participated also in the compilation of the $M v y$. Written prior to the translation-work proper, the $M v y$ does not contain a complete list of the sütras that, in due course, came to form the bKah-hgyur. Among the sütra titles included there is a long list of works that form part of the present Ratnaküta collection. Interestingly, there appears to be far reaching agreement between the list contained in the $M v y$ and those found in the Indian Buddhist Sanskrit literature of the eighth century AD. In the Siks, for instance, we find thirteen of the fifteen Ratnaküta works that occur in the $M v y \cdot{ }^{171}$ Of these thirteen, eleven are also mentioned by Bu-ston in his Chos-hbyun, ten of which appear also in the Mvy.

A great number of texts common to both the Siks and $M v y$ are also found among the Tibetan documents of Tun-huang. Altogether, these manuscripts contain twenty fragments of Ratnakūța sütras. In a few instances, entire texts have been preserved while in others little more than a brief citation or a reference in the colophon is extant. ${ }^{172}$ Ten of these texts concur with those quoted by Sāntideva while six accord with the Ratnakūta sütras enumerated in the $M v y$. The selection of the texts itself does not seem to reflect a premeditated choice. And again, there is no evidence to indicate that this group of nineteen texts was conceived of as a

169. Otani bKah-hgyur Catalogue, p. 231, n. 1, folio 123a; (ref. Kajiyama).

170. Ch'en, 1946, pp. $53 \mathrm{ff}$.

171. Sāntideva quotes from the following eighteen texts: $R k t+3,9,12(?), 15,16,18,19,24,25,28,29,37,38$, 43, 44, 45, 47, 48. See also Candrakirti's Prasannapadā which refers to seven Ratnakūta works: $R k t$ 3, 16, $24,25,43,45$, and 47 (Vallée-Poussin, 1903-1913). Note that all of these seven texts are also among those quoted by Săntideva.

172. References to following Ratnakūta sūtras are contained in the various collections the Tibetan manuscripts from Tun-huang:

Amitāyurvyūhanirdeśa (Rkț 5), Dharmadhätuprakrtyasambhedanirdeśa (Rkṭ 8), Daśadharmakasūtra (Rkt 9), Raśmisamantamuktanirdeśa (Rkț 11), Bdp (Rkṭ 12), Hymn addressed to Pūrna (Rkṭ 17?), Rāṣtrapālapariprcchā (Rkt 18), Mahäpratihäryanirdeśa (Rkț 22), Maitreyasimhanãda (Rkț 23), VinayaviniścayaUpālipariprcchā (Rkt 24), Adhyāsyasa mcodana (Rkt 25), Viradattagrhapatipariprcchā (Rkț 28), Sumatidārikāpariprcchā (Rkł 30), Gangottarapariprcchā (Rkt 31), Simhapariprcchā (Rkț 37), Maitreyapariprcchā (Rkt 42), Kp (Rkt 43), Ratnaräśsisūtra (Rkt 44), Ratnacūdpariprcchä (Rkt 47) and a certain text called Mahäratnakütasütra which may be a reference to the $K p(R k t 43)$. For their respective listing see: Lalou, M. Fonts Pelliot Tibetain, Paris, 1927, and La Vallée Poussin, Oxford, 1962. 
part of a greater collection or even to represent some cross-section of the latter. Since it is not possible to establish the exact period in which these documents were deposited in the Tun-huang caves, few chronological inferences can be drawn. ${ }^{173}$ Nonetheless, judging by the large number of references found to Ratnaküta sütras in its materials, it is clear that the Ratnakūta must have been a popular collection in Central Asia.

Considering that Sāntideva's list itself comprises only eighteen Ratnakūta citations, the degree of concordance with those of the $M v y$ and the Tun-huang material is very high. In none of these three source categories is there any explicit reference to a greater collection of which these texts might have formed a part. Therefore we may infer the existence of fluctuating, but commonly accepted, sütra lists in circulation in Northern India during the eighth and ninth centuries $\mathrm{AD} .{ }^{174}$ In due course, these were transmitted to the Buddhist circles of Central Asia and perhaps played a role in the formation of the Tibetan Tripitaka. ${ }^{175}$

The earliest inventory of the Tibetan canon dates back to the beginning of the ninth century. Known as the catalogue of the 'Lhan-dkar collection' commissioned by Khri-gtsugslde-brtsan, it speaks of a Ratnaküta consisting of forty-eight texts. The exact circumstances in which this inventory was compiled are obscure, though it seems certain that it was drawn up as part of the conversion efforts by the royal family to establish Buddhism in Tibet. The authenticity of the Lhan-dkar listing is well established. Lalou has shown that the dating and bibliographical details (e.g., names of translators, locations, etc.) correspond to what we know from other sources about the initial translation activity in Tibet. ${ }^{176}$

The authors of this catalogue carefully distinguish between translations that were done from the Sanskrit originals and those based on Chinese versions. Of the forty-eight Ratnakuta

173. There is no conclusive evidence when the caves themselves were sealed. Pelliot suggested that this may have taken place during the first half of the eleventh century while Uray proposed a date as early as 1002 $\mathrm{AD}$. Tibetan literary activity itself appears to have diminished in the Tun-huang area in the first half of the ninth century (Rona-tas, Acta Orientalia Hungarica, 21, pp. 381-3).

174. Considering that Buddhist scholars from Central Asia and Bactria frequently participated in these translation teams, one cannot exclude the possibility that such lists might have even existed in Central Asian Buddhist circles other than those of Tun-huang. So far, however, I have not been able to trace any evidence which would support this thought.

175. Even if we accept this compilation mechanism, several question remain unanswered. Why, for instance, did the Tibetan compilers of the $h K a h-h g y u r$ adopt the Chinese model of the Ratnakut $a$ and, at the same time, fail to grant equal treatment to the Mahassamnipāta? The first attested reference to the compilation of the Mahäsammipäta in its present format goes back to $\mathrm{AD} 594$. Given the popularity of this collection in China, the fact that more than two hundred years separated this date from the first wave of organised translation activity in Tibet and the adoption of the Ratnakutta format, one would expect to find this collection also in the hKah-hgyur. This, however, is not the case although all of its texts are included on an individual basis in the 'Sütra Section'. On the compilation of the Mahäsamnipäta, see: L'Inde Classique, ii, pp. 437-438.

176. Lalou, 1953, pp. 315-16. 
translations listed in this catalogue not a single text is identified as going back to Chinese translations. This indicates that the seven Chinese-based Ratnakutta translations we possess today were composed at a later date. Either the early Sanskrit-based translations had vanished during the years of civil strife or they were too poorly executed to warrant inclusion in the manuscript collections of the thirteenth century. Apart from the omission of the Saptasatikaprajñāpäramitā, the contents and structure of the Lhan-dkar Ratnaküta collection agrees closely with Bodhiruci's edition. Thus, the earliest period for which we can affirm the existence of an almost complete Tibetan version of the Ratnaküta collection is the first half of the ninth century $\mathrm{AD}$.

It is worth noting that this period coincides with the epoch in which a cautious revival of Sino-Tibetan relations after the signing of the peace treaty in 821/23 AD took place. This chronological concurrence is perhaps yet another factor in favour of our hypothesis that the formation of the Tibetan Ratnaküta was based on, or at least influenced by, Chinese editions. For, there can be little doubt that the political rapproachment which took place in that period between China and Tibet was accompanied, if not preceded, by a renewal of contacts in the cultural sphere. For even during years of bitter enmity cultural contacts with Tibet's most powerful neighbour never appear to have been totally severed.

\section{Miscellaneous Sources}

The texts that comprise our fourth category of sources belong to a number of apparently unrelated literary traditions. Sthaviravāda sources, for instance, associate a certain Ratnaküța (whether the sütra or the collection is uncertain) with Buddhist schools prevalent in South India. ${ }^{177}$. The Nikāyasamgraha, a fourteenth-century text of the Singhalese tradition on the history of Buddhism in India and Sri Lanka, speaks of three classes of non-orthodox literature that, after their origin in India, were brought at a later stage to Sri Lanka. ${ }^{178}$ These texts, it says, were doctrinally close to the Vaitulya and Väjiriya schools and included works embodying the 'sciences' such as the Ratnaküța. The same source relates that Ratnakütaśästras were composed in the Andhaka schools (along with the Ratthapälagajjita which may have been

177. Adikāram, E.W. 1946, p. 99 ff.

178. Nikāyasamgraha: composed by Devarakșita (Dharmakïrti). Ed. by de Silva, A.; Gunasekera; Gunawardhana, Sri Lanka Government Press, 1907. Trsl. by Fernando, Sri Lanka, Govt. Press, 1908. 
the doctrinal predecessor of the $R p, R k t 18$ in Bodhiruci's edition). ${ }^{179}$

The oldest surviving manuscript fragments of the entire Ratnaküta collection have been preserved in a Khotanese document. It is a manuscript discovered in the Khotan area at the beginning of the twentieth century by group of Japanese scholars. Fragments of it were identified and published by Kuno Horyū in $1938 .{ }^{180}$ They contain passages of the $K p$ which correspond to sections of the ninth-century Sanskrit manuscript edited by Stael-Holstein one decade earlier. ${ }^{181}$ It is assumed to have been composed sometime between the third and fifth century $\mathrm{AD} .^{182}$

Finally, I should mention a number of early South Indian inscriptions that are indirectly relevant for the study of Ratnaküta literature. They are found chiefly at the celebrated Buddhist sites of Amarāvatī and Nāgārjunikoṇụa in the Āndhra country. As Wayman has shown in his study of the Śrimālädevisimhanäda, many of these inscriptions are of importance since they allow us to infer the historical context in which the texts appeared. ${ }^{183}$ For the $S m s$, they allowed him to pinpoint the period and location of its origin with some precision to South India of the third century. By implication, many of Wayman's findings on the Sms might be equally applicable to Ratnakūta sütras of similar orientation, most notably Aśokadattāvyākarana and Vimaladattapariprech $\bar{a}$ which show close affinity in contents and setting.

179. Nikāyasamgraha, $1907, \mathrm{pp} .8 \mathrm{ff}$.

180. Bukkyo Kenkyū, iii, 2, 1938, pp. 1-40.

181. Stael-Holstein's manuscript, damaged and some pages missing, was discovered in the 1890's in Khotan and purchased by the Russian consul at Kashgar. To the present day it is kept in the State Library of the Leningrad Academy of Sciences. See: Mirnov, N.D. : Catalogue of Indian Manuscripts At Leningrad, Catalogi Musei Asiatici, i, St. Petersburg, 1914 (chapter xi, p. 333).

182. Another Ratnaküta text of which early fragments have been discovered in Central Asia is the Ratnaräsi. Published by Hoernle in 1916 it has been tentatively dated to the fifth to sixth century AD (op. cit., p. xii-xxxi). Finally, there are a number of references to Ratnaküta sütras in the Book of Zambasta (Emmerick, 1968). These are the Bhadra-vy (p. 10), Vup (p. 189) and again the $K p$ (p. 139). In one fragment, well over twenty pages long, Maitreya appears as main-protagonist alongside the Buddha (pp. 53-76). Although not positively identified, we have of course several texts in the Ratnakut $t a$ that seem to have been inspired by the cult of Maitreya ( $R k t .23,40,41)$. While all of these postdate the $K p$ and Ratnarāsi fragments by approximately four centuries, they are testimony to the Ratnakutta's enduring popularity in Central Asia. It is difficult to determine just exactly for how long this popularity lasted. It is striking, however, that in the same source the Ratnaküta does not figure in a section that gives three of the four major sütra collections of the day, that is, the Prajñäpāramitā, Buddhāvatamsaka and Mahāsamnipāta (p. 187). This seems to suggest that it was more the individual sūtras of the Ratnakutta and not the collection itself which enjoyed popularity in Central Asia.

183. Wayman, A. 1974 , pp. 1-16.

In his study on the $\$ m s$ ( $R k t$ 48), Wayman utilises archaeological evidence discovered at these sites to place the date of composition of the $S m s$ tentatively within the İksavāku rule of the third century AD. He then cites inscriptions of the second and third centuries $\mathrm{AD}$ that have been found at the same locations. They indicate the presence of the Pūrvaśaila and Uttarasaila, two late sub-sects of the Mahāsanghika school, and that of the Mahāsanghika sub-sect called Caitya from which they issued. These data and doctrinal parallels found in the $M v u$ a text of the Mahāsanghika-Lokottaravāda, prompted him to associate the $\hat{S} m s$ with the Mahāsanghika school of the third century AD (Wayman, 1974, p. 3). 


\section{Conclusion}

In the light of the available information and the wealth of its documentation, a few concluding observations seem appropriate.

The Ratnakuta collection as it stands today was edited at the beginning of the eighth century in China by Bodhiruci, a South Indian Tripitaka master. In addition to compiling the collection, he participated significantly in the translation of the texts. Before Bodhiruci the history of the collection is rather obscure, though there is evidence to suggest that it must have existed in a similar form some fifty years earlier. At that time it was esteemed by scholars as an important collection which enjoyed considerable prestige.

Little can be said that is conclusive about the earliest phases in the formation of the 'original' collection. It seems certain that the Ratnakūta was shaped in India. There is evidence that suggests that already from very early on (perhaps because of similarity in contents) certain Mahāyāna texts came to be informally grouped together. This group, which may have comprised as many as twenty or more sütras, was rendered into Chinese in the third century by Dharmarakșa. Sañntideva and other Buddhist writers of later centuries called on them as scriptural authorities. It is probable that by the time Hsüan-tsang visited India in the seventh century $\mathrm{AD}$ they had already assumed the shape of a formal collection entitled Mahäratnaküta. However, owing to the fact that Sāntideva, Candrakirti and Asanga seem unaware of it, one suspects that, in its earliest phase, the collection had been restricted to some local tradition.

A number of sources point to South India, during the early centuries of our era, as the cultural context in which the Ratnaküta may have been originally compiled. However, little sound evidence has been uncovered to support such a view. Several texts that are currently included in our collection appear to have been of South Indian origin, and Bodhiruci, the person who played a major role in shaping the collection as it stands today, was a native of this area. Yet, no source apart perhaps from the relatively late Nikāyasamgraha actually confirms South India as the place of its compilation. The fact that Hsüan-tsang acquired the Bodhisattvapitaka in northern India would seem to suggest that the Ratnakūta collection had gained some wider circulation by the first half of the seventh century. Similarly, no evidence has as yet been produced that would associate the formation of the Ratnakuta with any specific personality. By the time Bodhiruci received the request for translating the Ratnaküta 
sütras, its overall structure had probably already been determined.

The South Indian origin of several of the texts included in the Ratnakutta and their doctrinal affinity to what appears to have been early Mahāsanghika thought, point perhaps to some connection between the Ratnaküta sütras and the Āndhra schools. ${ }^{184}$ The $R p$, for instance, appears originally to have been part of the literary tradition of these early South Indian schools. ${ }^{185}$

The earliest references to a collection of sütras bearing the name Mahäratnakūta are found in Chinese translations of Indo-Buddhist commentarial literature. There is a certain disagreement among modern scholars with regard to the authenticity of their Indian originals. In any event, their Chinese translations of the early fifth century $\mathrm{AD}$ contain several references to a Ratnakutta collection, consisting of at least five works from among those currently included. The bulk of the first translations were executed between the second and third centuries in Chinese Central Asia, suggesting that the Ratnaküta was an apparently well-known body of scriptures possibly as early as the third century AD. In this event, it would have been among the first Buddhist texts to have reached Central Asia and China, thus forming a part of the earliest cross-cultural expansion of Buddhist thought. Manuscript remains of early Ratnaküta texts found in the Khotan area support such a view.

Undoubtedly, the corpus of Ratnakūta sütras enjoyed particular popularity in Central Asian regions. Not only has its oldest surviving manuscript been rediscovered in Central Asia but Chinese sources emphatically point to its wide circulation among Central Asian Buddhist communities.

The forty-nine sütras comprising the Ratnakūta literature cover practically the complete spectrum of (early) Mahāyāna thought. The impression gained is that the collection may have been compiled as part of an early conversion activity, with the aim to provide a well-balanced cross-section of Buddhist thought. Such a motive for its compilation would account for the almost complete absence of evidence on the formation and existence of an Indian Ratnaküta collection. If this is the case it would strengthen its ties with those Central Asian areas where

184. The following five sects are usually listed as the principal schools of 'Āndhra Buddhism': the Caitika (an offshoot of the Bahuśrut ìya), the Pürva Śaila, the Apara Śaila, the Rajagirika and the Siddhārthika. These are reported to have originated during the reign of Sātavāhana Emperor Meghasvāti (or -svādi) in the first century $\mathrm{BC}(H I B$, p. 310$)$.

185. Warder suggests, that "as to their (i.e., the Andhra schools') literary expression, some of the early (short) Mahāyāna sūtras long afterwards collected in the 'Great' Ratnakūta group may have been taken over from the Ändhra schools". However, he goes on to concede that in many instances these may have been modified in ways that would be hard to trace (Warder, 1980, p. 329). 
the earliest traces of the Ratnaküta literature have been discovered.

Doctrinally, large sections of the Ratnaküta are dominated by expositions on the path and ideal of the bodhisattva. Particular emphasis is laid on the cultivation and actual implementation of the practices that mark his spiritual progress. While the philosophy of sünyatä has evoked immense attraction among generations of scholars and intellectuals, it was the teachings about the bodhisattva that made the Mahāyāna successful as a religion across Asia. Not only could it easily win admiration, but being adjustable to an infinite variety of human circumstances the bodhisattva doctrine could also be taken as the basis for immediate action. As a central component of Mahāyāna spirituality, the bodhisattva concept was therefore an integral part and corner stone of all missionary activity. Naturally, one would expect this doctrine to play a major role in a corpus of texts apparently compiled with the intention of serving as both the spiritual inspiration and doctrinal authority in such a conversion process. 


\section{Chapter Two}

\section{Analysis of the Bodhisattvapitaka}

The $B d p$ is the twelfth of forty-nine texts included in the Ratnaküta. As already shown, the exact historical circumstances in which the Ratnaküta sütras were first collected are difficult to determine. From the viewpoint of historical analysis, we can only assume that it was compiled in the middle of the first millennium $\mathrm{AD}$. Due to the lack of independent evidence the place of compilation and the motive for their being assembled remains uncertain.

Since external evidence is unsatisfactory and scarce, I propose to shift the focus of attention to the material that is included in the Ratnaküta sütras themselves. Thereafter, we should be able to identify the rationale behind the Ratnakutta's structure and learn something about the interconnections holding its sütras together. Our evaluation, though not exhaustive, will furnish us with sufficient data to gain a clear idea of the principal concerns expressed in the Ratnaküta, and particularly of its vision of the bodhisattva.

The most suitable starting-point for the analysis of the bodhisattva ideal is undoubtedly the $B d p$ itself. Not only it is the sole text in the collection entirely devoted to the bodhisattva by title and in content, but it is also the longest of the forty-nine texts, containing the most comprehensive treatment of bodhisattva training. While other Ratnakūta sütras discuss the bodhisattvacary $\bar{a}$, none of them goes to such lengths in listing its principles and setting out how they should be implemented.

Because of the special position held by the $B d p$ in the Ratnaküta collection, I propose to begin with a structural analysis of its contents. The main-objective is to establish the framework in which the bodhisattvacary $\bar{a}$ is mapped out and to uncover the literary expedients that are employed to that end.

Structural and Literary Traits

The structure of the $B d p$ is lucid in its overall presentation, but somewhat obscured by the disagreement in its translations on the number and scope of the chapters. In Hsüan-tsang's 
seventh-century translation (T 310.12) the contents of the $B d p$ is divided into twelve chapters, each of which forms a logical, in substance well-delineated discussion of the assigned practices. ${ }^{1}$ This contrasts with the ninth-century Tibetan (P 760.12) and eleventh-century Sung (T 316) translations, both of which contain only eleven chapters. For no good reason they merge chapters eleven and twelve, making the prajñäpāramitā chapter final and leaving Hsüan-tsang's last chapter without a title. ${ }^{2}$

Without a Sanskrit original, there is no immediate explanation for this, since Hsüan-tsang's more coherent lay-out is overshadowed by the Tibetan and Sung translations. On closer examination of the content and colophons of the individual chapters it becomes clear, however, that it is the twelvefold chapter division of Hsüan-tsang's translation that has the soundest claim to originality.

To begin with, in Hsüan-tsang's translation the contents of each chapter clearly mark in discrete sections identifiable aspects of the bodhisattva training. All major practices are given individual treatment and assigned to separate chapters. In all but the last chapter this pattern is also adhered to in the Tibetan and Sung translations. Here, the controversial final chapter inappropriately combines a lengthy, partially philosophical exposition of the Perfection of Wisdom, several sets of bodhisattva practices, a brief description of the means of conversion and a detailed account of Śākyamuni's prediction of enlightenment. Such disarrangement of topics runs in marked contrast with the otherwise strictly observed thematic division. ${ }^{3}$

Furthermore, the merging of topics is inconsistent with the path profile that is given at the beginning of chapter five. ${ }^{4}$ We learn here that a discourse on the bodhisattva training should comprise three successive areas of practice, that is, the pursuit of maitri (presumably standing for the four immeasurables ${ }^{5}$ ), practice of the pāramitā and the cultivation of the samgrahavastu. In view of the importance of this thematic outline (it is the only of its kind in the whole text),

1. Hirakawa, A., "Bosatsuzo-kyo to Hojakukuyo", $S K$, 45-2, 209, 1971, pp. 1-26; Ono Gemmyo, Bussho Kaisetsu Daijiten, Tokyo (Daito Shuppansha) 1933-36 (ref. Pedersen).

2. R, folio 695.1

For a comparison of Hsuan-tsang's translation and Dharmarakșa's eleventh-century Sung version, see: Pedersen, 1976, pp. 15-23.

3. There is, however, one line of reasoning that might explain the merging of the prajñäpäramitā and samgrahavastu sections. According to the Bbh (p. 213.4-7), the samgrahavastu form a part of the training in prajñāpāramitā. Assuming that this proposition gained acceptance in Indian Buddhist circles (but I have found no other sources that hold this view) it could possibly account for the fusion of the two chapters in the later manuscripts on which the Tibetan and Sung are based.

4. R, folio $264.5-6$.

5. In the Yogācārabhūmi of Sangharakșa the apramāna are actually equated with maitrï-bhävanā (Demiéville, 1951, pp. 359-363). 
it is surely uncharacteristic that the text should not have been structured into the separation of practices by chapters, especially since even practices of lesser significance have been conscieniously kept apart. ${ }^{6}$

Taking these organisational traits into account, it is improbable that the discrepancies that distinguish Hsüan-tsang's well-structured version from the convoluted Tibetan and Sung renderings are due to negligence on part of the translators. Rather, the relative proximity in date of the latter two translations and their shared structural details suggest that they may derive from a later, possibly corrupted, Sanskrit manuscript of a different reading. ${ }^{7}$ On the basis of these thoughts, I therefore propose to adopt Hsüan-tsang's division into twelve chapters as the original design of the $B d p$.

The length of the twelve chapters varies considerably, ranging between fifteen and one hundred and sixty folios. Broadly speaking, we can differentiate three categories.

First, there is a group of short chapters each of which consists of no more than twenty folios. The subject matter that is included in these chapters is treated very succinctly. They are generally free from lengthy narratives or strings of examples and are reasonably easy to grasp. Chapters two, three, five, six and eight belong to this category.

Second, there are three chapters of moderate length, averaging fifty folios each. These are chapter one, ten and twelve. Their style is less concise than that of the first category and some recourse is taken to narratives and stereotyped literary expressions. Nevertheless, their contents are easy to follow and undue digressions are kept to a minimum.

Finally, there are four chapters of well over one hundred folios, namely, chapters four, seven, nine and eleven. The unmethodical arrangement of contents of some of these chapters obscures the otherwise unconvoluted exposition of the $B d p$. Individual discussions are spread over many pages filled with examples, peripheral digressions and lengthy narrations so that

6. See, for instance, $\mathrm{R}$, folio $671.4-679.6$

Matters are further complicated by the disagreement that exists between the Tibetan and Sung translations. While Tibetan translations lack chapter headings for the sections on the Perfection of Wisdom, means of conversion and Śākyamuni's prediction (but nevertheless refer to a twelfth chapter at the very end of the discourse proper ( $R$, folio 737.5)), the Sung translation treats the discussion of the Perfection of Wisdom as a separate, fully identified chapter. Yet, like the Tibetan it does not assign a chapter title to the section on the means of conversion and Sākyamuni's prediction.

7. We find similar parallels in contents between the Tibetan and Sung translations of the $K p$. Here too, it is the Tibetan and the tenth-century Sung versions that correspond most closely among all extant versions (see: Weller, 1965, pp. 8-9). 
thematico-logical connections tend to vanish in the wealth of material. ${ }^{8}$ Moreover, their expositions repeatedly fail to match the outlines of contents, leaving the reader confused over the direction of the discourse. ${ }^{9}$ Disorder and inconsistency increase in relation to the length of the chapters.

From the literary viewpoint, all twelve chapters are reasonably homogeneous and share many characteristics. All chapters, except for one, contain both prose and verse sections. ${ }^{10}$ The verse portions are regularly incorporated in the prose to summarise or restate in poetic form the issues previously raised. Also, verses are frequently (though not invariably) employed in direct speech, especially when it is addressed to the Buddha. The verse metre most frequently employed consists of seven syllables per line. This is followed closely by a metre consisting of nine syllables per line. ${ }^{11}$ While these two types of metre are generally kept apart in distinct verse clusters, they do intermingle in some rare instances. ${ }^{12}$

The prose sections of the $B d p$ are dominated by a rather rambling narrative style. In the most common pattern of exposition the Buddha discourses on a selected theme in response to a brief question posed by the interlocutor. In the course of his discourse the Buddha switches freely between the first and third persons indicative singular, assuming the role of persons appearing in the narrative portions. Since the concise dialogue-format characterising the majority of Ratnakūta texts is found only in some isolated places, there are very few passages that contain well-defined and succinct statements. The narrative style with its wealth of examples tends to interfere with the flow of conceptual links between individual topics.

In some chapters, this situation is redressed by the incorporation of sets of mnemonic-type lists summarising the bodhisattva's practices. The most frequent numerical configuration is that of tetrads followed by lists of tens and fives. All lists appear regularly in clusters, making up larger groupings and often provide the back-bone for the exposition. In chapters six and seven, for instance, lists of bodhisattva ethics stand at the very heart of the discussion and these constitute practically the only section dealing with the proclaimed theme. ${ }^{13}$ In the

8. This applies, in particular, to chapter seven and nine. In chapter nine see, for instance, the portion of the text that describes the exploits of the two brothers, Samvara and Samvarasthiti ( $R$, folio 486.2-513.6).

9. Compare, for instance, the heading that is given in chapter eleven ( $R$, folio 615.6-616.1) with the actual contents of the subsequent exposition ( $R$, folio 616.2-685.5).

10. The only chapter that has no verse section is chapter five ( $R$, folio 262.1-284.5). Chapter eight contains only one short cluster of verses ( $R$, folio 413.4-414.3).

11. For a discussion of the verse metre in Tibetan translations of Buddhist texts see: Michael Hahn, 1971, pp. 50-65 and 1985, pp. 201-206.

12. See, $R$, folio 381.5-382.7; folio 493.7-495.1; folio 497.2-498.2.

13. In chapter six: $R$, folio $286.6-292.5$; in chapter seven: $R$, folio 368.6-371.6. 
longer chapters, they have the additional function of providing the framework in which the exposition unfolds. In view of the $B d p$ 's length, such lists become valuable structural expedients for breaking up the contents.

A common feature is that the internal chapter organisation is poorly systematised. While there is every indication that the overall structure of the $B d p$ follows a well thought-out plan, no obvious outline is followed in the chapters themselves. In the shorter chapters this lack of systematisation has less importance. Elsewhere, however, it challenges the reader's ability to absorb and link the individual points of argument.

This situation arises from two factors. First, the issues that are raised in the discussions are poorly linked. This is especially evident in the longer chapters where sets of practices are only peripherally related and lack logical connection. Chapter nine, for example, though nominally on the perfection of vigour, deals with a broad spectrum of issues many of which have little direct bearing on virya. ${ }^{14}$ This is further aggravated by the extensive use of examples and parables. Again, most of these are found in the longer chapters, particularly in the ninth. While it is of course true that the extensive use of stock-phrases, picturesque language and many examples forms an integral part of the Indian literary heritage generally, there are only a few texts where they dominate the exposition to such an extent as in the $B d p$.

The factor chiefly accountable for this internal intricacy is the frequency of references to jātaka-type stories. ${ }^{15}$ In all, we can distinguish fourteen samples of jātaka stories. Most of these are found in chapter nine. There are no jătaka references anywhere before chapter five - this is interesting because it is in this chapter that the instructions on the bodhisattvacarya begin. ${ }^{16}$ All the following chapters with the exception of ten and eleven contain references to the previous lives of the Buddha. ${ }^{17}$ It is important to note that they are generally used to

14. In other chapters the situation is not very different. In chapter seven we meet with indiscriminately arranged descriptions of the bodhisattva's moral conduct in the form of listed norms of conduct. Since the style in which these attainments is presented is predominantly descriptive and non-technical, I conclude that, apart from their primary task of defining the scope and nature of the bodhisattva training, their function was to serve as inspiration and to encourage others to take up the bodhisattva training.

15. A summarised account of the various rebirths of Säkyamuni in the $B d p$ is contained in Bu-ston's Chos $h b y u \dot{n}$ (Obermiller, 1931-32, i, p. 125).

16. Compare this point of departure for the jätaka with the account that is given in the $M v u$ where we are told that jātaka related to the Buddha do not go back further than the eighth stage (Sénart, 1882, p. 105.6-14).

17. The following references are given in the $B d p$ to previous buddhas: 1 . Mahāskandha ( $R$, folio 262.5$) ; 2$. Kuhanachanda (hchos mos?) ( $R$, folio 295.5); 3. Prasamgraha ( $R$, folio 297.4); 4. Varasambhāra ( $R$, folio 379.2); 5. Sālaräja (R, folio 385.4); 6. Vipaśyin ( $R$, folio 448.1); 7. Abhyudgataräja (R, folio 486.3); 8 . Uttaptaviryata ( $R$, folio 504.5); 9. Sucarita ( $R$, folio 508.2); 10. Dipamkara ( $R$, folio 519.5); 11. Padmottara $(\mathrm{R}$, folio 539.3); 12. Ratnagarbha ( $\mathrm{R}$, folio 542.6); 13. Atyuccagāminin ( $R$, folio 546.7); 14. Mahāvīrya ( $R$, folio 549.3). 
illustrate a particular aspect of the teaching, rather than to retell the events of his lives. ${ }^{18}$ Nor is the Buddha always the main-protagonist in these stories. Frequently, the impression one gains is that recourse to jätaka-type settings was solely taken to lay down some historical frame of reference.

From a structural viewpoint their incorporation enhances the overall coherence of the exposition. They furnish the discourse with a temporal framework since all jātaka references appear in strict chronological order. ${ }^{19}$ As a result, the treatment of the bodhisattvacary $\bar{a}$ receives a sense a continuity and even dynamic purpose matching the Buddha's career as a graded progress across his previous existences. ${ }^{20}$ The narrative framework and graphic style of presentation also simplifies the lines of argument. Many sections of the text are given an unmistakably descriptive flavour in which abstract thought-patterns are kept to a minimum.

\section{The Bodhisattva Path}

Having dwelt on the literary character of the $B d p$, I now propose to look at the thematic structures by which the bodhisattvacarya is explained. In the foregoing section I pointed to the loose internal organisation that prevails in most of the $B d p$ 's chapters. The impression prevails that the individual practices serve to exemplify a greater scheme. The contribution of the jätaka-type narratives to this 'sense' of coherence has already been mentioned. There are also more important factors in play and I shall turn to these next.

The most powerful device for achieving the effect of continuity is without doubt the adoption of the traditional sequence of the päramitā. Practically all treatises on the bodhisattva from early on have incorporated this scheme into their visions of the path so that it became soon accepted as the fundamental structure of the training. ${ }^{21}$ The training scheme of the $B d p$

18. The exception is the account of Sajkyamuni's prediction to buddhahood at the end of chapter tweive (R, folio 698.7-735.3) that seemingly serves no other purpose than to retell the actual event in full.

19. Much of the course of Sākyamuni's career is traced in the $B d p$, starting in his legendary encounter as Prince Caritavirya with the Buddha Mahäskandha and ending with his prediction to buddhahood by Dipamkara. Also the references that are drawn to events between those two cornerstones purport to follow the chronological order of their occurrence. This can be deduced from the cosmic dates that are assigned to the periods in which the events are placed. For references, see the passages in which the various buddhas are introduced.

20. It is important to bear in mind that this impression rests largely on factors that are associated with the historico-temporal plane. Except in chapter eleven, no such continuation is evident, although later treatises on the bodhisattva propose certain models of internal, conceptual continuation for the individual practices raised in the $B d p$. I have discussed these schemes in chapter four.

21. The sixfold training structure is already attested in the $A$ sta (pp. $163 \mathrm{ff} ; 292-93 ; 310,322 ; 412-13$ ) and $V k n$ 
is thus cast in the mould of a well-established pattern; the traditional order of the perfections is kept and they are dealt with in individual chapters.

Apart from following the päramitā sequence, we have other hints that point to the implementation of a particular overall plan. First, there are several passages in the text itself that outline the order in which the bodhisattva training should proceed. The most important is found in a section belonging to chapter five that sets out the description of the path as follows: ${ }^{22}$

"O lord, what is the path to enlightenment? O Prince, the path to enlightenment comprises benevolence towards all sentient beings, striving after the perfections and compliance with the means of conversion. This is the path to enlightenment."

The order in which the practices are cited in this passage corresponds to the order in which they appear in chapters five to twelve of the $B d p$. Other references suggesting a successive conceptual interconnection between the individual perfections are given in chapters seven and eight. $^{23}$

It is hence apparent that the text is not moulded in such a way as to depict the bodhisattva career on the scheme of the ten stages. ${ }^{24}$ An explanation for this might be that the $B d p$ predated the formulation of the tenfold design. ${ }^{25}$ Other scholars have suggested that because of some geopolitical isolation at the time of its composition, the author was not aware of the

(pp. 17-18, 29, 96-7, 108, 130, 157, 167, 216, 240, 259). But, in neither of these two works has it been implemented or does it become the guiding principle for the organisation of the bodhisattva training. Rather, it is only referred to in passing without having any significant impact on the structure of the exposition. Considering the very early date of both texts, this is perhaps not surprising. Other early works that give greater importance to the structural role of the six perfections in the organisation of the bodhisattvacary $\bar{a}$ are the $A k n$ (pp. 42.3.1-55.2.7) and $R c d$ (pp. 231.4.7-236.2.7).

22. $\mathrm{R}$, folio $264.4-5$

The description of the training proper ends on folio 698.7 , just before the account of Sākyamuni's prediction to buddhahood begins. Thus, we note the following training structure: (1) cultivation of the apramāna (chapter five); (2) pursuit of the șadpäramitā (chapter six to eleven); 3. practice of the samgrahavastu (first part of chapter twelve). This path scheme occurs also on folio 582.6-584.4 where it includes the bodhipākșika dharma, samatha and vipaśyna that dominate much of chapter eleven.

23. $\mathrm{R}$, folio $302.2-7$; folio 408.3 ; folio $409.7-410.2$.

24. In his Chos-hbyun (Obermiller, 1931, i, p. 125), Bu-ston suggests correlating chapters six to twelve of the $B d p$ to the first seven stages of the $D b h$ scheme. While it is not difficult to see why Bu-ston chose to draw these parallels (chapter six deals with dänapäramitā, hence stage one; chapter seven with śilapāramitā, hence stage two, etc., up to chapter twelve devoted to prajñāpāramitāa), it is important to note that this proposition is purely conjectural and not supported by the text itself. The $B d p$ contains no reference that would suggest that its exposition of the bodhisattva training follows the tenfold scheme of the $D b h$, or indeed any other linear order.

25. Wayman, 1980, p. 218. 
existence of such a scheme. Today we can discount both hypotheses since I have found several instances in the text itself where explicit reference is made to the tenfold scheme. ${ }^{26}$ But this does not resolve our problem. We still do not know why our text favoured the basic scheme of the six perfections over the ten stages, especially since indications are that the ten gained rapid acceptance in Mahāyāna circles. ${ }^{27}$

The best explanation for the present is that at the time of the $B d p$ 's composition the tenfold scheme had not yet won universal approval. This might indicate that the acceptance of the ten stages might not have been as swift as generally assumed. In fact, there are several other early Mahāyāna works that refer to the tenfold scheme in passing but do not implement it in their description of the bodhisattvacarya $\bar{a}$. There must have been for quite some time a substantial faction within the Sangha unconvinced of its merits. If we interpret the growing circulation of the $D b h$ as a sign of the increasing acceptance of the scheme, it was probably not until the second/third century that this indecision was resolved. ${ }^{28}$ The fact that the $B d p$ refers to the tenfold scheme on two occasions and even distinguishes the scope of the individual stages places its date of composition in the period that immediately preceded the formulation of the tenfold plan. ${ }^{29}$ At any earlier time the $B d p$ would have been unfamiliar

26. The relevant passages on the bodhisattva stages run as follows:

"The bodhisattva who abides on the eighth, ninth or tenth stage, this bodhisattva is of great wisdom. He dwells on the great stage (mahäbhümi)" ( $\mathrm{R}$, folio 123.3-4).

"When he has acquired these three states (viz., the state of Cakravartin, Indra and Brahmā), he accomplishes the ten stages of the bodhisattva" (R, folio 294.1).

27. The earliest reference to the ten stages of the bodhisattva that can be dated with some degree of certainty goes back to $188 \mathrm{AD}$. It is found in the appendix to a sütra called $P^{\prime} u$ sa nei hsi liu po lo mi ching 'Sūtra on the Bodhisattva's inner Practice of the six Perfections' (T 778) which was rendered into Chinese by Yen Fo-T'iau of the Eastern Han Dynasty (Rahder, 1929, p. 15) After that, the scheme gained prominence quickly and it became the major scheme to grade the bodhisattva's spiritual progress. Early references to the tenfold scheme are found in the $M v u$ (pp. 63-157) and $D b h$ (Daśa-bh, pp. i-xxvii, pp. 11-99). At a later stage, it was incorporated into the works of the Prajñāpāramitā literatute, most notably in the Pañca (pp. 225, 379); while it is not found in the Asta itself, it is also mentioned in the Ssp (pp. 1454-73) and in the Aștadaśasāh (T 220 ch. 490-91, pp. 490b-497b; ref. Rahder). A similar, though not identical scheme is put forward in the $G v$ (pp. 369-374). In the fourth century, it was adopted and refined in the $B b h$ (pp. 367-371). Finally, in the seventh century, it was taken up again by Candrakītti in his Madhyamakāvatāra, where it serves as the structural framework for the exposition of the bodhisattvacarya.

28. The first Chinese translation of the $D b h$ was carried out in $297 \mathrm{AD}$. Beyond that, we have no firm evidence about the period in which it might have been written. Modern scholarship has come up with a variety of dates for its composition. The earliest dating (by Conze) suggests a date as early as $100 \mathrm{AD}$. Rahder thinks to have identified certain sections of the Dbh in the Tathagatavisesanasütra (N 102); a text whose first translation goes back to 147-168 AD (Rahder, 1926, p. xxi). Other scholars have been less daring, allocating it to the late second or early third century. Whichever the precise date of composition, its doctrinal position indicates that it must have emerged some time after the $V k n$ and before the compilation of the Yogäcärabhūmi.

29. If we accept the logic behind this argument, we would have to place the composition of the $B d p$ at the latest in the middle, or perhaps at the end, of the third century. However, since the earliest attested reference to the ten stages is already found in a work of the second century, it cannot be ruled out that the $B d p$ 's date of composition might also go back to the second century. The latter estimate would match the date that was proposed by Wayman for the $B d p$. He allocated its origin to 'around $100 \mathrm{AD}$ ' (Wayman, 1991, p. 9). 
with its structures, but at a later if it was not contemporary with it, it would have adopted them.

\section{Chapter Organisation}

In order to give an overview of the material included in the $B d p$, I shall provide at this point a synopsis of the principal issues being raised. Since the content of the practices is discussed separately in chapter four, I limit myself here to the structures that underlie their presentation.

Chapter one essentially provides an introduction to Buddhist spirituality. Convinced of the vanity of conventional ways of perception, the Buddha identifies the principal failings of worldly existence and discourses on the illusory and conditioned frames of reference in which life takes place. ${ }^{30}$ After the portrayal of reality the Buddha states the fundamentals of Buddhist doctrine by pronouncing a series of definitions of key terms, such as renunciation, knowledge and liberation. ${ }^{31}$ The chapter concludes with a brief sermon on the three root evils.

Chapter two opens with the prediction to buddhahood of the yaksa Kumbhira. He is the chief deity at the location where the Buddha is about to preach, and so entrusted with the setting. ${ }^{32} \mathrm{Next}$, there follows a picturesque account of the local scenery of the preaching site and the preparations that precede the Buddha's arrival. From the doctrinal point of view, this chapter is the least interesting. We learn practically nothing about the bodhisattva's training or the doctrinal context in which it is pursued. Like chapter one, its main concern is to introduce the reader to the Buddha's discourse.

Chapter three introduces the main topic of the $B d p$. It begins with a string of questions on the conditions and circumstances in which bodhisattvas attain supreme enlightenment. What follows next is essentially a characterisation of the thought of enlightenment (bodhicitta) and an evaluation of its intent (ásaya). ${ }^{33}$ As in chapter one, so also in this chapter the exposition

30. $\mathrm{R}$, folio 13.7-51.2.

31. $\mathrm{R}$, folio $51.5-56.2$.

32. The only other reference I have found to the yakșa Kumbhira is located in the Mahäsamājasütra. Here too, he is said to abide in the city of Rajāgrha on the Vipula mountain and to be in control of many thousands of yakșa. No more information is given (Waldschmidt in: Bechert, 1980, pp. 154, 162). See also: D II, pp. 253-62 for the Palli version of this text.

33. $\mathrm{R}$, folio $82.2-87.3$. 
concludes in a brief independently conceived discourse on a set of Buddhist fundamentals. Here, however, it is more in harmony with Mahāyāna thinking, spelling out its interpretation of impermanence, suffering, non-self and nirvāna.

Chapter four, entitled 'On the Inconceivable Nature of the Tathāgata', is entirely taken up with a description of the buddha-qualities. Structurally, it is the best systematised chapter, since it utilises the highly stylised mode of enumeration in which the buddha-qualities are traditionally presented. The description itself is exhaustive by all standards, detailing the Tathāgata's pristine cognition, morality and meditation, his physical perfection, wonderworking powers, tenfold powers, four assurances, compassion, enlightenment and the eighteen exclusive buddha-qualities. ${ }^{34}$

Structurally, this chapter is important in three ways. First, it lays down the foundation for the successful completion of the bodhisattva training, that is, faith in the nature and powers of the Tathāgata. Indeed, in the passage immediately following this chapter we learn that it is only after the bodhisattva has generated this faith that he qualifies to embark on the path. ${ }^{35}$ Second, it is important since buddhahood constitutes the ultimate goal of every bodhisattva's aspiration. In this respect, a description of the Tathāgata's qualities and powers must surely have been expected to have an inspiring, reassuring and strengthen impact on the bodhisattva's resolve while advancing on the path. Third, bearing in mind that tathägatahood constitutes the fulfilment of the bodhisattva training, the Buddha might have thought it advantageous to define its scope and attributes as a benchmark for all other spiritual achievements. In this role, chapter four serves to set out the goal-post for the bodhisattvacaryā.

With the end of chapter four we have come to an important break in the contents of the $B d p$. So far, all we have learned about the bodhisattvacarya $\bar{a}$ has revolved around preparatory exploits. In chapter five, we are introduced to the training proper. This is placed in the context of a jātaka narrative and also spelled out independently. This correspondence lends a personal note to the exposition and contrasts with the rather formal, detached tone of later

34. The impression of systematisation is reinforced by the fact that the whole chapter (which is the longest of the entire work) is organised into ten sections or limbs, each spelling out one of the ten Tathägata-qualities. The sequence runs as follows: (1) body (folio 100.7); (2) roar (folio 106.3); (3) pristine cognition (folio 110.1 ); (4) radiance (116.6); (5) moral conduct and meditation (folio 123.5); (6) wonder-working powers (folio 136.2); (7) ten powers (folio 143.7); (8) four assurances (folio 196.7); (9) great compassion (folio 215.4); (11) eighteen exclusive buddha-qualities (folio 235.1).

35. $\mathrm{R}$, folio $262.1-5$

In chapter three a similar idea is expressed, postulating faith as a paramount prerequisite for the spiritual advance of bodhisattvas in general ( $R$, folio 86.3-88.4). 
works on the bodhisattva. Since the jätaka reference is the first of its kind it establishes a connection between the teaching and the Buddha's personal spiritual advance. Both topics run parallel from now on and become progressively inseparable.

The common point of departure and thematic concurrence between the bodhisattva and jätaka underlines the significance of jätaka references, for there could be no better illustration of the bodhisattvacary $\bar{a}$ than the Buddha's own past spiritual experience. Such linkage not only gives authority to the discourse, but also highlights the role played by the jätaka-genre in the formulation of the bodhisattva doctrine. ${ }^{36}$ In view of this connection, it is not surprising that training phases are nowhere mentioned. Since schemes of the path do not figure in the jātaka themselves, it makes sense that the accounts of the bodhisattvacarya $\bar{a}$ that are modelled on the path of the historical Buddha should forgo these structural expedients. Following the opening passage, laying down the major areas of practice, the training proper begins with a discussion of the four immeasurables. Structurally, this section is of little interest since it presents the apramāna in a standard fashion and does not define their role in the general pattern of practice. Chapter five is thus a section that may demonstrate internally few intriguing structural features, but nonetheless is extremely important from the viewpoint of the overall composition.

Examination of chapter six reveals two points of structural significance. First, it formally initiates the discussion of the perfections and accordingly represents the first limb of the main body of the $B d p$ 's exposition. ${ }^{37}$ Judging by the length of the various chapters, one would assume that the treatment of the perfections varies greatly in detail. This impression is misleading, since the space that is actually given to the pāramita is not always in proportion to the total length of the chapters. This is particularly true of chapter nine, that includes a wide range of practices that are only indirectly related to the pursuit of virya. If one were to

36. Today, there is widespread agreement among scholars that the roots of the bodhisattva doctrine go back to the earliest strands of Buddhist thought. In particular, the jätaka have been the focal-point of several investigations. To quote Warder $(1983$, p. 9) on this matter: "It would seem that between these stray references in the jătaka and Theragatha and the full-fledged enumeration in the Buddhavamsa the doctrine (of the perfections) had been systematised as the 'principles which make the Buddha' (buddhakara dhamma, $B v$, ii.116)." Elsewhere, he argues that "this intrusive note (on pre-Mahāyāna practice) only strengthens the impression that the Theravada tradition on the perfections of the bodhisattva developed independently of Mahāyāna very likely from a common and pre-Mahāyāna origin in the jătaka tradition of the third century BC" (op. cit., p. 18). In the nikāya, these early doctrinal predecessors are particularly evident in the jätaka accounts of Sākyamuni's previous lives. But there are also other early works that contain isolated traces of the bodhisattva doctrine. Besides the well-known expositions of the Buddhavamsa and Cariyapitaka, a good picture of these early notions on the bodhisattva is found in the Nidānakatha $\bar{a}$, the introduction to the jātaka commentary (i, pp.16-25, 45-7, 74).

37. $\mathrm{R}$, folio 285.1 . 
purge it of all secondary issues, the relevant material would amount to little more than a third of its original length.

Another prominent feature of chapter six is that it introduces summaries of bodhisattva practices in the form of mnemonic-type lists. While lists of various types occurred already in earlier portions of the $B d p$ (most notably in chapters one and four ${ }^{38}$ ), it is only in this chapter that they assume the mnemonic, stereotypical character. ${ }^{39}$ The lists themselves occur rarely in isolation, but tend to appear in clusters forming larger groups. ${ }^{40}$ Usually neither the order in which their items are enumerated nor the succession of the lists displays any particularly thought-out pattern of arrangement. Hence, the scope and items of the lists overlap at several points with factors cited elsewhere. ${ }^{41}$

The custom of tabulating individual practices figures prominently in chapter seven. At one stage tetrads make up a section of well over twenty folios. ${ }^{42}$ By reason of the frequency with which enumerations recur, the impression is given that the entire exposition of chapter seven is founded on these lists. Although this is clearly not the case (there are numerous sections which dispose of lists altogether), from a structural point of view their incorporation is undeniably its most outstanding feature.

The conceptual organisation of chapter seven contains three major, largely independent, segments. The first section introduces the chapter's principal theme, viz., the bodhisattva's moral conduct, and expounds its spheres of application in the context of the doctrine of non-self. ${ }^{43}$ Other central elements are a list of ten mental factors and ten kinds of the thought of enlightenment. ${ }^{44}$ Since the relations between these three elements are reciprocal with each one of them conditioning the other two, the first part of chapter seven is conceptually coherent and largely independent.

The second part of chapter seven consists of numerous lists itemising the benefit accruing

38. $\mathrm{R}$, folio $28.5-34.1$.

39. R, folio $285.7-288.4$.

40. op. cit.; R, folio 368.1-371.6.

41. A good example of such overlapping is found in chapter seven amongst the moral precepts ( $R$, folio $368.1-371.6)$.

42 R, folio 341.1-364.6

Despite the fact that all the practices enumerated in these lists are in some way related to the bodhisattva and his moral training, they do not seem to form a coherent whole. While some itemise little more than incentives (simultaneously, inspiring and reassuring in nature), others iterate the qualities, powers and insights that the novice can expect to gain by embarking on the bodhisattva path ( $R$, folio 368.1-371.6).

43. R, folio 300.6-306.1.

44 The mental factors encompass three broad categories. (1) Faith in the Dharma; (2) Veneration of the teacher; (3) Inclination to follow resolutely the path ( $R$, folio 306.1-4). 
from reverence and moral integrity ${ }^{45}$ Culminating in an enumeration of sixty examples of pure moral conduct, it represents the core of the whole chapter.

In the third section, priority is given to those factors that impede moral conduct. ${ }^{46} \mathrm{In}$ keeping with Buddhist fundamentals, the text singles out desire (räga) as the most devastating force. ${ }^{47}$ Inspired by Mahāyāna reasoning, it is argued in the text that the best way to overcome this peril is to see its manifestation from the perspective of súnyată.

Chapter eight, much in contrast to chapter seven, displays a conceptually highly unified and coherent exposition. In part, this coherence is due to brevity. The points that are put forward are developed in logical sequence and build upon each other. The topic itself is introduced by means of a brief, definitive statement on the nature of the bodhisattva's patience. This gives way to a discussion of the various spheres and manifestations of patience. Essentially, the text distinguishes three kinds of patience, that is, conventional patience, bodhisattva patience and highest patience. ${ }^{48} \mathrm{I}$ have shown in chapter four that the actual contents of these types of $k s \bar{a}$ nti $i$ are far more intricate than their basic division would suggest.

In structure and organisation, chapter nine exhibits several features that distinguish its exposition from all preceding chapters. To begin with, it contains relatively few structural devices that punctuate so effectively the discussions in the other chapters. Therefore, it is rather difficult to break up its contents and to identify the individual teachings. But, it is second to none in the wealth of examples by which its postulates are illustrated. Since I have dwelt already on the effect these have on the comprehensibility of the text, it is sufficient only to draw attention to the particularly strong influence they have in chapter nine.

Next, we notice the astonishing diversity of material included in this chapter. So far, most chapters have been dominated by their main topics. With a few exceptions (most notably in chapter seven), they contained no significant digressions from the principal subject-matter. Chapter nine, in contrast, contains a great number of issues with ostensibly little bearing on the practice of vigour. Amongst the points raised we come across such seemingly unrelated

45. The nature of the qualities cited leaves little doubt that it is he rather than other people who chiefly benefits from these attainments. Most of them spring from the recognition of his previous faults and active training in teacher veneration.

46. $\mathrm{R}$, folio 375.7-403.6.

47. It dedicates well over twenty folios to the various manifestations of desire during which the pitfalls of sexual desire figure most prominently ( $R$, folio $375.7-403.6)$.

48. (1) conventional patience $(R$, folio 407.7-417.7); (2) bodhisattva patience ( $R$, folio 418.1-420.5); (3) highest patience $(\mathrm{R}$, folio 420.6-423.3). 
subjects as the future-destiny of the Dharma ${ }^{49}$, contempt of the Doctrine ${ }^{50}$, failings of grhapti and pravrajita bodhisattvas ${ }^{51}$, avarice ${ }^{52}$, self-sacrifice ${ }^{53}$ and Dharma-teaching. ${ }^{54}$ The perfection of vigour figures expressly only in one section of the text. ${ }^{55}$ Having said this, it is important to note that some effort has been made to relate the secondary issues to the perfection of vigour. Several of the examples that are cited to illustrate these secondary issues are configured to match both the issues they are supposed to elucidate and also the viryapāramitā.

Chapter ten displays few structural peculiarities that have not been met elsewhere in the $B d p$. Its rhetoric is filled with recurring statements, parallel phrasing, rich imagery and stereotyped lists of the kind I described in the foregoing sections. Structurally, it follows the internal organisation of the sets of practices it describes; enumerating and analysing in due order the four dhyāna, five super-knowledge, the interplay between means and knowledge, etc. As chapter ten makes only sporadic reference to examples and dispenses altogether with narratives, its exposition is rather methodical and orderly.

From the viewpoint of our structural analysis, the most interesting part is its concluding verse section. ${ }^{56}$ Unlike its counterparts in the other chapters, it does not summarise previous issues, but introduces new material in the form of a list of one hundred and one samādhi. The style of presentation of these meditations is rather perfunctory. Apart from the title and a few general attributes virtually no data of any significance are revealed. Since the verses are only vaguely related to the prose in both content and style, the whole section might have been composed independently.

In spite of its title, chapter ten has actually very little to do with the practice of meditation. While we learn a lot about the benefits resulting from meditation, we are told little about the practical and theoretical aspects of meditation itself. To all appearances, the chapter was designed primarily to spell out the significance of meditation in the bodhisattva training, to inspire faith in the workings and, above all, in the powers of meditative processes.

Conceptually, this preoccupation is borne out by the priority given to the ways in which

49. $\mathrm{R}$, folio $429.5-448.1$.

50. $R$, folio $448.2-453.1$.

51. R, folio 477.7-483.4.

$52 \mathrm{R}$, folio 483.4-513.6.

53. R, folio 515.5-526.6.

54. $\mathrm{R}$, folio 538.3-548.7.

55. $\mathrm{R}$, folio $468.1-476.6$.

56. $\mathrm{R}$, folio $587.1-590.1$. 
meditative attainments benefit the bodhisattva's spiritual advance. Particular attention is paid to the role that is played in this process by the five abhijñ $\bar{a}$. Their explication spans over more than two thirds of the whole chapter and dominates the exposition more than any other practice. ${ }^{57}$ Again, as in the case of meditation practice, little is said about the psychic processes lying at the heart of their operation. Instead, much stress is laid on their effects and on the role they assume in the training.

Chapter eleven, entitled 'On the Perfection of Wisdom', contains some of the most interesting thought in the $B d p$. As I shall discuss its content and structure at length in chapter four, I shall limit myself here to a few general remarks. Like chapter ten, it dispenses with all narrative and incorporates only a limited number of examples. Its verse sections are very few and generally rather short. Particularly striking, from the organisational viewpoint, is the frequent use of lists and sets of practices that organise its contents into well-delineated sections. Owing to the lack of picturesque language, its exposition is rather technical and displays only thought that is of immediate relevance to the Perfection of Wisdom.

The contents of chapter eleven falls into three technically distinct, but doctrinally interrelated portions. The first section is given over to propound the basic phases in the process of cognition, that is to say, the factors leading to the acquisition of wisdom and the attainments that spring from them. The most notable feature in this section is a list of seventy-two types of learning. Next, a series of practices intimately connected with wisdom is expounded. These include right view (samyagdrsți), correct seeing (yoniśo darśana) and correct penetration (yoniso praveśa). There are several indications that the discussion of these attainments is structured to reflect the first four phases of the Buddhist path, that is, the sambhāramārga, prayogamārga, darśanamārga and bhāvanāmārga.

The second section defines in greater detail those practices particularly relevant to mastery over Perfect Wisdom. Formally embedded in a list of ten types of 'skill' are included, amongst others, the pratisamvid, pratisarana, punya and jñānasambhāra, bodhipākșika dharma as well as samatha and vipaśyanā. As in section one, most of these practices were conceived of in relation to each other and represent a continuation of the cognitive processes initiated through the seventy-two forms of learning. The attainment of wisdom itself is marked by 'skill' in all dharma that signals true cognition of reality.

Turning to the structure of this tenfold division of 'skill', we notice certain 'irregularities' 57. $\mathrm{R}$, folio $551.5-572.4$. 
in its organisation. First, the sequence in which the individual 'skills' are listed in the introductory outline of contents corresponds only approximately to the succession in which they are actually raised in the text. While it is true that all items are included, they do not comply with the proposed order. 'Skill' in discursive insight (vijñāna) and direct knowledge (jñāna), for example, figure as a subcategory to 'skill' in pratisarana rather than (as announced) as an independent 'skill'. ${ }^{58}$ In addition, the text discusses 'skill' in the accumulation of merit and knowledge and 'skill' in the bases of mindfulness as principal 'skills', even though they do not figure in the heading. ${ }^{59}$ It is perhaps worth noting that all irregularities occur in the mid-section. Whatever the reason behind these modifications, it is clear that their impact on the overall scheme is negligible. It could even be argued that they reinforce the coherence of the exposition, since training in the smrtyupasthāna and jũānasambhära is certainly of advantage (if not altogether indispensable) to the generation of wisdom.

Approaching its conceptual climax, chapter eleven goes then on to define the exact cognitive contents of the perfection of wisdom. ${ }^{60}$ For this purpose, it deconstructs the word prajũāpāramitā in its component parts and discusses the nature of prajñ̄ā and pãramitā separately. In spite of this formal division, the two strands of analysis run largely concurrent and correspond in much detail.

Chapter twelve comprises two major sections. It begins with a comparatively brief exposition of the four means of conversion. Proportionally, their elucidation accounts for little more than a tenth of the chapter's total content. ${ }^{61}$ It will be recalled that the means of conversion stand at the very end of the $B d p$ 's path scheme. However, it is left open as to whether this positioning was meant to grade them as the culmination of the path, or whether they were placed there out of structural convenience. While the exposition itself contains some interesting propositions, organisationally it is rather unremarkable.

The second part of chapter twelve consists of the well-known jätaka episode describing Śākyamuni's meeting with Dīpamkara and the subsequent prediction to buddhahood. ${ }^{62}$ Unlike preceding jătaka used to illustrate the bodhisattva practice, this story serves no other purpose

58. $\mathrm{R}$, folio $634.7-636.5$.

59. $\mathrm{R}$, folio $649.5-662.3$; folio $639.7-649.2$.

60. $\mathrm{R}$, folio $685.7-690.1$.

61. R, folio 695.1-698.7.

62. $\mathrm{R}$, folio 699.1-737.4. An identical version of the narrative of Sākyamuni's prediction is found in the Dharmaguptaka Vinaya (Bareau, 1966, 1-16). 
than to relate the events of the narrative. Since its incorporation has no practical bearing on the bodhisattvacarya (it contains virtually no information of any value on the training itself) apart from signalling the completion of the path, the whole point of it telling it here is perhaps simply to keep the tradition of the event alive.

Two considerations might have led to its placing at the end of the discourse. In an exposition that is largely dedicated to the training of the bodhisattva but frequently deployed in the context of the Buddha's former lives, there could hardly be a more appropriate way of ending it than by retelling the final phases of Sākyamuni's exploits. This stratagem not only brings the series of jataka stories to its logical conclusion, but asserts the viability of the whole enterprise in an incontestable way. By singling out this ending, the $B d p$ not only re-enacts the context in which the bodhisattva training unfolds, but more importantly, sets it within a mythological frame of reference, thereby drawing ultimate authority from the experience of the Buddha himself. 


\section{Chapter Three}

\section{The Bodhisattva Ideal in the Mahāratnakūta Collection}

In our survey of the content of the Ratnakutta in chapter one we have learned of the wide range of topics included in its forty-nine sütras. It soon became apparent that many of them show a common interest in the bodhisattva. While examining the texts, I began to wonder whether this shared concern might have occasioned their being assembled into one collection.

In chapter two, I investigated the structural and literary features of the $B d p$. Taking the findings of this analysis as point of departure, I shall now assess the structure and presentation of the bodhisattvacarya in the Ratnaküta. Particular consideration will be given to the role played by the $B d p$ 's teachings amongst these sutras. The reasons for this emphasis are twofold. First, while many Ratnaküta sütras contain material on the bodhisattva ideal, the $B d p$ is virtually the only text practically exclusively dedicated to the bodhisattva. Second, no other text in this collection provides a similar wealth of detail on the bodhisattva as that found in the $B d p$. In length alone, it eclipses all other bodhisattva texts many times over. This raises the distinct possibility that its teachings might also have been invested with special role in the description of the bodhisattva ideal.

Taking into account the size and diversity of the collection a detailed analysis of all forty-eight texts would constitute a task so vast as to take it well beyond the scope of this thesis. Therefore, I have selected twenty-three sütras that are of particular relevance to the study of the bodhisattva ideal. Amongst these texts I include several sütras that may contain little new in terms of practice, but exhibit intriguing and seemingly unprecedented perspectives of the path.

Let me stress, however, that this selection is not to imply that the remaining twenty-five works ignore the bodhisattva ideal. On the contrary, among them there are several sütras containing some interesting insights. Generally, though, they treat other subjects more extensively and place the bodhisattva practice in a subordinate role or refer to it only in passing, and so are of minor importance to the present investigation. 
Categories of Bodhisattva Texts

As already indicated I shall analyse only those sütras containing most of the data on the bodhisattva. For this purpose, I distinguished two text groups. First, there are twenty-three sütras that place the bodhisattva ideal in the centre of their exposition. ${ }^{1}$ Since these works hold most of the relevant evidence, they become the bedrock for this study. Second, there is a group that comprises five texts containing isolated points of interest, but typically these refer to the bodhisattva ideal only in passing. ${ }^{2}$

For the sake of organisation, I propose to subdivide further the first text category by differentiating between:

1. Sütras whose aim is the explication of the bodhisattva ideal.

2. Sütras that discuss bodhisattva practices and attributes.

3. Sütras that focus on the bodhisattva doctrine.

The following ten texts belong to the first sub-category: ${ }^{3}$ The Rāstrapālapariprcchā, Ugraparipṛchāa, Kāśyapaparivarta, Svapnanirdeśa, Upāyakauśalyaparivarta, Sumatidarikapariprcchā, Vinayaviniścaya-Upälipariprcchā, Ratnacūdapariprcchā, Akșayamatiparip

The second sub-group consists of eight works: ${ }^{4}$ The Vimaladattāpariprcchā, Acintyabuddhavișayanirdeśa, Bhadramāyākāravyākarana, Mahāprātihāryopadeśa, Susthitamatidevapu-

1 These are the Svapnanirdeśa (Rkṭ 4), Pürnaparipṛcchā (Rkt 17), Rāṣtrapälaparipṛcchā (Rkt 18), Ugrapariprcchā (Rkt 19), Vidyutpräptapariprcchā (Rkt 20), Bhadramāyā̄kāravyäkarana, (Rkt 21), Mahāprätihāryopadeśa (Rkț 22), Vinayaviniścaya-Upālipariprcchā (Rkt 24), Subāhupariprcchā (Rkt 26), Sürataparipṛchāa (Rkt 27), Vìradattagrhapatipariprcchä(Rkt 28), Sumatidarikapariprcchā (Rkt 30), Gangottarapariprcchā (Rkt 31), Aśokadattāvyäkarana (Rkt 32), Vimaladattäpariprcchā (Rkṭ 33), Susthitamatidevaputraparipr.cchä (Rkt 36), Upāyakauśalyaparivarta (Rkț 38), Darikavimalaśuddha (Rkț 40), Kāsyapaparivarta (Rkṭ 43), Ratnarāśsi (Rkț 44), Akșayamatipariprcchā (Rkṭ 45), Ratnacüdapariprcchā (Rkt 47) and Śrimālä devisimhanäda (Rkț 48).

2. The most prominent examples of this group are the Trisamvaranirdesaparivarta (Rkt 1) Tathāgatācintyaguhyanirdeśa (Rkt 3), Daśadharmakasütra (Rkț 9), Pitāputrasamāgama (Rkț 16) and Acintyabuddhavișayanirdeśa (Rkt 35).

3. Besides the $B d p$, it is only the $U g$ (colophon of T 323), Prn (attested in the T'ang catalogue; Mochizuki, 1931-36, p. 3441a 5-25; ref. Schuster) and $R p$ (pp. 59.20-60.2) that contain references to the bodhisattvacary $\bar{a}$ in their title.

4. In most cases, the relevant section is introduced by shifting the focal point to the bodhisattva training. See: Prn (23, pp. 231.3-32.5.4) Vimaladattäpariprcchā (24, pp. 108.5.1-111.3.8), Susthitamatidevaputraparip!rchā (24, pp. 130.4.6-134.1.4), Bhadramäyākäravyäkarana (23, pp. 7.3.3-9.3.7). In other cases, however, the distinction becomes more blurred with sets of practices being freely interpolated in the description of the main topic, e.g., Viradattagrhapatipariprcchä (24, pp. 84.2.2-85.1.3) and Mahäprātihäryopadeśa $(24$, pp. 19.5.1-20.31; 20.3.5-21.3.7; 22.4.5-23.4.8). 
trapariprcchā, Subāhupariprcchā , Vīradattagrhapatipariprcchā and Pürnapariprech $\bar{a} .^{5}$

The third sub-category is comprised of three sūtras: The Srimālādevisimhanāda, Aśokadattāvyākarana, Gangottarapariprcchā and the Süratapariprccha ${ }^{6}{ }^{6}$

Besides these twenty-one texts, there is one more sütra that seemingly places the bodhisattva in the centre of its exposition. This is the Ratnaräsisütra. The reason why 1 declined to allocate a place in either of these categories to this sütra is simple. It does not mention the bodhisattva. The Ratnarāsisintra discusses the conduct and practice of the religious practitioner (śramaṇa) in what is formally a Mahāyāna frame of reference, but curiously does not refer to him as bodhisattva. Since the centre of interest is the Vinaya observing monk, it is clear that the text presupposes the monastic environment as framework for the spiritual training. On the basis of eye-witness reports, we know that in practice bodhisattvas were bound to the spirit of the monastic code and often pursued their careers in monasteries. ${ }^{7}$ Thus, it seems that the disciplinary reprimands that are voiced in the Ratnarāsisistra are directed at all practitioners partaking in the monastic training and so apply also to the bodhisattva.

Like practically all Mahāyāna sūtras, the Ratnakūta's bodhisattva texts operate within the gnoseologic parameter of Mahāyāna ontology. This is most ostensibly borne out by the frequency with which they draw connections with its axioms of emptiness (śünyatā), sameness (samatā) and inapprehensibility (anupalambha) that most accept as the philosophic substratum for their expositions. The extent to which these principles come to play a role in the bodhisattva training varies greatly from text to text. While some sütras refer to them only in passing ${ }^{8}$, others assess the whole practice in strict accordance with these axioms. Frequently, it is achieved by defining every bodhisattva activity in terms of śünyatā from the very outset. ${ }^{9}$

5. In chapter one, I pointed out that in an early T'ang catalogue the Prn carries the alternative title Bodhisattvapitaka. While it is true that virtually all portions of its exposition have some bearing on the bodhisattva ideal, it is only a relatively small part that contains explicit information on the bodhisattva training itself. Most of these data are found in its first chapter, entitled 'On the bodhisattvacary $\vec{a}$ '. However, since this chapter is extremely short, spanning barely ten out of one hundred and fifty folios, even this part of the Prn does not provide much information on the training. Hence, I did not include the Prn amongst the ten Ratnaküta works whose centre of interest is the bodhisattvacaryā.

6. For the most part, these texts contain no explicit references to the bodhisattva training per se. Their importance lies chiefly in the doctrinal frame in which they set the pursuit of the bodhisattva ideal. This allows often for inferences about the theoretical dimensions of the bodhisattva doctrine as contrasted with the more practical aspects of its implementation in the training itself.

7. Our knowledge of monastic customs is chiefly based on the reports we have from Chinese pilgrims who travelled to India and Central Asia around the middle of the first millennium AD. For details on the prevailing state of affairs in Buddhist monasteries, consult: Beal, 1884; Legge, 1886.

8. The sütras belonging to this category are most prominently the $R p, U g$, Svapnanirdesia and Ratnaräsis. In these, no attempt is mađe to link the tenets of Mahāyana ontology with the practice itself. Thus, their teachings on the bodhisattva assume invariably a very realistic, urgent perspective.

9. This applies in particular to the Vup, Sumatidarikapariprcchä and Upäyakausalyaparivarta. A similar 
Owing to this somewhat defiant system of reasoning which challenges the validity of action in general, the bodhisattva thought inevitably becomes less persuasive. ${ }^{10}$

Let me stress, however, that the texts that use unmitigated philosophical reasoning throughout are in a clear minority. ${ }^{11}$ The vast majority display an astonishing measure of spiritual pragmatism in their vision of the bodhisattva. This emphasis on practical concerns is best exemplified by the weight that many give to the ethical dimensions of the career. In addition, great heed is consistently shown to the more religious facets of the training, including concepts such as faith, veneration, discipline, vigour and purity.

Sütras whose Aim is the Explication of the Bodhisattva Ideal

Broadly speaking, in this category we can distinguish four different approaches in the discussion of the bodhisattva ideal.

First, there are sütras that display a high degree of informality and structural liberty in their

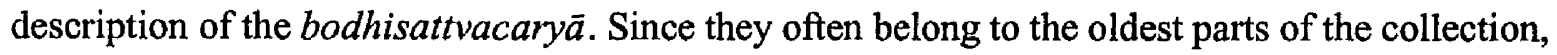
their style of exposition is non-technical and lacks many of the elaborate subtleties that prevail in later strands of bodhisattva works. ${ }^{12}$ There is every indication that they present the early ideas of the Mahāyāna movement. Since, at this stage, the finer points of the bodhisattva doctrine had yet to be worked out, priority is given to more fundamental, inspiring considerations about the general scope and nature of the bodhisattva training.

The most prominent works of this type are the $R p$ and $K p \cdot{ }^{13}$ Both texts contain numerous

though less systematised line of reasoning is adopted in the Bhadra-vy, Kp, Sms and Susthitamatidevaputrapariprcchä.

10. This approach is found, above all, in those sütras that I included for their indirect contributions to the bodhisattva doctrine. More will be said about the ways in which it affects the presentation of the bodhisattva.

11. The best-known of the more philosophical Ratnakutta works are the Trisamvsranirdeśaparivarta, Saptaśatikanämaprajñāpāramitā, Acintyabuddhavișayanirdeśa, Pitāputrasamāgama, Mañjuśribuddhakșetragunavyūha, Samantamukhaparivarta. Other less known works are the Vidyutprāptapariprcchä and, perhaps, the Gangottarapariprcchā.

12. The uncomplicated form of presentation corroborates details that we extricated from Chinese sources about the early date of their composition. Chinese translations of these texts attest that several of them go back to the early centuries of the Christian era. Two of them were first rendered into Chinese during the second century $\mathrm{AD}$ and many others followed suit in the third and fourth centuries. Altogether we know of five Ratnakūta sütras that reached China during the earliest phase of the translation activity in the late Han dynasty. Of these, two are linked to the devotional strands of Pure Land Buddhism $(R k t) 5,6)$, one is associated with the cult of Maitreya (Rkt 41) and two fall in the first category of bodhisattva sütras (Rkt 19, 43). For an exemplary analysis of the characteristics that mark the relationship between the date, style and contents of these works, see: Weller, 1965, Einleitung, pp. 5-58.

13. Other examples from this category of works of inspiration are the $R c d, P r n$ and, of course, the $B d p$. 
bodhisattva practices and disclose ways in which these interrelate. Apparently in order to distinguish the bodhisattva's qualities from those of other religious practitioners, a marked effort has been made in both sütras to describe the virtues and attributes particular to the bodhisattva. In the $K p$, this process of delineation is cast in a somewhat negative mould, since the text invites conclusions by 'rhetorically' listing traits that fall well short of the bodhisattva's high standards. Standing alone, this indirect mode of reasoning might indicate an early date of composition for the $K p$ at a time when the bodhisattva doctrine was still in its formative period and evolved in reaction against previously existing ideas. ${ }^{14}$

If we survey the practices that are included in these early sütras, we note that most texts accentuate the principles of early Buddhist practice and, in particular, the ethical side of their production. Mahāyāna practices such as the pāramitā or upāyakausalya are relegated to the background and figure only sporadically. What is more, none of the texts proposes any formal scheme for the bodhisattva training. The practices are cited either on an individual basis or otherwise are loosely drawn together in tetrads. ${ }^{15}$

Second, we have sütras that display a high degree of organisation in their discussion of the bodhisattva. It would seem plausible that these texts were included to balance the structural latitude of works like the $K p$ and $R p$. Two sütras, in particular, stand out for their well-structured outlines of the training, that is, the Svapnanirdesia and Akșayamatipariprcch $\bar{a}$.

In the Svapnanirdesa, more than half of the exposition is dedicated to showing the interplay that links the diverse attainments of the ten stages. ${ }^{16}$ Priority is given to those factors that specifically correlate the notion of practice with that of progress along the path. The path-scheme itself emulates the tenfold design of the Daśabhümika. The picture drawn of the career is rather sterile, since it is locked into the formal structure of the path and swerves nowhere from its linear order. This close adherence to the successive training-phases may point to the

14. This is also true of the $R p$, since it too sets out to define the nature of the bodhisattva in opposition to the qualities of the śrāvaka (Ensink, pp. v-xvi).

15. There is ample room for speculation as to the reasons that led to this structural laxity. First, there is the fact that both works belong to the earliest strand of bodhisattva sütras not only in the Ratnakut $t a$, but probably in the Mahäyāna as a whole. Texts containing such early thought might be expected to be less organised in their presentation than those of later centuries when the bodhisattva doctrine had fully matured. Second, being conceived as works of inspiration, they might never have intended to provide a systematic description of the training. We know of several other Mahãyanna works where clarity and logical coherence are sometimes disregarded in favour of 'emotional' subject matter aimed at the more imaginative traits of the human mind. Thus, it might have well been thought that a terse, systematised style of exposition would inevitably diminish the appeal of texts whose chief function it was to attract following to newly formulated ideas.

16. 22 , pp. $97.2 .8-109.2 .8$. 
rationale behind the sütra's incorporation in the Ratnakutta; namely, to furnish the collection with a text that systematically classifies, and sets in a well designed scheme practices that are elsewhere haphazardly cited.

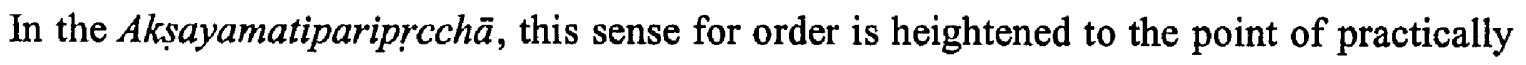
encompassing the whole breadth of the bodhisattva training. It involves an abridged, highly systematised presentation of all major practices and phases of the bodhisattva's career, including the bodhicittotpāda, pranidhāna, the ten stages and affiliated perfections, meditations and magic spells. ${ }^{17}$ From the structural point of view, the Aksayamatipariprcchä's presentation of the bodhisattvacarya excels all other path schemes in the Ratnaküta. Beginning with the cittotpäda and concluding in the bodhisattva's acquisition of quasi-magical, buddha-like powers, it follows not only the chronological order of the career, but also points to the interrelationship between the successive attainments. The päramitā are closely linked to the ten stages; the meditations are generated by sets of vows and, in turn, lead to the acquisition of magical powers.

Third, we have texts that are wholly dedicated to a specific set of bodhisattva pratices. Good examples of such texts are the Vup and Upāyakauśalyaparivarta. ${ }^{18}$ As their titles indicate, the bodhisattva's code of discipline in the Vup and skilful means in the Upāyakausalyaparivarta lie at the heart of the discussion. While the Vup explores the foundations of moral integrity and its manifestations in the bodhisattva's conduct, the Upäyakausalyaparivarta explicates the operations of skilful means in the bodhisattva's fulfilment of his pledge to universal liberation. Both practices are of cardinal importance to the completion of the career. The reluctance shown in both texts to discuss any topic not closely linked to their causes testifies to the enormous prestige of the practice of silla and upāyakauśalya.

Fourth, there are sütras that lay stress on the factors separating the lay path from that of the mendicant ideal. The most prominent sütras of this class are the $U g$ and Sumatidar-

17. On reading the Aksayamatipariprcch $\vec{a}$, it becomes immediately evident that every effort was made to cast its account of the bodhisattva path in the mould of the scheme of the ten stages as codified by the $D b h$. In structure and terminology both works exhibit close parallels and it certainly looks as if most, perhaps even all, of its lay-out has been borrowed from the $D b h$. Apart from this structural similarity, there is otherwise little substance that connects the two, since the Aksayamatipariprccha is an infinitely shorter work and does not take up most of the detail that is set out in the $D b h$.

18. Other texts dominated by individual practices are the Ratnaräsis and, albeit to a somewhat lesser extent, the Rcd. In the Ratnaküta, this phenomenon of devoting whole sütras to one concept only is not limited to expositions on the bodhisattva. There are several other texts that focus on a limited range of thems, most notably the Bhadrapālaśreșthipariprcchā, Raśmisamantamuktanirdeśa, Ayușmannandagarbhävakrāntinirdeśa, Akșobhyatathägatasyavyüha and, of course, the Amitäbhavyūha. 
ikapariprccha ${ }^{19}{ }^{19}$ First, both texts go to considerable lengths to present a complete picture of the nature and aptitude of grhapti bodhisattvas. Further, neither encourages the outright condemnation of its opposing ideal. Even in the passages where they directly contrast the qualities of grhapti bodhisattvas with those of its pravrajita counterpart, an amicable tone is maintained.

The $U g$ is most explicit in this matter and postulates that the highest form of bodhisattva practice consists in a combination of the virtues of both ideals. ${ }^{20}$ That is to say, it proposes to join the compassion, dedication and altruism of the grhapti bodhisattva with the discipline and renunciation of the recluse. The practices and attainments advocated in the $U g$ coincide with those qualities traditionally associated with the two schemes; for the lay path it is faith, generosity and reverence, whereas for the recluse it is contentment, concentration and deep understanding.

Sütras that Discuss Bodhisattva Practices and Attributes

I now propose to widen our investigation and to consider those sütras containing specific, if sporadic, discussions of bodhisattva practices and attributes. Since they appear generally out of context or are crudely integrated into the plot they serve to illustrate, it seems to me that many of these passages could indeed be interpolations of later times. Amongst the eight texts to be considered here, we can distinguish two principal currents of exposition.

First, there are texts where the passages focus quite specifically on the bodhisattva practice. These are primarily 'action-oriented' and contain only few references to the bodhisattva's qualities or attributes. This is particularly evident in the Mahäprātihāryopadeśa and Prn. In the Mahāprātihāryopadeśa a long section is taken up by a detailed, itemised description of the mechanisms behind the practices themselves. ${ }^{21}$ There is virtually no reference to the

19. Other texts of this category are the Aśokadattävyākarana,Virradattagrhapatipariprcchä, Gangottarapariprcch $\bar{a}$ and philosophically, the $S m s$.

20. As the Ug is a composite work whose focal-point shifted over the centuries, its conclusions were also subject to change. In the words of Schuster: "The three Chinese translations, the Tibetan and the Sanskrit fragments preserved in Siks, do not represent the same recension of the text. All translations of the text present similar pictures of the lay and recluse bodhisattvas. Yet there is a radical difference of opinion between the oldest version of the $U g$ (T322) and all the others about what is the superior bodhisattva vocation, and why" (Schuster, op. cit., pp. 79, 315).

21. 23, pp. 11.4.4-23.4.5. 
immediate fruits that would result from such practices. ${ }^{22}$ In the Prn, too, an entire chapter is devoted to the bodhisattva training and the individual practices pursued in its course. ${ }^{23}$ It is structured in tetrads that allow for only brief comments on the practices themselves, unlike the corresponding passage in the Mahäprātihāryopadeśa that contains much more detail. ${ }^{24}$

Second, we have several sütras where the focal-point shifts towards descriptions of the bodhisattva. Here, emphasis is placed on the qualities of the bodhisattva rather than on the practice itself. Even the most outstanding practices, such as the päramitā or samgrahavastu, do not appear in their expositions. The main objective is no longer to explain the practical concerns of the training, but forge a new ideal from traditional collections of religious maxims. Generally, they do not investigate the way these were accomplished in the first place. Examples of this shift in emphasis are contained in the Darikavimalaśuddha and, to a somewhat lesser extent, in the Subähupariprccha ${ }^{25}$ The Darikavimalaśuddha places specific bodhisattva attributes and powers in the foreground, whereas the Subāhupariprcchā presents the bodhisattva ideal in subtly inspiring but more general terms. Apart from this difference in tone, both sütras were clearly based on similar assumptions that place them side by side amongst the Ratnaküta works.

\section{Sütras that Focus on the Bodhisattva Doctrine}

Much of our attention so far has been directed at the practical facets of the bodhisattva training. This is appropriate in view of the predominantly 'action-oriented' nature of most Ratnaküta sütras. This feature however is not shared by all texts, as some concentrate on the theoretical perspectives of the bodhisattva ideal. These I have grouped together as sütras that deal with doctrinal issues or contain only indirect references to the bodhisattva. They are

22. $24, \mathrm{pp} .15 .5 .7-16.3 .5$

The fruits and bodhisattva qualities that spring from the training are iterated separately towards the end of bam-po two (pp. 19.5.1-20.3.1) and again in the middle of bam-po three (pp. 22.4.5-23.4.8).

23. This is chapter one. Incidentally, this chapter, entitled: 'On the bodhisattvacarya', is the only of all forty-nine texts (except the $B d p$ ) that bears a title which is immediately related to the bodhisattva training (23, pp. 231.1.6-232.5.4).

24. The other texts containing passages that focus on the more active or dynamic aspects of the bodhisattva ideal are the Bhadra-vy (24, pp. 7.3.3-9.3.7), Vimaladattäpariprcchā (24, pp. 108.5.1-111.3.8) and Susthitamatidevaputrapariprcchä (24, pp. 130.4.6-134.1.4).

25. The third text which belongs to this category is the Viradattagrhapatipariprccha (in particular, pp. 84.2.2-85.1.3) and, of course, the $B d p$. 
separately examined further below, so it will suffice to note just two of their characteristics here.

First, all of them pass over the practical aspects of the bodhisattva training and include only a few statements immediately relating to the vision of universal liberation. At first glance, they do not seem to be of great import to the bodhisattva ideal. On closer examination, we find this is misleading. The $S m s$ is the text where such philosophical priority is most conspicuous. The work abounds with allusions to the doctrinal background of the various career-phases. It not only adds new thought, but also draws parallels with several other Mahāyāna works and traces correlations with their propositions.

Second, practically all sütras in this category endeavour to highlight the issues separating the attainments of the śāvaka from those of the bodhisattva, often over many pages. These discourses assume an overwhelmingly theoretical flavour with little illustrative material and not much interest is shown in the practical application.

On the basis of this preliminary investigation, it is now possible to venture some opinion on the motives behind the inclusion of the $B d p$ in the Ratnaküta. In chapter one, I pointed to textual evidence that suggests that the $B d p$ was widely esteemed for its treatment of the perfections. This finding is corroborated by the results from our survey of its contents, showing that the päramitā stand at the centre of the $B d p .^{26}$

So far very little has been said about the päramitä in the context of the Ratnakūta. The reason for this omission is that the $B d p$ is practically the only text in the entire collection that treats the six perfections with more than passing reference. ${ }^{27}$ This is astonishing, considering the great attention that is given to the bodhisattva in every other detail in the Ratnakuta. Without the $B d p$ its depiction of the bodhisattvacarya would lack the most prominent set of bodhisattva practices.

26. I know of no other Mahāyāna sūtra that propounds the pāramitā in quite the depth that the $B d p$ does. Even texts that are intimately linked to the bodhisattva's cause mention them only in passing. In the $D b h$, for instance, the perfections appear only briefly at the end of each stage (Daśa-bh, p. 30; cf. $\$ g s$, pp. 141-150). Likewise, in the $V k n$ they are cited only twice in full and also there little attention is given to their implementation (pp. 96-7, 157). Even in the voluminous Pañca, we find only sporadic discussions of the pāramitā altogether amounting to little more than a tenth of its exposition (e.g., pp. 263-67, 400-4, $453-64,488,509-526)$. One is led to conclude that the perfections were either considered to be very elementary and therefore required no specific explanation, or (and this seems much more likely) that behind the $V k n$ and texts like it there might have been well-known sütras where the pāramitā were propounded in detail so that to discuss them once again would have been otiose.

27. The only exception is perhaps the $R c d$, since in this work the perfections do receive considerable attention at the beginning of the discourse (24, pp. 231.4.7-236.2.7). 
With the $B d p$ 's exposition of the päramitā, the picture becomes complete. Indeed, there is then practically no aspect of the bodhisattva training that is not discussed or touched upon at least once in the forty-nine texts. We find works of inspiration that provide general information on the scope of the training and extol the qualities of the bodhisattva's accomplishments; texts that explore the major practices to be cultivated by bodhisattvas; sütras that instruct in the order that the practices are to be undertaken and demonstrate how they interact with each other; works that propound especially selected practices warranting exclusive treatment; texts that address the controversy of the lay/mendicant distinction and lay down the frameworks for their respective training; and finally sütras that give the bodhisattva ideal a more philosophically 'objective' treatment through examination of the theoreticl principles lying at the heart of its doctrine. Clearly, in view of this thematic completeness, the notion that the Ratnakutta might have been compiled on the basis of a premeditated scheme now seems less absurd. On the contrary, it might well be argued that without a calculated plan such extraordinary degree of balance in diversity could not have been achieved.

The high standing of the bodhisattva in Ratnakuta works is confirmed by the multitude of practices that are introduced in the course of their expositions. Since I discuss many of these in the context of the $B d p$ in chapter four, I shall investigate here the extent to which they convey a complete picture of the bodhisattvacarya $\vec{a}$. In particular, I shall probe whether their arrangement manifests any indications why they were included in the Ratnakūta collection.

\section{Bodhisattva Vow}

Adopting the order of the career progress, I suggest to look first at the ways in which the texts describe the bodhisattva's vow (pranidhāna). The most advanced expositions of the bodhisattva vow are given in the $S m s$ and Akșayamatipariprcchä. In both texts the vow is divided into ten component parts each of which addresses one specific training-perspective. ${ }^{28}$ In the Akșayamatipariprccha $\bar{a}$, the enumeration follows the succession of the pāramitā with each vow containing a pledge to practice the corresponding perfection. Its presentation is accordingly very formal. In the $S m s$ the situation is different. Here, the pranidhäna is embedded in the narrative and designates a specific point in Srimālā's spiritual advance. As a 28. 24, pp. 204.1.2-2.4; 24 , pp. 252.1.5-5.2. 
result, the description is very much alive and vibrates with her yearning for enlightenment. The contents of the individual limbs do not seem to follow any formal design, but reflect the underlying vision of the bodhisattva. Genuine desire for universal welfare is also displayed in the vow that is set out in the $U g$. As in the $S m s$ and $A$ ksayamatipariprccha $\bar{a}$, it is cited at the beginning of the discourse and introduces the spiritual quest of the main protagonist, in this case the householder Ugra. Yet, in contrast to the former two, its formulation is rather archaic and may well belong to the earliest examples of its kind.

All other sütras containing references to the bodhisattva vow relate its function to a specific purpose or mention it only in passing. Good examples are given in the Aśokadattāvyäkarana, $B h a d r a-v y$ and $R p$. While none of these works discusses the bodhisattva vow in detail, all uphold its cardinal importance for the bodhisattva career. In the Aśokadattāvyäkarana, for instance, it is listed amongst eight dharma that remove blemish from household life-an issue of foremost concern to its defence of the lay path. ${ }^{29}$ The Bhadra-vy and $R p$ give somewhat less attention to the bodhisattva vow. It appears inconspicuously halfway through a long sequence of tetrads spelling out all sorts of bodhisattva practices. ${ }^{30}$ No attempt is made to set the vow apart from the principles cited next to it. Neither is the reference itself very explicit, since it broadly correlates the fulfilment of the vow to the accumulation of the roots of virtue and learning. ${ }^{31}$

Then, we have several sütras that either build conceptually on the vow or allude to its scope and effects. First, there are those texts where it constitutes the rationale behind many of

29. 24, pp. 101.2.5-3.3.

30. Bhadra-vy, pp. 43, 96 ( $\$ 103) ; R p$, p. 14.11-12.

The vows themselves are very similar in contents and represent variations on what must be considered the simplest and perhaps earliest form of the bodhisattva's pranidhäna.

In the Bhadra- $v y$, the bodhisattva pledges (1) to abide in samsära until he has saved all sentient beings; (2) to strive to learn the disposition of all beings so that he can instruct them in a suitable manner; (3) to acquire wholesome dharma, to defeat Māra and to accomplish enlightenment; and (4) to teach the Doctrine to the world in just one word.

In the $R p$ the vow is vaguer (Ensink, op. cit., p. 15):

"There is no salvation, no refuge nor relief whatever for the world that errs on the way of the conditioned. I must release all beings, therefore I make my vow to attain the highest enlightenment."

Both are conspicuously similar to the vows that are included in the $A s t a$ and $M v u$; these are probably the oldest of their kind. In the $A s t a$ (trsl. Conze, 1973, p. 254) it runs:

"We have crossed over, we shall help beings to cross over. Freed, we shall free them. Recovered, we shall help them to recover. Gone to Nirvāna, we shall help them to go to Nirvāna."

In the $M v u$ (p. 138.16) the vow is given in precisely the same form as in the Așta. In this profile it is also found in the Saddhp (pp. 122-3).

31. In the $R p$ there is another reference to the bodhisattva vow. This time it is made by prince Punyarasmi when he pronounces his willingness to follow the Buddhist path. Although very similar in contents to the former, it is less accentuated and easily overseen (p. $44.17 \mathrm{ff}$ ). 
their propositions. The best-known examples of this kind are the Vup and Upāyakausalyaparivarta, where the fulfillment of the vow is fundamental to their theses. ${ }^{32}$ Second, there are works that assimilate its significance, scope and implications without incessantly going back to the vow itself. A good example of this kind is the $U g$. This text places the vow at the very heart of its teaching by linking its concomitants of altruism and selfless service with the moral and disciplinary zeal of the recluse..$^{33}$

\section{Bodhisattva Practice}

Broadly speaking, the training that leads to the implementation of the vow is composed of two categories of practice. First, it includes a number of principles that were adopted from the earlier strands of Buddhist practice. Although with the advent of the Mahāyāna these practices were 'officially' relegated to the background, many survived as the very bedrock of the bodhisattva training. Second, we have practices that were developed in the Mahāyāna itself. The most prominent amongst these are of course the pãramitā. It is their treatment in the Ratnaküta that I shall consider next.

The Ratnaküta sütras approach the perfections in three different ways. First, there is one text that places the pursuit of the parramitā in the centre of its exposition. This is the Bdp. However, one should also mention the Aksayamatipariprccha and $R c d$ since both contain some material on all six (or ten) perfections. In the middle section of the Aksayamatipariprcch $\bar{a}$, the pāramitā are briefly discussed and, thereafter, recur in connection with the various path-stages. ${ }^{34}$ And yet, since the sütra is an extremely short work and does not explain the training in the pāramitā beyond a number of attributes, we learn little about how to pursue them. ${ }^{35}$ In the $R c d$, the situation is not very different. ${ }^{36}$ Here too, we have a work that

32. Vup, pp. 108-114, § $33-40$.

33. In the $U g$, by being placed at the very beginning of the discourse, the vow is employed in a very effective way. In a few lines it sets out the gist of the whole work and is easily memorised. Like those of the $R p$ and Bhadra-vy, it is early in both format and orientation and very close to that of the $A s \operatorname{ta} a$ and $M v u$. It runs as follows (23, p. 259.3.1-2):

"I shall liberate those who have not yet been liberated, and release those who have not yet been released. Those who have not yet been comforted, I shall comfort. Those who have not yet been freed from affliction, I shall bring about their freedom from affliction."

34. 24, pp. 204.2.6-205.4.7.

35. In the Peking edition of the Tibetan Canon the whole text extends barely over seventeen folios (24, pp. 203.3.7-206.5.4).

36. Besides Sthiramati's commentary on the $K p$ and Chinese commentaries on the $S m s$, the Rcd is the only text 
considers all perfections, but does not place them in the centre of its exposition. ${ }^{37}$ Instead, it is the bodhipāksika dharma that become the focal-point of much of the discourse.

Next, there are works that contain partial discussions of the pāramitā. In some of these, treatment is only nominal and rarely exceeds a few lines. This is the case in the Kp, Prn, Sms, Süratapariprcchā and, perhaps, the Bhadra-vy. Typically, they refer to the six päramitā only in passing or allude vaguely to their implementation. The $K p$ goes furthest by simply referring to another text for a more detailed exposition of their contents. ${ }^{38}$

A limited treatment of selected perfections is also found the Sumatidarikapariprccha and $R p$. Here, however, the perfections are not explicitly referred to by name, but are implied by the nature of the practices. It is worth noting that the practices that occur with greatest frequency in this connection are those constituting the bodhisattva's moral training (adhiśilaśikșā). That is to say, they are dāna, śila, kṣānti and also, according to some, virya. ${ }^{39}$

Finally, there are several texts that discuss only one of the six (or ten) perfections. The selected the pāramita is invariably explored at great length and stands at the centre of the discourse. This is the case in the $U g, V u p$ and, of course, in the Upāyakauśalyaparivarta. Each of them treats its selected perfection in exhaustive detail and looks at it from a number of perspectives, with very little overlapping between the discussions. The $U g$ explores dāna,

of our twenty-one bodhisattva sütras that is furnished with a commentary. It is called Ratnacüdasūtracaturdharmopadeśa (T1526) and exists in Tibetan and Chinese translations. Tibetan sources attribute it to Vasubandhu, but the validity of this authorship has been challenged. Demiéville (BEFEO, 44, p. 391, n. 5), however, says that this commentary is not extant in Tibetan.

37. The Rcd begins with a discussion of the six päramitā (24, pp. 231.4.7-236.2.7) which is immediately followed by a lengthy exposition on the bodhipakssika dharma (24, pp. 236.2.8-244.2.8). Its total volume spans well over one hundred folios (24, pp. 229.5.1-251.1.8).

The positioning of the bodhipakssika in the middle of the discourse and the detail with which they are treated indicates that they were thought to stand at the very heart of the bodhisattva's training; probably right next to the päramitä. The description of the individual factors is carefully phrased and a lot more exhaustive than all other references to the bodhipāksika elsewhere in the Ratnaküta. Hence, it becomes a distinct possibility that just as the $B d p$ was seen as the authority on the perfections, so the Rcd might been held in high esteem for its contribution on the bodhipäksika dharma and therefore warranted inclusion in the Ratnaküta.

38. 24, p. 189.2.6-7

For text-critical comments on the passage in which the $K p$ refers to the $B d p$ for the practice of the perfections, see: Weller, op. cit., p. $67, \S 6.1($ n. 5,6$)$. Other Ratnaküta internal references to the $B d p$ are found in the $U g$ (p. 267.2.5-6) and Upayakausalyaparivarta (p. 162.1.7-2.8).

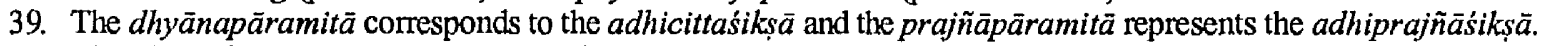
The allocation of the viryapäramitä is less clear-cut and varies from author to author, some associating it with the adhicittaśiksä and others with the adhisílassiksāa. This threefold division of the pāramitā was widely accepted in Mahāyāna circles and probably represents attempts to reconcile the practices of the bodhisattva to those of early Buddhism. Amongst others, it is spelled out in the Msg, Bbh and Madhyamakavatära. sGam-po-pa propounds a similar scheme (Guenther, 1971, p. 149). For further references to this scheme see: Eimer, 1976, pp. 113 ff. 
the Vup expounds silla and the Upāyakauśalyaparivarta explains upāyakauśalya. Generally, the chosen perfection is treated on its own and not linked with other practices. ${ }^{40}$

Treatment of the practices that complement the bodhisattva's training in the päramita $\bar{a}$ is generally rather uniform. But for shifts in emphasis (largely due to varying contexts in which the ancillary practices are called upon), few texts exhibit any substantial differences in their choice and discussion of these practices. Repeatedly, our attention is drawn to the pañcasilla, apramāna, samgrahavastu, rddhipāda, abhijñā, dhutanga and bodhipākșika dharma, to mention just a few of the more frequent principles. ${ }^{41}$ Besides these well-established sets, one meets also with a fair number of individual, less codified practices, such as reverence, eloquence, self-sacrifice, selfless service, faith and learning.

Also the framework in which these practices are embedded is remarkable uniform. Generally, they are summed up in mnemonic-type lists of the kind I have already discussed in connection with the $B d p$. In view of this consistency, it is tempting to conclude that many of these better known principles might have been based on some ancient, uniform stock of practices. What is surprising, however, is the extent to which the texts exhibit similarities in style and tone. It has been generally assumed until now that the concise sütra style is particular to the early phase of Mahāyāna literature. In the Ratnaküta, however, these features are shared by early and late works alike. ${ }^{42}$

40. The exception is the Upäyakausalyaparivarta. Here, a specific practice, viz., the perfection of skilful means is related to numerous other training aspects to which it becomes the frame of implementation. Hence, although priority is given to showing how skilful means influences the training as a whole, it is set repeatedly in contexts that disclose its application to specific practices. At the beginning of the exposition (24, pp. 151.4.8-152.1.8), for instance, it is shown how upayakausalya affects the practice of the päramitä. In section two and three (24, pp. 156.2.3-167.5.8) it is taken to account for the Buddha's inexplicable past conduct. Thus, although upäyakausalya is the focal-point that determines the perspective for all other practices, it is not the sole topic of the Upäyakausalyaparivarta.

41. As complete sets of practice, these are found above all in the Ug, Süratapariprcchā, Ratnarässi, Rcạ, Rp and $K p$. In other texts, commonly just one or two aspects of these categories are cited or else the respective principles are not discussed under the official headings but listed on their own merits. This is particularly the case in the Bhadra-vy (\$ 79-121), Aśokadattāvyäkarana and Sumatidarikapariprcchā.

42. Compare, for instance, the style of exposition of such early works as the $\mathrm{Kp}, \mathrm{Ug}$, Maitreyapariprcchādharmāsta (trsl. second century) or Rcd (trsl. third century) with that of the Aksayamatipariprccha (trsl. eighth century), Sms or Pps (trsi. fifth century). It will be noted that, although doctrinally far apart, all seven works show affinity in literary style and share a conspicuous preference for concision in the presentation of their cases. 


\section{Bodhisattva Path}

When discussing the types of bodhisattva expositions existing in the Ratnaküta, I have pointed to the Svapnanirdesia and Aksayamatipariprcchā as two sūtras whose descriptions of the bodhisattvacaryā emulate the daśabhümika scheme. Identification of the tenfold design caused no difficulty, since the expositions of both texts are firmly locked into their structures. There are, however, Ratnaküta works where the path-design is less clear.

A good example is the daśabhümika scheme that is found in the Sms. Being essentially a philosophical work, the $S m s$ displays few clear-cut statements on the bodhisattva path. Much of what we know about its vision of the bodhisattva path is therefore based on exegetical works. ${ }^{43}$ A key passage pointing to the adaptation of the tenfold design is contained in the second chapter where Srīmālā speaks of the bodhisattva's successive renunciation of body, life-force and possessions. ${ }^{44}$ Although, at first glance, no specific design emerges in this reference, it shows parallels with other works where the three types of renunciation are related to the ten stages. We learn in the Mahāvastu that from the eighth stage onwards bodhisattvas begin to renounce their property and take up the mendicant path. ${ }^{45}$ This ties in with what the queen, says: by renunciation of the body, bodhisattvas attain the buddha-body (presumable the transcendental body first attained on the acaläbhümi); renunciation of the life-force settles bodhisattvas in Dharma-activity (by common consent on the sädhumatïbhümi), and by renouncing all possessions they are certain to receive honours from all beings (at the dharmameghābhümi when the bodhisattva is encircled by the Sangha).

Further evidence of the adoption of the daśabhümika scheme is found in a series of references to four kinds of merit (guna). ${ }^{46}$ Of these, the $R g v$ links 'limitless merit' (gunāprameyatā) to the seventh stage, 'completeness of merit' (gunasarvatā) to the eighth stage; 'inconceivable merit' (gunācintyatā) to the ninth stage; and 'pure excellence of merit' (gunaviśuddhiparamatā) to the buddha-stage. ${ }^{47}$

There are yet more passages in the $S m s$ that allude to a scheme for grading the progress of the bodhisattva. These propose to divide the bodhisattva path into two major phases. According to the $M s l$, quoting a passage from the $S m s$, the practitioner goes first through a 'progress-phase'

43. For a list of commentaries that were written on the Sms in China, see Wayman, 1974, pp. 9-11.

44. 24, pp. 255.5.3-256.1.5.

45. $M v u$, p. 105.11-14 (ref. Wayman).

46. 24, p. $254.3 .8-4.2$.

47. Rgv, pp. 264-265 (ref. Wayman). 
comprising the attainments of the srāvaka, pratyekabuddha and 'newly-set-out' bodhisattva. ${ }^{48}$ Then he passes through the 'fulfilment-phase' that is set by the 'three stages of the body made of mind' ${ }^{49}$ These, Queen Srīmālā associates with the advanced bodhisattva. Although the three path-stages are raised at several occasions in the $S m s$, at no point it is made fully clear to which phases they actually correspond. ${ }^{50}$ Also the commentaries do not offer conclusive advice. Instead, they cite references to three stages in other Buddhist scriptures. ${ }^{51}$

The Sms belongs probably to the later strands of the Ratnaküta. This might have influenced the rather complex picture that it draws of the bodhisattva path. Our next example, the $U g$, in contrast belongs to the earliest bodhisattva sütras. Hence, it is not surprising that, like the $B d p$, it does not follow any 'prefabricated' path scheme, but develops a plan of its own. ${ }^{52}$ In essence, many of its teachings revolve around the factors that distinguish the training of the pravrajita bodhisattva from that of its lay counterpart. While the controversy surrounding these two ideals is an old one, its conclusions are remarkable and warrant closer investigation. At several places in the $U g$ we are told quite clearly that the paths of the grhapti and pravrajita bodhisattva represent nothing but two consecutive career stages that eventually

48. $M s l$, p. $70.3-10$

The quotation itself is however not found in the $S m s$.

49. Wayman associates the so-called 'body made of mind' to special cases of perception, to their reflected image in the three reaims and to birth. Starting from these assumptions, he concludes that it must refer to a duplicate of the coarser body; and that indeed the 'body made of mind' is assigned to the 'nonfluxional realm' with its reflected image in the coarser body assigned to the 'fluxional three realms'. I must admit that $I$ am not certain that I understand his terminology and the reasoning behind his argument. Since it is only of minor import to our present discussion, I shall not digress, but refer to the passages in which Wayman develops his case; that is: Wayman. 1974, pp. 29-31.

50. 24, p. 254.3.8-5.4, pp. 255.4.2-257.4.5.

51. Chinese commentaries (Chi-tsang, p. 173) point, for instance, to an account that is given in the Lankāat that arranges the 'three bodies made of mind' alongside the ten $b h \bar{u} m i$, correlating the first body to stages one to five, the second body to stages six and seven and the third body to the eighth, ninth and tenth stages (pp. $211-214)$.

52. The clearest indications of such scheme are found in a section on stüpa rites:

"When shall I [the bodhisattva] renounce the filth of household-life? When shall I abide and fare just in this way? I shall generate, just so, the thought of wishing to go forth to mendicant life, of no longer remaining in household-life at all and to pursue the conduct of supreme enlightenment. All those who go forth to mendicant life and hasten to the empty forest of solitude realise perfect enlightenment" (23, p. 265.4.6-5.2).

For further details, see: 23 , pp. 265.5.3-267.1.6 and p. 270.3.2-4. These statements on the path phases are corroborated by the sequence in which the individual aspects of the bodhisattva training are cited in the $U g$. The first section sets out to define the nature and training of the lay bodhisattva. It describes the typical lay attributes of faith, generosity, morality and veneration $(H I B, \mathrm{pp} .67-84)$, each of which is then individually taken up in section two to six ( $\S 2$, morality; $\S 3$, healing; $\S 4$, home; $\S 5$, generosity; $\S 6$, stūpa worship). Next, departing from the ideal of the householder, section seven lays out in detail the practices of the äryavamssa. In part, these are taken up again in section eight that deals with secluded dwelling. As in all preceding sections great stress is laid on the reasons lying behind the individual practices and, above all, justifying the renunciation of household-life in favour of forest seclusion. Finally, towards the end of the discourse, the training schemes of the lay and mendicant ideals are merged and five dharma are put forward that characterise the training of the new, combined path (23, pp. 272.3.6-4.7). 
come together in the ideal of the 'accomplished bodhisattva'. ${ }^{53}$ While it is the grhapti bodhisattva who comes closest to the realisation of buddhahood ${ }^{54}$, he cannot achieve this without having first gone through the phases of renunciation and discipline of the mendicant path. $^{55}$

The text distinguishes three path-phases. First, there is the phase of the superbly motivated, though technically ill-equipped, householder. He has raised the thought of enlightenment and proceeds on the path to buddhahood, but his progress is hampered by lack in purity and understanding. Then follows a phase in which the bodhisattva spends his days as a recluse in the forest, exerting himself to attain the degree of insight and purity required to implement his resolution with utmost success. Finally, in the third phase of his training, the bodhisattva returns to the world of the householder and resumes his task of liberating all sentient beings. ${ }^{56}$

\section{Householder and Recluse}

Out of the twenty-three bodhisattva works in the Ratnaküta, seventeen take up this somewhat controversial issue. Of the seventeen, eight ${ }^{57}$ uphold the training of the grhapti bodhisattva and nine ${ }^{58}$ endorse the pravrajita bodhisattva as the higher ideal. Numerically, there is almost parity between the two groups. But before rushing to conclusions, let us look at the ways in which the texts argue their cases. As in previous instances, I have selected from each group one sütra that is particularly well-suited to serve as an example.

The Aśokadattāvyākarana is in many ways representative for the advocates of the lay

53. Ug, 23, p. 272.3.7-4.7.

54. 23 , pp. $272.5 .7-73.1 .6$.

55. 23, p. $270.2 .4-4.6$.

56. 23, p. $271.2 .7-3.1$ :

"And furthermore, $\mathrm{O}$ householder, in accordance with the Buddha's instructions the pravrajita bodhisattva must live in the forest abode, thinking to himself: "In this place I shall accomplish all virtuous practices. Having adhered to it by reason of roots of virtue, afterwards, I shall go to towns and villages to preach the Dharma."

A similar concept in found in chapter nine of the $B d p$ where the bodhisattva is encouraged to withdraw into solitude prior to promulgating the Dharma ( $R$, folio $540-41$ ).

57. These are the 1. Sms, 2. Sumatidarikapariprcchä, 3. Aśokadattāvyākarana, 4. Vimaladattäpariprcchä, 5. Gangottarapariprcchā, 6. Susthitamatidevaputrapariprccha $(24$, pp. 139.3.3-142.2.3 only), 7. Viradattagrhapatipariprccha, $8 . \mathrm{Ug}$ (in the $U g$ the position is less clear as it changed over the centuries). Of these seven works, number $1,2,3,4$ and 5 endorse also the potential of the female bodhisattva.

58. These are the $B d p, R p$, Susthitamatidevaputrapariprcchä, Bhadra-vy, Ratnarāsí, Süratapariprechä, Kāśyapaparivarta, Akșayamatipariprcch $\bar{a}$ and Pürnapariprcchā. 
ideal. ${ }^{59}$ First, it belongs to those texts in which the grhapti/pravrajita distinction is vehemently brought to the fore and thus is probably the main reason for its composition. Like most of the sütras propounding the lay ideal, it is rather short and deals with few other issues. Second, there is its vivid description of the challenge launched at even the most senior monks by Princess Assokadattā. This is commonplace in this type of text, where the dialogue is typically sharp and full of irony. At the end (and this too is characteristic for the householder/recluse debate in the Ratnakūta), it draws up a set of practices that bridge the differences between the two ideals to produce the ideal of the 'accomplished bodhisattva' very much along the lines of the $U g$. Doctrinally, this is achieved by merging the maxims of purity, insight and meditation of the recluse with the compassion, selfless service and self-sacrifice of the householder. ${ }^{60}$

Our second example, the Ratnaräsisi, is less accommodating to the householder. It advocates strict observance of the monastic code of conduct and encourages the revival of the mendicant ideal. The reasons standing behind these concerns are well-known from the early suttas. First, it is concerned with the personal benefit that accrues to the religious by way of physical and mental purity. ${ }^{61}$ Second, it wishes to ensure the Sangha's continuing ability to provide fields of merit for lay followers, as a loss might damage its financial standing. ${ }^{62}$ In order to kindle a desire for purity, the Ratnarāsi extols the benefits that spring from meticulous adherence to the Vinaya and praises those who genuinely withdraw into seclusion. ${ }^{63}$

The assumption behind this commitment to a monastic-type discipline is that lay life is inevitably defiled and thus not suited to spiritual purification. Like the Bdp, the Ratnarāsi warns of the worldly evils of desire, greed and conceit and goes to great length to contrast them with the virtues of the disciplinarian framework of mendicant training.

59. 24, pp. 96.2.4-103.2.8.

60. The points include (1) to purify the body and gain faith in enlightenment; (2) to generate kindness and compassion; (3) to master all worldly affairs because of/with compassion; (4) to be able to give up one's life and to achieve ingenuity; (5) to be able to make infinite vows; (6) to accomplish the perfection of wisdom and become detached from all views; (7) to develop unwavering, infinite courage and vigour; (8) to acquire unhindered pristine cognition as a result of attaining the realisation of the non-arising of dharma $(24$, p. 101.2.5-3.3).

61. 24, pp. 207.1.2-5.6.

62. 24, pp. 207.5.7-208.1.6; 208.3.5-209.1.5.

63. That is to say, it is to adopt wholeheartedly the practices that are included in the arryavamsia and to pursue the various meditative practices out of genuine desire for purification (24, pp. 208.1.6-4.2, 214.3.3-5.8). There is reason to believe that these ideals had not always been fully upheld, since the texts abounds with examples that illustrate how the monk should not conduct himself (24, pp. 210.1.1-211.5.5). In keeping with Vinaya tradition, these episodes are presumably cited on the basis of some true occurrence and might well reflect the state of the Sangha at the time of the composition of the Ratnaräsí. On evidence of moral laxity in the Buddhist communities of Central Asia during the fourth century where fragments of the Ratnaräsi have been found, see: L'Inde Classique, ii, p. 415. For further evidence of criticism of indiscipline in early Mahāyāna sütras, see $K p, p p .162-171, \S 111-120$. 
Two issues warrant particular attention, since they disclose rather conclusively what the Ratnarāśi considered an ideal environment. First, (and this is accentuated throughout the text) no monk should expose himself unnecessarily to contact with the laity. Every interaction between lay followers and bhiksus has to be sanctioned by the monastic community and must strictly serve its interests. ${ }^{64}$

The training that such isolation was intended to advance consists of two main components. On the one hand, we have a strictly regulated monastic regime of intense supervision and willing submission. ${ }^{65}$ The one issue that recurs constantly is the principle of personal accountability. Although it is applied to practitioners of all levels, it is argued that it is especially mandatory for those who hold a leading office in the monastic precinct. ${ }^{66}$

The Ratnaräsis also spells out the less regulated path of the recluse. Since this career is beyond immediate control of monastic sanction and depends on the practitioner's willingness to honour the norms of the Dharma, the sutra's tone changes from the prescriptive to a descriptive one. Rather than postulating strict rules of conduct, it gives practical advice and describes the kind of conduct that benefits a recluse's progress. In essence, these take the form of guidelines in combining the spirit of the Vinaya with the practicalities of forest-dwelling.

As forest life is described after the monastic training, it could be argued that the Ratnarāsis proposes, like the $U g$, some stratification in the training. At first, the practitioner is expected to subscribe to the disciplinarian rigour of monastic training. During this period he is being schooled in the fundamental precepts of Buddhist spirituality. Then, having mastered the concept of non-self and achieved a high degree of mental and moral stability, he is allowed to withdraw into seclusion in order to internalise what he was taught in the monastery during prolonged periods of meditation. Let me stress, however, that while such a succession of training phases would accord with the principles of spiritual purification and seems corroborated on contextual grounds, it is not explicitly proposed in the Ratnarāsis.

The practices themselves build largely on the aspiration and training of the arhant-ideal. ${ }^{67}$ Valid for the recluse and monk alike, they centre on the general categories of síla, samädhi

64. This implies meticulous observance of the prätimoksa rules in general and, in particular, the strict adherence to those Vinaya precepts that regulate the moments when monks and laity come into contact with each other, viz, on alms-round, while travelling, at public ceremonies and so forth. For details on these rules see the Pavāranakkhandhaka and Kathinakkhandhaka sections of the Culavagga in the Khandhaka of the Păli Vinaya.

65. 24, pp. 211.5.6-213.2.3.

66. 24, pp. 212.5.2-213.2.2.

67. See, in particular, 24, pp. 206.5.5-208.3.5. 
and prajña and the seven sets of bodhipākșika dharma. But what is perhaps more surprising than the absence of specific bodhisattva practices, is the general indifference of treatment to the bodhisattva's chief aspiration of universal liberation. Except for one cluster of practices that encourage a generally positive disposition towards people, no explicit commitment to their liberation is made. Clearly, this disinterest in the fate of other beings and the implicit refusal to open the monk's aspirations to the laity points to an early origin of the Ratnaräsis. ${ }^{68}$

\section{Bodhisattva Doctrine}

These findings lead us to our next topic of examination, that is, the position of bodhisattva works in the Ratnaküta in the overall development of the bodhisattva doctrine. I have already pointed to four Ratnakūta sütras $(5,18,19,43)$ that have features linking them with the earliest strands of the bodhisattva doctrine. Since they typically abound in lengthy descriptions of the bodhisattva qualities, I have called them works of inspiration. The earliest attested translations of these sütras go back to the second century $\mathrm{AD}$. While in at least two cases these have been subject to modifications, much of their original thought belongs without doubt to the earliest phase of the bodhisattva doctrine. ${ }^{69}$

Next, we have several sütras where the links with early Buddhist practice are less evident.

68. There are several factors that might have accounted for the Ratnaräsis's unusual doctrinal orientation and the weight that it gives to the observance of monastic precepts. First, one will have to consider the time of its composition. The terminus ad quem of the Ratnaräsis is the end of the third century $\mathrm{AD}$ since one of its Chinese translations (T 310.44) goes back to this period. Beyond that, we know little about its literary history. Other clues that might be of relevance to the Ratnarāsis's historical evaluation are given in a few manuscript fragments that were discovered at the beginning of this century in Central Asia. The language of the fragments is Sanskrit written in the Upright Gupta script (Hoernle, 1916, pp. ix-xxxii, 116). The use of the Upright Gupta script raises the possibility that the manuscript might date back to the fourth or fifth century AD (Hoemle, 1916, p. xiii). While this alone can scarcely be regarded as sufficient evidence for a secure dating, it is in line with the date of the earliest Chinese translation of the Ratnaräsis. For details on the language of surviving manuscript fragments of the Ratnaräśsi, see: Hoernle, 1916, pp. 116-121. There is yet another hint to be gleaned from the few surviving lines of the Central Asian manuscript. This is the Ratnaräsis 's area of circulation. It will be recalled that we have evidence of the Ratnakutata's popularity in Central Asia. Most of these had been discovered in the caves of Tun-huang. The fragments of the Ratnaräsi were located near Kucha, in the extreme north-west of present-day China. The geographical distance that separates both places underlines the Ratnaküța's wide dissemination in Central Asia. More importantly, however, Kucha tells us about the Ratnaräsis's sectarian affiliation. Hsüan-tsang, in his report on Buddhism in Kucha, refers to Kucha explicitly as a town that was under strong Sarvāstivādin influence (Beal, 1884, i, pp. 19-20). Clearly, an affiliation with one of the prevailing sects of early Buddhism would account for the hinayānistic orientation of the Ratnarāśi's exposition. It would make good sense for Sarvāstivādins to take on travels in foreign lands those sütras which teach the basics of Buddhist spirituality and lay down the framework in which it is to be pursued.

69. See: Weller, op. cit., pp. 8, 9, 14-15, 17-23; Schuster, op. cit., pp. 79-82, 325-334. 
These embrace Mahāyāna thought more wholeheartedly and venture beyond the concepts of the early suttas. In these texts we meet with what were probably the first attempts to tackle the newly evolving thought in a systematic fashion. Much of their 'pioneering spirit' is directed at the bodhisattva practice itself which is typically reduced to its component parts. The most important works of this class are the $B d p$ and $R c d$. Both contain detailed descriptions of individual bodhisattva precepts and set tentatively out to reinterpret śrāvaka practices. Yet, they do not draw up a scheme of the path or disparage the maxims of the mendicant ideal.

Then, we have a group of sütras that seemingly take such basic matter for granted and shift the centre of their interest to subtler issues. ${ }^{70}$ For the most part, they define the ways in which the bodhisattva path differs from that of the srävaka. Another trait they have in common is the dexterity with which they employ Mahãyāna philosophy to defend their views on the bodhisattva. This is most graphically carried out in the Aśokadattāvyākarana and Vimaladattāpariprcchā; two texts in which all controversy about the need for purity and restraint is dissolved into Emptiness.

Other advanced bodhisattva sütras place organisational concerns in the centre of their exposition. In them, the issue that receives most attention is the search for an ordered scheme to grade and allocate the practices to path-stages. This coordination is executed most effectively in the Aksayamatipariprccha where practically all major practices are given a place on the path. The nature of the practices themselves is of little concern in these texts.

Finally, there is a small group of sütras that include doctrinally the most advanced thought on the bodhisattva. The complexity of their content indicates that, by then, all the fundamental components of the bodhisattva doctrine were in place. Here, we find few references to the actual bodhisattva training, since familarity with it is apparently taken for granted. The best-known exponent of this category is the Sms.

\section{Literary and Structural Characteristics}

Having explored thematic considerations, I shall examine next the formal aspects of the collection and investigate whether previous findings can be corroborated by stylistic or

$\overline{70 .}$ The most prominent sütras of this category are the Vinayavinišcaya-Upälipariprcchā, Upäyakausalyaparivarta. Other less-known works are the Svapnanirdesa, Viradattagrhapatipariprccha, Sumatidarikapariprcchā and Acintyabuddhavișayanirdeśa. 
literary evidence. Surely, if we are to accept the hypothesis that the Ratnaküta's present format is the outcome of religio-literary arbitrariness, we would expect to find a variety of uncoordinated styles and literary genres. Moreover, its overall tone could be trusted to reflect the fortuity of its composition and exhibit a wide spectrum of religious and literary 'miscellanea'. If, on the other hand, its compilation proceeded on a premeditated plan with a specific objective, the chances are that its contents would display a certain stylistic and thematic coherence. Selected literary genres might be expected to recur in a number of works and favoured techniques of exposition would prevail throughout.

Since the evaluation of these issues is subject to interpretation and rests on personal judgment, it is perhaps wise to concentrate on matters that are verifiable through statistical investigation. It is these that I shall address first.

A feature common to practically all Ratnakūta sütras is the brevity and succinctness of their expositions. With the notable exception of the $B d p$, only a few of the texts exceed one hundred Tibetan blockprint folios. Indeed, the majority fall well short of this mark, with a considerable number averaging thirty folios or less. ${ }^{71}$ The range of topics discussed in these discourses is invariably narrow. Owing to the brevity of the expositions, formal chapter-divisions are found only in seven out the total of forty-nine sütras.

The briefness of the physical format is paralleled by a conceptual succinctness. In most sütras little consideration is given to issues not immediately related to the main topic. Since the use of examples is generally kept to a minimum, the reasoning follows clearly perceptible lines of thought. It is very rare for these to be interrupted by lengthy, picturesque or explanatory digressions. ${ }^{72}$ Despite this conciseness the Ratnaküta is by no means a particularly technical, or even philosophical collection. ${ }^{73}$ The themes that are raised in the discourses explain typically basic Mahāyāna tenets, elucidated with much common sense and persuasively in brilliant dialogues.

71. Out of the total of forty-nine texts, thirteen sütras belong to this category of short works. They are Rkt 10 , $13,28,29,30,31,32,33,34,37,42,43$ and 44 . A further sixteen sutras are of moderate length, that is, they measure seventy-five folios or less. These are $R k t 4,8,9.14,17,21,22,24,25,26,27,35,41,43,46$ and 48. The average length of the remaining twenty works is one hundred folios plus, with the notable exceptions of the Bdp (well over five hundred folios), Pps (three hundred and fifty folios) and Tathagatäcintyaguhyanirdeśa (two hundred and thirty folios).

72. These appear above all in the $R p$ (pp. 34-59), Upäyakausalyaparivarta (pp. 156.2.3 ff.), Mañjuśribuddhaksetragunavyüha and $B d p$ (chapter vii, ix, xii).

73. Exceptions to this rule are those Ratnakūta works which cast their expositions in predominantly abstract, philosophical terms. Good examples are found in the Acintyabuddhavisayanirdeśa, Pitäputrasamägama, Saptaśatikaprajñāpāramitā, Āyūsmannandagarbhāvakrāntinirdeśa, Bhadrapālaśreșthiparipṛcchā, Raśmisamantamuktanirdeśa and Susthitamatidevaputrapariprcchä. 
This leads us to another characteristic that is shared by practically all Ratnaküta sütras, that is, the extensive use of swift-paced, sharp interlocution. Unlike the tendency to prolixity of later strands of Buddhist scriptures, in the Ratnaküta dialogue is employed with great effect throughout. First, by maintaining the focus of the question its dialogues avoid discursive, drawn-out monologues. Second, a frequent variation of the interlocutors ensures that the subject is looked at from various angles. Finally, perhaps accounting for the collection's popularity, the dialogues enliven the discourse and imbue it with a degree of wit and surprise. Controversial issues are not concealed behind long-winded descriptions, but brought to the fore and become subjected to unrelenting probing.

Another stylistic feature that is widely shared by Ratnakūta sütras is the use of lists as a means of summarising the various facets of the bodhisattvacary $\bar{a}$. The most frequent configuration is that of tetrads, closely followed by lists of tens and fives. Some scholars have suggested that these lists might have influenced, or even led to, the compilation of the sütras into one single collection in the first place. ${ }^{74}$ While one cannot but acknowledge the conspicuous frequency with which these mnemonic-type lists recur throughout, I fail to see the rationale for such a motive. ${ }^{75}$ These lists have no intrinsic value on their own except for explication. I find it difficult to accept that a structural expedient, however widespread and well-suited, should have prompted the amalgamation of forty-nine sütras. ${ }^{76}$ I suspect that the regular recurrence of these lists is little more than a consequence of their prevalent use in the early bodhisattva sütras. ${ }^{77}$ It seems quite natural that they should figure in a collection full of texts that place the bodhisattva ideal in the centre of their exposition.

The reasons that lie behind their original incorporation are straightforward and well-attested

74. Schuster, op. cit., pp. 37-38 (also n. 88).

75. To my knowledge, amongst the bodhisattva works there are only three texts that dispose of them altogether, that is, $R k t 31,32$ and 35 . The most frequent configuration is that of tetrads: $R k t 12$ contains thirty-six tetrads, $R k t 17$ thirty tetrads, $R k t 18$ twelve tetrads, $R k t 19$ ten tetrads, $R k t 21$ forty-three tetrads, $R k t+30$ eight tetrads, $R k t 33$ six tetrads, $R k t 35$ four tetrads, $R k t+43$ twenty tetrads and $R k t+44$ sixteen tetrads. Other popular lists are those of ten (particularly frequent in $R k t, 12,17,19,27,35,43,44,45$ and 48) and those of thirty-two (see: $R k t$ 12, 27, 38, 43 and 45).

76. This proposition becomes even more questionable if we recall the kind of sütras included in the Ratnaküta. While such solution is conceivable when it is a matter of relatively unimportant, miscellaneous texts, it is very much less so in a collection of works of the class of the $K p$, Amitäbhavyūha or Ug. Moreover, this explanation does not account for the inclusion of those sütras that are entirely devoid of lists. None of the following ten works contains any lists: $5,6,11,15,20,31,35,38,39,46$. At least five of these contain well-known, important expositions that surely prompted the inclusion in their own right.

77. It will have been noted that virtually all sütras in which such lists appear are works that concentrate in one way or another on the bodhisattva. Indeed, their occurrences are conspicuously infrequent amongst sütras which do not deal with the bodhisattva. This suggests that the employment of series was largely restricted to elucidating the individual aspects of the bodhisattvacarya and not, as it has been suggested, a structural feature common to all Ratnakūta sūtras. 
in many early suttas. ${ }^{78}$ On the one hand, tetrads were undoubtedly intended to facilitate memorisation. For a tradition that relied over many centuries on oral transmission, such structural device was both ingenious and indispensable for its survival. On the other hand, the adoption of enumerations had the effect of organising its tenets and gave the impression of completeness to its structures.

Somewhat surprisingly, this care for order is not always reflected in the overall design of the sütras. More often than not, the sections making up the expositions display little thematic coherence. While in some sütras this does not present much of a problem (either because the subject is well-known from other sources, or because the chain of reasoning is perfectly lucid and self-explanatory), there are several others where the lack of conceptual continuity undermines the intelligibility of the contents. Owing to interruptions in their lines of thought, these texts may appear thematically fragmented.

Finally, I wish to draw attention to some minor, although not altogether insignificant, literary characteristics typical of Ratnakūta works. First, presumably by reason of the prevalent dialogue-format, it is only in isolated cases that we come across extended narrative portions. Generally, narrations are kept short and occur only at places where their inclusion clarifies some enigmatic pronouncement. ${ }^{79}$ This dispensation with embellishing components intensifies the impression of succinctness that is otherwise conveyed by the brevity and thematic conciseness of the sütras.

Buddhist scholarship has shown that several of the Ratnakutta sütras underwent change in the course of their history. ${ }^{80}$ Conclusive signs of such modifications are found, above all, in the $K p$ and $U g{ }^{81}$ Comparisons between the various Chinese translations of the $K p$ have

78. The best example of this type of list is probably found in the Silavagga of the Dighanikaya (D, I, pp. 3-26) where they make up roughly half of the Brahmajälasutta. They occur also in a number of other early suttas in an almost identical form, which suggest that they probably go back to a common, pre-Buddhist source (M I.79; M I.76, 77; M II.3; Mahāvagga v, 8.3). Like the Ratnaküța sütras, its lists address ethical concerns predominantly and give a broad outline of Buddhist conduct. As a matter of fact, many of the issues raised in the tetrads of the Ratnakutta have parallels in those early enumerations. That, in turn, invites the conclusion that the precepts of the bodhisattva, too, might have grown out of these ancient rules of conduct. However, it is difficult to establish a direct link between them, since most of these precepts are little more than general norms of behaviour not exclusive to Buddhists.

79. See, typically, $R c d(24$, p. $248.1 .3-249.5 .8)$ where the Buddha illustrates the practices of the bodhisattva with the help of examples of his own conduct during previous lives. This pattern is a relatively common one and can be observed in a number of Ratnaküta sütras. Other examples are contained in the $R p$ (pp. $34-58$ ) and in the Upāyakausalyaparivarta (24, pp. 156.2.3 ff).

80 Stael-Holstein, 1926, pp. x-xii; Weller, 1965, pp. 8-11; Schuster, op.cit., pp. 79-83; Régamey, pp. ix-x; Python, 1975, p. 5, § 5; Finot, 1901, p. vi.

81. Other texts that contain some indication that their contents might have been subject to revision are the $B h a d r a-v y$ and $R p$. In contrast to the $K p$ and $U g$, however, here the case is less clear-cut and rests largely on conjecture. For a brief evaluation, see: Régamey, 1938, p. 9; Ensink, 1952, p. x-xi. 
revealed that a portion roughly equivalent to a tenth of its total length has been interpolated at the end of the work. This insertion grew over the centuries and found its way eventually into the ninth-century Tibetan translation. ${ }^{82}$ The same methodological principles have also disclosed the composite, evolving nature of the $U g .{ }^{83}$

82. For an analysis of the nature, extent and development of interpolations in the $K p$, see: Weller, op. cit., pp. 9-10; Stael-Holstein, op. cit., pp. x-xiii.

83. An evaluation of the various kinds of bodhisattvas that are described in the $U g$ is given in: Schuster, op. cit., pp. 325, 328 (cf. pp. 184-194, 214-223). On the basis of his seventh-century Sanskrit manuscripts, Bodhiruci seemingly felt the need to retranslate both the $K p$ and $U g$. Thus, it is only the later versions of these texts that are currently included in the Ratnaküta collection. This is true of great many Ratnaküta sütras. The details of their translations are given in Appendix iii. 


\section{Conclusion}

If we take now a step back from the detail of the preceding analysis and evaluate the information we have so far extricated, two conclusions come to the fore. First, it emerges that amongst the forty-nine Ratnakutta sütras there is not a single text that gives a complete account of the bodhisattva career. On the contrary, we have several texts that limit their expositions specifically to a few selected aspects.

The reasons that led to a specific choice of topic vary of course. In some cases, the subject no doubt reflects the doctrino-historical circumstances that prevailed at the time of composition. In others, the selection was probably the outcome of careful reflection in response to acutely felt omissions, new inspiration or reinterpretation. In others again, a particular preference might have been prompted by recurring misinterpretation or misdemeanour. Whatever the reasons for the various styles, topics and organisational features, their diversity makes it quite plain that the texts drew on a multiplicity of backgrounds and motives for inspiration.

This leads us to the second conclusion. Amongst the twenty-three sütras under consideration, there are not even two works that concur exactly in their approach to the bodhisattva ideal. In practically every sütra, the focal-point rests on a different assumption or exemplifies some specific point of view. Moreover, the texts differ not only in thought and structure, but frequently display methodological dissimilarities also.

We have noted further a large degree of coordination and complementarity between the individual sütras. Indeed, there is not a single, major issue that is dealt with twice. Repetitions occur only in minor instances, or at occasions rendered inevitable by the context. Needless to say, this coordination is not the merit of the texts themselves, but attributable to the learning and skill of the person(s) who brought them together in the Ratnaküta. The outcome of their endeavours has been of great success, providing a well-balanced, comprehensive account of the bodhisattva that covers virtually every key idea of his career.

It has been argued in the past that this complementarity is coincidental and a mere by-product of an arbitrarily executed textual selection. While it is difficult (if not impossible) to establish that this was not the case, I doubt that a random assortment of this size could possibly yield such perfectly consistent patterns of thought. Even less, if we recall the proclivity to repetition 
and assimilation (in both content and approach) that is a feature of Mahāyāna sūtras in general. A haphazardly compiled collection would undoubtedly have inherited this propensity for reduplication. Furthermore, echoing local or sectarian preferences, its contents would almost certainly tilt in favour of some prevalent textual tradition. There are no indications pointing to the predominance of any one specific tradition amongst Ratnakūta works.

But let us return to the objection that it is precisely because the sütras do not exhibit an all-embracing conceptual framework that they cannot have been assembled to a premeditated plan. While it is true that there are several areas of thought that stand in isolation, rather than stressing the connections that do not exist (and I admit there are some), I propose to look at the issues linking the individual texts. Of these, the most conspicuous is the constantly recurring reference to the bodhisattva ideal. The other, most noticeable, connecting element is a close affinity in literary style. With a few exceptions, practically all forty-nine texts are written in a very factual, perspicuous and concise idiom that forgoes the stylistic niceties of long-winded embellishments.

One should also bear in mind that what is apparent to us today might not have been so in the middle of the first millennium $\mathrm{AD}$ (and vice versa). It is entirely conceivable that the compilers might have sought to implement a scheme whose logic is no longer perceptible by us. It would be a mistake to conclude that because we fail to discern any intent behind its present structures no such objective ever existed.

Finally, one is surely ill-advised to proceed from the assumption that its compilers had access to the whole range of Mahāyāna scriptures as we know it today. The wide dissemination of Mahãyāna thought renders it improbable that, even if the collection had been assembled at a time when all currently known Mahāyāna sūtras were already extant, its compilers could have been aware of all of them. From their point of view the collection might have been fully comprehensive though today we know that this may not be the case.

Whichever its omissions with regard to Mahāyāna doctrines in general, we have seen that the Ratnakūta's treatment of the bodhisattva ideal is all-inclusive and considers every relevant career-aspect. What is more, the general picture emerging of the bodhisattva is extremely well-balanced. The scale of this systematisation suggests that calculated efforts were at work at least during those phases when the bodhisattva works were being put together. It is too early to say if such a plan existed for the other topics, although it is difficult to see why it 
should have been specific to the bodhisattva.

In chapter one, I proposed that the Ratnaküta might have been compiled for missionary purposes. This view appears corroborated by the predominantly non-technical nature of its bodhisattva sütras. Clearly, more than anything else it is the initial appeal of a text that determines its success in persuading listeners of the logic of its propositions. For new thought to gain acceptance it is necessary to use simplicity in reasoning and an inspiring tone. We have seen that in the Ratnaküta these two qualities are widely shared by its bodhisattva works.

The role assigned to the $B d p$ in this missionary process rested on two of its features. First, it was highly esteemed for the detail in which it describes the training of the bodhisattva. Above all, its exposition was commended for the treatment of the six perfections. Crossreferences in the collection itself suggest that, at least as far as the pāramitā are concerned, the $B d p$ was thought to be at the very heart of the Ratnakūta's vision of the bodhisattva.

The $B d p$ also contributed to the missionary efforts by furnishing the collection with the hugely popular jātaka-genre. To the present day, iconographic depictions and wall-paintings across Asia bear witness of the repute and affection in which the accounts of Sākyamuni's former lives were held. In the $B d p$, these were taken up and coupled with the training of the bodhisattva. The outcome was twofold. On the one hand, the jätaka served to authenticate the practices themselves. On the other hand, their role was to inspire faith in the image of the bodhisattva. They not only made the scope of the new ideal clear, but more importantly for the conversion of other peoples, they provided the urgently required proof that its sublime accomplishments were attainable. Since the $B d p$ is the only major Ratnakutta text combining the bodhisattva ideal with the former exploits of Sākyamuni, it must have enjoyed great popularity amongst the newly converted peoples of Asia. 


\section{Chapter Four}

The Bodhisattva Doctrines and Practices in the Bodhisattvapitaka within the Context of other Scriptural Traditions

Our discussion of the $B d p$ 's structure in chapter two has shown that large parts of its exposition are dedicated to the six perfections (päramitā). This fact has given great acclaim to the $B d p$ and developed into something of a hallmark by which it came to be widely known. In addition to the parramită, two other sets of practice are singled out and granted special status in the $B d p$, that is, the immeasurables (apramanna) and the means of conversion (samgrahavastu). Taken together, these three sets of practice constitute the skeleton of the bodhisattvacarya $\bar{a}$ in the $B d p$.

The description of the path is not limited to these cardinal areas of instruction, but encompasses a number of other well-known practices. However, these are rather subordinate in rank and are incorporated in the discussion of the päramitā. Prominent examples include the superknowledge (abhijñā), learning (śruta), 'skill' (kauśalya), unique knowledge (pratisamvid), reliance (pratisarana), accumulation of merit (punyasambhära) and pristine cognition (jñānasambhāra), thirty-seven factors of enlightenment (bodhipākșika dharma), perfect mental quietude (śamatha) and insight (vipaśyanā).

In addition to these well established groups, we meet with a number of precepts that are discussed individually. ${ }^{1}$ The majority of these is found in chapter eleven where they are introduced in a list of seventy-two types of learning and involve such practices as penetration (praveśa), good conduct (pratipatti), application (prayoga) vision (darśana), reflection (manasakāra), reverence (pradakșina) and attentiveness (avikșepa). ${ }^{2}$ Although they are classed together under the heading of learning at the beginning of chapter eleven, the exposition of these practices in the text itself does not follow the order or organisation of their introductory listing.

1. In my discussion of the bodhisattva practices, I shall consider only those practices that are known to promote and hence precede the attainment of buddhahood. By this criterion, the attributes, practices and powers of the Tathāgata fall outside my investigation. The contents of chapter four which deals exclusively with the buddha-qualities-most notably the powers (bala), assurances (vais̄äradya), wonder-working powers (rddhi), liberations (vimoksa), great compassion (mahäkarunāa) and exclusive buddha-dharma (ävenika-dharma) - has therefore been excluded.

2. I have provided a list of these practices in Appendix i. 


\section{The Thought of Enlightenment}

The first reference to the bodhisattva in the $B d p$ occurs in chapter three. Chapters one and chapter two are introductory to the whole exposition and do not consider the training of the bodhisattva. In chapter three, entitled 'On the Thought of Enlightenment', Săriputra raises the topic of the bodhisattva ideal by asking the following question: ${ }^{3}$

"By what means do [bodhisattvas] enter into enlightenment?

What is the goal of these heroes?

How do they accomplish excellent enlightenment?

Please explain these distinguished teachings.

How do the heroes act

In order to [dispense] medicine to all living beings?

Through the production of what kind of dharma

Do they become buddhas, the most excellent of men?

How do [bodhisattvas] convert sinners

After they dwelled on the seat of enlightenment?

How do they attain supreme and perfect enlightenment

After they traversed ten million buddha-fields?"

In response to this question, the Buddha speaks of the thought of enlightenment (bodhicitta) and says: ${ }^{4}$

"O Sāriputra, when a bodhisattva is in possession of a certain single dharma, he takes hold of buddha-qualities and other immeasurable [qualities]. Which is this single dharma? It is the thought of enlightenment of excellent intent. O Saariputra, when he is in possession of just that single bodhisattva dharma, he shall grasp the

3. R, folio 81.4-7.

4. $\mathrm{R}$, folio 81.3-5. 
buddha-qualities and other immeasurable [qualities]."

In the ensuing discussion, the Buddha considers the thought of enlightenment from several points of view. First, he examines its nature and attributes. Particular attention is given to the bodhisattva's intent (äsaya). In the $B d p$, intent is primarily described as a stabilising factor that assists the generation of the bodhicitta. ${ }^{5}$ As an ethical concomitant to the bodhicitta, äsaya is rooted in conventional experience and arises from compassion. Intellectually, it operates in the cognitive realm specifically with regard to the vision of true reality. Eventually, these interacting currents are drawn together to result in the unfolding of 'pure intent'.

The other important concomitant to cittotpāda is determination (adhyāśaya). However, owing to their conceptual proximity, differences between äśaya and adhyāsaya tend to blur. Some clarification is provided by the description of adhyäsaya in the Bbh. Here, adhyāsaya is characterised as persistence, understanding and resolve-preceded by faith and insight in the Dharma-towards the buddha-qualities. ${ }^{6}$ It is therefore primarily concerned with the bodhisattva's own spiritual progress. ${ }^{7} \bar{A}$ śaya, in contrast, designates a broader principle and is more intimately connected with the cittotpäda, since its main purpose is to achieve rapid progress in the implementation of the vow. According to the $B b h$, it is divided into the subcategories of seven virtuous intentions for sentient beings (kalyānāsaya) and ten pure intentions (äśayaśuddhi). ${ }^{8}$ Above all, however, we find that äsaya promotes the practice of the six perfections to which it lends impulses of six different kinds. ${ }^{9}$

Intent and determination are often complemented by correct conduct (prayoga) as the third major factor influencing the progressive implementation of the bodhisattva's resolve. ${ }^{10}$ In the $M s l$, we read to this effect: ${ }^{11}$

The first production of the thought of enlightenment of the bodhisattva is likened to earth because it is the basis from which all buddha-qualities and related accumulations spring. Accompanied by intent (äsaya), the production of the thought of enlightenment resembles fine gold because his intent towards the welfare and

5. Msl, p. 14.5-9.

6. $\quad B b h, \mathrm{pp} .313 .4-314.8$.

7. $\quad B b h$ p. 18.17 (cf. $M v s$, p. 85.1; Yamaguichi, 1934).

8. $\quad B b h$ pp. $312.5-313.3,333.4-16$.

9. $M s l$, p. $102.13 ;$ Msg, pp. $188 \mathrm{ff}$.

10. Cf. Kawamura, 1983, p. 141.

11. $M s l$, pp. 14.27-15.6. 
benefit [of beings] is not susceptible to change. Accompanied by correct conduct (prayoga), it resembles the new moon on the fifteenth day of the month because his virtuous qualities (kuśaladhama) increase. Accompanied by determination (adhyäsaya), it resembles fire because he aquires more and more attaiments like a fire that consumes all types of fuel."

In the Süträlamkāaravrttibhāssya ${ }^{12}$, these categories of cittotpāda signals four junctions in the bodhisattva's career and are linked with the attainments of each level. ${ }^{13}$ Thus, the first type of cittotpāda is associated with adherence ( $\bar{a}$ dhimokșika) operating during the preliminary phase of training (adhimukticaryābhümi) ${ }^{14}$ The second cittotpāda is dominated by pure determination (śuddhädhyāsaya) and leads to progress on the first seven stages. It is called pure because it is free from the subject/object dichotomy and because it is attained through equipoise (upeksāa). The third type of cittotpāda is characterised by its ability to accomplish the maturation (vaipākika) of sentient beings, because at this level (stage nine and ten) non-discriminating awareness (avikalpajñanna) arises in conjunction with the spontaneous practice of the päramitā. Finally, the fourth kind of cittotpāda, operating at the tenth stage, is called obstruction-free (anāvaranika) since it is untainted by misconceived emotion and discursive thinking. ${ }^{15}$

The above exposition of the cittotpa $\bar{a} a$ is clearly advanced and draws on a rich heritage of ideas. An early predecessor to this scheme is found in the Bdp. Like the Sütrālamkāravrttibhäsya, it distinguishes several phases in the generation of the thought of enlightenment and proposes a certain dynamic. In all, the $B d p$ speaks of ten forms of cittotpāda. However, their allocation

12. TTP, 108, p. 233.2.6-3.7.

13. $M s l$, pp. 16.5-17.9.

14. The relevant passage in the $M s l$ (p. 14.5-6) runs as follows:

"That mind directed towards enlightenment is zealous application (ädhimoksika); it is pure in determination (adhyāsaya) on another [stage]. It is thought of as a matured state, and likewise, freed from obstruction."

15. The division of the cittotpāda is most elaborate in the Abhisamayälamkāra (pp. 18-37) where it is divided into twenty-two kinds of cittotpāda. In agreement with the $M s l$, the first three are said to be accompanied by chanda, äsaya and adhyäśaya marking three successive stages during the ädikarmikasambhärabhümi. In disagreement with the $M s l$, the fourth cittotpada is attended by prayoga. It operates on the adhimukticaryābhümi corresponding to the prayogamārga. Next follow ten kinds of cittotpāda each of which is associated with one of the ten perfections. The following five cittotpa $\vec{d} a$ are accompanied by the abhijñā, punyaljīānasambhära, bodhipākssika dharma, śamatha/vipaśyanā and dhäranīpratibhäna that, taken together, account for the viśeșamärga of the last five stages (Kośa, vi, p. 278). Cittotpāda number twenty is attended by the four dharmoddana and becomes functional on the preparatory path of the buddhabhümi. Finally, the last two cittotpāda are generated in two distinct phases of the buddhabhümi where they are accompanied by the ekayänamärga and the dharmakäya. 
to specific path phases it rather vague and bears little resemblance to the ten stages of the $D b h .{ }^{16}$ Curiously, the ten cittotpāda are not included in chapter three but occur in the śilapāramitā chapter.

According to this scheme, the first two cittotpãda are most fundamental in that they bring about understanding of impermanence, impurity and insubstantiality of the body and carry as reward-if sustained by Tathāgata worship-the attainment of the perfect buddha-body. ${ }^{17}$ The third and fourth kinds of cittotpāda concern mistaken conduct of the past, in particular lack of reverence towards superiors and ill-contemplated pursuit of sense pleasures. Awareness and correction of these faults lead to rebirth among men and place the bodhisattva in contact with virtuous friends. ${ }^{18}$ As a collateral, the fifth cittotpāda bestows insight into one's past conceit and violence, makes the bodhisattva understand the workings of the law of karma and removes confusion that led previously to evil conduct. Through possessing these five kinds of cittotpāda, the bodhisattva becomes fearless, attains means (upāya) and knowledge (jñana) and increases his meritorious deeds. ${ }^{19}$ Having understood the causal link between ignorance, irreverent comportment and ill-regard for the Dharma, the bodhisattva generates the sixth, seventh and eighth cittotpāda that render him inseparable from religious instruction. He is accomplished in learning, benevolence, buddha-worship and dwells in the company of the noble ones, abiding in high abodes. ${ }^{20}$

Through the ninth cittotpäda the bodhisattva perceives that aimlessness used to mar his conduct. It calls to mind the need for constant mental concentration on enlightenment and unreserved devotion of all resources to its attainment. Furthermore, the ninth cittotpāda gives a clear picture of the bodhisattva's resolute wandering and cites numerous practices that pertain to it. These include faith, honesty, solitude, reverence, modesty, chastity as well as pursuit of the pāramitā and bodhipākșika dharma. At this stage, being rewarded for insight into past mistakes, the bodhisattva becomes familiar with the perfections (which he now pursues with great vigour) and, supported by pristine cognition and merit, prepares to take up the seat of enlightenment. ${ }^{21}$

\footnotetext{
16. Note that also the Madhyamakāvatära (Mavbh, pp. 12.13-13.1) and Daśabhümika speak of ten cittotpāda. Apart from the number and a certain dynamic towards the more advanced path-stages, the $B d p$ does not seem to share much with these schemes. This is not surprising, if we recall that the $B d p$ ignores the plan of the ten stages while it is the rationale behind the ten cittotpāda in the Daśabhümika and Madhyamakāvatāra.

17. R, folio 309.5 .

18. $\mathrm{R}$, folio 314.2 .

19. $\mathrm{R}$, folio $320.6 ; 324.5-325.3$.

20. R, folio 238.4-329.1.

21. $\mathrm{R}$, folio 336.6 .
} 
Finally, the bodhisattva fully grasps the eminence of his teacher and appreciates his erudition in faith, moral conduct, learning, modesty, chastity, renunciation and wisdom. This prompts him to express approval of the teacher's thinking and to pay lip-service to all instructions. He is now himself accomplished in moral conduct and becomes a receptacle of buddhacompassion. ${ }^{22}$

In the discussion of the cittotpada in chapter three, we find no allusions to the existence of this sketch in the sillapāramitā chapter. Its characterisation of the thought of enlightenment is kept general and sheds light on only two areas. First, it describes the attributes that differentiate the cittotpäda from ordinary mentation. By and large, these attributes correspond to those of the bodhisattva's intent. That is to say, it is pure, steady, persistent, luminous and so forth. Then, also in analogy to intent, it is portrayed as the foundation of buddha-qualities, including the fivefold dharma-aggregate (dharmaskandha), powers, assurances and a venika dharma. ${ }^{23}$

In the next passage we learn about the fruits that result from the cittotpäda and äsaya. The presentation is very straightforward and consists essentially of an enumeration of the benefits that accrue from the cittotpāda and āsaya. Already at this early stage the bodhisattva is destined for enlightenment and attains a physical appearance beyond blemish; he is invincible, not affected by worldly dharma, skilled in the path and becomes a benefactor, guide and refuge to all sentient beings. ${ }^{24}$ In particular, he attains clear vision (vidarśana) that establishes faith in the law of karma and causes him to refrain from the ten non-virtuous paths of action (akuśalakarmapatha). ${ }^{25}$ If he receives early support from spiritual friends, he comprehends dependent co-origination, culminating in true dharma vision. ${ }^{26}$

Considerable emphasis is given to the notion of renunciation, in general, and the need to become a monk, in particular. Ordination into mendicant life is considered a natural imperative as it provides the framework to a successful completion of the practice. ${ }^{27}$

Three factors that are to recur throughout the exposition of the training figure as concomitants to the cittotpāda. These are learning (śruta), conscientiousness (apramäda) and correct reflection (yoniśo manasakāra). ${ }^{28}$ Their areas of application are briefly dwelt on, viz., knowledge of teachings for learning, constraint of senses for conscientiousness and insight

22. $\mathrm{R}$, folio $340.4-6$.

23. $R$, folio $85.1-4$.

24. $\mathrm{R}$, folio $85.4-86.4$.

25. $\mathrm{R}$, folio $87.1-3$.

26. R, folio 88.4-91.3.

27. $R$, folio $92.1-3$.

28. R, folio 92.5-96.4. 
into causation and the non-existence of dharma for correct reflection. These allow the bodhisattva to penetrate the four axioms of the teaching (dharmoddana), proposing that karmic formations (samskāra) are impermanent and suffering; that dharma are non-self and calm nirvāna. ${ }^{29}$ Appreciation of these postulates prompts the bodhisattva to comprehend impermanence; to eliminate all traces of desire; to produce the entrance to liberation and meditation on emptiness and to become acquainted with the notion of signlessness.

If we turn now to evaluate the $B d p$ 's vision of the cittotpāda and compare it with the schemes found in other sources, we note at first a general consent on its chief elements. The $B d p$ agrees that the two most important components of the bodhicittotpäda are an unshakable desire for enlightenment (sambodhikāmanāsahagata) and a paramount concern for the welfare of all other beings (parārthālambana).$^{30}$ By implication, it also recognises two separate phases of its production, that is the actual taking of the vow (bodhipranidhicitta) and the ensuing implementation (bodhiprasthānacitta).

Many Mahāyāna sūtras argue that the bodhicittotpāda is not a static entity generated only once at the beginning of the path proper but that it is continuously retaken and evolves through practice. In the $A k n$, for instance, it is generated in conjunction with the accumulation of merit and pristine cognition, six perfections and four immeasurables which determine the attainments that result from its generation. ${ }^{31}$ This is also the view of the $B d p$ since it proposes at several places a close association between the cittotpāda and pāramitā and other practices. $^{32}$

Differences occur only when we look in detail at the psychological processes that prompt and accompany the generation of the thought of enlightenment. I shall now turn to the Bodhisattvabhümi in order to explore the nature of some of these differences.

In line with its overall organisation, the $B b h$ introduces the first raising of the bodhicitta as the second support ( $\bar{a} d h \bar{a} r a)$ of the training. The treatment is divided into two sections. To begin with, the text lays down the attributes and modes of the cittotpāda. It suggests five different approaches of investigation. First, there is a perfect resolution (samyakpranidhāna) that is upheld throughout the training and generates the aspiration (prärthana) for universal liberation. ${ }^{33}$ This aspiration itself represents the cittotpāda proper. ${ }^{34} \mathrm{Next}$, the $B b h$ defines

29. R, folio 96.5-97.5.

30. E.g., $A k n$, pp. $39.5 .4-40.2 .5 ; B b h$, p. $12.6-13$.

31. $A k n$, pp. 39.5.7-40.1.4.

32. R, folio 84.7-85.3.

33. $B b h$, p. 12.3 . 
the scope and object (álambana) of the bodhicitta, namely, enlightenment for himself and deliverance of his fellow beings. As an auspicious force in its own right, the cittotpada accumulates (samcaya) all those roots of virtue occasioning enlightenment and weakening the three root evils in beings. Besides, it is seen as the root of enlightenment, source of the bodhisattva's compassion and foundation (samniśraya) of moral conduct.

The conditions (pratyaya), causes (hetu) and powers (bala) that bring about the engendering of the thought of enlightenment are as follows. ${ }^{35}$ As for the conditions, the $B b h$ gives learning about the Tathāgata's miraculous powers, hearing the Doctrine and observance of the imminent decline of the Dharma. ${ }^{36}$ Each of these factors suffices to inspire the generation of the bodhicitta. The causes that prompt the cittotpäda are of a more personal and immediate nature. ${ }^{37}$ They include the cause of lineage (gotra) that leads inevitably to cittotpãda due to previous achievements, the presence of virtuous friends (kalyānamitra), compassion, knowledge, meditation, investigation and great enthusiasm for enlightenment. ${ }^{38}$ The powers that inspire the cittotpāda generally depend on the bodhisattva's own capabilities. In particular, they are brought about by the roots of virtue accumulated during previous rebirth or meritorious conduct in the present life. ${ }^{39}$

Having generated the bodhicitta, the bodhisattva becomes immediately a field of merit that others can draw on through reverence and devotion..$^{40}$ Thus, the raising of the thought of enlightenment launches him automatically onto the path and creates a valuable source of merit. Moreover, it increases the bodhisattva's resources derived from his gotra, guarantees success with magic spells (mantrapadāni) and bestows experience in dealing with the lower

34. Bbh, p. 12.9 .

35. In the $D b h$ (Das $a-b h$, p. 15.1-6), we learn that the production of the thought of enlightenment is inspired by the fourth of ten vows taken by the bodhisattva while he dwells on the early phase of the pramuditābhīmi:

"In order to attain the bodhicittotpāda, supported by the true instruction of the path of the stages that incorporates the entire bodhisattvacaryā ... he takes the fourth vow (pranidhāna)."

The $M s g$, distinguishes three motives prompting the generation of the thought of enlightenment (iii.5). These are (1) recognition that innumerable beings reach enlightenment every moment, (2) the wish to attain the intent (ásaya) to practice generosity and related virtues in order to attain enlightenment; (3) desire for universal perfection arising from unlimited moral conduct.

36. $B b h$, pp. 13.21-15.17.

37. Compare these with the causes that are given in the $M s l$ (p. 14.10-15) which speaks of compassion as the

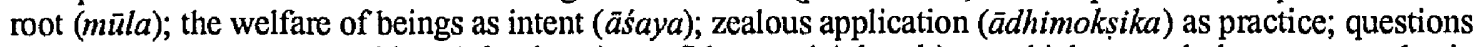
relating to knowledge as object (álambana); confident zeal (chanda) as vehicle; moral observance as basis (pratisth $\bar{a}$ ); encouragement and approval of giving to adversaries as obstacle; faith in virtue as advantage (anuśamsa) since it accumulates merit and knowledge; constant application to the perfections as deliverance (niryāna).

38. $B b h$, p. $15.11-17$.

39. $B b h$, p. 17.8-21.

40. $B b h$, pp. 19.19-20.27. 
destinies. $^{41}$

If we now revert to the $B d p$ 's cittotpa $\bar{a} a$ exposition and compare its vision with that of the $B b h$, the first thing to notice is the limited scope of the $B d p$ 's explanations and its basic logical structures. In the $B d p$ we meet with repetitions and a fair amount of inessential material. Structurally, although not entirely without its own internal logic, the $B d p$ 's account therefore lacks the organisation of the $B b h$ 's description.

In content, however, the two works do not stand as much apart as it might seem at first sight. They share the two fundamental elements of the cittotpãda, that is, the personal aim of full enlightenment and the aspiration of universal liberation. Furthermore, the two texts agree that the cittotpāda functions as the root of compassion and provides the foundation of moral conduct. While this point is not illustrated in the $B b h$, the $B d p$ refers to the ten virtuous deeds (kuśalakarmapatha). ${ }^{42}$ Both works also concur in their evaluation of the impact of the cittotpāda by making tathāgatahood the secured long-term achievement. ${ }^{43}$

Differences arise only when we turn to the conditions that induce the cittotpäda. The $B d p$ does not cite any of the factors that are given in the $B b h$ as cittotpa $\overline{d a} a$ causes. Association to virtuous friends and learning, for instance, are given amongst its concomitants, but not explicitly as causes. ${ }^{44}$ Other factors, such as fearlessness, lineage (gotra) or awareness of the decline of the Dharma do not figure at all in the $B d p$, whereas learning of the buddha-qualities is mentioned as a motive.

With regard to the advantages that accrue from a successful cittotpāda, the $B d p$ and $B b h$ run very close in spirit. According to the $B b h$ the bodhisattva produces at first the gates (dvāra) that lead to virtuous practice that turns him into a supreme field of merit. ${ }^{45}$ In the

41. According to the $D b h$, the bodhisattva immediately upon generating the thought of enlightenment achieves ten rewards. (1) He surpasses the stage of ordinary men; (2) he embarks on the fixed career (niy $\bar{a} m a$ ) of the bodhisattva; (3) he is born in the Tathāgata family; (4) he becomes faultless in all kinds of speech; (5) he abandons all worldly conduct; (6) he enters into supramundane conduct; (7) he dwells in the ultimate essence of bodhisattva practices; (8) he is settled in the bodhisattva-abode; (9) he reaches the equality of the three times; (10) he becomes fixed in the Tathāgata lineage certain of perfect enlightenment (Daśa-bh, pp. $11-12, \mathrm{U})$.

In the Madhyamakavrtti (xviii, 5), quoting the Maitreyavimokșa, we are told that:

"Just as the son of a king almost immediately after his birth-being in possession of the royal characteristics - surpasses by the greatness of this lineage (gotra) all officers, even the most senior ones; in the same way, the bodhisattva almost immediately on generating the first thought of enlightenment-being born in the royal family of the Tathägata-surpasses even the most senior srāvaka and pratyekabuddhas by virtue of the power of his bodhicitta and compassion."

42. $\mathrm{R}$, folio $87.1-5$.

43. $R$, folio 85.2.

44. R, folio $88.2 ; 88.4 ; 89.4-90.1$.

45. $B b h$, p. 19.3-17. 
$B d p$ a major point is the bodhisattva's permanent escape from the grasp of Māra and the ensuing immunity from worldly dharma ${ }^{46}$

The most interesting difference lies in the role they ascribe to intent (ásaya). We have seen that in the Bbh (and $M s l$ ) äsaya figures alongside adhyassaya and prayoga as the most important concomitant of cittotpāda. Thus it comes as a surprise to learn that neither adhyāśaya nor prayoga are present in the $B d p$ 's treatment of the cittotpāda. What is more, ásaya is not portrayed as an 'independent' principle supportive of the cittotpāda, but as an attribute of the latter. No doubt, these differences are important and probably ascribable to the different dates of composition of the $B d p$ and $B b h$. The treatment of the cittotpada in the $B b h$ is clearly doctrinally more advanced and includes several issues that are not considered in the $B d p$. In essence, however, their evaluations of the scope and function of the cittotpāda agree and are founded on similar assumptions about its role in the bodhisattva training.

46. R, folio 85.4-86.2. 


\section{The Four Immeasurables}

Having introduced the spiritual foundation of the bodhisattva ideal, the $B d p$ spells out the buddha-qualities. This is done in chapter four. The reasons for dealing here with the buddhaqualities I have discussed in chapter three. I excluded them from my investigation, since they do belong to the bodhisattva practice proper.

The first bodhisattva practices that are expounded in the $B d p$ are the four 'immeasurables' (apramāna). ${ }^{47}$ These include benevolence (maitrī), compassion (karuñā), sympathetic joy (muditā) and equipoise (upekșa ). While the sequence in which these are discussed corresponds to the standard order of their presentation, their interpretation displays several divergences from other treatises on the apramāna. ${ }^{48}$

For the historical Buddha the practice of the appamañna was always twofold. First, its four members - benevolence towards sentient beings, compassion with their suffering, sympathetic

47. Alternative titles for this group of practices are brahmavihära (residences of Brahmā)—a term that is particularly widespread in early canonical literature-and cetovimukti (thought liberation).

In Pāli sources, we can distinguish two principal conceptual contexts for the brahmavihära. First, there is the famous sutta where the Buddha is shown instructing Dona on the various types of brahmins (A III, pp. 224-5). Here, among a long list of qualities, the Buddha cites the four instructions as practices that assist in making a brahmin equal to Brahmā. The Buddha goes on to say that a brahmin who pursues the four 'ways of living like Brahmä' (brahmavihära) attains rebirth in the charming world of Brahmā. Elsewhere, Brahmã himself is described as possessing universal benevolence (M I, pp. 370-1) -a subject that was taken up by the commentators (Manorathapürani ii, p. 204)-showing that if an individual developed Brahmā's virtues, he himself could attain the status of Brahma after death. As the 'ways of living like Brahmā' refer to the cultivation of maitri, etc., in a meditative context (D I, pp. 250-1; Vism, iii.30; Aronson, 1975, pp. 81-83) - usually at the level of the first dhyanna-the commentaries take them to represent absorptions or states of mind that spring from the cultivation of benevolence, etc., $(P s, \mathrm{ii}, \mathrm{p}$. 353). We have therefore two principal ways of translating the term brahmavihära. First, if interpreted as 'way of living like Brahmā' it refers to an individual who cultivates universal benevolence just as Brahmā does. Second, if looked at from a meditative context, brahmavihära is best understood as 'sublime way of living' modelled on the fourfold instructions of the Teviggasutta. The latter interpretation is favoured by Buddhaghoșa, although he acknowledges both possibilities (Vism, ix.106). For a full treatment of these variants in interpretation, particularly with regard to the Theravāda commentarial tradition, see Aronson, 1975 , pp. $96-110$.

48. To my knowledge, the only comprehensive study of the four immeasurables to date is that by H.B. Aronson, entitled: Love, Compassion, Sympathetic Joy and Equanimity in Theraväda Buddhism; $\mathrm{PhD}$ Dissertation, University of Wisconsin, 1975. In addition, drawing on the findings of his doctoral research, Aronson published several articles and one monograph on this subject (see: bibliography).

References to the apramâna (brahmavihāra) in Buddhist sources are numerous. In the nikãya, useful material is found in D II, p. 196; III, p. 220; Th, i.649; Jätaka i, p. 139; II, p. 61. For a Theravāda interpretation, see: $V i s m$, i, pp. 111, 295; $A s$, p. 192. For Sanskrit sources, see: Kośa, viii, pp. 196-203; Saddhp, p. 142; Dhsgr, § 16; Kp, p. 15, § 25.25; Msl, pp. 121.10-124.2, 163.13-172.20, 184.3-8; Bbh, pp. 241-49. Other references are found at $A m r t$ (B), pp. 188-9; Abhidh-d, p. 428; Msg, x.10, pp. 290-91; Akn, 34, pp. 56.3.7-58.5.6; Pañca, pp. 181-183, $V \mathrm{~km}$, pp. 96, 155. For further references in Chinese (translations of) Buddhist texts, see: Lamotte, 1973, p. 52*. 
joy with their happiness and equipoise towards sensual attachment and hostility-played a role in placing the practitioner in the heavenly abodes. Second, finding their way into the gnoseologic scheme of the Buddhist path, the appamañna assumed importance in the meditative processes that culminate in liberating insight- the pinnacle of Buddhist cognition. ${ }^{49}$

In a well-known passage from the Atthakasutta, the appamañna are cited as one of eleven practices that liberate the mind, eliminate all hindrances and prompt freedom from bondage. ${ }^{50}$ In essence, they are seen as an integral part of those meditations that secure a high rebirth and further progress on the path to liberation up to the stage of the non-returner. According to the Anguttaranikāya ${ }^{51}$, if accompanied by insight in the particular and general features (svasämänyalakkhana) of aggregates, they lead to the realisation of the first three paths and fruits, while for those who are established in insight and pursue equipoise at the level of the fourth absorption attain rebirth in the Suddhāvāsa heaven. ${ }^{52}$

The mental processes leading to the generation of insight in conjunction with the appamañna are laid down in the Vatthüpamasutta. ${ }^{53}$ Here, the Buddha describes how a monk on realising the defiled nature of greed, conceit, hostility and so forth attains a steadfast conviction in the triratna and-by means of cultivating the appamañña-acquires true cognition. Buddhaghoṣa explains that the main advantages of their cultivation, as a basis supporting insight during meditation is that they free the mind from defilements through suppression. ${ }^{54}$ As the resulting

49. Despite some excellent research in this field, the exact origin of the four immeasurables has not yet been resolved. Back in 1928, C. A. F. Rhys Davids pioneered the view that they might not be the brainchild of the Buddha but that he adopted them from some other teacher. One of the central arguments to this hypothesis has always been a passage in the Samyuttanikãya (S V, pp. 115-21) where a group of non-Buddhist śramana let it be known that they too cultivate a practice involving benevolence, compassion, sympathetic joy and equipoise and wish to learn in how far theirs differs from the Buddha's. Supporting evidence in non or pre-Buddhist sources is rather thin and limited to several passages in the Upanișad (Chänd. 815.1). Buddhist scriptures themselves (D II, pp. 220-252) preserve an account where the Buddha, during previous lives, receives instructions in the absorption of compassion from the Brähmana tradition. A similar point is made in the Mahāsudassanasutta (D II, pp. 186-7) where we learn that, as a bodhisattva, he practised benevolence, compassion, sympathetic joy and equipoise. Today it is virtually impossible to determine whether the accounts of the Buddha's previous conduct are accurate depictions of his pre-enlightenment training or whether they simply superimposed post-enlightenment practices on his early struggle to buddhahood. What appears certain, however, is that in the discourses they were not considered unique to the Buddha's vision but practised also in early non-Buddhist circles (Arsonson, 1984, p. 21).

50. M I, pp. 349-51.

51. Cited in Manorathapüranī, iii, p. 126.

52. A similar, though not identical scheme is proposed in the Haliddavasanasutta (S V pp. 119-121) where the thought of benevolence leads to rebirth in the realm of the Subhakitana gods; the thought of compassion in the sphere of the inifinity of space (ākāsannantyāyatana); the thought of sympathetic joy in the sphere of the inifinity of consciouness (vijñannantyāyatana) and the thought of equipoise in the sphere of nothingness (äkimcanyayatana). The main difference between the schemes is that the Haliddavasanasutta allows for rebirth in the arüpyadhātu while the Manorathapüranī restricts becoming to the rüpadhātu.

53. M I, pp. 36-9.

54. Vism, p. 693. 
mental clarity persists for some time after the yogin has emerged from this meditation, he is able to apply this newly gained awareness to the development of insight in the characteristics of the component parts of that particular meditation. The four appamañña thus play a significant role in the process of mental purification and operate as a force that conduces to dharma discernment.

On another occasion, the Buddha connects the appamañna practice with the gnoseologic training by differentiating the usual instructions leading to rebirth in the heavenly abodes from those conducive to insight and total liberation: ${ }^{55}$

\begin{abstract}
"Monks, with regard [to that question], a monk cultivates the factor of enlightenment of mindfulness in connection with benevolence, ... he cultivates the factor of enlightenment of equanimity in connection with benevolence." (The same formula is repeated for compassion, etc.)
\end{abstract}

This union, coupling the immeasurables with the factors of enlightenment, is perhaps the clearest indication of the contribution that was made by the Buddha to the doctrine of the immeasurables. By linking benevolence, etc., with the cultivation of the cognitive faculties pertaining to liberating insight, he shifted emphasis away from their prevalent ethical and psychological yield to integrate them in the gnoseological structure of the path. ${ }^{56}$

In the Mahāyāna the apramāna became integrated into the scheme of the bodhisattva. As a result, modifications occurred with regard to the motive, scope and cognitive foundation of

55. S V, p. 119; Kośabhāṣya, p. 146.13-14 (cf. Warder, 1980, pp. 95-97).

56. In later Abhidharma works and some commentaries, the immeasurables receive detailed attention in particular with regard to their aspects, objects and benefits. See, for instance, As (pp. 192-7) which contains an exemplary exposition on the mental states that pertain to the four brahmavihära. See also: Satya (S), ii, pp. 369-374.

In the Kos $a$ we learn that they are only practised by and exclusively directed towards sentient beings who dwell in the kämaloka (op. cit., pp. 200-203), with benevolence directed towards those who are happy (sukhita), compassion towards those who are suffering (duhkhita), sympathetic joy towards those who are rejoicing and equipoise leading to an impartial attitude towards all beings (op. cit., pp. 197-200). Compare aiso Warder who proposes that the apramāna were chiefly intended to be by practised by monks and recommended to laymen only in a few instances (1980, p. 197). More importantly, the Kośa allots the four practices to the various stages of meditation, saying that sympathetic joy is restricted to the first two dhyāna, while the remaining three operate in all four dhyäna and at the stages of the anägamya and dhyānāntara (op. cit., pp. 197-199). For a summary of their functioning, see Kośa, pp. 200-201.

An alternative Sarvāstiväda view on the impact of the apramäna is given in the Amrtarasa $(A m r t(B), \mathrm{pp}$. 188-89). Here, each of the four members is said to eliminate one or several passions, to generate right speech and right action and to produce forces that are dissociated from thought. In detail, maitri is held to eliminate spitefulness (vyāpāda); karuña overcome harm (vihimsā); muditä eliminates dissatisfaction (arati) and upeksā suppresses both malice and desire (räga). This enumeration follows closely a list that is given in the D III, pp. 248-9 and is also found in the $A b h i d h-d$, p. 428 (cf. $M p p s$, iii, p. 1242). 
their implementation. We have seen that the srāvaka practised the apramāna chiefly for the sake of their own mental purification and meditative advance. For the bodhisattva, echoing their origin in the cittotpāda ${ }^{57}$, the chief purpose of the apramāna lies in their usefulness in bringing about universal welfare. In a sense, rather than meditative in nature, the area of application is closer to that of the notion of universal benevolence, etc., attributed to them in a famous passage in the Anguttaranikāya. ${ }^{58}$ The bodhisattva achieves this through the dedication of all merit that accrued to him by practising the apramāna: $:^{59}$

"O son of good family, if a bodhisattva considers all beings in this way, how does he produce great benevolence? O Mañjuśri, a bodhisattva who considers them thus, says to himself: 'I am going to expound the Law to beings in the way that $I$ have understood it.' Thus he produces towards all beings a benevolence which is truly protective (bhütisaranmaitri) ... What is great compassion to the bodhisattva? It is the abandoning to sentient beings without retaining any of all good roots enacted or accumulated. What is the great sympathetic joy of the bodhisattva? It is rejoicing in and not regretting giving? What is the great equipoise of the bodhisattva? It is benefiting impartially without hope of reward."

The qualities that are ascribed to the apramāna and in particular to benevolence are numerous. They are said to be free from passion and attachment, to be unperturbed, pure and of good intention, to ripen sentient beings, to penetrate true reality and indeed, to be spontaneously awakened. ${ }^{60}$ They are associated with the six perfections that supersede the factors of enlightenment as regular concomitants of the apramāna. We read in the Pañca that a bodhisattva who courses in the apramanna practises the six perfections in a way that allows him to specifically utilise his expertise in the pāramita. ${ }^{61}$ In the $V k n$ a similar idea is expressed where the apramāna are linked with the perfections since they inspire their appropriate pursuit. They are fixed to giving because they lead to generosity in teaching; to morality because they assist in maturing sentient beings; to patience because they protect the bodhisattva himself and other people; to vigour because they help to bear the burden of all beings; to

57. $V k n$, p. 96.

58. A III, pp. 224-5.

59. $V k n$, op. cit., p. 96 (trs!. Lamotte).

60. Vkn, op. cit.., pp. 155-6; $A k m$, pp. 56.3.7-58.5.6; Mppś, iii, p. 1258.

61. Pañca, pp. 181-82. 
meditation because they abstain from tasting its flavour and wisdom because they obtain it in due time. ${ }^{62}$

Another difference between the śrāvaka and bodhisattva interpretation of the apramäna is the object and domain in which they operate. Unlike the śāvaka who develop the apramãna in response to grievances in the kämadhätu, the bodhisattva extends their application to all spheres of the universe. ${ }^{63}$ Indeed, it is this spatial expansion that is usually given as the etymological explanation of the word apramāna: ${ }^{64}$

\begin{abstract}
"A bodhisattva dwells in a thought connected with benevolence, etc.-a thought that is vast, extensive, non-dual, unlimited, ... a thought that radiates friendliness in the ten directions of the world confined only by the dharmadhätu and the sphere of space."
\end{abstract}

Or, in the words of the $A k n:{ }^{65}$

"Just as the sphere of beings is immeasurable-there is no exhaustion-just so the bodhisattva's cultivation of friendliness is immeasurable and in that there is no

62. Vkn, op. cit., p. 157.

63. Note, however, that their limitation to the kāmadhātu has been refuted by Buddhaghoșa in connection with his analysis of samādhi (Vism, iii.20). Implying that 'immeasurable meditations' are free from the restrictions that prevail in the kāmadhātu and can serve as basis for the highter levels of dhyäna, Buddhaghoșa proposes that the appamañna represent intentions associated with the liberation of mind that operate both in kämadhătu and rüpadhātu (Vism, iv.74). Moreover, they are measureless not only because of the types of mind they accompany, but also because of the nature of their objects (Vism, ix.110):

"All of them, however, occur with a measureless scope, for their scope is measureless beings: and instead of assuming a measure such as 'maitri, etc., should be developed only towards a single being, or in an area of such an extent', they occur with universal pervasion."

In both their scope of object and development, for Buddhaghoșa the appamañña are therefore immeasurable. The association of maitrĭ etc., with the adjective immeasurable is however not totally new. It occurrs already at one place in the Dighanikāya (III, pp. 233-4) where Sāriputra in summing up the teachings of the Buddha describes the fourfold instructions as 'the four immeasurables' (catasso appamaññayo). However, the specific designation of maitri, etc., as referring to a state of mind that is measureless - either in terms of object or development-appears to be rather late as it is only found in the Abhidhamma (Vism, ix.105-10; Aronson, 1975, pp. 66-76). And yet, according to some, maitri, etc., are not universally immeasureable in the Mahāyāna sense, since they do not operate in the arüpyadhătu (cf. Kośa, viii, pp. 199-200).

64. Pañca, pp. 181 (trsl. Conze); an almost identical passage is found in the Dbh (Daśa-bh, p. 34; L).

65. $A k n$, p. $56.4 .2-3$

In the Mpps, this definition is given further details by adding two distinct sets of measurement (iii, $\mathrm{p}$. 1262). First, there is the 'true' immeasurable, that is to say, those things that cannot be measured by any person or saint. These include space, nirväna and the nature of beings (sattvasvahbāva). Second, there are those things that although in principle mensurable are beyond reckoning of ordinary beings and become in this sense immeasurable. These consist of items such as the weight of Mt. Sumeru or the number of drops in the ocean. Since the measurement of such objects is known by the Buddha, they do not serve as a gauge for the apramāna. 
exhaustion."

Finally, there is a distinction in their implementation. On this matter, we read in the $A k n:^{66}$

"Benevolence is threefold. What are the three? Benevolence directed at living beings as object pertains to the bodhisattvas who have produced the first thought of enlightenment. Benevolence directed at dharma as object pertains to bodhisattvas who have embarked on religious practice. Benevolence without object pertains to those bodhisattvas who have attained the conviction of the non-arising of all dharma." ${ }^{67}$

This interpretation has grown, of course, out of the philosophical vision of Mahāyāna ontology, denying independent own-being (svabhāva) to worldly existence. Tuned to this conception of reality, the apramanna exhibit three degrees of purity. On the first level, when the bodhisattva pursues them with the conviction that he is dealing with 'real' people, he is still subject to impurity. ${ }^{68}$ When he replaces sentient beings with dharma as the object of his benevolence, he is exposed to both purity and impurity, depending on his mental awareness. It is only after he has realised the true nature of sentient existence (bhütalaksana) and becomes convinced of the non-arising of dharma that his practice of the immeasurables becomes pure. ${ }^{69}$

The $B d p$ shares many of these Mahāyāna features about the apramāna. Beginning with maitri, the $B d p$ takes up the question of scope and explains that the bodhisattva's benevolence

66. $A k n$, p. $57.2 .3-5$

The Sanskrit of this passage is preserved as a quotation in the Siks, p. 212.12-14. An identical presentation of the three modes of benevolence is also found in the $M s l$ (p. 121), Dhsgr ( $\$ 130$ ) and Bbh (pp. 241-2). For further references to the three types of maitri, see: Mppś, iii, pp. 1250-51.

67. Note that the three kinds of maitri are traditionally compared to the giving of ordinary objects, to the giving of precious objects and to the giving of the cintämani (Mpps, iii, pp. 1253-4).

68. In the Siks (pp. 212.15-213.2; trsl. Bendall), the first level of practice are presented in a slightly different light:

"Benevolence has the Buddha as its object of thought, the bodhisattvas, the disciples, all creatures as its object of thought. Here when it has all beings as its object of thought, it comes first by accumulating benefit and blessing upon a beloved being with meditation. Upon such a one he should accumulate benevolence; then upon acquaintances; then upon strangers; then upon neighbours; then upon fellow-villagers and so with other villages; and so on until he continues devoted to one region, spread all over it, covering it. So with the ten regions. But this procedure does not apply to the benevolence towards buddhas and the rest."

69. Mppś, iii, p. 1245. 
is called immeasurable as it demands application in a sphere of beings that is beyond measure. ${ }^{70}$ Presumably, this explanation is also valid for the remaining three apramana, although it is not applied to them explicitly in the appropriate sections. ${ }^{71}$ After that, the $B d p$ gives a brief overview of the application of benevolence. It is simultaneously seen as a personal protection for the bodhisattva and as practice for the benefit of others. The aspects that are cited, however, refer invariably to the bodhisattva himself. Through the apramana he is freed from malice, anger, passion, fear and negligence and acts in accordance with the noble path. The liberation of sentient beings - being mentioned only once-does not stand in the foreground.

Among the advantages that accrue from benevolence, the $B d p$ discusses in particular wealth, honour and fame, vast accumulations of merit, physical perfection, rapid advance on the path and rebirth among gods and men. ${ }^{72}$ The fate of sentient beings receives little attention and is

70. The alternative explanation of their title 'immeasurable' is often that the amount of merit produced through the practice of benevolence, etc., exceeds all measure (Kośa, viii, p. 196; Mppś, iii, p. 1243). According to the early sources, however, the merit that is generated through them is not of any kind, but specifically brahmanic merit (brahmäpunya) which can only be consumated in the seventeen heavens of the Brahmaloka (A V, p. 76; Kośa, iv, pp. 250-1).

71. Reference only to maitri in the explanation of the apramāna is by no means particular to the $B d p$. As an issue, it is specifically raised in the Mpps (v, p. 2257) and occurs in several other sütras. The reason behind this choice is the assumption that benevolence is the most important of the four apramanna and accrues the greatest amount of merit. Therefore, it is held to outshine the other apramanna not only in the quantity of merit, but also in quality and to be the only type of meditation that is pure (anäsravabhāvanā). This raises the question of the relationship between the four apramäna. While the nikaya are virtually silent in this respect, the commentaries propose an ideal topical progression through the four members. Particularly in the Vism this point is made. At first, the meditator wishes for the welfare of all sentient beings. Next, he recognises the great suffering that afflicts his fellow beings and generates great compassion. Then, he ponders the great prosperity of the very same beings for whom he cultivated benevolence and compassion and takes sympathetic joy in it. Even if they are not prosperous in the present life, he rejoices at their future wealth. Having done so, his conduct towards beings has come to an end and he observes sentient beings as a neutral observer (Vism, ix.109). This scheme is of course rather theoretical, since if progress depends on external circumstances, there would be no possibility of advance beyond compassion. Hence, in actuality, progress is dependent on 'skill' in each subject of meditation and ignores external circumstances. We have therefore in the apramāna something approaching an ideal hierachy of meditation in which the meditator advances through the rarefied spheres of existence. This interpretation has, in the past, generated the misconception that upekșa--being the last in the traditional sequence--would supplant or supersede the other three. Based on the the causal link between upeksa and equanimity as a factor of enlightenment ( $P_{S}$, i.85; Vism, xiv.157; Aronson, 1975, p. 274) not shared by the other apramäna, it was suggested that upekșā eclipes maitri, karuna and muditä. That this is not the case has been shown by Arsonson, 1979, p. 8 . Although completing the practice of the apramana and therefore at the pinnacle of their cultivation, the four remain at all times fundamentally complementary in nature. Cf. Mppś, iii, pp. 1255-58.

72. Note the parallels to the benefits that are cited in the $B b h$ as stemming directly from the practice of the apramanna which, while considering the fate of sentient beings, emphasise personal attainments. They include dwelling in supreme bliss, generation of an immeasurable accumulation of merit, strengthening the intent (äsaya) of enlightenment and holding back all suffering in samsāara (Bbh, pp. 248.23-49.6).

For the Mpps too the benefits are chiefly of a personal nature. Thus, a bodhisattva who embarks on the practice of benevolent meditation (maitrisamädhi) escapes burning when he is immersed in fire, he survives poisoning, he escapes injury during military service, he does not die a violent death and is protected by benign divinities (Mpps, iii, p. 1273). The same list of advantages is also said to spring from practices of the remaining immeasurables despite their allegedly inferior nature. However, the fruits themselves are only attainable by persons belonging to the aryan-fold since the practice of the immeasurables 
only indirectly referred to when the bodhisattva is described as "accomplished in protection of the simple-minded" ${ }^{73}$ Much greater emphasis is given to the personal purity of the bodhisattva and his progress along the path. ${ }^{74}$

In this context, the $B d p$ links benevolence with the six perfections, indicating that it prepares the ground for their successful cultivation. ${ }^{75}$ We saw that by doing so it concurs closely with apramäna expositions in other Mahāyāna works. Next, the Buddha distinguishes between the 'ordinary benevolence' of the srāvaka that is solely directed at personal liberation and the 'great benevolence' of the bodhisattva that aims at universal welfare. ${ }^{76}$

In conclusion, the $B d p$ draws attention to the different kinds of maitri. That is, benevolence that has living beings as its objects and is based on the generation of the bodhicitta; benevolence that has dharma as its objects and is realised when the bodhisattva is established in the path; and benevolence that is objectless and reserved to bodhisattvas who are accomplished in patience $(k s \bar{a} n t i) .{ }^{77}$ While the exact scope of these three categories is not elaborated, it is well known from later sources.

According to the $B b h$, the three modes of reference (sattvālambana, dharmälambana, anālambana) apply to all four immeasurables and are not restricted to benevolence. ${ }^{78}$ Philosophically, it makes the point that the object of the 'objectless application' corresponds to the foundation of being (dharmadhātu) or thusness (tathata).${ }^{79}$ Whilst the first level is also attainable by adherents of heterodox thought, the second by srāvaka and pratyekabuddhas, the third is restricted to bodhisattvas. ${ }^{80}$ Benevolence, compassion and sympathetic joy are

is well beyond the scope of ordinary beings (Mpps, iii, p. 1272; other lists at Mpps, pp. 792, 2257, 2362 . Compare this list with the advantages given in M II, pp. 207-8, A II, p. 129; IV, p. 150; V, p. 342, Vinaya (v, p. 140), Patis (ii, p. 130) and Vism (p. 253); Kośa, iv, p. 124; Mvu, pp. 421-22 and Catuhśatakatikka (TTP, 98, p. 222.5.1-3; ref. Lang).

73. R, folio 267.4 .

74. R, folio $267.3-6$.

75. R, folio 268.3.

76. A similar division is proposed in the Mppś (iii, pp. 1253-4).

77. $\mathrm{R}$, folio $269.2-4$.

78. Bbh, pp. 241.16-18.

79. The same point is also made in the Msl (p. 221) and in the Buddhabhümisūtraśästra (Mppś, iii, p. 1250, n. 1). In the $M p p s$--reflecting pure Madhyamaka thinking - it is regarded as synonymous to the true character of things (dharmannām bhütalaksanam), pure and simple, without the idealistic connotations of $B b h$ 's model.

80. Bbh, p. $242.15-25$

Also consult the Mpps on these issues that contains a particularly detailed account on the scope of application of the apramāna (iii, pp. 1242-1279). To sum up, at first, it compares benevolence, compassion and sympathetic joy with regard to their objects, scope and actual effect on the yogin's psyche. Then, having established their exact function, it defines the three areas of application. Benevolence directed at sentient beings is only practised by ordinary beings (prthagjana) who engage in meditational exercise or by those adepts who undergo training (saiksa) that is still subject to impurity. Those who generate benevolence with regard to dharma are either arhants who have destroyed all impurities, pratyekabuddhas 
assembled with a resolution to bring about bliss while equipoise is brought about by the resolution of profit. ${ }^{81}$ Whichever the orientation of the apramana, in the end all of them are founded on compassion engendered by the perception of worldly misery. ${ }^{82}$

Of the four apramāna, compassion is granted the most detailed treatment in the $B d p .^{83}$ Depicting it as the spiritual basis to the whole bodhisattva ideal, the Buddha explains: ${ }^{84}$

"O Prince, what is the bodhisattva's great compassion? O Prince, his great compassion is the basis of his desire for supreme and perfect enlightenment. For instance, just as the basis of the life-faculty of sentient beings is inhalation and exhalation of breath, in the same way, 0 Prince, is great compassion the basis of the bodhisattva's accomplishment in the great vehicle." .

After this opening passage, the $B d p$ spells out the ten factors that prompt bodhisattvas to unfold universal compassion. ${ }^{85}$ Most of these factors relate to the perception of the wretchedness of worldly existence and its inherent conceptual flaws such as belief in a self, wrong views, desire for perverted pleasure, exposure to the five obstructions (āvarana $)^{86}$, delusion and conceit. In response to these conditions, the bodhisattva generates compassion that is sustained

or buddhas. This level of attainment is conditional on elimination of the perception of a self (ätmansamjña $\bar{a})$ and transcending the notion of identity and difference (ekatvānyatvasamjñă). The third level of attainment in benevolence is reserved to the buddhas, since operating beyond objects (anālambana), it does not rest in either the conditioned or unconditioned. Knowing that all objects are unborn, unreal and misconceived, their benevolence does not lean at, or function within, time but rests in non-distinction. Notwithstanding, they do not abandon sentient being to their fate but, relying on wisdom relative to the true character of things, unfold their benevolence to best effect. The same division is also applicable to the thought of compassion (karunācitta), but it is not put forward for sympathetic joy and equipoise.

81. Cf. Mppś, iii, pp. 1255, 1258 .

82. The $B b h$ underlines this point by including a list of one hundred and ten kinds of suffering $(B b h$, pp. 243.2-47.2) and discussing a group of nineteen specific forms of suffering that constitute its object ( $B b h$, p. 247.8-18).

Two of these are also hinted at in an important section in the $M s l$ where in chapter seventeen (pp. 221.9-224.3), twelve verses are devoted to the immeasurables. At first, close agreement prevails between its exposition and that of the $B b h$. Both works classify the apramāna practice in three levels, viz., practice targeted at sentient beings, practice aimed at dharma and practice directed at objectlessness, born out by thusness (tathat $\bar{a})$ and reserved to those who are free from false imagination (te hy avikalpatvād anälambanāh).

83. Note, that unlike the discussions of maitrī, muditā and upekșā that concur almost verbatim to their counterparts in the $A k n$, the $B d p$ 's exposition of compassion contains strikingly many discrecpancies from the karunā section in the $A k n$ (p. 57.2.6-5.6)

84. R, folio $269.5-270.1$.

85. R, folio $270.5-276.4$.

86. These are desire (rāga), hatred (dvesa), delusion (moha), regret (vipratisarā) and doubt (samśsaya). On the various types of obstruction attested in Buddhist literature, see: Kośa, i, p. 51; iv, p. 18, 20; vi, p. 276; Siddhi, pp. 639-657; Dhsgr, § 115, 118. 
by contemplation, imperturbability, reverence, purity, practice and vigour. ${ }^{87}$ It becomes the motivating force (including pristine cognition) that establishes an intense communication between the bodhisattva and sentient beings, exposure to which nourishes, in turn, compassion. ${ }^{88}$

The third immeasurable, sympathetic joy (muditā) is the least distinctive in the $B d p$ 's discussion of the apramāna. ${ }^{89}$ Its characterisation amounts to little more than a list of enchanting examples taken from the bodhisattva's conduct. The bodhisattva delights in all aspects of the Dharma, he takes pleasure from solitude and the accomplishment of the six perfections, he approves of congeniality, lack of hatred, physical purity and rejoices in spiritual exertion. ${ }^{90}$ In order to underline this commitment, the text gives a string of examples that illustrate the bodhisattva's devotion to his teachers, parents, sentient beings and good conduct in general. Judging by this passage alone, the main benefit of sympathetic joy is indefatigableness in the pursuit of enlightenment since it rekindles enthusiasm for the path in times of weariness. ${ }^{91}$

Acquisition of the fourth immeasurable-equipoise (upekșa $)$-is divided into three phases, depending on the object at which it is directed. At first, the bodhisattva learns to assume equipoise towards defilement (kleśa).$^{92}$ He maintains high spirits when rejected and defamed or, conversely, is not deluded when praised. He stays calm and unaffected in both misery and bliss and does not develop preferences for either friends or foes, but attains complete impartiality. Whatever the circumstances to which he is exposed, the bodhisattva abides in perfect mental equilibrium and does not allow any factors such as appreciation or aversion, pleasure or distress to influence his judgement and conduct.

Next, he trains in equipoise that applies to situations in which the bodhisattva is exposed to physical abuse and torture. Entitled, 'equipoise to protect oneself and others'

87. R, folio $276.5-277.4$.

88. R, folio 277.3-278.4.

89. Aronson (1975, pp. 256-59) has made the same observation on the place of mudita in the nikäya. But for two instances, cited only in conjunction with the other immeasurables (D I, p. 73; A I, p. 243), it is the least explored member of the apramana. In essence, it seems to epitomise an attitude that prevails among persons whose aptitude and interests are compatible. Cultivated in response to displeasure, it becomes an anitdote to internal unwholesomeness and generates great merit. Its relationship to the meditative attainments of the practitioners is explained as follows (A I, p. 243):

"Monks, at the time (when monks live harmoniously), monks are living in the sublime way of living. That is to say, pleasurable interest arises in him who is joyous due to the liberation of the mind which is of sympathetic joy. He whose mind shows pleasurable interest experiences bodily calm. He who has a calm body experiences happiness. He who is happy becomes concentrated."

90. $R$, folio $278.5-279.7$.

91. $R$, folio $282.7-283.1$.

92. $\mathrm{R}$, folio $280.7-281.7$. 
(ätmaparärakșanopekșa $)^{93}$, it allows him to stay aloft over all types of anguish and to forego the thought of retaliation. This type of equipoise springs from the bodhisattva's resolution and is sustained through constant exertion in search for virtue. ${ }^{94}$

The third manifestation of upekșā is applied to right and wrong moments (kāalakālopekșa $).^{95}$ Now, the bodhisattva maintains composure when confronted with irreverence, blame, impurity and despicable demeanour. He abides in equanimity when challenged by persons who do not share his faith in the Dharma, who engage in practices at a wrong time (in particular with regard to the perfections 99 or who are otherwise ill-synchronised in their conduct. In sum, whatever challenge he is confronted with, the bodhisattva carefully weighs the situation, judges with a tranquil and impartial mind, and adjusts his response accordingly. ${ }^{97}$

If we compare these features with the apramāna in other writings, we note several parallels. First, the $B d p$ speaks of a threefold mode of apramāna practice, distinguishing between sattvālambana, dharmālambana and analambana. We have seen that this is a theme that is common to virtually all Mahāyāna treatises. It is invariably ascribed to the $A k n$ and not to the $B d p$ from which the $A k n$ appears to have taken it. ${ }^{98}$ In the $B d p$, the standard formula is extended to include the stages where the various levels of practice are reached, viz., the sattvälambana practice at the first generation of the thought of enlightenment (prathamacittotpāda), the dharmālambana practice at the moment of constancy in the path, and the anālambana practice at the acquisition of patience ( $k s \bar{a} n t i)$. In the $A k n$ this formula is divided into two sections, the first gives the levels of practice and the second provides the moment at which they become operational. ${ }^{99}$ Moreover, by making the "conviction of the non-arising of dharma' (anutpattikadharmakșānti) the terminus ad quem for the anälambana practice, the $A k n$ modifies the occurrence of the third level. In the path scheme of the $D b h$, this would mean that the anälambana practice is not attained before the acaläbhümi, while the $B d p$ 's 'accomplishment in patience' might conceivably be already attained at the prabhākaribhimmi. ${ }^{100}$ However, as the treatises on the bodhisattva are completely silent on this

93. R, folio $282.1-283.2$.

94. $\mathrm{R}$, folio 282.7 .

95. $\mathrm{R}$, folio $283.1-284.1$.

96. $\mathrm{R}$, folio $283.3-6$.

97. In the $B d p$ it is explicitly said that none of three types of upekșa are conferred by the buddhas, but are self-attained and form a distinct part of the his resolution $(\mathrm{R}$, folio 282.7$)$.

98. E.g., Siks, p. 212; $M p p s$, iii, p. 1272 (other occurences in Bbh, pp. 241.18-242.51 and Msl, p. 121.11-12).

99. $A k n$, p. $57.2 .3-5$.

100. Daśa-bh, p. 36.16-17 
matter, their positioning must remain uncertain.

The $B d p$ agrees with those sources that confirm that maitri reaches greatest effectiveness when it is coupled with other practices, in particular the pāramitā or bodhipākșika dharma. It also speaks of these practices as forces on which the apramāna rely for inspiration. ${ }^{101}$ Other parallels exist in its assessment of compassion as the foremost of the apramäna and its explanations for their immeasurability.

Points where the $B d p$ differs concerns the profits of the apramanna, the nature of equipoise and the presentation of the material. We have seen that many texts-early and late-devote at least some attention to the states of rebirth gained as a result of apramāna practice. This is not the case in the $B d p$. In the whole chapter there is not one explicit reference to 'ways of living like Brahmā' (brahmavihāra). ${ }^{102}$ Rebirth in the rūpadhātu or arūpyadhātu, so central to most other expositions of the apramāna, does not figure at all. Instead, every reward is immediately dedicated to universal liberation. Another peculiarity is the division of equipoise. Apart from the $A k n$ no other text proposes to divide upeksä into three distinct categories of application. What is more, neither of the types of upeksā is taken up independently in any of the texts I consulted. Whether this omission constitutes an oversight or was deliberate we cannot tell. The inclusion of apramāna quotations in other sources from the $A k n$ that are purged of the threefold division points to the latter.

Then there is also the lack of coordination between the different apramana in the $B d p$. Deviating from standard practice to grant a degree of cohesion to the four members-be it only through a collective set of benefits-the $B d p$ looks at each of the apramana in isolation. For instance, no use is made of the integrating function of meditation as frame of reference for their implementation. As a result, the presentation appears fragmented and in want of

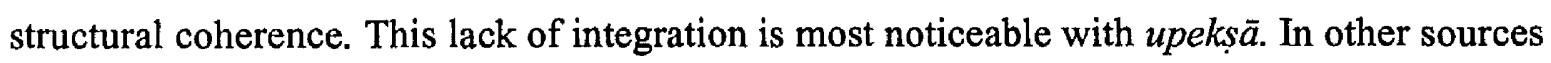
the exposition of upekșa is completely interwoven with the practice of meditation as it quietens the emotions, stirred up by benevolence, compassion and sympathetic joy. In the $B d p$ no such link is proposed. ${ }^{103}$ Without the technical language of dhyana, its account is essentially descriptive and serves to demonstrate the scope of the bodhisattva's attainment in

Note, that in the translation of the Siksäsamuccaya, the position of the $A k n$ has been misquoted by replacing the 'conviction of the non-arising of dharma' as the beginning of the third level with 'patience preparation for a future state' $(A k n$, p. 57.2.5; Sikș, p. 212.14; trsl. p. 204).

101. $\mathrm{R}$ folio $268.5-69.1$

102. In the $B d p$, there is only one reference to Brahma and that makes no mention of the notion that a bodhisattva might gain rebirth in the Brahmāloka ( $R$ folio, 267.4).

103. Mppś, iii, p. 1258. 


\section{Apramāna}

equipoise. 


\section{The Perfection of Generosity}

Chapter six introduces the main body of the bodhisattva practices. It marks the formal beginning of the exposition of the six perfections, starting with generosity (dāna). The subsequent chapters deal with one pāramitā each.

Methodologically, much of what has been said about the $B d p$ 's presentation of the four apramāna holds also true for the treatment of the dānapāramitā. ${ }^{104}$ The whole account of däna is primarily descriptive and offers little information on the psychological impact of its practice. The chapter begins by enumerating the objects that are typically to be given. These fall into two categories, that is, external gifts (bāhyam dānam) and internal gifts (ādhyātmikam dānam). Although not defined as such by name, this division clearly governs the $B d p$ 's classification of gifts. ${ }^{105}$ First, the bodhisattva gives material gifts (āmișadāna) such as food, clothes, jewels, pleasure-grounds including relatives and dear ones. Then, he trains in giving away his own body in self-sacrifice. ${ }^{106}$ The order in which these gifts are listed suggests a ranking according to the degree of difficulty. That is to say, at the lowest level, the bodhisattva provides food, drink and clothing. ${ }^{107}$ Then, embarking on higher levels of dāna, he renounces precious objects. Next, the bodhisattva trains to abandon his family and finally, at the highest level, sacrifices his body. ${ }^{108}$ The gift of the Doctrine (dharmadāna), a major factor in the practice of generosity and acknowledged by most texts, is not cited in chapter six. ${ }^{109}$

104. Candrakirti, in his commentary to the Catuhsataka (TTP, 98, p. 215.3.2-4.4; ref. Lang), gives the following etymological explanation of the word dãna. He begins by deriving dāna from the root do meaning 'to cut' saying that it alludes to death. Hence, the word dana is said to give pleasure to a practitioner since it induces disgust (udvega) for the cycle of birth and death. Then, he acknowledges a relation between dāna and the root dã meaning 'to give', noting that the three types of giving include all perfections (ämisadāna covering dāna; abhayadāna covering silla, kșānti; dharmadāna covering dhyāna, prajñā-with all three are linked with virya) and as a channel of the teachings pleases the bodhisattva. Finally, he says that dāna may also be derived from the root de meaning 'to guard' and $d a$ 'to purify'. The rationale behind these associations is that the bodhisattva's body, speech and mind are, as yet, in need of guarding and purification since future births are determined by the presence of desire. Thus, because dāna reminds the bodhisattva of other births, it inspires joy in bodhisattvas (cf. Mppś, ii, pp. 698-700).

105. This twofold division is well known from dāna treatment in the sástras. See, for instance, $B b h$ (pp. 114-123) and $M p p s$ (v, p. 2238).

106. $\mathrm{R}$, folio $285.1-7$.

107. On the bodhisattva's practice of alms-giving, see: $M s g$, pp. $224-25$.

If, however, limited in his possessions by the constraints of mendicant life, the bodhisattva dispenses writing instruments (lekhāni), ink (mași ), manuscripts (pustaka) and the gift of the doctrine (Vup, p. 30, $\S$ 20).

108. This scheme is also found in the Mppś, ii, pp. 750-51. At another place, however, the Mppś distinguishes between ämisadāna as inferior giving; giving of the body as mediocre giving and generosity accompanied by mental detachment as the supreme type of giving (Mppś, i, p. 297).

109. It is, however, discussed in chapter nine (folio 539-546), ten (folio 563) and eleven (folio 628-631). 
After listing the objects of dāna, the $B d p$ describes the mental states that accompany the practice of giving. ${ }^{110}$ It distinguishes forty different factors (divided into four lists of ten each) that turn ordinary generosity into pure generosity. Major concerns are the need for impartiality, dedication of generosity to enlightenment and the objective of universal liberation. A gift should not be bestowed out of wrath or pleasure, it must not have any detrimental effect on the recipient and need not be motivated by desire for retribution. ${ }^{111}$ In other words, the whole

Looking at the development of the concept of giving, we note that, at first, references to a consciously perceived division in the objects of dāna are less articulated. In the four principal nikāya, a division between dāna objects is attested only once. In the Anguttaranikāya (A I, p. 89), we read:

"Monks, there are two gifts. What are these two? The material (ämisa) and the spiritual

(dhamma). These are the two. Of these two, the spiritual gift is preeminent."

Yet, already in early Mahāyāna sūtras, the concept of the gift of the doctrine was fully acknowledged and enhanced in value. In the $K p$, the gift of the Doctrine is elevated to the supreme task of a bodhisattva, eclipsing even compassion, benevolence and communication of the thought of enlightenment (p. $79, \S$ 20 ). It is undertaken with a pure heart and virtuous motives without expectancy for anything in return (p. $79, \S 20.1)$ If correctly performed, involving uniform, impartial and open-handed preaching (p. $73, \S 12.3$; $\S 44)$, the gift of the Dharma secures immeasurable merit and prompts the state of unobscured insight ( $p$. $80, \S 22.1$ ). He teaches the Doctrine to all beings just as he received it himself and does not hold anything back (p. 61, § 1.2). By doing so, he imparts the thought of enlightenment and inspires sentient beings to strive to buddhahood (p. $79 \S 20.3 ;$ p. $73, \S 12.2$ ).

In later literature this distinction grew in importance. The gift of the doctrine is cited in the Pañca (p. 459) as the only dāna object alongside material gifts and figures in the $U g$ and $V u p$ among the objects of generosity of householders ( $V u p$, p. $30, \S 20 ; U g$, p. 259.5.5). Its exact contents is defined in the Kos $a$ (iv, p. 252) as "correct, undefiled teaching of the sütra literature". Those who teach the Doctrine with an impure mind or out of mistaken design such as gain, respect or reputation forfeit all merit that would otherwise fall to them.

In the Mpps the condition of the gift of the Dharma, whether that of the srāvaka or bodhisattva, depends for status on the intention (cetana $)$ and mental state with which it is being given. If it is preached for personal gain, with mistaken views about the self or otherwise overshadowed by delusion, it is wholly impure and of laukika rank. If, however, it is taught out of pure intention and with wholesome thought the gift of the Doctrine attains lokottara status and introduces to the Buddhist path (Mppś, ii, pp. 693-5). Besides the gift of the Dharma and material gifts, the Mpps distinguishes a third category of dana, that is the 'gift of homage and respect' (püjasatkāradäna). It consists in showing veneration and is inspired by pure faith (prasädacittaviśuddhi). Pure faith figures also amongst the causes and conditions that give rise to giving in general. In the Mpps , these are compassion, faith and respect (or a combination of both); an object that is to be given (pure or impure) and a recipient who operates as a field of merit (either destitute or honoured).

Note the contribution of the $M s l$ and $M s g$ with regard to dāna by extending the traditional division into material and the spiritual objects to include the gift of security (abhayadāna). According to the commentary of the Msg, it serves to constrain violence (ghätakanivärana), assists the shy or apprehensive (bhiruparitrāna) and anchors the bodhisattva's altruistic intention in his practice (Msg, pp. 224-5). Defined as protection from the fear of lions, tigers, seizure, kings, thieves, water, etc., $(B b h$, p. 133.17-19), it pertains, however, more to the realm of sila and reflects the bodhisattva's rejection of violence. (Meadows, p. 176.10; Lin Li-kouang, 1949, p. 250; Mpps', ii, p. 700). The Dhsgr ( $\$ 105$ ) cites in the place of 'giving of fearlessness' the 'giving of benevolence' (maitrídana) that is probably an elucidation of the more obscure concept of abhayadāna.

Somewhat surprisingly, the gift of security does not figure as an independent category in the $B b h$. Instead, we find the traditional division into external objects and internal objects (p. 144.23). The gift of the Dharma-identified as the supreme gift (pp. 127.11-128.1)-falls as an individual object in the class of external gifts, but does not form a separate category (pp. 119.25-120.3). It is, however, cited at p. $133.12-13$ where the $B b h$ gives material objects, the Dharma and security as the three objects that lead to bliss in this world and the next.

110. R, folio $287.7-288.5$.

111. These precautions are not essential to the $U g$, where it is argued that to fulfil other people's desires is the highest aim of the dānapāramită (pp. 261.2.6-3.2). The negative side-effects that total compliance with 
section warns of aspects that might render an act of giving worthless and even counterproductive by way of mistaken attitudes or motivations. ${ }^{112}$ By doing so, the $B d p$ establishes a connection between the practice of generosity and morality. That is to say, it qualifies the act of giving in moral terms and determines its value on the basis of the donor's intention and the choice of objects that are given. It is only if both are of high moral standard and fully compatible with the ideal of the bodhisattva that pure generosity is accomplished.

This association of generosity and morality is not particular to the $B d p$. It occurs already in the nikāya and is given prominent treatment in the $U g .{ }^{113}$ The rationale for the joined practice of dāna and silla is twofold. First, moral impurity defiles the spirit of giving since it leads to corruption and expectations of reward, and hence obstructs the attainment of pure generosity. Second, there is the incompatibility of attachment and impartiality ${ }^{114}$ Impartiality is a decisive

their wishes may produce are easily annulled by means of the bodhisattva's resolve (pranidhäna):

"Now it is time for the dānapäramitā and I shall give in accordance with that person's wishes. I shall cause the person who makes requests to be satisfied. If giving wine to him, I must soothe that person so that he shall attain right mindfulness (samyaksmrti) and shall not be caused delusions. Why? To know how to satisfy another's desire, this is the dānapāramitā. Householder, for this reason, by making a gift of wine to someone, the bodhisattva does not draw away from the Buddha."

112. An exemplary account of the ideal circumstances of generosity is found in the $B b h$. As some of the early sütras, the $B b h$ devotes considerable attention to the objects and circumstances where the bodhisattva's dāna operates (pp. 132.23-133.2). The overriding purpose behind the practice of giving is to mature sentient beings. Gratification of sense desire is acknowledged to occur but regarded as an unavoidable by-product (pp. 117-118). The bodhisattva takes great care to differentiate between the needs of beings and gives only objects that promote their spiritual interest. The chief reward for the donor becomes exemption from rebirth in the lower destinies, provided that he gives with a pure, impartial state of mind that does not allow favouritism. The bodhisattva does not take advantage of others or seeks personal benefits from giving (p. 121.3-4). His practice of giving is marked by faith and devotion, proceeds in a timely fashion and does not lead to any harm (p. 132.26-7).

An important requirement for correct giving is knowledge of what constitutes the appropriate gift in a given situation and the awareness that ultimately no objects exist (pp. 123.18-124.22; 129.8-11). The gifts of the bodhisattva comprise specifically the four apramäna, as they have great impact on the recipient's spiritual welfare (p. 129.12-15). The chief impediments to a successful pursuit is lack of habit, lack in worthy gifts, attachment to pleasing objects and delight in the prospect of future reward $(\mathrm{p}$. 129.16-21). Delay in the progress in giving occurs particularly when a bodhisattva only owns a few objects that are worth giving and is requested to hand these over to his enemy; when he is asked to renounce what is dearest to him or what he has become accustomed to and when he must give away those dharma that he has acquired with great trouble himself (p. 132.3-12). The most effective antidotes against these obstacles are intellectual penetration (prativedha), endurance of suffering (duhkhäahivāsanä), cognition of misconception (viparyäsaparijñana) and insight into the emptiness of karmic formations (samkārasāratvadarśana) (p. 131.6-13). As reward for practising dāna-if practised with determination (adhyäsaya) and in conjunction with the pratisamvid -the bodhisattva comes eventually face to face with true reality (p. 131.20-27).

Compare this position with the Mpps (ii, pp. 670-72) that informs that dāna reaps greatest reward if the gift is valuable, uncommon, well-timed, adjusted to local circumstances, in harmony with the requirements of mendicants, offered to members of the Sarigha, continually and conditioned.

113. A connection of similar type is also established in the $K p$, where offerings of material objects such lamps, if only to acquaintances, are said to contribute to the final elimination of traces of impurities (keśavāsanā) only if they are undertaken in conjunction with moral conduct.

114. $U g, 23$, p. 264.4.3-5.7. 
factor in the bodhisattva's practice of dāna since it is intrinsically connected to the pledge of universal liberation. Violation of the principle of impartiality by whatever means would affect the very foundation of the bodhisattva's quest and place him on the level of a srāvaka.

Depending on the context, attachment comes into play on two levels. In the nikäya, the Buddha .speaks of it in terms of sensual desire. ${ }^{115}$ The implication is that sensual desire corrupts the monk's psyche in general and renders him unfit to follow in the mendicant path. In the $U g$ which discourses on the lay path, the bodhisattva is warned of inappropriate attachment to his family and worldly possession, since this would obstruct his balanced pursuit of the middle path between worldly desire and renunciation. In a sense, giving is therefore dependent on disciplinarian vigour to fully unfold. However, morality is also reinforced by the practice of giving. For it is through unlimited generosity that the root evils of desire, hatred and delusion are most effectively weakened.

Having discussed the moral dimension of dāna, the $B d p$ gives three lists detailing the benefits derived from internal and external giving. ${ }^{116}$ Benefits accruing from material gifts are predominantly physical in nature or generate spiritual gain relevant to this world. The system of retribution that governs the granting of daily requisites follows well-established patterns, promising future affluence in precisely the items that were renounced. The gift of luxurious items and family members, however, pertains to a higher order and is rewarded with physical perfection or important spiritual faculties such as the dharmaskandha, pristine cognition (jñāna) or divine ear (divyaśrotra). ${ }^{117}$ The borderline between those two categories is rather fluid as reward patterns occasionally become blurred. Self-sacrifice and renunciation of all worldly pleasure are of the highest category, since they place the bodhisattva practically on the level of the Tathāgata through giving the buddha-qualities and all-knowing. ${ }^{118}$

115. In the progressive talk formula (anupubbikathā) we read to this effect:

"Then the lord gave a progressive talk ... namely talk on giving, talk on moral conduct and talk on heaven. He revealed the danger, elimination and impurity of sensual desires, and the benefit of desirelessness. When the lord knew that the mind of ... was ready, soft, without hinderances, uplifted, settled, then he revealed the special dhamma teaching of buddhas: suffering, arising, cessation, the path" (D I, p. 110; trsl. Gethin).

116. For alternative lists of dāna benefits, see: $S a m a \bar{d} h$, ii, pp. 326-332 and Mppś, v, pp. 2218-25.

117. R, folio 291.4-5.

118. R, folio $292.3-7$

Compare these benefits with the rewards of generosity that are typically cited in the nikayya. In the Silasutta (A III, pp. 38-41), for instance, the Buddha distinguishes five advantages that accrue through giving - four in this life and one in the next. In this life, the benefactor is well-thought of and friend of many people. The wise will always be eager to accompany him and he attains great renown. Whatever company he enters, he moves with confidence and converses freely. At death, as a result of his generosity, he is assured a rebirth in the heavenly realms of the gods. A similar set of benefits is found at A III, pp. 32-33. 
For the $B d p$ the most important determinant of the amount of merit that springs from dāna is therefore the object that is given and the purity of the donor's (drāyaka) thought. It disregards the role of the beneficiary (pratigrāhaka) as a field of merit (punyakșetra). ${ }^{119}$ Already in the early suttas, we learn that the amount of dana reward depends not only on the act of generosity and its object, but even more so on the spiritual state of the donor. In the Vacchagottasutta, the Buddha explains: ${ }^{120}$

"O Vaccha, gifts given in the case of the virtuous are of great fruit, not those given in the case of the wicked. By 'virtuous' I mean one who has abandoned five qualities and possesses five qualities. What are the five qualities he has abandoned? Sensual desire is abandoned, malevolence, sloth and torpor, excitement and flurry, doubt and wavering are abandoned. These are the five. And of what five qualities is he possessed? He possesses the constituents of morality possessed by the adept, the constituents of concentration, the constituents of insight, the constituents of emancipation, the constituent of release by knowledge and vision of the adept. He has these five qualities. Thus, where five qualities are abandoned and five possessed, a gift is of great fruit, I declare."

Thought to this effect is also expressed in the Dakkhinavibhangasutta where the Buddha discourses on the four degrees of the purification of offerings. Distinguishing offerings purified by the donor, by the beneficiary, neither by the donor nor by the beneficiary and by both the donor and the beneficiary, he rejects all but the last variant as insufficient and concludes that the supreme gift is always that which is given by an accomplished monk person to an accomplished monk. ${ }^{121}$

Building on this proposition the nikāya came to differentiate various degrees of dāna purity. Besides the donor/beneficiary factor, it is above all the intention behind an act of giving that determines its value. In the Sangitisutta, the Buddha speaks of eight bases of giving that influence the result of dana. ${ }^{122}$ These include the presence of a recipient, fear,

119. On the notions of punya and punyakșetra, see Lamotte's notes in La Concentration de la Marche Héroique, pp. 231-33.

120. A I, pp. 161-2 (trsl. Woodward).

121. M III, pp. 256-7 (cf. Kośa, iv pp. 236-8).

122. According to the Abhidh-sam, the value of the act of giving (dānakarma) depends on the purity of its base (nidāna) and endeavour (utthāna)--non-greed, non-hatred and non-delusion-the choice of objects and his mental, vocal and physical bearing at the moment of giving. It is called accomplished, only when 
reciprocity, hope for reciprocity, knowledge of the virtue of generosity, altruism, desire for fame or repute and peace of mind. ${ }^{123}$ The point is made that in order to maximise the value of generosity, the donor should carefully assess his thinking and purify the intent that motivates his act of giving. For an act of generosity to be fully purified, it requires faith, respect, personal commitment, timeliness ${ }^{124}$ and must be executed without causing distress to the recipient. $^{125}$

According to the Kośa, the mechanism of retribution evolves in four areas of operation. Vasubandhu postulates that gifts can either be beneficial to oneself, to others, to both or neither. ${ }^{126}$ Merit itself is divided into two categories. ${ }^{127}$ On the one hand, there is merit that arises by virtue of the sole fact of abandoning during the process of dāna (tyāgānvayapunya). It is generated through the production of a mental dharma of abandoning (parityāgadharma), constituting the intention to give and represents the act of giving proper. This form of merit accrues when gifts are presented to a caitya. On other hand, there is the merit produced by its enjoyment (paribhoganānvayapunya). It is merit that results from joy by the recipient in the objects that were bestowed. ${ }^{128}$

The amount of merit depends, besides the benefactor's mental state, also on the status of the beneficiary. We saw that spiritual achievement in both the donor and beneficiary constitutes the purest form of giving and entails supreme merit. Thus, we read in the Kośa, citing a sütra from the Madhyamāgama ${ }^{129}$, that retribution proceeding from gifts made to the āryan community increases with the holiness of the beneficiary.

Corresponding to the standing of the beneficiary, the resultant merit falls into four categories. First, there is the field of merit characterised by destinies (gati). Here, the condition of birth of the recipient has great impact on the amount of merit that is acquired through giving.

performed frequently, impartially, with indifference (aniśrita) and, in particular, if associated to a commitment (Abhidh-sam (R), pp. 94-5).

123. D III, p. 258 (see: also A IV, p. 236)

The Amrtarasa (Amrt (B), p. 89) records a tradition of seven mistaken ways of giving. These include giving with pride (abhimänena), giving for the sake of glory (kirttaye), giving for the sake of power (baläya), giving accompanied by violence (sabrśa), giving with motivation (hetupratyaya), giving with the hope of reward and giving to the Sarigha with discrimination (vibhanga). In contents, this enumeration contains little new and is based on the lists in D III, p. 258, A IV, p. 60, pp. 236-37; cf. Kośabhäșya, p. 270.

124. On timely gifts see: A III, p. 41.

125. A III, p. 172; cf. D III, pp. 356-7.

126. Kośa, iv, p. 234.

127. Kośa, iv, pp. 244-5.

128. Kośa, iv, p. 244

Cf. $A m r t(B)$, pp. 87-88 for a variant interpretation of this mechanism of retribution.

129. Madhyamāgama, TD 1, p. 722 b 22. 
Second, there is the factor of suffering. A gift to a needy person-sick, disabled or in any other physical distress-confers incalculable merit on the donor. In third place the Kośa cites "excellence through benefactor" as a condition that influences the field's quality. For illustration, Vasubandhu quotes gifts to one's father, mother or other benefactors as producing particularly abundant merit. ${ }^{130}$ Third, we read that a field of merit excels through its qualities. Thus, "a retribution one hundred thousand times greater than a gift made to a persons who uphold moral conduct" will accrue to sponsors of bodhisattvas. ${ }^{131}$

Having examined some of the aspects of dāna in non-Mahāyāna texts, I return to the $B d p$ and appraise its exposition of dāna. The $B d p$ agrees with most other sources that a major benefit of generosity is the elimination of the fault of avarice (mätsaryadosa). ${ }^{132}$ This is a very fundamental proposition which is found in even the earliest expositions. In addition, it speaks of freedom from birth in the lower destinies (durgati) as a reward for the practice of danna. ${ }^{133}$ This too is consistent with the early views, but it is at odds with later thinking that postulates the need for unabating selfless service and self-sacrifice in the bodhisattva training. Next, the $B d p$ takes up the ancient scheme of three causes and conditions (hetupratyaya) that give rise to generosity and determine the amount of merit produced. However, by focusing on the object (deya) and motivation (cetanā) of giving, but largely ignoring the issue of the beneficiary's purity, it shows more concern for the active side of dana practice. ${ }^{134}$

Perhaps as a collateral, the $B d p$ pays little attention to the benefits that accrue to the beneficiary from dana practice. That this is inconsistent with the reciprocity of the ideal of

130. This category refers primarily to the seven aupadhika-punyakriyavastu (on the aupadhika-punyakriyavastu and the punyakriyavastu in general, see: note 132 in my translation of chapter eleven).

131. Kośa, iv, pp. 234-38

This passage seems to fit ill with an explanation found in the Dakkhinivibhangasutta (M III, pp. 254-5) that proposes that gifts given to the Sarigha produce greater merit than offerings bestowed to the Buddha. For a brief discussion of the import of the Maijhimanikãya passage, see: La Vallée Poussin, 1980, p. 237 n. 3.

132. E.g., $M p p s$, v, pp. 663,2388

In the Mpps (p. 2388), we find also a convenient overview of the various types of renunciation (tyāga). First, there is giving of gifts through the abandoning of material goods. Second, there is the attainment of bodhi through the abandonment of the fetters (samyojana). Both are fully attained at the seventh stage. Other types of tyāga are given as internal (ädhyātmika) and external (bāhya), light (laghu) and difficult (guru), the material gift and the gift of the doctrine, the mundane and supramundane gift, the latter being exempt from discrimination (avikalpita) and imagination (asamkalpita).

133. R folio 296.7 .

134. The only passage in the $B d p$ that could be interpreted as taking into account the role of the beneficiary is a jätaka narrative that describes the offerings of the weaver Dhāvani to the Tathāgata Kuhanachanda. This weaver attains innumerable auspicious rebirths culminating in enlightenment solely by virtue of his gifts to a Buddha - the highest of all recipients. But even here, the focus is quite clearly on the gifts that he offered and his persistence in doing so, and not on the spiritual status of the Tathāgata ( $R$, folio 296.3-298.6). 
giving, founded on the interchange of ämișa and dharma or ämișa and punya, need not be emphasised. ${ }^{135}$ To all appearances, the $B d p$ views dāna above all as a pursuit that is advantageous to the bodhisattva's own advance. Characteristically, preaching of the Dharma-traditionally wellspring of the altruistic dimension of giving -is cited only once in passing. ${ }^{136}$

It could of course be argued that giving of material items has a dual function. On the one hand, it brings to maturation the buddha-qualities and, on the other hand, attracts sentient beings to the Buddhist path. This interpretation would link the practice of amișadāna with the dānasamgrahavastu. As the other three samgrahavastu could be categorised as dharmadāna (they are all concerned with preaching), also material giving raises the prospect of substantial spiritual benefits to other beings. ${ }^{137}$

Towards the end of the chapter, the $B d p$ elucidates the overall context in which the dānapāramitā operates. ${ }^{138}$ It qualifies the reward mechanism by stressing that happiness in this world is only a by-product and does represent the raison d'être of däna. Since they are subject to the law of karma worldly benefits occur automatically in response to wholesome deeds, whether desired or not. In spite of such demotion, they are nevertheless valued and indeed become the 'launching pad' for the career of the bodhisattva. The $B d p$ explains this in the following words: ${ }^{139}$

"O Śāriputra, a bodhisattva, mahāsattva who persists in perfect enlightenment when giving worldly objects becomes not only a universal monarch but also acquires the states of Indra and Brahmā, even though he might not desire them. Once he has attained these three states, he accomplishes the ten stages of the bodhisattva and acquires the ten powers and four assurances of the Tathāgata. ... It is in this way, O Sāriputra, that the Tathägata attain deliverance by means of the retribution of their [worldly] deeds."

This thought is expanded in the next passages where the practice of giving is linked with

135. Ug, p. 260.5.4-5; Kośabhāșya, pp. 268-69; Amrt (B), p. 86.

136. $\mathrm{R}$, folio 300.1 .

137. The samgrahavastu appear in the $B d p$ on folio $695.1-698.7$.

138. For a lucid account of the interrelation of dāna and the other pāramitā, see: Mppś (ii, p. 750-769). Another account of the relationship between the päramita and dāna, showing how grhapti bodhisattvas cultivate sila, etc., in granting alms to beggars, in found at $U g$, p. 263.1.6-2.6.

139. $\mathrm{R}$, folio $294.1-4$. 
the cittotpāda and becomes the platform of the whole of the bodhisattva practice: ${ }^{140}$

"O Sãriputra, once he has generated benevolence towards beggars, a bodhisattva who pursues generosity acquires by virtue of his cittotpāda the uninterrupted buddha-contemplations ... . O Sāriputra, the bodhisattva assumes all forms of wonder-working powers. O Sāriputra, when former Tathāgata pursued the bodhisattvacary $\bar{a}$ they procured such buddha-qualities by means of worldly gifts. O Sāriputra, a bodhisattva who aspires to non-dying, enlightenment and nirvāna engages in giving worldly objects."

Finally - setting a precedence for päramitā illustration in all subsequent chapters-the $B d p$ gives an example of the jätaka-genre in order to demonstrate the worthwhile effects of practising dāna. The association of jātaka-type narratives and dāna practice has of course long been recognised. In particular, it was brought into connection with the rise of Mahāyāna Buddhism. ${ }^{141}$ Many scholars have indicated the rising popularity of the jātaka-genre in the proto-Mahāyāna movement and suggested that its description of the Buddha's former practice prepared the ground for the ascent of 'new', revised sets of practices in Buddhism. ${ }^{142}$ Above all, this holds true for the practice of generosity. The Buddha's willingness in the jätaka to abandon all possessions including his own life must have left a lasting impression on the minds of many people. ${ }^{143}$ Their popularity and wide circulation is well attested by their numerous recensions ${ }^{144}$ and reproductions in iconography across Asia. ${ }^{145}$

Ample testimony of this change is found in the literary documents of the Mahāyanna. The

140. R, folio 294.6-295.3.

141. Much has been written on the circumstance in which this transformation might have taken place and numerous, partly contradictory, scenario were proposed. For a survey of these theories, including a good bibiography, see: Bauman, 1988.

142. E.g., Lamotte. "Sur la formation du Mahāyāna". Asiatica, 1958, p. 377-80, "Mahāyāna". in The World of Buddhism. ed. Bechert; Gombrich, 1984, p. 90.

143. Particularly enchanting examples of the bodhisattva's selfless service and self-sacrifice are found in the Vessantarajātaka (Cone; Gombrich, Oxford, 1977), Mahājanakajātaka (Jātaka, vi, p. 34); Candraprabhajātaka (Mppśs, ii, pp. 715-6) Sarvadajātaka (Jătaka, no. 514; tịkā, v, pp. 36-57). For an example of such edifying stories preserved outside the jātaka collection, see the narrative of Velāma in Anguttaranikāya IV, pp. 392-396.

144. On the popularity of the jätaka genre in South Asia and the numerous recensions that attest this trend, see: Cone; Gombrich, 1977, pp. xv-xliv; Spiro, 1970, pp. 107-8, pp. 346-47; Gombrich. Precept and Practice. 1971, pp. 91, 93. For the persisting importance of jätaka in general, see: Spiro, 1970, pp. 18-21, 126, 153, 359 and Winternitz. Indian Literature. 1933, ii, p. 153.

145. See: Foucher. La Vie du Buddha. 1949 (introduction); Foucher, "Note sur l'itinéraire de Hiuan tsang en Afghanistan". Études Asiatiques, i, pp. 261-2; Foucher. La vieille route de l'Inde de Bactres à Taxila. i, Paris, 1942, pp. 130-32; Lamotte. HIB. pp. 644-685. 
first Mahāyāna sūtra to devote an entire chapter to the practice of giving was the Ug. Firmly anchored in the conduct of lay-bodhisattvas and acknowledged as fundamental to their training, dāna stands in the $U g$ at the centre of the whole discourse. The chief beneficiaries of the lay bodhisattva's dāna practice are mendicant monks. As his most elevated gifts are given to the Sangha, the bodhisattva trains to achieve the standards of morality of the monks. ${ }^{146}$ Since he is in equal measure wealthy and devoted to universal liberation, generosity becomes the grhapti bodhisattva's best-known practice and lends viability to his training in society. ${ }^{147}$ In the $U g$, the practice of giving consists chiefly of material objects. ${ }^{148} \mathrm{On}$ an immediate level, the imparting of his wealth is intended to alleviate the suffering of beings. However, if perfected, it becomes the discipline by which he purifies himself of the three root defilements ${ }^{149}$ and supports the conviction of the non-existence of a self. ${ }^{150}$ Not before the bodhisattva has rid himself of all three defilements becomes this transformation into all-knowing feasible. ${ }^{151}$ What is more, his practice of dāna becomes also the very basis for all other attainments, most notably the remaining five perfections-that, in turn, sustain his accomplishments in generosity. Giving free from expectations for reward is here characterised as the perfection of wisdom. ${ }^{152}$ Indeed, by promoting insight through a series of mental exercises relating to generosity that guide on his path ${ }^{153}$, dāna practice becomes something of a middle path between the extremes of worldly life. ${ }^{154}$ In the end, the grhapti bodhisattva's entire activity is undertaken in and for the practice of giving, since it is at once the principal means of liberation and, when perfected, liberation itself.

The grhapti bodhisattva receives the inspiration to dāna from mendicants who dwell in temples and whom he visits frequently for instruction. ${ }^{155}$ Ironically, in terms of dāna practice,

146. Ug, p. 267.1.2-2.8; p. 265.2.6-3.3.

147. Schuster, op. cit., p. 330.

148. At several places we read that the lay bodhisattva gives the gift of the Dharma by preaching its doctrines to his fellow beings. By and large, these are exception in an exposition where material objects are the principal items of dāna. But as this charity is inspired by Dharma and teaches Dharma by example, Schuster argues that the gift of the Doctrine goes well beyond Dharma instructions proper (op. cit., ii, p. 156-7). In principle, this of course holds also true for the $B d p$ and indeed all other works (e.g., $V k m$, p. 112). And yet, since no such connection is indicated in the texts themselves, I feel that such an inference would only blur the lines between the various types of giving and contribute little to clarifying the intent of our sources.

149. Ug, pp. 262.5.8-263.1.2.

150. op. cit., p. 263.2.7-3.2; p. 263.5.5-8; p. 264.4.3-5.7.

151. op. cit., pp. 262.5.8-263.1.6.

152. op. cit., p. 263.1.6-2.6.

153. op. cit., pp. 262.3.7-267.1.2.

154. op. cit., pp. 262.5.3-263.1.6.

155. op. cit., p. 267.3.2-4.4. 
the householder soon becomes superior to the mendicants, since they postpone däna cultivation proper until after dharma-cognition. ${ }^{156}$ In the $U g$ dāna constitutes therefore an important link connecting the householder with the mendicant ideal. Initially aroused by bhiksus, it perfects the conduct of the grhapti bodhisattva. At a later stage the monks are set to join him in order to train themselyes in dāna.

Another early text that discusses generosity in some detail is the $A \mathrm{kn}$. Its treatment of dãna has many features in common with the $B d p \cdot{ }^{157}$ It too discusses the practice of giving in the context of the six perfections. In both the $K p$ and $U g$ dana is treated largely independently of the other perfections. The $A k n$ 's exposition consists mainly of lists that enumerate the various objects of dāna and the mental states that accompany pure generosity. These enumerations address concerns similar to those of the $B d p$ and share a large stock of practices with the lists in the $B d p .^{158}$ Other parallels exist in the reward mechanism. Like the $B d p$ the $A k n$ explains that gifts of luxury lead to physical perfection, the giving of family members to high spiritual attainments and the giving of the body to the buddha-body. Differences are only found in the concluding passages, where the $A k n$ sets out to define the cognitive processes that accompany the practice of dāna. Here, we learn that dāna, when perfected, is pervaded by the absence of distinguishing marks (änimittaparibhävitva), operates in the sphere of emptiness (śünyatākāraprasādhita) and is not entangled in the affairs of the triple world (traidhātukāsamș̣șța). ${ }^{159}$

The dāna exposition in the $A k n$ represents an important watershed in the treatment of the practice of generosity. After it, departing from the numerative, highly laborious schemes of the early Mahāyāna texts, sütras adopted a more succinct style in their discussion of generosity. Increasingly, descriptions of dāna became replaced by investigations in its conceptual foundations and scope of operation.

Early traces of this re-orientation are found in the Rcd which shows much greater interest in

156. op. cit., p. $272.2 .4-3.2$

The mental preparation for the householder's practice of dāna is laid down in a list of fourteen deliberations that encourage liberal giving. These include recognition of the transiency of dharma, seeing the reality of non-self and perceiving that dāna frees the practitioner from fear, bonds of samsāra and the threat of Māra $(U g$, p. 262.3.7-4.7).

157. 34 , pp. 42.3.1-44.4.2.

158. Note that in $A k n$ like the $B d p$ the gift of the Doctrine receives only scant attention and does not stand in the foreground. In a lengthy enumeration of items that are being given by bodhisattvas (pp. 42.2-43.1.1), the gift of the Doctrine figures only indirectly in five places (pp. 42.5.1-6), but is even then never clearly established as the object of dāna.

159. op. cit, p. 43.2.8-3.1. 
the mental operations underlying and manifest pure generosity. ${ }^{160}$ At first, the sütra lays down the conditions that are favourable to the pursuit of generosity. ${ }^{161}$ These consists in unreserved impartiality in the act of giving towards all beings whether evil and virtuous; generation of the mind of enlightenment with the knowledge of the sameness of all dharma (sarvadharmasamatā); resolve that the roots of virtue accrued through giving do not become transformed into personal gain; unshakable faith in the three aspects of giving.

Then, proceeding from this first, largely preparatory practice, the Buddha defines those attributes that transform giving into pure giving. Above all, these consist of cognitive processes that dominate the donor's mind at the time of giving. The bodhisattva discards the eight mistaken views concerning the self and becoming; he is free from propensities (vāsanā) linking the donor with desire and the lower vehicles; his body, speech, mind and intention are fully purified; he passes beyond desire for reward; transcends the fears of pride, conceit and evil works and realises emptiness all around. ${ }^{162}$ Throughout the practice, his mind is set on the welfare of beings, buddha-qualities, marks of a mahapuruṣa and buddha-field.

The Rcd's trend towards succinctness and conceptualisation is set forth in the $V k n$ that is entirely devoid of lists of dāna objects. Casting aside old established precepts on alms-begging and its footing in morality, Vimalakirti advocates for unity of the benefactor, beneficiary and the object given (trimandalapariśuddhi) to become the basis of pure dāna practice. ${ }^{163}$ By doing so, he dismisses practically all early principles of dāna practice and adjusts the notion of giving to the Mahāyāna tenet of 'universal sameness' (sarvadharmatā) ${ }^{164}$ As a collateral of this overturn, he rejects the validity of distinctions in the objects of dāna. Thus, the gift of the doctrine is no longer restricted to preaching, but includes material goods as Dharma offering (dharmayajña). ${ }^{165}$

After the $V k n$, this thought was taken up in numerous Mahāyāna sūtras and became the basis for dāna practice. A good example is found in the Pañca. Acknowledging the validity of the threefold purity, it distinguishes a mundane and supramundane mode of generosity. On worldly dāna application, we read: ${ }^{166}$

160. 24, pp. 231.4.6-232.4.3.

161. op. cit., pp. 231.5.2-232.1.8.

162. op. cit., p. 232.2.1-3.3.

163. $V k n$, pp. 51-52.

164. M III, pp. 256-7; A I, pp. 161-2.

165. $V k n$, p. 112.

166. Pañca, p. 264 (trsl. Conze). 
"Held by three ties the bodhisattva gives a gift. What are the three? The notion of the self, the notion of others and the notion of a gift. To give a gift held by these three ties, that is called the worldly perfection of giving; it is called 'worldly' because one does not swerve from the world, does not depart from it, does not pass beyond it."

Rooted in the conviction of the inapprehensibility (anupalambha) of dharma, supramundane giving takes as its object the threefold purity of giving: ${ }^{167}$

"The supramundane perfection of giving, on the other hand, consists in threefold purity. What is threefold purity? Here a bodhisattva gives a gift, and he does not apprehend a self, a recipient, or a gift; also no reward for his giving. He surrenders that gift to all beings, but does not apprehend those beings, or himself either. And, although he dedicates that gift to the supreme enlightenment, he does not apprehend any enlightenment. ... It is called supramundane because one swerves from the world, departs from it, passes away from it."

Crucially important to both modes of giving, is the bodhisattva's willingness to transfer the gift itself and all the merit he gained through it to his fellow beings: ${ }^{168}$

167. Pañca, p. 253a (trsl. Conze)

The notions of mundane and supramundane levels of giving are taken up in the $M p p s$. Mundane giving (laukikadäna) consists in ordinary generosity or gifts granted by members of the āryan-fold, but accompanied by impure thoughts. This last point is subject to controversy as some have argued that every gift from the $\bar{a} r y a$, even if of impure motivation, is by definition, supramundane since they have cut off all fetters (samyojana) of existence through the apranihitasamädhi (op. cit., i, pp. 322-23).

Supramundane giving (lokottaradāna) has as its object items that are unreservedly pure and conforms to the true character (bhütalaksana) of the Dharma. It includes also relinquishing one's own life, if it is done out of concern for the welfare of beings (Mppś, ii, pp. 688-691). Every act of giving exclusively aimed at escape from samsära is impure, since it ignores the suffering of sentient beings and lacks interest in the 'true' teaching of the Dharma (Mppś, ii, p. 677). This position is fundamentally based on a passage in the Velämasutta (A IV, pp. 392-96) where the Buddha recounts an episode of his previous life as bodhisattva. Similar criteria apply to the donor. Persons who freely give away their riches but fail to abandon giving are mundane in character. Those, however, who resolve to renounce material objects and the concept of giving-knowing that they both are ultimately non-existent (anupalabdha)-are supramundane operators (Mppś, ii, p. 724).

168. Pañca, p. 176 (trsl. Conze)

In the final analysis even this tenuous link with conventional reality must be abandoned, since any thought of having given something away might lead to pride and satisfaction. In the words of the Vajracchedikä:

"A gift should not be given by a bodhisattva who is supported by an object; a gift should not be given by a bodhisattva who is supported anywhere. A gift should not be given by a bodhisattva who is supported by matter, sound, scent, taste, touch or mind objects. For Subhüti, a gift is to be given by a bodhisattva mahäsattva in such a way that he does not support himself even on the notion of a sign" (Vajracchedikä; Vaidya, 1961, p. 76; ref. Meadows). 
"Furthermore, O Sāriputra, the perfection of giving of a bodhisattva who courses in perfect wisdom and gives gifts consists in that, with attention associated with the knowledge of all modes, he turns over to full enlightenment that gift which he gives, after he has made that wholesome root [which results from the act of giving] common to all people."

It is on this note that $B d p$ concludes its discussion of dāna. Linking generosity with the cittotpãda, it sums up the fundamental principles of dāna practice as follows: ${ }^{169}$

"O Sāriputra, a bodhisattva who is skilful gives [gifts] to many people, even if [what is given] is small. His practice excels by virtue of the power of his pristine cognition. It is strengthened by the power of his wisdom. It is without limit by virtue of his power of dedication."

This survey of the development of the concept of dāna allows us to draw some conclusions about the treatment of generosity in the $B d p$. The nature of presentation suggests that the $B d p$ 's exposition of generosity belongs to the earliest strands in Mahāyāna sūtras. The extensive use of enumerations, the predominantly descriptive tone and the application of the jātaka-genre as a vehicle of explication all point to an early date of composition. It is difficult to establish the period of time of its formulation, but the fact that the $B d p$ does not expose the practice of dāna to the principles of Mahāyāna ontology and shows no interest in conceptualising indicates that it probably predates the discussions of the $V k n, P a \tilde{n} c a$ and Rcd. For the bodhisattva in the $B d p$, the practice of dāna involves quite clearly true hardship and unfeigned renunciation. That the $B d p$ does not include the gift of the Dharma among the objects of giving is further evidence of its antiquity because it suggests that teaching had not yet

This non-support of the bodhisattva when giving is extended in the Gaganagañjasũtra to the gift itself (Śiks, pp. 270.14-271.1):

"Just as space is immaterial, so the gift is independent of matter; just as space is without feeling, so the gift is detached from all feeling; in the same way, it is without consciousness, unconditioned and bears the characteristic of non-manifestation; just as space pervades all buddha-fields, so that gift is pervaded with compassion for all creatures; just as space is always transparent, so his gift is clear of the nature of thought; just as space illuminates all creatures, so his gift gives life to all creatures ... by absence of duality, gift is clear of the marks of illusion."

169. $R$, folio $298.5-6$. 
become a major concern of the bodhisattva. In later texts this position was fundamentally revised and dharmadāna became a major, if not the most important, aspect of the practice of generosity.

It is also of interest to note the connection between generosity and morality. When the $B d p$ discusses the forty manifestations of $d \bar{a} n a$ and the mental states that accompany pure giving, it is clearly concerned to show that giving is an intrinsically moral practice that can only flourish if it is applied within the confines of pure morality. We have seen that this link between dāna and śila is not particular to Mahāyāna thinking but had already been established by the Buddha in the Dighanikāya. In the Mahāyāna, the dāna/šila association is most evident in the early sütras. Apart from the $B d p$, it is found in the $U g, K p, R p, A k n, P r a S$ and Sukhävativyyüha. In response to shifts in perception that were occasioned by the increasingly powerful presence of the ontological postulates of siunnyat $\bar{a}$ and samat $\bar{a}$ this connection waned in later literature. Already in the $V k n$ it became delegated to the background and it is altogether absent from the Pañca. In a sense, its disappearance was inevitable and represents the logical outcome of a vision of reality that rejects the validity of all worldly experience and operates beyond the parameter of purity and impurity. The fact that it is found in the $B d p$ and placed very much in the centre of the exposition of dana is yet another indication that the $B d p$ is a work of great antiquity and belongs to the earlier strands of Mahāyāna sütras. 


\section{The Perfection of Morality}

"For ordinary people, for those who originate in the word [of the buddha],

For persons who are predestined to the awakening of pratyekabuddhas,

And for sons of the buddha there is no other cause but morality

[That leads to] supreme happiness and worldly delight."170

This verse, composed in the seventh century by Candrakirti, is eloquent testimony of the high esteem in which Buddhists of all ages held moral integrity. Valued for the disciplinarian rigour and purificatory effect morality impressed on those who subscribed to its observance, the practice of morality formed from early on a pillar of Buddhist spirituality. Echoing this importance, it was juxtaposed to meditation and wisdom and became one of the three cardinal practices the Buddha grew never tired of expounding.

In particular, moral conduct was valued for its preparatory role in the spiritual development. In the Dasuttarasutta, the Buddha included the following counsel amongst eight conditions that occasion wisdom: ${ }^{171}$

"Self-restraint in accordance with the pätimokkha code, equipped with wholesome conduct, recognising danger in even the smallest transgression, [a monk] trains in the moral precepts (sikkhāpada)."

The sāmaññaphala stage by stage account of the path in the sillakhandhavagga of the Dighanikāya draws a clear picture of the dynamics governing the progress of spiritual purification. This process starts with sila as the preliminary stage, proceeds through its intermediate stages with the practice of samādhi and culminates in the cultivation of pañña. ${ }^{172}$ The spirit of this scheme is encapsulated in a well-known passage of the 170. Mavbh, p. 41.17-20.

171. D III, p. 285.

172. This progressive characterisation of the path recurs numerous times in the nikãya. In the Majjhimanikāya (M I, pp. 178-89, pp. 267-71, pp. 344-8; III, pp. 33-6, pp. 134-7), we find several examples of slightly abbreviated versions. The same pattern, if adjusted to an altered frame of reference, is epitomised in the scheme of the seven perfections (visuddhi) of the Rathavinitasutta and, of course, in the overall structure of the Visuddhimagga. 
Mahāparinibbānasutta: ${ }^{173}$

"Such is sïla, such is samādhi, such is pañña. When imbued with sïla, samādhi is of great fruit and benefit. When imbued with samãdhi, pañña is of great fruit and benefit. When imbued with pañña, the mind is rightly freed from the āsava, namely the āsava of sensual desire, the äsava of becoming, the äsava of views, the äsava of ignorance."

In spite of this hierachical structure, it would be a mistake to infer that morality, meditation and wisdom are practised in isolation and succession. ${ }^{174}$ For, in practice all three are inextricably linked together and can only flourish in conjoint efforts: ${ }^{175}$

"Just as Gautama, one might wash hand with hand or foot with foot, even so pañña is fully washed by sila and sila is fully washed by pañña. Where there is silla there is paññā, where there is pañña there is sila. One who has sīla has paññā, one who has pañña has sila. [Silla] and pañña together are declared the summit of the world."

The best canonical treatment of sila is not to be found among the scattered references of the four principal nikāya, but in the Patisambhidamagga. ${ }^{176}$ For the Patis, the quality of sila is primarily determined by its scope and depth of application. Measured by as a series of factors that compromise moral integrity, these include transgressions motivated by considerations of gain, fame, family, physical well-being and life-and-death. ${ }^{177}$ It is only when silla is wholly unaffected and well beyond such worldly concerns that it fosters spiritual growth and becomes the basis for nibbāna. ${ }^{178}$

In order to be fully beneficial to these attainments, moral conduct must have its foundation in cognition and operate in combination with restraint, non-transgression, volition and

173. D II, p. 81 ; repeated on pp. $84,91,98$ (trsl. Gethin; my punctuation).

174. For a more detailed discussion of their interrelation see: Gombrich,1984, pp. 91-102 and Gethin, 1987, pp. 399-400.

175. D I, pp. 124 (trsl. Gethin; my punctuation)

Samãdhi is omitted in this scheme as the Sonadandasutta, from which this quotation stems, investigates the path phases only in terms of moral conduct and wisdom.

176. Patis, i, pp. 43-48.

177. A commentary on this section is found in Vism, i, p. 12 .

178. Patis, i, p. 44. 
consciousness-concomitants (cetasika). According to Buddhaghoșa ${ }^{179}$, quoting canonical sources, morality as restraint refers above all to the restraint through the pätimokkha code ${ }^{180}$, mindfulness, knowledge, patience and energy. ${ }^{181}$ Sila as non-transgression applies to compliance with whatever commitments of virtue one has undertaken. Since these vary with the respective vows, silla ranges from non-violation of the pañcasila to full adherence to all Vinaya rules. Conceptually, morality as volition and consciousness-concomitants go hand in hand as they represent two aspects of the same mental factor. The volitional dimension refers to the positive intention (cetan $\bar{a})$ that is present in one who refrains from killing, etc., while, its consciousness-concomitants are those aspects of consciousness that arise together as the factor of abstinence. ${ }^{182}$ If applied to the ten wholesome acts of refraint, morality as volition accounts for the cetan $\bar{a}$ that generate the first seven non-actions, while its consciousnessconcomitants generate the three remaining states of non-covetousness, non-ill-will and right view. $^{183}$

On the basis of these distinctions, the Patis draws up five categories of sila, namely, abandoning, abstention, volition, restraint and non-transgression, and relates them to each of the ten non-virtuous actions. The most important benefit that flows from these five modes of sila is 'non-remorse cognition' ${ }^{184}$ It is so because it prepares the ground for higher understanding of the path which prompts the practitioner to carry out all practices as required. ${ }^{185}$

Buddhaghoșa, greatly expanding on the silla section of the Patis, proposes nineteen aspects of morality. ${ }^{186}$ Of particular interest for the present study is his understanding of mundane and supramundane morality. Citing a passage from the Vinaya, he establishes that sila that is still subject to the cankers is essentially mundane. ${ }^{187}$ It brings about improvement in future states of existence and constitutes an indispensable prerequisite for deliverance. Supramundane morality, in contrast, operating beyond worldly constraints, is capable of leading directly to

179. Vism, i, p. 8 .

180. According to the Kosia (iv, pp. 47-48), propounding a Sautrāntika point of view, the discipline of the prātimoksa code falls into four categories. Morality (śila) redressing that which is unjust; good conduct (sucarita) that is praised by the wise; action (of body and speech) because it is action by nature; and discipline (samvara) because it constrains body and speech.

181. D I, p. 70; M I, pp. 10-11; Sn. 1035.

182. Cf. Atthāsalini, iii, chpt. v, pp. 103-106.

183. Vism, i, p. 7

184. See also A V, p. 1 where we read: "Ānanda, profitable habits (virtues) have non-remorse as their aim and non-remorse as their benefit."

185. Patis, i, p. 47.

186. Vism, i, pp. 10-51.

187. Vin, v, p. 164. 
nibbāna and represents the plane of 'reviewing knowledge'. ${ }^{188}$

Purification itself is brought about through four modes of practice and behaviour. ${ }^{189}$ First, there is purification by teachings. This form of purity originates in hearing and observing the rules of the Pätimokkhasutta. Second, purification by restraint refers to consciously undertaken abstention from sensual indulgence. It evolves from a resolution to that effect and varies according to the commitments. Third, purification by search is achieved through conscientious probing resulting in rightful acquiring of requisites. Fourth, purification by reviewing emerges from mindful scrutiny of those objects that one plans to appropriate prior to the acquisition proper in order avoid unintended offence. ${ }^{190}$

The Mahāyāna sūtras incorporated many of the above concerns into their interpretation of sila. This is attested by the great number of silla expositions that revolve around the issues that are expressed in the tenfold virtuous activity (kusalakarmapatha). But they also went beyond this scheme which was expanded to comprise numerous other qualities and practices. Religiously, many of these new precepts grew out of the resolve to achieve universal deliverance and accommodate therefore a much greater spiritual ideal. This led to a conceptual expansion of the notion of silla beyond the parameter of the prätimokșa code.

Cognitively, this expanded interpretation of morality required a new frame of reference to

188. Vism, i, p. 13 .

Next, Buddhaghoșa distinguishes moral conduct that is natural, necessary, customary and due to previous causes ( $V$ ism, i, p. 15). A similar characterisation of the nature of moral conduct is found in the $B b h$ where we read that sila should be understood as adopted, natural, habituated or conjoined with means. Adopted morality is that on which the threefold morality of the $B b h$ is modelled. Natural morality is undertaking physical and vocal activity that is entirely pure because of the nature goodness of the mental continuum that is established in the bodhisattva fold. Habituated morality characterises the moral conduct by which the bodhisattva has grown accustomed to the threefold morality in his previous lives. Morality that is conjoined with means refers to the bodhisattva's reliance on the four means of conversion in order to encourage to virtuous activity of body and speech (Bbh, p. 184.6-22).

According to the Kośa, combining material from two discourses of the Anguttaranikāya (II, p. 121; IV, p. 364), morality is of four types. First, there is morality of fear. One observes this out of concern for loss of the daily necessities, out of concern for a bad reputation, out of fear of chastisement and out of fear of birth in the evil destinies. Second, there is mercenary morality that one adheres to out of attachment to life in the good destinies, to pleasures and to honours. Third, there is morality that is suitable to the factors of enlightenment that pertain to persons of right view. Fourth, there is pure morality that, being free from stain, is free from vices (Kośa, iv, p. 248).

189. Vism, i, pp. 43-44.

190. In the Kosa (iv, pp. 247-8), moral purity is attributed to rejection of the causes of immorality (viz, the kleśa and upakleśa), to the workings of the four bases of mindfulness (vi, p. 158) and to reliance on the peace of nirvāna. Then, it considers five additional causes of moral integrity. These are purity of the deed itself (renouncing of evil deeds); purity of their attendants (renouncing the preparations or the means of killing, etc.); absence of the disturbance from vitarka (kāma, vyāpāda and vihimsāvitarka); its supervision through mindfulness (Buddha, Dharma and Sangha - that includes the renunciation of undefined actions) and its application to nirvāna (op. cit, iv, p. 248). 
allow integration into the revised philosophical tenets of Mahāyāna thinking. The calls for purity of body, speech and mind indexed to a world that itself had no independent claim to existence beyond the level of convention must have startled the minds of many Buddhists of the day. In order to allay this bewilderment and to reconcile what appeared to be contradictory demands, Mahāyāna thinkers drew up a blueprint that distinguished two levels of truth. On the lower or conventional level, the need for moral integrity was upheld. On a higher level of understanding - reserved to those of rare spiritual gifts-'reality as it is' (yathābhüta) revealed itself as having the characteristics of same (sama), unborn (anutpanna) and calm (śänta), operating beyond the categories of purity and impurity. Seen from this absolute viewpoint, all endeavours in morality lose in their meaning and become harmful to liberation since they obstruct conceptual 'unbecoming' by superimposing non-existent predicates on reality.

It was from this kind of changes in perception that there eventually emerged a new type of ethics - the bodhisattva morality (bodhisattvasizla). Based on the amalgamation of the vastly expanded mission and the new vision of reality, Mahāyāna sūtras came to propose a moral ideal that was tailored to the spiritual aspiration of the bodhisattva. Dismissing the early prohibitive schemes of the śrāvaka as inadequate, the bodhisattva morality superseded the ancient conventions and replaced them with a scheme that allowed for a free interplay between cognitive realisation and the religious obligation of universal liberation.

That this process was slow is attested in several early Mahāyāna sütras where we find the treatment of silla still bearing close resemblance to the ideal of early Buddhism. ${ }^{191}$ That is to say, it continues to revolve around the tenfold virtuous activity, to emphasise the threat of desire and to operate within (be at the margin of) the confines of śāvakayāna ontology. A good example is the $U g$. Here, the treatment of silla is still dominated by an exposition of the pañcaśila. ${ }^{192}$ Following well-established pattern, it discusses the five limbs and points to the

191. Asta, p. 427; for a list of eleven, see: Asta, p. 324 (cf. Saddhp, pp. 275-296).

Another example is the $D b h$. The $D b h$, however, stands out for the fruits it proposes arise from the kuśalakarmapatha. According to this text the kuśalakarmapatha lead to the state of pratyekabuddhahood when purified through the insight of its attainment. They encourage purification of the bodhisattva's stages, perfections and conduct if practised in the spirit of the bodhisattva's pranidhana and lead, if fully purified, to the state of buddhahood itself (Dasia-bh, p. 26.1-13).

192. As if appended to the chapter, the $U g$ adds in a few lines the remaining five silla of the akusalakarmapatha so that in fact all ten factors are present (pp. 261.2.6-3.5).

The pañcasila correspond to the first five precepts in a list of rules known in Päli as the sikkhäpadāni (Skt. sikșäpadäni). Both refer essentially to those precepts a layman is expected to observe when he enters into the Buddhist community and, to some extent, define his spiritual status. In the Buddhist training, their role is chiefly preliminary as they prepare the commitment to higher disciplinary practices. In substance there is no difference between the pañcaśila observance of śrāvaka and bodhisattvas since it spells out a basic moral ideal that is quite independent from the cittotpäda and pranidhäna. In a controversial article 
disadvantages arising from their violation, with desire (räga) rated as the most serious obstacle. ${ }^{193}$ Traces to the new ideal are few and do not affect the spirit of the treatise. They occur only once in a brief passage indicating compassion behind harmlessness and in a reference to 'caring generosity'.

In the Rcd, sịlla is given a more advanced treatment. In particular, it displays several concepts that link it unambiguously with the Mahāyăna. First, it states that the bodhisattva's whole practice of morality is rooted in the cittotpāda. ${ }^{194}$ Whatever its manifestations, the overriding purpose of the sila practice is the universal liberation of beings. This objective is achieved by the traditional practice of the daśakuśala in conjunction with selfless service and resolve. The motivation behind the bodhisattva's moral training is therefore Mahāyāna, while the means to achieve progress therein are outlined along the conventional understanding of silla. For the author of the Rcd, no doubt, moral purification takes place in a world of 'real' obstacles, genuine impurity and is achieved through a set of practices specifically designed to overcome them.

In the $A k n$ this understanding of morality is taken up and further integrated into Mahāyāna ontology. At first, like the Rcd, the $A k n$ looks at morality from a conventional point of view and enumerates a great number of attributes that pertain to moral perfection. ${ }^{195}$ Although the list commences with the daśakuśala, many of the items go well beyond its scope and link sila specifically with bodhisattva practices. ${ }^{196} \mathrm{Next}$, the $A k n$ investigates the nature of morality in the light of the doctrine of non-attribution (asamäropa), concluding that morality of the foundation of being (dharmtāsila) prevails when there is absence of names and signs

(1963), Hirakawa has pointed out that in several versions of the Asta the daśakusala are identical with the daśasila of the nikāya to conclude that the daśakuśala were originally the morality of laymen after which they were adopted by the Mahāyanists as the basic discipline for lay and recluse bodhisattvas (p. 75). Alleging that the daśakuśala were neglected by nikāya Buddhism and taken up in reaction by the Mahāyāna, he argues that the pañcasila became the new basis of the bodhisattva morality. This raises several problems: First, the pañcasilla do not correspond to the first five elements of the daśakusala but have counterparts in the sikșapadäni. Second, for the $U g$ on which much of his claim rests (p. 94), the pañcasilla are enjoined for laymen-not recluses. Third, not even the daśasila and daśakuśala correspond in contents. All this indicates that the situation was much more complex than suggested by Hirakawa and that we cannot speak of a direct, verbatim borrowing between the morality of srāvaka and bodhisattvas. Both, no doubt, shared a common conception of morality - that, according to Gombrich, (1984), had a pre-Buddhist origin-and were guided by similar principles. But to stipulate a direct line of borrowing seems certainly to oversimplify matters.

193. Ug, p. 261.1.2-2.6.

194. Rcd, p. 232.4.5.

195. $A k n$, pp. 43.4.2-44.1.7.

196. The $A k n$ includes, for instance, unloquacious morality (amukharasíla), peaceful morality (śāntisílla), morality which grasps adequately gentle speech (suvacahpradaksinagrahaśila), morality of bringing sentient beings to maturity (sattvaparipācanaśíla) and morality guarding the Dharma as manifestations of śila (p. 44.4-6). 
(nämasamketa), since "morality is where there is no attribution of body, speech and mind". 197 If seen from the paramārtha point of view and subjected to the same philosophical rigour as all other phenomena, it becomes a non-practice (adharma) of no independent existence. With such propositions in hand, the $A k n$ draws a clear line in the understanding of morality. By fully integrating moral conduct in cognition and by making its purity dependent on insight rather than practice, it blurs the distinctions between silla, samādhi and prajūā as never before. It is true that also in the $A k n$ the cognitive dimension is still dominated by practical concerns of morality; and yet, its cognitive propositions clearly herald a new type of understanding of silla. ${ }^{198}$

The first sutra to undertake a clear commitment to this ontological interpretation was the $K p$. Here, in a memorable passage, we learn: ${ }^{199}$

"Die Moral, Kāsyapa, wird Moral genannt, bei der kein Selbsthaftes, kein Wesen, kein Nominalismus des Wesen, kein zu Tuendes, kein nicht zu Tuendes, kein Bewirken, kein nicht Bewirken, kein Wandel, kein Nichtwandel, keine Ausführung, keine Nichtausführung, kein Name, keine Gestalt, kein Attribut, kein Nichtattribut, keine Ruhe, keine Beruhigung, kein Erfassen, kein Aufgeben, kein zu Erfassendes [existiert]. ... O Kāsyapa, die Moral is ohne Einflüsse, nichts zugehörig, abgesondert von der Dreiwelt, fern von all Basis im Leben."

It is argued that monks who still considered moral conduct as a 'real' concern involving independently existing beings and of sensory experience that is based on mistaken assumptions (upalambhadrstitika)-however conscientiously they might have observed the precepts-failed to accomplish moral purity. ${ }^{200}$ In the words of Candrakirti: ${ }^{201}$

"If [a bodhisattva] sees in moral purity an own-being (svabhāva)

By that very reason, his morality is not pure."

Besides this reinterpretation of silla, the $K p$ makes another important contribution to the

197. op. cit., p. 44.1.8-2.4.

198. op. cit., p. $44.2 .4-7$.

199. Kp, pp. 202-206, § 140-142 (trsl. Weller).

200. op. cit., pp. $191-2, \S 134$.

201. Mavbh p. 37.17-18. 
understanding of morality. We have seen that so far conventional morality is chiefly concerned with the daśakuśala, either set in the context of prohibitive regulations or aligned to the thought of enlightenment. This concept is not absent from the $K p$. It encourages repeatedly constraint of the senses ${ }^{202}$, correct conduct ${ }^{203}$ and genuine observance of monastic precepts ${ }^{204}$ as the principal means to overcome evil propensities. ${ }^{205}$ Where it differs is the stipulation for extensive roots of virtue (kuśaladharma) to complement compliance with the regulative strands of sila so that they may result in maximum benefit. This recognition, it is true, is not totally absent in other texts. However, in the $K p$ it is for the first time that the accumulation of roots of virtue-if only tentatively - is proposed as a regular concomitant of morality. ${ }^{206}$ In later Buddhist literature, most notably the $B b h$, this association contributed to making the accumulation of roots of virtue an integral part of bodhisattva morality.

In the $V k n$, apparently building on the concerns of the $K p$, but leading them to a logical conclusion, Vimalakirti clarifies the impact of mind on moral conduct: $:^{207}$

"A fault exists neither on the inside, nor on the outside, nor between the two. ${ }^{208}$ And Why? Because the Blessed One has said: 'By the defilement of the mind are beings defiled, by the purification of the mind are they purified. Honourable Upāli, the mind exists neither on the inside, nor on the outside, nor between the two. So it is with a fault as it is with the mind, and with all dharma as with a fault: they are not separated from suchness.' ... All dharma are without arising, disappearance and duration, like an illusion, a cloud or a flash of lightening. Those who know this are called the true guardians of the discipline."209

202. $K p, \mathrm{p} .46, \S 22.1$

203. op. cit., p. $13, \S 6.2$

204. op. cit., pp. 18-19, § 8; pp. 191-2, § 134.

205. op. cit., p. $45, \S 21.1$.

206. $K p$, pp. $10-19 ;$ pp. $41-44, \S 5,6,8,19,20$

The advantages that accrue from the roots of virtue are manifold, but always personal to the bodhisattva. The means by which a bodhisattva accumulates roots of virtue are fourfold, viz., delight in solitude, practice of the means of conversion, selfless service and self-sacrifice and insatiability for roots of virtue (op. cit., p. $41, \S 19$ ). In the $K p$, the only factor capable of removing their accumulation is mind (citta) that, though utterly insubstantial, represents a real threat to the bodhisattva's morality since it is associated with the sense pleasures but difficult to trace (op. cit., p. 149, §102).

207. $V k n$, pp. 71-73 (trsl. Lamotte).

A very similar version of this passage is also found in the $K p$ (p. 144, § 98) and in the Mpps' (ii, p. 861).

208. The reasoning behind this thought is explained in the $K p$ (pp. 206-10, $\S 142-44$ ) where the point is made that the formulation of an idea on a concept incurs conceptual bondage (samjñäbandhana) and that the only mode of escape from its trappings is given through entry into the attainment of the extinction of consciousness and sensation (samjñ̄ävedayitanirodhasamäpatti).

209. On the notion of non-separation the $V k n$ (p. 192; trsl. Lamotte) adds: 
The Pañca, introduces a third element that, while tacitly present in all Mahäyāna sütras, has never before been specially mentioned as a factor affecting sila practice. This is the bodhisattva's resolve to mature all sentient beings: ${ }^{210}$

"Coursing in the perfection of morality ... endowed with this skill in means, the bodhisattva grows in wholesome roots, courses in the perfection of morality, matures beings, and purifies the buddha-field. But he does not aspire for any fruit from his morality, which he could enjoy in samsära, and it is only for the purpose of protecting and maturing beings that he courses in the perfection of morality."

While it is difficult to assess the influence such a passage might have had on subsequent developments, it is striking that many of its key elements found their way into later scholastic literature. ${ }^{211}$ In the $B b h$, for instance, one meets with exactly the same silla division proposing discipline, collecting wholesome roots and ripening of beings as chief components of moral conduct. $^{212}$

The first element, entitled morality of the vow (samvarasilla) is said to vary according to the seven commitments that are open to Buddhist followers. ${ }^{213}$ Recognising the variety of

"Good and bad are two. Not seeking after either the good or the bad, understanding that the sign and the signless are not two, this is penetrating into non-duality ... To say, 'this is impure and that is pure' implies duality. If one grasps dharma from the angle of their sameness, one no longer produces either a notion of impure or a notion of pure, but one is still not notion-free ..." (cf. Madhyāntavibhäga, p. 221. 24).

210. Pañca, p. 489 (trsl. Conze).

As the overriding concern of the bodhisattva training in general, this intention figures in one way or another in all sütras we have looked at so far. Most notably, it is implied in the Rcd's depiction of sila where the thought of enlightenment is given as the foundation of moral conduct. Yet, prior to the Pañca, no text cites 'morality as benefiting beings' (sattvānugrähakaśila) as a quality that pertains specifically to moral conduct--let alone, as its raison d'être (cf. $\$$ gss, p. 142).

211. For a concise, if slightly inaccurate, survey of sources in which these issues occur, see: Hōbōgirin, 1929-1930, "Bosatzukai", pp. 142-146.

212. Bbh, p. $138.24-27$

The same division appears also in the Siddhi (pp. 631-32) and is incorporated in the scheme of sila propounded in the $M s g$ (pp. 212-13). In the Msg, however, it does not serve as an overall classification, but-representing 'superiority in kind'-forms part of a fourfold scheme that distinguishes 'distinction in kind' (prabhedavisesa), 'distinction founded in rules that are common and not common' (sädhäranāsādhäranaśikșaviśeșa), 'distinction in immensity' (vaipulyavišeșa) and 'distinction in depth' (gambhiryavisesa). Compared with the plan of the $B b h$, the scope of this classification is rather limited and leaves many issues unexplained.

213. Altogether, action of discipline falls into three categories: (1) action included in the discipline of the prātimokșa vow, (2) action included in the discipline of meditation (dhyānasamvara), (3) action included in the discipline of (supramundane) purity (anāsravasamvara).

As discipline of the prätimoksa vow Buddhism distinguishes eight kinds of commitment-not seven (Abhidh-sam (R), p. 90). These are the discipline of monks (bhikșusamvara), nuns (bhikșunisamvara), of 
human circumstances, the $B b h$ integrates both the lay and monastic side in its vision of the bodhisattvaśila. ${ }^{214}$ However, the description of the bodhisattva's samvaraśila suggests that it is in fact firmly placed within the monastic environment. ${ }^{215}$

The second component of silla involves the accumulation of factors of virtue (kuśaladharmasíla). ${ }^{216}$ The bodhisattva achieves this through a variety of practices, including reverence, mindfulness, compassion, seclusion and of course the practice of the päramitā. Of particular interest are the five aspects of wisdom. These enable the bodhisattva to learn about the advantages that accrue from virtue, the causes of virtue, distortions (viz., the four mistaken views), non-distortions and about the obstacles to accumulating virtue. ${ }^{217}$

The third aspect of morality is directed at the welfare of sentient beings (sattvānugrāhakaśila) and specifically concerned with those practices that allay their suffering. ${ }^{218}$ It includes training in skilful means, means of conversion, generosity ${ }^{219}$, protection ${ }^{220}$, compliance when appropriate

those who undergo training (siksamānasamvara), novices (śramanerasamvara), female novices ('śāmanerisamvara), lay-followers (upāsakasamvara), female lay-followers (upāsikāsamvara) and the discipline of fasting (upavāsasamvara). Possibly Asanga saw a correlation with the seven groups of moral observance that are comprised in the discipline of the prätimokssa vow, viz., päräjika, sañghävaśeșa, aniyata, nihsargika-pāyantika, pāyantika, prātideśaniya and saikșa. A good summary of some of the issues pertaining to the eight types of discipline is found in the Kośa (iv, pp. 41-47).

The discipline of meditation refers to abstention from indulgence in sense pleasures at a time when the seeds of defilement stemming from immorality, particularly those of sexual desire, are cut off during the first three stages of meditation. The Kośa (iv, p. 41) adds that while the prātimoksasamvara belongs to the kāmadhätu, the dhyannasamvara operates only in the rūpadhätu.

Discipline of (supramundane) purity constitutes pure abstention that is attained through internal insight of truth by the force of one's attention to pure realms (Abhidh-sam (R), pp. 90-91). They exist among the gods of the kāmadhätu and rüpadhātu (with the exception of the asamjiñasattva and the gods of the intermediate dhyāna), though never in the arüpyadhätu since discipline belongs to the sphere of matter which the arūpyadhătu gods cannot possess (Kośa, iv, p. 105).

The discipline that arises from meditation and the pure discipline are concomitants of the mind; not the prätimoksa discipline since it continues to exist in persons whose mind is bad or neutral, or who is unconscious (Kośa, iv, p. 51).

For further detail on the prătimokșa morality, see: Kośa, iv, pp. 87, 94-101; Pațis, pp. 43-44. For an appraisal of the upavāsasamvara see: Kośa, iv, pp. 64-72 and Mppś, ii, pp. 825-39.

214. $B b h$, p. $138.18-23$

While, in general, this attitude is very common in Mahãyäna sūtras and śăstras, it is rare that it becomes as explicitly expressed as it is here in the $B b h$. In most cases, the proposition that the bodhisattvacarya can either be pursued in a monastic environment or as a layman is tacitly assumed. Notable exceptions to this rule are the $V k m, U g, V u p$ and Upassakasizlasütra. For a succinct discussion of the various aspect that pertain to the lay and monastic ideal, including a list of references in Pāli and Sanskrit sources, see: $V k n$, pp. 75-77.

215. $B b h$, p. $141.2-6$

For an account of the kinds of action that infringe on discipline (asamvara), their impact on the bodhisattva's spiritual development and the psychological reactions they occasion, see Abhidh-sam $(R)$, pp. 91-98.

216. $B b h$, p. 139.1-3.

217. op. cit., p. $144.9-16$.

218. op. cit., p. 140.4-28.

219. op. cit, p. 147.7-25.

220. op. cit., p. 146.14-19. 
and resistance when necessary ${ }^{221}$, sympathetic joy ${ }^{222}$ and performance of wonder-working powers. ${ }^{223}$

For the cultivation of the threefold morality to become successful several preconditions have to be met. ${ }^{224}$ First, the bodhisattva requires a learned instructor in order to correctly receive his silla instructions. Second, it is essential that the bodhisattva acquires a fully purified intention (adhyāsaya) since it determines judgement in the application of the precepts. ${ }^{225}$ If he is thus equipped, two more dharma emerge, viz., an undertaking to correction after failure and mindful avoidance of failure through respect. Accurate reception, pure intent and reverence are by themselves highly effective in preventing breaches of the bodhisattvasilla. ${ }^{226}$

In the $B b h$, the reception of the bodhisattvasisla is inextricably linked with the taking on a commitment (samvara) in moral observance. Having solemnly declared his yearning for instructions in morality, the bodhisattva pledges: ${ }^{227}$

\begin{abstract}
"I, of such and such a name, declare before all the Tathāgata and bodhisattvas of the great stage of the ten directions. Before them I undertake all the moral precepts of the bodhisattva and the entire bodhisattva morality; the morality of the vow, the morality of accumulating factors of virtue and the morality accomplishing the welfare of sentient beings that the bodhisattvas of the ten directions of the past, present and future have trained in."
\end{abstract}

The scope and effectiveness of this samvarasila is thought to be superior even to the prätimokșa vow - the most demanding of the eight traditional commitments. Theoretically, it enables the bodhisattva to train himself by following his own judgement. In practice, however,

221. op. cit., pp. $147.25-150.13$.

222. The bodhisattva applauds in particular those beings who have attained the qualities of faith, morality, learning, renunciation and wisdom (op. cit., p. 150.13-19).

223. op. cit., pp. 151.13-152.14

A summary of the impact of this practice is given in a section detailing the eleven modes by which the bodhisattva is established in the morality of accomplishing the welfare of sentient beings. However, since this covers much common ground I shall not go into the detail of these factors (op. cit., pp. 144.23-152.17).

224. op. cit., p. 137.14-25.

225. I have found no other text in which these requirements are stipulated. Most treatises simply refer for the foundations of morality either en bloc to the combined practice of the daśakuśala (Mppś, ii, pp. 782-819, Daśa-bh, pp. 26-27), or accentuate absence of (sexual) desire and hatred in conjunction with correct views as factors generating morality (Mavbh, p. 33.3-6).

226. $B b h$, pp. 137.26-138.7

These three elements correspond to cardinal issues around which much of the exposition in the $B d p$ revolves (folio 306.1-4, 314.2-320.6).

227. $B b h$, pp. 181.21-182.2. 
he is advised to listen regularly and to consult the basket of the bodhisattva scriptures (bodhisattvapitaka) since it assists him in the observance of the moral precepts. ${ }^{228}$

Modelled in name and number on the 'defeats' (pārājika) of the srāvaka Vinaya, the Bbh lays down four factors that signal failure in morality. Characteristically, these do not refer to moral violation in the traditional sense, but address backtracking in the bodhisattva's resolve. The four are (1) desire for praise and respect, (2) close-fistedness in wealth and Dharma, (3) anger and (4) repudiation of the bodhisattvapitaka. ${ }^{229}$

Repeated intentional violation of these leads to instantaneous and permanent forfeiture of his roots of virtue and loss of the cittotpäda. ${ }^{230}$ However, should the bodhisattva show only weak or medium involvement-even if his undertaking is relinquished-he retains the opportunity to receive once again the vow of morality in the same lifetime. ${ }^{231}$ Moreover, once the vow is taken in accordance with the regulations and not abandoned, it maintains validity throughout the numerous life-cycles of his career. ${ }^{232}$

228. $B b h$, p. $156.7-11$

To the Mpps (ii, p. 586) moral conduct is self-promoting. It proposes that attainments in the pañcisla of the upassaka inspire the tenfold morality of the sramana that, in turn, when perfected, lead to the discipline of the monks (prätimoksa). This, again, occasions the next higher form of morality, morality springing from meditation (dhyānaśìla), from which arises-once accomplished-pure morality (anāsravaśìla). Cf. $B b h$ (p. 186.16-19) that distinguishes, unfortunately without further elaborating, five modes of morality that are furnished with giving, patience, vigour, meditation and wisdom.

229. $B b h$, p. $158.2-5$

This list of pārājika is not the only one that was drawn up for the bodhisattva. In the Brahmajälasūtra-a late text of doubtful authenticity - we meet with ten dharma that entail defeat and deprive the bodhisattva of his status. These include, besides the pañcasila, bringing others into disrepute, avarice, boastfulness at the expense of others, malevolence and calumny of the three jewels (DeGroot, 1967, pp. 32-39; Eidman, 1958 , pp. 392-3).

230. The second factor leading to the relinquishment of all moral undertakings is the bodhisattva's abandonment of his resolution (pp. 159.23-160.2).

231. $B b h$, p. $159.9-24$

It appears that the concept of the opportunity of regeneration was introduced by the Vup. We saw that the bodhisattva's observance of morality-like all other aspects of the training -is decisively influenced by his determination (adhyäśaya). Expressed and strengthened in the commitment of the vow and resolution, it provides the bodhisattva with a stable and firm basis for his entire conduct. Since it is raised consciously and deliberately, this intention creates a mental shield that resists evil and, should it be breached, allows for swift restoration.

For the srāvaka, the only means of spiritual renewal is given in the highly formalised confession-ritual (Vin, ii, p. 126, 192; iv, p. 18). While this is also available to the bodhisattva, it has lost much in formality and has gained a more personal note. In the Vup, the issue that matters most is no longer exact compliance with procedure, but the candidate's genuine regret and his undertaking to prevent a repetition of the transgression (Vup, pp. 36-38).

On the provisions for a confession of sins, see: $B b h$, p. 181.6-21; Vup, pp. 31-37; Ug (cited in Siks, p. 290.3-6, but attributed to the Vup); Kp, p. 170, § 119; Saddhp, p. 210; Lal, p. 379. Passages raising the possibility of private confessions are also found in the nikāya: D I, p. 85; M I, p. 438; III, pp. 244-7; S I, p. 24; II, p. 127, 205; A I, p. 238; II, p. 146; IV, p. 377.

232. This is not the case of srâvaka discipline, where commitment to the discipline is only valid for the present life-time (Kośa, iv p. 63). The argument behind this proposition is that the person one would become would be different, that this new person would not be able to apply himself to the rules and that he would not remember undertaking them (Kośa, iv, pp. 63-64). 
The gravity of moral transgressions other than the four defeats depends (as in the srāvaka Vinaya) very much on the circumstances in which they were committed. ${ }^{233}$ In general, acts committed out of indolence, irreverence, greed, desire, pride, negligence or ill-will—the very antitheses to the bodhisattva's resolution-are considered transgressions involving defilement. If developed out of forgetfulness, illness, mental distraught or ignorance, the fault is a transgressions without defilement. ${ }^{234}$

Finally, infringement on morality that originates in the bodhisattva's pranidhäna is entirely free from fault or stigma. ${ }^{235}$ In order to elucidate this precarious issue, the $B b h$ draws up several scenarios where the violation of each of the daśakuśala is not only condoned, but becomes a vital expedient to the promotion of spiritual welfare among beings. ${ }^{236}$ Hence, according to the $B b h$, "there is nothing that is categorically a fault" on the bodhisattva's path. This thought is carried further in a preamble to examples that describe the scope and flexibility of the bodhisattva's moral conduct: ${ }^{237}$

"Even in the case of what is reprehensible by nature, the bodhisattva acts with such skill in means that no fault ensues; rather there is a spread of much merit."

In other words, by virtue of his expertise in skilful means ${ }^{238}$, the bodhisattva is allowed-at times even encouraged - to commit transgressions of disobedience (pratiksepanasāvadya) if, by doing so, he benefits sentient beings. ${ }^{239}$ We saw that for the srāvaka, moral contravention occurs only within the sphere of physical and vocal activity. Mental inaptitude is not directly addressed by the prātimoksa rules. This does not hold true for the bodhisattvasilla where mental improbity (cittāpatti) is fully recognised as a source and manifestation of moral infringement. ${ }^{240}$

233. Bbh, pp. $160.10-165.1$.

234. $B b h$, p. $180.10-12$.

235. The text gives an example in which the bodhisattva is invited to a house but chooses not to accept the invitation. If he rejects it out of enmity or resentment he has committed a defiled fault, but if he does not attend because he learned of the opportunity to hear a Dharma discourse of great value he is free from fault (Bbh, pp. 162.25-164.7).

236. $B b h$, pp. $164.19 \mathrm{ff}$.

237. $B b h$, pp. $165.26-166.1$.

238. Cf. $M s g$, p. 216.

239. He is, for instance, encouraged to accept vast quantities of robes, alms-bowls, beds, rugs and even gold and silver to redistribute them among sentient beings (Bbh, p. 165.8-22).

240. $M s g$, p. 214.

Generally, rather than actively transgressing certain rules, it is abstention from required actions that is regarded as a severe violation of the bodhisattva's morality. For instance, should a bodhisattva who is in 
But now to the $B d p$. In emphasis and orientation, its treatment shares a common understanding with that of early Buddhism. Since moral improbity is held to lead inevitably to spiritual ruin, its main concern revolves around the need for conventional moral integrity. The presentation possesses therefore many of the hallmarks of the prohibitive vinaya-type approach, while, at the same time, it allows for adjustment to the increased scope of the new ideal.

The bedrock for the whole exposition is the insistence on the conscious and intentional abstention from the ten evil paths of action (akusalakarmapatha) ${ }^{241}$ It takes up over a third of the chapter and is divided into the spheres of body (killing, theft and sexual misconduct), speech (falsehood, slander, harsh and frivolous talk) and mind (covetousness, animosity and wrong views): ${ }^{242}$

\section{"There are ten modes of auspicious action.}

The bodhisattva who is skilled adheres to them.

The wise one who does not act through body, speech and mind

Is said to be in possession of moral conduct."

And yet, in spite of this accentuation, the treatment of the daśakuśala itself provides little insight into the workings of purification. Instead of discoursing on the psychological processes that practice of them triggers, the $B d p$ devotes most attention to the benefits flowing from

possession of wonder-working powers fail to employ them in a situation where they would inspire faith, he would be guilty of a serious transgression. Similarly, should he fail to rebuke people who are in need of reproach or does not mete out a punishment for wrongdoing when he would be perfectly capable of doing so, he commits a defiled fault $(B b h, \mathrm{pp} .179 .18-180.10)$. Passivity with regard to his duties articulated in his pranidhāna weighs more heavily than infringement on the letter of the prätimoksa precepts. A concise list of attributes pertaining to pure morality appears at the end of the Silapatala (op. cit., pp. 186.23-187.15).

241. The Sanskrit terms are as follows: (1) prānāitighāta, (2) adattādāna, (3) kāmamithyācāra, (4) mrșāvāda, (5) paiśtunyavāda, (6) pārusyavāda, (7) sambhinnapraläpa, (8) abhidhyā, (9) vyāpāda and (10) mithyādrști (Mvy 1687-1698). For references in the nikāya, see: M I, pp. 42, 360; III, p. 23; S IV, p. 313; V, p. 469; A, I, p. 226. Sanskrit references are found at $M v u$, i, p. 107.13; Daśa-bh, p. 23.6; Siks, p. 69.13 and $D h s g r$ $\$ 56$ (cf. Amrt (B), pp. 89-91). For a full discussion of the akusalakarmapatha, see: Mppś, ii, pp. 782-819. On their role in the bodhisattva-path, the $D b h$ comments (Daśa-bh, pp. 26.5-9):

"The ten good paths of action-as they are completely purified by the wide, immeasurable state, by the arrival at great compassion, by grasping skilful means, by the state of being bound to the next vow, by non-abandoning of all beings, by taking hold of the broad buddhaknowledge-conduce to the complete purity of the stages of the bodhisattva, to the complete purity of the perfections and to the full extent of the career."

242. $R$, folio $304.2-3$

This list recurs three times during the discussion of the sillapāramitä ( $R$, folio 368.2-6; 403.7-404.3). As it introduces at each occasion a new aspect of the practice of moral conduct, it was probably conceived of as laying down the individual areas of application that make up the overall scope of the bodhisattva's morality. This tenfold division is of course very ancient and is well known from the nikäya (cf. D III, p. 214; A, I, pp. 49, 52, ff). 
their cultivation and the impact they have on the bodhisattva's advance.

The acquisition of such benefits is dependent on the interplay of two factors. On the one hand, adjusting to Mahāyāna ontology, the $B d p$ invalidates moral conduct and denies it any role in the path. ${ }^{243}$ As we have seen, this is common practice in Mahāyāna sūtras and represents the paramārtha point of view. On the other hand, on a conventional level, síla becomes a major force in the bodhisattva practices. It is held indispensable for the completion of the path, in general, and gives rise to a series of important mental factors. In the $B d p$, such factors include faith, vigour, trust in retribution of deeds, trust in morally and wholesome deeds, aspiration to the noble lineage (äryavamśa $)^{244}$, respect and veneration of teachers, withdrawal in search for the Dharma and unreserved commitment to enlightenment. ${ }^{245}$ Although it stops short of pronouncing a causal relationship between them and the kuśalakarmapatha, the $B d p$ indicates that they operate on a reciprocal basis and arise simultaneously to reinforce each other's presence. ${ }^{246}$

Through the roots of virtue that are generated by the kusalakarmapatha in conjunction with faith, etc., the bodhisattva produces ten forms of cittotpāda. These are based on moral integrity, reverence and yearning for spiritual instruction, and lay down the phases in his cognitive growth.

In spite of the shared context in which the ten kusalakarmapatha, ten mental dharma and ten cittotpāda occur-except for a broad association with the practice of morality-no connection between their members seems to exist. It is true that the ten mental factors and the forms of cittotpāda cover roughly the same ground (both emphasise the role of reverential conduct towards one's teacher and include search for the Dharma and insight into the workings of karma), yet at no point is there any indication of the relation in which they might develop.

243. $\mathrm{R}$, folio $302.5-304.1$

244. According to the $U g$ (pp. 271.5.1-272.1.7) acquisition of the äryavamśa is one of the chief manifestations of pure morality in pravrajita bodhisattvas. Other concomitants include practice in the thirteen dhutaguna, seclusion, honesty, correct reflection, rejection of mistaken views, calm insight into the workings of the body, fearless acceptance of emptiness and signlessness and the generation of compassion. Apart from a broad contextual agreement with the mental factors in the $B d p$, these show few parallels.

245. $\mathrm{R}$, folio $306.1-4$

There is a certain overlap between these ten factors and the five indriya cited as antidotes to moral impurity in the Anguttaranikäya (A V, p. 192). Moreover, several of them appear repeatedly in conjunction with moral conduct to define the attributes of true bhikkhus and figure among practices conducive to enhanced aspiration and high rebirth (M III, pp. 99-103). In this context, their chief function becomes to provide for the cognitive stability that is required for sound refraint from the three root evils.

On the benefits, see: D II, p. 86; M I, p. 33; A III, pp. 251-2 and Vism, i, p. 14.

246. The single most important factor underlying the bodhisattva's moral stance becomes the resolution undertaken in his vow to benefit all sentient beings. Although not explicitly mentioned in this capacity, the orientation of the sila practice leaves not doubt that it is that intention which rules his conduct at all times (R, 307.2). 
Furthermore, both schemes do not agree on the position in which they list the shared practices. Faith and vigour, for instance, the first two limbs of the ten mental dharma, figure in the cittotpāda at the very end. Moreover, some of the key issues of the cittotpāda do not occur at all among the ten mental dharma. Correct understanding of the body, the threat of desire, hatred and delusion, and headlong pursuits are only found among the ten cittotpäda.

In the absence of any positive evidence, we cannot stipulate any firm connection between the akuśalakarmapatha, mental factors and the types of cittotpāda. The only common denominator is a shared, if broad, association with moral conduct. This link, however basic, is rather pronounced and recurs on several occasions. For one thing, the generation of the ten mental dharma is conditioned by abstention from killing, etc. This would link them with the ten cittotpāda, as these too cover some common ground with the mental dharma.

Other parallels are found in the ethical connotations that are raised by the ten cittotpāda. We have seen that the first two, as if producing basic mental requirements, lead to a correct understanding of the body. To view the body as empty, essentially impure and impermanent weakens the propensity for attachment and removes the foundation of desire. Next, recognition of previous anger, violence and bitterness (realised with the fourth and sixth cittotpäda) instigates the mental processes that inspire the abandonment of hatred (dvesa). Finally, appreciation of the faults of past misconduct-as manifested in lack of respect, mental confusion, ignorance of causation and purposeless straying-refers to delusion (moha), the third of the three root evils. All ten cittotpāda therefore have a bearing on the very factors that cause moral impurity. The destruction of desire, hatred and delusion is achieved with the tenth cittotpāda in which moral conduct is fully realised in conjunction with faith, modesty, chastity, learning, renunciation and wisdom. ${ }^{247}$

Cognitively, pure moral conduct triggers a series of insights into the workings of phenomenal existence. Evolving in conjunction with correct reflection (yoniśo manasakāra), the bodhisattva develops aversion towards karmic formations, loses interest in sense pleasures, rejects empirical knowledge and develops a defence mechanism against hatred and desire. ${ }^{248}$ First, on the emotional level, he trains in order to see in every sentient being his mother and father of

247. On the pillars of moral impurity, the $A k n$ records:

"Morality is the absence of evil causal dispositions, the non-arising of mistaken views and elimination of hindrances like regret; morality does not abide by unwholesome roots of covetousness, anger and delusion" (p. 44.3.2-3).

248. R, folio 376.1 . 
previous lives. ${ }^{249}$ This allows him to recognise in situations that arouse sensual desire his mother as the object of passion. Likewise, in situations of great injustice, he restrains his anger by recognising his father as the aggressor.

Since it leads-if entwined with incorrect reflection-to unfavourable rebirth in the evil destinies ${ }^{250}$, desire is singled out as the most acute threat to the bodhisattva's moral integrity. ${ }^{251}$ In order to eradicate desire, the $B d p$ proposes three methods that protect the bodhisattva from attachment. ${ }^{252}$ First, it advises him to consider-as deterrent and cause for compassion-the

249. R, folio $384.7-387.2$.

250. R, folio $388.6-7$.

251. In this context, serving to exemplify the pitfall of sensual desire, we find a diatribe against the wife (folio $389.1-395.2$ ) similar to that contained in the $U g$ (pp. 263.5.6-264.3.4).

Judging by later discussions of Mahāyāna morality, this view was not destined to last. In the Vup--marking an important stepping stone in the development of the bodhisattvasila -it is lack of altruistic compassion and hatred that replaces desire as the most severe and resilient impediment to moral perfection ( $V u p$, pp. 50-51). In an earlier passage the Buddha adds the third member, delusion, that he qualifies as a grave defilement that is difficult to eliminate since (Vup, pp. 31-32):

"Attachment under the influence of the ramification of transmigration becomes the seed of rebirth; hatred, because it is quickly eliminated becomes a step towards the evil destinies; delusion, because it is difficult to eliminate becomes the cause occasioning one's fall into the eight hells."

While this is not exactly the position of the $B d p$ in chapter seven, elsewhere we meet with statements that run very close in intent ( $R$, folio $415.1-2)$ :

"Māra obtains the opportunity to harm a bodhisattva whose mind is wrathful even after he has entered the great vehicle. If he obtains this opportunity, the bodhisattva will be cut off from supreme and perfect enlightenment, for a bodhisattva who is evil-minded becomes inattentive when pursuing enlightened conduct."

252. In the $B d p$ desire is defined as attachment to the objects of the five senses, and above all, to the fetter of form (rüpa). It is seen to obstruct hearing of the Dharma, taking refuge in the triratna, seeing the Buddha, receiving the (eighteen) blessings as well as preventing faith, moral conduct, learning, chastity, modesty and wisdom to unfold ( $R$, folio 390.2-7). As such, it is identified as the most potent threat to the training of the bodhisattva.

However, according to the Vup, an even greater threat to moral integrity is posed by conceit (adhimäna). Interpreted as a side-aspect of delusion in the threefold root defilements, it bars the bodhisattva from attaining his goal by deceptively magnifying his own attainments (ätmokarśa) and depreciating those of others (parāvajña) (Siddhi, p. 346). The means by which conceit is overcome vary with the spiritual outlook of the practitioner. For the srāvaka, it is above all avoidance of speculative and inconclusive thought that prevents its arising. The bodhisattva, however, is advised to eschew premature judgement on the quality of his progress in training and to learn to distinguish mistaken views from correct ones ( $\mathrm{Vup}$, pp. 53-54). For unlike other defilements, liability to conceit not only subsists in the more advanced stages of the path but, moreover, increases in attraction with the rate of progress in purification (Asta, pp. 385-95).

In the Vup, the Buddha distinguishes two areas of conceit. First, it draws attention to conceit operating on the moral plane. It occurs when the bodhisattva compares his degree of purification with that of ordinary beings and, judging it inferior, concludes that its holders of little worth ( $\$ 47)$. This form of moral conceit may also arise on the basis of his spiritual powers and attributes $(\S 48)$-illusory or real —on the basis of attainments such as the buddha-qualities and even through perceived superiority in material wealth or worldly position ( $\$ 17)$. Second, conceit arises at the cognitive level in response to inessential speculation (Vup, p. 54). This issue is also taken up in the Samdhis (ÉLa), pp. 47.19-48.15. Since deliverance is only achieved by totally abandoning thought representation (sarvavikalpapavigata) in favour of the acceptance of inconceivability (Vup, pp. 53, 64), all discursive thinking is detrimental to liberation and becomes, particularly if of academic hypothesis, a potential cause of vanity ( $V u p$, p. 55$)$ :

"By means of what measure do monks evade conceit? The Tathăgata replied to the venerable Upāli: Monks are altogether liberated from conceit if they do not harbour wrong views (abhiniveśa) concerning the inconceivability springing from all-knowing." 
suffering of beings. ${ }^{253}$ The prospect of exposure to such a high degree of misery alone prevents immoral behaviour from arising. ${ }^{254}$ Second, the $B d p$ recommends as an incentive ${ }^{255}$ the contemplation of the excellent qualities of the members of the aryan-fold. ${ }^{256}$ Without complete purity, such excellence will always be beyond the reach of a bodhisattva. Third, the practitioner is reminded of the illusory character of sensory perception and the unreliability of the data it provides. ${ }^{257}$ In the spirit of purest Mahāyāna thinking, the $B d p$-taking the example of sight-shows that all perception is utterly devoid of own-being and, hence, cannot give cause to meaningful attachment. ${ }^{258}$

The location on the path of such an attainment is only vaguely indicated. Judging by the benefits that accrue to a bodhisattva from the roots of virtue, it pertains to the more advanced stages. ${ }^{259} \mathrm{He}$ is in the position to attain cessation at will ${ }^{260}$, he possesses great powers and physical perfection, and is separated from buddhahood by only five rebirths. ${ }^{261}$ There can be

253. R, folio 390.5-392.4.

254. Cf. M III, pp. 99-103.

255. On generating these two antidotes, the bodhisattva ponders ( $R$, folio 395.3-397.1):

"I shall tread the path of excellent beings and not the path of miserable beings. I shall tread neither the path that leads to hell nor the path that leads to the birth-destiny of animals. I shall not tread the path that leads to the realm of Yàma. I shall not tread the path of moral transgression. I shall not tread the path that is associated with moral transgression ... ."

256. R, folio 395.3-396.4.

257. R, folio 400.5-403.6.

258. R, folio 403.4

The importance of correct reflection for moral integrity is attested in practically all Mahāyāna treatises that address the issue of purification. A good example is the $V_{u p}$ that follows the trend and submits the notion of morality to the philosophical rigour of its ontological propositions. Proceeding from the conviction of the non-arising of dharma, it concludes that all moral conduct is perpetually accomplished and not subject to training, progress or retribution ( $/ u p$, p. 60$)$ :

"Once acknowledged that all dharma are by nature quiescent (samähita)

Desire, hatred and delusion become non-existent.

And if dharma are themselves deliverance and free from desire,

Provided that they are unsupported, they exist already in nirvanna."

Repudiation of such insight is above all based on mistaken views concerning the self and the possibility of moral acquisition. As long as these two misconceptions prevail, moral conduct, however elated, is prone to the defilement of conceit and misapprehension. It is not before the bodhisattva has achieved the revolution at the basis (áśrayaparäurttit) born from wisdom that he becomes capable of generating pure morality (Msg, p. 16):

"The mistaken view concerning the self is wrongful clinging to the [notion of the] self and mine. Through its influence, conceit of the self becomes. When one leans at the self or mine, one becomes conceited. Born from genuine affection, that is to say, born from attachment towards the self, the defilments of the mistaken belief in a self and conceit arise."

Pure morality it therefore always dependent on the presence of correct vision. For the $V u p$, this is 'seeing reality as it is'. In other words, moral perfection is always subject to understanding its operations from the paramärthasatya level and cannot be attained through conventional understanding (samprrtisatya). Unless the paramārthasatya vision has been attained, conceit will remain a serious impediment to the bodhisattva's advance (Vup, p. 53).

259. R, folio 341.1 .

260. R, folio 341.6 .

261. This information can be gleaned from the number of rebirths that are cited before the bodhisattva attains buddhahood ( $R$, folio 341.2-364.6). From the moment of his attainment in moral conduct, he will be 
no doubt that the foundation of these qualities lies in the bodhisattva's accomplishment in the perfection of morality: ${ }^{262}$

"O Sāriputra, one who pursues the bodhisattva's moral conduct for the sake of [understanding] the meaning of the bodhisattvapitaka and venerates and honours his teacher obtains such virtuous, most excellent, boundless, inconceivable and measureless blessings. It is in this way, O Sarriputra, that the bodhisattva who firmly pursues the bodhisattvapitaka attains great power and cultivates the bodhisattvacaryā through pure moral conduct."

After the description of the benefits that accrue to bodhisattvas who are accomplished in moral conduct, the $B d p$ draws up fifty qualities that pertain to moral purity. ${ }^{263}$ Close to fifty percent of these attributes fall into easily recognisable groups. The first ten qualities coincide with the kuśalakarmapatha, five are characterised by the pāramitā, four are linked with the apramañ and three with the refuge in the triratna. ${ }^{264}$

The remaining twenty-seven concomitants spell out (without any discernible order) the general facets of the bodhisattvasilla. Going beyond the narrow interpretation of morality, the $B d p$ announces that the bodhisattva dwells in hermitages as part of his moral training; that he examines his own mistakes rather than condemning others; that he develops sentient beings, grows content with little, and weakens his attachment to worldly phenomena. As a reward, he attains a whole array of qualities that lend support to his training. ${ }^{265} \mathrm{He}$ acquires patience, confidence and composure; he becomes invincible, reclusive, faithful, truth-loving and realises the impermanence of karmic formations, ${ }^{266}$ he attains fearlessness, passes beyond low rebirth

reborn as (1) man, (2) god, (3) accomplished man, (4) cakravartin becoming recluse and (5) buddha (folio $343.4-7,446.7)$.

262. R, folio $367.7-8$; see also folio $341.1,362.2$.

263. R, folio 368.2-371.4.

This enumeration recurs almost verbatim at the end of the chapter, coinciding in 44 out of the 53 items that are listed there $(\mathrm{R}$, folio 403.7-407).

264. The same association of morality is proposed in the $A k n$ where silla is linked with the practice of the pāramitā (p. 43.5.6-8) and apramāna (p. 43.5.4-5).

265. R, folio 371.5-372.3.

266. A more structured approach to the benefits is given the $B b h$, proposing three blessings that keep the bodhisattva in touch with the needs of sentient beings. First, he is accomplished in practice (siks $\bar{a})$; that is, he does not violate any moral precepts and learns of evil conduct as soon as it is committed. Second, he attains an excellent intent (ásaya). This involves monastic ordination, dedication to roots of virtue and constant focus on the Doctrine rather than on livelihood. Third, he is furnished with the blessing of the previous cause (pürvahetu). By virtue of previously accumulated acts of merit, he never lacks daily requisites. On the contrary, the retribution of wholesome deeds committed in former lives provides him 
and learns to devote selflessly his resources to the liberation of beings.

Thus, the practice of the sillapāramitā revolves not only around his personal moral integrity but includes, in equal measure, the purity and fate of his fellow beings. ${ }^{267}$ The differing degrees to which both aims are discussed suggest that the $B d p$ gives greater weight to the bodhisattva's personal moral attainment. That this is only a temporary priority is eloquently expressed in the following verse: ${ }^{268}$

"Now I act benevolently towards sentient beings without exception.

Now I guide sentient beings who paid allegiance to evil.

Accomplished in the joy of the Dharma, with my mind free from desire,

I seek the basket of enlightened conduct."

with great wealth that he readily shares with all beings ( $B b h, \mathrm{pp} .182 .14-183.16)$. Compare this list with the benefits that are cited in the $M s g$ (p. 215) and $M s l$ (p. 104.14-17). The Bbh adds that up to the moment of full enlightenment, the bodhisattva experiences five advantages arising from the training in sila $(B b h, \mathrm{p}$. 187.19-27). He comes to the notice of the buddhas; he dies in a state of great elation; in whatever state he is reborn, he is always accompanied by fellow bodhisattvas that are of equal moral attainment; he is furnished with the infinite aggregate of merit that fulfils the perfection of morality in this life and he acquires a form a natural morality whose essence always is with him in perpetuity. Cf. $K p$, p. $195, \S 136$; Samādh, Dutt, 1941-53, ii, pp. 329-331, 332-4.

267. E.g., $M p p s ́$, ii, pp. 853 ff; Daśa-bh, p. 26, Q.

268. R, folio $328.3-4$. 
The Perfection of Patlence

In the suttas of early Buddhism the practice of patience (Pāli: khanti; Skt: kṣānti) did not play a very prominent role. ${ }^{269}$ It rarely receives independent treatment, but is generally explained in conjunction with other practices such as benevolence (to which is becomes an important prerequisite) or is cited as a concomitant to morality and wisdom. ${ }^{270} \mathrm{~A}$ good example of its treatment is given in a stanza in the Mahapadānasutta in which the Buddha recounts the pätimokkha rehearsal of Vipassi: ${ }^{271}$

"How may you best discipline the flesh?

Be patient, monks, be forbearing.

What is the highest, what is the best?

O monks, the buddhas say it is nibbäna.

For he is no wanderer who harms

269. The exact linguistic origin of the term kșanti does not appear to be as straightforward as it is generally taken to be. In Mahāyāna literature, one finds two kinds of meaning. First, when linked with general suffering and injury, $k s \bar{a} n t i-$ taken from the root $k s a m$ : 'to endure, bear'-is generally translated as 'patience' or 'tolerance'. This corresponds closely to the Pāli term khanti. There are, however, several other instances, the most prominent example of which is the term anutpattikadharmaksānti, where ksänti carries the meaning of 'intellectual receptivity' (Edgerton, p. 199, col. 2). In those cases it would seem to go back to the root form kam, meaning 'to like, to be inclined to', of which the form kșänti would then be a incorrect Sanskritisation of the Păli form khanti.

In a study of this problem, Sasaki suggested that the word $k s \bar{a} n t i$ is a Buddhist Sanskrit development of the Palli khanti that, since stemming from the root kam, should be understood as 'willing to' and not as 'endurance' or 'tolerance'. Citing numerous passages from both the Päli and Sanskrit, Sasaki proposes that the correct Sanskritisation of khanti should have been känti going back to the root kam. Passages from the Kośa refering to kșānti as 'adhimätra satya-kșamanäd itit ưsmagatāvasthyām mrị satyam kșamate rocate' and its commentary by Haribhadra defining kșānti as 'ksamana-rüpena ca kșāntaya utpadyante' $(A k v$, p. 611) seem to suggest a more positive connotation than is expressed by 'endurance'. This is also borne out by numerous texts in the Păli Abhidhamma and by Buddhaghoșa's usage of the term khanti in the Vism itself. In the Dhammasangani (p. 230), we read for instance: ' $y \bar{a} h$ khanti khammanatã adhiväsanatã accandikkam anasuropo attamanatä cittassa, ayam vuccati khanti'. That this willingness is implied in the idea of anutpattikadharmaksānti has been recognised by most modern scholars.

If we are to accept his argument, the question remains whether all occurrences of the word ksanti in bodhisattva works imply this positive mental disposition. For the bodhisattva ideal, such adaptation would not present much of a problem, since-according to doctrine-the bodhisattva should gladly succumb to all forms of suffering, injury and torture as he thereby removes past karma and brings patience to a climax. Grudging endurance tallies only ill with the grandeur of the ideal and is probably not what was intended.

270. See, for instance, S I, p. 222 where patience is recommended when dealing with fools, weak beings or perons of otherwise inferior disposition who require a monk's benevolence in order to progress spiritually (cf. Vism, ix, pp. 295-96).

271. D II, p. 49 (the same verse occurs also at Dhammapada, no. 184). 
His fellow man; he is no recluse

Who inflicts injury on his neighbour."

The context and wording of this verse suggests a close correlation between patience and the observance of the pätimokkha precepts. Quite clearly, the Buddha wishes to make the point that impatience deprives the monks of composure and thus leads to ill-contemplated actions that violate the disciplinary code. Although rarely explicitly stated, a correlation between morality and patience figures at several places in the nikäya. ${ }^{272}$ The role of khanti in these contexts is generally of a supportive nature. It appears as a complementary virtue that facilitates moral observance, since it removes those āsava that might otherwise obstruct śila. In other contexts, patience is not aimed at one particular area of defilement, but weakens-if accompanied by vision, control, use, avoidance, elimination and mental development-the whole range of the $\bar{a} s a v a$ and contributes to the attaining of nibbāna. ${ }^{273}$

The Patis expands the interpretation of khanti so as to include in its meaning in addition to its moral dimension also a cognitive aspect. On the one hand, patience is held to weaken sense-desires, to inspire renunciation and generally to induce the practitioner to follow the path of the arhant. ${ }^{274}$ On the other hand, khanti is recognised as part of the mental processes that prepare the monk for the more taxing doctrines of the Dhamma. This applies above all to the teaching of the marks of existence (salakkhana) and mental instability. ${ }^{275}$ Indeed, willing acceptance of the notion of anātman prior to full penetration of its reasoning becomes indispensable for spiritual progress. At a later stage, having comprehended the validity of this proposition and seeing the general characteristics of dhamma the practitioner attains patience that conforms to reality. ${ }^{276}$ In due course, this allows him to enter upon the certainty of truth and makes the fruits of the path available to him. ${ }^{277}$

It would appear therefore that khanti consitutes some important element of the Buddhist training. First, it bestows psychological strength, resilience and confidence to resist the 'attractions' of moral transgression and increases the monk's receptivity to the more daunting

272. M II, p. 43; S I, pp. 162-3, p. 226; Vism, i, p. 18.

273. M I, p. 10.

274. Patis, xix, p. $171(\S 14)$, xx, p. $183(\S 23)$.

275. op. cit., i, p. 106.

276. op. cit., xxix, pp. 235-242.

277. Patis, xxix, pp. 236 (cf. A III, p. 441).

The advantages that accrue from the practice of patience correspond, for the most part, to the blessings that arise from generosity and morality; A III, p. 253. 
aspects of Buddhist thinking. Second, it figures among the five principal aspects that characterise the ideal of the recluse. ${ }^{278}$ And yet, there is no passage in the nikāya that gives a coherent account of its role and position in the training. ${ }^{279}$

History has shown that this obscurity was not to last. The timelessness, intense worldly exposure and philosophical abstractions acompanying the emergence of the bodhisattva ideal meant that the practice of patience was to rise 'phoenix-like from the ashes' and figure among its most important practices.

However, this process was a gradual one and took several centuries to complete. In the earliest strand of Mahāyāna literature, the role of kṣānti was at first limited to patient endurance of outright physical hostility and to the 'conviction of the non-arising of dharma' (anutpattikadharmakșānti). ${ }^{280}$ In the Rgs both elements are merged to form the introductory verse to the perfection of patience: ${ }^{281}$

"When he hears someone else speaking to him harshly and offensively,

The wise bodhisattva remains quite at ease and contented.

[He thinks:] 'Who speaks? Who hears? How, to whom, by whom'?

The discerning is [then] devoted to the foremost perfection of patience."

Although not clearly differentiated as separate aspects of $k s a \bar{a} t i$ in this incipient phase, most early texts already distinguish what later treatises describe as sattvaksāanti and dharmakșanti. ${ }^{282}$ The distinction is found in the $P a \tilde{n} c a^{283}$ and recurs as the most fundamental one in many other discussions of $k s \bar{a}_{n}{ }^{2}{ }^{284}$ As alluded to in the Rgs, the role of dharmaksānti

278. A III, p. 362:

"Patience and forbearance are the [recluse's] aim; wisdom is his quest; virtue is his resolve, nothing is his want, nibbāna is his ideal."

279. Khanti as a pärami does, of course, appear in several instances in the Pāli literature. It is mentioned in the Jãtaka (i, pp. 45-7) and occurs at numerous instances in the commentarial literature to the Buddhavamsa (Madhuratthavilāsinī, i, p. 76) and Cariyāpițaka (Dhammapāla: Cariyāpitakatīkā, pp. 321-22). Since these references are late and were produced almost certainly in response to Mahāyāna developments, they fall outside the present context.

280. Rgs, xxx. 8-14; Saddhp (pp. 136.10, 266.1, 327.4, 403.8, 419.6, 437.1); Sgs (p. 143, § 28, p. 160, § 48); Sukhävativyūha $(S B E$, pp. 39-40, 51) and $K$ p (p. 18, § 8.4, p. 39, § 18.2, p. 49, § 24.17). The references in the Saddhp and Sukhävativyūha have been largely misinterpreted. H Kern (p. 134) rendered the term anutpattikadharmaksānti as 'acquiescence in the eternal law' while M. Müller took it to mean 'resignation of consequences that have not yet arisen'.

281. Rgs, xxx. 8 (trsl. Conze).

282. Mpps, ii, p. 865 .

283. Pañca, p. 512 (trsl. Conze).

284. $A k n$, pp. 44.4.5-45.4.8; Rcd, pp. 233.3.6-234.1.1; Bdp, folio 407.3-423.4; Sgm (cit. in Siks, pp. 102.30-103.27); Pps (cit. in Siks, pp. 101.10 ff), Gv (cit. in Siks, pp. 101.4 ff). 
is generally one of support. It represents a mental precondition for the acquisition and retaining of spiritual fruits and prepares the practitioner for the moment when he comes face to face (abhimukhi) with reality itself. ${ }^{285}$

From early on it was recognised that this conviction could not be a static attainment but is subject to progression. ${ }^{286}$ In the Așta where it is discussed in the context of the first five stages and operates as a purely verbal profession (ghoṣānugā) kṣānti designates preliminary acceptance of reality based on faith and approbation. ${ }^{287}$ Once attained through the power of previous prayers, it is wholly dependent on will-power (adhimukti) and does not involve cognitive factors. ${ }^{288}$ Shortly before the bodhisattva becomes aware of the sameness of all dharma (sarvadharmasamatä), he attains the preparatory condition of patience proper (anulomikikșānti), but is still deprived of the conviction of their non-arising. ${ }^{289}$ According to the $D b h$, this event is a precondition for reaching the abhimukhibhümi and stands in direct relation to insight into the own-nature of dharma while, in the Sukhāvatīvyūha, it is attributed to service that the bodhisattva renders to former buddhas. ${ }^{290}$ This process culminates in the definite and final acquisition of the anutpattikadharmakșänti. ${ }^{291}$ Granting the bodhisattva true insight into the workings of reality, it raises him beyond worldly concerns: ${ }^{292}$

"A bodhisattva who possess the conviction of the profound dharmata does not become impassioned toward that which draws to desire, nor does he become

285. Asta, pp. 38-39.

286. Allusions to the various degrees of anutpattikadharmaksänti are found in the Asta (pp. 38-39), Vkn (pp. 25,222 ) and Sukhāvativyutha (Müller, 1968, p. 51). Compare these standard versions with the more unusual scheme in the Dhyānasamädhisütra (T 641, k. 2, p. $285 \mathrm{a} 10 \mathrm{ff}$ ) that distinguishes between utpädaksānti enduring all injury, torment and insult that is inflicted on the bodhisattva; anulomikikșānti constituting the recognition of impermanence and the insight that bhütalaksana is alaksana; and anutpādakșānti that marks merely further progress in the anulomikikșänti practice (ref. Lamotte).

287. Asta, p. 232.18-20

In the Samādh (Dutt, 1941-53, ii, pp. 280.17-281.5), the preconditions of ghosānugāksānti are wellillustrated by a lyric (pp. 276.1-280.16) said to induce its realisation. Primarily, these factors relate to cognitive abandonment of the notion of self in persons and dharma (p. 279.2-10), to giving up all forms of attachment and aversion (pp. 278.15-279.2), to listening to the Doctrine (p. 280.1-4) and to seclusion (p. 280.9-12).

288. Müller, $1968, S B E$, p. 51

289. Cf. Rp, p. 34.13-14: nāham rāṣtrapāla teșam ānulomikām api kṣānti vadāmi, kutah punar buddhajñānam . "O Raștrapāla, I do not attribute to them even the conviction preparing (lit. conforming) to (anutpattikadharma), still less to buddha-knowledge." Ensink's translation of the term ānulomikäm ... $k s \bar{a} n t i$ as 'conformable patience' is an unfortunate choice as it fails to convey the preparatory connotation of ānulomikiksānti (Ensink, 1952, pp. 32-33).

290. Dasia-bh, p. 47.17-21

For translations of the passages leading to the attainment of anutpattikadharmaksanti see: Suzuki, 1975, pp. 226-7; Müller, 1968, p. 51.

291. Saddhp, pp. 136.9-10, 266.1, 419.6, 437.1; Lal, pp. 36.9, 440.21

292. Samädh, Dutt, 1941-53, ii, p. 95.6-7. 
angry or deluded."

In the scheme of the $D b h$, it takes place on the acaläbhümi and represents the entrance to all-knowing due to the non-differentiation of suchness (tathatāsamanirvikalpa). ${ }^{293}$ In the plan of the Sukhāvativyyüha ${ }^{294}$, however, this last step is once again attributed to devotional practices, in particular to performance of past prayers. ${ }^{295} \mathrm{Few}$ texts agree on the individual fruits that ensue from the conviction of the non-arising of dharma. In general, it is thought to coincide with the bodhisattva's final prediction to buddhahood ${ }^{296}$ and to furnish him with the status of irreversibility. ${ }^{297}$

In addition to these variants, some texts make also a distinction between different types of anutpattikadharmakșānti. ${ }^{298}$ In the Pañca, the Buddha cites two varieties that are differentiated

293. Daśa-bh, pp. 63.26-64.6; $M s l$, p. 134.16

Virtually all later commentaries agree on allocating this event to the eighth stage $(M s l, p p .122 .2,131.17$; $B b h$, p. 350.27; Madhyantavibhäga, p. 105.10). The only exception is the Mpps that places anutpattikadharmaksänti on the seventh stage (v, p. 2462). Sattvakșanti, in contrast, the Mppś places on the second stage (v, pp. 2401-2), a proposition that is tenuously confirmed by the $D b h$ (Daśa-bh, p. 23.23).

Born of patience and kindness (ksanntisauratya), the bodhisattva is at this point no longer found in the six destinies but assumes the dharmakāya in order to convert beings with greatest effect (Mppś, $\mathrm{i}, \mathrm{pp}$. 330-31). On the notion of ksäntisauratya (khantisoracca), see: S I, pp. 100, 222; A II, p. 68; Saddhp, pp. 234.8, 236.9; Dbh, pp. 13.19, 37.11; Bbh, pp. 20.12, 143.27; Siks, cit. $A k m$, p. 183.14.

294. Müller, 1968, p. 51.

295. In the Avatamsaka an entire chapter (Sikșannanda: chpt. xxix) is devoted to the various kinds of $k s a n n t i$ that a bodhisattva generates in the course of his career. The first ksanti refers to accepting the teachings of the Buddha without fear or hesitation. The second designates the bodhisattva's acquiescence in reflecting on the nature of dharma and maintaining of mind of purity and serenity. The third corresponds to the anutpattikadharmakșanti. The fourth to the tenth are acquired when the bodhisattva realises that dharma are like an illusion (māyopamā), etc., (T 279, k. 44, p. 232b 9-10; ref. Suzuki, 1975, pp. 126-27).

In the Jen Wang hou kouo po lo mi king (T 245, 246) 'Perfection of Wisdom of the Good Law that Protects the State', a Chinese work of apocryphal origin, five kinds of $k s a n t i t i$ are listed. These include damakșānti, śraddhākșānti, anulomikiksānti, anutpādakșänti and nirodhaksänti. Apparently adjusted to suit the tenfold stages of the Daśabhümika, damaksänti is practised in the preparatory stages leading up to the adhimukticaryābhümi; śraddhaksānti on the pramuditā-, vimala- and prabhäkarïbhümi; anulomikīkșānti on the acrișmatī-, sudurjayä-, abhimukhïbhümi; anutpādaksāanti on the düramgama-, acalä- and sädhumatïbhīmi and nirodhakșanti on the dharmameghabhümi (T 245, k. 1, p. 826b 23-24; ref. Lamotte).

296. Several texts state that the acquisition of the 'conviction of the non-arising of dharma' coincides with the definite prediction (vyäkarana) of the bodhisattva to buddhahood: See, for instance, Saddhp, p. 266.1-2; (cf. Lal, p. 35.21; Msl, pp. 20.15, 141.27, p. 166.5-12); Akn, p. 45.4.8; Sgm, TTP, 33, p. 52.3.7; Samādh, Dutt, 1941-53, ii, p. 82.11-14.

297. Saddhp, p. 259.13: avaivartikakșäntipratilabdhäś ca bhavișanti ('and they will obtain the conviction of non-regression'). Cf. Bbh, p. 253.18; Daśa-bh, p. 71.12.

Note that in the Vup (pp. 30-31), none of these attainments is cited but anutpattikadharmaksānti leads to three categories of renunciation (tyagga), viz., ordinary renunciation, great renunciation and absolute renunciation. Here, ordinary renunciation refers to giving up of royal power (räjyaparityāga), great renunciation to abandoning of family members and absolute renunciation to sacrificing body and life. The practice of $k s \bar{a} n t i$ is thus set in close relation to the cultivation of the dana for whose perfection it becomes a precondition. This association is not an isolated case. A similar statement is found in the $R p$ (p. 12.2) where $k s \bar{a} n t i$ is cited in conjunction with the abandoning of all personal possessions (sarvastraparityäga).

298. At several places in Mahāyāna sütras one meets with phrases that clarify the implication of the three modes of kșänti. In the Tathāgatācintyagühyanirdeśa (cit. Madhyamakavrtti, p. 362.8), for instance, the 
according to the conditions that lead to their existence. ${ }^{299}$ These comprise a kind that is founded in the non-origination of defilements and another that arises due to persistence of cognition. Unfortunately, the text is silent on the attributes that mark these types from each other and neither does its commentary, the $M p p s$, elaborate upon them. ${ }^{300}$

The basis for the generation of patience is constituted by the thought of enlightenment, as it carries sufficient force to render the bodhisattva's body, speech and mind naturally exempt from vengeful thought. ${ }^{301}$ In turn, patience towards injury assists in safeguarding other qualities since it forestalls animosity which would otherwise exterminate his accumulation of roots of virtue. $^{302}$ Knowing that even if he were subjected to severe torture, the degree of suffering would be minuscule compared with his torment in hell had he retaliated, the bodhisattva exercises restraint at all cost. ${ }^{303}$ In the words of Candrakirti: ${ }^{304}$

"Because hatred directed against the sons of the Jina

Destroys in a moment the merit of generosity and morality

Accumulated over a hundred thousand years,

There is no defilement other than non-patience."

second type of patience is called śünyatänulomikikssānti 'conviction conforming to emptiness'. In the Vajracchedikā (Conze, 1958, p. 58.9), it is referred to as nirātmyakeșvanutpattikeșu dharmeșu kșānti while in the Lal (p. 36.9) it is characterised only as anutpattikeșu dharmeșu kșānti (ref. Lamotte).

In the $S a m a \bar{d} h$, a whole chapter is devoted to the description of the three kinds of patience. In particular with regard to its the characterisation of the ghoșänugäkșanti, this shows many parallels to the $G v$. Having discussed the three types of kșanti, the Samādh defines the three stages of the dharmanidhyānakșānti in terms of srutamayī, cintāmayi and bhävanämayī, saying (Dutt, 1941-53, ii, p. 82.7-10):

"That which arises from learning and reflection is called 'in accord' as it is conducive to realisation. That which arises from contemplation is the conviction of the non-arising of dharma."

299. Pañca, pp. 511-12.

300. Mppś, ii, pp. 912-26.

The Mpps distinguishes three types of dharmaksanti. First, when practised in its purest form, the bodhisattva does not see the attributes of patience, he does not see himself, he does not see those who do the insulting and he does not speculate on dharma. Second, if accompanied by perfect wisdom, the degree of patience does not regress (avivartana) and is free from agitation (aksobhanatā). He is released from all anger and offensive words, he does not inflict physical harm and experiences no doubt with regard to dharma. Third, bodhisattvas who recognise the true character of the perfection of wisdom see no longer dharma since their thought operates beyond the categories of opinion (abhiniveśa) and their subject. This last aspect furnishes them with the inner strength to assist even those persons who inflict serious harm on them (ii, $p$. 926).

301. $M a v b h$, p. $47.14-19$

According to the $M s l$ (p. 29.11), however, the bodhisattva's patience is based on his lineage (gotra), membership in which may precede the cittotpāda $(B b h$, p. 3.1-8).

302. $M a v b h$, pp. 48.17-20, 49.10.

303. op. cit., p. 50.15-18.

304. Mavbh, pp. 50.19-51.2

This position is corroborated by a passage in the $S g m$ where it is implied-though not explicitly stated-that if he were to seek revenge the bodhisattva would automatically forfeit all the roots of virtue and regress to the very beginning of his career (Siks, p. 184.12). 
Emotionally sustained by the thought of enlightenment, the bodhisattva realises the omnipresence of suffering, discerns its origin in past desire and resolves to abandon its causes. ${ }^{305}$ Suffering is manifested to him in the eight categories of support (adhisthāna), viz, attendance to the bases of mendicant life (niśraya), worldly conditions (lokadharma) ${ }^{306}$, modes of behaviour (iryapatha), properties (parigraha) of dharma, aspects of mendicant life (bhiksākavrtta), untiring application (abhiyogaklama), working for the benefit of sentient beings (sattvärthakriya) and attendance to duty (karaniya).$^{307}$ On the one hand, the eight categories indicate that suffering is a constant companion to the bodhisattva. Committed by his pledge to giving universal liberation, he complies with the aspects of mendicant life and works for the benefit of beings. On the other hand, by being exposed to them, the bodhisattva retains his vigour and endures suffering with patience. That is to say, they furnish him with meditative qualities that allow him to maintain composure at all times. ${ }^{308}$ Once he accomplished patience by accepting suffering (duhkhädhivāsanākșänti), he constantly concentrates on enlightenment with a purified rejoicing mind that is free from distraction.

Having described some of the most fundamental features of ksānti, we may now examine its characterisation in the $B d p$. Broadly speaking, its treatment of the perfection of patience is divided into two sections. In the first part, the $B d p$ looks at the practice of patience with regard to dharma (dharmakșānti) and sentient beings (sattvakșānti). ${ }^{309}$ According to the

305. Bbh, p. 192.11-22.

306. These are gain (läbha) loss (alābha), fame (nindā), ill-fame (praśamā), praise (yaśa), blame (ayaśa), happiness (sukha) and unhappiness (duhkha) (Mvy 873; Lal, pp. 352.10; 275.5). In the Bbh (p. 193.9-16), however, a slightly different list is given, including aläbha, ayaśa, nindā, duhkha, nāśa, ksaya, jāra, $v y \bar{a} d h i$ and marana. Compare this list with its Pāli equivalents in D III, p. 260, A IV, pp. 156 ff., Patis, i, pp. $22,122, V i b h$, p. 387 and that given in the $M v y(2342-48)$ which cite invariably eight dharma.

307. $B b h$, pp. $192.23-193.1$.

308. Bbh, p. 193.26-27.

309. R, folio 407-417.

In the sütra literature of the Mahāyāna, exemplifying the interplay between practice and cognition, this twofold division into sattvakșänti and dharmakșänti forms almost invariably the bedrock of kșänti discussions. According to some, complementary virtues that prepare for the practice of patience include moral impeccability, pursuit of the means of conversion, benevolence and compassion (Rcd, p. 233.3.8-4.4). These, governing the bodhisattva's relationship to fellow beings, contribute to the prevention of illcontemplated retaliation arising from anger but affect only patience on an ordinary level.

Also perceived as ordinary patience, sattvaksänti and dharmaksanti are characterised in the Akn by thirty-two manifestations ( $A k n$, p. 44.4.6-5.6). These fall into four categories. First, absence of those factors that run contrary to patience, e.g., hate, anger or aversion, etc.; second, the generation of factors that promote patience, e.g., pursuit of compassion, insight, etc.; third, the $A k n$ details the impact of these preparatory practices, e.g., purity of body, speech and mind, confidence, friendliness, etc.; and fourth, the reward that follows from the cultivation of patience, viz., high rebirth, aloofness, accumulation of roots of virtue, etc. The enumeration of these attributes in a closed list and its separation from pure patience 
$M p p s$, the rationale behind both types of patience is the notion of universal sameness (samatä). Having realised that beings and dharma lack distinguishing marks (laksana) that would allow for differentiation between the pure and impure, conditioned and unconditioned, the bodhisattva exercises total impartiality in his thought, recollection, affection and service. In other words, both kinds of patience rest on penetration of the doctrine of non-duality (advayadharmaparyāya) which enables him to enter into the 'suppression of controversy' (nirdvandva) ${ }^{310}$ In the $B d p$, however, this reasoning is excluded from the initial sattvaldharmakșanti discussion and pertains only to the highest patience (prakșānti). ${ }^{311}$

Patience with regard to dharma is subdivided into external and internal aspects. ${ }^{312}$ External patience refers to all those factors of distress that are influenced by the environment, including cold, heat, wind, sun, etc. Internal patience is applied to the suffering resulting from the eight worldly conditions, sickness and death. ${ }^{313}$

According to the Mpps', patience with external objects refers primarily to the bodhisattva's reluctance to apprehend the six categories of objects (sadbāhyasthüla) while forbearance with internal objects guards him from becoming engaged in any of the inner attractions (sadādhyātmikaruci). ${ }^{314}$

(visiuddhikșānti) and higher patience (sātyantaksānti) suggests that it is conceived of as basic. Since a similar distinction is also upheld in the $B d p$ and $R c d$ where the discussion of (basic) patience is followed by deliberations on pure and highest patience (prakssanti), it represents perhaps an antecedent to the threefold kșanti classification that is found in the Sukhävativyūha, Gv or $D b h$.

According to the Rcd, the next higher form of patience, pure patience (viśuddhiksānti), arises from the efficacy of careful investigation (prativeksa $\overline{\text { ) }}$ with regard to body and mind and from contemplation (bhāvanā) with regard to all dharma (Rç, p. 233.5.1-3). Here, kșänti arising from the examination of body and mind refers undoubtedly to physical and mental endurance of discomfort, insult and injury. $K$ șänti founded in contemplation of dharma is called sarvadharmavivekaksänti "conviction of the solitude of all dharma' and affirms their non-arising (Rcd, p. 233.5.4-5). Eventually, these two factors converge to form a type of ksänti that acknowledges the selflessness of persons (pudgalanairätmya) and convinces one of the non-existence of all dharma. Although slightly differently phrased, this concept accords closely to the notion of amutpattikadharmakșantit. Hence, the Rcd concludes by distinguishing two modes of pure $k s \bar{a}$ 'ti practice, viz, patience that affects the body and patience that corresponds to all dharma 'as they are' (Rcẹ, pp. 233.5.8-234.1.1). In the $A k n$, however, this distinction between the forms of viśuddhikșanti is not made (pp. 44.4.7-45.1.7).

310. Mppś, i, pp. 325-327

For a more detailed discussion of the notion of sameness of dharma and beings, see: Bbh, p. 286.11-24. On the conceptual proximity of samatā and kșanti see also Pañca (p. 4) where bodhisattvas are described as 'in possession of patience and sameness' (samatāksāntipratilabdha). As Conze has pointed out (1975, p. 37), the Tibetan and Mppś differ on the interpretation of this compound, suggesting that it should be translated as a tatpurusa meaning 'he acquires the patience acceptance of the sameness (of all dharma)'.

311. R, folio 420.5-423.5.

312. Mppś, ii, pp. 903-906 (cf. Pañca, p. 512).

313. In the $B d p$, we read of "six kinds of suffering that emerge from the body, abuse, heat deprivations of life and death" ( $R$, folio 407.5-6). In most other texts, including the Mppś, we find the eight conditions of existence (Mppś, ii, p. 905).

314. The șaḍa ăhyasthüla include cold, heat, wind, rain, etc., whereas the șadădhyātmikaruci comprise hunger, thirst, old age, illness, death and so forth (Mpps, ii, p. 904).

The Mpps's third type of patience-patience towards defilements (kleśakșānti)-rests on the recognition 
As both types of kșānti are concerned with non-mental objects (acittadharma) ${ }^{315}$ they are strongly influenced by the bodhisattva's advanced power of cognition and his resolution to postpone his entrance into nirvāna indefinitely. ${ }^{316}$ The former allows him to perceive the manifestations of reality 'just as they are' and saves him from the traps of Māra. ${ }^{317}$ Aware of the delusive character of phenomena, he gains sufficient inner strength to patiently endure all discomfort and hostility. ${ }^{318}$ The latter precludes the untimely elimination of the samyojana, since this would prompt him to abandon samsāra.

Until he has severed the fetters and attained the 'path devoid of depravity' (anāsravamārga), the bodhisattva is compelled to trust and accept the Doctrine on the basis of faith. Above all, this implies accepting the three seals of the Doctrine (trividhadharmamudrā) and eschewing the fourteen unanswered questions (caturdaśa $\overline{v y a}$ ăkrtavastu) ${ }^{319}$ without exposure to the obstacles (āvarana) or loss of the Middle Path. ${ }^{320}$

The $B d p$ does not dwell on external/internal dharmakșānti, but proceeds directly to patience with regard to sentient beings. ${ }^{321}$ This too comprises two areas of application. First, the bodhisattva bears verbal abuse with patience. ${ }^{322}$ Fearing that he might lose his roots of virtue and remaining firmly rooted in compassion and equipoise, he does not return the abuse but renews his pranidhāna. ${ }^{323}$ When in difficulty, the bodhisattva sustains his patience through recollecting (anusmrti) the Buddha, Dharma and Sangha which brings all dithering to an end. ${ }^{324}$ Second, the bodhisattva exercises self-control and forbearance towards beings who

of exposure to worldly influence. Until he has fully overcome all defilements, fetters (samyojana) and effects of the work of Māra that bind him to samsāra, the bodhisattva must put on his armour of patience (ii, pp. 906-908). Paraphrasing a passage from the $S n$ (v. 426b-428), the Mpps enumerates desire (käma), sadness (arati), hunger and thirst (ksutpipāsā), craving (trsnāa), languor and torpor (styānamiddha), fear (bhaya), doubt (vicikitsā) and anger (krodha) and hypocrisy (mrakssa) as the eight most damaging influences of Māra (cf. Lal, p. 261).

The $B d p$ (R, folio 415.3-7) distinguishes ten kinds of influence of Māra: (1) desire for food, (2) desire for clothing, (3) desire for worldly enjoyment, (4) desire for praise, (5) lack of desire for ordination, (6) lack of desire for virtuous dharma, (7) lack of pleasure in seclusion, (8) lack of desire for enlightenment, (9) desire for things other than pristine cognition, (10) irreverence towards one's teacher and benefactor.

315. Mppś, ii, pp. 903-4.

316. The Mpps looks at the various aspects of patience from twenty different viewpoints. However, since most of these express little remarkable thought and show conceptual overlapping, I shall not discuss them in detail (Mppś, ii, pp. 903-12).

317. Mppś, ii, pp. 904-6.

318. As in the $B d p$, the argument is enlisted that if he were to succumb to his suffering-and presumably retaliate against aggressors - he would be no better from ordinary beings. (op. cit., p. 906).

319. A list of these questions is contained in the Cülamälunkyasutta (M I, pp. 311-12).

320. Mppś, ii, pp. 912-13.

321. $\mathrm{R}$, folio $408-417$.

322. $\mathrm{R}$, folio $408-415$.

323. $\mathrm{R}$, folio $412.1,412.6$.

324. $R$, folio $410.3-412.2$

Since it is held crucial for the bodhisattva to regain his composure, several texts assign a particularly 
inflict physical harm upon him. ${ }^{325}$ Aware that wrath or retaliation in response to any such attack would cloud his mind and lead to inattentiveness, he puts on the armour of dedicated patience. Absent-mindedness is particularly damaging to the bodhisattva's prospect of buddhahood, since it renders him susceptible to the influence of Māra which would cut off enlightenment. ${ }^{326}$ For this reason, he is not only encouraged to meet hostility with indifference or tolerance, but moreover, to generate delight and joy: $:^{327}$

"When I am pelted with rocks, beaten with weapons and suppressed for a hundred thousand million world-ages I shall not forsake life for a single moment but think: 'Alas, this is marvellous. Sentient beings are noble, I shall not kill them.' "

Taking into account human psychology, the $B d p$ introduces then a new aspect of sattvaksānti, that is, conceit through exposure to praise and flattery. ${ }^{328}$ So far, $k s \bar{a} n t i$ found only application in antagonistic situations of hostility and menace. Now, we learn that praise too-appropriate or not-can have a damaging impact on the training and needs to be ignored..$^{329}$

A concise overview of the factors that pertain to the duhkhādhivāsana and parāpakāramarșana aspects of the kșānti is found in the Sikșāsamuccaya. For Sāntideva, endurance of suffering (duhkhādhivāsana) signifies "bearing and patience with personal pains, lamentations, unhappiness, despondency and anguish of mind" ${ }^{330}$ Its chief obstructing force is the fear of unhappiness $^{331}$ since fear alone is capable of leading to hatred (dveșa) and despondency (linata $).^{332}$ Since both emotions are incompatible with the ideal of the bodhisattva ${ }^{333}$, the practitioner should resist delight in happiness and gloom in misery. ${ }^{334}$ For the grhapti

important role to the timely generation of recollection (anusmrti) during the practice of patience. In this function, it is cited in the $A k n$ and $B d p$ and assumes a place of prominence in the $R c d$. While the former encourage only the recollection of the Buddha, Dharma and Sangha, the Rcd speaks of nine forms of

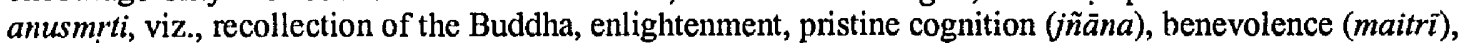
overcoming (vikräma), lion yawning (simhavijirmbhana), summit of insight (vilokitamürdha), primary and secondary marks (lakșanānuvyañjana) and accomplishment of all buddha-qualities (Rcd, p. 233.4.5-5.1).

325. R, folio 414.3-7 (cf. Pañca, pp. 519a-520).

326. R, folio 415.2 .

327. $\mathrm{R}$, folio $414.4-5$.

328. $R$, folio $419.4-420.3$

329. In the Mpps (ii, pp. 867-888), the application of forbearance is similarly extended to include exposure to flattery, excessive attention of benefactors and the allures of women.

330. Siks, p. 179.16-17 (cit. Rtm)

331. op. cit., p. 179.12-13 (cit. Dhsg).

332. op. cit., p. 179.13-14 (cit. Dhsg).

333. op. cit., p. 20.12 (cit. Bpm).

334. op. cit., p. 180.8-12 (cit. Ug). 
bodhisattva, it is furthermore important to avoid bias and to abide unaffected by the eight worldly conditions as their threat to the spiritual equilibrium is particularly great. $^{335}$

Despondency is overcome by the casting aside of imprudent (laghu) and irresolute (sukumāra) thoughts and by cultivating an invincible (aparajjita) and steadfast (aksobhya) intention to eradicate the kleśa. ${ }^{336}$ By doing so, the bodhisattva learns to withstand the onslaughts of Māra and maintains - - even when exposed to torture or in intense pain-the sensation of happiness (sukhasamjiña $).^{337} \mathrm{~A}$ decisive role in the struggle for patience is played by the sarvadharmasukhäkhrāntasamädhi since it turns all sensations of pain into pleasant, non-painful or indifferent experiences. ${ }^{338}$ For its unfolding, this samädhi is dependent on the bodhisattva's resolution (pranidhāna) of universal liberation no matter how much hostility is shown towards him. Manifesting universal benevolence, he settles in the sarvadharmasukhākhrāntasamādhi. ${ }^{339}$ The second concomitant to duḥkhädhivāsanākșānti is sympathetic joy (muditā). ${ }^{340}$ Distinct from physical bliss (sukha) in that it is primarily mind-based (caitasika) ${ }^{341}$, muditā governs those training-areas that are free from despondency, sorrow (daurmanasya) and ill-temper (arati). ${ }^{342}$ Finally, complementing sympathetic joy and absorption in the sarvadharmasukhākhräntasamādhi, the bodhisattva penetrates to the foundation of being (dharmatā). He realises that all sensations are based on illusion (māyākrta) whose creation is traceable to mental constructions (vithapanapratyupasthäna) that, in turn, proceed from past deeds (karmavipāka) of no predicable agent. ${ }^{343}$

The exposition of 'patience in enduring the misdeeds of others' (parāpakāramarșanaksāanti) is entirely based on the $\mathrm{Sgm}$. In brief, it distinguishes three types of antagonistic demeanour ${ }^{344}$, viz., injury, contempt and injustice, all of which the bodhisattva endures in composure without intent for retaliation $(v y \bar{a} p \bar{a} d a){ }^{345}$ The same elements are also found in the kșänti

335. op. cit., p. 180.2 (cit. Ug).

336. op. cit., p. 180.15-16 (cit. Gv).

337. op. cit., p. $182.5-8$ (cit. Pps).

338. op. cit., p. 181.13-14 (cit. Pps)

Note that in the Samädh (Dutt, 1941-53, ii, p. 79.9-12) it is patient endurance of injury caused by others - not suffering - that depends on the joint practice of meditation (leading to an unwavering mind) and wisdom (eradicating anger). Acceptance of suffering itself encourages the distinction of neyartha from nitärtha texts, to acquire vision of sameness (samatä) and to show devotion to the dharmatā (op. cit., pp. 78.1-4, 78.5-6, 77.15-16).

339. op. cit., p. 182.8-15 (cit. Pps).

340. op. cit., pp. 183.4-184.4.

341. Mpps', iii, p. 1256.

342. In the Mpps (ii, pp. 906-7) Arati is the name that is given to the second of Māra's inner hosts.

343. Siks, p. 180.3-5 (cit. Ug).

344. op. cit., p. $184.9-4$.

345. op. cit., p. 185.5 . 
discussion of the $B d p$. However, being a much earlier texts than the Siks it does not provide as clear a distinction as Sāntideva but refers to them rather freely and in conjunction with other aspects of kșänti.

So far, the $B d p$ 's exposition followed essentially 'patience in accepting suffering' (duhkhhādhivāsanäkșānti) and 'patience in enduring the misdeeds of others' (paräpakäramarșanakșānti). Presented in terms of sattvakșānti and dharmakșānti-but never using this terminology -it did not address the cognitive dimension of patience. That is to say, the $B d p$ looked at dharmakșänti solely from an empirical viewpoint and not from the standpoint which requires the bodhisattva to put up with suffering because of the intrinsic non-existence of dharma. ${ }^{346}$

Summed up as 'patience consisting in contemplating and adhering to the Dharma' (dharmanidhyānādhimuktikșānti), this type of kșānti is brought about by resolute and astute investigation into the Doctrine. ${ }^{347}$ Like duhkhāadhivāsanākșānti, it is established by means of eight factors, viz., by determination (adhimukti) in the qualities of the triratha, by examining the meaning of reality (tattvārtha) and the laws of causation, by the force of buddhas and bodhisattvas, by personal attainments, means of attainment and by the sphere that is to be known (jñeyagocara). ${ }^{348}$

It is this cognitive maturity that leads the bodhisattva of the $B d p$ to the third level of kșānti practice, namely, highest patience ( $r a b$ tu bzod pa, prakșānti). Passing through the process of

346. The discussion of this aspect--falling under the category of dharmanidhyānädhimuktiksānti-occurs in the second section of the chapter. Partly repeating what has already been said concerning duhkhāadhiväsanäkșänti (internal and external) and paräpakäramarșanakșänti, it reconsiders them under the heading of 'bodhisattva-patience' ( $R$, folio 417.3, 419.4). Then, separately, it introduces 'highest patience' (prakssanti). Although all three belong technically to the category of bodhisattva-patience, the conceptual proximity of the first two and the fact they are textually intermingled suggests a breach between them and 'highest patience'. Bodhisattva-patience itself is characterised by twenty-two attributes and attainments that accrue to the bodhisattva in the course of his career. But for the almost obligatory absence of anger, hatred, etc., few of these relate specifically to patience. That is to say, it accrues-if perfected-to bodhisattvas who are free from malice, wrath, harmful intention, quarrel and violence; to those who are watchful, caring, mindful of body, speech and mind, correctly reflecting, detached from nirvana, aware of the law of karma, physically, vocally and mentally pure, in contact with the gods, in possession of the marks of a Tathāgata, in possession of his voice and of all roots of virtue; beyond inflicting injury and above all accusations. In short, in possession of all the buddha-qualities ( $R$, folio 418.1-419.4).

347. The concept of dharmanidhyānädhimuktikșānti goes back to the earliest stratum of Buddhist thinking. Corresponding to the Păli dhammanijjhänakhänti, it occurs already in the Cañkisutta of the Majihimanikäya (II, p. 175). Here, with faith in the foreground of the discourse, it follows on 'hearing dhamma' (dhammasavana), 'retaining dhamma' (dhammadhäranā) and 'considering meaning as secondary' (atthupaparikkha) because 'one who considers meaning sees that in truth it is dhamma that support knowledge' (yasmā ca kho attham upaparikkhati, tasmã dhammā nijjhanam khamanti). This patience, in turn, prepares and reinforces zest (chanda) from which emerges activity (ussäha).

348. Bbh, p. 195.10-20. 
examination that characterises dharmanidhyānädhimuktikșānti, the bodhisattva learns to eschew the forms of patience that participate in discursive thinking or are otherwise based on misconception: $:^{349}$

"Patience that inquires 'Who is abusing and who is the abused?' is a patience that construes duality. This is not the highest patience. Patience that inquires 'Who abuses here?' is patience that counts dharma. ... Patience that inquires 'I course in [good] conduct, but he courses in bad conduct' is patience [that engages in] duality. This is not the highest patience."

Progressively refining his understanding of reality, the bodhisattva overcomes all forms of dichotomy and attains a vision of patience that operates beyond all predication: ${ }^{350}$

"What then is the highest patience? It is to understand emptiness without ever suppressing heretical doctrines or imputing emptiness. It is to understand emptiness without ever suppressing discrimination or imputing signlessness. It is to understand emptiness without ever suppressing one's resolution or imputing wishlessness. ... It is to understand emptiness without ever suppressing samsāra or imputing nirvāna. Patience practised in this way is the highest patience."

This process of realisation culminates in the bodhisattva's 'conviction of the non-arising of dharma' (anutpattikadharmakșānti) when he sees that: ${ }^{351}$

"Everything is unborn, unproduced and unarisen. The unarisen is without origination whatsoever. Since it is without origination, it is inexhaustible. The inexhaustible is the highest patience. It is neither conditioned nor unconditioned. It is never misconceiving. The non-established, non-increasing, genuinely non-multiplying, non-gathering and non-diminishing is without birth. That which is without birth is inexhaustible. If he is patient in this way [the bodhisattva] realises that dharma are unarisen."

349. R, folio $420.6-421.3$.

350. $\mathrm{R}$, folio $422.1-6$.

351. R, folio 422.7-423.4. 
This final deliberation bears all the hallmarks of the dharmanidhyānädhimuktikșānti. Having analysed conventional understanding of patience within the subject/object dichotomy, the bodhisattva now begins to fathom the meaning of emptiness. Thus, in a sense, he treads the middle way between categoric denial and mistaken imputation. This insight establishes him on the path leading to the highest patience that culminates in the recognition that dharma function beyond the parameter of origination or destruction in a space of no independent reality.

The spiritual ideal that is proposed in the $B d p$ as the highest patience was taken up by the $A k n$ as absolute patience (śin tu bzod pa, atyantakșānti). ${ }^{352}$ Intrinsically invulnerable (atyantāvranatā), it operates beyond apprehension (anupalambha) ${ }^{353}$ and the duality of antidotes (pratipakșaprahāna). ${ }^{354}$ Hence, absolute patience of the $A k n$ epitomises the bodhisattva's true cognition of reality. That is to say, it prompts avoidance of the construct of suppression/imputation (prativedhasamghata) and allows him to see that dharma are established beyond the predicate of patience. Although the text stops short of using the term anutpattikadharmaksānti to define its understanding of this highest or absolute form of patience, there can be little doubt that it propounds this very concept. ${ }^{355}$

The $A k n$, like the $B d p$, shows no indication that it was aware of the possibility of progression in anutpattikadharmakșānti. ${ }^{356}$ Adopting a purely cognitive approach to lay bare the reasoning leading up to the conviction of the non-arising of dharma, it does not contain any reference

352. I have found only one sütra where the threefold division into injury, suffering and dharma is not taken up. This is the Sarkarapariprccha (TTP, 33, pp. 248.5.5-50.3.8) where we meet with an division of $k s \underline{a} n t i$ into the four śramānakārakadharmas of abuse (ākrușta), anger (roșita), reproach (bhaṇdita) and beating (tâdita). In the Sarkarapariprcchä, these are set in direct relation to the stage of irreversibility, to the thirty-two marks of a great being, to possession of a buddha-field and to proficiency in the abhijñ $\bar{a}$-in brief to buddhahood itself (Mvy 8708). The cognitive dimension, implied in dharmanidhyānādhimuktikșānti, is treated separately but follows exactly along the lines of anutpattikadharmakșānti which is referred to as term (p. 250.1.4 7) and mentioned in conjunction with a prediction.

353. $A k n$, p. $45.1 .7-8$

The $A k n$ 's understanding of the absolute patience runs therefore close to that of the $R p(\mathrm{p} .12 .2)$ that employs the very term anupalambhadharmaksānti to characterise anutpattikadharmakșānti.

354. Contrast this interpretation of absolute kșanti with that found in the Pañca (pp. 3-4) where, according to the Tibetan, it is likened to the 'conviction of the sameness of all dharma' (samatāsarvadharmakșanti).

355. $A k n$, p. 45.7-8:

"That kind of patience that is conviction concerning the non-originated and conviction that things are unoriginated (anutpādakșānti) is absolute patience."

Cf. Larika, 203.11: anutpāde kșānti; Suzuki, 1978, p. 175, § 109; Akn, p. 45.3.46.

356. This is also the case in the $R c d, B d p, K p$ and many other early Mahāyanna sütras where patience is discussed as an individual perfection. 
to the terms ghoșānugāa, anulomiki- and pratilabdhäkșänti or to the thought that lies at their heart. With some reservation, this holds also true for the division into duhkhädhivāsana-, parāpakāramarșana- and dharmanidhyānādhimuktikșānti since none of these terms actually appears in the $A k n$. And yet, the apportionment of contents into three identifiable sections dealing with ordinary patience, pure patience and absolute patience suggests, perhaps, that it was known to the $A k n$, if only in a rudimentary form..$^{357}$

The benefits that accrue to the bodhisattva from the practice of kșanti are manifold but do not always agree. Hüang-tsang, commenting on the three types of patience, explains that parāpakāramarșanakșānti becomes the cause of the bodhisattva's ripening of sentient beings (sattvavipākapravrttihetu) while duhkhädhivāsanākșānti, granting powers to cope with pain, induces buddha-qualities. The third form of patience, dharmanidhyānādhimuktikșānti functions as support (áśraya) for the two preceding types of ksānti and describes the bodhisattva's attitude towards the Doctrine. ${ }^{358}$ The $M s l$ gives a more pragmatic account, citing indifference to animosity and flattery, concern for benefit and welfare, death free from repentance and rebirth amongst gods and men as the fruits that spring from the pursuit of patience. ${ }^{359}$

Among the sütras, the most advanced account is found in the Samādhirājasūtra. Here, we are told that a practitioner who has penetrated the ghosänugāmi level of anutpattikadharmakșänti abstains from disputes, penetrates the illusory nature of dharma, acquires knowledge of the scriptures, understands their meaning on the neyārtha and nitārtha level, attains faith and resolves to attain all-knowing. He reaches the stage of increased cognition (jñanavivrddha)

357. A similar situation is found in the $\operatorname{Sgm}(33, \mathrm{pp} .50 .1 .5-54.4)$. Here too, one meets with the ingredients of later developments but does not find any technical terminology. That is to say, the sūtra introduces $k s \bar{a} n t i$ by affirming its important role in the bodhisattvacarya in that is renders the bodhisattva inseparable from the thought of enlightenment. Furthermore, it prompts him to generate the intent (äśaya) of the six perfections (p. 50.3.4-6) and, sustained by great compassion, establishes a lasting link between the bodhisattva and other humans, buddhas and gods (p. 50.4.3-5). Patient endurance with regard to injury of body and speech refer to all intents to duhkhhädhivāsana and parāpakäramarșanaksānti while patience with regard to the mind discusses the motive behind the bodhisattva's struggle. The cognitive element enshrined in the term dharmanidhyänädhimuktikșanti is dealt with in the last section where Sāgaramati is giving a long discourse on the nature of dharma (pp. 52.3.7-53.4.1). Perception of it arises from the perfection of mediation and wisdom. Through meditation, the bodhisattva gains the required composure for the vision of dharma with insight (vipasyana a) in meditation to unfold (p. 53.2.6-8). This vision itself is wisdom and training in the perfection of wisdom leads to true realisation with regard to the characteristics (laksana) of dharma (p. 52.4.2-3).

358. Msg, p. 191

The same division, but without commentary, is also found in the Siddhi, p. 621 (cf. Sgs, p. 143, § 29).

359. $M s l$, p. $10816-21$

This set of five was almost certainly taken from the Anguttaranikāya where we come across a very similar scheme (A III, p. 254). 
and becomes fully settled in the teachings of the Buddha. ${ }^{360}$ Since most, if not all of these attainments are attributable to the bodhisattva's careful Dharma-pursuance, the text's comparison of the ghosānugāmi practice with the attainment of śrutamayiprajñ $\bar{a}$ is quite appropriate.

At the anulomiki level ${ }^{361}$, the bodhisattva ceases to waver in his undertakings. He attains the perfection of meditation, acquires the abhijñ̄a and rddhipāda and transcends all mental limitations. ${ }^{362}$ Thus, accomplished in insight (vipaśyanā) and perfect mental quietude (śamatha), he is wholly composed and traverses one hundred buddha-fields. ${ }^{363}$ Considering the intense meditative and reflective practice that marks marks this level of attainment, the juxtaposition to cintāmayiprajñ $\bar{a}$ is all but far-fetched.

Finally, at the pratilabdhā level of anutpattikadharmakșānti the bodhisattva sees innumerable buddhas teaching sentient beings and is conversant with their demeanour and armour. Jambudvipa becomes his buddha-field where he rules with inconceivable wonder-working powers and teaches the Dharma to all beings. ${ }^{364} \mathrm{He}$ abides wholly unaffected by mundane profit or renown. Established in the non-arising of dharma, he attains buddha-cognition and achieves the highest degree of benevolence and compassion. ${ }^{365}$ According to the Samädhiräja, this events takes place when the bodhisattva embarked on the sixth stage and received his final prediction buddhahood. ${ }^{366}$

In appreciation of these benefits, the bodhisattva also sets out to suppress anger in other beings. ${ }^{367}$ Thus, we learn in the Bodhisattvaprätimokșasütra that the bodhisattva cultivates patience not only in himself, but equally admonishes others to follow suit. Aware of the effects of anger and animosity, "he consoles and placates those who are angry, he appeases and heartens them"368 and explains: ${ }^{369}$

360. Dutt, 1941-53, ii, pp. 77.2-79.8.

361. Dutt, 1941-53, ii, pp. 79.9-80.12.

362. TTP, 31, p. 281.2.2-3.

363. Dutt, 1941-53, ii, p. 79.9-11.

364. TTP, 31, p. 281.2.4-7.

365. Dutt, $1941-53$, ii, pp. 80.13-81.10

Other attainments that are thought to accompany the conviction of the non-arising of dharma are sila,

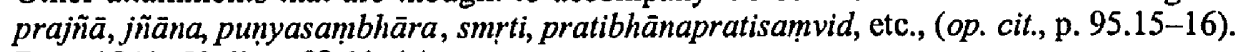

366. Dutt, 1941-53, ii, p. 82.11-14

We have seen that by most accounts this is not a standard posistioning.

367. $M s l$, p. 105.18-19 (cf. S I, pp. 162-3).

368. Siks, p. 188.17-18.

369. Pañca, p. 562-3. 
"There is nothing real or substantial from that your wrath is produced. An unreal fancy is this wrath. No real entity corresponds to it, nor is there a real entity that offends you, makes you feel anger or ill-will, or that makes you belabour others with sticks or swords, or rob one another of life. For when you get angry as a result of an unfounded imagination, you will be hurled into the hells, the animal world, the world of Yāma or any other place of low rebirth where you will experience painful feelings-intense, harsh and bitter."

In the $B d p$ the bodhisattva does not show such concern with the welfare of sentient beings. As in the previous chapters, the focus of the exposition rests rather narrowly on the training of the bodhisattva and ignores the wider issues that are involved in its application. We learn therefore very little about the benefits that accrue to him on the basis of the practice of ksanti and the impact it has on the goal of universal liberation.

The description itself concurs to a large extent with the principles that underlie the discussions of patience in other Mahāyāna sūtras. That is to say, it speaks of dharma- and sattvaksāanti, it distinguishes between duhkhādhiväsanākșānti, parāpakāramarșaṇakșānti and dharmanidhyānādhimuktikșānti and recognises the principle of anutpattikadharmakșānti as the highest manifestation of patience. There is however no direct reference to these technical terms as their contents is incorporated in the flow of the exposition.

The position of these main-components on the path is only vaguely indicated. Duhkhädhivāsanākșänti which corresponds in the scheme of the $B d p$ to ordinary patience is the lowest type of patience and is practised during the initial stages of the path. Although its exact position is not indicated, from the information on the next higher type of patience we may deduce that it probably prevails from the pramuditābhūmi to the prabhākarībhümi. After that, the bodhisattva embarks on the so-called bodhisattva-patience. Corresponding to the apakāramarșanakșānti, this type of patience becomes manifest when the bodhisattva has acquired wisdom. That is to say, when he is accomplished in the bases of mindfulness, when he has attained correct reflection, possesses a fully purified disposition and has mastered the factors of enlightenment. It is not clear for how long the parāpakāramarșanakșānti dominates the ksāniti practice of the bodhisattva. According to the $B d p$ it extends over the whole width of the path and leads to the acquisition of the buddha-qualities. This generates difficulties since it is at odds with the position of the dharmanidhyānādhimuktikșānti which is generally 
thought to fully manifest as anutpattikadharmakșānti on the acalābhümi. However, as the $B d p$ is completely silent on its positioning and does not distinguish it contextually from the bodhisattva-patience, we may assume that the parāpakāramarșanakșanti, dharmanidhyānādhimuktikșānti and anutpattikadharmakșānti (including perhaps the duhkhädhivāsanäkșānti) manifest concurrently from the eighth stage onwards. In other words, although they are initially accomplished in succession, from a certain level of attainment onwards (probably the eighth stage) all three types of patience merge into the 'conviction of the non-arising of dharma' where they coexist and find their true fulfilment. 
The Perfection of Vigour

"Vigour is a steadfast mental effort (cetaso 'bhyutsāha) leading to wholesome dharma. It is of armour (samnāha), practice (prayoga), free of weakness (alinatva), irreversible (avyävrtti) or insatiable (asantuști). Its purpose is to effect completion and attainment of favourable bearings."

This definition of vigour, given in the Abhidharmasamuccaya, sums up many of the issues standing at the heart of the bodhisattva's virya practice. ${ }^{370}$ First, it establishes the psychology of vigour. Second, it maps out the various phases where vigour becomes manifest. Although, at first sight no more than random attributes, samnāha, prayoga, etc., represent in fact rather distinct stages in the cultivation of vigour. Finally, Asanga defines the rationale behind virya. The phrasing is by no means coincidental, but takes into account changes in its objectives, leading from concern for personal advance to selfless devotion to universal liberation. For Buddhism to produce such an elaborate concept of vigour, it had to mature over many centuries.

In early Buddhism, vigour (viriya) figures as a frequently cited but little elaborated aspect of the srāvaka training. It is never expounded on its own but is invariably touched upon in connection with other virtues whose generation it assists. Viriya is discussed as part of the lists of the seven excellent qualities of monks ${ }^{371}$, five faculties (indriya $)^{372}$ and powers $(\text { bala })^{373}$. It appears under the five limbs of striving (padhāna $)^{374}$, seven factors of enlightenment (bodhyanga) ${ }^{375}$, five factors conducive to ripening ${ }^{376}$, eight conditions causing wisdom $(\text { pañ } \tilde{a})^{377}$, ten conditions that make for warding ${ }^{378}$ and need to be remembered ${ }^{379}$, and is

370. Abhidh-sam (R), p. 8.

371. M I p. 356

Identical formulations, but set in a different context are found in D II, pp. 237, 285; A IV, pp. 3, 110 .

372. S V, p. 225; D III, pp. 239, 278.

373. S V, p. 197; A III, pp. 2, 11; A V, p. 15.

374. M II, pp. 95, 128; A III, pp. 152, 155; D III, p. 237.

375. A IV, pp. 352-3.

376. A IV, p. 357.

377. A IV, pp. 153-5.

378. A V, pp. 23-24, 27-28.

379. A V, pp. 90-91. 
particularly associated with the moral precepts of the patimokkha code. ${ }^{380}$

The contexts in which it is discussed suggests that viriya was recognised as an important practice. Its opposite, indolence, is listed among the eight principal stains ${ }^{381}$ and mars renunciation of agitation, intemperance and immorality. ${ }^{382}$ Moreover, viriya is expressively perceived as a contributing force to many cardinal attainments of the Buddhist path, including mindfulness, ripening, recollection and wisdom. ${ }^{383}$ Quite clearly, for the Buddha viriya constituted a high-ranking dhamma in its own right: ${ }^{384}$

"O monks, this Dhamma is for the energetic, this Dhamma is not for the indolent."

In spite of such pre-eminence, references to viriya are predominantly succinct and summarylike. It is rarely analysed but surfaces in passages which follow stereotyped patterns of exposition that recur, without variation, in two or three variant readings throughout the nikāya.

The most frequent formula identifies viriya as the raison d'être of the sammappadhāna for which it serves along with faith, good health, honesty and wisdom as precondition. ${ }^{385}$ Accounting for approximately eighty percent of references to viriya in the nikāya, it typically runs as follows: $:^{386}$

"He dwells with stirred up energy for the sake of abandoning unskilled mental states. For the sake of acquiring skilful mental states, he is firm, of steady valour, perseverance in purpose amid skilful mental states."

In several places this type of reference is expanded to include the monk's refusal to abandon the burden of teaching and good qualities in illustration of his vigorous resolve. ${ }^{387}$ It appears that for the early Buddhists viriya was above all a mental factor: ${ }^{388}$

380. A IV, pp. 153-5, 357.

381. A IV, p. 195.

382. A V, p. 146.

383. These links are established in A V, pp. 23-24; IV, p. 357; V, pp. 90-91; IV, p. 153.

384. A IV 233; see also: M I, p. 481.

385. M II, p. 95.

386. M I, p. 356 (trsl. Gethin).

387. A I, p. 117.

388. S V, p. 111 . 
"O monks, that which is physical energy is always energy as a factor of wisdom.

That which is mental energy is always energy as a factor of wisdom."

The $A s^{389}$, citing this very passage, concludes that there is thus only mental energy and that whatever action results from the 'initial generation of energy' (viriyārambha), it springs from the psychological disposition towards viriya ${ }^{390}$ In spite of its operational restriction to the mental realm, the impact of viriya goes of course beyond psychic processes as its purpose is to overcome idleness (kosajja) through energetic practice. While its foundation is also mental, the method and means that manifest energetic conduct vary according to circumstances. ${ }^{391}$ The principal characteristics of viriya are grasping, strengthening and support of those wholesome mental states that are most liable to deterioration. ${ }^{392}$ In this sense, it is specifically cited in the $A s$ in conjunction with sil $a^{393}$ and recognised as the chief force that instigates and completes purification: ${ }^{394}$

"Livelihood purification is to be undertaken by means of viriya. For that is accomplished by energy because the abandoning of wrong livelihood is effected in one who has rightly applied energy. Abandoning, therefore, unbefitting wrong striving, this should be undertaken with energy by means of the right kind of striving consisting of alms round, etc."

This quotation introduces striving (padhäna) as the other major aspect of viriya that (in particular as a concomitant to the four sammappadhāna) motivates to virtuous conduct. ${ }^{395}$ If

389. $A s$, p. 145.

390. In the Kośa, the situation is very similar. Here (ii, p. 160), we learn that virya is primarily mental effort. It is said to refer at all times to wholesome action. The same thought is expressed in the Pañcaskandha: "Virya is energy of the mind concerned with the wholesome, the opposite to indolence."

391. $A s$, p. 120.

392. A vivid description of viriya in its supportive function is found in the Milindapañha (36):

"Just as, your majesty, a man might support a house that was falling down with an extra piece of wood, and being thus supported that house would no fall down-in the same way, your majesty, energy has the characteristic of supporting. Supported by viriya, no skilful dhamma are lost."

393. As, p. 120.

394. Vism, p. 40 (trsl. Nāanamoli)

395. In the Vism, Buddhaghoșa goes so far as to say that viriya is nothing but an alternative name for padhāna (Vism, p. 697), while in Bodhiräjakumārasutta (M II, p. 95) viriya is listed besides faith, health, integrity and wisdom as one of the independent qualities of striving. According to the Kosa (vi, p. 283), giving the constituents of vigour, virya comprises the four samyakpradhäna, limb two of the bodhyariga and the samyagvyāyama member of the Eightfold Path. 
vigour has exertion as its characteristic, it functions to strengthen the coexistent states and manifests resistance to surrender to unwholesome dhamma. ${ }^{396}$ In this context, agitation (uddhacca) - the basic condition for generating viriya-becomes the proximate cause of energy ${ }^{397}$ and gives it an important role in the completion of the training: ${ }^{398}$

"Energy (viriya) is the state of one who is vigorous (vira). Its characteristic is marshalling [driving]. Its function is to consolidate conascent states. It is manifested as non-relapse. Because of the words 'bestirred, he strives wisely' its proximate cause is a sense of urgency; or its proximate cause is the ground of the initiation of viriya. When rightly initiated, it should be regarded as the root of all attainments."

The application of viriya and knowledge thereof is inextricably linked with understanding the meaning of exertion. According to the Patis, it is acted out through training in the four sammappadhāna and produces the undertaking to abandon the seven obstacles in favour of renunciation. ${ }^{399}$ In this respect, its presence becomes a precondition "for the maintenance, non-corruption, strengthening, plentifulness, development and perfection of the arahant path" that is limited to those who fully subscribe to the practice of endeavour (padhäna) and bestirring (ārabhata). ${ }^{400}$

As one of the five indriy $a^{401}$, it has its origin in adverting unwholesome dharma, in zeal and attention through the influence of exertion, in focusing through the influence of the faculty of energy leading to the abandonment of idleness. ${ }^{402}$ Once in place, it is important that the faculty of viriya does not dominate any of the other four indriya as this would impede their development. ${ }^{403}$ Above all, however, it is imperative that the practitioner should balance

396. $A s, \mathrm{p} .121$.

397. Mil, i, p. 57.

398. Vism, xiv, p. 137 (trsl. Ñānamoli; cf. A II, p. 115).

399. Patis, pp. 103-4.

400. Patis, p. 104.

401. Several discourses in the Samyuttanikayya indicate that the viriyendriya and sammappadhanna conceptually cover exactly the same ground:

"What is the faculty of energy? Here the noble disciple dwells as one who has established energy. For the sake of abandoning unskilful dharma and arousing skilful dharma he is firm, of steady valour, unrelinquishing in purpose with regard to skilful dharma" (S V, p. 197).

Or, even more explicit (S V, pp. 196):

"In the four sammappadhäna there is the viriyendriya to be seen."

402. Patis, pp. 211, 209.

403. This, of course, is also true for the other four faculties as too strong a practice of any of them would obstruct the performance of their collective functions (Vism, iv. 46, p. 129; Vin, i, pp. 179-85, A III, pp. 374-6). 
vigour with concentration. The reason is that idleness poses a threat to meditation in those who possess little vigour, since concentration favours inactivity. Agitation, on the other hand, occurs in those who possess great energy but are restless in meditation since energy favours agitation: ${ }^{404}$

"When the sign arises, one bhikkhu forces his energy, thinking: 'I shall soon reach absorption.' Then his mind lapses into agitation because of the mind's over-exerted energy and he is prevented from reaching absorption. Another who sees the defect in over-exertion slacks off his energy, thinking: 'What is absorption to me now?' Then his mind lapses into idleness because of his mind's too lax energy and he too is prevented from reaching absorption. Yet another who frees his mind from indolence even when it is only slightly idle and from agitation when only slightly agitated, confronting the sign with balanced effort, [that one] reaches absorption."

In the Mahãyāna, the notion of virya has been modified in several respects. First, adjusted to the requirements of the new ideal, vigour is no longer targeted towards the bodhisattva's personal advance, but is devoted to the welfare of all beings: ${ }^{405}$

"They [the bodhisattvas] have pure and courageous minds and are linked with other beings and persons. [When] they are practising the perfection of vigour, as a maid servant is submissive to her master who is not subject to anyone else, so do the firmly wise submit to subjection by all beings."

Second, its practice is given a new meaning because of the unlimited duration of the bodhisattva path. In the nikāya, viriya was essentially interpreted as a supportive quality that promoted the generation of a wholesome mind-set. Its presence is especially required in meditation and has great impact on purification. Above all, it is related to practice and did not address the issue of time as a priority. With the expansion of the spatio-temporal dimension of Mahãyāna cosmology, the previous ideas on the length of the training became dramatically

404. Vism, iv.72, p. 137 (trsl. Gethin)

See also S V, pp. 112-114 where the Buddha construes the famous simile of the fire that cannot burn by lack of dry fuels (i.e., idleness) and cannot be put out by dry fuels (i.e., agitation), (cf. Vism, pp. $136,138)$.

405. Rgs, xxix.11 (trsl. Conze; cf. Pañca, p. 455). 
amended. As a consequence, even very early Mahāyāna sūtras draw connections between the need for perfect vigour and the formidable length of the path, arguing that it requires beings of truly extraordinary zeal. Such thinking is already attested in the Rgs and indeed figures in practically all Mahāyāna treatises on vīrya. ${ }^{406}$

Third, by applying their philosophical axioms on existence to the training itself, Mahāyāna sütras merged their ontological absolutism with the realism of the practice itself. For the perfection of vigour, as indeed for all other practices, this led to a radical shift in interpretation culminating in the admission of the futility of all endeavour: ${ }^{407}$

"When one has no notion of either body, thought, or being,

Abiding without perception and coursing in the Doctrine of non-duality

That has been called by the Buddha 'perfection of vigour'

Of those who long for blissful, imperishable unsurpassed enlightenment."

In spite of (or perhaps, because of) the predicament posed by the dismissal of conventional experience, the bodhisattva proceeds to train in vigour with unabated zeal: $:^{408}$

"To some he gives sons and daughters, and to others a kingdom. For the sake of others he sacrifices himself. In this way he works the weal of beings by whatever device it can be worked. It is thus that the bodhisattva who courses in perfect wisdom and is endowed with mental vigour fulfils the perfection of vigour even though dharma are signless."

This last quotation points to an important departure from early conceptions of virya. We have seen that for the srāvaka vigour was primarily a mental dhamma. In the Mahāyāna, this definition is no longer upheld. Already in the incipient phase, its sütras speak of physical and mental vigour. While it is probably true to say that mental vigour is still regarded superior as it creates the psychological foundation for the practical implementation, both are recognised and valued for their contributions. ${ }^{409}$

406. Rgs, xxx.4-5.

407. Rgs, xxx.7 (trsl. Conze).

408. Pañca, pp. 513-14 (trsl. Conze).

409. Pañca, p. 513:

"Here, the bodhisattva who courses in perfect of wisdom and is endowed with mental vigour 
Also mental vigour itself underwent some modifications. ${ }^{410}$ In the early Buddhism of Sákyamuni, it was always interpreted as an inherently dynamic force which promotes and sustains wholesome states, or prevents and destroys unwholesome states. For the Mahāyāna this is no longer the case, as mental vigour received a predominantly cognitive role: ${ }^{411}$

"The bodhisattva who courses in perfect wisdom and is endowed with mental vigour ... does not misconstrue anything whatsoever as permanent or impermanent, ease .or ill, self or not-self, conditioned or unconditioned."

Thus, rather than operating as the driving force behind the bodhisattva's exploits in virya, mental vigour became an agency bringing vïrya practice in line with Mahāyāna ontology. Its task was to free the bodhisattva from delusion and establish him in knowledge of sensefields, non-duality and dharmatāsthiti, culminating in the conviction of the non-arising of dharma. ${ }^{412}$

It is in consideration of these developments that the virya exposition in the $B d p$ needs to be examined. The $B d p$ introduces the discussion of vigour by pointing to the interaction between $k s ̦ a ̄ n t i$ and virya. For those who are dedicated to scriptural learning, it becomes a sine qua non for progress, as they meet with persistent envy and hostility. ${ }^{413}$

Such explicit association of learning and vigour is rarely found in Mahāyāna literature. In the few cases where a connection is established, rather than physical protection, vigour is directed more to accomplishing the task of learning itself. Thus, we learn in the Näräyanapariprcchā of the bodhisattva's great vigour in preaching the Dharma. ${ }^{414}$

\footnotetext{
gives no opportunity to unwholesome deeds of body and speech."
}

410. Cf. Ratnameghasūtra (cited in Siks, pp. 51.21-52.3).

411. Pañca, p. 513 (trsl. Conze).

412. $S g m, 33, \mathrm{pp} .62 .5 .8-63.1 .7$.

413. R, folio 424.1-426.3.

414. Siks, pp. $189.7-190.3$

It is in this context that Santideva gives the well-known quotation of the $A k n$ 's eighty types of learning to that $I$ have referred on several occasions already. For the exact contents of this list, see: Appendix $i$. In the $D b h$ (Daśa-bh, p. 33.23-27, J), as a precondition for the practice proper and leading to the first dhyanna, the bodhisattva focuses his vigour on the search for learning and the Dharma at the prabhäkarībhümi.

The $D b h$ itself contains very little on the practice of the viryapāramitā (Daśa-bh, p. 40.12-14, I). In the exposition on the acrișmatībhümi-the phase where training in virya should theoretically stand in the foreground-oniy one sentence addresses the bodhisattva's practice in virya, describing it as attentive (aprasrabdha), pure (apariklișta), unfaltering (apratyudhävartya), extensive (vipulya), infinite (ananta), earnest (uttapta), unequalled (asama), indestructible (asamhärya), aimed at the benefit of all sentient beings (sarvasattvaparipäcana) and saying that it discerns correct conduct from incorrect conduct (nayānayavibhakta). 
The combination of virya and kșānti is, in contrast, much more commonly attested in Mahāyāna sütras. It is in particular the attainment of anutpattikadharmaksānti that vīrya is related to: $:^{415}$

\begin{abstract}
"O householder, how does the pravrajita bodhisattva, living in the aranyavāsa, cultivate and fulfil the perfection of vigour? To this end, the bodhisattva should train himself thus: 'I shall not depart from this place, for it is essential that $I$ should realise the conviction of the non-arising of dharma." "
\end{abstract}

The rationale behind this association is the bodhisattva's change of body at the moment of anutpattikadharmakșānti. ${ }^{416}$ Immediately after the first production of the thought of enlightenment, his attainments are weak and incomplete and he strives to attain perfection in his training by means of practice in generosity, moral conduct and good intentions. Throughout this period, stretching form the prathamacittotpāda to the attainment of the perfection of meditation, his endeavours are physical, since they operate on the material plane where he experiences truly physical hardship. With the production of the abhijña at the point of mastery in meditation, physical effort is no longer required as he is now capable of transforming himself into whatever shape is best suited to assist sentient beings.

In the $B d p$, however, the link with $k s \bar{a} n t i$ is initially interpreted in the conventional sense. The bodhisattva is required to bear with the physical and vocal animosity directed at him under Māra's influence. ${ }^{417}$ In this respect, perfection in vigour provides a degree of psychological steadfastness in the pursuit of the path. ${ }^{418}$

415. Ug, p. 271.1.3-5.

416. Mpps, ii, pp. $970,711-12$, n. 1.

417. R, folio 424.3-6.

418. R, folio $243-246$

In the Mpps, the connection between virya and $k s \overline{a n t i}$ includes the conventional and ontological frame of reference of patience. First, the bodhisattva shows great diligence in quietly enduring all pain and hostility - be it physical or verbal-and remains unaffected by the fame and homage shown to him (ii, p. 986). Second, the bodhisattva is not deterred by the difficulty of his undertaking. Working for the benefit of beings, he shows great patience with their shortcomings and accomplishes even the most difficult tasks through the combined presence of virya and ksanti (ii, p. 949). This attainment of the $a b h i j \tilde{n} \tilde{a}$ coincides with the 'conviction of the non-arising of dharma' (Daśa-bh, p. 71.22-26), at which stage he obtains a new body called the 'body born from the Dharma-realm' (dharmadhätujakāya). From now onwards he is no longer concerned with physical vigour that dominated his 'body born from fetters and acts' (bandhanakarmajakāya) since the production of the thought of enlightenment, but enters the realm of mental vigour. As this latter body is born from the teachings of the Doctrine, it is in perfect concordance with reality and is no longer subject to the restraint of his samsanric corporeal existence. Depending for realisation on the state of anutpattikadharmaksänti, the link between virya and $k s \bar{a}$ ant $i$ fits well into scheme of the path. 
Rooted in pure altruism, the motivation is not the prospect of future happiness, but the aspiration to achieve universal welfare: ${ }^{419}$

"O Sāriputra, while delighting in purification, he accomplishes vigour not solely for the purpose of acquiring the sambhogakāya of mine. Rather, he enters into [vigour] in order to bring happiness and benefit to all sentient beings; to prompt sentient beings to understand [the bodhisattvapitaka] ... to prompt them to guard the noble path."

Immediate application of vigour is found in the practice of the päramitā and the unfolding of benevolence and compassion. ${ }^{420}$ While diligent training in the päramitā leads to the roots of virtue for the bodhisattva himself, resolute altruism reinforces his commitment to universal liberation. Hence, vigour is of fundamental importance to the bodhisattva's quest for buddhahood: ${ }^{421}$

"Vigour is the finest of virtuous dharma because on its basis there occur subsequent benefits. Through vigour pleasant dwellings and success arise, both mundane and supramundane. Through vigour one achieves the desired enjoyment in life. Through vigour, those [virtues] become purified. Through vigour [bodhisattvas] transcend reification and attain supreme enlightenment."

Motivated by the cittotpa $\bar{a} d a$ and supported by the armour of vigour, the bodhisattva embarks on the course of training. ${ }^{422}$ The term 'armour' (samnaha) points here to one of the three phases of virya practice. ${ }^{423}$ Definitions of samnāhavirya fall broadly into two categories.

419. $\mathrm{R}$, folio $428.4-7$.

420. $R$, folio $426.1-3$

For an account of the interaction between virya and the other perfections, see: $M p p s$, ii, pp. 927-35. In the $M_{s l}$ (pp. 105.25-106.5) vigour is classified into seven types corresponding to its function and contents. These are vigour in moral conduct, meditation and wisdom, physical and mental vigour, zealous (satkrtya) and constant (sätatya) vigour.

421. $M s l$, p. 114.4-14 (cf. Msl, p. 32.4-5)

See also $B b h$ (p. 201.21-25):

"Nothing else but vigour is the chief and best cause for maturing in this way all the virtuous dharma that generate [the bodhisattva's] enlightenment. For that reason, the Tathāgata points 422. $\mathrm{R}$, folio 445.6 . to vigour for the supreme and perfect enlightenment."

423. It is also the only member that is common to all schemes of vigour. The scholastic treatises of the Mahāyāna propose two classification of virya. First there is a scheme which recognises three types of 
First, we have a number of texts where armoured vigour is related to cognitive processes. In the $S g m$, for instance, armour is fundamental to the purification of the body and mind. ${ }^{424}$ As a mental dharma, its chief task is to generate sufficient resilience and strength for the bodhisattva to pursue pristine cognition (jñāna). Specifically, if combined with $k s ̦ a ̄ n t i$, it prepares for the conviction of the non-arising of dharma and thereby enables him to persist in the practice and search of the pure Dharma. ${ }^{425}$ Furthermore, it promotes insight into the psychological operations of name-and-form; it leads to understanding of the cessation of the subject/object dichotomy and prompts the bodhisattva to abandon grief, doubt, illness and conceit. ${ }^{426}$

Second, we have texts where the need for armoured striving is located in the demanding nature of the training itself, in its infinite length and vast objective. A good example of this type is the $A k n \cdot{ }^{427}$ Here, the focus rests on the need for steadfastness in the actual practice-above all in the pāramita - and the pledge to postpone parinirvāna until all beings have been placed in the thought of enlightenment.

In the siastras, however, it is generally agreed that armoured striving is motivated by both factors. ${ }^{428}$ It is understood to stand at the very beginning of the virya practice ${ }^{429}$ as producing encouragement and a firm commitment to the training in general, and strengthening virya in particular. ${ }^{430}$ In the $M s l$, these aspects are brought together in a single verse, although the

vigour, that is, 'armoured vigour' (samnāhavirya), 'vigour in accumulating wholesome dharma' (kuśaladharmasamgrăhakavirya) and 'vigour in working for the benefit of sentient beings' (sattvārthakriyāvirya). Among others, it is given in the Siddhi (p. 622) and Bbh (p. 200.10-11). Variants of this classification are found in the $M s l$ (p. 114.17-18) or $M s g$ (pp. 191-2) where vigour falls into 'armoured vigour' (samnähavirya), 'vigour in practice' (prayogavirya) and 'spirited, imperturbable, insatiable vigour' (alinam aksobhyam asamtuști virya). A further variation is given in the Dhsgr ( $\S 108$; cf. Mahäyänasūtrasamgraha, Vaidya; p. 338.1-2) which distinguishes between sammähavirya, prayogavirya and 'vigour directed at the supreme end' (paranișthä/parinișthävirrya).

The only major treatise that does not adopt either of these threefold schemes is the Mpps (ii, p. 946). Following the categorisation of the Pañca, it differentiates between mental and physical exertion (käyikacaitasikäsramısanatä). For the perfection of vigour itself, it proposes five constituent characteristics, including dynamism in action, ease in enterprise, steadiness of will power, eagerness of mind and perseverance in action (ii, p. 946). As the composition of these attributes indicates, it is probable-though not explicitly stated-that these cover vigour in both its mental and physical dimension.

424. 33, pp. 62.5.3-63.2.1.

425. op. cit., p. $63.1 .6-2.3$.

426. op. cit., p. 62.5.5-6.

427. $A k n$, p. $46.3 .2-4.5$.

428. Bbh, p. 201.2-4.

429. $M s g$, p. 191.

430. Bbh, pp. 200.26-201.2

According to Tsong-kha-pa, armoured vigour is based on former exertion and operates as a preliminary resolve (pranidhāna), leading to enthusiasm of mind, infinite accumulations of merit, freedom from obscurity and becomes the cause of irreversibility. A bodhisattva who generates faith and conviction in armoured vigour, attains steadfastness in his cause and accomplishes even the most difficult tasks with ease provided that he is motivated by yearning for enlightenment that it consolidates (Lam-rimchen-mo; trsl. Wayman, 1990, pp. 172-3). Like in the $A k n$, the need for armoured striving is defended by the extraordinary length of the training and extent of suffering the bodhisattva has to undergo in the 
distinction between samnāhavirya and prayogavirya becomes somewhat blurred: ${ }^{431}$

\begin{abstract}
"Bodhisattvas generate vigour in amour and application that is without equal in order to cleanse themselves and others of defilement and in order to attain supreme enlightenment. On account of this vigour they establish all sentient beings in the three types of enlightenment. And because they have attained pristine cognition, they equip the world with vigour forever."
\end{abstract}

In the $B d p$, as in the $S g m$, the focus of armoured vigour lies in cognition and learning. Highly meritorious in its own right, it produces roots of virtue far beyond the merit that is generated through dāna. It promotes birth under auspicious circumstances, pure associations and mental lucidity. ${ }^{432}$

In addition, armoured vigour draws the bodhisattva's attention to the ten obstructive conditions that, in turn, inspires discipline, compassion, mindfulness and joy in solitude. ${ }^{433}$ Appreciation of these factors operates as a catalyst which prompts the bodhisattva to overcome the obstructive conditions in other beings. ${ }^{434}$ For this purpose he pledges to persist in the true teachings at all times and does not fall prey to heterodox thought. ${ }^{435}$ Fear of Dharma misinterpretation is thus a chief concern for the practice of vigour. ${ }^{436}$ Besides vigour in studying the Doctrine, the bodhisattva works for the survival of the Dharma through endless preaching and altruistic

world (Bbh, p. 200.20-26).

431. $M s l$, p. $108.22-25$.

432. $\mathrm{R}$, folio $435.2-4$

The Samädh knows of ten concrete blessings that accrue from the cultivation of vigour. That is, bodhisattvas become generally difficult to satiate, they are received by buddhas and protected by the gods, they do not distort the teachings they have heard but retain the Dharma just as they have learned it, they enter the fold (gotra) of meditation, they experience little illness, attain happiness, possess sufficient food-stuff and do not turn into a lizard (musala) but resemble a lotus (Dutt, ii, 1941-53, pp. 335.14-336.2). For variants in the Tibetan, see: TTP, 31, p. 310.2.7-3.8.

433. $\mathrm{R}$, folio $439.3-6$

These are (1) exposure to the sayings of Māra, (2) physical blindness, (3) physical illness, (4) a distracted mind, (5) hatred and anger, (6) disputes and malice, (7) exposure to Māra and its works, (8) adherence to mistaken doctrine in times of decline of the Dharma, (9) desire for alms-bowls, robes and food among the monks, (10) sensual pleasure ( $R$, folio 436-42).

434. The Tathägatācintyaguhyanirdeśa (cit. in Sikss, p. 274.3-11) proposes ten concrete ways of improving the force of the bodhisattva's vigour. These include (1) renouncing the body and life but not the Dharma, (2) showing reverence to all beings, (3) feeling compassion with weak creatures and not to dislike them, (4) granting food to those who are hungry, (5) granting protection to those who are fearful, (6) dispensing medicine and cure those who are ill, (7) delighting the poor with great riches, (8) repairing shrines dedicated to the Tathägata, (9) adopting pleasant speech when speaking to people and sharing the fate of poverty with those who are poor and (10) carrying the burden of those who are exhausted. Cf. Mppś, ii, p. 943.

435. $\mathrm{R}$, folio $447.1-3$.

436. R, folio 436.2-438.6. 
Vìryapāramitā

efforts.

Thus inspired, he sets out to train in 'vigour accumulating roots of virtue' (kuśaladharmasamgrāhakavirya) $^{437}$ and manifests unfaltering, bold courage (anivartyaparākramavirya). ${ }^{438}$ This type of vigour is essentially bifocal. First, the bodhisattva is not discouraged from the path by the sheer distance of the goal, but devotes all resources to the practices concerned: $:^{439}$

437. The exact scope and nature of the kusaladharmasamgrähakavirya is little explained in Mahāyāna literature. I have found only two treatises that provide some detail on its generation. First, there is the exposition in the Sgm which recognises the contributions of four specific dharma (op. cit., p. 62.1.5-5.3). These are exertion (ärambha), courage (vira), investigation (pativeksana) and good conduct (pratipatti). Each of these dharma is applied to specific sets of practices whose potential they aim to maximise. Exertion is primarily applied towards the cittotpāda, dāna, silla and śraddhā (preparing the entry into the path) while courage focuses on the accumulation of roots of virtue and, in particular, on ksanti (leading to the suklavidarsana stage, the first of seven śrävakabhūmi stages). Investigation is employed to identify those things that bring greatest benefit to sentient beings, to dhyāna and to prajñ $\bar{a}$ (leading to mental purity: cittaprass $r a b d h i$ ). Finally, good conduct means bearing with committed dharma and engaging in skilful means (leading to irreversible pristine cognition: avaivartikajina $\bar{a}$ ). On a personal level, exertion purifies and leads to recollection of the body; courage purifies speech and leads to recollection of feeling; investigation cleanses the mind of impure dharma and leads to recollection of thought; good conduct purifies dharma and leads to their recollection (op. cit., p. 62.2.6-7, 4.7). Exertion cognises suffering, courage abandons the origin, investigation generates the path and good conduct realises cessation (op. cit., p. 62.4.6)

In the $B b h$ (p. 201.6-25), the accumulation of roots of virtue is dependent on diligent application to the six perfections and consists of seven qualities. First, it is not moved by harm which resulted from mistaken considerations, defilements, false teachers and suffering. Second, it is certain because of his paying respect (satktya). Third, it is infinite because it is founded in, and leads to, all areas of knowledge. Fourth, it is furnished with means that are designed to lead to the irreversible path and to penetrate sameness. Fifth, it is perfect vigour because the bodhisattva aspires to obtain things that ought to be obtained. Sixth, it is victorious because it is furnished with lasting application and seventh, it is free from pride because his undertakings in vigour are free from the thought-objects (ärambha). If his practice of vigour includes these seven qualities, the bodhisattva is predicted to accomplish all six perfections rapidly and to obtain enlightenment.

At the highest level, vigour in the accumulation of roots of virtue refers to the bodhisattva's diligence in acquiring the buddha-qualities. This means to accumulate the sum-total of roots of virtue including those that spring from the perfections and bodhipāksika ( $A k n$, op. cit., pp. 47.5.7-48.1.2).

438. $R$, folio $468.1-476.5$

In the $A k n$ (op. cit., p. 46.4.5-5.1) we have a similar subsection, entitled: 'imperishable courage' (aksaya paräkrama). Here, the purpose of courageous vigour is sixfold. It is found in the bodhisattva's effort to see the Tathägata, to hear the Dharma, to ripen sentient beings, to accumulate the roots of virtue and to attain all-knowing. It is called courageous because the bodhisattva enters into the world for the sake of other beings in order to discipline their faculties and to bring about their liberation. Its action is the undertaking to enter in the world intent to benefit other beings, its cause is the bodhisattva's great compassion and its essence is the unfaltering firmness of its commitment to vigour (op. cit., $\mathrm{p}$. 46.5.1).

According to the $B b h$ (p. 203.13-22), there are six factors that contribute specifically to the consolidation of the bodhisattva's unfaltering courage (drdhaparäkrama). These include persistent vigour because it ties to the cycle of existence; reverential vigour because it ties to exertion; naturally caused (nisyanda) vigour because of the power of previous causes; vigour arising from practice (prayoga) because, investigating and contemplating, it is bound to good morals; non-enraged (akopa) vigour because he is not angered by pain or injury; and insatiable (asamtustit) vigour because for him mediocrity is not sufficient. Although not stated, one suspects that these should be understood as both conditions for and the ideal manifestations of unfaltering courage.

439. Siks, p. 275.1-6 (33, p. 61.2.7-3.2). 
"O Sāgaramati, a bodhisattva who has committed himself to vigour must incessantly be of a steady and bold courage. The bodhisattva who is earnestly striving [to buddhahood] must not lay down his burden. O Sāgaramati, for bodhisattvas who exert themselves vigorously the supreme and perfect enlightenment is not difficult to attain. Why? O Sāgaramati, where there is vigour, there is enlightenment. But for those who are indolent, it is far off. There is no generosity, morality, patience, vigour, meditation or wisdom on the part of the indolent. They do not work for the benefit of others."

Second, it aims at universal liberation. For this purpose, the bodhisattva anchors his practice in samsāra, but dedicates his accumulation of roots of virtue to buddhahood. Indeed, according to the $S g m$, it is this 'double-tracked' approach that transforms the bodhisattva's virya into a practice of päramitā status: ${ }^{440}$

"Vigour by means of which [the bodhisattva] does not let go his yearning for all-knowing, by means of which he holds on to the generation of the power of the thought of enlightenment and is bound to samsāra while beginning to accomplish roots of virtue constitutes the perfection of virtue."

Thus, it is primarily the bodhisattva's perfection in vigour that prevents him from untimely entering ïnto nirvāna. ${ }^{441}$

The implementation of vigorous courage manifests mental and non-mental striving. ${ }^{442}$ 440. Siks, p. 187.9-11 (33, p. 51.1-2).

441. Mppś, ii, p. 982; R, folio 468.4-6.

442. The distinction of virya into a mental and non-mental dimension is undoubtedly the oldest and most fundamental classification of vigour. Already proposed in the nikāya, it was adopted in numerous early Mahāyāna sūtras as the basic division of vigour. Good examples of such early adoptions are the $A k n$ and Paña. In the $A k n$, the entire discussion of the viryaparamita is structured according to its mental/non-mental dimension. Non-mental virya is perceived in terms of its various sub-aspects, showing the bodhisattva's eight principal objects on which he focuses his energy. These include armoured striving (samnāhavirya), courageous striving (paräkramavirya), vigour in attaining (samudānavirya), vigour in ripening sentient beings (sattvaparipākavìrya), vigour in accumulating merit (punyasambhäravirya), vigour in accumulating knowledge (jñānasambhäravīrya), vigour in accumulating wisdom (prajñăsambhäravirya) and vigour in attaining buddha-qualities (sarvabuddhadharmasamudānavirya). The $A k n$, holding the mental dimension of virya to be superior distinguishes (like the $B d p$ ) a mentally active part that inspires physical and vocal action and a mentally inactive part that is in tune with the Dharma teachings on the nature of reality $(34, p$. 48.3.5-4.2):

"One who is established in all activity in order to fulfil the imperishability of mental vigour and is separated from all distinguishing marks (sarvanirmittāpagata), that one not only enters 
Although the non-mental plane refers primarily to exertion in body and speech, it is not limited to physical and vocal activity, but includes the commitment to universal liberation. First, it is aimed at the encounter with the Buddha when the bodhisattva receives his final prediction to buddhahood. ${ }^{443}$ Second, emerging as a collateral, the bodhisattva commits himself to the liberation of all sentient beings. ${ }^{444}$ These two prospects impel the bodhisattva to train with utmost vigour, whereby he accumulates incalculable roots of virtue as a matter of course. ${ }^{445}$ The magnitude of this task turns vigour quite naturally into a major practice. It causes the bodhisattva to honour his commitments even after he has attained enlightenment and allows him to venture fearlessly into the more daunting areas of Buddhist cognition. ${ }^{446}$

This confidence is rooted in the bodhisattva's unshakable trust in the path and in his increasingly accurate understanding of reality. On the first, the $B d p$ comments: ${ }^{447}$

"The bodhisattva boldly thinks: ... 'although the defilements of all sentient beings are incalculable and numerous, I shall seek to obtain a matching accumulation of wisdom and pristine cognition by means of this enunciation. I shall work hard and apply myself diligently. With vigour, I shall wholly appease the torment of desire, hatred, delusion of all sentient beings. I shall free them from this poison, suppress it and deliver them. I shall cause them to transcend it and establish them in the path leading to nirvāna." "

This attitude of confidence and courage appertains to the category of physical/verbal vigour, because it belongs to the more active, engaging part of the bodhisattva practice. Progress in the cognitive realm, in contrast, is firmly rooted in mental vigour. Superior to vigour of body

into all activity of distinguishing marks but is also established in activity of pristine cognition and performs every deed with the pristine cognition of all action."

Since, according to the $D b h$ (Daśa-bh, pp. 64.3-4, 64.23-27), separation from distinguishing marks is a chief characteristic of the acaläbhümi, mental vigour comes into operation at the eighth stage and coincides with the beginning of the bodhisattva's effortless activity (see below).

This understanding of the distinctions between the mental and non-mental dimensions of vigour tallies with the position of the Mpps (ii, p. 977). Here, the bodhisattva's physical vigour is summed up in the practice of the six perfections, in giving up all personal belongings and family members and, above all, in his readiness to pursue the training as long as required. Mental vigour, in contrast, is marked by the cultivation of wholesome dharma, by total faith and confidence, by freedom from indolence and, especially, by insatiability for Dharma investigation.

443. $R$, folio 468.2 .

444. R, folio 468.4 .

445. $\mathrm{R}$, folio $469.2,469.5$.

446. $R$, folio 472.6 .

447. $\mathrm{R}$, folio $473.1-6$. 
or speech, it becomes the driving force behind all other types of vigour and is thus crucial to the completion of the viryapāramita ${ }^{448}$ In the $B d p$, mental vigour is distinguished by an active and inactive mode of operation. While the exact relationship between the two is not explained, their contents and areas of application point to their complementarity: 449

\begin{abstract}
"What is vigour of the mind? It is activity and stillness of the mind. What is activity of the mind? It is endeavouring to enlightenment. What is stillness of the mind? It is non-appeasing the thought of enlightenment. What is its activity? It is great compassion towards all beings. What is its stillness? It is acceptance that there is no self." 450
\end{abstract}

Being essential to the fruition of all others practices, the ultimate reward of vigour is, of course, nothing less than perfect enlightenment. ${ }^{451}$ This view is also expressed in the $B d p .{ }^{452}$ More immediate benefits include a set of 'factors of elevation'. These ensure that the bodhisattva prospers (abhyudgacchati) because he pleases the present buddha, adheres to virtuous friends, attains birth under favourable conditions, is accomplished in inexhaustible and virtuous practices and follows the example of bodhisattvas who persist in the vow. ${ }^{453}$

Misinterpretations of vigour differ depending on the status of the practitioner. In the case of the grhapti bodhisattva, they include the abandonment of beings to their fate out of personal gain; to succumb to the pleasures of worldly life in violation of the moral code; to obstruct the Buddha's teachings in others while adhering to them himself; to fraternise with people

448. R, folio 473.7-474.2.

449. $\mathrm{R}$, folio $474.1-3$.

450. For the most comprehensive treatment of mental and physical vigour, I propose to turn once again to the Mpps (ii, pp. 970-72). Beginning with a definition of physical/vocal vigour as mental vigour transformed into corporeal forces or speech, the Mppś proceeds to elucidate the characteristics of mental and non-mental vigour. (1) While physical/vocal vigour manifests itself in action related to the perfection of generosity and morality, mental vigour is operational in conjunction with the $k s \bar{a} n t i$, dhyāna and prajīāpāramitā. (2) It is called bodily vigour when it is applied to external objects, but it is mental when it involves a special effort towards oneself (ädhyätmikaprayoga). (3) Coarse vigour is physical and subtle vigour is mental. All vigour that produces merit is physical while mental vigour generates wisdom. (4) The accumulation of wealth for distribution is physical vigour while selftransformation for the sake of others in order to attain buddhahood is mental vigour. (5) The practice of the six perfections is physical vigour while in possessing the true dharmakaya and producing the six päramitā, the bodhisattva pursues mental vigour. (6) To implement the bodhisattva training without ever.showing concern for life is physical vigour, but never to relax in search of dhyāna and prajinä is mental vigour.

451. Mppś, ii, p. 935, n. 1.

452. $\mathrm{R}$, folio 476.3 .

453. R, folio $476.6-77.2$. 
who despise the Dharma and to reproach people whose care he was entrusted with in an unjust, harsh fashion. ${ }^{454}$ Any of these five mistaken modes of conduct bars the bodhisattva from spiritual advance: ${ }^{455}$

"O Śāiputra, a grhapti bodhisattva who acquires the five [mistaken modes of conduct] fails to please the present buddha. He fails to adhere to virtuous friends. He does not obtain birth under favourable conditions. He truly wastes the roots of virtue that he has accomplished. He does not follow the example set by bodhisattvas, mahāsattvas who adhere to their vow, and thus fails to acquire supreme and perfect enlightenment swiftly."

For the pravrajita bodhisattva the situation is different. Here, misunderstood vigour manifests in moral transgression, abuse of the Doctrine, desire for profit, honour or praise, mistaken views about the self and avarice for the houses of others. ${ }^{456}$ Of these five dharma, however, only avarice is set in direct relation to the practice of vigour, presumably because its consequence (fear of rebirth in hell, blindness and, when reborn as man, of life in the distant border-regions) are particularly daunting. The overriding concern for the rejection of avarice lies therefore in its threat to the bodhisattva's personal advance. ${ }^{457}$ This preoccupation links unfaltering vigour with virya practice concerned with the accumulation of roots of virtue. ${ }^{458}$

The third area in which vigour finds application is the bodhisattva's commitment to bring about universal liberation (sattvārthakriyāvirya). ${ }^{459}$ In the $B d p$ this is expressed through a

454. $\mathrm{R}$, folio $477.3-480.6$.

455. $\mathrm{R}$, folio $480.7-81.2$.

456. R, folio $483.1-3$

Compare these downfalls with the position in the $U g$ (op. cit., p. 273.1.7-2.1) that affirms that a pravrajita bodhisattva is by definition vigorous, since he has renounced the comforts of worldly life.

457. R, folio 513.5-7.

For a concise analysis of the various side qualities of vigour, e.g., zeal, perseverance, energy, vigilance, etc., see: $A$ bhidh-sam (R), pp. 119-20.

458. The Mppś (ii, p. 1020), based on canonical sources, speaks of four qualities that manifest vigour in the pravrajita bodhisattva. These include observance of moral conduct (sillasampatti), control of senses (indriyesu guptadvāratä), moderation in eating (bhojane mäträjñutāa) and application while staying awake (jägaryām anuyoga). Lamotte identified at A II, pp. 39-40 one of their occurrences in the nikāya. See also: S II, p. 219; A I, p. 113.

459. $\mathrm{R}$, folio $514.2-539.1$

According to the $B b h$, vigour in benefiting sentient beings manifests eleven modes of practice (op. cit., p. 201.26-27, but given on pp. 144.24-152.21). First, the bodhisattva renders assistance by assessing the needs of beings and decides what action is most appropriate to fulfil them. Second, he contributes actively to the appeasement of their suffering though practical and conceptual help (pp. 144.26-145.19). Third, he persists in showing gratitude and respect to those sentient beings who have helped him. Fourth, he protects frightened sentient beings from fear, be it the fear of wild beasts, robbers or 
series of jātaka-type stories depicting the edifying effects of Sākyamuni's previous selfless service on the spirituality of innumerable beings. Three elements dominate the narratives. First, we have the recurring use of the physician/patient simile. This is designed to elucidate the bodhisattva's commitment to humankind and to underline his unique influence to their well-being. Second, physically his endeavours are sustained through the practice of vigour that endows him with great resilience. ${ }^{460}$ Third, a key role in the practice of 'vigour in working for the benefit of beings' falls to the dharmakäya. On the one hand, it braces the bodhisattva for the enormous hardship and gives him sufficient stamina to pursue the path without wavering: ${ }^{461}$

"O lord, of what nature is the bodhisattva's dharmakayya? The lord replied: 'O Sāriputra, his dharmakāya is firm, steadfast, unfaltering, compassionate, nonperishing and unborn. He converts [sentient beings] by means of various bodies. Although it is multiplied by the power of converting beings, like a vajra, it does not perish in fire or is hurt through weapons. It is firm and does not waver. $O$ Săriputra, it is in this way that the bodhisattva who is of unfaltering vigour and persists in the dharmakāya pursues effortlessly the perfection of vigour."

On the other hand, the dharmakäya introduces to the dichotomies of worldly convention and establishes the bodhisattva in true reality: $:^{462}$

defamation (pp. 145.20-146.4). Fifth, the bodhisattva relieves the suffering of sentient beings who have experienced calamity of loss of property. Sixth, he shows great vigour in cultivating generosity in accordance with the needs. Seventh, the bodhisattva attracts wealthy beings around him in order to obtain goods and implements with the aim of redistributing them to the needy at a later occasion (pp. 146.13-150.12). Eighth, the bodhisattva complies with the expectations of sentient beings. He lives as one of theirs among them and follows their habitual action. Ninth, the bodhisattva applauds whenever good deeds or qualities come to his attention, whether they be associated to learning, renunciation or wisdom (p. 150.13-19). Tenth, he punishes sentient beings in proportion to the nature of their offence. Eleventh, the bodhisattva resorts to his wonder-working powers in order to frighten sentient beings off immoral action (pp. 150.20-152.17).

460. This point is dramatically exemplified at the example of Säkyamuni's endurance when his body is carved up in order to appease the suffering of beings following the demise of Dipamkara $(R$, folio 519.4-527.1).

461. R, folio 527.1-528.2.

462. $\mathrm{R}$, folio $532.4-7$

In the $S g s$ (pp. 144-45), the entire exposition of the perfection of vigour is dominated by this very theme, showing that the bodhisattva while nominally still functioning within a samsanric frame of reference has indeed passed well beyond its concerns, fetters and physical limitations. In the $S g s$, the reason behind this elevated state of existence is the bodhisattva's entry into the süramgamasamädhi that takes place on the tenth stage (op. cit., pp. 131-2, $\S 21$ ). We might infer from this information that the attainments cited in the $B d p$ under the heading of mental vigour culminating in the acquisition of the dharmakäya belong likewise to a later, if not the latest, phase of the bodhisattva career. 
"O Sāriputra, again, a bodhisattva who is endowed with the dharmakāya-although freed from time, origination and destruction-teaches in terms of origination and destruction in order to ripen sentient beings. Although subject to death, he knows that all dharma are non-dying and that the accumulation of karmic formations is non-existent. Although born, he knows that all dharma are unchanging and undying. Although becoming, he knows that all dharma are unborn. One who relies on the Doctrine and its body, on nourishment and power in order to ripen sentient beings pursues the perfection of vigour with unfaltering spirit by means of the spontaneously arisen, previous resolution."

While it is possible to distinguish these two roles of the dharmakāya as conceptually separate aspects, in practice no such distinction can be upheld. For, in essence, they epitomise of course nothing but the interplay between the cognitive faculties and practical means that, if well-balanced and truly interactive, become the only means of achieving any of the perfections. 


\section{The Perfection of Meditation}

The perfection of meditation (dhyänapäramitā), examined in chapter ten, represents the penultimate pāramita in the training-scheme of the $B d p .^{463}$ In type and conceptual emphasis, the exposition shows all hallmarks of what - for want of better terminology - has been termed as a Mahāyāna approach to dhyāna. ${ }^{464}$ That is to say, the thrust of the discussion does not revolve around the psychological processes at work during meditative experience, but investigates the ways in which meditation contributes to the implementation of the bodhisattva vow. As a result, dhyāna is described not so much for the technical detail of the mental processes at the heart of meditation as for its impact on the spiritual advance of the practitioner himself and, more importantly, on that of his fellow beings. For the $B d p$, meditation is not solely an instrument of thought purification, but constitutes above all a means of moral edification.

In the $B d p$ the true scope of meditation therefore extends well beyond the psychological experience. It is at once contemplation and gnosis; it becomes the foundation to a broad range of cognition, culminating in supreme enlightenment; it frees the bodhisattva from doubt and lends itself to refined speech; it disentangles him from mistaken views and generates the conditions for acts in miracles. Dhyana assumes therefore a unique position amongst the päramitā and retains great importance until the very last phases of his career.

Ordered to retrace the bodhisattva's progress through meditation and the benefits thereof, these practices come as a series of individual building blocks. Altogether, we can distinguish ten, perhaps eleven, such units. Following the order of their occurrence in the text, these include (1) a passage on the traditional four $\operatorname{dhy} \bar{a} n a^{465}$, (2) the abhijñ $\bar{a}^{466}$, (3) the distinction

463. Chapter ten of the Bodhisattvapitaka has already been object of an academic investigation. It is the topic of a PhD-dissertation, written by Dr. K.P. Pedersen at Columbia University, New York, 1976. Since Dr. Pedersen utilised only Chinese translations of the $B d p$ which--judging by her English translation-do not always agree with the Tibetan versions, her discussion was of limited help to my examination. Furthermore, her analysis of the contents contains some rather significant methodological shortcomings, particularly with regard to the choice of material she consulted and the depth to which she carried out her analysis. Notwithstanding its weakness, her contribution has its distinct merits, not least because it allowed me to draw comparisons between the Chinese and Tibetan versions. As a study of the dhyānapäramitā, however, it should be treated with caution because Dr. Pedersen has failed to bring out many of the important features that mark its treatment in the $B d p$. Not wishing to diminish her labour, I shall draw attention to these shortcomings only when my findings appear irreconcilable with her analysis.

464. Pedersen, 1976, p. 79.

465. $\mathrm{R}$, folio $550.2-51.3$.

466. $\mathrm{R}$, folio 551.7-72.4. 
between abhijña and $j \tilde{n} \bar{a} n a^{467}$, (4) the realisation of dharma-sameness (dharmasamatā) brought about by $j \tilde{n} \bar{a} n a^{468},(5)$ the interplay between prajīa and upāya $a^{469},(6)$ the role of the abhij $\tilde{n} \bar{a}$ in the training ${ }^{470}$, (7) the nature of non-regressing abhijñā (acutyābhijñ̄a $)^{471}$, (8) the nonapprehension of dharma $a^{472}$, (9) the marks and nature of the bodhisattvadhyāna ${ }^{473}$ and (10) an enumeration of fifteen foremost (pūrvamgama) contemplations of the dhyānapāramita ${ }^{474}$, including a list of one hundred and one samādhi. ${ }^{475}$ Setting out with the assumption that these blocks were not positioned in an arbitrary fashion but represent individual thoughts that form a scheme of conceptual coherence, it is clearly essential to identify the rationale behind their concatenation.

The least problem in this regard is posed by the first two sections. Section one, dealing with the four dhyāna in what is the traditional way of exposition, is easily discernable as the basis to the whole discussion. ${ }^{476}$ Briefly citing the respective mental attainments that mark progress along the four dhyäna, its function is to sketch the psychological states that equip the bodhisattva with the refined awareness of worldly existence and prepare the more elevated phases of cognition. This role is amply documented in Mahāyāna literature and therefore needs not be discussed here. ${ }^{477}$ It occurs invariably at the beginning of discussions on dhyäna and - epitomising a practice adopted from early Buddhism-generally receives little attention. Typically, it does not extend beyond an enumeration (and brief characterisation) of the major

467. R, folio $572.4-73.7$.

468. $R$, folio $574.2-75.7$.

469. R, folio $576.1-78.3$.

470. $R$, folio $578.4-80.2$.

471. R, folio $580.2-81.1$.

472. R, folio $581.2-84.4$.

473. R, folio $584.5-86.2$.

474. $\mathrm{R}$, folio $586.3-87.1$.

475. In her study of this chapter, Pedersen identified eight more units bringing the total number to eighteen. Apart from a number of obvious, but not very ground-breaking distinctions (between the individual $a b h i j \bar{n} \bar{a}$, for instance), these do not help in understanding the structure of the chapter and so have been omitted here.

476. Descriptions detailing the psychological processes and attainment experienced by practitioners during meditation are very stereotyped and occur in virtually all strands of Buddhist literature. For references in the nikāya, see: $M p p s$ s, ii, pp. 1023-4.

In Sanskrit literature, they are extant in the Lal (p. 129), Pañca (p. 167), Daśasāhasrikā (pp. 98-99), Dbh (Daśa-bh, pp. 33.28-34.17), Kośa (ii, p. 199; iii, pp. 2, 22-3, 167; vi, pp. 177, 198, 221-3) and are even included in the $M v y(1478-81,1492-5)$. A particularly lucid, if exhaustive treatment of the various experiences pertaining to Buddhist meditation is found in the Vism (pp. 84-90 up to p. 373) and, above all, in the Kośa (viii, pp. 127-224).

In view of its rich documentation, I shall not reiterate the states that accompany the practitioner's progress through the various dhyäna and samäpatti but point to a highly recommendable summary of these experiences in Lamotte's introduction to the $\$ g s$ (pp. 16-26).

477. $A k n$, p. 49.1.2-2.3; Bbh, p. 207.2-7; Ug, p. 271.1.5-8; Daśa-bh, pp. 33.28-34.17. 
categories of meditation levels. ${ }^{478}$ The reason for their apparent neglect in Mahāyāna sūtras is probably twofold. First, all of these are also attainable by śāvaka and pratyekabuddhas and so are not particular to Mahāyāna thinking. Second, their impact on the bodhisattva's vow is relatively small, since they primarily occasion personal advance that has no direct effect on the well-being of sentient beings. ${ }^{479}$

In exegetical writings on the pāramitā, this class of meditation bears an independent status and is called 'meditation leading to a blissful abode in this life' (drștidharmasukhavihārāya dhyāna) ${ }^{480}$ Its chief task consists in suppressing vain imagination (vikalpa), pride (manyanā), attachment (trṣna $)$ and marks (nimitta) and in promoting mental and physical tranquillity, repose and a blissful life in this world. ${ }^{481}$ Invariably listed as the first type of meditation, drștidharmasukhavihārāyadhyāna is unmistakably regarded as the lowest type of meditation and has little more than a preparatory function to dhyāna practice proper.

Dhyāna practice proper is epitomised by the second phase of meditative training that, in later literature, came to bear the title 'meditation of production' (abhinirhāradhyāna). ${ }^{482}$ Building on the contemplations of the first phase, it is characterised by the abhijña and their preparatory concentrations. ${ }^{483}$ As most of the preliminary absorptions are shared with the srāvaka and pratyekabuddhas, it is abhijña and pristine cognition (jĩāna) that figure prominently

478. For a analysis of these classes of meditation, see: $M p p s$, iii, pp. 1209-1309. According to the $B b h$, however, the bodhisattva attains the vimoksa, abhibhvāyatana and krtsnayyatana not before the second stage in the dhyanna-practice (p. 207.19-23).

479. In the $A k n$ (pp. 48.4.5-49.1.2) the traditional list of meditations is replaced by an enumeration of sixteen types of dhyana that are specific to the bodhisattva. While these are presented as independent forms of meditation, their nature makes it clear that they sum up the various aspects of the bodhisattvadhyana. These are (1) meditation that is not attached to anything as it is aimed at the tathägatadhyāna (not included in dhyāna list of Pañca, pp. 198-203), (2) meditation that is not to be tasted (Bbh, p. 208.13-16), (3) meditation that has as object compassion since it is aimed at the purification of defilement, (4) meditation that allows for return to the kämadhätu, (5) meditation completing preparation for the abhijña, (6) meditation leading to fitness of thought since it represents knowledge of the power of thought, (7) meditation of knowledge of all forms of dhyāna and the ways of departing, (8) totally peaceful meditation that surpasses the samädhi of all vehicles, (9) meditation wholly undisturbed due to its infinite certitude (Msl, xix.38, p. 166. 25), (10) meditation that serves as antidote to mistaken practice since it subdues all vice, (11) meditation that amounts to penetration into wisdom since it operates beyond all worlds, (12) meditation that is preceded by the intention to liberate all beings, (13) meditation that prevents the interruption of the triratna since it fulfils the tathägatadhyäna, (14) meditation that is not slackening since it is always concentrated, (15) meditation that leads to control over all dharma since it fulfils the buddha-qualities and (16) meditation that pervades space on account of its vast knowledge.

480. Bbh, p. 207.10-11; Siddhi, p. 622; Msg, p. 192.

481. $B b h$, p. 207.9-10; Msg, commentary, p. 192.

482. According to the Siddhi (p. 622), its full title is bodhisattvasamādhigunanirhāryäya dhyāna.

483. These include, besides unspecified meditations particular to the tathagatagotra, eight vimoksa, ten $k r t s n a \bar{y} y a t a n a$, four abhibhvāyatana, pranidhijinäna, aranäjñāna and, according to the $B b h$, also the four pratisamvidjñāna (p. 207.21-23). 
in Mahāyāna texts. ${ }^{484}$ In the $A k n$, the different roles of the two are neatly summed up: ${ }^{485}$

"For what serves meditation as preparation? Fulfilment of the abhijña and pristine cognition. What is abhijña and what is pristine cognition? Vision of the appearance of all forms is abhijñ $\bar{a}$. Knowledge that the dharma of all forms are imperishable without realising the imperishable Dharma is pristine cognition. Hearing of all words is abhijña $\bar{a}$. Knowledge that all sounds are ineffable and timeless is pristine cognition. Knowledge of the thoughts of all sentient beings is abhijñā. Refraining from realising the cessation of thought when perceiving the cessation of thought is pristine cognition."

Broadly speaking, this characterisation holds also true for the $B d p$. As indicated in the list of topics, the theme that follows immediately on the drstidharmasukhavihärāyadhyāna phase is abhijñ $\bar{a}$ with the discussion of pristine cognition being third. ${ }^{486}$ The vast majority of Buddhist sources, both Pāli and Sanskrit, expound the abhijñā in the following sequence: (1) rddhividhijñāna, (2) divyaśrotrajñāna, (3) paracittajñāna (also called cetahparyāyajñāna), (4) pūrvanivāsānusmritijñāna, (5) divyacakșujñāna (also called cyutyupapādajñāna) and (6) ăsravaksayajñanna. ${ }^{487}$ As the last item, knowledge of the destruction of the äsrava, is a characteristic of arhantship and occurs only in the life that ends in entry into nirvāna, it is not applicable to the long-term training of the bodhisattva and Mahāyāna sūtras tend to exclude

484. For examples among the sūtras, see: $A k n$, p. 49.1.2-2.2; Pañca, p. 514; Daśa-bh, pp. 34.19-24; For the śästras, see, for instance: Bbh, p. 207.17-25; Msg, p. 192; Siddhi, p. 622.

The one exception is the $U g$ (p. 271.1.6-7) that indicates that the bodhisattva engages already during phase two in a teaching and conversion activity.

According to the $M s g$ (pp. 221-224), this phase includes besides the practice of the mahärddhi and duskaracarya $\bar{a}$, the cultivation of the six pāramita, the deliberate generation of ten kinds of roots of virtue, the attainment of ten buddha-qualities, the ripening of sentient beings, the purification of the buddha-field and the production of buddha-attributes.

Attainment of the five/six abhijina manifestations is dependent on the successful practice of meditative absorption. Passages attesting this dependency are already found in the earliest strands of Buddhist literature. Thus, we read in the Samaññaphalasutta (M I, p. 77) that their presence arises only in "a concentrated mind that is pure and composed, free from fault, unstained, supple, alert, stable and wholly unperturbed". This association between meditation practice and the cultivation of the abhijña has ever since formed the backbone to the Buddhist understanding of the abhijña .

485. $A k n$, p. 49.1.2-7.

486. References to the six abhijina are plentiful and spread throughout the Buddhist canon. For a selection of occurences, see: Mppś, iv, pp. 1809. For references to the abhijña in Sanskrit literature, see: Kośa (vii, pp. 97-126), Catusparișasütra (Waldschmidt, 1957, pp. 432-34), Daśa-bh (pp. 34-36), Pañca (pp. 83-87), Bbh (p. 58.13-18), Siks (p. 243), $M s l$ (p. 25.2-10, p. 185.11-17) and Dhsgr (\$ 20).

487. Of these pürvanivāsānusmrtijñāna, cyutyupapādajñāna and äsravaksayajñāna correspond to the three sciences (vidy $\vec{a}$ ) of the same name that the Buddha attained during the three watches in the night preceding enlightenment (D III, pp. 220, 275; A V, p. 221; Kośa, vii, p. 107). 
it from their discussions of $a b h i j \tilde{n} \bar{a}^{488}$ The $B d p$ is no exception.

Where it does differ from most texts, however, is the order of presentation, discussing first

divyacakșus, second divyaśrotra, third paracittajñāna, fourth pūrvanivāsānusmrtijñāna and fifth $r d d h i v i d h i j \tilde{n} a \bar{n} a{ }^{489}$ No reason for this change of sequence is given in the $B d p$ itself.

The Dhyānasütra (cited in the Mppś) provides the following explanation. ${ }^{490}$ At first, the

bodhisattva obtains divine sight. Having seen all beings, but being unable to hear their

sounds, he then seeks the abhijĩ $\bar{a}$ of divine hearing. Furnished with divine sight and hearing,

488. Representing this view, the $V k n$ explicitly excludes the sixth super-knowledge from the abhijina practice of the bodhisattva (p. 130; trsl. Lamotte):

"A domain where the six super-knowledge are explored, but without arriving at the knowledge of the destruction of the impurities (assravaksayajinanna), such is the domain of the bodhisattva." This position is slightly qualified in the Mpps (iv, pp. 1817-18) arguing that a bodhisattva who has destroyed his impurity (kșināsrava) may elude nirväna provided that the traces (väsanāa) of his impurity still prevail. Traditionally, destruction of impurity motivated by the yearning for personal liberation meant arhantship and subsequent nirvāna. In the Mahāyāna, this proposition was modified to make room for the ideal of the bodhisattva. Accordingly, for a bodhisattva who utterly destroyed his klesa and the flow of $v \bar{a} s a n \bar{a}$, the attainment of àsravaksaya occurs only at the tenth stage, shortly before he achieves buddhahood. However, incomplete exhaustion of impurity, viz., with the vāsanā still intact, means that a bodhisattva-determined to utilise the remaining klesavāsanä to prolong his liberating activity - sheds all constraints while traversing samsära. Held to take place on the eighth stage (Mppśs, ii, p. 1801), it enables him to assume the manifestations of the dharmadhätujakaya in this quest for universal liberation and to return to samsära without fear of contamination.

The $R g v$ (pp. 245-6), citing the Sgm, distinguishes eight factors that prevent the bodhisattva from actually realising the destruction of the äsrava. These are (1) non-satiety in seeking merit, (2) intentional acceptance of existence through origination, (3) earnest desire to meet with the buddha, (4) indefatigability in ripening sentient beings, (5) strenuous effort to acquire the Dharma, (6) diligent application to benefiting sentient beings, (7) non-abandoning of the propensity of desire for dharma and (8) nonreluctance from fetters of the highest virtue. Referred to as 'defilements endowed with virtuous roots' (kuśalamülasamprayuktā kleśäh), they fasten the bodhisattva by means of compassion to this world but protect him by means of cognition from personal exposure to worldly defilements. Springing from the cultivation of the five $a b h i j \tilde{n} \bar{a}$ fostered through meditation, all eight become collectively operational on the sixth stage (abhimukhibhīmi) - the moment when the bodhisattva comes for the first time 'face to face' with reality -and prompt him to abide in meditation in order acquire the bodhyanga (op. cit., pp. 250-2).

Also in the Rgv (op. cit., pp. 227-28) we find an interesting passage elucidating the relationship between ăsravaksaya, äsravaksayajñāna and the five mundane abhijñă. Likening their contributions to the manifestations of a lantern, the text suggests that the worldly abhijña have a "characteristic of engaging in (pratyupasthanna) the extinction of darkness that is opposite to knowledge which perceives an object (arthannubhava)"; that knowledge of the destruction of the äsrava resembles 'heat' because of its characteristic of engaging in consuming the fuel of the active force and defilements, leaving no residue; and that the actual destruction of the assrava resemblance colour because of its perfect purity resulting from moral and cognitive attainments. When becoming simultaneously manifest at the 'immaculate sphere', they are inseparable from each other, identical and in union with the absolute. In spite of the tendency to discuss all six abhijña a en bloc, there are a few texts in which äsravaksayajñanna is excluded. Apart from a few instances in the nikāya (e.g., S II, pp. 121-22) this applies particularly to works belonging to the Sanskrit tradition, viz., $M v u$ (i, p. 284..3; ii, pp. 33.11, 96.1), Divya, p. 321.3; Saddhp (pp. 134.11, 141.9, 254.14) and Siks (p. 243.13).

489. I have found just three texts in which the abhijiñ are discussed in the same sequence, that is, the Dhsgr (§ 20). Pāramitäsamäsa (Meadows, p. 228-232. vss. 40-66) and $A k n$ (pp. 58.5.6-61.5.3). Apart from these, only the $M v y$ (202-208) appears to list the abhijina in this order. Most other texts place the faculty of $r d d h i$ at the beginning of the list and the divyacaksus at the end (e.g., Pañca, pp. 460-61, Daśa-bh, pp. 35-6, M)

490. Mppś, iv, p. 1823. 
but still ignorant of their languages, sorrow and joys, he seeks the unique knowledge of language (niruktipratisamvid). ${ }^{491}$ Knowledgeable in other people's languages, but ignorant of the their thought, the practitioner seeks knowledge of the thoughts of others. Still not knowing their place of origin, he sets out to acquire the abhijñ $\bar{a}$ of their previous existence and to heal their mental ailments (cittavyädhi). For this purpose he seeks the abhijña of the destruction of the impurities. However, even though he has mastered five abhijñ $\bar{a}$, the bodhisattva is not able to carry out transformations (nirmāna) and is therefore still unable to liberate beings in great numbers, so he resolves to pursue the abhijñā of magical powers. ${ }^{492}$ The reason why the rddhividhya is generally cited at the beginning is not because it is attained before the other abhijña $\bar{a}$, but because of its great impact on the liberation of beings. ${ }^{493}$ In this sense, for the bodhisattva, it is the most important of all six. Divyacakșus, on the other hand, is cited first because, being the easiest to acquire, it is the natural starting point for the pursuit of the

491. Clearly, this reference to the niruktipratisamvid comes as a surprise and raises some questions about the scope of the divyaśrotrajnanna. Does the text indicate that the attainment of the niruktipratisamvid precedes the acquisition of the abhijiñ $\bar{a}$ ? What is the relationship between the divyaśrotrajñana and niruktipratisamivid? The idea in the Dhyānasütra is that the divyaśrotrajñāna enables the bodhisattva merely to hear the sounds of all beings-not to understand their meaning. This interpretation is borne out in several other passages where the cognitive factors are suspiciously omitted (e.g., $M p p s$, iv, p. 1822). Conceptually, however, both types of knowledge operate on the same level as the divyaśrotrajñanna and niruktipratisamvid, operating in the kämadhätu and the first dhyāna, fall into the category of samvvrtijñāna (Mppś, ii, p. 1042, iii, p. 1619). Thus, while it may carry personal benefit, for a compassionate practitioner to win maximum benefit from the divyaśrotrajinanna-for both himself and others-the text advises him to complement it with knowledge of vocal expressions (nirukti).

The key to a correct understanding of the appearance of the concept of niruktipratisamvid is found when recalling that in the Dhyanasütra we have a text belonging to early Buddhism. Its interpretation of the niruktipratisamvid has therefore to be seen in a Śrāvakayāna frame of reference. The view that divyaśrotrajñāna does not lend itself to understanding languages and sounds is not found in Mahāyāna works (Mppś, i, pp. 330-31, 1822; $B b h$, pp. 67.25-69.10). On the contrary, it is highly valued and figures among the chief benefits that accrue to the bodhisattva from meditative practice (Msg, p. 224, § 8.8-9).

492. According to the Mpps (ii, p. 1043) the bodhisattva's power of transformation increases with his advance through the four dhyāna stages. It springs from the thought of creation (nirmānacitta) and, during the first dhyāna, is operational on the kämadhātu. During the successive stages it functions also in the rüpadhătu (cf. Kośa, vii, p. 114). As all types of rddhi have matter as object (rüpälambana), arising successively, the bodhisattva is compelled - should he wish to see, hear or touch any object- to call again on the cognition of the Brahmaloka experienced during the first dhyāna (Mppś, i, p. 330). Altogether, one distinguishes fourteen different types of nirmānacitta, accomplishing eight kinds of creation. These include decrease, increase, taking away weight, exercising power (vaśitvakarana) over physical shapes, possessing the superhuman power of Indra, drawing apart and together, causing earthquakes and personal transformation. Finally, there are four additional types of creation that address transformation of substances. These spring either from learning in magic, the abhijiñ forces of retribution and meditation-all dealing invariably with matter-and are bound to the kämadhătu (Mppś, i, pp. 381-3).

493. In fact, the Mpps (iv, p. 1820) states quite emphatically that the advanced nature of the cognitive requirements for the attainment of the rddhi are such that, being linked with space and observing the mark of emptiness, it cannot but stand at the end of a long process of schooling. A similar view is also held by the Kosa (vii, p. 104), adding that this preparation (prayoga) leads in each and every case to mastery (vasitia ) in rddhi, that is the eighth of the ten vasita that manifest on the acaläbhümi (Daśa-bh, p. 71.15-16). 
abhijūa $\bar{a} .^{494}$

In the $B d p$, the rationale behind the cultivation of abhijñ $\bar{a}$ is twofold. By means of those abhijña that involve cognition, the bodhisattva gains a complete picture of samsāric existence and penetrates the processes that sustain and perpetuate its continuum ad infinitum. ${ }^{495}$ Exposing him to the vastness of sorrow that particularly prevails in the evil destinies, they strengthen his resolve to dedicate all resources to its complete eradication. ${ }^{496}$ This cognitive aspect of the first four abhijña is complemented by a second, active element that shows the ways in which their cosmic knowledge has an immediate, practical effect on the training proper. The most effective of these means is provided by rddhividhyabhijñā itself. ${ }^{497}$ As it depends for profitable implementation on knowledge acquired through the four preceding abhijñ $\bar{a}$, it is cited in the $B d p$ in last position.

The actual division into cognitive and practical elements is somewhat blurred in the $B d p$, since its functional demarcation is not always implemented. This is particularly true of the divyacakșus that is credited with immediate and de facto influence on the conduct of beings. ${ }^{498}$ For example, it said to grant the bodhisattva power over the moral conduct of beings ${ }^{499}$ and to introduce beings to the practice of the pāramitä: ${ }^{500}$

494. The distinction between 'easy' and 'difficult' abhijñā applies to all beings except the most advanced bodhisattva. This, at least, is the reason that is given by the Mpps in reply to the question why the bodhisattva Sākyamuni, during the night preceding his enlightenment, began his abhijñā practice with the rddhi and not the divyacaksus (Mppś, iv, p. 1825).

495. R, folio 553.3-5.

496. $\mathrm{R}$, folio 555.5 .

497. A survey of the types of iddhi/rddhi that arhants and bodhisattvas attain in the course of their career is given below, note 516 .

498. According to the Mppś (i, pp. 330-31), divine sight falls into two major categories, depending on the causes that lead to its unfolding. First, there is the kind that arises from exercise (bhavvan $\bar{a})$. This form of divine sight is wholly based on the practice of the abhijñ $\bar{a}$ and is undoubtedly the kind exhibited in the Bdp. The second kind of divyacaksus arises on the basis of retribution (vipäka). Strictly speaking, its presence is independent of training in the abhijiñ as it arises on the basis of insight. To be precise, it is only attained by bodhisattvas who, having reached the 'conviction of the non-arising of dharma', are not found in the six destinies but appear by virtue of their dharmakaya in the world in order to convert beings. This form of divyacaksus is not found among worldly, newly-set-out bodhisattvas who have not attained the dharmakāya.

499. $\mathrm{R}$, folio 554.2 .

500. R, folio 555.3-556.1

In the Ratnolkadhärani (Siks, p. 328.1-9; trsl. Bendall) we read in connection with the effects of miraculous feats:

"Some instruct all creatures in a thousand expedient by means of the Tathăgata's worship, by means of infinite gifts and generosity, by means of the practice of all [types of] asceticism, some by means of indestructible and imperturbable patience, by means of the heroism of austerity and vows, by means of meditation and calm in the hermitage, by means of the knowledge discriminating what is good, by means of thousands of expedients ... by means of the miracles of the conduct of the great vehicle" (cf. Mppś, pp. 1049, 1111; Siks, pp. 334-7).

The $B b h$ (p. 210.3-17) adds that the bodhisattva who is established in the dhyānaparamita disciplines sentient beings by the three types of miraculous display (rddhiprätihärya), that he grants elocution to the ill-spoken and bestows memory to the forgetful. 
"His divine sight means that he does not show hostility towards those who seek [instruction]; that he is not angered by those who transgress the moral precepts, but that he watches over their harmful thoughts. It means that he encourages the indolent and instructs the agitated in the branches of meditation. It gives true sight of wisdom to those who are of aberrant wisdom."

Spanning much of samsāra ${ }^{501}$, the divyacakșus is particularly important since it endorses the bodhisattva's vision of suffering and liberation. On the one hand, it generates awareness of and compassion towards the afflicted sentient beings-the raison d'être of the vow itself. ${ }^{502}$ On the other hand, allowing for glimpses at the state of buddhahood, it kindles a personal ambition and encourages in times of weariness. ${ }^{503}$ Both points are clearly expressed in the $B d p$ and, although conceptually not correlated, unmistakably form the backbone to its treatment of the divyacakșus. ${ }^{504}$

The twofold approach, distinguishing cognitive and practical elements, is also adopted in the discussion of divine hearing (divyaśrotra). Here, the point is made that the bodhisattva's

501. Strictly speaking, the divyacaksus operates-like the rddhi and divyaśrotra and, according to some, also the paracittajñäna and cyutyupapādajñana-only in the kämadhătu and rüpadhātu as it depends for its objects on matter. Hence it arises only from the four dhyāna and not from the formless samäpatti (Kośa, vii, p. 102). In the Kosiabhāsya (pp. 429.17-430.3) we are told that the scope of the divyacaksus varies according to the persons who generate it. If they do not make any specific effort, śrävaka are able of survey one Sähasta universe, pratyekabuddhas one Dvisāhasra universe and buddhas one Trisāhasra universe. However, should they apply themselves to the divyacakșus vision, śrāvaka can extend their sight to one Dvisāhasra universe, pratyekabuddhas to one Trisāhasra universe and buddhas to infinite universes. Like the divyaśrotra, the divyacaksus is only attainable by persons who have eliminated all desire. This state is achieved when the practitioners is freed from all passions pertaining to the kämadhatu when he embarks on the dhyãna of the rüpadhätu (Mppś, v, p. 2273).

The $M s l$ (p. 143.8-10) distinguishes five kinds of sight springing from the cultivation of rddhipäda. These are the (1) eye of flesh (mänsacaksus), (2) divine sight (divyacaksus), (3) noble vision of wisdom (äryaprajñācakșus), (4) Dharma-vision (dharmacaksus) and (5) the buddha-vision (buddhacakșus).

502. This thought is of course not exclusive to the $B d p$, but occurs in most Mahāyāna sütras where the abhijña are discussed (cf. Mpps', ii, pp. 1055-6). That it found its place with this role into the scheme of the path at a very early stage is attested by a passage in the Asta (p. 403; trsl. Conze) where we read that:

"[The bodhisattva] surveys countless beings with his heavenly eye, and what he sees fills him with great agitation: so many carry the burden of a karma which leads to immediate retribution in the hell, other have acquired unfortunate rebirth, other are doomed to be killed, or they are enveloped in the net of false views, or fail to find the path, while other who have gained a fortunate rebirth have lost it again. And he attends to them with the thought that: 'I shall become a saviour to all those beings, I shall release them from all their suffering.' "

503. R, folio 554.3-5:

"Having seen [the congregation of buddhas and bodhisattvas], the divine sight prompts the bodhisattva to accomplish the armour of the holy person, [to acquire] correct conduct and practice, recollection (smrti), mindfulness (samprajäna), steadfastness in the path and in pristine cognition [showing that] all dharma are liberated, skill in pristine cognition in the attainment of dhârañ including skill in wisdom, knowledge and means."

504. Both points are, for instance, raised next to each other in R, folio 553.2-554.3. 
capability to understand the whole range of sound-human and non-human-has important implications not only because it allows him to grasp the teaching in their true compassioninducing spirit and retain them in their entirety ${ }^{505}$, but moreover, to transmit these faithfully to his audience. ${ }^{506}$ In particular, it enables the bodhisattva to attune his discourses to the need and receptivity of his listeners. ${ }^{507}$ For the $B d p$ the ground that is covered by the divyaśrotra is therefore in many ways comparable to that of the Mahāyāna conception of niruktipratisamvid, a point which as was already made in connection with a reference in the Dhyānasūtra.

The third abhijñ $\bar{a}$, knowledge of the thought of others (paracittajñāna), grants insight into the mental disposition of all beings, irrespective of spatial or temporal constraints. In particular it allows the bodhisattva to assess the degree that their faculties have been exposed to, or moulded by, the bodhisattva practices ${ }^{508}$ and so permits him to ease beings into the appropriate vehicle. $^{509}$ The main purpose of learning other people's thought is therefore to dispense instruction in the most suitable way. ${ }^{510}$

"Even though [the bodhisattva] goes among his listeners, he discerns all of them immediately; and having discerned [their aptitude], he teaches the Dharma to sentient beings in exact accordance with their disposition."

Since it influences the speed and success rate of the bodhisattva's conversion activity-the only gauge against which his progress is ultimately measured-knowledge of the thought of others clearly plays an important role.

The fourth abhijñ̄a, knowledge of the recollection of previous births (pūrvanivāsānusmrtijñāna) is aimed chiefly at the bodhisattva's personal advance. ${ }^{511}$ According to the $B d p$, the main benefit of this type of knowledge is not so much the recollection of the previous existences per se, but penetration into the circumstances that brought them about in the first place. ${ }^{512}$ The rationale behind this emphasis is the need for awareness of the mechanisms

505. $\mathrm{R}$, folio 558.2 .

506. $\mathrm{R}$, folio 558.6 .

507. $\mathrm{R}$, folio $558.7-559.2$.

508. $\mathrm{R}$, folio $560.6-61.3$.

509. $\mathrm{R}$, folio $562.3-563.2$.

510. $\mathrm{R}$, folio $564.4-5$.

511. For discussion of the psychological processes that underlie the pürvanivāsānusmrtijināna and their parallels in Indian systems contemporary to the Buddha, see Eliade: Yoga: Immortality and Freedom, 1969, pp. 180-85, 186-199. Consult also Demiéville, P.: "La mémoire des existences antérieures" (BEFEO, 1927, pp. 283-98) from which much of Eliade's detail is drawn.

512. R, folio $566.6-67.2$. 
that determine becoming and the assumption of a suitable attitude towards existence. In particular, it has the benefit of preventing conceit to arise: ${ }^{513}$

"O Sāriputra, taking into account [the marks of] suffering, transience, non-self and emptiness, the bodhisattva is not infatuated with beauty, wealth, servants, sovereignty or with a yearning to become a cakravartin, Indra, Brahmā and worldguardian ... assuming these existences intentionally (samcintya) only in order to ripen all sentient beings."

He acknowledges, disapproves and repents his previous impure action and undertakes to dedicate his roots of virtue to the cause of enlightenment. ${ }^{514}$ Pledging to continue the lineages of the three jewels, the bodhisattva sustains his recollection through the supporting power of the dharmadhātu that leads to equipment in punya, jūāna and pāramitā, since: $:^{515}$

"It is in this way that all the dharma of the past, present and future are kept in memory by the power that generated this recollection."

That such an accumulation of qualities is foremost a personal achievement is amply documented in Buddhist literature. Also in the Bdp training in the recollection of previous births is primarily of personal benefit and has little immediate impact on others.

In contrast the abhijñ $\bar{a}$ of magical power $(r d d h i)$ is entirely oriented towards the spiritual advance of sentient beings. While many texts diverge on the scope and kinds of magical power that are included in $r d d h i^{516}$, virtually all agree that its prime objective is the conversion 513. R, folio $567.2-5$.

514. $\mathrm{R}$, folio $567.6-7$.

515. $R$, folio $568.1-5$, folio $568.5-7$.

516. Compare, for instance, the types of $i d d h i$ in the S V, p. 264 with those cited in the Dasa-bh (pp. 34-36). Later Mahāyana scholars produced further subdivisions that allocate the rddhi elements to thematic groups. A good example of such academic digression is found in the Mpps (ii, pp. 329-30). Here, distinguished by their character as either displacement (gamana), creation (nirmäna) or noble magic power (äryarddhi), the rddhipäda fall into three major categories. The gamana-ciass consists of four rddhi types, that is (1) unobstructed movement by flying like a bird, (2) instantaneous change of location, (3) plunging and emerging and (4) instantaneous disappearance. The rddhi of the nirmanna-class consist in the change of the (1) size, (2) power of multiplication and (3) the possibility to create at will whatever is desired. Finally, the rddhi of the aryarddhi-class concern the conversion of impure substances into pure ones. This last type of $r d d h i$ is held to be available only to a Buddha (cf. D III, p. 112; Kośa, vii, p. 111, viii, p. 210). According to the Kośa (vii, p. 113), the gamana-class of rddhi comprises only three $r d d h i$, that is transportation, miracles (adhimoksa) and rapid displacement with the speed of thought.

Adopting a slightly different classification, the Kośa distinguishes $r d d h i$ by the method of production (vii, pp. 122-3). Accordingly, on one level, it differentiates between $r d d h i$ stemming from cultivation (bhävanā) 
of beings. ${ }^{517}$ With this function, $r d d h i$ assumed great importance in the Mahāyāna where their application is strongly encouraged and praised as a factor of immense potency. This thoroughly positive attitude constituted a departure from the dogmatism and more cautious approach among the more conservative circles of early Buddhism. In many Păli sources, the Buddha appears to endorse their performance only hesitantly and with a series of stringent reservations. ${ }^{518}$

or meditation (dhyäna) and innate (upapattiläbhikā) rddhi. Expanding on this division, it considers also rddhi springing from spells (mantrakrta), rddhi springing from herbs (oșadhikrta) and rddhi springing from acts (karmaja) as distinct categories of rddhi. As it does not give examples of these five classes, concentrating instead on further ever more complex subdivisions, we are dealing here probably with a division of little but academic bearing.

517. E.g., Mppś (iv, pp. 1819-22), Śgs (p. 221), Daśa-bh (p. 36), Saddhp (pp. 72.1-78.5), Bbh (pp. 63.1-69.10, 152.10-14), Msl (p. 185.10-16) and $M s g$ (p. 294, § 15).

The other important use to which the rddhi are put to is that of buddhapüja. Several treatises mention this as a specific purpose of the bodhisattva's attainments in rddhi (e.g., Mpps, ii, p. 1055, Saddhp, pp. 404-422).

Compare with the list that is given in the $M s l$ (pp. 142.13-143.16) distinguishing six types of realising the rddhipāda, consisting of (1) sight (darśana), (2) instruction (avavāda), (3) stable miraculous power (sthitivikridita), (4) resolution (pranidha), (5) mastery (vaśitā), (6) Dharma attainment (dharmapräpti).

518. The question of the Buddha's attitude to the use iddhi as part of the conversion process has long occupied Buddhist scholarship. The single most important source for this controversy has always been the Kevaddhasutta (D III, pp. 211-15). In a series of comments in the introduction to his translation of the Kevaddhasutta, TW Rhys Davids suggests that the Buddha strongly disapproved of their use. Half a century later, this proposition was taken up by Louis Gomez, arguing that the Buddha rejected the use of $i d d h i$ chiefly because two of three types of wondrous display (pätihäriya) are not the exclusive property of the enlightened and are available to practitioners of the magical arts of Gandhāra (Gomez, in: Lancaster, 1977 , p. 221). The validity of this argument has been challenged by Gethin on the basis of an alleged linguistic misinterpretation (Gethin, 1987, p. 196). The gist of Gethin's criticism of this position revolves around the assumption that the practice of the iddhi were 'unnatural' to the nikāya in the sense that stand apart from Buddhist practice. Springing from meditative absorption just as the jhäna, the iddhi appear indeed fully integrated into the srāvaka training. The reason why the Buddha disapproved of Kevaddha's request for an iddhi demonstration, he argues, is not because he dismissed iddhi as such but because he feared that the public display of their kind would yield no tangible results in terms of conversion.

Arguing that for the faithful, the performance of miracles would only serve to reinforce the trust and amazement that they hold anyway, while the sceptic would dismiss it as a magical trick with no deeper significance, Gethin contends that the Buddha thought the same way. As a result, in contrast with those monks who were willing to comply and conjure miracles, the attainments of the arhant would clearly lose in standing for the laity - an effect the Buddha had clearly every interest to avoid. While somewhat failing to explain the Buddha's apparent readiness to endorse the other two types of wondrous display, that is the wondrous display of mind-reading (ädesanā) and the wondrous display of instruction (anusāsani), Gethin's argument has undeniable attractions. Above all, it tallies well with the Vinaya rule (ii, p. 112; trsl. Gethin) that the Buddha pronounced in response to Piṇụola Bhāradvāja's performance of miracles before the inhabitants of Rājagaha:

"O monks, a display of miraculous $i d d h i$ beyond the capacity of ordinary men is not to be

exhibited to the householders. If someone exhibits [such], there is a dukkata offence."

The reason that given in support of this rule is that:

"It is neither [conducive] to trust for those without trust, nor to growth for those with trust.

Indeed, O monks, it is [conducive] to lack of trust for those without trust and to loss [of trust]

for some of those with trust."

Today, it is of course impossible to know for certain what exactly led the Buddha to this attitude. Buddhist sources record several well-known instances in the early days of his ministry where he seemed quite prepared to engage in the public display of iddhi. Perhaps, he was guided in this judgement by his personal experience at Uruvelä, when hoping to convert Kassapa, the ascetic, he was confronted with the absurd situation of a 'thraumaturgic impasse'.

The Kośa (vii, pp. 111-12) cites as additional reason for the Buddha's apparent criticism of the display of rddhi the fact that rddhiprâtihārya (as well as ädesanäprātihārya) captivates the minds of the audience for only a short time, while the anuśassaniprātihärya inspires the production of wholesome and benefiting 
By the time the earliest Mahāyāna sūtras appeared, much of the disquiet about the suitability of miracles to further the cause of Buddhism had apparently evaporated. The rich imagery found in the $S a d d h p^{519}$ and the tentative inclusion of miraculous feats in the otherwise rather technical discussions of the $A s t^{520}$ bear testimony to their early presence in Mahāyāna literature.

Whatever the dissent concerning the use to which rddhi could be put, Pāli and Sanskrit works show broad agreement on the conditions that lead to their mastery. In virtually every source that discusses the performance of $r d d h i$, we learn that they depend for generation on extensive and deep meditation. ${ }^{521}$ In particular, acquisition of magical powers is associated with training in the four bases of success ( $r d d h i p \bar{a} d a) .{ }^{522}$

attitudes. Hence the firm affirmation that anuśäsaniprātihārya is the best form a miraculous display (prätihärya).

519. The Saddhp contains what is probably the best known early example of the use of rddhi for benefiting others in Mahāyanna sütras. The passage I have in mind is, of course, that of the image of the burning house conjured up in order to encourage sentient beings to leave the world and follow the path of Buddhism (pp. 72.1-78.5). Other examples of rddhi are found in chapter fourteen (op. cit., pp. 297-314) describing the emergence of bodhisattvas from suddenly appearing gaps in the earth.

520. Asta, pp. 381, 383-4, 464a-465, 466.

521. The fullest canonical account of the method of their generation is found in the Patis (ii, pp. 205-6). Here, we read that the iddhi depend for unfolding on four 'planes of success' (iddhiyābhümiyo), on the four iddhipāda, on 'eight footings of success' (iddhiyāpadāni) and on 'sixteen roots of success' (iddhiyāmülāni). Referring to this passage in the Vism (xii.49-50,54-5), Buddhaghoșa explains that the four levels are nothing but the four jhäna (xii.49); that the eight footings denote the iddhipāda-each one considered from the aspect of concentration and from that of its basis (that is chanda, viriya, citta and vimamsā) - and that the sixteen roots target the various obstacles that perturb consciousness (xii.54-55). He adds that before a monk can become proficient in the seven iddhi, he has to master all eight 'basic absorptions', meaning that he is capable of entering each of the eight attainments on the basis of all eight kasina at will (Vism xii.2-7). Although held to be extremely difficult to achieve and therefore limited to very few, he allows for the option that, besides buddhas and pratyekabuddhas, very advanced disciples may acquire iddhi at the threshold of arhantship (xii.11).

522. In the Pâli Canon, the iddhipäda are regularly presented in the following stereotyped description (D II, pp. 213-4; trsl. Gethin):

"Here a monk develops the basis of success that is furnished both with concentration (samādhi) gained by means of desire to act (chanda), and with forces of endeavour (padhānasamkhāra). He develops the basis of success that is furnished both with concentration gained by means of vigour (viriya) and with forces of endeavour. He develops the basis of success that is furnished both with concentration gained by means of mind (citta) and with forces of endeavour. He develops the basis of success that is furnished both with concentration gained by means of investigation and with forces of endeavour."

As indicated by this brief passage, the iddhipäda consist primarily in an interplay of three elements: meditation, forces of endeavour and the four factors that bring about absorption (chanda, viriya, citta, vimamsā). It is therefore slightly incorrect to associate the bases of success with any of these three factors in particular. The commentaries on the Samyuttanikāya and Vibhanga leave no doubt that the significance of the interaction lies in the sustaining and promoting of the process of meditative attainments $(\mathrm{Vibh}, \S$ 303).

The exact nature of chanda, viriya, citta and vimamsā is left undiscussed in most iddhipāda contexts of the nikayya. Gethin points to an simile in the $S v$ (ii, pp. 642-3), indicating that their chief objective is to represent progressively easier means of achieving one's purpose-the person who is endowed with vimams $\tilde{a}$ being in the best position (Gethin, p. 174).

This view tallies approximately with the interpretations found in the Sanskrit sources of the northern tradition. Here, chanda-, viriya-, citta- and mimämsāsamädhi are typically interpreted as mental one- 
Generation of four bases of success is also the point of departure for the $B d p$ 's exposition on $r d d h i$, where their presence becomes a chief requirement for any kind of magical prodigy (rddhiprätihärya). ${ }^{523}$ of particular interest is the $B d p$ 's listing of desire, intimidation and sovereignty alongside the traditional $r d d h i p a \bar{d} a$ of chanda, virya, citta and mimāms $\bar{a} .^{524}$ The reason for their presence becomes clear when we look at the areas in which the bodhisattva's magical force is displayed. First, setting out to attract following by addressing people's yearning for physical beauty, he assumes exquisite shapes and colours. ${ }^{525}$ Second, by demonstrating immense strength, the bodhisattva disheartens conceited, wrathful or presumptuous beings, thereby creating favourable conditions for their instruction in the Dharma. ${ }^{526}$ Finally, equipped with $r d d h i p a \bar{d} d a$, the bodhisattva generates vast miraculous powers (adhișthāna) that allow him to transform phenomena at will. ${ }^{527}$ By so doing, he creates

pointedness attained through proper application of zeal, constant application of virya, the power of concentration previously cultivated, hearing the Dharma and insight (Abhidh-sam (R), p. 121). In close concurrence with the Păli formula, Sanskrit sources speak of the first rddhipāda as being furnished with chandasamädhi and prahānasamskāra, with chandasamādhi being acquired through the strengthening (adhipati) of chanda and so forth for virya, etc. Sanskrit sources do not identify the prahänasamskāra with virya (as they propose for the four samyakprahäna), but associate it with desire to act (chanda), striving (vyāyāma), faith (śraddhä), peace (praśrabdhi), mindfulness (smrtí), clear comprehension (samprajanya), volition (cetäna) and equipoise (upekșä), (Satya (S), ii, p. 42; Abhidh-sam (R), p. 121; $M v \dot{s}$, p. 51.11-52.3, iv.4).

For a considered assessment of the place of the iddhipäda in the Buddhist path, see: Gethin, 1987, pp. 155-199).

523. According to the $S g s$ (p. 221), rddhiprätihărya are manifested in eighteen different kinds. However, the text does not elaborate on the nature of these eighteen types and I have found no passage that could be interpreted to illuminate this reference.

A concise Mahāyãna definition of the three types of miraculous display (prātihārya) is found in the Rgv (p. 363):

"It is indicated that the omnipresence [of the Buddha] through the display (vikurvita) of the body in all the worlds of the ten directions constitutes the miraculous display through feats (rddhiprätihärya). The illumination of the thicket of mental conduct of living beings, as involved in the mind, by knowing the variety of thoughts is the miraculous display through mind-reading (ädesianāprätihärya). And with reference to the path leading to deliverance, [the Buddha] preaches and instructs in the path by the example of the utterances of his voice-this is the miraculous display through instructions (anuśasatiprātihārya)."

524. R, folio 569.3 .

525. $\mathrm{R}$, folio $569.6-70.2$

Similar, but more elaborate descriptions of the lengths the bodhisattva is prepared to go in transforming his body are found in the $V k n$ (pp. 183-184; cit. in Sikș, pp. 324-27), Ratnolkadinärañi (Sikș, pp. 330.13-332.8) and $M p p s$ (ii, p. 984; cf. p. 1055).

On the contributions of krtsnäyatana, vimoksa and abhibhväyatana to the transformation powers of the bodhisattva, see: Mppś, iv, pp. 1820-21, iii, pp. 1291-1307.

526. R, folio $570.3-71.2$.

527. $R$, folio $571.3-2$

The meaning of the term adhișthana is somewhat ambiguous in this place. Although it may carry several meanings, on contextual grounds, I do not believe that any other translation than 'miraculous power' is appropriate here (Edgerton, pp. 15-16). Being itself a widely attested meaning, it occurs with this sense several times in similar contexts in the $S g s$ (pp. 187, 194, 196, 212, 222).

In this section, the $B d p$ proposes that a bodhisattva who possesses the adhisthanna of miraculous power becomes capable of performing feats of magnification and diminution on a vast scale, such as reducing the size of the ocean to a cow's footprint and vice versa. This example and others are reminiscent of passages in the $V k n$, describing similar feats $(V k n$, pp. 138-39, 140). 
immense rapture in his audience, prompting his listeners to adopt the Buddhist faith and resolve to work for enlightenment themselves. ${ }^{528}$

A further peculiarity is the type of classification that the $B d p$ proposes for $r d d h i$. In later Mahāyāna writings, $r d d h i$ is generally differentiated by its areas of operation. The best known division is that of the $B b h$ where $r d d h i$ is distinguished by action affecting transformation $(\text { pārināmika })^{529}$ and by action affecting creation (nairmānika). ${ }^{530}$ Elsewhere, this twofold classification is extended by a third aspect, displacement (gamana), allowing the bodhisattva to appear in every location at will. ${ }^{531}$ The rddhi classification of the $B d p$ into form (rūpa), power (bala), miraculous power (adhișthāna) and prodigy (rddhiprätihārya) has a much narrower focus, since its members are specifically designed to eradicate tendencies of desire (kāma) and intimidation (vibhișana). ${ }^{532}$ Consequently, the display of $r d d h i$ shows little diversity and concentrates on the impact of rüpa, bala and adhișthāna. ${ }^{533}$

The $B d p$ next distinguishes the scope of the abhijña from that of pristine cognition (jñāna). This difference is primarily one of focus. That is to say, to a bodhisattva the abhij $\tilde{n} \vec{a}$ are less

The Kosia (vii, p. 119), citing as example the longevity of Mahākāsyapa's bones (Divya, p. 61), holds the view that the factor of adhișthana furnishes the miraculous feasts of bodhisattvas with a life-span well beyond that of their creator. Manifested in the thought 'it shall last' that is generated before the miracle, it furnishes the feat with unlimited life. This position, however, has been challenged in other texts, arguing that the long duration of miracles accompanied by adhișthana is founded in protection granted by the gods (Nyãyabindu, p. 47, trsl., Bibl. Indica Series).

I do not know Pedersen's (p. 110) reasons for translating adhișthāna here as 'blessing'-a highly enigmatic rendering that does not seem to fit the context, leading to sentences such as: "The teachings of the bases of !ddhi of all blessing-thought can all be developed by the bodhisattva-mahäsattva in accordance with the object of his blessing-thought" (op. cit., p. 110).

528. $\mathrm{R}$, folio $572.1-4$.

529. According to the $M s g$ (p. 221), rddhi of transformation allows the bodhisattva to set in motion (kampana) houses, etc.; to set his body ablaze (jvalana); to illuminate (spharana); to render visible (vidarsana); to transform the four great elements (anyathïbhävakarana); to come and go in samsāra freely (gamanā); to decrease and increase phenomena (samkssepaprathana); to insert all matter into his body (sarvarüpakäyapraveśana); to adapt to the customs of others (sabhägatopasamkrānti); to appear and disappear with a great retinue (āvirbhāvatirobhāva); to submit other beings to his will (vaśitvakarana); to overpower the magical powers of others (pararddhyabhibhava); to grant insight (pratibhädāna), memory (smrtidāna) and bliss (sukhadāna) and to emit light-rays (raśmipramokșa).

This list is also found in the $B b h$ (pp. 58.23-59.2). Cf. $M s l$ (pp. 148.14-153.10) and Daśa-bh (pp. 34-35, M).

530. In the $B b h$ (p. 63.25), $r d d h i$ of creation involves either the body (käyanirmäna) giving rise to appearance similar or different from the complexion of the agent, or creation of voice (vägnirmäna) with the sole purpose of teaching the Dharma. In the Buddhabhümiśästra (6, p. 318, col. 2; 7, p. 325, col. 1-2; ref. Lamotte), however, a third dimension, that of the mind (cittanirmanna) is added to the creation of body and voice, giving rise to images in the bodhisattva's own mind (svasambaddha) or in that of other beings (parasambaddha), (cf. Siddhi, pp. 794-795).

531. Mppś, i, pp. 328-30.

532. $\mathrm{R}$, folio 569.3 .

533. I have found only one other text that cites these three aspects as distinct elements in its rddhi discussion. This is the Ratnolkadhärani (Siks, p. 330.11) where we come across the following sentence:

"With miracles of rdddhi manifesting the psychic powers of the Tathāgata, through form, miraculous power and strength altogether (samantāt), through their ability of mind-reading, through revealing (anuśástrí) their rddhi they convert sentient beings." 
important for the knowledge they impart than for the contribution they make to the active aspects of his training. They allow him to traverse the fields of all buddhas, to appear in the five spheres of existence and to overwhelm with brightness even the most purified heavenly abodes. ${ }^{534}$ The abhijīna have therefore immediate bearing on the bodhisattva's conversion activity. Pristine cognition, in contrast, operates on the cognitive plane. Where the abhijña generate unlimited sound perception, jũāna realises ineffability. When the abhijña allow the bodhisattva to observe the minds of all beings, jñanna sees the cessation and non-cessation of thought. ${ }^{535}$ In other words, while he is dependent for his active training on the abhijñ $\bar{a}$, it is to jūana that he owes insight into the frame of reference in which they manifest.

The bodhisattva learns of the mental defilements that pervade samsāra through the branches of dhyāna and his miraculous powers of mind (cittādhișthäna). This inspires him to win dhyāna in equal number. ${ }^{536}$ Thus committed (samādāna) and sustained by the conviction of the equality of practice, he achieves a high degree of concentration (samähita) and attainment (samāpatti) in sameness. ${ }^{537}$

On the basis of this insight, the bodhisattva acquires tranquillity ${ }^{538}$ and discernment. These

534. $\mathrm{R}$, folio $573.2-5$.

535. Compare this picture of the relationship between the abhijña and cognition with the account that is given in the Kośa (vii, pp. 98-112). Here the abhijña (vii, pp. 100-1), given the same status as all other religious practices, represent the knowledge of the path of deliverance (vimuktimārgaprajñā). The rddhi, divyacaksus, divyaśrotra and pürvanivāsānusmrtijñāna belong to the sphere of conventional knowledge (samvrtijñana). The abhijñā manifesting paracittajñāna allows specifically for the attainment of dharmajñanna, anvayajñāna, märgajñāna, samvrtijñäna and, of course, paracittajñäna. As the äsravaksayajñāna (resembling the tenth of the tathägatabala), it leads to six or ten types of knowledge (Mppś, iii, pp. 1472, 1508) and belongs to all stages of dhyäna (Kośa, vii, p. 101). The first five abhijñă, in contrast, leaning on the four dhyanna but not on the arüpyasamäpatti for their object, consist of matter and are always bound to the dhyāna stage (or the next lower one) on which they became manifest (Kośa, vii, p. 104). All abhijñā are either acquired by means of detachment (vairägya) if already practised in previous lives, or are otherwise mastered by present effort (prayoga). Founded on the practice of mindfulness, they correspond to specific bases of mindfulness (Kośa, vii, pp. 105-7). The abhijñā of rddhi, divyacaksus and divyaśrotra correspond to the kāyasmrtyupasthāna since they have matter as their object (cf. Mppś, iii, pp. 1121-2). The abhijña of paracittajñana includes the smrtyupasthāna of vedanä, citta and dharma because it has thought and mentation as its object. Finally, the abhijiña of pürvaniväsānusmrtijñäna and āsravaksayajñāna, having as their objects the five skandha, have as their nature all four smrtyupasthanna (Kośa, vii, p. 106). In moral terms, all six abhijiña-but for the divyacaksus and divyaśrotra-are wholesome (sibha) since they improve spiritual practice (Kośa, vii, p. 107).

536. R, folio 573.7-74.1.

537. R, folio 574.5-7 (cf. folio 574.7-75.1)

In the $A k n$ (p. 49.2.4), the argument runs slightly different, suggesting that the bodhisattva becomes concentrated because he is established (sthita) in sameness and not because he is accomplished in meditation. On the other points, however, both texts concur closely. The doctrinal foundation at the heart of this thought is well-known from a number of other, perhaps earlier, Mahāyāna sütras. It is found, for instance, in the $S g s$ (pp. 125, 131, 133, 139, 234) and $V k m$ (pp. 55-56, 122-23 and the whole of chapter vii, discussing non-duality (advaya)).

538. Here, in an effort to describe the composure of the bodhisattva's disposition it is likened to the stability of the four mahäbhüta. This is a well-known simile that occurs in a number of Mahāyāna sūtras (e.g., $A k n, \mathrm{p}$. 49.4.3-4) describing the bodhisattva's serenity of mind. 
allow him to manifest all forms of worldly activity without ever ceasing to uphold his practice (dharma) and meditation (samähita). ${ }^{539}$ It frees his practice from dithering and commotion, leads to moderation in speech (amukharatā), equips him with knowledge of suitable meditation conditions and sustains serenity. ${ }^{540}$ In the $R c d$, it is explicitly stated that 'entry into certainty' (nyāmāvakrānti), realisation of attained fruits and non-accumulation (anabhisamskāra) are not the aims of meditation. ${ }^{541}$ Its chief function consists less of realising attainments (here epitomised by the trivimokșa) than to guide other people towards them. ${ }^{542}$ Thus, even when meditating on 'emptiness furnished with the best of all excellent forms' (sarvakāravaropetaśünyatā) that allows him to see the non-arising of dharma, the bodhisattva persists in his altruistic outlook. He generates conduct that is indiscriminating, faultless and unconcerned with its own flavour (svarasavähin).$^{543}$ By virtue of his meditation, he achieves

\section{R, folio 575.7}

The notion of the perpetually meditating bodhisattva is common to several early Mahāyāna sütras. In the $S$ Ss (p. 145), for instance, it forms the backbone of the entire discussion of the dhyannapāramitā. Realising that all dharma are eternally concentrated (sadāsamähita), the bodhisattva holds on to meditation in order to subdue his thoughts (cittadamanärtha) and to convert sentient beings with greatest efficiency. While the bodhisattva of the $S g s$ is of the highest stage (p. 183), in full possession of all rddhi, there are other examples of less-advanced bodhisattvas who abide incessantly in meditation.

540. R, folio 575.4-7

This list of attributes is the closest the $B d p$ comes in spelling out the benefits that accrue through meditation. In contrast with the other perfections, Buddhist sütras produced relatively few of such lists on dhyana. One example of such rare enumeration is found in the Samädh, distinguishing the following ten kinds of benefits: (1) persistence in training, (2) performing good conduct, (3) living a life free from affliction, (4) possessing well-guarded faculties, (5) experiencing joy, (6) liberation from desire, (7) serenity despite the impressive accumulation of meditation, (8) liberation from the sphere of influence of Mära, (9) dwelling in the sphere of the Buddha and (10) ripening (others) to liberation (Dutt, 1943-53, ii., p. 338.6-11; cf. TTP, 31, p. 310.3.8-4.8).

Compare the realism of this list with a characterisation of 'pure samãdhi' in the $U g$ (p. 272.1.8-2.3) that focuses on the psychological attainments of one-pointedness, cognition of the non-abiding of thought (apratișthitacitta), non-differentiating thought (aprapañcacitta), mastery of thought (cittavasitia a) and unperturbed thinking (aksobhacitta). Another example of a more advanced list of the benefit arising from the practice of meditation is found in the Msg (pp. 223-4). Here, we read of ten exploits (duskaracaryā) that accrue to the bodhisattva from superior thought (adhicitta).

But for a number of points that relate, in the Mahāyāna, to the path of the bodhisattva, the Śāvakayāna understanding of benefits that arise from concentration agrees is in broad agreement. For a good example of the Theravāda view, I propose to turn to the Vism where Buddhaghoșa identifies (1) blissful abiding, (2) insight, (3) super-knowledge, (4) the prospect of higher rebirth and (5) cessation as the principal advantages that spring from meditation (Vism, pp. 371-372).

541. Rcd, op. cit., p. $234.4 .5-6$

According to the $B b h$ (p. 358.2), the attainment of nyāmāvakrānti represents the third vihära of the śrāvakabhümi scheme. Edgerton (pp. 314, 298) suggests to take nyāma for niyāma, thus rendering nyämävakränti as 'entry into certainty' but this does not tally with the Tibetan 'absence of defect'. For a discussion of the term nyāmāvakrāntivihāra, see: Gv, p. 320.22; Asța, pp. 331.10, 322.5.

542. Rcd, op. cit. p. 234.4.6-5.2.

543. Rgv, op. cit., p. 264

The notion that the meditator must not become attached to the flavour (rasa) of his absorption is a well-established maxim in Buddhist meditation. Indeed, any dhyana that is associated with enjoyment (äsvädanasamprayukta) is regarded as impure and accordingly condemned in most sütras (e.g., Lañkäv, p. $212.14 ; M s l$, p. $160.14 ; K o s i a$, viii, p. 144). One reason why the texts do not tire of warning the recluse from this mishap is the danger of confusing attachment (äsanga) with the practice of dhyanna as both induce the mind to focus on a conceived object (Mppśs, ii, pp. 1056-7). The bodhisattva succeeds in 
impeccability (avikala) in the perfections, incessant exertion in ripening sentient beings and acquisition of buddha-qualities. ${ }^{544}$

An important element of these meditative attainments is the interplay of means (upāya) and wisdom (prajña $).{ }^{545}$ While it is not necessary to go into the detail of this well-known pattern it is perhaps of interest that meditation is a constituent in both practices. That is to say, the $B d p$ quite explicitly maintains that dhyāna practice is essential to the generation of means and wisdom. The difference between the two is then not one of substance, but of focus. When aimed at the suffering in the world, dhyana generates compassion, ripens sentient beings, produces buddha-qualities and manifests miraculous powers; but when concerned with outright cognition, dhyāna inspires a vision of reality where sentient beings do not exist, roots of virtue vanish and buddha-fields resemble space. ${ }^{546}$ It is therefore only by the combined presence of prajīa and upāya that the bodhisattva decides to return to the kāmadhātu and continues his quest of universal liberation. ${ }^{547}$ One ramification of this paired operation is that, depending on context and purpose, meditation is capable of performing either on the

disentangling himself from attachment to samādhi by realising that all dharma (including of course meditations) are non-dual and hence no cause for attachment (op. cit., pp. 1049-50). The potentially devastating consequences such misapprehension might entail are exemplified by the downfall of Udraka Rämaputra that occurred in response to his undue attachment to the dhyāna and samāpatti (Mppś, ii, pp. 1050-52). As in many other cases, the common wisdom of such advice had little validity for Vimalakirti who reportedly sustained himself with nothing but the flavour of this trances $(V k m$, p. 29).

544. Rcd, op. cit., pp. 234.5.2-35.1.8 (cf. Rgv, op. cit., p. 265)

According to the Mpps (ii, p. 984), the bodhisattva returns to the world from meditation in solitude only when he has obtained the power of the abhijiña . Assuming all types of form in order to convert sentient beings when he dwells in their midst, the bodhisattva guides them by whatever instructions and means he deems appropriate to their deliverance.

545. R, folio 576.1-78.4.

546. In a passage of the $U g$ (op. cit., p. 272.4.2-4), upayakausalya is given credit for holding the grhapti bodhisattva in this world in spite of his attainments in meditation:

"Furthermore, $\mathrm{O}$ householder, with regard to the empty house (presumably a quiet secluded place) the grhapti bodhisattva practises the four dhyāna but does not enter into the samäpatti by virtue of his skilful means."

This sentence seems to suggest that without upayakausalya the bodhisattva would cease his work in samsāra and withdraw into blissful realms of the samāpatti. Although this point is not made in the $B d p$, the gist that the bodhisattva stays in the world in spite of the opportunity to retire temporarily from suffering is perhaps implied by the untiring reiteration that upāya means worldly engagement while dwelling in the samäpatti ( $R$, folio 576.2-78.3).

Compare this proposition with a passage in the $D b h(D a s i a-b h$, p. $36, \mathrm{M})$ where we learn that:

"The bodhisattva enters into and emerges from dhyāna, vimokșa, samädhi and samāpatti but is not born by their power ( $v a s^{\prime} a$ ), except when he arises by the power of his resolution, witnessing the fulfilment of the factors of enlightenment. Why? Because the bodhisattva possesses the mental continuity (cittasamtati) achieved by skilful means."

547. Mppś, ii, p. 1044

This touches on another important distinction between the śrāvaka- and bodhisattvadhyãna. Unlike any other being, the bodhisattva may enter into dhyanna while still in possession of a thought of the kämadhātu. He is capable of doing so by reason of his cultivation of virtue (guna) and because his fetters (samyojana) are weak (op. cit., p. 1446). 
conventional (samvrti) or absolute (paramärtha) level of reality. ${ }^{548}$

\begin{abstract}
"Equanimity and realisation while attaining all conceivable factors of enlightenment stand for means. Completely purified, untroubled pristine cognition of the Tathāgata, bliss of objectless meditation, discernment of unobstructed perception, purification of all perception, meditation on the perfection of all bodhisattvas, practice of meditation devoid of meditation stand for wisdom."
\end{abstract}

Meditation doctrinally assumes thus the role of a nexus, linking the mundane practices of dāna, sỉla, kșānti (and virya) with supramundane cognition of prajñă..$^{549}$ On the one hand, it depends for cultivation on the four worldly pāramitā. Elimination of the five major obstacles to meditation (viz., covetousness, malice, indolence, regret, wastefulness and doubt) and generation of the five dharma that conduce to its unfolding (viz., zeal, vigour, recollection, thoughtfulness and mental one-pointedness) clearly require schooling in generosity, etc. ${ }^{550}$ On the other hand, meditation enhances training in first three perfections, since it provides the required mental focus. ${ }^{551}$

Adopted to the abhijñ $\bar{a}$, these variant planes of dhyanna led the $B d p$ to recognise two types of abhijñā, viz., ordinary super-knowledge and non-regressing super-knowledge (acutyäbhijñ $\bar{a}) .{ }^{552}$ As indicated by their titles, the difference between the two is one of progress or degree of perfection. That is to say, the practice of ordinary abhijñ $\bar{a}$ is chiefly concerned with the five traditional areas of application and focuses on the conversion of sentient beings. ${ }^{553}$ Granting supernatural powers in vision, hearing, mind-reading, recollection and $r d d h i$, it guides to the 'great entry' (mahāpravrtti), engineers the attainment of pristine cognition, operates as a factor that conduces to deliverance (nirvedhabhāgīya) and addresses supramundane practices (lokottaradharma). ${ }^{554}$ The time-span of its operation is not fully

548. R, folio $577.6-578.1$.

549. Mppś, ii, pp. 984-990, 928.

550. These ten dharma are cited in the Mpps (op. cit., pp. 1013-23) as the chief causes/obstacles to a successful meditation. Although this list is by no means the only one that is proposed in Buddhist literature, it does seem to cover the contents of most other enumerations.

551. Mpps, ii, pp. 985,1055

Besides the association with the other päramita, it is the connection to mastery over the bodhipākssika that most texts underline. It is mentioned is the Pañca (pp. 514-15), appears in the Dbh in the stage following his attainments in dhyāna (Daśa-bh, pp. 38-39, C) and is listed in the Mpps (ii, p. 1043) alongside the other samädhi the dhyānapāramitä brings about.

552. R, folio $578.4,580.2$.

553. R, folio $579.2-80.1$.

554. R, folio 579.6. 
indicated in the $B d p$. Its link with the mastery (vasita) over all dharma ${ }^{555}$ and the abhiseka conferral suggests that it extends from the acaläbhūmi to the dharmameghabhümi. ${ }^{556}$

This advanced positioning on the path is corroborated by a list of one hundred and one samādhi that appear at the very end of the chapter. ${ }^{557}$ We know of several instances in Mahāyāna sūtras where the attainment of samādhi-enumerated in lengthy lists-signals the completion of the path. ${ }^{558}$ Generally, these samädhi do not represent individually attained meditations, but point to modalities in that the bodhisattva's final meditation manifests itself. Accommodating all practices simultaneously cultivated ${ }^{559}$, they represent the highpoint of training when the bodhisattva operates purely from within an infinite sphere of absorption. ${ }^{560}$ Needless to say - relying on the dharmakāya while moving through an empty, unmarked and purposeless space ${ }^{561}$ - the bodhisattva does so with greater efficiency than he has ever been able to achieve.

It is only at this point that the third and last phase of meditation sets in. Entitled 'meditation

555. According to the $D b h$ (Dasa-bh, p. 71.7), the attainment of mastery over dharma follows on the bodhisattva's production of knowledge about the body (kāyajñänäbhinirhära) at the eighth stage. Consisting of ten types of mastery (āyurvaśitā, cetovaśitā, parișkāravaśitä, karmavaśitā, upapattivaśitā, adhimuktivaśitiā,

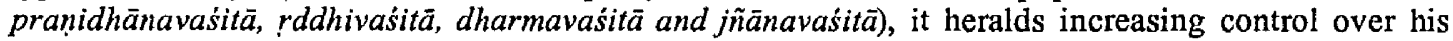
appearance-himself abiding in the 'immaculate sphere' (anäśravadhätu) - and leads to refined conversion methods. In the scheme of the $B b h$ (pp. 352.26-353.7), the acquisition of ten (somewhat differently conceived) vasitä takes place at the tenth vihära. Here, as in most other sources, it springs from the attainment of the abhijña a and jñanna leading to a perpetual company with buddhas (pratyutpannabuddhasammukhāvasthita).

Besides these bodhisattva treatises, the vasitia are mentioned in a broad range of Mahāyāna sūtras, including the $G v$ (p. 83.10), Dhsgr (§ 74), Lankäv (p. 1.10), Lal (pp. 45.14, 94.19, 274.21), Ug (p. 272.2.2) and $M v u$ (i, p. 282.15-20). As so often with lists of this type, the order of enumeration does not always correspond (Mvy 770-80). We find also some variation in contents (e.g., Mvu) that indicates that the concept of the vasitäa might have been new to Mahāyāna Buddhism. Indeed, the suttas of early Buddhism do not disclose any list corresponding to the vasitia attributes of the bodhisattva.

556. Daśa-bh, pp. 71.7-18, 82.1-85.9

In broad terms, this allocation of rddhi matches even the otherwise 'non-conformist' career-plan in the $G v$. Here, as elsewhere, we learn that the bodhisattva's capability of performing magical feats depends on his entrance on the dharmadhatu. Although this falls on the sixth stage (p. 372.15-18), it does not allow the bodhisattva to assume apparitional bodies immediately. For this to happen, he has to wait until he reaches the seventh stage at which he "having purified the dharmakäya completely pervades the fields with his own body". But even at this advanced stage he has not yet attained complete mastery over all $r d d h i$ and remains thus unable to proceed to purify of his buddha-field (op. cit., p. 372.20). For, according to the $G v$, the full attainment in miraculous powers-accompanying effective maturation of beings-takes place at the ninth stage after the bodhisattva has attained full proficiency in all types of meditation (op. cit., p. 373.1-4).

557. R, folio 587.2-90.1.

558. Daśa-bh, p. 82.9-21; Pañca, pp. 142-43; Sgs, p. 132; Akn, p. 50.4.3-4.6. In the Gv (op. cit., p. 369.23-24), the bodhisattva is said to attain mastery over all samädhi already at the ninth stage, while in the $B b h$ (p. 354.14-23) he has to await the twelfth vihära.

559. Sgs, pp. 141-150, § 26-38; pp. 152-154, § 42-46.

560. The Mpps (ii, p. 1048) indicates that this is a common feature of the bodhisattva's practice of the dhyannaparramita and is not limited to his meditation on the advanced stages. However, the text hastens to add that this applies only to bodhisattvas furnished with the dharmakayya - a qualification that unmistakably points to the later career phases (op. cit., pp. 1048-9).

561. Mppś (i, p. 324): sūunyatāpranihitānimittagocara. 
at the service of others' (sattvārthakriyädhyāna), it is wholly targeted at the universal suppression of sorrow. ${ }^{562}$ According to the $B b h$, the sattvārthakriyādhyāna involves total compliance with the wishes, customs and, above all, spiritual needs of beings. It compels the bodhisattva to teach the Dharma, to appease physical misery, to protect from terror, to show gratitude and generosity as appropriate and to dispense impartial rebuke. ${ }^{563}$ Clearly, such diverse requirements allow only bodhisattvas of advanced stages in possession of the dharmakāya to attain the sattvārthakriyādhyāna.

The characterisation of non-regressing abhijñ $\bar{a}$ is more problematic, since the $B d p$ offers few benchmarks against which it could be measured. It is implied-but not stated-that the acutyābhijña $\bar{a}$ presupposes the attainment of the five ordinary abhijñă. The basis of its manifestation is complete mental purity cultivated during intentional (samcintya) absorption in the four dhyāna, eight vimokșa, three samādhi and nine samāpatti. It represents liberation from the fetters of impurity (kleśa) and is beyond residence on the summit of contrariness (viparyāyāgräśraya). ${ }^{564}$ Based on knowledge of the sameness of all dharma, it precludes attachment (abhiniveśa) ${ }^{565}$ to either dharma or adharma.

Abhinivesia itself is the object (artha) of all practice (dharma). ${ }^{566}$ In a nutshell, the $B d p$ argues that non-attachment is the foundation to spiritual maturity that prevents delusion, indolence and impassioned disputes to cloud the bodhisattva's judgement. It prepares acceptance of universal sameness and immunity to imputation (aparyāpanna) and-repudiating form (samsthāna) and appearance (nimitta) - leads via pursuit (anvaya) to spiritual realisation (adhigama). ${ }^{567}$

In the present context, pursuit and realisation constitute two different, yet acutely overlapping and complementary aspects of the bodhisattva's training. Taken separately, each represents a major path-element; with pursuit standing for untiring cultivation of individual practices and realisation denoting understanding of their ontological invalidity. In practice, however, this

562. Hence, its alternative title that is given in the Siddhi (p. 622) as 'meditation of the accomplishment of duty' (kṛtyānușthānadhyāna).

563. $B b h$, pp. 207.25-208.9

In essence, we are dealing here with the same list of behavioural norms towards the laity that was given already in the Sila- and Viryapatala (Bbh, pp. 144.24-152.17, 201.26-202.1).

564. R, folio 580.6 (phyin ci log gi rtse mohi gnas); cf. Edgerton, p. 491.

565. According to Edgerton (p. 53), abhiniveśa carries two possible meanings, viz., when leaning on classical Sanskrit it is 'strong attachment' or, in affinity to Pāli abhinives'a, any false belief, that in Buddhism is particularly the "heretical belief of the existence of a self' (Siks, p. 198.21). In the context of dharma-sameness the word abhinivesa could possibly be interpreted in either terms, with 'strong attachment' beings perhaps the more plausible translation.

566. R, folio 581.3-4.

567. R, folio 581.6-82.3. 
distinction becomes meaningless as pursuit and realisation merge into one another to produce the pledge to universal liberation in spite of the conviction of the non-arising of dharma: ${ }^{568}$

"He shows benevolence but knows that there is no self. He is compassionate but knows that there are no beings. He cultivates sympathetic joy but knows that there is no life-force. He abides in equipoise but knows that there is no person. ... He ripens sentient beings but his mind is of pristine purity. He retains the holy Doctrine but knows the indistinguishable dharmadhätu. ... He turns the wheel of the Dharma, but knows that there is no turning. He instructs on passing into great nirvāna, but knows of its sameness of own-being of samsāra."

In an apparent allegory on the miraculous powers of the abhijñ $\bar{a}$, pursuit and realisation produce holy beings (satpurușa) that are capable of performing miracles (äścarya) and supernatural feats (adbhüta). ${ }^{569}$ The text is silent on the reasons behind this comparison. However, we are probably not much off the mark in interpreting it as an effort in the enhancement of the standing of more ordinary practices. Echoing the views of Sākyamuni Buddha, it was probably feared that a display of miraculous feats would make a far greater impression on an ill-informed laity clamouring for supernatural interventions than the rather less spectacular selfless striving of dedicated bodhisattvas. Hence, the departure from the dazzling descriptions of $r d d h i$ practices that dominated much of the first part of the dhyana chapter to the more austere analysis of the principles underlying the training proper.

568. R, folio $582.6-84.3$.

569. $\mathrm{R}$, folio $582.4-5,584.4$. 


\section{The Perfection of Wisdom}

The last of the six major pāramitā, prajñāpāramitā, is discussed in chapter eleven. Of all twelve chapters of the $B d p$, this chapter is the most important with regard to the bodhisattva practice. For, it contains as part of the discussion of prajñ $\bar{a}$ not only those elements traditionally associated with expositions of prajñā, but includes also a large number of ancillary wisdom practices. In its description of them, the $B d p$ draws substantially on Mahāyāna thinking. The style of composition indicates that it comes from a time when descriptions of these practices were still not fixed. What is perhaps most striking is not the content but the arrangement of the material. In apparent disregard of well-established structures found elsewhere, the $B d p$ develops a picture of wisdom that contains little evidence of a particular design despite the fact that it acknowledges some sense of organisation. In order to show what is meant, I have drawn up a list of contents:

1. Sruta, praveśa, pratipatti

2. Sambhāra

3. Prayoga

4. Dar'śana

5. Bhāvanā

6. Skill in skandha, dhātu and āyatana

7. Skill in satya

8. Skill in pratisamvid and pratisarana

9. Skill in punyasambhära and jñānasambhāra

10. Skill in smṛtyupasthāna

11. Skill in bodhyanga

12. Skill in āryāṣțänigamārga

13. Skill in śamatha and vipaśyanā

14. Skill in samyakprahāna, indriya and bala

15. Skill in ekayānamārga

16. Skill in pratītyasamutpāda and dharma 
While the contents of the types of 'skill' presents no difficulty-virtually all practices discussed here are understood to contribute to the generation of wisdom ${ }^{570}$ - the order of their arrangement proved complex and difficult to unravel. The concatenation of śruta, praveśa and pratipatti; the position of samyakprahāna, indriya and bala behind the āryāștāingamārga; the role of 'skill' in skandha, dhätu, ayatana, satya in relation to the pratisamvid and pratisarana, to indicate just a few issues, diverge from established patterns and are problematic.

\section{Initial Phases in the Training of Wisdom}

The exposition of Perfect Wisdom begins in the $B d p$ with a survey of the factors that generate wisdom. By identifying (1) seventy-two types of learning (śruta), (2) forty-one methods (praveśa) of acquiring learning and (3) good conduct (pratipatti) as causes, the Bdp emulates the ancient scheme of 'wisdom arising from learning' (śrutamayiprajñā), 'wisdom arising from reflection' (cintämayīprajñ̄a) and 'wisdom arising from contemplation' (bhāvanämayīprajñā). ${ }^{571}$

Virtually all abhidharmic treatises on the path agree that wisdom generated through learning, reflection and contemplation belongs to the earliest phase of the training. It is associated with the four bases of mindfulness and becomes manifest on the path of equipment (sambhäramärga). ${ }^{572}$ In the $B d p$, this allocation is confirmed by their position at the very beginning of the discussion of prajña

The first limb, sruta, does not present much of a problem since it accords closely with the established notion that learning is the first, and most fundamental, precondition for the arising of wisdom. Focusing on the wording of the instructions rather than on their meaning, it introduces the practitioner to the teachings of the Dharma and initiates the cognition

570. For the three conditions leading to prajñā, see: $M B T$, ii, pp. 198-99, § 9; Srotabhümi, TTP, 109, p. 296.3.1-5. For 'skill' in skandha, dhätu and ayatana, satya and pratityasamutpäda, see: $M v s$ (N), p. 37. For the pratisamvid and pratisarana, see: Bbh, pp. 214.10-14, 257.16-22. For punya and jñānasambhāra, see: $M B T$, iii, p. 12.20-22. For the bodhipākșika, see: Kośa, vi, pp. 282-4; Mvś (N), p. 50-55 and quotations in $M p p s$, iii, pp. 1119, 1132-36. For samatha and vipaśyanä, see: $M B T$, iii, p. 1.7-13; Bugault, 1982, p. 92.

571. See, for instance: D III, p. 219; Vibh, pp. 324, 325; Kośa, vi, pp. 143-44; Bbh, p. 183.1.3-6.

572. Kośa, vi, pp. 159, 287; Abhidh-d, p. 362; Abhidh-h (W) p. 140; Abhidh-sam (R), pp. 116-7; Amrtar (B), pp. 201-2; DPP, p. 20.

For full discussions of the fivefold path scheme, see: Kośa, v, pp. iv-xi; HIB, pp. 677-686; Frauwallner, Abhidharma-Studien iii, pp. 82-89; Günther, 1957, pp. 290-377 and, in particular: Ruegg, 1990, pp. $150-209$. 
process. At first sight, however, our list of seventy-two forms of learning appears to go well beyond this definition. Instead of learning, it is more concerned with the study of the bodhisattva practices proper. ${ }^{573}$ At this early stage, śrutamayiprajña is founded on confidence in the words of the Buddha and is sustained by faith. ${ }^{574}$ In the $A k n-t i k \bar{a}$, Vasubandhu explains that the individual types of learning do not represent learning itself, but those factors that lead to learning. He says that each factor is the cause of learning, that it has learning as cause and that it shares its own-being with wisdom. ${ }^{575}$ Hence, our seventy-two forms of learning stand not so much for learning in the narrow sense of the word, but point to a series of complex interactions facilitating the attainment of wisdom. ${ }^{576}$

The second type of wisdom, cintämayiprajīna , leads to a sound understanding of the four noble truths. Chiefly, though not exclusively, concerned with meaning ${ }^{577}$, it occasions a type of certainty that is founded in rational examining (yuktinidhyāna) wholly independent of faith or external authority. ${ }^{578}$ Like śrutamayiprajñ $\bar{a}$, it is dialectical in nature and of provisional value. ${ }^{579}$ It still pertains to the laukika domain and operates in a defiled consciousness (säsrava vijñana). The applicability of the cintämayiprajña $\bar{a}$ concept to the $B d p$ 's list of forty-one methods of acquiring learning is ambiguous. For one thing, the terminology does not correspond; instead of founding it on cintā, the $B d p$ says that it springs from yoniśo manasakāra. ${ }^{580}$ Vasubandhu does not give much weight to this difference, perhaps because he is aware that yoniśo manasakāra often occurs in its verbal form manasi karoti as a synonym to cintayati. ${ }^{581}$

573. This is particularly true of the items in the latter portion of the list, starting with item no. 29. The whole list is given in the Appendix i.

574. A IV, p. 82; Kośa, vi, p. 143.

575. $A k n-t i k \bar{a}$, TTP, 104, p. 181.3.6-4.1.

576. Cf. Vibh, p. 325.

577. The Vaibhāșika hold that the relationship between names (näma) and meaning (artha) is reciprocal, saying that cintāmayiprajña secures the meaning by means of the wording (vyañjanena) as much as it secures the wording by means of the meaning (Kośa, vi, p. 143). This thesis is refuted by the Theravāda Abhidhamma saying that cintämayipañina arises separated from hearing (Vibh, pp. 324-5).

578. M I, p. 265.

579. The nature and relationship between the three is illustrated by a simile in Kosia (vi, p. 143). The gist of this interpretation, suggesting a temporary value for the first two types of wisdom, but explained by means of the artha/vyanijana pratisarana, is also found in the Samdhis (p. 105.1-26). To sum up, during the śrutamayi phase, the bodhisattva, having turned towards deliverance, focuses on the literal meaning of the texts, but fails to realise the meaning of designations. Then, he includes the meaning of the letters into his investigation. Progressing towards liberation he is now capable of realising worldly designations. Finally, through contemplation he learns of the intentions of the texts and-independent of the letter-acquires knowledge of those dharma that pertain to liberation.

For alternative explanations of their relationship see: $M s l$, pp. 54.9-14, 85.3-6. According to the $M s l$ (p. 56.4-10), however, the three types of wisdom do not supersede each other, but are jointly required in order to penetrate the basis of reality (dharmãlambana).

580. Edgerton, p. 387, col. 1; pw, pp. 1082-83.

581. Rp, p. 59.4; Daśa-bh, p. 12.21 (for further references see: Edgerton, p. 418, col. 1). 
He postulates that praveśa corresponds with yoniśo manasakära ${ }^{52}$ that he likens elsewhere to insight concerned with reflection $(\operatorname{cint} \bar{a})^{583}$, thereby practically identifying praveśa with cintā. Since, in the Bdp, yoniśo manasakära is the method by which śruta is acquired, a strong link between praveśa and cintā is established. ${ }^{584}$ The methods by which the bodhisattva acquires what he has studied are divided into forty-one practices. ${ }^{585}$ Of these, however, only twenty-three are included in the list of seventy-two types of learning. ${ }^{586}$

This together with the actual phrasing indicates that emphasis is not so much placed on content as on progress to the state of perfect wisdom. ${ }^{587}$ Typically, the forty-one methods begin by taking up one of the forms of learning and discuss its effect on the training. This becomes the basis of knowledge and leads to understanding arising from reflection (manasakära). Finally, having attained this type of understanding, the bodhisattva performs good conduct which announces bhävanā as the last and supreme condition of wisdom.

582. $A k n-t i k a \bar{a}$, p. $181.3 .2-3$

Statements underpinning the identity of cintā, yoniśo manasakāra and praveśa in their relationship to śruta are found at several places. In the $M s l$, we read that śruta and yoniśo manasakära are jointly required for the bodhisattva to enter into the 'character of the knowable' (jñeyalaksanapraveśa). Elsewhere we are told that at the moment when thought associated with correct reflection (yoniśomanasakārasamprayuktaka) —corresponding to right view (samyagdrsți) -is born, mental perception (manovijñäna) that has been impregnated with learning (śrutavāsanä) is being eradicated (Msg, p. 65). Both factors are thus closely united in operations that are directed at the acquisition of transcendental cognition (lokottaracitta) and co-function in a way reminiscent of the śruta/cintä interaction. Corroborating this interpretation, the Mpps (ii, p. 1110) underlines the conceptual proximity between manasakāra and cintämayi on the one hand, and its link with learning (śravana) on the other hand, by pointing to their combined presence in the schooling of the bodhisattva who penetrates the dharma-character (dharmalakșana).

583. $A k n-t i k \bar{a}, \mathrm{p} .183 .4 .3-4$.

584. R, folio 590.6

This very thought is also expressed in the $M s l$ (p. 7.3-4) that says that "on the basis of learning (śruta) correct reflection (yoniśo manasakāra) arises; from that reflection emerges a knowledge that has thusness (tattva) as its object".

585. In the $A k n$ (p. 51.1.6-2.7) we meet with a parallel list as far as context and title are concerned. Although professing to itemise the ways of penetrating correct reflection, it contains only thirty-two elements and shows an altogether different content. Unlike the $B d p$ that addresses a broad selection of aspects, including all six perfections, the bodhipakssika, veneration and dedication, the $A k n$ superimposes a distinctly cognitivemeditative orientation on its list. Virtually all of its members deal with mental penetration into seeing 'reality as it is' and neglect the more practical aspects by which this is brought about. These contemplative overtones led Vasubandhu to comment that, in the $A \mathrm{kn}$, the ways of penetrating correct reflection exemplify

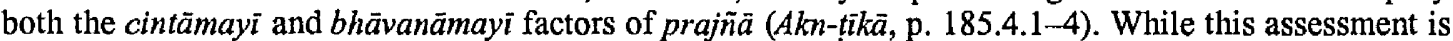
doubtlessly correct and fairly unproblematic for the $A k n$, in the $B d p$-as I shall show-the case is somewhat more ambiguous.

586. I have given a list of these items in note 13 of my translation.

587. Hedinger $(1984$, p. 53$)$ describes $b h \bar{a} v a n a \bar{a}$ as a generic term, subsuming all other meditative practices. He cites as evidence a passage from the Vism (pp. $101 \mathrm{ff}$ ) that draws up forty areas of application of bhāvanā and an alternative division of bhāvanä into stages that was proposed by Bhāvaviveka (Frauwallner, 1956, pp. $230 \mathrm{ff}$ ). Whatever the benefit of these, somewhat artificial, schemes, it is probably fair to say that to date the best and most coherent exposition of bhāvanā is still Kamalasila's account in the Bhävanäkrama $(M B T)$. On the different definitions of contemplation (bhāvanāa) in Sarvāstivāda thought, see: Kośa, iv, pp. 248-50; vi, pp. 283-88; vii, pp. 15-25, 49-54, 64-66. 
According to the $B d p$, bhävanāmayiprajñā manifests 'good conduct' (pratipatti). In content, however, it is purely cognitive and consists of transcendental, non-defiled (anāsrava) knowledge $(j \tilde{a} a n a) .{ }^{588}$ As the chief characteristic it bears a sound understanding of dharma ${ }^{589}$

I have found in several sources evidence that underpins this analogy between śruta, praveśa and pratipatti on the one hand and śrutamayi-, cintāmayī- and bhãvanāmayīprajña $\bar{a}$ on the other hand. To begin with, there is the commentary on the $A k n$ that speaks of passages in the $A k n$ that are similar to those in the $B d p$ as corresponding to śrutamayi-, cintämayi- and bhāvanāmayīprajñă ${ }^{590}$ The $A k n-t i k \bar{a}$ identifies quite explicitly the śruta and praveśa sections of the $A k n$ with the concepts of śrutamayi- and cintämayiprajña. There are however difficulties with regard to bhāvanāmayiprajñ $\bar{a}$. According to the commentary, 'wisdom arising from contemplation' is included in the $A \mathrm{kn}$ 's discussion of praveśa. In fact, the notion of pratipatti is altogether missing in the $A k n$. This raises the question as to whether pratipatti plays any part in the threefold scheme of wisdom or whether it is an independent 'wisdom practice'. In order to resolve this problem, we have to consider the following factors.

First, it is important to note that pratipatti is appended to the Bdp's exposition of praveśa. We have seen that pratipatti follows after the practice of śrutamayi- and cintämayiprajñ $\bar{a}$ and seemingly eclipses both in attainment. The wording of the $B d p$ leaves no doubt that it builds on the realisations of śruta and cintā and brings them to their logical conclusion. This matches the characterisation of bhävanämayiprajña in the Samdhis and is not incompatible with the explanation in the Kośa which assigns a temporary value to śrutamayi- and cintāmayīprajña $\bar{a}$. The variant interpretation in the $A k n-t i k \bar{a}$ could be explained by the absence of pratipatti in the Akn which compelled Vasubhandhu to account for all three types of

588. Satya-s (S), ii, pp. 485-88; Kośa, vi, pp. 143-44

For the $B b h$, the definition of wisdom is broader. That is to say, it distinguishes three central areas of attainments that add up to prajña. These are 'skill' in penetrating reality (i.e., realising that it is empty, without characteristic, etc.), 'skill' in the five classical sciences (vidhya $)$ and in three types of accumulation (i.e., benefiting, non-benefiting and neither ... nor ...) and 'skill' in benefiting sentient beings. Although listed as such only once, all three elements recur many times as the chief components throughout its discussion of prajīa $\bar{a}$ and are clearly central to its understanding of prajñäpäramitä (Bbh, pp. 212.10-213.1).

589. $\mathrm{R}$, folio $599.6-7$

This interpretation is wholly in line with the fruits that accrue to the practitioner in the Bhävanākrama. Citing a passage from the $S a m a \bar{d} h$, it proposes that pratipatti is central to the recognition of the unbornness of dharma (MBT, i, pp. 198-99). The reasoning that lies at the heart of the bodhisattva's insight of the non-origination of dharma springing from śruta and cintā is then spelled out by Kamalaśíla on pages 199-202 (§ 10).

According to the $M s l$, śrutamayi and cintämayīprajña are realised well before the bodhisattva has embarked on the path proper. That is to say, he attains them prior to the adhimukticaryābhümi. Bhāvanāmayīprajña in contrast, becomes manifest for the first time on the adhimukticaryäbhümi, but is still subject to refinement during the remaining stages (p. 75.12-15).

590. $A k n-t i \bar{k} \bar{a}, \mathrm{p} .185 .4 .1-7$ (translations of the relevant sections are given in my notes in chapter five). 
wisdom through śruta and cintā alone. That this caused difficulties is attested by the atypically convoluted style of explanation in his annotations on the sruta and praveśa sections.

Second, there is a passage in the Satyasiddhiśāstra where bhāvanāmayiprajñā is defined as 'practice in conformity with the Dharma which is applied in one's actions and in one's life' (dharmānudharmapratipatti). ${ }^{591}$ A similar connection is also made in the Bhävanākrama where pratipatti, echoing the interplay between means and wisdom, becomes the locus of the bodhisattva's cognition. ${ }^{592}$

Third, the Dighanikāya contains a passage that defines the factors of path-attainment (sotāpattyanga) as learning the good Dharma (saddhammasavana), correct reflection (yoniso manasakāra) and dhammānudhammapatipatti. ${ }^{593}$ These are the very components that are cited in the $B d p$. What is more, the attainments of the sotaāpanna consist in freedom from the view of individuality (sakkāyaditthi), freedom from doubt (vicikicchă) and observance of the precept and vow (silabbataparāmāsa) (with the last two being merely examples of wrong view (micchādtthi $))^{594}$ which are all linked with right view (sammaditthi) or wisdom (pañ̃ña).

Fourth, there is a section in the Bhāvanākrama that says that the cultivation of the three types of wisdom follows immediately after the practice of the five preliminary perfections. ${ }^{595}$ This is exactly the case in the Bdp. Although Kamalasilila does not cite his sources-and he may have been inspired by any text-the parallels to the scheme of the $B d p$ are obvious. ${ }^{596}$

Having completed its discussion of the three types of wisdom, the $B d p$ proceeds to describe the fruits that spring from the practice of learning, reflection and contemplation. Summed up

591. Satya (S), ii, p. 486 (cf. Geiger, Pãli Dhamma, Munich, 1921, pp. 115-6)

Note also in this connection the integration of śruta and pratipatti. On this, the $V k n$ says, in one place, that "bodhi is the seat of learning (śruta) because it consolidates religious practice (pratipatti)" while it affirms elsewhere that "skill in learning results from practice" (pp. 97, 109 respectively). On the role and interaction of learning and religious practice, see: Rahula, History of Buddhism in Celyon, Colombo, 1956, pp. 158-9 and Manorathapürani $(i, p .93)$ which sums up the reasons for the preference that was given historically to learning in Theravāda communities.

592. $M B T$, ii, pp. 222.4-223.5.

593. D III, p. 227 (the fourth factor, "association with good persons" (sappurisasamvesa), is cited at a later place in the $B d p$ ).

594. For references to the samyojana, see: M I, p. 9; S V, p. 12; for the explanation that doubt and lack of vow observance are nothing but manifestations of wrong view, see: Dhs, pp. 75-80, 182-3 (ref. Gethin).

595. $M B T$, ii, p. 198.4-8

According to $D P P$, p. 20 , the generation of the three types of wisdom is an essential feature of the sambhäramärga. As I shall demonstrate, this is exactly the path-phase we are concerned with at present.

596. Of interest in this context is also the picture that is given to the conditions of wisdom in the $B b h$. Apart from the customary factors of learning and reflection, it speaks of a power of careful consideration (pratisamkhyänabala) and a power of contemplation (bhävanäbala). The former is said to determine the bodhisattva's conduct in the world - promoting virtue and preventing mistakes-while the latter establishes him in infinite wisdom of the stage of uniformity (samăhitabhümika), being the eighth stage (Bbh, p. 213.8-14). 
as 'correct vision' (yoniśo drști), these revolve around dharma cognition. Although not explicitly stated, the context indicates that this particular type of vision is founded on mindfulness concerning dharma (dharmasmrtyupasthāna). For, dharmasmrtyupasthāna-whose practice subsumes the other three smrtyupasthāna and corresponds to insight (vipaśyanāa ${ }^{597}$-is decisive to the perception of dharma. ${ }^{598}$ Specifically counteracting the misconception of the self (ätmaviparyāsa) (but in Mahāyāna treatises generally extended to include the empty and uniform nature of dharma ${ }^{599}$ ) dharmasmrtyupasthāna is intimately bound up with prajñā, itself defined as Dharma-discernment (dharmapravicaya). ${ }^{600}$

At this early stage of the path insight arising from mindfulness of dharma is still hampered by the presence of natural defilements (räga, moha, dvesa) and certain weak types of misconception (viparyāsa). Of inferior quality when practised on the sambhāramārga $a^{601}$, the resulting Dharma-discernment is therefore imperfect and extends only to the particular and general characteristics (svasämänyalakșana) of things. ${ }^{602}$ However incomplete, it enables the bodhisattva of the $B d p$ to distinguish between virtuous and non-virtuous dharma. ${ }^{603}$ This faculty of differentiation is of crucial importance to the completion of the sambhāramārga. First, on the level of day to day conduct, it allows the bodhisattva to re-focus his efforts in accordance with his purified intention. For this re-evaluation to take place the bodhisattva engages in deep meditation in order to attain the light of wisdom (prajñäloka)-an indispensable factor for experiencing reality directly. ${ }^{604}$ Second, in the long-term, recognition of virtue is necessarily a precondition for the planting of the roots of virtue that lead to deliverance (mokșabhāgìya kuśalamüla). As their accumulation lies at the very heart of the training on the sambhāramārga, adherence to kuśaladharma and abandoning of akuśaladharma assumes immense importance. ${ }^{605}$

597. Satya-s (S), p. 448; Gethin, 1987, p. 634.

598. Kośa, vi, p. 159; Abhidh-d, p. 360.5-11; Nett, pp. 83-84.

599. Rcd, p. 238.3.7-4.5; Mppś, ii, pp. 1193-4 (cf. pp. 1167-1169).

600. Abhidh-sam (R), p. 8; Mppś, ii, p. 1046; Kośa iv, p. 283.

601. $H I B$, p. 612; Kośa, vi, pp. 158-159.

602. Kośa, vi, pp. 159-162.

603. R, folio 601.4 .

604. $M B T$, ii, p. $204.13-15$.

605. $\mathrm{R}$, folio $601.4-5$

The $B d p$ does not give any detail on how the moksabhägīya are planted during the sambhäramārga. According to Lamotte, the bodhisattva overcomes desire within himself by practising the moral precepts that secure him a place in the lineage of the noble ones (āryavamsia). That is to say, he learns to be content with few clothes (cìvara), almsfood (pindapäta) and humble seating (śayanāsana), he delights in nirvāna and the path that leads to it. Then, meditating on the repulsive aspects of life (aśubhabhävanāa), the bodhisattva engages in breathing exercises (änäpänasmrti) that allow him to focus on the eradication of desire and distraction and thereby prepare him to enter into the smrtyupasthāna (HIB, p. 613). For 
When the bodhisattva has thus identified dharma according to their general features and accumulated roots of virtue, he embarks on the prayogamārga and enters into meditation in order to penetrate true reality. ${ }^{606}$ In the scheme of the $B d p$, he undertakes initially to free himself from those obstructions (ävarana) that threaten to impede his practice. ${ }^{607}$ Following the ancient path model, he achieves this goal through the four perfect efforts (samyakprahäna). The practice of the perfect efforts takes place immediately after the smrtyupasthanna ${ }^{608}$ and signals the bodhisattva's entrance into the path of application at the mürdhan level of the nirvedhabhāgĩya. ${ }^{609}$ The function of the samyakprahäna is twofold; to cultivate skilfull dharma and to abandon gross obstacles that impede the unfolding of perfect wisdom. Since the $B d p$ does not specify which obstructions are overcome through the samyakprahana at this stage, it is difficult to ascertain on textual grounds alone whether it refers exclusively to the kleśāvarana or also includes the jñeyāvarana. But according to general opinion it is only the obstructions of the defilements that are addressed here. ${ }^{610}$ Their elimination prepares for the transition from the worldly (laukika) to the transcendental path (lokottaramārga), which is heralded by the attainment of right view (samyagdrsțiti) doctrine (dharmālokamukha). ${ }^{612}$

The acquisition of right view is dependent on two causes. First, the bodhisattva must learn

canonical references, see: D III, p. 224; A II, p. 27; otherwise: Kośa vi, pp. 146-153.

606. At this stage, we find in most texts references to the four nirvedhabhägiya, that is usmagata-, mürdhan-, ksänti- and laukikägradharma (e.g., Abhidh-sam (R), pp. 105-6; Kośa, vi, pp. 169-72). As the nirvedhabhāgiya are said to spring from bhävana - a practice that is not explicitly mentioned in the $B d p$ alongside śrutamayí- and cintämayiprajñ $\bar{a}$ - it is perhaps not surprising that they are not given in this context.

607. $\mathrm{R}$, folio $602.5-7$.

608. Some of the most important schemes have been conveniently tabulated by Gethin (1987, pp. 637-639). Note that to the Theravāda tradition, the generation of the sammappadhāna forms part of the transcendental path (Vism, xxii, p. 35) while in path schemes of the Sarvāstivāda it belongs to the laukika realm (Kosia, vi, p. 287).

609. Abhidh-d, p. 362.14-15; Kośa, vi, p. 287.

610. Virtually all texts agree that both types of avarana are not eliminated before the practitioner embarks on the transcendental path. For sūtras, see: Rcd, p. 239.4.3-5.8; for śästras, see: $M v s ́(N)$, pp. 53.13-55.5; Abhidh-sam (R), pp. 118-24; $S$ rāv-bh (Sh), pp. 236-7; MBT, ii, pp. 214.23-7, 217.9-15.

611. A comparison with the Sarvāstiväda path model reveals that these accomplishments, revolving around on the notion of right vision (samyagdr!stit), correspond to the insights that are associated with the darśanamärga. However, rejecting the axioms that lie at the heart of Sarvāstivăda psychology, the $B d p$ does not associate right seeing with the gradual comprehension (anupürvābhisamaya) of the sixteen thought-moments that pertain to vision of the four noble truths (Kośa, vi, pp. 184-193).

The structure of the path model and the prefix a rya (presumably identifying it as the first fruit of the path that, according to the Kośa (vi, p. vi) takes place during the first moment of the bhävanämärga indicating stream-entry) leave little doubt that we are dealing here with the lokottara aspect of samyagdrstit. Reserved to either the darśanamärga or bhävanämārga (depending which sources one chooses to follow, the eightfold path can manifest itself on either of them) its presence here is a further indication that we have reached the lokottara level of the path.

612. $\mathrm{R}$, folio $604.1-3$. 
to listen to other people's statements. ${ }^{613}$ Recognising the danger of pride to those who are isolated from the Dharma the $B d p$ regards congenial listening to the words of others as a factor stimulating liberation by itself. ${ }^{614}$ Second, the bodhisattva has to reflect correctly on the contents of what he has heard. Since failure to do so inevitably leads to misconduct on the path, the $B d p$ places correct reflection and listening to other people's statements on the prayogamārga. ${ }^{615}$ As a methodological prerequisite, śruta and cintā are not restricted to the path of equipment, but also figure also on the path of application.

Having dealt with methodology, the $B d p$ defines the actual contents of prayogamārga. Perhaps in numerical analogy to the nirvedhabhāgìya, it gives as its principal components correct practice (yoniśo prayoga), correct vision (yoniśo drsți), correct penetration (yoniśo praveśa) and correct speech (yoniśo vāc). ${ }^{616}$ Of these four, correct practice and penetration serve as causes to the attainment of samyagdrsțti, while correct vision and speech represent its conditions.

613. This concept is not new to the Mahāyăna but occurs already in the nikãya as the two conditions bringing about right view (M I, p. 294; A I, p. 87). Both factors are fundamental to a correct perception of the Dharma and in conjunction with wisdom arising from learning, reflection and contemplation stand at the very core of a monk's cognitive progress. This point is fully scrutinised in the Nett (p. 8, trsl. Gethin):

"The teacher or a fellow practitioner in the position of a teacher teaches someone Dhamma. Having heard this Dhamma he gains confidence. Therein, whatever is investigation, energy, consideration, examination, this is wisdom produced by hearing. Whatever is investigation, consideration, examination, contemplation in dependence on what is thus heard, this is wisdom produced by reflection. The knowledge that arises at the stage of seeing or the stage of development for one engaged in bringing to mind by means of these two kinds of wisdom is wisdom produced by development. From the utterance of another there is wisdom produced by hearing; from appropriate bringing to mind undertaken individually there is wisdom produced by reflection; the knowledge that arises both as a result of the utterance of another and as a result of appropriate bringing to mind undertaken individually is wisdom produced by development."

In the Mahāyana, the role of these two factors became integrated into the respective visions of the path. For Yogācāra followers, statements of others (parataś ca ghosali) and correct inner reflection (adhyātman ca yoniśah manasakärah) - being also the cause to right view-perfume (bhävayanti) either knowledge springing from learning (śrotavijñanna), mental perception (manovijñäna) or both. In due course, at the arising of correct reflection, both types of knowledge vanish and are replaced by lokottara thinking pertaining to right view and leading to transcendental purification (Msg, p. 65).

A rather different interpretation of the term parato ghoso was introduced by Peter Masefield. According to Masefield (1986, p. 50), parato ghoso does not refer so much to the worldly realm of instructions from teachers, but is an expression indicating a channel of communication between the beyond and religious experience. Translating it as 'sound from the beyond', Masefield suggests that this type of transcendental sound is channelled to the sravvaka only by the Buddha (and his closest followers), implying that right view or religious truth is wholly dependent on the disclosure of this sound for unfolding. This interpretation of the term parato ghoso has been disputed, not least because it fails to take account of several other contexts where it quite clearly does not carry this metaphysical connotation. For a discussion, see: Gethin, 1987 , pp. 424-25.

614. R, folio 604.7 .

615. By placing the focus on sravana and yoniśo manasakāra as factors promoting right view, the $B d p$ underlines once again its conceptual proximity to a proposition in the Mpps (ii, p. 1110) according to which it is these two elements that have greatest bearing on the generation of wisdom.

616. $\mathrm{R}$, folio $606.5,606.6,608.7,610.1$ respectively. 
In the true spirit of Mahāyāna ontology, the $B d p$ states that correct practice is based on recognition of the sameness of all dharma. Thus, if fully accomplished, correct practice does not manifest any verbal or physical activity but unfolds in non-practice. ${ }^{617}$ Conceived as practice free from obstruction, doubt or predication, it steadies the roots of virtue accumulated on the sambhāramärga and brings their development to a high-point-an event close to the mürdhan phase of the nirvedhabhāgīya. ${ }^{618} \mathrm{Next}$, as if to mirror the arrangement at the beginning of the chapter where yoniso darśana followed on śruta, yoniśo manasakāra and pratipatti, the $B d p$ specifies the concept of 'vision of all dharma' ${ }^{619}$ Above all, this constitutes insight into dharma-sameness. ${ }^{620}$ Then, taking up the notion sarvadharmasamatā, the $B d p$ develops a vision of reality that-sustained by the conviction of the non-arising of dharma-precludes dharma-predication of any kind and effects withdrawal from path-activity. ${ }^{621}$ Once again, it is possible to see parallels to the nirvedhabhägiya scheme. For a bodhisattva who enters into its first phase, called usmagata, reality loses much of its 'true objectivity' as he begins to grasp (albeit only incompletely at his early stage) the empty and non-existent character (svabhāva) of external worldly phenomena. ${ }^{622}$

While the notions of correct practice and correct seeing are well expounded, their mutual relationship is unclear. Echoing conventional perception that practice (prayoga) precedes seeing (darśana), correct seeing is said to be based on correct practice. ${ }^{623}$ However, since correct practice becoming non-practice presupposes recognition of dharma-sameness-the very foundation of correct seeing-one cannot help but to conclude that practice and seeing are supportive of each other.

As if to accentuate this reciprocity, in correct penetration and speech the order of their relationship is reversed. That is to say, by proposing that penetration constitutes the basis of correct speech, the cognitive element is placed ahead of the practical aspect and becomes

617. R, folio 605.7 .

618. $D P P$, p. 35 .

619. $\mathrm{R}$, folio 601.3 .

620. $R$, folio 612.4-6.

621. R, folio $607.3-608.2$

This section, being repeated almost verbatim at a later stage, is of considerable importance for the understanding of the argument, since it indicates that correct practice/correct vision and correct penetration/correct speech have equal influence on the bodhisattva's cognition. That is to say, both enable him to see dharma in accordance with reality, to attain non-seeing, and finally to enter into the certainty of truth.

622. Siddhi, pp. 578-9.

623. See, for instance: $R$, folio $606.5,612.5$. 
essential to its occurrence. ${ }^{624}$

Correct penetration consists of two important components. ${ }^{625}$ First, there is the cognitive element that allows the bodhisattva to penetrate phenomenal existence. This springs from perfect mental quietude (śamatha), insight (vipaśyanā) and discrimination (vikalpa) ${ }^{626}$, and unfolds before the bodhisattva's eyes a world that is impermanent, dependently originating, empty, signless and wishless. Yet, by virtue of his commitment to universal welfare-the second element of penetration - this newly won understanding, although alone sufficient to guarantee entry into nirvāna, does not tempt him to abandon samsāra. ${ }^{627}$ On the contrary, he assumes rebirth in the kāmadhätu, cherishes the Doctrine, develops compassion and cultivates skilful means. ${ }^{628}$ Accommodating in equal measure cognition and compassion, correct penetration is thus perfectly balanced.

If this binary disposition is juxtaposed to the nirvedhabhāgiya, parallels to the kșānti phase immediately spring to mind. At this stage, having shed all misconception concerning the self (as subject) and dharma (as object) of perception, the bodhisattva is no longer subject to low rebirths; yet he continues his endeavour for deeper understanding and greater welfare in the world. This postponement, that involves trusting accepting the validity of the noble truths without further scrutiny, constitutes an important crossroad, since it determines the practitioner's allocation to the gotra of the srāvaka, pratyekabuddhas or buddhas. ${ }^{629}$

The fourth constituent, correct speech, is acquired through the interplay of the factors that prepare right vision (samyagdrștit). Presumably it is selected for its dual function; reflecting personal maturity and representing the principal means of conversion, correct speech is described as congenial, well-founded and in perfect harmony with true reality. By characterising

624. R, folio 608.6-7.

625. Compare these with the four components of the nirvedhabhägiya (Abhidh-sam (R), p. 105; Kosia, vi, pp. 169-178).

626. R, folio 608.7-609.1

Samatha and vipasyana are of key importance to the psychological processes that mark prayoga cognition-and indeed beyond. While samatha has already occurred on the sambhäramärga, its impact is still felt on the path of application as its fruit becomes manifest on the prayogamārga. Vipaśyana $\bar{a}$ in contrast, representing the bodhisattva's cognitive faculties, although directed at the very same vision of reality does not arise prior to the path of application (DPP, p. 34). Most sources agree, however, that beyond the early path phases, śamatha and vipaśyana operate as a syzygy. Constituting the perfect path if practised jointly, they are best understood as one-pointedness of mind (cittaikägratä) observing the nine stations of mind (cittasthiti) and exact analytical investigation of reality (bhütapratyvekșa $),(M B T, \mathrm{iii}, \mathrm{p} .3$; $S r a \bar{v}-b h$, pp. 363-5). For their manifestations on the lokottara consciousness, see; Msg, pp. 167, 171. Their role on the laukikamärga during the four basic dhyāna is explained in: $M B T$, iii, pp. 15-17.

627. R, folio $609.1-4$.

628. R, folio 609.7-610.1.

629. Kośa, vi, p. 175. 
correct speech as speech of reality and truth, the $B d p$ inspires once again a comparison with the nirvedhabhägìya model where the last phase, called laukikāgradharma, is marked by the direct perception of the characteristics of the noble truths. ${ }^{630}$ As in the $B d p$, this attainment is based on the four pratisarana. It issues from unobstructed meditation (änantaryasamādhi) but still within the laukika domain and prevails independently of sense perception. ${ }^{631}$ Confirming the laukika status, the $B d p$ says that at this stage, even if the bodhisattva is accomplished in penetration and speech, his vision lacks clear insight (vidarśana) and he is still subject to discursive thinking (vikalpa) like ordinary beings. ${ }^{632}$

To rid himself of the residues of mistaken mental apperception, the bodhisattva embarks on the darśanamärga. Heralding entry in the lokottara phase of the path ${ }^{633}$, it consists of a series of thought moments no longer concerned with the general characteristics of dharma, but with the four noble truths.

In the $B d p$, entry into this path-phase is announced by stating that persons who accomplish either correct practice and correct vision or correct penetration and correct speech are assured of the prospect of vision of dharma. As already implied, this type of vision is transcendental by nature and echoes the conviction of the non-arising of dharma: ${ }^{634}$

"What is looking at all dharma in accordance with reality? It is non-seeing. Non-seeing is an expression for unborn. Unborn is an expression for unarisen. What is unarisen? It is an expression for invisibility."

For the $B d p$, correct vision is not specifically linked with the abandoning (prahāna) of defilements or with patience (kșānti) and knowledge (jñāna) concerning the noble truths ${ }^{635}$, but it accrues from right vision (samyagdrstiti) for those who penetrate the sameness of practices and attainment. Yet, the fundamental psychological experience that marks the progress through the thought-moments of the darsanamärga follows the Abhidharma accounts rather

630. Siddhi, pp. 575,$581 ;$ DPP, p. 36.

631. Siddhi, pp. 578, 581-3.

632. $\mathrm{R}$, folio $611.4,608.7-609.1$

The presence of vikalpa would suggest that the bodhisattva has not yet reached the darśanamärga, but dwells still on the prayogamārga .

633. Kośa, vi, p. 290; Abhidh-d, p. 362; Amrtar (B), p. 74; Abhidh-sam (R), p. 107. For a discussion of the various types of darsanamārga, that is the tattvadarśanamārga-a path that is characterised by nondiscursive knowledge (nirvikalpakajñanna) - and the two categories of the lakșanamärga, that is avyavasthitasatyadarśanamārga or the vyavasthitasatyadarśanamärga, see: Siddhi, pp. 588-600.

634. R, folio 607.5-7.

635. Kośa, vi, p. 183. 
closely. The $B d p$ describes a vision of reality where the practitioner sheds all misconceptions (viparyāsa), especially the view of individuality (satkāyadrștit) ${ }^{636}$, and acquires a direct comprehension (abhisamaya) of conditioned reality. ${ }^{637}$ His wisdom becomes unobstructed (anäsrava) and he identifies the general characteristics of dharma. He realises that the nature of dharma is impure and yet congruent with nirvāna, that dharma are (like persons) without self and utterly indistinguishable. ${ }^{638}$ In spite of the removal of all tendencies to passion (anuśaya) and understanding conditioned existence, he is still subject to the laws of samsāra since the path of vision-merely eliminating those defilements abandoned by seeing-leaves countless innate defilements (sahajakleśa) untouched.

In order to eliminate these, the bodhisattva embarks on the next path-phase-the path of contemplation (bhāvanämärga) ${ }^{639}$ The moment of entry into the bhāvanāmärga marks a critical threshold in the bodhisattva's career-stages. For, immediately on entry the bodhisattva penetrates the certainty of truth (samyaktvaniyämāvakrānti) - the first fruit of religious life (śrämanyaphala) - that guarantees irreversible progression to liberation. ${ }^{640}$ As this attainment, drawing on cognition acquired during the first fifteen thought-moments of darśanamārga, marks admission into the fold of noble persons (äryapudgala), ${ }^{641}$ it is the clearest indication yet that the $B d p$ 's bodhisattva has advanced to the transcendental domain. ${ }^{642}$ The exact entry-level, however, is left undetermined, since (at least among the srāvaka) penetration into the certainty of truth may lead to a variety of spiritual conditions, depending on the degree of

636. R, folio 613.3, folio 613.7-614.1.

637. The various types of direct comprehension (abhisamaya) that occur on the darśanamärga are discussed in the Siddhi (pp. 601-605).

638. R, folio $612.2-6$.

639. Kośa, vi, p. 257.

640. This is the view of the Sarvāstivāda and Theravāda school (Bareau, 1955, pp. 140, 212). Mahäsanghika and Mahīsāsaka sources refute the notion of the irreversibility of the śrotaāpanna (Bareau, 1955, pp. 66, 185).

641. Abhidh-sam (R), p. 152; Kośa, vi, p. 182.

642. $\mathrm{R}$, folio 607.3 , folio $608.1-3$

Besides the lokottara bhävanämärga, which is the standard level of cultivation (tracing the career of the sotaāpanna, sakṛdāgāmin and anāgāmin), the texts speak also of a laukika bhävanämārga. This path is impure and inferior to its lokottara counterpart as it does not progress through 'reflection on the nature of things' (tattvamanasakära) and the person on it fails to grasp the general characteristics of dharma. But it has still considerable preparatory value as the Buddha has demonstrated. Being an ordinary person when he approached the Bodhi-tree, the Buddha had previously eradicated all innate passions of the world by laukika meditation. All that was left to him therefore was to comprehend the four noble truths in their sixteen aspects and to destroy a set of nine innate passions linked with the naivasamjñäyatana and bhavāgra that he could not eradicate on the laukika bhāvanāmārga level (for explanation of this restriction, see: Kośa, vi, p. 233). Applying to each of them the prahānamārga and vimuktimärga thought, he then reached bodhi in thirty-four thought-moments (Kosia, ii, p. 206; vi, p. 177). The problem with the attainment of the fruits of the laukika bhävanämārga is that its disconnection from the kleśa is only temporary (Kosia, vi, p. 233) and leads, unless carried further, only to rebirth among the Brahmā gods. (For further detail, see: $H I B$, pp. 617-8; Kośa, vi, pp. ix-xi; Abhidh-sam (R), pp. 110-113). 
residual attachment. ${ }^{643}$ For the $B d p$ the proposition of non-regression would seem to indicate that its location on the path is rather more advanced, since true irreversibility does not occur before the eighth stage. ${ }^{644}$

Having introduced the bhāvanāmärga, the $B d p$ spells out the attainments that accrue through repeated meditation (punah punarāmukhïkarana). The bhāvanāmārga of the bodhisattva, agreeing in content with the srāvaka model, is characterised primarily by the destruction of hitherto intact defilements. Based on wisdom and affecting innate defilements in the käma-, rüpa- and arüpyadhātu, the bodhisattva is no longer linked with any conditioned dharma, but permanently emancipated from the fetters of worldly phenomena. ${ }^{645} \mathrm{He}$ has dispelled practically all obstacles constituted by defilement (kleśāvarana) including adventitious bonds ${ }^{646}$ and rises above conditioned activity to pursue his career beyond the parameter of good and evil: ${ }^{647}$

"He is emancipated from the eight worldly conditions. He is emancipated from the twenty secondary defilements including self-conceit, grave conceit and perverted conceit. ... He is emancipated from all lowly and wicked dharma. He is emancipated from the activity of all evil, including contentious and defiled activity, activity of the aggregates, activity of the lord of death and activity of the Evil One ... He is emancipated from avarice and generosity, morality and immorality, patience and malice, vigour and indolence, meditation and disquietude, wisdom and folly, furtherance and impediments of the perfections, knowledge and nescience."

Prepared now by the destruction of the defilements through direct comprehension, he gradually eliminates the obstacles to knowledge (jñeyāvarana) ${ }^{648}$ Having cast aside all heterodox views based on the belief of the self, he relinquishes discursive thinking and rejects the dichotomies of classification: ${ }^{649}$

643. The actual entry level is determined by the degree to which he has eliminated the concomitants of desire. For details, see: Abhidh-sam (R), p. 152.

644. Daśa-bh, p. 71.12; Bbh, p. 290.21 (cf. p. 235.18); $M s l$, p. 176.22; $M v u$, i, pp. 1.3, 63.13-14.

645. R, folio 613.4.

646. $\mathrm{R}$, folio $613.5,614.2$.

647. R, folio 614.3-6.

648. Siddhi, pp. 610-11.

649. $\mathrm{R}$, folio $614.3-7$. 
"He is emancipated from all multiplicity, including multiplicity of buddha-fields, buddhas, sentient beings and dharma. He is emancipated from conditioned reflection of all sentient beings, including nescience, knowledge, discursive insight, conventional and absolute truth. He is emancipated from the bases of all reflection, thought and consciousness; including perseverance [in] formlessness, signlessness, causelessness and unconditioned wisdom."

While not very different in meaning and content from the bhāvanāmārga of the srāvaka, there is divergence on the factors that prompt its attainment. For the śrāvaka, the bhävanämārga represents the abandonment of defilements through the vision of the noble truths. ${ }^{650}$ As we have seen, in the $B d p$ the bodhisattva's rejection of conditioned existence is not so much due to the systematic analysis of the noble truths, as by recognition of the sameness of dharma through Perfect Wisdom. ${ }^{651}$

\section{Perfect Wisdom and Skill}

With the end of the bhāvanämärga section we have come to an important break in the $B d p$ 's exposition of prajñāpāramitã. So far, much of chapter eleven followed the ancient model of the śrāvaka career. In the remainder of the chapter (which constitutes approximately seventy-five percent of its overall length) the scheme of progress is not immediately evident. That is to say, although not without a sense of order-all but three out of eighteen subsections show clear traits of systematic arrangement-no principle emerges that would establish an overall connection between the various practices. For this we shall have to turn to other treatises on the bodhisattva.

The content of this section is defined by eighteen types of 'skill'. Through the practice of 'skill' the bodhisattva attains an increasingly refined understanding of reality that culminates eventually in the acquisition of wisdom. The various types of 'skill' indicate the practices that play a role in this process. They include, for example, the pratisarana, pratisamvid, bodhipākșika dharma, samatha and vipaśyanā and punya- and jīānasambhära. The overriding

650. DPP, pp. 24-6; Abhidh-sam (R), pp. 110-17.

651. Cf. $D P P$, pp. $41-2$. 
purpose of these practices, and therefore also the purpose of 'skill', is to investigate the nature of reality. This investigation manifests different points of emphasis and proceeds from various angles, depending on the nature of the individual practices. 'Skill' in skandha, dhātu, àyatana and satya, for instance, aims to destroy the belief in a self (ātmadrști), whereas 'skill' in vipaśyanä is designed to reveal to the bodhisattva the non-existence of dharma (dharmanairātmya).

In spite of this topical fragmentation, all eighteen 'skills' share the same objective, namely, the attainment of wisdom. In the $B d p$, wisdom is defined as 'skill' in all dharma. The method by which such 'skill' is acquired is called 'discerning wisdom' (prajñäpravicaya) and comprises all the practices that are included in the various types of 'skill'. ${ }^{652}$ In essence, 'skill' represents therefore the means of investigation through which the bodhisattva accomplishes Perfect Wisdom. ${ }^{653}$

The practice of 'skill' (kausalya) is not particular to the Bdp but is found in numerous treatises on the path. It occurs in the Akn, Dbh, Lkdh, Prn, Rtm, Samdhis, Bbh, Srotabhümi, $S b h$, Prbh, Mvs and Vism. ${ }^{654}$ Although there is some overlapping in contents between the 652. R, folio $615.5-7$

Already in the nikāya, we note a close connection between discernment (usually Dharma-discernment) and wisdom (M III, p. 85; S V, p. 111). Taken up by the abhidhamma literature (Dhs, p. 11), it developed into one of the chief characteristics of wisdom to appear besides the traditional factors of "knowledge of the destruction of the impurities' (äsravakșayajñāna) and 'knowledge of their non-arising' (anutpädajñäna); e.g., Kośa, vi, p. 240; Siddhi, p. 313; MBT, iii, pp. 14-15. See also, Mpps, ii, pp. 1101-1104.

653. Note that this interpretation is at odds with the explanation of 'skill' in the $A k n-t i t k \bar{a}$ (pp. 194.5.5-195.1.2). Here, we read that 'skill' is not so much a tool of investigation as a designator of the objects (älambana) or things (vastu) to be understood by wisdom.

654. The $B b h$ (pp. 308.9-309.6) distinguishes ten kinds of 'skill'. These are (1) 'skill' in means in order to remove hostility in angry beings, (2) 'skill' causing ordinary beings to enter (the path), (3) 'skill' causing beings who have entered (the path) to ripen, (4) 'skill' in delivering sentient beings who have been ripened, (5) 'skill' in worldly śăstras, (6) 'skill' in discerning the arising of mistaken observance in moral conduct of commitments, (7) 'skill' in the unsurpassed resolve, (8) 'skill' in the Srāvakayāna, (9) 'skill' in the Pratyekabuddhayāna, (10) 'skill' in the Mahāyāna. Altogether, these produce the five cardinal actions of a bodhisattva. By the first four types of 'skill', the bodhisattva achieves his own benefit and that of his fellow beings. The fifth 'skill' renders him invincible. The sixth 'skill' establishes him in the vow-observance. By the seventh type of 'skill' he accomplishes all future objectives and by the eighth, ninth and tenth types of 'skill', the bodhisattva teaches the Dharma in accordance with the faculties, lineages and resolutions of the people whom he tries to convert. These objectives are clearly quite different from those postulated in the $M v s$ or $B d p$ and do not appear to be connected to their types of 'skill'.

Compare these lists with the rather different enumeration that is found in the Ratnameghasutra $(35, \mathrm{p}$. 182.5.1-3), distinguishing the following ten kinds of 'skill' of bodhisattvas: (1) 'skill' in the non-existence of a self (anātman), (2) 'skill' in the ripening of deeds (karmavipäka), (3) 'skill' in the conditioned (samskrta), (4) 'skill' in the flow of existence (samsärasantana), (5) 'skill' in the transitoriness of existence (samsăranivrtta), (6) 'skill' in the Srāvakayăna, (7) 'skill' in the Pratyekabuddhayāna, (8) 'skill' in the Mahāyāna, (9) 'skill' in refraining from evil deeds (mãrakarmatyāga), (10) 'skill' in non-regressing wisdom (anirvrttaprajñā). An alternative sixfold list is given in the Samdhis (pp. 116.15-119.4), distinguishing (1) 'skill' in the production of the thought, (2) 'skill' in the duration of thought, (3) 'skill' in the destruction of thought, (4) 'skill' in the increase of thought, (5) 'skill' in the decrease of thought, (6) 'skill' in means.

The Vism (pp. 128-136) lists ten kinds of 'skill' in absorption (appanākosalla). These include (1) 'skill' in 
various expositions of 'skill', I have not discovered two lists that match exactly. In most texts, the purpose of the enumations of 'skill' is mainly organisational, that is, to break up the (bodhisattva) practice into smaller units in order to make the discussion more managable. The topics that are included in the discussions of 'skill' vary greatly, ranging from very general themes (such as 'skill' in the three vehicles) over specific bodhisattva practices (such as 'skill' in liberating sentient beings) to practices of cognition (such as 'skill' in the nonexistence of a self). In spite of this diversity there are some types of 'skill' that appear in most lists. Above all, these are 'skill' in skandha, dhātu, āyatana, satya and pratītyasamutpāda. These five 'skills' figure in the Bdp, Akn, Prn and in all commentarial discussions of 'skill'. Generally, they occurr in the order in which I have cited them and stand at the beginning of the exposition of 'skill'. The factor that ties these five types of 'skill' together is that all of them deal with cognition and introduce the practitioner to the futility of the belief in a self. They are included in sections that discuss the nature of reality or form a part of the expositions of wisdom (prajñā) and knowledge (jñāna).

This applies also to the $B d p$. In addition to the 'skills' of skandha, dhātu, àyatana, satya and pratityasamutpāda the $B d p$ includes in its exposition of prajñ $\bar{a}$ 'skill' in pratisamvid, pratisaraṇa, punyasambhāra and jñänasambhāra, smrtyupasthāna, bodhyañga, āryāșțāigamārga, śamatha and vipaśyanā, samyakprahāna, indriya, bala, ekayānamārga and dharma. 'Skill' in each of these practices contributes to the attainment of wisdom. While the content of the practices follows mostly well-established traditions of thought, the exact use to which they are put in the $B d p$ is less obvious. As the text itself contains practically no clues that would explain their role in the training of wisdom I have turned for explication to exegetical writings.

The most instructive account of the practice of 'skill' is found in the Madhyāntavibhäga. In chapter three, entitled 'Tattvaparipṛcchā', the Madhyāntavibhāga discusses 'skill' in skandha, dhātu, āyatana, pratītyasamutpāda, sthānāsthāna, indriya, adhvan, satya, yāna and samskrtāsamskrita dharma. ${ }^{655}$ According to the commentary, all ten types of 'skill' contribute

cleansing the basis, (2) 'skill' in maintaining balanced faculties, (3) 'skill' in the sign, (4) 'skill' in timely exertion, (5) 'skill' in timely restraint, (6) 'skill' in timely encouragement, (7) 'skill' in timely equipoise, (8) 'skill' in avoiding poorly concentrated persons, (9) 'skill' in cultivating concentrated persons, (10) 'skill' in resoluteness upon concentration. These form part of the general description of the development of samädhi, as they serve to describe the general mental and physical attitudes conducive to concentration and do not appear not to be related to the ten 'skills' cited in the $B d p, R t m, M v s$ or $B b h$.

655. $M v \dot{s}(N)$, pp. $44-49$.

Note that with the eight types of 'skill' of the $A k n$ the $M v s$ shares all but two kinds, viz., 'skill' in the inevitable/impossible and 'skill' in faculties. These are exactly the two items by which the list in the $M v \dot{s}$ 
to the destruction of the belief in a self (ätmadrsți) and have important bearing on the understanding of reality. ${ }^{656}$ Each of the 'skills' addresses one particular aspect of the belief in a self. The $M v s$ reduces the belief in a self to ten component parts. In an order corresponding to the ten 'skills' these are: (1) the illusion of oneness (ekatvagrāha); (2) the illusion of causality (hetutvagrāha); (3) the illusion of the experiencer (bhoktrtvagrāha); (4) the illusion of the agent (kartrtvagrāha); (5) the illusion of independent action (svatantragrāha); (6) the illusion of dominion (adhipatitvagrāha); (7) the illusion of permanence (nityatvagrāha); (8) the illusion of the support of defilement and purity (samkliștavyavadānatvagrāha); (9) the illusion of the meditator (yogitvagrāha); (10) the illusion of an entity that is either released or bound (amuktamuktatvagrāha). ${ }^{657}$ Of these ten illusions, number 1, 2, 3, 4, 8 and 10 are relevant to our study of the $B d p$ since they are destroyed through forms of 'skill' that are also found in the $B d p$. They are 'skill' in skandha, dhätu, āyatana, pratītyasamutpāda, satya and samskṛtäsamskṛta dharma. ${ }^{658}$

According to the $M v s^{\prime}$, 'skill' in aggregates prevents the bodhisattva from falling prey to the view that there exists a single reality-an atman-in the five skandha. ${ }^{659}$ The $A k n-t i \bar{l} k \bar{a}$, commenting on a parallel passage in the $A k n$, corroborates this view through a list of examples that illustrate the empty, non-substantial nature of the aggregates. ${ }^{660}$ Like the $B d p$, in order to broaden its explanation, the $M v s$ peruses the aggregates in relation to the world and draws the conclusion that it also shares the same characteristics of manifold conditions (anekatva), compression (abhisamksepa) and divisions (pariccheda) ${ }^{661}$

exceeds that of the $A k n$. The $B b h$ (p. 4.6-8) contains yet another shorter version of this list, being reduced to 'skill' in skandha, dhātu, āyatana, sthänāsthāna, satya and pratityasamutpāda. These are said to figure specifically in the training of śravvaka and pratyekabuddhas, but are also acquired by the bodhisattva. The same list is included in the Srotabhümi (109, p. 287.3.2-3), where it occurrs alongside gotra, lakșana, etc., in a sequence of sixteen types of attraction (samgraha). It appears also in the Prn (23, p. 237.4.4-5).

656. $M v s ́(N)$, p. 37, 10b.5, p. 40.1-2.

Without regard to philological evidence, the parallel occurrences in the $A k n, B d p, D b h, B b h, S b h, P r b h$, etc., nor context, Stephan Anacker takes the term kauśalya to stand for upäyakauśalya (1986, pp, 240-245). Realising the incongruities that are produced by such an interpretation-but apparently not prepared to rethink his position-he attempts to explain these away by the samvrtisatyalparamarthasatya concept, remarking somewhat unconvincingly: "It is interesting that Vasubandhu regards the basic Buddhist analysis of the 'personality' as being only a provisional expedient against the view of individual self ... they are not to be taken literary; they are only temporary antidotes to suffering inducing conceptions, and must ultimately be abandoned themselves" (op. cit, p. 281, n. 42).

657. $M v s(N)$, p. 44.14a.1-2.

658. I ignore here the fact that the $B d p$ cites also 'skill' in faculties (indriya) among its eighteen factual types of 'skill' ( $R$, folio 673.3-75.2) as this has practically nothing in common with the $M v \dot{s}$ 's 'skill' in indriya. I have discussed the implications of this nominal parallelism below. For a definition of kausalyalakausalya, see: Srotabhümi, p. 303.2.8-5.2.

659. $M v s(N)$, p. 45.14a.6-14b.1.

660. For the context in which these are set, see my notes to the translation of chapter eleven.

661. $M v s^{\prime}(N)$, p. 45.6-7. 
Skill in elements is important for the destruction of the belief in a self, since it removes the notion of causality. The fault with causality lies in imagining that a self exercises true causal activity by bringing the various dhatu into existence. In order to repudiate this misconception, the $M v s$ s likens dhātu (divided into internal dhätu, external dhātu and cognition-dhātu) to seeds (bija) alternating simultaneously as cause and effect. ${ }^{662}$ Although the problem of the origin of the bija's potency to generate is not addressed ${ }^{663}$, 'skill' in elements eliminates the misconception that the self is capable of causal activity by removing agency from its realm to that of karma. ${ }^{664}$ This interpretation corresponds with the treatment of 'skill' in dhätu in the $B d p$. Postulating that the elements do not bear any characteristic (laksana) by which they would be established as independently existing, the $B d p$ points out that their sameness is rooted in insubstantiality and non-becoming. Clearly, things that lack substantiality and becoming, being neither conditioned nor unconditioned, are not subject to any causal agency.

Roughly comparable with the illusion of causality is the illusion of agency. Appearing in the $M v s^{\prime}$ in the fourth place ${ }^{665}$, it also addresses causal misconception, except that causality is limited to cognition, whereas the illusion of an agency embraces all types of effects. Both $B d p$ and $M v s$ indicate that the mistaken belief in a self as agent is best met by 'skill' in the law of dependent co-origination. ${ }^{666}$ More interested in eradicating the misconception that an agent persists in experience than in the twelve members, both works propound that there is no independent agency to trigger any operation outside ignorance, superficial reflection and the causal series itself. ${ }^{667}$

Having discussed causality, the $M v \dot{s}$ proceeds to the question of experience. It argues that all experience-whether based in the present life or linked with future retribution-cannot be rooted in a self but is conducted through sensefields. ${ }^{668}$ For the $B d p$, however, 'skill' in sensefields implies, above all, recognition of the sameness of all sensefields. This assumption

662. $M v s(N)$, p. 45.14b.2 (cf. Siddhi, p. 122, and, for a full treatment of the philosophical problems associated with the bija theory, pp. 100-123).

663. For an ingenious attempt to solve this problem, see: Siddhi, pp. 102-9.

664. The $A k n-t i \bar{k} \bar{a}$, says that the meaning of $d h \bar{a} t u$ corresponds with the meaning of holding characteristics and has the meaning of cause-with khams, bija and dbyinis being synonyms for 'cause' giving rise to the powers, etc., of the Tathägata (p. 195.5.2-4).

665. In the $B d p$, 'skill' in pratityasamutpāda is placed last in the ten skills. The rationale for this positioning is obvious, since penetration of dependent co-origination figures among the factors signaling the attainment of wisdom. In a sense, it brings the discussion of prajñ $\bar{a}$ to its logical conclusion, followed only by 'skill' in dharma. On contextual grounds I have decided to treat it alongside the first four types of 'skill', although it will figure again in my discussion of the $B d p$ 's path scheme.

666. $M v \dot{s}(N)$, p. 45.14b.4-6; Bdp, R, folio 681.3-683.4.

667. R, folio 682.6-683.3; Mvś (N), p. 45.14b.4-6; cf. Kośa, iii, p. 56.

668. $M v s(N)$, p. 45.14b.3. 
reduces discrimination between virtue and non-virtue ad absurdum and prompts the bodhisattva to discourage others from sensefield activity since it only increases mental instability. Even though he identifies the sensefields for what they are-and so abides unperturbed and unaffected by worldly experience-the bodhisattva persists in the path experience. ${ }^{669}$

So far, we have had little difficulty in interpreting the $B d p$ 's 'skills' in terms of the $M v s$ 's thought on the belief in a self. The very nature of the objects under discussion-skandha, dhātu and āyatana-reveals this purpose. Matters become less clear when we investigate 'skill' in satya for its influence on the illusion of the belief in a self. According to the $M v s$, 'skill' in truth refers above all to the four noble truths. ${ }^{670}$ This view is also expressed in the $B d p$ where four out of six passages deal with the noble truths. ${ }^{671}$ Besides an interest in the truths, these five passages have one shared concern. They assume the insubstantiality of the person and attempt to demonstrate that the self has no effect on the validity of the noble truths. At first we learn that knowledge of suffering is to see that the aggregates are unborn, that suffering is without origination and destruction, indeed that all dharma are uniform. ${ }^{672}$ The aggregates themselves - though they are the basis of truth-perception-are in fact empty, unborn and in a complete state of cessation. ${ }^{673}$

Looking at these propositions in conjunction with the belief in a self based on the illusion of support of defilement and purity (samkliștavyavadānatvagräha), the connection between 'skill' in satya and the doctrine of non-self becomes obvious. Common (defiled) perception would require purity and defilement - the two cardinal facets of the noble truths-to possess a support or subject which could be defiled or pure. ${ }^{674}$ The significance of 'skill' in satya lies not only in the perception of defilement (duhkha/samudaya) ${ }^{675}$ and purity (nirodha/mārga) ${ }^{676}$,

669. That is to say, he draws them away from the ten ignoble paths of samsära (Akn-țikā, pp. 197.5.6-203.4.8; Msl, p. 124.3-15).

670. $M v s ́(N)$, p. $47.15 \mathrm{~b} .3$.

671. The passages that do not touch on the concerns of the four noble truths investigate the relationship of the various levels of experience, that is to say, conventional truth (samvrtisatya), absolute truth (paramärthasatya) and the truth of characteristic (lakșanasatya). As these sections have already been subject to scrutiny, I shall refrain from discussing them again. For interpretations of the concept of the three truths in Buddhism, see: Wayman, 1980, pp. 220-21; Freeman, 1991, pp. 97-115; Sasaki, 1964-5, pp. 236-251; Pagel, 1990, pp. 8-10. Note, however, that in the introductory passage to 'skill' in satya it is the four noble truths that are explicitly cited as the object of this type of 'skill' ( $R$, folio 620.4.-6).

672. $R$, folio $620.6-621.2$.

673. $\mathrm{R}$, folio $622.1-6$.

674. Hsien yang sheng chiao lun (T 31, p. 545c; trsl. O'Brien):

"Because the fruit of one's past deeds inclines one to practice evil deeds we imagine that there is someone who is defiled. Because it inclines one to practice right deeds, we imagine that there is someone who is purified. But this illusion comes from not understanding the four noble truths."

675. Kośa, vi, p. 122. 
but-as shown by the $B d p$-it rejects also the need for a self to sustain their presence. Knowledge of truth provides a self-contained explanation of their arising and destruction, revealing a fluctuating basis (the aggregates), the character of this basis (non-existence), the nature of the experience (ferry-like) and its origination (no-birth)-four notions that render the presence of a self superfluous to sustain purity and defilement.

To take stock and return briefly to the question of this chapter's overall organisation, we can make two observations concerning the purpose of the types of 'skill' investigated so far. First, the texts make it plain that their primary role is to remove the misconceptions about the self. In this sense, the $B d p$ 's first four kinds of 'skill' (including perhaps the more distant 'skill' in dependent co-origination) display a common objective and so were presumably conceived en bloc.

This hypothesis, however plausible, leaves several questions unanswered. If the eradication of the belief in a self is limited to 'skill' in skandha, dhātu, āyatana, satya (and pratityasamutpāda) what is then the role of the remaining types of skill? Moreover, if perceived as a group of practices, what is their exact location on the path? It seems unlikely that such a major feature of the training should have been devised without thought being given to its position.

In general, descriptions of the path tend to place the elimination of the belief in a self at the beginning of the path. ${ }^{677}$ There is evidence in the $B b h$ that supports an early position for our five types of 'skill' also. Here, we learn that they (plus 'skill' in the inevitable/impossible) function as bases of knowledge mastered by śāvaka, pratyekabuddhas and bodhisattvas alike. The remaining types of 'skill' are only accessible to bodhisattvas. ${ }^{678} \mathrm{We}$ may infer, therefore, that 'skill' in skandha, etc., represents a kind of a spiritual foundation on which the bodhisattvacarya $\bar{a}$ is built. ${ }^{679}$ Furthermore, as revealed by passages in the $S b h$ and Prbh, the

676. Kośa, vi, p. 120 (cf. Kośa, i, p. 8).

677. For the tenfold scheme, see: Daśa-bh, pp. $31.10,43.17$; for the fivefold scheme, see: $D P P$, pp. $21,37$.

678. $B b h$, p. 4.6-8

Note that the descriptions of 'skill' in skandha, etc., follow closely the definitions that are given in the $S b h$ and contain many traits of Śāvakayāna orientation (cf. Srāv-bh (Sh), pp. 237-49). A useful indicator of the degree to which the first five types of 'skill' are associated with the Srāvakayãna in the Sbh is obtained if we look at the sources on which the $S b h$ drew for inspiration ( $\$ r \bar{a} v-b h(S h), \mathrm{pp}, 240-49)$.

679. This, at least, is the opinion of the $B b h$, which remarks (p. 3.14-18):

"Among them, the lineage of all the sraavaka and pratyekabuddhas becomes pure through the purification of the obstructions of defilement, not through purification of the obstructions pertaining to the knowledgeable. However, the lineage of bodhisattvas becomes pure not only through purification of the obstruction of defilement, but also through purification of the obstruction pertaining to the knowledgeable." 
scope of 'skill' even differs between the srāvaka and pratyekabuddha. ${ }^{680}$ For a srāvaka, only the 'skills' in skandha, dhātu, äyatana, pratītyasamutpāda and sthānāsthāna are attainable whereas a pratyekabuddha also transforms satya into an object of 'skill' ${ }^{681}$ The scope and advancement in 'skill', it seems, become a type of gradation demarcating the three vehicles.

By themselves, these findings do not explain the position of 'skill' in skandha, etc., in the overall scheme of the $B d p$. The key to this problem is found outside the $B d p$. A glance at the list at the beginning of the current investigation shows that 'skill' in skandha, dhätu, āyatana and satya is placed between the discussion of the bhāvanāmārga and 'skill' in pratisamvid. The chief characteristics of the bhāvanämärga are the practice of meditation and the attainment of the śramanyaphala. In the $S b h$, 'skill' in skandha, etc., occurs precisely in conjunction with these two training aspects. They are an important attribute particularly for the śrotaāpanna ${ }^{682}$ and become objects of meditation (ãlambana) in the srāvaka training. ${ }^{683}$ This would seem to tally with the contemplative practice supposedly undertaken on the bhāvanāmārga in general, and in its laukika phase in particular. ${ }^{684}$ Hence, there appears to be a case for linking 'skill' in skandha, etc., with the discussion of bhāvanāmärga - the implication being that 'skill' forms a part of it. ${ }^{685}$

To find a connection between 'skill' in skandha, etc., and 'skill' in pratisamvid has proved more problematic. Essentially, we find two apparently contradictory views. One propounds that the pratisamvid lead to 'skill' in skandha, etc., and the other that 'skill' in skandha, etc., provides a basis for the acquisition of the pratisamvid. Having considered the evidence, I am inclined to adopt the first opinion.

In support of the first view we have a statement in the $D b h:^{686}$

680. Srä̀ं-bh (Sh), pp. 237-249; Prbh, pp. 376-7.

681. For the pratyekabuddha, 'skill' in skandha, etc., is present in all three major phases of this training. Judging by the brief passages in the Prbh, it prepares the ground for the "penetration of the certainty of truth' via direct comprehension (abhisamaya) and the eventual attainment of the state of certainty itself (op. cit.). This interpretation would place 'skill' in skandha, etc., on the darśanamārga.

682. Śäv-bh (Sh), pp. 177.8-183.11.

683. op. cit., pp. 193.4-258.13

For a superior edition of this passage, see: Schmithausen, 1982, pp. 460-472. A parallel account of the psychological experiences underlying these meditations is found in the Abhidh-sam (R), pp. 134-36.

684. For details on these meditations during the bhāvanämärga, see: Kośa, ii, pp. 134-6, 180, 205; iii, p. 196; vi, pp. 186-189 and chapter viii; Abhidh-sam (R), pp. 110-11; Mpps, iii, pp. 1213-1328; MBT, iii, pp. $1-8$.

The association of the pratisamvid with meditation is further corroborated in a key passage in the $B b h$ that affirms that they constitute knowledge springing from meditative practice (bhāvanāmayam ... jñ̄anam). $B b h$, pp. 258.6-7, 258.9-10, 258.12-13, 258.15-16.

685. According to the $B b h$, the three types of wisdom (i.e., śrutamayi-, cintāmayi- and bhāvanāmayīprajñā) themselves are conducive to the attainment of the lower six kinds of 'skill' (Bbh, p. 33.10-15).

686. Daśa-bh, p. 78.3-4. 
"By the unique knowledge of own-being of things (arthapratisamvid), the bodhisattva enters into the attainment of 'skill' in aggregates, elements, sensefields, truth and dependent co-origination."

A similar proposition is also found in the $B b h:^{687}$

"Reliance on the boddhisattva's four [kinds of] unique knowledge should be known to lead to 'skill' in the five bases of the bodhisattva; being 'skill' in aggregates, elements, sensefields, dependent co-origination and the inevitable/impossible."

This passage also underpins what we have already inferred from the $S b h$ and $P r b h$ concerning 'skill' in skandha, etc., being cognitive foundations. Ironically, it is this function that gives weight to the alternative position. To this effect we read in the Visuddhimagga: ${ }^{688}$

"Now, the things classed as aggregates, sensefields, elements, faculties, truths, dependent co-origination, etc., are the soil (bhīmi) of this understanding [of the unique knowledge]. Two purifications, viz., purification of virtue and consciousness are its roots. Five purifications, viz., purification of view, purification by overcoming doubt, by knowledge and vision of the path ... are the trunk [of their understanding]."

To the Vism knowledge of the aggregates, etc., is quite clearly a cornerstone to the development of the patisambhida ${ }^{689}$ Likewise, it is probably no coincidence that knowledge of the aggregates and knowledge of the four noble truths are discussed immediately before the unique knowledge. ${ }^{690}$ Additional support for this proposition, however, is thinly spread and subject to interpretation.

Introducing this statement on the relation between 'skill' in skandha, etc., and the pratisamvid the $D b h$ comments that the bodhisattva "understands by the unique knowledge of designations the methodical (asambheda) 'skill' distinguishing the knowledge of dharma" (op. cit., p. 77.22-23).

687. Bbh, p. 258.17-20.

688. Vism, p. 443.

689. Having discussed the qualities of the patisambhida, as if to underine the importance of a correct understanding of the aggregates, etc., to their generation, the Vism dedicates the next seventy pages to a description of their nature, functions and attributes (Vism, pp. 444-516).

690. Vism, p. 440. 
In the $S b h$ the context places the practice of 'skill' into a meditative structure, specifically, on the bhāvanāmārga. Apart from the practice of the dhyäna, etc., advancement through the bhāvanāmārga involves a number of ancillary practices, particularly the noble eightfold path and joint practice of 'perfect mental quietude' (śamatha) and 'insight' (vipaśyanā). ${ }^{691}$ If we accept that 'skill' pertains to the bhävanāmārga or, at least, to meditation, by implication it is possible to draw a link between 'skill' and śamatha/vipaśyanā. This connection allows us to utilise a passage in the Samdhis where we learn that: ${ }^{692}$

"Bodhisattvas who cultivate perfect mental quietude and insight possess the unique knowledge of the own-being of things and the unique knowledge of designation."

This statement suggests that the attainment of (at least two) pratisamvid springs from the practice of samatha and vipaśyan̄a ; that is to say, from meditation on the bhāvanāmärga. In other words, it arises from the very context in which 'skill' in skandha, etc., is being developed. This position is sustained by the content that is given to the pratisamvid in the Samdhis. In common with the $B d p$, the Samdhis dwells on precisely those practices that were the focus of 'skill'. More than just the fact of it referring to the problem of the self and defining the aggregates, elements, sensefields and noble truths ${ }^{693}$, it is the brevity in which these are treated that suggests that the bodhisattva was assumed to acquire 'skill' prior to the pratisamvid. In this sense, 'skill' in skandha, etc., would provide the cognitive foundation on which the pratisamvid would develop.

And yet, on balance, I do not think that these clues-however persuasive-allow us to disregard the unequivocal statements of the $D b h$ and $B b h$. They say quite clearly that it is the pratisamvid that lead to 'skill' in skandha, etc., and not vice versa ${ }^{694}$ It is perhaps appropriate

691. Abhidh-sam (R), p. 126; Kośa, vi, pp. 279-80, 300-301; viii, pp. 130-31, 146, Satya-s (S), pp. 448-49; $M B T$, iii, pp. 205.5-207.11.

692. Samdhis (ELa), p. 98.1-4.

693. Samdhis (ELa), pp. 99.12-13, 99. 16-23, 100.12-14, 102.15-19, 103.1

It is perhaps significant that all of these references occur in the arthapratisamvid section that-while in second position in the Samdhis - is the first of the pratisamvid in the Bdp. By placing it at the beginning (a move that is non-standard by most treatises on the pratisamvid), the Bdp brings the arthapratisamvid references to skandha, etc., close to the section on skill-a device that might have served to accentuate an otherwise rather weak and indirect connection between the two sections.

694. It is conceivable that the relationship between 'skill' and pratisamvid has changed in the course of Buddhist history. However, the chronological closeness of the $B d p$ and $D b h$, on the one hand, and the $B b h$ and $V$ ism on the other hand apart from the fact that such re-interpretation would have involved a total reversal of whichever position was the original, renders this possibility remote. 
to consider both positions as equally valid within their own textual traditions until further evidence comes to light to clarify the matter.

But now let us move on to look at the actual treatment of the pratisamvid. In contents the $B d p$ adopted what have become well-established patterns of exposition. ${ }^{695}$ Under the heading of arthapratisamvid it discusses the own-being of things and scrutinises reality from the viewpoint of the absolute truth, including some of the broader principles that pertain to the path attainments. ${ }^{696}$ Similarly, dharmapratisamvid, revealing knowledge of instructions and designations that introduces to the names and characteristics of phenomena, deals largely with standard issues. ${ }^{697}$ Niruktipratisamvid and pratibhänapratisamvid bestow intimate knowledge of languages and confer great eloquence. ${ }^{698}$ Traditionally appreciated for their role in conversion activity, they have less bearing on the cognitive dimension of the training than on that aspect of the vow committing the bodhisattva to spread the Buddha's teachings. ${ }^{699}$ As

695. More specifically, it agrees, for instance, with the Mppś (iii, p. 1619) that the pratisamvid manifest three levels of attainment, depending on whether they are practised by śāvaka, pratyekabuddhas or bodhisattvas. It also agrees with the Vibhassa (op. cit., p. 1616) that the object of the arthapratisamvid is the absolute truth (paramärtha).

It is perhaps worth noting that the $B d p$ contains by far the most detailed analysis of the pratisamvid, covering almost nine folios in the Peking edition. In the suttras, the next best presentations are found in the Samdhis (ÉLa), pp. 98.1-103.5, and Daśa-bh, pp. 77.1-79.3, while in the śästras it is the Mppś, Bbh and $M s l$ that give the best account (references see below).

696. $\mathrm{R}$, folio $624.2-625.5$.

697. $\mathrm{R}$, folio $626.7-628.5$.

698. R, folio 628.6-631.2.

699. See, for instance, $B b h$, p. 353.19; Daśa-bh, pp. 77.1-5, 79.4-7 where teaching and the becoming of a dharmabhanaka are named as the chief purpose of the pratisamvid (cf. Abhidh-sam (R), p. 172).

While the nature of the four pratisamvid is generally well-explained, their exact scope is only insufficiently indicated. Two passages in the nikāya would indicate that in early Buddhism they did not belong to the most elevated path practices. They were apparently within the reach of 'ordinary' monks' (A I, p. 24, A II, p. 161) and, for Sāriputra, attainable only a few months after ordination (A II, p. 160). Although by nature inseparable and simultaneously acquired, differences in ranking exist. For the Kośa (vii, pp. 89-94), the pratisamvid fall into two categories. First, the dharma- and niruktipratisamvid pertain to the sphere of worldly knowledge (samvrtijñana) and operate only in the stages of the kämadhătu and dhyāna (the niruktipratisamvid is restricted to the first dhyanna, while the dharmapratisamvid pertains to all four dhyäna stages; Kośa, vii, p. 93). The reason given is that they have as objects nämakāya and languages. The other two, artha- and pratibhannapratisamvid, belong, by implication, to the lokottara consciousness. Found in all nine stages of meditation and corresponding respectively to the ten and nine kinds of knowledge (jĩäna) - the nirodhajñäna being excluded from the pratibhänapratisamvid (Kośabhäșya, pp. 418-19) and only attained by masters of meditation (samädhivaśisamprakhyāna) - they were evidently regarded to be of a higher order. To some extent, this grading is echoed in the Mahāyāna interpretation of the unique knowledge, in particular with regard to the pratibhanapratisamvid. The contents of the first two, that is, artha- and dharmapratisamvid correspond largely to the srāvaka interpretation, in the sense that the chief concern is the examination of reality (Siddhi, p. 70). Employing a comparable methodology but producing variant results, both śrāvaka and bodhisattvas investigate through them the own-nature (svalaksana) of phenomena and the terminology commonly used to designate them. Differences only arise with the nirukti- and pratibhānapratisamvid. For the śrãvaka, niruktipratisamvid has as object 'expressions of language relative to the thing designated and the designation' (atthadhammaniruttäbhiläpa) or more generally speech $(v \bar{a} c)$. This led to its emphasis being placed on philological knowledge of grammatical 
these general facets of the pratisamvid are widely documented, I shall confine my analysis here to those issues in which the $B d p$ deviates from the standard model..$^{700}$

Differences relate primarily to organisation and allocation. The first, most noticeable, difference lies in the order in which the artha- and dharmapratisamvid occur. Most texts I consulted place the dharmapratisamvid at the beginning of the four, followed artha-, niruktiand pratibhānapratisamvid. In the $B d p$-perhaps for reasons of continuity-the sequence between dharma- and arthapratisamvid has been reversed so that it is arthat that introduces the unique knowledge. ${ }^{701}$ Second, the allocation of some of the topics diverges from that of other texts. For instance, the $B d p$ incorporates in arthapratisamvid the theme of the noncharacteristics of dharma and a reference to the pratisarana-two issues belonging to the dharmapratisamvid according to the $M p p \dot{s}^{702}$ Similarly controversial, though possibly correct, is the inclusion of the eighty-four thousand types of dharmaskandha under dharmapratisamvid. These, according to the $M p p s$, pertain to the pratibhānapratisamvid. ${ }^{703}$ The $B d p$ 's incorporation of a number of specific path features in the arthapratisamvid is also striking, when in most other texts its treatment does not go beyond the own-characteristics (svalakșana) of dharma. ${ }^{704}$

forms, syntax, etc. (Vibh, pp. 295-9; Prajñaptapādaśästra cited in Kośa, vii, pp. 93-4). Now, judging by the material included in Mahāyāna treatises on the subject, for the bodhisattva, knowledge of nirukti is more a question of fluency in languages - human and non-human. Philological detail is rarely mentioned and is certainly not the focus of attention ( $B b h$, pp. 258.11-13, 353.17-354.26). The reason for this adjustment is the central role of preaching in the bodhisattva training, particularly during the final stages. Recognising the need for effective communication, the pratibhänapratisamvid sets the previous pratisamvid to best effect. Being the last and highest form of unique knowledge, it merges the data of the previous three in order to pass them on to others for conversion and designates "l'habilete dans le discours qui procède de la connaisance des êtres à convertir" (Siddhi, p. 652). The bodhisattva is now in the position to adapt his exhortations to the spiritual faculties of beings (Mpps, iii, pp. 1622-23); he is accomplished in wisdom and magical powers which allow him to alter his appearance and birth-destiny at will; he is well-versed in all branches of knowledge and their texts. In short, he has assembled all necessary ingredients for an effective communication of the teachings of the Dharma. It is no coincidence that this attainment takes place close to the pinnacle of his career (Daśa-bh, pp. 77.1-81.3; Bbh, pp. 353.8-354.11), since it is only from the eighth stage onwards that he himself is fully accomplished in the Dharma, skilful means and magical powers. During the sädhumatïbhümi (corresponding to the pratisamvidvihära of the Bbh), these three factors are then complemented with attainments in languages and eloquence to become the pillars of his conversion activity.

700. Good accounts of the general nature and scope of the pratisamvid can be found in the $V i b h$, pp. 293-305; Vism, pp. 372-76; Mppś, iii, pp. 1616-24; Kośa, vii, pp. 89-94; Kośabhäsya, pp. 418-21; Amrtar (B), pp. 214-15; $B b h$, p. 258.4-17; $M s l$, pp. 138.19-139.16 (for further ref. see: $M s g$, pp. 53-54*).

701. The standard order, for instance, is found in the Dbh, Samdhis, Kosa, Abhidh-sam (R), Amrtar (B), Bbh, $M s l, D h s g r$ and $M s g$ while that of the $B d p$ is only attested in the Vism, Pañca, Akn, Samädh and Mppś. Dayal suggests (p. 262) that these differences reflect a shift away from the formula that is found in the nikāya, giving precedence to the pratisamvid of artha over dharma. Taking into account the meagre evidence for such a claim (there being only one occasion in the primary nikãya where this sequence is attested; but see: Patis, i, pp. 88, 119; ii, pp. 150, 157, 185, 193; Vibh, pp. 293-305; Vism, pp. 440 ff), he later acknowledges that this is pure speculation (p. 264).

702. R, folio 625.5; Mppś, iii, p. 1621.

703. R, folio 627.3-628.5; Mppś, iii, p. 1623.

704. See, however, Samdhis (ELa), p. 104.7-27. 
If nothing else, these discrepancies show that the contents of the individual pratisamvid were exposed to change longer than their consistency in later treatises might imply. ${ }^{705}$ This itself is not surprising, considering that most early sources provide a bare outline of their contents. In the four principal nikāya, the only references to the patisambhidā are found in the Anguttaranikāya and even these give away little of their scope. ${ }^{706}$ Even many of the early Mahāyāna sütras are silent on the contents of the pratisamvid. The $A s ̦ t a, V k n, K p, U p, S g s$, Saddhp and Bhadra-vy, to name just a few, contain only a handful of allusions. ${ }^{707}$ Apparently, interest in the details of the pratisamvid only arose with the second wave of Mahāyāna sütras, producing the kind of exposition we find in the $B d p, A k n, D b h$ and Samdhis.

Much of what has been said about the pratisamvid applies also the pratisarana that follow on the pratisamvid in exposition of the $B d p .^{708}$ They are not found as a complete set in the early suttas, though they are already attested in their initial stages in the Digha- and Majjhimanikāya. ${ }^{709}$ From a few scattered references in Sākyamuni's discourses the pratisarana progressed to a fully developed set of practices with a secure place in the bodhisattva training. ${ }^{710}$ As is so often the case when concerned with bodhisattva practices, one is well advised to look for the most instructive account to the $B b h .^{711}$

But first to the $B d p$. The discussion of the pratisarana in the $B d p$ is rather unusual in several respects. First, there is the astonishing amount of detail about the individual reliances. Except for the $A k n$, I have found no other text that comes anywhere near its exposition in length. Second, the $B d p$ casts its treatment of the pratisarana in a non-standard order, leading

705. Note that in the $V \mathrm{kn}$, the contents of artha- and dharmapratisamvid appear to have merged into a single concept. In chapter xii, $\S 11$ (p. 260), we meet with the term bhütärthadharmapratisamvid that Lamotte took to mean "infallible penetration concerning the Law in its true meaning". I do not know what prompted Lamotte to swerve from the pratisamvid context here, but to translate it as "unique knowledge concerning the own-being and designations of reality" seems more appropriate.

706. A II, p. 160; III, pp. 113, 120

The earliest canonical account of any length is found in the Patis (i, pp. 86-87, 121-22), while the most detailed analysis of the Abhidhamma is given in the Vibh (pp. 293-305).

707. Vkn (p. 260), Sgs (pp. 150, 188), Saddhp (pp. 202, 204), Bhadra-vy (R), p. 20.17-18; Pañca (p. 211); they are altogether absent from the $A s t a, K p$ and $U g$.

708. During the first half of this century, much useful material on the pratisarana has been collected by Étienne Lamotte and Louis de La Vallée Poussin. Most of this has been published in footnotes to the Abhidharmakośa (Kośa, ix, pp. 246-48) and Le Traité de la Grande Vertu de Sagesse (Mpps, i, pp. 536-41) and in "La critique d'interpretation dans le Bouddhisme" (Annuaire de Institut de Philologie et d'Histoire Orientales et Slaves, 9, 1949, pp. 341-61).

709. D II, p. 124; cf. Waldschmidt, 1950-51, p. 238.24.1-3 (dharmatälpudgala), D III, pp. 127-8, M I, p. 265 (nîtärtha/neyärtha); M II, p. 240 (artha/vyañjana); Vin, i, p. 40 (nïtärtha/neyārtha).

710. The first sütra to give a detailed account of the four pratisarana appears to have been the Catuhpratisaranasütra. This text, however, extant in several Sanskrit, Tibetan and Chinese versions, is a relatively late composition. Nevertheless, it is still regarded as one of the principal sources on the pratisarana and is regularly cited in conjunction with the four reliances (viz., Mppś, i, p. 536; Lamotte, 1949, p. 4).

711. Bbh, pp. 256.23-58.3. 
to repetitions and some convolution. Third, taking full advantage of the samvrtisatya/ paramārthasatya dichotomy, its uniform technique of explication is surprising.

The first pratisarana discussed is 'reliance on the spirit as opposed to the letter' (artha/vyañjana). The $B d p$ provides many examples to explain why it is the spirit that is given ultimately precedence. The thought that only the spirit contains the true meaning of the Dharma in the final analysis, whilst the letter is little more than an expedient for expressing and reaching it, is of course not new. It is already mirrored in the famous stanza of Sāriputra uttered in response to Aśvajit's admission that, as a novice, he could not propound the Dharma in full::12

"Let it be so, my friend. Tell me a little or a great deal of it, but speak to me of its spirit. I need only the spirit, so why be preoccupied with the letter?"

Such preoccupation with the meaning stems from the conviction that purely literal exegesis is certain to produce incomplete or even mistaken interpretations and will fail to lead to liberation. ${ }^{713}$ Equally, it was always appreciated that flawless preservation of the letter is essential to discovering the correct meaning, for: ${ }^{114}$

"If the phrases and syllables are wrongly arranged, the meaning in turn is impossible to discover."

Recognition of a combined need for a clearly formulated textual basis and perception of the spirit as the ultimate bearer of Buddhist thought also inspired the $B d p$ in its discussion of the artha/vyañjana pratisamvid. Taking a more positive view by proposing complementarity (but pertaining to different levels of cognition), the text does not tire in reiterating the benefits that spring from their integration: ${ }^{715}$

"The letter-disciplining body, speech and mind-instructs in achieving all attainments of learning and purity. The spirit-not apprehending body, speech and

712. Vin, i, p. 40.

713. Lankäv, p. 196.4-11.

714. Nett, p. 21 (ref. Lamotte).

715. $\mathrm{R}$, folio 632.4-633.3. 
mind-purifies the non-accumulation of karmic formations. ... The letter, being the receptacle of all that has been heard, is the root of wisdom. The spirit is the ineffable meaning. The letter instructs in the practice of the thirty-seven bodhipākșika dharma. The spirit realises the fruit of their practice. The letter instructs in suffering, its origin and the path. The spirit realises its cessation."

After the discussion of the artha/vyañjana pratisamvid, the Bdp expounds direct knowledge and discursive insight (jñānalvijñāna). At first, however, for reasons that are not entirely clear, it interposes a brief section introducing reliance on sūtras of precise/provisional meaning (nïtärtha/neyārtha) and reliance on the foundation of being/person (dharmatā/pudgala). This interpolation is practically devoid of information beyond the standard formula. Both pratisarana are explained in detail after the jñāna/vijñäna pratisarana, and yet they are styled to conclude the entire fourfold pratisarana discussion even though jñāna/vijñāna pratisamvid has not been mentioned. This is probably another piece of evidence of the $B d p$ 's conceptual 'immaturity' ${ }^{716}$ Things are further complicated by the introductory passage to the jñana/vijñana section which says that-in apparent reference to the artha/vyañjana pratisamvid-direct knowledge and discursive insight fall under 'skill' in the letter. Tellingly, the $A k n$ that otherwise follows the $B d p$ so closely does not show these incongruities. ${ }^{717}$

After a fruitless search for an explanation in the standard works, I came across the following passage in the Tchou wei mo kie king: ${ }^{718}$

"There are two sorts of dharma. First, vyañjana or the letter. Second, artha or the spirit. One should not rely on vyañjana. There are two sorts of artha. First, artha known through discursive insight (vijñäna). Second, artha known through direct knowledge (jñāna). Vijñana only seeks after the five false and illusory object of desire (kāmaguna). It does not seek after the real truth. Whereas jñāna seeks after the real truth and destroys the five objects of desire. Thus one should rely on artha known through jñāna and not rely on artha known through vijñāna. It is in order to seek after artha known through jñ̄ana that one relies on jĩāna."

716. I have discussed this convolution in greater detail in note 114 of my translation.

717. $A k n$, p. 64.2.4.

718. T 1775 , chpt. 10, p. 417a.10-25 (I follow here Lamotte's translation; Lamotte 1976, p. 262). Note that in early Mahāyāna literature most lists of the pratisarana begin with the pair dharmatälpudgala, the only exception being the Bhadra-vy (R), p. 100. 
To us, the significance of this interpretation concerns the inclusion of $j \tilde{n} \bar{a}$ ana/vijñāna under 'skill' in the letter. Uniquely among treatises on the pratisarana, it establishes a logical connection between the four pratisarana and explains the late reference to vyañjana. Kumārajiva's choice to place the focus on artha-not vyañjana-and to make it the target of jñāna and vijñāna, introduces a further complication, though it throws some light on the underlying structure of the $B d p$ 's treatment of the pratisarana. In order to link the exposition of jñanalvijñana with that of arthalvyañjana, the $B d p$ returned to arthalvyañjana so as to provide vyañjana as the object of jīäna/vijñäna. The fact that direct knowledge is not in the least concerned with literal understanding-perception of words being by definition part of conventional (vyavahāra) knowledge-is apparently ignored: $:^{719}$

"The bodhisattva attaches great importance to direct knowledge of realisation and not to mere discursive insight of the letter or the spirit, arising from listening and reflecting. Understanding that what should be known through knowledge arising from contemplation cannot be recognised through discursive insight arising from listening and reflecting [alone], he abstains from rejecting or denying the teachings given by the Tathāgata, profound as they are."

Next, the $B d p$ contrasts the attributes of jĩana with those of vijñäna. It establishes direct knowledge in the lokottara domain and defines discursive insight as the ordinary cognition subject to false mental constructions: $:^{720}$

"Discursive insight persists in the sphere of conditioned dharma but does not wander in the unconditioned [while] direct knowledge is perception of the unconditioned."

In essence, the treatment of the third pratisarana, contrasting sütras of provisional meaning (neyārtha) with those of precise meaning (nitärtha), is rather similar with the artha/vyañjana

719. Bbh, p. 257.16-21 (cf. Samdhis (ELa), p. 105)

Perhaps because it noted this incongruity, the Pelliot manuscript omits the paragraph which contains the reference to 'skill in letter' (Pelliot, 977, 1b.7-2a.2).

720. $\mathrm{R}$, folio $636.4-5$. 
pratisarana. This is the case because of the conceptual closeness of artha and nitärtha on the one hand, and vyañjana and neyärtha on the other hand: ${ }^{721}$

"The bodhisattva who resorts to the spirit (artha) and not to the letter (vyañjana) penetrates all enigmatic words (samdhāyabhāsita) of the lord buddhas."

In order to distinguish those texts to be taken literally from those requiring interpretation, the $B d p$ goes to some lengths to describe the attributes of neyārtha and nitārtha sütras. As main criteria it suggests purpose, content, style and philosophical explicitness. Depending whether a text advocates the perpetuation of path activity or supports the immediate cessation of all action; whether it sets out to elucidate the conventional truth or absolute truth; whether it explains impurity or achieves complete purification; whether it partakes in duality or not, we are dealing with either a neyārtha or nitärtha sütra. Texts that add non-essential material, written in a pleasing style, are neyārtha whereas sütras that are terse and profound are nitärtha. ${ }^{722}$ The fact that most, if not all, of these criteria are highly subjective and produce no overall and generally valid guidelines is not addressed in our text. ${ }^{723}$ Aware that literal interpretations (yathärutārthagrāha) fail to accomplish Dharma comprehension ${ }^{724}$, Buddhist scholars of all ages frequently drew attention to this problem: ${ }^{725}$

721. $B b h$, p. 108.23-24.

722. Kośa, i, p. 75:

"Rien n'établit que ce sūtra soit de sens clair; le fait qu'il s'exprime en termes de définition ne prouve rien; car Bhagavat donne des définitions qui portent seulement sur l'élément essentiel ou capital de l'object à définir."

723. In fact, to my knowledge Buddhism has never succeeded in establishing such a general principle of identification, even though several attempts were made to this effect.

See, for instance, a section in the $M p p s$ s (i, pp. 539-40) where Kumärajiva proposes that sütras containing allegations that are obvious and readily comprehended are nitärtha, while texts where the meaning is unclear and teach views through skilful means that seem at first incorrect and require explanation are neyärtha.

For the Samädh (Dutt, 1941-53, ii, p. 78) it is above all a question whether a text seemingly acknowledges the reality of the self:

"Whoever knows the value of texts that have a precise meaning knows the way in which emptiness has been taught by the Sugata; but wherever reference is taken to the individual, human being or man, he knows that all those texts should be regarded as possessing provisional meaning."

For Buddhaghoșa, in contrast, texts that wish to lay claim to nïtärtha status, must deal with impermanence, suffering and non-self, because "independent of the Tathägata's appearance in the world, causality-this fundamental essence of things remains". Sütras that deal with individuals and speak of the pudgala should be treated as neyärtha since from the absolute point of view no individuals exist (Manorathapürani, ii, $\mathrm{p}$. 188; ref. Lamotte). See also $M a d h$. vrtti (p. 43) that accepts principles of distinction that are rather similar to the first two and last five of the $B d p$.

724. $M s l$, p. $138.10-11$.

725. $B b h$, pp. 257.8-16. 


\begin{abstract}
"A bodhisattva who places faith and confidence in the Tathāgata-only trusting his very word-relies on sütras of precise meaning and not on sütras of provisional meaning. By relying on sütras of precise meaning, he cannot swerve from the Dharma and Vinaya. Indeed, in sütras of provisional meaning the interpretation of the meaning-[typically] diffused in several directions - is ill-defined and causes hesitation. Hence, if a bodhisattva does not adhere to sütras of precise meaning, he might swerve from the Dharma and Vinaya."
\end{abstract}

The last pratisarana, advocating reliance on dharmatā as opposed to the person, is in many respects the most fundamental of all four. Summing up the concerns that led to the formulation of the 'four great authorities' (mahāpadesa), it establishes the superiority of Dharma 'compatibility' over personal authority, however respected the person in question might be. ${ }^{726}$ In recognition of the many shortcomings that taint the human mind, the acceptance of the Dharma should not rest on blind faith ${ }^{727}$ but it should grow out of sound reasoning based on personal experience and understanding. ${ }^{728}$ To quote once again from the $B b h:^{729}$

\begin{abstract}
"He who relies on sound reason and not on a person's [authority] does not swerve from the meaning of thusness. He does not depend on others when confronted with the Dharma."
\end{abstract}

The $B d p$, however, is not so much concerned with the benefits that accrue through this pratisarana, than to define the concepts of pudgala and dharmatā themselves. ${ }^{730}$ Thus, instead of arguing from the changeableness of the human mind, it explains that the Buddha's use of the term pudgala is nothing but an expedient means and should not be taken literally. ${ }^{731}$ Warning that undue attachment to the pudgala would harm one's prospects of liberation, the $B d p$ invites one to strive for a complete understanding of reality and to turn this into one's

726. D II, pp. 124-126.

727. M I, p. 133.

728. M I, p. 265.

729. $B b h$, p. $257.6-8$.

730. Note, that we have a number of inconclusive variant readings in the $B d p$, alternating between $d$ harma (folio 638.1) and dharmata (folio 631.5, but Pelliot, 977, 1a.2: dharma; 638.7; 639.4). Judging by the context no difference in meaning is intended.

731. $\mathrm{R}$, folio $638.2-7$. 
refuge. Since reality bears the characteristics of sameness and lies beyond discrimination, perception must not be conducted through sensory cognition (dhātu), but is to be gained only through dharma-observance and reliance on the foundation of being. ${ }^{732}$

Accumulation (sambhāra) of merit (punya) and pristine cognition (jñāna) is the first major practice 'skill' in which is not included in the introductory list. ${ }^{733}$ Building on attainments of the pratisamvid and pratisarana, both types of accumulation form a highly esteemed aspect of the training and, according to some, are rivalled only by generosity (dāna) in benefit. ${ }^{734}$

732. R, folio 639.1-5.

733. Although by far the best known types, Buddhist sources record a number of alternative and frequently numerous kinds of accumulation. In the Lalitavistara, for instance, we meet with accumulation in punya, jñana, samatha and vidarśana, while in the Siks (p. 191.4-5) we learn of a dharmasambhära and a sarvadhyānaprajñanigasambhära (p. 182.18). The $A k n$ speaks besides the standard accumulations of punya and jīanna of a prajñäsambhära and buddhadharmasambhära (pp. 47.1.7-48.1.3). The longest list of sambhära $\mathrm{I}$ have discovered is found in the $\operatorname{Karuma} p(Y)$ (i, pp. 338.5-341.7) containing forty different types of accumulation.

In the Yogäcärabhümi, we meet with the following explanation:

"There are four kinds of accumulation. First, the accumulation of merit. Second, the accumulation of pristine cognition. Third, the accumulation of the past. Fourth, the accumulation of the present. The accumulation of merit is that by which one obtains the regular equipment and the abundant jewels; by which one meets the truly rich fields as his good teachers and friends; by which one becomes free from many obstructions and applies oneself to discipline. The accumulation of pristine cognition is that by which one accomplishes the brilliant knowledge and has powers and faculties; by which one discriminates the doctrines of right and mistaken views; by which one attains the regular doctrine, meaning, teaching and exhortation. The accumulation of the past is that by which one attains now the accomplishment of the various faculties owing to the gathering of good faculties in previous lives. The accumulation of the present means that in this state of existence one-wishing to attain virtue-ripens his faculties and equips himself with restraint of morality and faculty" (T 30, p. 446b; trsl. Honda, 1968, p. 216).

734. Bbh, p. 216.4-11

According to the same text (op. cit., p. 35.2-5), the two sambhära become collectively the primary causes of enlightenment. While merit is the principal (pradhana) cause, it is pristine cognition that is of supreme importance. The causes of ripening, ripening itself and the reward springing from ripening all stem from merit but merit depends on pristine cognition (jñānaśrita) which removes all defilements (samkleśa), (op. cit., p. 34.26-27; cf. Msl, p. 139.18-19). This view is mirrored in a passage in the Dbh (Daśa-bh, p. 67.16) where, at the eighth stage, the accumulation of the roots of virtue (kusalamülasambhāra) is held essential to the acquisition of supernatural faculties. On the effects of punya and jñannasambhära, the $D b h$ remarks (Daśa-bh, p. 45.1-4):

"Because [the bodhisattva] augments the accumulation of merit, he becomes insatiable. Because he seeks the accumulation of pristine cognition, he becomes a person of unfaltering vigour. Because he gathers an accumulation of benevolence and pity he becomes a man of unweary intention."

A further indicator of the importance of punya and jñana is perhaps their inclusion in a number of lists at the upper end of the path containing factors that mark the attainment of the next higher path-stages $(D a s i a-b h$, pp. $55.6,63.20,82.4)$. For another overall correlation of the two sambhära with the various path phases, see: $M s l$, p. $140.10-14$.

An even greater role is played by punya and jnāna in the implementation of the commitments of the bodhisattva's vow ( $M s l$, p. 44.7-11):

"For the sake of sentient beings, I shall acquire an accumulation of merit and pristine cognition.

When an accumulation of merit and pristine cognition has been assembled, all living beings will obtain absolute purity up to the degree of strength of the ten powers (daśabala) as the highest point of unobstructed knowledge." 
They liberate the bodhisattva from personal affliction while he is coursing in samsära; they remove all types of misconception and settle him in the four sciences (caturvidha), including in the accumulation of 'skill' in skandha, etc. ${ }^{735}$

In the $B d p$, these rewards are not specifically mentioned, because its exposition is less concerned with the fruits that spring from punya and jinana than with the factors that promote their acquisition. This is particularly evident in the discussion of jñ̄anasambhāra where a careful distinction is made between the causes and conditions that lead to the accumulation of pristine cognition. In the section dealing with punya, the chain of reasoning is somewhat blurred by the wealth of examples brought together in order to illustrate the kind of conduct that is particularly conducive to the accumulation of merit. At first, taking up the ancient formula of the bases of meritorious works (punyakriyāvastu), the Bdp considers merit acquired through generosity, morality, contemplation, benevolence, vigour, gratitude and virtue transformation. ${ }^{736}$ Then, abandoning the structures provided by the punyakriyāvastu, it introduces a further dozen or so randomly arranged 'ancillary' practices. Central elements to this assortment are the virtues of teaching, generosity, morality, patience, vigour and reverence. ${ }^{737}$ Their presence here is expected, since in particular dāna, síla, kșānti (and vìrya) constitute the chief components of the accumulation of merit. ${ }^{738}$ Having defined the kind of practice that is particularly profitable to the acquisition of merit, the $B d p$ turns its attention to the underlying reward mechanism. In the $B d p$, as in most other works ${ }^{739}$, the highest reward for the accumulation of merit is the acquisition of a perfect body-the buddha-body. ${ }^{740}$ Praised for its purity, physical beauty and intellectual impeccability, it is portrayed as an

And yet, in spite of their widely attested importance to the training, by nature, they belong to the laukika path of the bodhisattva (Kośavyākhyā, cit. in Kośa, iv, p. 77). This view is also attested in the $A k n-t i k \bar{a}$ (p. 248.5.2) where they are said to represent the sambhäramärga, a path phase that is commonly held to represent the earliest phase of the path (DPP, pp. 18-20, 33-34).

735. Bbh, p. $34.17-25$

See also Tathāgataguhyasūtra (cit. in $M B T$, ii, pp. 12.20-12.21) where this very position is concisely put forward:

"The accumulation of pristine cognition has as its aim the destruction of all defilements; the accumulation of merit serves to assist all beings. $O$ lord, this is why the bodhisattva mahāsattva endeavours to acquire the accumulation of pristine cognition and merit."

736. $\mathrm{R}$, folio $639.7-640.5$

A discussion of the principles that underlie the punyakriyāvastu is found in note 132 of my translation of chapter eleven.

737. $\mathrm{R}$, folio $640.5-41.3$.

738. Bbh, p. 33.3-15; Kośa, vii, p. 78.

739. Mavbh, pp. 62.19-63.2.

740. The perfect buddha-body accruing to a bodhisattva on the basis of merit is the rüpakäya. Encompassing the sambhoga and nirmanakäya (Mavbh, pp. 62.19-63.1), it is characterised by innumerable forms of merit, manifesting wonderful and incomprehensible attributes (cf. La Vallée Poussin, $J R A S, 1906$, p. 234; $M s l$, pp. 38.18-21, 41.11-14, 44.17-45, 47.19-21). 
embellishment of great distinction that, no doubt as a reference to the bodhisattva's eventual attainment of buddhahood, adorns the Dharma, Bodhi-tree and Bodhi-seat (bodhimanda). ${ }^{741}$ Moreover; the punyasambhāra frees from rebirth in the lower destinies, consolidates merit, leads to unshakable faith in the Doctrine and buddha-qualities. ${ }^{742}$

In view of the above detail, it is surprising that in the exposition of jñanasambhāra the prospect of reward does not figure at all. Instead, practically all attention is given to the causes that generate and augment pristine cognition. For the $B d p$, there are three causes of jñānasambhāra. First, the bodhisattva develops an ardent longing (chanda) for pristine cognition. This manifests itself in desire to procure the Doctrine whose meaning he studies with great zeal. ${ }^{743}$ Second, there is the support of virtuous friends (kalyānamitra). Guiding the enquiring mind to the Dharma, the virtuous friend becomes a source of inspiration, support and information transforming the bodhisattva's initial and feeble Dharma interest into a potent force. ${ }^{744}$ Third, there is the application of the advice that the bodhisattva has received from virtuous friends. ${ }^{745}$ Intent on wholesome conduct, in particular with regard to meditation, reflection and moral purity the bodhisattva strives to apply the teachings of the Dharma just as told. ${ }^{746}$ In contrast to the practices aimed at the acquisition of merit, pristine cognition focuses chiefly on facets that are conducive to understanding, such as contemplation and investigation. $^{747}$

Thus matured, the bodhisattva manifests the conditions that accompany the accumulation of wisdom. ${ }^{748}$ For the $B d p$ these are untarnished understanding of reality, modesty and virtuous

741. $\mathrm{R}$, folio $641.4-642.3$.

742. $\mathrm{R}$, folio 643.2 .

743. $R$, folio 643.4 .

744. $R$, folio $643.5-7$.

745. Another factor that is given in the $B b h$ (p. 34.2-7), viz., previous exercise in the accumulation of pristine cognition, does not appear in the $B d p$ as a separate cause of jīānasambhāra. However it could be argued that the last portion, entitled "exertion in the accumulation of pristine cognition" refers to the bodhisattva's previous practice in pristine cognition. For the $B b h$, this exercise must have taken place in the past. Yet, as the exact point in time is undefined, we may assume that previous exercise was meant in the broadest terms, that is, exercise prior to the attainment of jinanasambhāra (Bbh, p. 34.4).

According to the $B b h$, the three causes apply not only to jñ̄anasambhära but also to punyasambhära (Bbh, p. 34.2). Moreover, there they are conceived in sequence. That is to say, longing for the Dharma leads to the acquisition of pristine cognition, the presence of a virtuous friend stabilises it and previous practice increases its accumulation (op. cit., p. 34.3-4). In the $B d p$, this distinction is not explicitly made, although the passage "after [his virtuous friends] have realised that he is a receptacle of the Dharma, they instruct him constantly with great concentration in the Doctrine; after he has heard the Doctrine, he exerts himself in the accumulation of virtuous practices" could well be interpreted in this light.

746. Note that the $B b h$ (p. 33.5-6) associates pristine cognition with prajñāpāramitā only.

747. This is roughly in line with the thinking of the $B b h$ (p. 33.21-24), proposing that it is prajña springing from learning, reflection and contemplation-in conjunction with virya and dhyana-that has the greatest effect on the accumulation of pristine cognition.

748. Cf. $B b h$, p. 33.22 . 
conduct. Through merging the cognitive dimension with the more practical side of the path the bodhisattva maintains his commitment to the welfare of sentient beings whilst recognising the futility of discursive, binary thinking. ${ }^{749}$

Having discussed the causes and conditions that generate the accumulation of pristine cognition, the $B d p$ looks further afield to define the practices that increase its size and scope. Echoing the widely affirmed connection between the pāramitā and sambhāra, these primarily consists of generosity, morality, patience, vigour, meditation, wisdom and (skilful) means. ${ }^{750}$

749. $\mathrm{R}$, folio 645.3 .

750. Each of these practices is discussed in one of the twelve tetrads that make up much of the concluding section of the treatment of the jñanasambhära. Excepting the perfection of generosity, their presentation is sequential and very straightforward. The dänapäramitä differs from the rest in that it extends over three tetrads-all others are dealt with in one-with a fourth on the powers (bala) being appended. Generosity has a special position in the $B d p$ where three types of giving are itemised, viz., the granting of material objects and respect (tetrad one), the granting of protection (tetrad two) and the bestowal of support (tetrad three). The rationale for the inclusion of the bala at this point is not fully clear. In all, I have identified three potential avenues of thought that might help us to understand this rather curious positioning of the bala.

First, there is the possibility that the inclusion of the bala here was intended to complement or qualify the three types of danna. Generosity is less concerned here with the customary giving of wealth or Dharma, but refers chiefly to the granting of support and protection. These two spheres of dana naturally require strength and resolve. Building on the assumption that the bala constitute a more active force than the indriya, that they are the indriya made strong and of greater intensity in application, the $B d p$ may have wished to substantiate the claims of protection and support through their interpolation. As Gethin has shown, the image of, or association with, physical strength is by no means foreign to the characterisation of the bala (M I, pp. 121, 244).

The second train of thought revolves around the interpretation of sraddh $\bar{a}$-the first of the five bala. Investigating the perception of śraddha in Vedic literature, Köhler (and after him Hara) has unearthed a significant amount of material suggesting that to early Vedic priests śraddhä meant, above all, generosity (Spendefreudigkeit). In later times (with the Samhita and Brähmana), with the increasing demystification of the universe, he argues (pp. 44, 57), the notion of generosity gained more and more independence from its concomitant 'devotion' (Hingabe) and eventually became the dominant meaning of the term śraddha . He places this last phase in the period of the Upanisad (Chänd. Up and Brhad Up; pp. 68-70). Proposing that this trend towards rationalisation continued in the times of the Buddha, he presents a series of quotations from the nikāya to show that generosity is besides faith the second cardinal meaning of $\dot{s} r a d d h a \bar{a}$ in early Buddhism. As Gethin observed, he is rather selective in doing this and discusses chiefly contexts involving the granting of alms, thereby blurring the act of giving with a mental predisposition of faith (S I, pp. 22, 32, 42; A III, p. 34). While sraddhā in these quotations appears to support his views, the rather specific context weakens his argument.

Leaving aside the findings in the nikāya, his conclusions for the Veda alone seem to establish some connection between dāna and sraddha in the sense of Hingabe. Of particular interest is a passage from the Yoga Sütra that lists five requirements for yogic meditation (Yoga-S 1.20). These correspond verbatim to the five bala (or indriya for that matter). Now, according to the commentary, śraddha is here best interpreted as devotion (yogavisaye cetasah prasādah) (p. 70). In our context, this could be taken to link däna and protection. For giving to have greatest effect, the presence of an affective element is certainly of advantage and an addition to merit. In a very loose sense, it is thus perhaps not too far-fetched to see a trace of this association in the addendum of the bala to dana.

Third, we note a certain parallelism between the five supports (upastambhana) that are cited in the $M v u$ (ii, p. 280.16-17) and our list of bala. To be precise, all five supports, except the first, are identical with the five powers. The first support, instead of being śraddha as in the bala, is chanda. Now, the question is whether there is any evidence for us to construe a link between śraddha and chanda. The answer to this is yes. According to the Abhidh-sam (R) (pp. 7-8), the purpose of sraddha $\bar{a}$ is to provide a foundation for chanda, in turn giving a base to virya (cf. Siddhi, pp. 309-10). Moreover, in the Nett (p. 15) we learn that chandasamädhi appears in the context of the iddhipāda as mental one-pointedness, possessing saddh $\bar{a}$ as dominant force. The link between śraddha and chanda is further reinforced by the interpretation of the 
Besides the six/seven perfections, it is only insatiability and the powers (bala) that are seen to augment the accumulation of pristine cognition. ${ }^{751}$ However, if we read on to the end of the discussion, we find that neither of them is included among the practices that promote jñänasambhāra. Instead, it is the four merit-generating apramāna that occur alongside the perfections. $^{752}$

This choice is problematic and raises several questions. First, virtually all the texts I have consulted agree that dāna, síla and kșānti play no role in the generation of jñānasambhāra. ${ }^{753}$ They are applicable to punyasambhära, so their inclusion here among the factors that generate jñannasambhära clearly comes as a surprise. The picture is less clear with regard to virya and dhyāna about which differences in opinion prevail, depending on the circumstances of their cultivation. ${ }^{754}$ Then, why has the cultivation of upāya been omitted in the final round-up if it figured as an apparently independent (päramitä-like) practice in the tetrads? The answer is that probably upāya had not yet been fully recognised in status as a fully-fledged perfection, and was thus excluded from the final count. Also the inclusion of the apramana is problematic, since all accounts agree that they do not appertain to jñänasambhāra. Conversely, the powers-forming part of the bodhipākșika dharma that belong to the jĩānasambhära producing practice of dhyāna-do figure in its acquisition, but are not cited in the resumé.

faculty of faith in the Pāli commentaries (Ud-a, p. 305; Vibh-a, p. 125; Vism, p. 464; As, p. 120; ref. Gethin), where saddha is regularly interpreted as a commitment (adhimutti). As a psychological force, $\dot{s} r a d d h \bar{a}$ must therefore be understood as a type of basic confidence that-manifesting commitment and resolve-triggers the wish to embark on the path. Seen from this angle, sraddha is then one step behind chanda in the concatenation of mental factors leading to path practice. Note, that in the Srotabhümi (p. 287.4.6), set in a meditative context, chanda occurs alongside śraddhā, virya and upāya as the four types of application (prayoga) operating as factors stabilising meditative concentration.

751. A third factor, the accumulation of paths, rather than increasing jñanasambhära is held to prompt its penetration and stands so apart in function ( $R$, folio 648.1-2).

752. For the Kośa (vii, p. 78), the practice of the dhyānapäramitä, if manifested in the cultivation of the four apramāna, contributes to the accumulation of merit. If dealing with the cultivation of the bodhipäksika, it promotes the accumulation of pristine cognition (cf. Kośa, viii, pp. 196-205 and Daśa-bh p. 45.1-3, citing besides a punya- and jīānasambhāra also a maitrī-and krpāsaṃbhära).

753. According to the $M a v b h$ (p. 62.18-19), this role pertains only to dhyāna and prajinā, while virya constitutes a kind of ancillary practice required for both punya and jinanna (cf. Samdhis (ELa), pp. 72.5-10, 131.19-22).

754. Kosa, vii, pp. 77-78; Bbh, p. 33.7-24; Mavbh, p. 62.15-19; Msl, p. 139.22-23. 
Practices that Conduce to Enlightenment

The bodhipäkșika dharma themselves occupy a central position in much of the remainder of chapter eleven. Taking up over a fifth of its content, they constitute the most distinct category of practices included in the discussion of prajñāpāramitā. The reason for their preponderance is obvious. First, since they operate as "factors contributing to enlightenment" 755 , their cultivation becomes mandatory for every bodhisattva who courses in Perfect Wisdom. ${ }^{756}$ Then, prajñ $\bar{a}$ itself is a chief member of the ten or eleven 'ingredients' (dravya) of the bodhipākșika, represented by the four smrtyupasthāna, prajñendriya, prajñābala, dharmapravicaya and samyagdrsți ${ }^{757}$ Moreover, the thirty-seven practices originate themselves in wisdom arising from learning, reflection and cultivation-the very foundations of prajñ $\bar{a} .^{758}$

While in spirit very close to those bodhipāksika expositions found elsewhere in the Mahāyāna, their discussion in the $B d p$ manifests several peculiar features. Primarily, these affect organisational abnormalities, the actual phrasing of the formulae and their inclusion into an expanded list of practices. Since the scope, intent and nature of the bodhipäkșika have been already adequately researched by others, I shall limit my analysis to facets where the $B d p$ differs from the more 'standard' interpretations. ${ }^{759}$

One is struck first by the extent to which the wording of the $B d p$ 's description deviates from that of other bodhipākssika accounts. A comparison with formulae from both Pãli and Sanskrit sources reveals that, except for the samyakprahāna, it stands very much on its own. ${ }^{760}$ Having examined most texts on the subject, I found only two works containing a

755. Mpps, iii, p. 1119. For other definitions following these very lines, see: Kosia, vi, p. 282; Satya-s (S), ii, p. $41 ;$ Abhidh-d, pp. 357-8.

756. Ssp (Ghosa), pp. 55-56.

757. Kośa, vi, pp. 283-84; Amrtar (B), p. 208; Abhidh-d, p. 358.5-14; Mppś, iii, p. 1046 (cf. Srotabhūmi, p. 291.2.1-3).

758. Kośa, vi, p. 284.

759. The bodhipa assika dharma have already been subject to several investigations. The most exhaustive and resourceful study - albeit limited to their treatment in the nikāya and Păli Abhidhamma works-is that by Rupert Gethin (PhD Dissertation, University of Manchester, 1987). Other, often rather brief or partial investigations have been carried out by Étienne Lamotte (Mppś, iii, pp. 1119-1207) and J. Bronkhorst (BSOAS, 1985, pp. 305-20). References to the bodhipäksika are extremely numerous in both Pâli and Sanskrit literature. In the Mahăyāna, they are known to occur in the following sütras: Bdp, TTP, 23, pp. 82.3.8-85.3.4; Kp, § 95; Ug, p. 269.3.8-4.3 (part.); Rp, p. 2.9 (part.); Rcd, 24, pp. 235.3.4-44.2.6; $A k n$, 34, pp. 66.4.3-71.2.1; Arthav (S), pp. 28-42. For references in the Dasa-bh, Pañca, Ssp, Karunap, Samädh and Lal and many others, see: Dayal, p. 80, Edgerton, p. 402 and Lamotte, p. 1120. See also Gethin (1987, p. 661) for references in Sarvāstivāda literature and, of course, for a complete table of references in Pāli sources.

760. The most common specimen of such bodhipäksika quotations have been convieniently collected by 
similar phrasing. These are the Akn and Arthavniścayasütra (Arthav). I have already pointed to the far-reaching borrowing between the $A k n$ and $B d p$ and so resemblances in the wording of the bodhipākșika are not surprising. Of greater interest are the parallels between the $B d p$ and Arthav, since they represent texts of rather different orientation and purpose. ${ }^{761}$ Here, the borrowing is only partial (affecting merely the faculties (indriya) and noble eightfold path $(\bar{a} r y a \bar{a} t ̦ \bar{a} \operatorname{ngama} r \mathrm{rga})$ ) and appears to be indirect. ${ }^{762}$ Comparison with the wording in the $B d p$ and $A k n$ reveals a very close verbal proximity with that of the $A k n$ that suggests that the Arthav adopted the passages on the indriya and āryāștāingamārga from the $A k n$-not from the $B d p .^{763}$ While the dating of the Arthav is, as always, problematic, analysis of its contents has shown that most of its portions post-date both the $A k n$ and $B d p$ by several centuries. ${ }^{764}$ Assuming the $B d p$ 's influence on the $A k n$, we have a textual lineage that covered may be as many as five centuries, starting with the $B d p$ 's lending to the $A k n$ from which its contents reached the Arthav, to be finally included in the Siks, where the indriya section is also quoted from the $A k n .^{765}$.

The $B d p$ 's apparent uniqueness in description does not extend to the spirit of its bodhipākșika exposition. Virtually every aspect raised has counterparts in meaning in some other bodhipākșika discussion elsewhere in Mahāyāna works.

Starting with the smrtyupasthana (the second type of 'skill' not cited in the heading), the proposition is that each type of mindfulness combats one of the principal four misconceptions (vipary $\bar{a} s a)^{766}$; this is frequent among post-canonical strands of Buddhist literature. Though not found in the nikāya, the Sarvāstivāda Abhidharma adopted it as the chief task of the smrtyupasthāna and it is also found in most Mahāyāna treatises on the subject. ${ }^{767}$ Probably

Lamotte in a preliminary note to the Mpps's bodhipākssika discussion (iii, pp. 1119-1132).

761. Unlike the $B d p$, the Arthav is a highly technical work consisting of stereotyped explanations of twenty-seven groups of practices. Likened by Ferrari in contents and nature to the Dhsgr and $M v y$, it proceeds step by step through the aggregates, elements, sensefields, bodhipäkșika, pratisamvid, etc., on each of which it contains definition-like descriptions. For an assessment of its contents, see the introductions to Ferrari's and Samtani's editions of the Arthav.

762. Arthav (S), pp. 32.6-33.1 for in the indriya; pp.320-22 for the äryästängamārga.

Comparing the formulae collected by Lamotte with those of the Arthav (pp. 28.9-42.12), we gain the impression that their wording in the Arthav represents a combination of Păli and Sanskrit sources, as if its authors had consulted a variety of texts before composing their own version. This is true for all but the indriya and äryāsțāingamārga section which, as already observed, appear unique to the $B d p / A k n$ tradition.

763. I have given the Sanskrit text of the Arthav's indriya and äryāștāngamärga sections in notes to the edition.

764. Arthav (S), pp. 61-67; Ferrari, 1944, pp. 546-49.

765. Siks, pp. 316.13-317.13.

766. On the misconceptions, see: A II, p. 52; Vibh, p. 451; Kosia, v, p. 21; Amrt (B), pp. 226-227; Mppsi, ii, p. 925; iii, p. 1150.

767. In the nikāya, the connection between the vipalläsã and satipațthāna is not clearly stated. See, however, A 
drawing on these traditions, the $B d p$ confirms that to consider the body mindfully-internally and externally-leads to a pure body of sound conduct. ${ }^{768}$ The same holds true for the discussions of feeling, thought and dharma that explain mindfulness as distinguishing pleasant from unpleasant feeling, permanence from impermanence and self from non-self. ${ }^{769}$ But the $B d p$ differs in the stress it places on viparyāsa itself. When discussing kāyasmrtyupasthāna, for instance, it is only in the very last passage that the issue of purity/impurity is raised. Much of the preceding material revolves around the theory of non-self with regard to the body and the use to which the body is put. With the exception of vedanāsmrtyupasthāna, that is entirely dedicated to the correct interpretion of feeling, very little is also said about viparyāsa in the remaining bases of mindfulness. Both cittasmrtyupasthāna and dharmasmrtyupasthāna touch on viparyāsa almost incidentally and give greater consideration to issues that develop from the affirmation of impermanence and non-self. ${ }^{770}$ In the discussion of mindfulness concerning thought it is the distinction between 'creation' and 'foundation of thought' that stands in the foreground, whereas in the exposition of mindfulness concerning dharma the concept of dharma-sameness prevails. ${ }^{771}$

In addition to the references to the viparyāsa there is one more element in the $B d p$ that is common to all four types of mindfulness. This is the adaptation of the individual members to the bodhisattva's concern for the welfare of sentient beings. When speaking of kāyasmrtyupasthäna, the $B d p$ commits the body to universal subsistence, to the conversion of gods and men and the postponement of entry into nirvāna. ${ }^{772}$ Likewise, investigation into feeling is explicitly aimed at explaining feeling to others. ${ }^{773}$ Through mindfulness concerning thought the bodhisattva acquires the paracittajñanna that allows him to perceive samsāric delusion and, in turn, sustains the resolve for universal liberation. ${ }^{774} \mathrm{~A}$ similar mechanism is

II, p. 52 and Vibh, p. 376. For the Sarvāstivāda Abhidharma, see: Amrt (B), pp. 203-4; Kośa, vi, p. 162. For the Mahāyāna, see: Kp, pp. 137-9, § 94-95; Rcḍ, pp. 236.2.8-239.4.3; Arthav-ț (S), p. 208; Srāv-bh (Sh), pp. 303-12; Mppś, iii, pp. 1144, 1150.

768. R, folio 651.6 .

769. Reference to these position can be found on $\mathrm{R}$, folio $652.1-653.2$; folio $655.1-7$; folio 596.1-660.1 respectively.

770. This is a common feature of the discussions of the smrtyupasthāna in the Mahāyāna. In the Käsyapaparivarta (Kp, p. 139, § 95), for instance, these notions become the raison d'être of the smrtyupasthanna exposition. In most traditional accounts, eradication of the notion of a self is only a side-issue to the bases of mindfulness. See, for example: D II, pp. 290-314; M III, pp. 83-5, 135-6; S V, pp. 149-50; Kośa, vi, pp. 159-161; Vism, p. 464. There is, however, one passage in the Dighanikāya that appears to be heralding future concerns (D II, p. 216).

771. See: R, folio 656.3-657.6; folio 660.1-661.3 respectively.

772. R, folio 651.7 .

773. R, folio 652.6-653.2.

774. $R$, folio $657.7-658.2$. 
at work in the examination of dharma. Having recognised the sameness of non-arising dharma, the bodhisattva sees that all dharma are pure. And yet, retaining awareness of the suffering in saịsāra he does not give way to the conclusions of no-birth, but reappears in order to look after sentient beings. ${ }^{775}$

It is hardly surprising that the commitment to universal liberation should figure in the smrtyupasthanna of a work such as the $B d p$. It is also found in the Rcd and referred to in number of other bodhisattva scriptures. ${ }^{776}$ Other widely shared points include references to the mahābhüta and Tathāgata-body in the kāyasmrtyupasthāna ${ }^{777}$, the enumeration of the different types of sensations in the vedanāsmrtyupasthāna ${ }^{778}$ and, of course, the philosophic background postulating a vision of reality that-exceeding the limits of suffering, impurity, non-self and impermanence-envisages universal purity, sameness and non-origination. ${ }^{779}$

The most remarkable among the bodhipākșika in the $B d p$ are probably the perfect efforts (samyakprahāna). ${ }^{780}$ Where other accounts explain their operations rather mechanically in terms of types of vigour (vidhavirya), the $B d p$ presents a logically coherent explanation of their functioning. ${ }^{781}$ Once again the key term in its explication is correct reflection (yoniso manasakāra). As a conceptual synonym for zeal (chanda) concerned with avoiding unwholesome dharma, it stands at the very heart of the bodhisattva's spiritual training. ${ }^{782}$ Causing persistant preventive refraint from non-virtue and the withdrawal from already produced unwholesome dharma, it becomes the cognitive foundation for the training in general and precludes the presence of unskilful dharma. The nature of the unskilful dharma, however, is kept rather vague; they are not characterised beyond their incompatibility with morality, meditation and wisdom. Conversely, we learn about the factors that lead to their presence and the antidotes that do away with them. Epitomised by the root evils of desire,

775. $\mathrm{R}$, folio $660.2-5$; folio $661.4-5$.

776. TTP, 24 , pp. $236.5 .2-8,237.4 .12-2,239.5 .8$.

777. Mppś, iii, p. 1188; Rcd, p. 236.3.4-5.

778. Mppś, iii, pp. 1190-91.

779. Mppś, iii, pp. 1187-1194.

780. For examples of Päli and Sanskrit versions of the basic formula of the sammappaddhäna/samyakprahanna, see: Lamotte (Mppś, iii, pp. 1123-24) who cites passages from the Dighanikāya (III, p. 221) and Pañca (p. 207).

In contrast with all other known accounts of the bodhipäkșika, the samyakprahäna are not the practice that follows on the smrtyupasthāna in the Bdp. Defying the traditional order, the next practices cited are the bodhyariga. However, in order to do justice to the integration of the thirty-seven factors into a logically consistent description of the path, I discuss the seven sets in their standard order. Just what might have prompted this change in sequence-no doubt a major issue-is discussed further below.

781. See, for instance: $M v \dot{s}(N)$, p. 50.19-24; Abhidh-sam (R), p. 120; $M p p s$, iii, pp. 1176-77.

782. R, folio 672.2-673.4. 
hatred and delusion, they arise from attachment, anger and ignorance and are removed by considering the antidotes of impurity, benevolence and causality. ${ }^{783}$ By virtue of dharmasameness, pacification itself induces abandonment in the sense of non-apprehension (anupalambha) and hence becomes a stepping-stone in the bodhisattva's attitude towards reality. ${ }^{784}$

Having distinguished virtuous from non-virtuous dharma through correct reflection, the bodhisattva applies himself to generating wholesome dharma. ${ }^{785}$ This process consists of three phases, that is, initial intent (chanda), acquisition of diligence (virya) and perseverance (āsthitikriya). While each of these is fundamental to the planting of roots of virtue, it is only through their combined presence in the practitioner's mind that virtue hitherto unarisen is produced. The magnitude of the bodhisattva's aspiration means that this operation knows no limit. ${ }^{786}$ Motivated by the commitment to universal welfare, the bodhisattva does not allow his newly accumulated merit to disperse uncontrolled. On the contrary, he goes to great lengths in securing the roots of virtue in order to transform them into enlightenment. Such roots persist, says the $B d p$, because the thought that led to their becoming was itself supramundane and because they are founded in lokottara practices independent of the traidhätuka. By this context, the $B d p$ indicates that the generation of wholesome dharma itself pertains to the lokottara realm. ${ }^{787}$ Since the perfect efforts are anchored in laukika practice, the $B d p$ appears to be drawing a line between a laukika effort and a lokottara realisation of that effort. ${ }^{788}$

In a way, the $B d p$ therefore has accommodated its discussion of the samyakprahana to the ancient belief that the four correct efforts embrace the whole Buddhist path. Already characterised in the nikãya as general endeavours of restraint, abandonment, development and protection-and thus furnishing each part of the formula with a positive content-the

783. R, folio 673.5-7.

784. R, folio 673.7-674.1.

785. For the $S b h$ (Śāov-bh (Sh), pp. 318.12-320.19), a person who cultivates the samyakprahāna possesses eight types of effort-predisposition (prahānasamskāra) that are designed to destroy his propensities (anuśaya) and to fulfil his meditations. These are (1) zeal (chanda), (2) endeavour (vyāyāma) corresponding to vigour (virya), (3) faith (śraddhâ), (4) tranquillity (praśrabdha), (5) mindfulness (smrtî), (6) awareness (samprajanya), (7) volition (cetană) and (8) equipoise (upekșā).

786. $\mathrm{R}$, folio $674.2-3$.

787. $\mathrm{R}$, folio $674.7-675.2$.

788. Such a position would seem to echo the view of the Vibhanga commentary (Vibh-a, p. 219; ref. Gethin, p. 630) which distinguishes between lokiya and lokuttara interpretation of the sammappaddhäna. Here, depending whether the perfect efforts pertain to the 'prior stage to all' (sabbapubbabhäga)--which represents a kind of preparatory phase indicating advance to the practice proper-or go beyond this stage, the sammappaddhāna are either worldly or transcendental in nature. 
samyakprahana epitomise for the $B d p$ a blueprint of the course of practice complete in itself. $^{789}$ The difference between the nikayya and $B d p$ are that while the former provide a specific focus for the four practices (restraint being characterised as the guarding of senses; abandonment as the renunciation of thoughts governed by desire and hatred; development as the cultivation of the bodhyanga and protection as the contemplation of ugliness $)^{790}$, the latter puts principles rather than individual practices in the foreground.

In most discussions of the bodhipāksika, probably all according to Gethin, the practices to follow on the samyakprahāna are the bases of success (rddhipäda). ${ }^{791}$ In the $B d p$, however, the rddhipäda are not discussed following the samyakprahäna. In fact, there is no full treatment of the rddhipāda anywhere in the $B d p$, though its author must have been aware of them because of several brief references to the rddhipäda in the Dhyāna Chapter. ${ }^{792}$ Today, it is difficult to establish the reasons that prompted their omission without comment in the Prajña Chapter. A contributing factor for this may have been the consideration that the $r d d h i p a \bar{d} a$ are not an absolute requirement for the destruction of the $\bar{a} s r a v a .{ }^{793}$ Being particularly associated with mastery over meditative attainments and powers, they are not part of those practices that aim at wisdom-acquisition, but pertain to the domain of meditation (dhyāna). We have seen that for the $B d p$ the single most important means to prajñ $\bar{a}$ is investigation (pravicaya). Now, if we adopt Cousins's distinction between the śamatha- and vipaśyanāyāna ${ }^{794}$, investigation is doubtlessly closer to the 'vehicle of insight' so neglect of the rddhipãda might almost be expected. Moreover, the fact that they have already been referred to in the Dhyāna Chapter - albeit only sketchily-might have been reason enough for their omission in the praj $\tilde{n} \bar{a}$ context.

Bypassing the rddhipāda, the $B d p$ therefore moves directly from the samyakprahana to the faculties (indriya). However, of all the faculties' traditional members only śraddhã is given full consideration. ${ }^{795}$ Characterised as confidence in the existence of other worlds, in the law of karma, in the bodhisattvacary $\bar{a}$, in causality and in the ontological doctrines of the Mahāyāna,

789. A II, p. 74 .

790. D III, p. 225; A II, pp. 16-17.

791. Gethin, 1987 , pp. 508-9.

792. $R$, folio $569.3-570.2$

Note that the rddhipāda are also omitted from a list of bodhipäksika dharma on folio 277.7.

793. Compare, for instance, the lists of khināsavabala that are found in A V, p. 175 and Patis, ii, pp. 173-4 with that of the D III, pp. 283-4 where the iddhipäda have been omitted (Gethin, 1987, pp. 496-7, 498).

794. Cousins, $B S H S$, pp. 56-68.

795. For a definition of the five spiritual indriya, see: Kosia (ii, pp. 154-7) and Siddhi (pp. 309-314). 
faith becomes in the $B d p$ very much a spiritual foundation. ${ }^{796}$ Again, this role of faith is already attested in the nikāya ${ }^{797}$ where-essentially affective in nature and directed at the Buddha or his enlightenment-its function is to instigate and set in motion a process culminating in wisdom, for which it also provides continuing support. ${ }^{798}$ As if to underline this point, the remaining indriya are only mentioned by name and in relation to the forces that shape the succession of their occurrence. In order to obtain the result in which he believes, the bodhisattva makes an effort (virya). ${ }^{799}$ When he exerts effort, mindfulness (smrti) is initiated. From mindfulness springs concentration of mind (samādhi) as to avoid distraction and from that arises consciousness that corresponds to the object (prajñä). The logic behind this concatenation is perfectly sound and it is perhaps not very surprising that there is an almost verbatim passage in the Kośa. ${ }^{800}$

Of still greater interest are the advantages that accrue from the indriya. For the $B d p$, these are of the highest order since they include the buddha-qualities and access to the stage of prediction (vyakaranabhümi) which is generally held to correspond to the acalābhümi. ${ }^{801}$ Most other schemes place mastery over the indriya well before the eighth stage. ${ }^{802}$ Yet, the association of the faculties with the event of the prediction might provide the key to their

796. This, of course, is true for Buddhism in general. See, for example, the nature and names of the seven categories of ārya where the śraddhānusārin occupies the lowest rank (Kośa, vi, 273-282). Note, however, that in Kosia (vi, p. 289) all indriya are actually aimed at supramundane dharma. For the Theravāda, the five spiritual indriya are the exclusive domain of the ärya-pudgala and are therefore always lokottara (Gethin, p. 264).

797. M I, pp. 142, 294, 444, 479; S IV, pp. 226, 298-9; A III, p. 165.

798. Research documenting the reciprocal relationship between śraddhā and prajĩa has been carried out by a number of scholars. For summaries of their findings, see: Carter, Dhamma, Tokyo, 1978, pp. 103-6; Ergardt, 1977, pp. 144-6; La Vallée Poussin, 1908, ii, pp. 32-43.

799. According to the Abhidh-sam (R), pp. 7-8, sraddha first must provide a basis to chanda that, in turn, becomes a foundation for the generation of virya.

800. Kośa, vi, p. 287

A similar relation between the five indriya is also posited in the Mpps' and $R c d$. The $M p p s$ includes, like the $B d p$, faith in the bodhisattva training, faith in causality and moral integrity and confidence in emptiness, sameness, etc., as manifestations of the śraddhendriya (Mpps, iii, pp. 1195-96). For the Rcd, it is above all rejection of the heretical views positing a self (ätmadrsți) and faith in buddha-qualities (pp. 240.5.6-41.2.7). Compare these with the expositions on sraddha given in the $S b h$ and $K p$. But for one or two minor points, their explanations have virtually nothing in common with that of the $B d p$. In the $K p$ we learn that the five faculties function as antidotes to doubt, inertness, forgetfulness, distraction of mind, absent-mindedness and misconceptions (pp. 137-39, §95-96). In the Srāvakabhūmi, the faculty of faith should be taken as the four types of faith verified, vigour as the perfect efforts, mindfulness as the bases of mindfulness, meditation as the four dhyāna and wisdom as insight into the noble truths (Srā $v-b h(S), \mathrm{p}$. 232.7-18; cf. $M v s ́(N)$, p. 53.4-8).

801. The various types and occasions at which predictions to buddhahood take place, I have discussed in note 233 of my translation of chapter eleven.

802. According to the Sarvāstivāda Abhidharma (Kośa, vi, pp. 287-89, Abhidh-d, p. 362.16-17), the attainments of the indriya correspond to the kșanti stage of the nirvedhabhāgiya that, traditionally, is situated on the prayogamārga. For alternative locations on the path, but always situated on the prayogamärga, see: Abhidh-sam (R), pp. 116-7 and Abhidh-h (W), ii, p. 140.

For Mahãyāna schemes, see: Daśa-bh p. 39.3-4; Bbh, pp. 338.24-341.6. 
unusual arrangement after the bodhyanga and āryāṣtāingamārga. But more of this later. ${ }^{803}$

The discussion of the five powers (bala) does not pose any of such difficulties. ${ }^{804}$ Conforming to the well-known proposition that the powers represent little more than an advanced, actively more effective phase of indriya practice, the $B d p$ 's main concern is to illustrate the bodhisattva's invincibility in sraddha, virya, etc. ${ }^{805}$ To this effect, the $B d p$ sets each of the bala in contexts that render their practice particularly laborious and concludes that even in the most adverse situations faith, etc., is unassailable at the level of bala. That is to say, the bodhisattva's faith in the Dharma is not deflected by the treachery of Māra. ${ }^{806} \mathrm{He}$ is unsurpassed in vigour by even the combined determination of all gods and men. His mindfulness cannot be shattered by intrusion of any type of defilement. When contemplating, he maintains deep absorption during the first dhyāna regardless of persisting in altruistic conduct that involves him in the bustle of worldly life; he sustains investigation during the second dhyāna, sympathetic joy during the third dhyāna and finally disquiet at universal suffering during the fourth dhyāna. Indefeatable in cognition, he acquires the most formidable crafts and skills that, springing from wisdom and knowledge, he puts to use in his quest of liberation. ${ }^{807}$ The presence of such impediments is, of course, far from accidental. For, his initial resolve (pranidhäna) constrains not only escape from the pressures of samsära but, more to the point, actually requires that

803. It is evident that the only viewpoint from which the $B d p$ examines the faculties is a spiritual one. That is to say, it excludes from consideration the remaining seventeen constituent indriya that shape human experience in general (La Vallée Poussin, Nirväna, 1925, Paris, p. 237). For the Mvś, in contrast, it is chiefly these 'controlling principles' that stand in the centre of its discussion of 'skill' in indriya. Giving the illusion of dominion in the sense that certain powers are held to fall to specific faculties for specific purposes-e.g., the eye having the ability to see objects and hence be sovereign over the object-the $M v \dot{s}$ $(M v \dot{s}(N)$, p. 46.23) warns that there is no agent that rules over these faculties since they are independent. For our purposes, it is of interest that the five spiritual indriya are thought to pertain to worldly purification (laukikavisuddhi) only, while the 'faculties of knowing what is not known' (anäjñatamājiñasyāmindriya) - the second type of purification-are sovereign with regard to transcendental purification (lokottaraviśuddhi). This confirms what we learned about their status from Sarvāstivāda schemes and tallies with the positioning in the $A k n$ and its commentary. The anājinatamājñäsyãmindriya are manifest on the darśanamärga and inspire desire to know the four truths, etc., (Kośa, ii, p. 117) while lokottaravisuddhi is 'eradication of defilements through transcendental conduct' (lokottaramārgenakleśanām prahānam; Mvś-t, p. 156.7).

804. For parallels in the fruits of bala see: Rcd (pp. 241.2.7-242.1.4) and Amrt (B), p. 205.

805. For Palli references to this effect, see: M I, pp. 121, 168, 244; S V, p. 220; Patis, i, pp. 6-7 and Atthasälini, p. 295. A good Sanskrit reference is found in the commentary to the Arthav (S), pp. 226-7; cf. Kośa, vi, p. 286).

806. See, $R c d$ (p. 241.2.7-3.1) where we come across exactly the same theme in conjunction with the śraddhäbala. The Rcd abounds with other, rather interesting, manifestations of bala (pp. 241.2.7-42.1.4). For, instance, it proposes that śraddha causes the acquisition of the seven riches (5.4) and power over zealous application (adhimukti); power of virya leads to the accomplishment of the bodhyanga (5.4) and power over liberation (3.7); smrti entails the six recollections of the bodhisattva (5.5) and power over the fifth dharmaskandha (3.7); dhyāna eliminates the seven bases of consciousness and prompts great mental power (3.8); prajiñ removes the eightfold mistaken conduct $(5.5-6)$ and purifies the conduct of all beings (3.8).

807. $R$, folio $677.4-679.6$. 
he expose himself to the very conditions from which he seeks release. Taking account of these constraints, the $B d p$ merges two concepts in its exposition of the five bala. On the one hand, it follows the traditional line that the bala are superior to the indriya in attainment, while on the other hand, it employs typical bodhisattva imagery to illustrate the origin, scope and nature of the obstacles that must be overcome by the cultivation of faith, etc. ${ }^{808}$

Few traces of such adaptation are found in the treatment of the factors of enlightenment (bodhyanga). Emulating the bodhipāksika tradition of early Buddhism, the $B d p$ provides rather terse, definitive accounts of the focus and nature of each of the seven limbs. Judging by my reading of sütra material, its explanations have no parallels in other texts. In spirit and practice, they correspond for the most part to ancient interpretations. Only in the ontological domain do differences prevail. For example, there is the conclusion in the smrtibodhyanga that the recollection of dharma establishes knowledge of the lack of own-being of dharma-an opinion seemingly at odds with the ancient ideas of reality.

The $B d p$ explains smrti in terms of recollection and presence of mind that, manifesting careful examination and analysis, command a vision of things just as they are. Next, the bodhyanga of Dharma-discernment (dharmapravicaya) is explained in terms of contextually adjusted approaches to the various types of instructions that make up the Dharma. As Gethin shows, this interpretation is one of several aspects that stand at the very heart of the concept of dharmapravicaya in the nikāya. ${ }^{809}$ Vigour (virya) is portrayed as a quality of strength and dedication, specifically directed at those factors that contribute to awakening, viz., Dharmadiscernment, purification, meditation and equipoise.

This choice of 'vigour targets' contains a clue to the bond between the next two bodhyanga, namely, joy (priti) and tranquillity (praśrabdha). Traditionally linked as factors that bring about a positive mental disposition, priti and praśrabdha are intimately related to each other in practice and result. ${ }^{810}$ The nature of this relationship is best summed up in the ancient 808. $\mathrm{R}$, folio 679.6

Note also that preference is given to the bala over the indriya as practices leading to the accumulation of pristine cognition. Here, as in the bala section proper, each of the bala is specifically adapted to the bodhisattva training, when it says that faith promotes reverence; vigour is targeted at learning; mindfulness prevents oblivion of the thought of enlightenment; meditation helps faith in dharma-sameness and that wisdom assists acquiring the power of learning ( $R$, folio 646.1-3). For examples of sources where reference to the bala (when subsequent to the indriya) are given only scant attention, see: Abhidh-sam (R), pp. 123-4; Amrt (B), p. 205; Mvś (N), p. 52.20; Mppś, iii, p. 1200; Satya-s (S), p. 43.

809. Gethin, 1987, pp. 283-295; cf. Abhidh-sam (R), 1980, p. 123.

810. See, for instance, Mahāparinirvānasütra (Waldschmidt, 1956, p. 292, 30.27) where we read that joy (priti) associated with the body leads to tranquillity (praśrabdha) of the mind (cf. Mvy 1587-95). 
formula, saying that "the body of one whose mind is joyful becomes tranquil and one whose body is tranquil experiences happiness". ${ }^{811}$ As this cohesion of emotional fulfilment and mental quietude is mediated through the body and involves purification of body and mind in meditation $^{812}$, priti and praśrabdha are closely coupled and, to some degree, dependent on each other. ${ }^{813}$ It is not a coincidence that we also find close terminological parallels echoing this link in the $B d p$ 's description of the bodhyanga of joy and tranquillity.

The sixth bodhyanga, meditation (samädhi), has two aspects, on the one hand effecting realisation of the Dharma and, on the other hand, awakening to the workings of dharma. In a sense, this characterisation goes beyond the standard definitions of the samädhibodhyanga which content themselves with one-pointed, sustained meditative examination of the nature of dharma ${ }^{814}$ However, since both aspects contribute equally to the destruction of the depravities (āsrava) and go hand in hand, this deviation should perhaps not be given undue weight. ${ }^{815}$

Equipoise (upekșā), to early Buddhism, is essentially a feeling that is neither painful nor pleasant (aduhkhāsukhā vedanā $)^{816}$ As a bodhyanga, however, it is less a feeling pertaining to the vedanäskandha than a skilful mental factor of the samskāraskandha. ${ }^{817}$ Having the quality of balance, specifically regarding co-nascent dharma-that in the context of the bodhyanga must mean perfect balance between smrti, etc. - it settles a restless mind into a state of equipoise thereby rendering it conducive to enlightenment. ${ }^{818}$ It is exactly these concerns that are addressed in the upekșäbodhyang $a$ of the $B d p$. Eschewing the latent tendencies to attraction and dislike, it is characterised as a quiescent mental state that is not diverted by the extremes of worldly experience. In other words, it is thought freed from all types of turbulence and anxiety, unaffected by hatred and desire and in harmony with the noble path

811. Gethin, 1987, p. 299

The idea that praśrabdha affects body and mind in equal measure is disputed by the Sarvāstivāda because it would expose a factor of awakening, belonging by definition to the lokottara path, to the impurities of the body pertaining to the laukika domain. For a full discussion, see: Kośa, ii, pp. 157-59.

812. Cousins, Religion, III (1973), pp. 120-2.

813. Amrt (B), p. 206:

"Ici, quand il médite, le corps et la pensée sont légers, dociles et en sécurité (yogaksema) et ils s'adaptent à la concentration (samädhyanuvartin)-c'est le membre relaxation." Cf. Mppś, iii, p. 1202.

814. Vism, xiv, p. 139; Mppś, iii, p. 1201; Amrt (B), p. 207; Msl, p. 144.18-19; cf. Rcd, p. 242.1.4-5.2

For a considered discussion of the operational scope of meditation in Theravāda Buddhism, see: Cousins, Religion, iii, 1973, pp. 115-131 (especially, p. 122).

815. Gethin, 1987, pp. 288-292.

816. S V, p. $210 ; V i b h$, p. 123.

817. Arthav-t (S), p. 230.3-5; cf. Kośa, ii, pp. 159-60.

818. A good account of the different viewpoints on the intent, scope and operations of upekkha in early Buddhist literature is found in Aronson, 1979, pp. 1-18. For a resourceful interpretation of Aronson's findings, see: Gethin, 1987, pp. 302-8. 
itself. $^{819}$

The noble eightfold path (āryāsțāngamārga) is itself the object of investigation under the ninth type of 'skill'. Here, in contrast to its 'mainstream' description of the bodhyanga, the $B d p$ casts aside the old-established explanations of the nikāya to replace them with a set of altogether new interpretations. The picture that emerges of the eight limbs-although in spirit compatible with the ideal of the path itself-is to my knowledge unique to the $B d p .^{820}$

I shall give here a brief outline of the standard presentation in the nikāya to show just how much it differs. ${ }^{821}$ In this scheme, right view (sammadditthi) is knowledge concerning the constituents of the four noble truths and becomes accordingly a form of wisdom. Right resolve (sammāsankappa) covers three areas of thought, that is, thoughts of non-desire (nekkhamma), non-hatred ( avyāpāda) and non-violence (avihimsā). Right speech (sammāvācā) is manifested by refraint from falsehood (musāvāda), slander (pisunāvāāā), harsh speech (pharusāvācā) and idle talk (samphappalāpa). It is right conduct (sammākammanta) to refrain from assaults on sentient beings (pānatipāta), not taking what is not given (adinnādāna) and avoidance of violations of celibacy (abrahmacariya). The contents of right livelihood (sammājiz va) are rarely spelled out, but generally explained as "renouncing wrong modes of livelihood and making a living by means of right livelihood" (micchājīvam pahāya sammājīvena jīvitam kappeti). Right effort (sammāvāyäma) is explained in terms of the basic sammappadhāna formula in the same way that it is found in the Bdp. Right mindfulness (sammāsati) is characterised by the basic satipatțāna formula ${ }^{822}$ and right meditation (sammāsamädhi) is illustrated by way of the customary sketch of the four jhäna.

Before contrasting this presentation with the eightfold path in the $B d p$, I wish to make three general remarks. First, as already observed by Gethin, the wording and type of characterisation of the eight members is not coincidental, but was designed to link into many of the regularly recurring themes of the nikāya. ${ }^{823}$ This might have put constraints on its phrasing and

819. The discussion of the individual factors of enlightenment extends in the $B d p$ over three folios, starting on folio 662.7 and ending on folio 665.4 .

820. To be precise, it is only found in the textual lineage where the $B d p$ appears to be the foundation text. As indicated, it is also contained almost verbatim in the $A k n$ (pp. 70.4.4-71.2.1) and Arthav (S), pp. 320-322.

821. M III, p. 251; see also: D II, p. 311; S V, pp. 8-10; Patis, i, pp. 40-2; Vibh, pp. 104-5. The bare list of the eight factors appears, of course, at many more places throughout the nikāya. According to Gethin (1987, p. 314), it is itemised no less than sixty-four times.

822. For examples of the basic formula, see: D II, p. 290; D III, pp. 58, 141, 221, 276; M I 339-340; S V, pp. 141-192, 294-306; A IV, pp. 457-8.

823. Gethin, 1987, p. 364. 
terminology. Second, several of the definitions have close parallels where their members form part of other sets of practice. So, right view, right effort, right mindfulness and right meditation all display practically identical explanations in the faculties (and powers) of wisdom, vigour, mindfulness and meditation. ${ }^{824}$ Finally, the contents of right speech, right conduct and right livelihood epitomise the very concerns of the early Buddhist ideal of morality. Recurring as principal items in the sillakkhandhavagga of the Dighanikāya ${ }^{825}$, identical to four of the pañcasila and corresponding to six of the ten kusalakarmapatha, they rank among the most visible indicators of a monk's spiritual progress.

If we turn now to the description of the noble eightfold path in the $B d p$, we immediately notice that such features are absent. In content, none of the descriptions of the eight factors shows any traces of linking either its definition with the wider frame of reference of the bodhisattva training-be it through the inclusion of key terminology or adaptation of otherwise well-known formulae - or to secure moral conduct as its spiritual epicentre. On the contrary, the whole presentation has a generality of tone that is practically devoid of references to concrete practices.

The first limb, right view (samyagdrstit), is explained in terms antithetical to its opposite, wrong view (mithyādrsțti), and displays little positive argument. This also holds true for the explanation of right resolve (samyaksamkalpa), only declaring that right resolve does not result in räga, dveșa or moha, but that it establishes the five pure aggregates (dharmaskandha) co-resident with bodhi ${ }^{826}$ The following three factors, that is, right speech (samyakvāc), right conduct (samyakkarmānta) and right livelihood (samyagājīva), traditionally epitomising ethical integrity, do not contain any of the 'morality markers' that are brought up in the early formula. In their place, the $B d p$ rather sweepingly defines right speech as intrinsically worthwhile and innocuous dialogue that abounds with beneficial application and is persuasive of the truth of the sameness all paths. Right conduct is measured by the kind of reward it is likely to

824. For concurring definitions with the indriya and bala see, for instance: S V, pp. 196-200.

825. D I, pp. 1-4.

826. $\mathrm{R}$, folio $666.5-6$

According to the $K p$ (p. 209, $\S 144$ ), cited here in Weller's German translation, these five skandha define nirvāna:

"Die geistige Sammlung, die Weisheit, die Erlösung, die Schau des Erkenntniss der Erlösung, ilhr Ehrwürdigen, wanden nicht durch die Wiedergeburten and erlöschen nicht völlig. Durch diese Gegebenheiten, ihr Ehrwürdigen, wird das Nirväna angedeuted, doch sind diese Gegebenheiten leer, abgesondert, nicht zu fassen as reale Objekte."

For Pāli references, see: D III, p. 279; S I, p. 99; A I, p. 162. Alternative titles of the dharmaskandha are found in Dhsgr $\S 23$ (lokottaraskandha); Mvy 104-8 (asamasamäskandha); Kośa, i, p. 48; vi, p. 297; Kośavyäkhyā, p. 607.10 (anäsravaskandha), (ref. Lamotte). 
produce. A fortiori, it excludes unwholesome action, but-aspiring to a lasting cessation of all consequences of action-is aimed ultimately at the exhaustion of all types of activity.

The next limb, right livelihood, being characterised by a series of concrete attributes, is the single exception to these general descriptions. Its content is the ideal of mendicant life and, in particular, the four precepts of the äryavamśa conduct. ${ }^{827}$ Besides, it is free from foolishness, hypocrisy and violence but governed by modesty, vigilance, contentedness and moral purity. In spirit, many these characteristics are very close to the path ideal that was introduced in the sílapāramitā which might, therefore, be legitimately taken to provide for the moral base in the eightfold path. The references to the mendicant ideal and, specifically, to the arryavamsia seem to suggest, however, that these facets go well beyond the moral domain, and trace, in fact, a paradigm of the bodhisattva's way of life interpreted in terms of right livelihood.

Right effort (samyagvyãvāma) marks a return to the rather condensed and yet imprecise explanations. Accordingly, we learn very little of its exact application other than generalities. Right effort is held to advocate virtuous conduct against mistaken conduct, to promote the eradication of the propensities of defilement and to introduce to the truths and the noble path itself.

In its explanation of right mindfulness (samyaksmrti)—notably eschewing references to the stock formula of smrtyupasthana - the $B d p$ draws on elements that pertain to mindfulness in the nikāya. ${ }^{828}$ That is to say, it is seen as a self-possessed, composed and attentive state of mental awareness manifesting in the practitioner a high degree of presence of mind. ${ }^{829}$ Then, it examines the phenomena that surround the bodhisattva and tests them for their usefulness or inadequacy - as the case may be-in relation to the path. Finally, and perhaps most importantly, samyaksmrti is a force of recollection calling to mind the commitment to the path and, by implication, to universal liberation.

It is this concern with the suffering of beings that also resonates in the definition of right meditation (samyaksamādhi). Its psychological content-in principle no doubt related to the experience of the śrāvaka-is declared as composure towards reality, particularly in view of

827. R, folio 667.4 .

828. Gethin, 1987, p. 88 .

829. This association with mental awareness is not particular to the nikāya, but became a generally characteristic of mindfulness. For the Sarvāstivāda, we read:

"The faculty of mindfulness is a name for accurate designation concerning the body, etc., as it is discerned by wisdom. A mind that has become acquainted with [mindfulness] does not experience loss of object. Such lack of loss is the faculty of mindfulness" (Abhidh-d, p. 360.14-16). 
its constituents (dharma). To the $B d p$, however, this alone does not suffice to turn 'meditation' into 'right meditation'. For this transformation to take place, it is vital that serenity is acquired with a higher, very specific goal in mind, namely, the liberation of all sentient beings. As if to underline this element of altruism, preaching is included as an important aspect of right meditation. ${ }^{830}$ This adjustment grew no doubt from the re-invigorated concern for the fate of the world the Buddhist communities in ancient India became preoccupied with and so is by no means coincidental.

The differences in approach between the path formulae of the nikāya and $B d p$ are so evident that they require, I think, no further illustration. As shown, apart from the reinterpretation of right meditation, most do not affect the spiritual core of the path, but centre on stylistic matters and detail of explanation. Most striking perhaps is the lack of reference to key bodhisattva terminology and the little use of established formulae. This is not a general feature of āryāștāngamärga descriptions in Mahāyāna literature. Usually, the eight factors are harmonised with the other bodhisattva practices in terms of a large degree of common vocabulary. ${ }^{831}$ A good example of this is the account given in the $R c d .{ }^{832}$ Its explanations of the individual members are interspersed with a wealth of key concepts that occur elsewhere in connection with the bodhisattva training. Thus, right view is explained in terms of śūnyatā and advaya ${ }^{833}$; right resolve consists of 'skill' in śamatha and vipaśyanä, producing insight into dharma-sameness ${ }^{834}$; right livelihood is specifically developed in order to purify and ripen other beings ${ }^{835}$; mindfulness means, above all, recollection of the practice of the pāramitā and postponement of entry into nirvāna ${ }^{836}$ while meditation, although overtly concerned with the four noble truths conduces to a profound understanding of emptiness and all-knowing. ${ }^{837}$ A similar abundance of key terminology is manifest in the Mahāyāna interpretation of the āryāștāingamärga given in the Mppś. ${ }^{838}$ Here, however, emphasis is not so much placed on specific bodhisattva practices as on philosophical concepts, such as bhütalaksana, anabhisaṃkāralakșana, śünyatā, sarvajñajñāna and sarvakarmasamatā. Although not as

830. R, folio $668.4-6$.

831. E.g., Ssp (Ghosa), pp. 1427-39; Ug, p. 269.3.8-4.2; Rcd, pp. 242.5.2-44.3.6; Arthav (S), pp. 34-42; Śäv-bh (Sh), pp. 327.8-330.18; Mppś, iii, pp. 1203-7; Abhidh-sam (R), pp. 123-4.

832. 24, pp. $242.5 .2-244.2 .6$.

833. op. cit., pp. 243.1.3-2.5.

834. op. cit., pp. 243.3.3.

835. op. cit., pp. 243.5.6.

836. op. cit., pp. 244.4.1-8.

837. op. cit., pp. 244.2.2-5.

838. Mppś, iii, pp. 1203-1207. 
convincing an example as the account in the Rcd, the Mpps nevertheless documents the tendency in the Mahäyāna to adjust the descriptions of the eightfold path to contemporary thinking. For good reason, this trend is not manifested in the $B d p$.

Interpolated into the discussion of the bodhipāksika dharma, between the noble eightfold path and the perfect efforts, is an exposition of 'skill' in perfect mental quietude (samatha) and insight (vipaśyana $){ }^{839}$ One key element in the description of samatha is mental composure (cittaśānta). Effecting serenity, contentment, patience, ease of mind and imperturbability with regard to the senses, it stands at the very heart of the bodhisattva's meditative experience and is as such recognised in the $B d p$. The attainment of composure itself signals the eradication of a series of factors certain to obstruct absorption. According to the Bhāvanäkrama, these include indolence (kausidya), forgetfulness with regard to the object of meditation (ālambanavismarana), distraction (vikṣepa), agitation (auddhatya), absence of effort (avyāyāma) and effort (vyāyāma). ${ }^{840}$ In the $B d p$, none of these is explicitly referred to, but we find their presence in a number of terms that betray their elimination. ${ }^{841}$ Further details of the meditative contents are revealed by the inclusion of reflection (manasakāra) and thorough examination (pratyavekșanāa). ${ }^{842}$ According to the Bhāvanākrama, reflection plays an important role particularly during to the first phase of samatha practice where it is concerned with the body and dharma-objects that are also given in the $B d p$. It is essentially a preparatory practice, technically known as 'images devoid of concepts' (nirvikalpakapratibimba), because the bodhisattva has not yet succeeded in evaluating their true value, that leads to full investigation ('images accompanied by concepts' savikalpakapratibimba) during vipaśyanā ${ }^{843}$ As structure,

839. For references to śamatha/vipaśyanā in the nikāya, see: M I, p. 494; III, pp. 289, 297; S IV, pp. 194-95, 295, 350, 352; V, p. 52; A II, p. 157. For the Mahayyanna, see the contribution made by the Samdhis on samatha/vipaśyana (Samdhis (ELa), pp. 88.1-97.27). Good expositions in the scholastic literature are found in the $B b h$ (pp. 109.7-110.13), Msl (p. 146.6-28) and, above all, in the account drawn up by Kamalaślla in his Bhāvanākrama (MBT, ii, pp. 205-214; iii, pp. 1-13).

840. $M B T$, ii, § 14, pp. 207-8; $M B T$, iii, pp. 9-11.

841. R, folio $669.2-3$.

842. At first sight, to find references to pratyavekșana and manasakāra in the śamatha section comes somewhat as a surprise, since both terms are elsewhere specifically associated with vipasyana. See, for instance, $\dot{S g s}$, p. 256; Samdhis (ELa), pp. 89, 92, 96 and MBT, iii, pp. 4.16, 5.17. However, as made clear by the context, for the $B d p$ their focus is not the nature of the pudgala or dharma - as it is during vipasyana practice-but the functioning of the yogin's body. Therefore, in the $B d p$ they carry less the meaning of the sharp, analytic investigation that is the characteric of them during vipasyana practice than an generally observing purpose. For a discussion of these terms in the context of meditative practice, see: Demiéville, 1987, pp. 79-80.

843. $M B T$, iii, pp. $1.13-2.5$

The Bhävanäkrama stresses that part of this reflection is particularly concerned with the body of the Tathāgata - a topic not mentioned in the Bdp. For a list of alternative objects of meditation during the 
the $B d p$ accepts the traditional eight branches of meditation supplemented by the apramāna-a division also found in the Samdhis. ${ }^{844}$ In contrast to the Bhāvanäkrama ${ }^{845}$, the setting of samatha practice and its preparations are little discussed in the $B d p$, although it indicates that seclusion away from the bustle of worldly life is the ideal location.

The bodhisattva, having come into contact with true reality through reflection, produces insight (vipasyana $\overline{\text { ) }}$ into the nature of reality. For the $B d p$, this newly won realisation is threefold. ${ }^{846}$ First, focused on his own body, it allows him to penetrate its true nature and to conclude that the individual (pudgala) does not exist. Then, he widens his field of vision and applies the principles behind this insight to the world at large. Grasping the workings of causality and fruit attainment, he penetrates reality and sees that dharma are non-existent (dharmanairātmya) ${ }^{847}$ According to the Bhävanākrama, it is exactly this vision of reality, manifesting insight into pudgalanairätmya and dharmanairätmya, that distinguishes vipaśyanā from other types of cognition and turns it into correct analysis (bhütapratyavekșa) ${ }^{848}$ Finally, having acquired accurate vision of dharma and the context where they occur, the bodhisattva shifts his attention to the objects of his meditation (älambana) only to realise that they also lack own-being (svabhāva). ${ }^{849}$ At this stage, his understanding of reality has passed beyond all mental constructions to allow him to perceive the absence of concepts (nirvikalpa) and developments (nisprapañca). ${ }^{850}$ Thus accomplished, insight is no longer to him a part of conventional cognition, but rests in equal measure on seeing and non-seeing. Also called perfect seeing (samyagdarśana), it establishes him in the highest form of bodhisattva activity that incurs no karmic traces whatsoever.

For this achievement to take place, it is essential that samatha and vipaśyanā are practised jointly throughout. As the two principal factors in meditation, they are inextricably linked like "two oxen harnessed to a plough", to quote a canonical simile. ${ }^{851}$ With well-developed

samatha cultivation, see: Samdhis (ELLa), pp. 88.8-89.19 and Abhidh-sam (R), p. 126.

844. Samdhis (ELa), p. 93.1-10

For material on the psychological experiences that distinguish upekșa arom śamatha, see: Samdhis (ELa), p. 97.11-26; Kośa, ii, pp. 25, 159; viii, p. 147; Siddhi, pp. 334, 370, MBT, iii, p. 9.20-21.

845. $M B T$, iii, pp. 3.4-4.12.

846. The threefold division of vipaśyanā in the $B d p$ is mirrored in the account of the Bhāvanākrama (MBT, iii, pp. 5.18-8.17). For an alternative division, see: Samdhis (ELa), p. 92.14-30.

847. R, folio $670.1-2$.

848. $M B T$, iii, p. 5.14-17.

849. R, folio 670.6 .

850. $M B T$, iii, p. 7.14-15.

851. D III, pp. 213, 273; M I, pp. 494, 289; A II, pp. 156-7; Patis, ii, p. 92; See also: Siks, p. 119; Bbh, p. 207. 2-6; Msl, p. 91.25-26; $M B T$, iii, p. 10.4-7. For further references, see: Kośa, viii, p. 131. 
vipaśyanā but weak samatha, thought is agitated like a lamp exposed to strong winds so that reality is not clearly seen. But, if śamatha prevails over vipaśyanā, sleep is close at hand and reality will never be perceived. ${ }^{852}$ Hence, the view that samatha precedes as practice the cultivation of vipaśyan $\bar{a}$-although ocassionally expressed in Buddhist literature and also implied in the $B d p$-appears to be a more theoretical proposition. ${ }^{853}$

\section{The Acquisition of Wisdom}

The last type of 'skill' that is considered in the $B d p$ is 'skill' in dharma. Not included amongst the ten primary kinds of 'skill', but appended to the introductory statement, its function is to conclude the prior discussion. The key element in all six examples of 'skill' in dharma is the bodhisattva's dexterity in transforming attainments of the conditioned into attainments of the unconditioned. He transforms the predisposition (samskāra) of body, speech and mind into all-knowing; he does not depreciate Perfect Wisdom through the five preliminary perfections; he leads sentient beings to enlightenment through the means of conversion; he does not cut the fetters of samsāra, but cleanses himself of worldly defilements; he remains unaffected by impurity in spite of his presence in the traidhätuka; he is acquainted with the teachings of emptiness, etc., and yet, he does not realise the unconditioned. ${ }^{854}$

The significance of these examples is twofold. First, it is shown that a bodhisattva who is skilled in dharma - conditioned and unconditioned alike-is in fact equipped with all-knowing. Second, since spiritual realisation devoid of 'skill' and wisdom cannot produce liberation, it testifies to their indispensability and discloses the benefits skilful interaction between the conditioned and unconditioned delivers. ${ }^{855}$ Emulating the ancient model of the integration of means (upāya) and wisdom (prajĩñ)-the former being part of the conditioned, the latter epitomising the unconditioned-'skill' in dharma accentuates the functional relationship

852. MBT, iii, p. 9.22-10.5; Samdhis (ELa), p. 90.15-21.

853. In a sutta of the Anguttaranikāya, for instance, we have Ānanda declaring that a bhikkhu who claims to have attained arhantship is in possession of one of four paths, that is, the path cultivating vipassana preceded by samatha; the path cultivating samatha preceded by vipassanā; the path in which both are yoked together or a path where the bhikkhu's mind is agitated by dhamma (A II, pp. 156-7). See also Papañcasūdanī (v, p. 504) where Buddhaghoșa proposes that samatha and vipassanā belong to different moments (nānākkhanikā), leading to a serial attainment of the three marks and vipassanā (ref. Ruegg; cf. Kośa, viii, p. 131). In Māhäyana texts, consult: Samdhis (ELa), p. 90.3-14; Siddhi, p. 597; MBT, iii, pp. $1-3 ; D P P$, p. 17.

854. R, folio 685.1 .

855. $\mathrm{R}$, folio $685.4-5$. 
coupling the actual practices to the cognitive realm. This accounts also for the positioning of 'skill' in dharma at the very end of the discourse outside the formal structure of the ten skills. For, 'skill' in dharma sets out to establish their interconnection by fusing the worldly pāramitā with the perfection of wisdom; by uniting learning, reflection and contemplation; by merging the pratisarana with the pratisamvid; by joining punyasambhāra with jñānasambhāra; and by blending samatha and vipaśyana

This interpretation, obvious on textual grounds and well-known from other sources, does not present much of a problem. Difficulties arise, however, if we attempt to reconcile the $B d p$ 's intent behind 'skill' in dharma with that of the ten 'skills' in the $M v \dot{s}$. As already seen, for the $M v s^{\prime}$ 'skill' is essentially a means of illustrating the futility of the belief in a self (ätmadrsti $i$ ). In line with this thinking, 'skill' in conditioned and unconditioned dharma (likewise placed as the tenth 'skill' at the end of the discussion) is employed to show the 'illusion of an entity that is either bound or released' (amuktamuktatvagräha). ${ }^{856}$ The idea is that such illusion consists in imagining that a self is at first tied to samsära by defilements and later liberated from them. Since only conditioned dharma are subject to the samyojana, 'skill' in conditioned and unconditioned (i.e., all) dharma is explained to counteract this illusion. ${ }^{857}$

While this approach to 'skill' in dharma is consistent with the interpretation of the preceding nine types of 'skill', it does not show any obvious relation to our passage in the $B d p$. The only link with the $M v s$ 's standpoint is perhaps the $B d p$ 's proposition that the transformation to enlightenment takes place on the basis of discerning all dharma as unconditioned enlightenment in the first place. ${ }^{858}$ This eliminates the need for purification and explains the abstention from realising the unconditioned. It would also account for the bodhisattva's twofold approach to reality. Moreover, in a sense, it removes by implication the process of deliverance from the individual that is of key concern to the $M v s^{\prime}$.

\section{Phases in Perfect Wisdom}

I now propose to investigate the structural principles that underlie the arrangement of the 856. $M v s(N)$, p. 44.10 .

857. $M v s(N)$, p. $48.6-7$.

858. R, folio 683.7 . 
prajñāpāramitā practices. Following the bodhisattva practice proper, ${ }^{859}$ the $B d p$ discusses material that seems to include a blueprint of the bodhisattva's career phases. This blueprint-integrated into the discussion of 'skill' in solitary wandering-gives an approximate idea of the scope and nature of the various phases. However, since the text itself is anything but explicit I have had to turn once again to the $A k n-t i k \bar{a}$ that contains a brief passage on a parallel section in the $A k n .{ }^{860}$ Guided by its analysis, it became possible to break up the contents of 'skill' in solitary wandering as follows. ${ }^{861}$ At first, during the initial phase extending from the first cittotpāda to the adhimukticaryābhümi, the bodhisattva practises only in his own interest, as he is unable to dispense instruction and benefit to others. ${ }^{862}$ During this period, wholly independent and self-sufficient, he lives the life of a recluse and is isolated from the world. In spite of immense effort, his practice of the pāramitā is flawed. The process of pāramitā purification takes place during the second phase and follows on the attainment of patience. Although the $A k n$-țika does not indicate the span of this period, our analysis of ksänti has revealed that this is unlikely to occur prior to the seventh (sudurjayäbhīmi) or possibly the sixth stage (arcrișmatibhümi). Still left to his own devices, he secures the perfections all by himself and resolves to achieve unsurpassed attainments. Advance to the third phase is marked by the acquisition of the vision of dharma-sameness. Having removed all obstacles related to defilements (kleśāvarana) and having decisively weakened those pertaining to knowledge (jñeyāvarana), the bodhisattva attains mastery of the means of conversion (samgrahavastu). This allows him to develop fellow beings and plant the roots of virtue with unprecedented impact. ${ }^{863}$ Finally, at the fourth stage, freed from all impurity, he overcomes the last remaining obstacles and, taking a seat on the vajra-throne, attains enlightenment. This, of course, signals the end of the bodhisattva's advance to buddhahood.

Clearly, this division, however plausible, is rather general. Moreover, it does not seem to stand in direct relationship to the content of the Prājñ $\tilde{a}$ Chapter, since it aproaches the bodhisattva path in a much broader fashion. I suggest to leave its evaluation on the side for

859. For reasons that will become apparent, I take them to include the pratisamvid, pratisarana, punyaljñānasambhära, bodhipāksika as well as śamathatvipaśyanā.

860. $A k n$, pp. 72.1.8-73.2; $A k n-t i k k a ̈$, pp. 271.4.4-272.2.1.

861. Text references to key sentences in the $A k n-t i \hat{l} k \bar{a}$ and discussions of the terminology are given in my notes to the translation of chapter eleven.

862. $A k n$-tikkā, p. 272.1.1; Bbh, pp. 84.21-85.7, 86.4-11.

863. As reference to the means of conversion is omitted in the $B d p$ but found in the $A k n$, we must ignore the samgrahavastu phase. This, however, is immaterial to the characterisation of the path phases since vision of dharma-sameness is in any event fixed to the eighth stage $(S g s$, p. 131) at which point the bodhisattva has already attained mastery over the samgrahavastu and sets out to ripen beings with immense effect (Daśa-bh p. 57.16). 
the time being and to turn instead to the structures of the wisdom-practices themselves.

Reading through the chapter, the first thing one notices is the break between the section leading up to 'skill' and the discussion of 'skill' itself. The former section, starting with the seventy-two kinds of learning and ending with the bodhisattva's emancipation from defilements, is markedly less structured than the other parts of this chapter. Although much of its material is well-known from earlier sources, insufficient use of 'context markers' introduces some ambiguity regarding the conceptual interrelation between the practices and the training phases they represent. Notwithstanding, it is possible to outline a general structural pattern. As shown, large areas of the arrangement of the practices bear reminiscence to the first four of the five traditional path phases, comprising the sambhāramārga,prayogamārga, darśanamārga and bhāvanāmārga. In establishing this correlation, I considered the few 'context markers' available and compared the $B d p$ 's position with the contents of the various stages known from other sources. The picture that emerged from this analysis-although not beyond controversy in detail-supplies continuity between the individual practices.

Next, the $B d p$ introduces a series of 'skills' that are apparently related to the foregoing accomplishments. Most commentaries agree that the first four of these represent the cognitive attainment of the srāvaka. Since their objective (that is, the eradication of the belief in a self) is not particular to the training of the śrāvaka, but equally pertains to the bodhisattvacary $\bar{a}$, they are cited also in the $B d p{ }^{864}$ When we turn to the pratisamvid difficulties arise because these exhibit no clear conceptual link with the destruction of the belief in a self. What is more, our sources disagree on their position in the path, some arguing that the pratisamvid spring from 'skill' in skandha, etc., while others assert the contrary. Judgement on this matter will have to await further research. Whatever their exact relation to the first four types of 'skill', the pratisamvid are an integral part of prajñāpāramita ${ }^{-865}$ and their overall task is well attested by their content. Above all, they introduce the bodhisattva to those areas of knowledge that will be of greatest demand in his career; that is, they give an accurate understanding of reality - in conventional and absolute terms - and the ability to communicate effectively with other beings. ${ }^{866}$ Their relation to the bodhipākșika is of utmost importance to the bodhisattva. For, not only do they allow for the perception of the individual dharma 'in accordance with

864. $B b h$, p. $4.6-8$.

865. $B b h$, p. 214.9-15.

866. In the $A k n-t i k k \vec{a}$ (p. 242.1.4-7), this interpretation is brought out by the purpose to which the pratisamvid are set, that is the 'attainment of power in teaching'. 
reality' (yathābhüta), but moreover, prompt him to postpone indefinitely their realisation. ${ }^{867}$

The rationale for joining the pratisarana with the pratisamvid poses fewer difficulties, since both are closely related in contents and spirit. This is particularly true of the arthapratisamvid and dharmapratisamvid, as knowledge of the own-being of things and designations becomes almost a prerequisite for considered reliance on any of the four pratisarana. The impact of the niruktipratisamvid on the pratisarana is smaller, since the knowledge of languages has immediate bearing only on the artha/vyañjana and neyärtha/nitärtha distinction. In a sense, three out of four pratisamvid represent something of a basis of cognition to the pratisarana therefore. Once established, their conceptual proximity could be taken to explain the irregular order in which the pratisarana are presented. That is to say, by beginning the discussion of the pratisarana with the artha/vyañjana combination in the place of the dharmatā/pudgala pair-which most other texts cite as the first pratisarana-the $B d p$ might have intended to express a parallelism with the pratisamvid where artha is cited as the first item. ${ }^{868}$

Being thus trained in knowledge and well-focused in his practice, the bodhisattva embarks on the training proper. Dual aspected from the very beginning, it begins with the accumulation of merit and pristine cognition. By accumulating merit, the bodhisattva works for the benefit of sentient beings, since it furnishes him with the roots of virtue that he dedicates to their liberation. By the accumulation of pristine cognition, in contrast, he accomplishes the destruction of his own, personal defilements. This division-although rather theoretical since both practices go hand in hand-is remarkably well-delineated in the $B d p$, with each accumulation mirroring its designated task. For the $A k n-t i k \bar{a}$, referring to the slightly edited path model of the $B d p$ in the $A k n$, this path phase represents the very beginning of the bodhisattva's 'organised career', that is, it coincides with the sambhäramārga ${ }^{869}$ This, of course, is a standard classification

867. $B b h$, p. $259.9-13$.

868. Note that in the scheme of the Bbh (pp. 256.23-259.6) and $M s l$ (pp. 138.3-139.17), the pratisarana precede the pratisamvid on the basis that the former give rise to the latter. This view is also expressed in the Bhadra-vy (pp. 45.31-46.2). While Régamey (p. 100) is certainly mistaken in considering the pratisarana to be a "free interpretation of the four normal pratisamvid", in terms of their conceptual proximity, his observation is perhaps not as out of place as might at first appear. Of some interest in this context is the $B b h$ 's comment that the pratisamvid are the agency giving rise to the cultivation of the bodhipasksika dharma (p. 259.9-11). This gives a logical connection to its order of beneficial dharma listed in the Bodhipakșyapațala, viz., pratisarana, pratisamvid, punyaljñānasambhāara, bodhipākșika, samathalvipasyanā. But for the reversal of the pratisarana and pratisamvid (and perhaps the positioning of the samyakprahana, indriya and bala), this is exactly the order that is found in the $B d p$ (note that the same order of practices is also found in the $M s l, p p .138 .3-149.4)$.

869. $A k n-t i k \bar{a}$, p. 248.5.2. 
that need not be discussed here. ${ }^{870}$ Of far greater import to the present context is the question whether this position is reconcilable with our earlier identification of sambhāramārga. If not, we would have to reconsider most of our observations on the first section of chapter eleven. However, as this problem is not isolated but recurs on three other occasions and requires detailed analysis, I shall postpone its discussion for the time being.

Subsequent to accumulation, that according to the $A k n-t i k i \bar{a}$ constitutes the only element of the sambhäramärga ${ }^{871}$, the $B d p$ introduces the four smrtyupasthāna. To the $A k n-t \bar{l} k \bar{a}$ their practice, emulating the Sarvāstivāda path model, signals entry on the prayogamārga ${ }^{872}$ While this classification is in itself not remarkable and is found with minor variation at several places, its adaptation for the $B d p$ raises a whole series of questions. The reason for this is quite simple. In the $A k n$, the bases of mindfulness introduce the traditional order of the bodhipākșika (with the samyakprahāna, rddhipāda, indriya and bala all part of the prayogamārga), whilst in the $B d p$ the smrtyupasthāna are immediately followed by the bodhyanga. According to the Sarvāstivāda path, this would mean that for the $B d p$ the prayogamärga consists only of the bases of mindfulness, since the bodhyanga already herald entry into the next phase-the darśanamärga. ${ }^{873}$ Practically all sources agree that the darśanamārga consists only of one set of practices, be it the bodhyanga or āryāșțāngamārga ${ }^{874}$ Depending on which choice is made for the darsanamärga, the bhāvanämärga as the penultimate stage of the path is occupied either by the factors of enlightenment or the eightfold path. According to the explanations of the $A k n-t i \bar{k} \bar{a}$ on the parallel scheme in the $A k n$ this would be the āryāștāngamārga ${ }^{875}$ The eightfold path, being traditionally the last of the seven sets, concludes the treatment of the bodhipākșika in most texts. ${ }^{876}$ At first sight, this

870. Siddhi, pp. 564-74; Abhidh-sam (R), pp. 104-3; DPP, pp. 33-34.

871. $A k n-t i \bar{k} \bar{a}$, pp. 248.5.3-49.4.2.

872. $A k n-t i \grave{k} \bar{a}, \mathrm{p} .249 .5 .3-4$ See, for instance, Kośa, vi, p. 287; Abhidh-d, p. 362.12-13.

873. Abhidh-h (W), ii, p. 140; Mvs', iv.8-10

There exists some disagreement on the distribution of the bodhyanga and āryāsțāngamārga to the darśanaand bhàvanämärga. For the Kośa (vi, p. 288) and the Abhidh-d (p. 362), the bodhyanga represent the bhävanämärga with the darśanamärga being taken up by the eightfold path, while the opposite is asserted by the Vaibhāșika (op. cit.) and the $A k n-t i t k \bar{a}$ (p. 266.1.3). The differences between the two schemes have, however, little bearing on substance, since both paths form part of the transcendental realm; it is chiefly a question of reconciling the traditional order of the bodhipasksika with the view that the meditative context of the bodhyanga should be associated with the contemplation of the bhävanämärga.

874. Abhidh-d, p. 365; Kośa, p. 288; Mvś (N), pp. 33.14-16; Abhidh-sam (R), pp. 116-7 (different terminology); Abhidh-h (W), p. 140.

875. $A k n-t i \bar{c} k \bar{a}$, p. 267.3 .5 .

876. For references to examples in the nikāya, see: Gethin, 1987, pp. 501, 510, 524 6; for Mahāyāna references, consult any of the following texts: $K p, \S 95 ; V k n$, p. 20; Daśa-bh, pp. 38.16-39.11; Rct, pp. 235.3.4-44.2.6; $A k n$, pp. 66.4.3-71.2.1; Arthav (S), pp. 28-42; Pañca, pp. 204-208. 
model is also endorsed in the $B d p$, since the practices that immediately follow on the $\bar{a} r y \bar{a} s ̦ t a \bar{n}$ gamärga, that is, samatha and vipaśyanā, do not belong to the bodhipāksika. On their analogous occurrence in the $A k n$, the commentary remarks that śamatha and vipaśyana constitute the means by which the practical aspects of the path are taught. ${ }^{877}$ I shall demonstrate below that this position, although unusual, is not irreconcilable with other path interpretations. The presence of the samyakprahāna, indriya and bala following samatha and vipaśyanā poses far greater difficulty.

In order appreciate the problems given by this presentation, it may be helpful to recall some of the more general features of the bodhipäkșika dharma. Embodying Buddhist spiritual training at the higher stages of the path, the bodhipāksika are not a random assortment of practices, but constitute a coherent body of methods specifically designed to bring about enlightenment. On the one hand, whether in the form of individual sets, or from the point of view of their 'ingredients' (dravya), each of the seven categories is understood to reproduce the Path in its own right. On the other hand, epitomising the collective and individual means of reaching awakening, full development of any one of the sets brings to fulfilment all seven. Thus, as a spiritual unity whose individual members stand in close relation to each other, they constitute the very hub of the path.

This and the mnemonic constraints of oral literature, led to an early standardisation in their presentation, including stockphrases and formulae to aid elucidation. As a result, beyond abhidharmic detail, explanations of their contents generally display few differences in substance. Also the number of practices shows little variation, so that all thirty-seven are usually discussed en bloc. The order in which they are treated is nearly always the same, starting with the smrtyupasthāna and ending with the āryāsțāngamārga. Even in expanded lists it is extremely rare that the seven sets are separated. When juxtaposed to other practices, the thirty-seven dharma regularly stand at the centre with the remaining practices clustered around them.

When differences occur, these are mainly due to variations in context affecting the status of individual practices. In several works expanded lists of bodhipäkșika are met with. Generally, this occurs in the context of meditation practices. Depending whether they are addressed collectively on the lokottara path or individually in conjunction with higher applications of samatha and vipaśyan $\bar{a}$ in the phase immediately preceding the emergence of lokottara consciousness, the bodhipāksika are ranked either as lokottara or as laukika practices.

877. Akn-tikiā, p. 267.3.6. 
Finally, in their attempts to draw up a coherent scheme of the Buddhist experience, scholars have developed several models correlating the seven sets to the stages of the path. Of these, the best documented account is by the Sarvāstivāda school. However, even their distribution of the bodhipāksika fluctuates, showing that these endeavours were never brought to a conclusion. Indeed, we also meet with propositions that indicate a continuous and simultaneous presence of all thirty-seven factors at the higher, transcendental levels of the path.

With these considerations in mind, let us return now to the bodhipässika in the Bdp and reassess those areas where anomalies occur. The first incongruity we have noted is the isolation of the smrtyupasthāna on the prayogamārga, with three of its traditional co-residents being separated from the bulk of the bodhipāksika. Editorial adjustments in the order of their presentation in the $A k n$-resulting in the interpolation of the samyakprahāna, rddhipāda, indriya and bala between the smrtyupasthāna and bodhyanga-indicate that such positioning was already viewed with suspicion in ancient Indian Buddhist circles. ${ }^{878}$ Besides depriving the prayogamārga of much of its contents, their position at the very end overturns a whole tradition. For, as Gethin has shown, the order of the seven sets was already established during the four primary nikāya and rapidly assumed an air of inviolability. ${ }^{879}$ Indeed, judging by Gethin's survey of Pāli sources and my own reading in the Mahāyāna, the $B d p$ 's sequencing has no parallel anywhere in Buddhist literature.

The sole presence of the smrtyupasthāna on the prayogamärga is less problematic. First, as already noted, Buddhism never produced any fixed and final scheme of distribution of the bodhipaksșika to the stages. Discrepancies are greatest with regard to the first two path phases, some placing the smrtyupasthāna on the sambhäramārga, others on the prayogamärga or their equivalents. ${ }^{880}$ Second, the very nature of the smrtyupasthana could conceivably be taken to allow for this interpretation. Since they are well-known from the Mahāsatipațthānasutta as embodying on their own the whole Buddhist path and of great importance as basic instructions in meditation, the smrtyupasthanna-it could be argued-stand at the centre of all types of practice. ${ }^{881}$ This consideration, it seems, led the compiler of the Kośa to refer to the smrtyupasthāna twice, distinguishing a lower and higher level of cultivation; first, as the practice dominating especially the adikarmikamärga and, second, as the foundation to all

878. $A k n$, pp. 66.4.3, 68.5.1, 69.3.2, 69.4.1, 69.5.6, 70.2.3.

879. Gethin, 1987, pp. 500-26, and conclusions: pp. 527-533.

880. Compare, for instance, the schemes of the Kośa, vi, pp. 287-88; Abhidh-d, p. 362; Abhidh-h (W), p. 140; Abhidh-sam (R), p. 116-7; Mvś (N), pp. 50-55 and Mppś, iii, pp. 1148-1149.

881. D II, p. 290; M I, p. 55. 
four nirvedhabhāgīya. ${ }^{82}$ Since the nirvedhabhāgīya are the very practices that make up the contents of the prayogamārga $a^{883}$, the $B d p$ 's identification of the smrtyupasthana with the prayogamārga perhaps is less inept than it appears at face value.

Having already considered the omission of the rddhipāda and the inverted correlation between the bodhyangaläryāṣtāngamārga and darśana/bhāvanāmārga, I shall proceed directly to the interpolation of samatha and vipaśyanā. To be sure, the occurrence of samatha and vipaśyanā alongside the bodhipākșika is by no means unusual. They are found in a great number of expanded bodhipākșika lists from both the Pāli and Sanskrit traditions. ${ }^{884}$ Furthermore, the meditative experiences pertaining to perfect mental quietude and insight are integral to most aspects of bodhipäkșika cultivation. While for some texts this connection is only manifest in selected sets ${ }^{885}$, others define all thirty-seven factors in terms of their association with śamatha and vipaśyanā. A good example of the latter approach is found in the Satyasiddhiśastra where all but three of the bodhipāksika practices are identified as belonging either to samatha or vipaśyana $\overline{ }^{886}$ However, the exact role of perfect mental quietude and insight in relation to the thirty-seven bodhipaksṣika is little discussed. Gethin, quoting a passage from the Nettippakaranāttha, suggests that in certain lists the seven sets might have served to exemplify how samatha and vipaśyanā are fulfilled. ${ }^{887}$ In other contexts, most notably the Dhammasangani and Visuddhimagga, they further the arising of active skilful consciousness that operates in the phase prior to (pubhabhāga) the lokottara path. ${ }^{888}$ This would place samatha and vipaśyanā in the final phase of the prayogamairga.

882. Kośa, vi, pp. 159-178, 287.

883. This view is expressed in numerous texts. It is found in the Abhidh-sam (R), pp. 105-6; Kosia, vi, pp. 169-78; Mv's (N), pp. 33.14-16, 52; Abhidh-d, p. 362 and is discussed in DPP, pp. 20, 34-37. There are only a few texts that reject the nirvedhabhägiya at the heart of the prayogamārga. One such example is the $A b h i d h-h(W)$, ii, p. 194. However, rather than outright rejection, their omission from the prayogamārga is perhaps the outcome of a different terminology, since the association of the perfect efforts, bases of success, faculties and powers with striving (vyāyama), one-pointedness (cittaikägratā), weak $(m r d u)$ and sharp (tikssna) is also present in the description of its equivalent to the prayogamārga.

884. For examples of such lists, see: Gethin, 1987, pp. 510, 524-26

See also: Srotabhümi (p. 287.3.2-7) which interpolates the pratisamvid between the eightfold path and samtha and vipaśyanā.

885. See, for instance, the $S b h$ (Srāv-bh (Sh), pp. 325-7) relating samatha and vipaśyanā to the bodhyariga, with praśrabdha, samädhi and upekșā manifesting śamatha; dharmapravicaya, virya and prïti constituting vipaśyanā while smrti is held to consist of both śamatha and vipaśyanā.

886. According to this text, samatha is manifest in the first three types of smrtyupasthäna, in all rddhipäda, in the first four indriya and bala, in three of the bodhyanga and two of the āryāstāingamārga. All others, with the exception of the three silla factors of the äryästāangamärga, the smrtendriya and smrtibala are held to pertain to vipaśyanā (op. cit., ii, pp. 448-9).

887. Gethin, 1987, p. 515.

888. Dhs, pp. 9-29; Vism, pp. 137-38, iv.74-5; p. 459, xiv.121; pp. 669-70, xxi.129-30; Sp, ii, p. 494; Sv, ii, p. 564; iii, pp. 883-4; $P_{S}$, iii, 243-4. For these and further references, see: Gethin, 1987, pp. 625-27. 
In Mahãyãna works, their relationship to the bodhipākșika is explained differently. Typically cited after the description of the bodhipāksika, they are given a firm place in the lokottara consciousness and interpreted as the culmination of the seven sets. ${ }^{889}$ Thus, we read in the Bbh that samatha secures non-discrimination (avikalpana) of the bodhipäkșika, whilst vipaśyana embodies their accurate perception in accordance with the highest truth and differentiation (vyavasthāna). ${ }^{890}$ It is probably in this context that one has to interpret the statement in the $A k n-t i k \bar{a}$ that samatha and vipaśyana jointly embody the practice of the bhāvanāmärga. That is to say, dwelling on the path of contemplation linked with wisdom ${ }^{891}$, the bodhisattva is no longer concerned with the individual practices or their particular fruits of realisation ${ }^{892}$, but looks at them from the absolute point of view. Citing smrti as example, the $B b h$ explains: ${ }^{893}$

"In which fashion does the bodhisattva perceive the thirty-seven bodhipākșika dharma from the viewpoint of the Mahāyāna? Here, the bodhisattva dwells considering the body as body, but he does not perceive the body as an existing body, nor as a body that does not exist in any way. He perceives the exact nature of the foundation of being of the body. This is for him to consider the body from the absolute point of view."

For the bodhisattva, samatha and vipaśyanā are therefore not so much part of the dhyānic processes that lead to the acquisition of the bodhipāksika, as the group of factors that establish their position in the Mahāyāna scheme of things. ${ }^{894}$ In the $B d p$, awareness of this frame of reference is dependent on composure and reflection and produces a vision of reality whose parameter consist in pudgalanairātmya, dharmanairātmya and animitta. Inevitably, the pursuit

889. E.g., Srotabhūmi, p. 287.2.4-5

This is only true if cited in conjunction with the bodhipasssika dharma. Their overall functions in the path as a whole are far more multifarious and vary, depending on the respective phase of the training. A description of their changing roles on the path-starting with their function as causal basis to the attainment of the adhimukticaryabhumi and ending with their contribution to the purification of the buddha-field during the eighth, ninth and tenth stages-is given in the $M s l$ (p. 146.10-26).

890. Bbh, pp. 260.11-261.2.

891. R, folio 670.1 .

892. R, folio 671.3 .

893. $B b h$, p. 259.15-22; cf. $M s l$ p. 146.6-27.

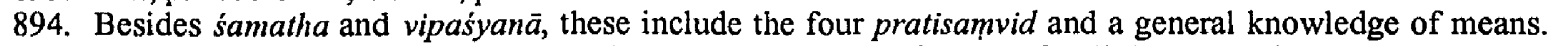
They prompt the bodhisattva to look at the thirty-seven factors of enlightenment in accordance with reality, but without realising them (Bbh, p. 259.9-11). 
of the bodhipäkșika within this framework cannot but be affected by such understanding, generating a novel type of consummation that is based on their very non-existence (anupaladhitäm upādāya). ${ }^{895}$ This insight does not occur by chance, but is inspired by the meditative and cognitive exercises that lie at the heart of the seven sets themselves. Thus, as factors finalising the conceptual context for the bodhisattva's bodhipāksika practice, the positioning of samatha and vipaśyanā after the bodhipākșika proper makes particularly good sense since it takes into account the role of the thirty-seven practices in securing their realisation. ${ }^{896}$

This cannot be said about the position of the samyakprahāna, indriya and bala. Apart from infringing on the traditional order of exposition, their location beyond the bodhipa assika series raises the question of their status. That is to say, since they follow on practices that are to all intents part of the lokottara consciousness, is it safe to conclude that they also pertain to the lokottara phase of the path? If not, what are the effects on our scheme? Does it mean that our signposts have to be cast aside or re-interpreted?

In order to answer these questions, it is necessary to consider the status of the bodhipäkșika in general, and that of the samyakprahāna, indriya and bala in particular. In the Kośa, echoing the ancient view that all bodhipasksika pertain to the higher stages of the path, we learn that the seven sets may be without assrava ${ }^{897}$ By implication, this must mean that all thirty-seven factors are potentially part of the lokottara consciousness. Summing up the Theravāda position on this matter, Gethin writes: ${ }^{898}$

"Strictly speaking, from the point of view of abhidhamma, we can only say that the satipatțäna, sammappadhāna, iddhipäda, bala, bojjhañga and maggañga function truly and fully when brought to the stage of the lokuttaracitta; this is their natural and proper level."

Conceding that this is not the whole truth since the Pāli commentaries do in fact allow for

895. Mppś, iii, p. 1135 .

896. A very revealing passage to this effect is found in the $M s l$, where it says that samatha, here likened to stillness (sthāna) of thought, and vipaśyanā, held to correspond to dharma investigation, are in fact based on the bodhipāksika factors of samyaksamädhi and dharmapravicaya (p. 146.6-10). Indeed, their positioning following the bodhipäksika is found in a number of important works. It is given in the $B b h$ (p. 259.15-22), Msl (p. 146.6-27), Abhidh-sam (R), (p. 126), Pañca (pp. 208-210; as parts of the string of meditative attainments) and in the $V \mathrm{~km}, \mathrm{p} .40$.

897. Kośa, vi, pp. 284, 290.

898. Gethin, 1987, p. 240. 
laukika cultivation of the bodhipākșika, Gethin draws attention to the work of Bareau who established that worldly indriya practice is also catered to in the Vătsiputriya path. ${ }^{899}$ Here, the indriya are ranked as laukika in the context of the four nirvedhabhägiya, to be precise, as laukikägradharma immediately preceding the emergence of lokottara consciousness. ${ }^{900}$ The proposition of the Vātsiputriya ties thus in with the distribution of the bodhipāksika to the various path phases. As already indicated, according to the Sarvāstivāda, the samyakprahāna, indriya and bala fall all into the prayoga phase. Allocated to three of the four nirvedhabhāgiya - with the mürdhan level reserved for the missing $r d d h i p a \overline{d a}$-in terms of the path at least, they are thus clearly of laukika rank.

For the commentaries of the Päli tradition the situation is more fluid than that. Proposing that the shift from the laukika to the lokottara experience rests more than anything on the context in which they are pursued (that is to say, depending on whether they are practised during the 'prior stage' separating ordinary practice from transcendental practice or during the lokottara path and fruit itself) the bodhipākșika are either laukika or lokottara in nature. In theory, it seems, this would allow for both levels of cultivation of the thirty-seven factors. Yet, in practice, as Gethin has shown, this principle does not apply evenly to all seven sets, but is only valid for the samyakprahana, indriya and bala-with the other sets pertaining invariably to the lokottara mind. ${ }^{901}$

Now, without going into the details of why this is so, we note that it is precisely these three practices which are 'out of order' in the $B d p$. Bearing in mind what has been said on the laukika/lokottara potential of the bodhipākșika, two explanations spring to mind. First, we cannot discount the possibility that the samyakprahāna, etc., had been randomly positioned in their present location. This would explain the presence of laukika practices in a section of the path that, by common agreement, arises within the lokottara consciousness. Spotted as an error by a learned reader, it was not allowed to perpetuate itself, but got redressed and brought into line with the traditional bodhipākșika sequence when adopted for the $A k n$. The problem with this interpretation lies in the improbability that such a major structural defect

899. Bareau, 1955, p. 118.

900. Note that the interpretation of their status is far from resolved. To the Vibhajyavāda, for instance, the five indriya are exclusively lokottara because they are held to have immediate bearing on the acquisition of four fruitions of arhantship (Bareau, 1955, p. 172). The Sarvāstivāda protagonists, in contrast, appear to have adopted the Theraväda view and interprete the indriya as characterising the five components in their generality (op. cit., pp. 143, 145-6). For a full treatment of the understanding of the indriya formula in Pāli literature, see: Gethin, 1987, pp. 231-269

901. Gethin, 1987, pp. 240, 630 . 
should have escaped notice, particularly in view of the renown and early codification of the seven bodhipākșika sets. ${ }^{902}$

Alternatively, if not a mistake, their placement is deliberate and grew out of some undisclosed consideration. Whatever the reason, their installation towards the end of the path suggests that the three were not interpreted as laukika practices in their prayogamārga context, but in the bodhipāksika's original role as spiritual exercises of the highest order ${ }^{903}$ Epitomising the 'practice' of the bhāvanāmārga, they could arguably represent a phase that develops the meditative pursuits of the smrtyupasthäna, bodhyanga, āryāștängamārga, samatha and

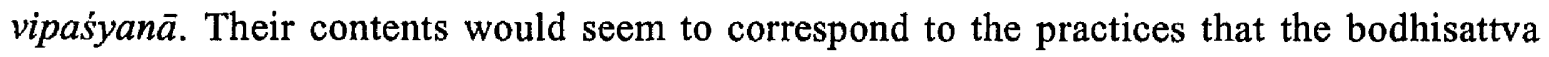
undertakes after emerging from meditation. ${ }^{904}$ Moreover, taken together, they cover most of the antidotes designed to prevent meditative defeat, viz., faith, zeal, effort, tranquillity, mindfulness, attentiveness, reflection and equipoise. ${ }^{905}$

Needless to say, if this interpretation is accepted we cannot maintain the allocation in the $A k n-t \bar{i} k \bar{a}$, since this would interfere with the presumed lokottara status of the samyakprahana, indriya and bala. We would also be at a loss to explain the editorial modifications in the $A k n$. One would think that such carefully devised scheme would not be abandoned without due consideration. Equally intriguing is the fact that Buddhist literature does not record the rationale behind this scheme. I have not found a single text in which the samyakprahāna, indriya and bala are similarly placed.

Taking all factors into consideration, it would thus appear that their positioning-novel but probably deliberate and, in a sense, consistent with the $B d p$ 's path model-failed to attract support in Buddhist circles, became isolated and was soon forgotten. Even when encountered (as it must have been by the author of the $A k n$ ), its structure was not accepted but modified and brought into line with the established order of the bodhipäkșika. While the rationale may therefore be lost, the very fact of its survival in the $B d p$ reminds us, once more, of the fluctuations in thought that influenced the shaping of the bodhisattva doctrine and the multiple

902. The possibility that the $B d p$ was unaware of the traditional sequence can be safely ruled out, as it gives a complete and orderly listing of the seven sets at R, 630.3-6. In other places, however, without apparent reason or clear pattern, it gives only a selection of the bodhipäksika $(\mathrm{R}$, folio $592.1 ; 596.5-98.1)$.

903. Theoretically, there is still the possibility that their presence on what is to all purposes the bhāvanāmārga might point to the impure (anäsrava) or laukika phase of path of contemplation (Kosa, vi, p. 119, ii, p. $117, \mathrm{v}, \mathrm{pp} .103-4)$. Their positioning after the noble eightfold path and after the lokottara practices of samatha and vipaśyanā, however, does not give much credibility to this hypothesis. Cf. Abhidh-sam (R), p. 110, which distinguishes between a laukika and lokottara phase of the bhävanämärga.

904. MBT, iii, pp. 9.1-11.20.

905. $M B T$, iii, p. 10.8-12. 
forces that were party to this process.

Leaving behind the intricacies of the bhāvanāmärga, we shall now turn to the last phase of the bodhisattva path. Interpreted by the $A k n$ - tik $\bar{a}$ as 'isolated awakening' (pratyekabodhi), it covers the attainment of enlightenment and the cognitive realisations that stand in wisdom at its very heart. For the $B d p$, as for most other treatises, the chief components of prajĩ $\bar{a}$ are penetration into the laws of dependent co-origination and insight into the general characteristics of dharma. Accordingly, the $B d p$ divided the climax of the path into 'skill' in solitary wandering (ekayānamārga), 'skill' in dependent co-origination (pratītyasamutpāda) and 'skill' in all dharma.

The connotations of 'skill' in solitary wandering are many and vary to some degree within each context in which they appear. ${ }^{906}$ Broadly speaking, we can distinguish five concepts that are united in the term ekayānamārga. First, there is the idea that the ekayānamārga covers the totality of Buddhist practices, specifically with reference to the seven categories of bodhipäkșika dharma. ${ }^{907}$ Second, it describes the mystical nature of a path that is well-delineated and easily followed since it does not deviate into side-roads. Third, being only wide enough for one person, it can only be travelled alone. ${ }^{908}$ Fourth, the path is one in the sense that it is traversed and accomplished only by the best, the Buddha. Finally, the ekayānamārga is one in as much as it leads to only one place, namely nirvāna. ${ }^{909}$

The reason why I have reiterated the findings of previous research here is straightforward. Practically all of these aspects of the ekayāna concept are mirrored, in one way or another, in the $B d p$ 's 'skill' in solitary wandering. That the 'single path' is all-encompassing and includes all practices corresponds to the bodhisattva's commitment to the six perfections. Its description as a path that unified, well-defined and without forks is played on when the bodhisattva's conduct is characterised as self-sufficient and independent of others. On a path whose course is straight and unambiguous, external guidance is obviously unnecessary. Next, as the path is

906. The term ekayāna is, of course, not a new entity to Buddhist research and has already attracted the attention of several scholars. For interpretations of the term ekayāna in the context of the smrtyupasthāna, see: Gethin, 1987, pp. 117-129 and Ruegg, 1969, p. 178; for an assessment in Prajĩäpāramitā works, in the $V k n$ and Samdhis, see: Lamotte, 1976, pp. 109-111.

907. Nidd, i, pp. 4555-6.

908. Böhtlingk; Roth (pw).

909. These interpretations are largely taken from the Pāli commentaries where they occur at several places. See, for instance, $S v$, iii, pp. 743-4, $P s$, i, pp. 229-30 (ref. Gethin). The gist of these meanings is corroborated by the Wörterbuch (Bechert, vi, p. 442), attributing the following interpretations to ekāyana: 'zu nur einem Ziel gehend oder führend'; 'sicher, zuverlässing'; 'notwendiger Weise zu einem bestimmten Punkt hin oder vorbei führend' and 'der einzige Weg'. 
narrow and grants place only to one traveller, the bodhisattva is unaccompanied and on his own. Knowing that it is only travelled by the best, the bodhisattva resolves to accomplish attainments that have not been achieved by any other member of the aryan-fold. The idea that the ekayana is one in the sense that is has only one destination is expressed in terms of ending in enlightenment under the Bodhi-tree. Appropriately, this is attained through one thought-moment only after the bodhisattva has defeated the host of Māra single-handedly.

The import of this imagery for the path scheme is obvious. The presence of all pāramitā, the proposition that the ekayanna is only traversed by the most advanced practitioners, their total independence from other agencies, the vision that its final destination is nothing less than enlightenment-all these attest great achievement and place the bodhisattva very close close to the goal of buddhahood ${ }^{910}$ In other words, 'skill' in solitary wandering is a metaphorical way of signalling the conclusion of the training in Perfect Wisdom. Drawing on imagery belonging to the ekayanna concept, it illustrates the bodhisattva's resolve, strength and independence as well as the uniqueness of the attainment itself.

The exact contents of these achievements are laid down in 'skill' in pratityasamutpāda and 'skill' in dharma. First, the bodhisattva discerns the causal mechanisms underlying conditioned existence. Realising that causality is not limited to sentient life but lies at the basis of all phenomena, he perceives dharma as inactive, motionless and non-self and therefore fundamentally inapprehensible (anupalambha): ${ }^{911}$

"All dharma are subject to causes, conditions and their combinations. What is subject to causes, conditions and their combinations is not the basis of a self, life-force or person. It is without reckoning whatever."

Notwithstanding this recognition, the bodhisattva does not abandon sentient beings to their fate, but subscribes to attainments in 'non-cessation' and 'non-exhaustion'. Thus schooled in the conditioned and unconditioned, the bodhisattva now reaches the pinnacle of his training. No longer concerned with his personal advance or the prospect of merit, he dedicates his resources entirely to universal liberation. Since he is in perfect command of all practices and

910. See, for example, the scheme of the Abhisamayälamkära $(\mathrm{I}, 1 \mathrm{e}, 21)$ where the penultimate generation of the bodhicitta is linked with the ekayanamärga. Subordinate in importance only to the cittotpada of the dharmakäya, the ekayānamārga manifests unmistakably only towards the very end of the path.

911. R, folio 682.6-683.1. 
fully acquainted with true reality, he does not fall prey to the defilements of the world in spite of constant exposure to their influence. The reason for this immunity lies in the integrated presence of 'skill' and wisdom that, being the underlying principles of his progress through the final path phases, will lead him eventually to all-knowing. ${ }^{912}$

912. The reference to the combined presence of 'skill' and wisdom in a truly accomplished bodhisattva adds another dimension to our perception of the role of 'skill'. We have seen that so far, 'skill' is primarily portrayed as a means bringing about understanding of reality-in short, wisdom. It contributes to the elimination of the belief in a self and involves training in a number of ancillary practices. Now, however, it is cited alongside wisdom as a separate factor of apparently equal importance. This shift in interpretation is not wholly unexpected but reflects the general drift in the description of 'skill' in dharma, announcing in clear termis the interaction between 'means' and 'wisdom'. The nature of their interaction and its manifestations are not discussed in the Prajñ $\bar{a}$ Chapter, but are given separate treatment in the chapter twelve in the context of the samgrahavastu. 


\section{The Means of Conversion}

No practice exemplifies the coordinated interaction between cognitive attainments and practical 'skills' better than the means of conversion (samgrahavastu). ${ }^{913}$ Technically pertaining to Perfect Wisdom although essentially complementary, the samgrahavastu achieve great momentum particularly during the final stages of the path. ${ }^{914}$ They enable the bodhisattva to attract the attention of his fellow beings and secure conditions where he can effectively communicate the Dharma. By virtue of this capacity, the samgrahavastu are frequently considered as a sub-species of skilful means particularly concerned with the maturation of sentient beings. ${ }^{915}$ Like so many other bodhisattva practices, their presence in the path has its origin in the suttas of early Buddhism. ${ }^{916}$ Starting as secondary practices in the nikāya, their status increased dramatically in the Mahāyāna where they came to rank amongst the most important bodhisattva practices. ${ }^{917}$ The basic constituents of the samgrahavastu are giving (dāna), friendly speech (prīyavāditā), service rendered (arthacary $\bar{a}$ ) and pursuit of a common aim (samānärthatā). Judging by a passage in the $B d p$ and the explanations of the $B b h$, acquisition and function of each member is to some extent dependent on the presence of the former.

First let us consider the account of the $B b h$. People are attracted to the bodhisattva through his generosity, thinking that to listen and behave as proposed by the bodhisattva is profitable. Then, having shown generosity, the bodhisattva prompts them to accept his reasoning through

913. Noting that in Sanskrit works often only one or two of samgrahavastu occur, Dayal infers that the set of four is a rather 'later development' in Sanskrit literature. Evidence in several early $R k t+$ sūtras, however, suggests otherwise. In the $U g$ (p. 262.5.6-7), $K p$ (pp. 41, 50; § 19, § 25), Bhadra-vy (R) (pp. 44, 97) and, of course, in the $B d p$ references to the samgrahavastu are invariably to the set of four. Already well-known in pre-Mahāyāna texts, it seems more likely that the four were taken over en bloc by the newly emerging movement as part of the established and widely recognised features of the path, as indeed were many other of the early practices (viz., pratisarana, pratisamvid, bodhipāksika, etc.). Moreover, the texts to which Dayal points are markedly later in origin. He cites, for instance, the composite $M v u$ (iii, pp. 383.11, 407.13), Ssp (Ghosa, p. 280.12) and Jätakamala (pp. 2.1, 92.12), texts which hardly pertain to the first wave of Mahāyāna works.

914. Bbh, p. 213.4-7.

915. Bbh, pp. 261.20-62.8; Msl, p. 147.4.

916. For occurrences of the four means of conversion in the nikāya, see: D III, pp. 152, 191, 232; A II, pp. 32, 248; IV, pp. 219, 364; S V, p. 330. In Pāli called sangahavatthu, they occur as danna, peyyavajjam, atthacariyä and samānattată. See, also, Mvu, i, p. 3.11; ii, p. 395.8; Dhsgr, § 19; and Lal, pp. 38.16, $160.6,182.6,429.13$.

917. For a measure of their prominence, see their position and the detail that is dedicated to them in the $B b h$ (pp. 217-230) and $M s l$ (pp. 116.8-117.21). For a treatment of upāyakausalya, see: Pye, Skilful Means, 1978. 
friendly speech. Thus enchanted by his logic and instructed in the Dharma, they are separated from evil tendencies and introduced to virtue through his service. Finally, providing an example to others, the bodhisattva adjusts his own conduct to the ideal of the Dharma so that beings will not accuse him of hypocrisy, but will emulate his behaviour. ${ }^{918}$

In the $B d p$, while accepting the gist of this account, the connection between the individual elements is explained differently: ${ }^{919}$

"Giving is of bodhisattvas who have generated the thought of enlightenment for the first time. Friendly speech is of bodhisattvas who persist in their practice. Service rendered is of bodhisattvas who are irreversible. Pursuit of a common aim is of bodhisattvas who are held back by only one birth."

This passage contains three important elements. ${ }^{920}$ First, it suggests that the practice of the samgrahavastu is not reserved to advanced bodhisattvas, but figures right from the beginning in the training. Second, it indicates that the acquisition of the members is separated by vast time-spans. Let us recall that even the most conservative estimate separates the four points that are mentioned here by one world-age (asamkhyeya) each. ${ }^{921}$ Third, it hints at some form of interconnection between the samgrahavastu and suggests that the attainment of each member builds on the preceding one. The exact nature of this link is eloquently expressed in the imagery of the next paragraph: ${ }^{922}$

"Giving is the ground of the roots of enlightenment. Friendly speech is the developed shoot of enlightenment. Service rendered is the blossoming flower of enlightenment. Pursuit of a common aim is the resulting fruit of enlightenment."

In its characterisation of the samgrahavastu, the $B d p$ draws a great deal on material from the foregoing chapters. It describes giving as generosity inspired by thoughts of benevolence; friendly speech as charming words rich in sympathetic joy; service rendered as exertion in

918. $B b h$, pp. $112.18-113.6$.

919. R, folio $698.2-4$.

920. Compare this distribution of the samgrahavastu with the scheme that is drawn up in the $M s l$ (p. 117.3-9).

921. Dasa-bh, p. xvii

For further detail on the length of the bodhisattva's career, see: Siddhi, pp. 731-33.

922. $\mathrm{R}$, folio $698.4-6$. 
worldly conduct born from compassion and pursuit of a common aim that is marked by equipoise transformed to all-knowing. ${ }^{923}$ Alternatively, it speaks of generosity in terms of the dānapāramitā; of friendly speech in terms of the silla- and kșāntipāramitā; of pursuit of a common aim as the dhyāna- and prajñāpäramitā. To interpret the samgrahavastu in terms of the apramāna and pāramitā is rather unusual and not found in any of the standard reference works. This is perhaps of particular interest to the $B b h$, since this work-like the $B d p$-discusses the samgrahavastu immediately after the pāramitā. ${ }^{924}$

In substance, however, most sources give remarkably uniform descriptions of the means of conversion. Thus, the dānasamgrahavastu is invariably held to encompass material and spiritual gifts. Since a supreme value is placed on the giving of the Dharma, their focus rests invariably on dāna-factors that affect the bodhisattva's preaching activity. To a large degree this is also valid for the $B d p$, although it includes 'protection' as the third object of giving. Also the prīyavāditāsamgrahavastu is chiefly referred to in conjunction with the gift of the Doctrine. ${ }^{925}$ Having established the Dharma as focus, it is here the positive attitude to preaching that stands in the foreground. When practising arthacarya, the bodhisattva's perspective in teaching shifts once more. Now, it is no longer the mode or tone of his words that matters, but the concern to demonstrate the practical and spiritual benefits of the Dharma. ${ }^{926}$ For the spiritually more advanced, the bodhisattva acts as guide and supervises their progress along the path. That is to say, he dispenses instructions in the three vehicles, he establishes people in equipoise and the accumulation of merit and knowledge, he praises the advantages of solitude and meditation.

These characteristics, all taken from the $B b h$, aim quite clearly at the benefit of others. For the $B d p$, however, rendering service is also concerned with the bodhisattva's own progress. ${ }^{927}$ This proposition is surprising since, according to the $B d p$ 's own scheme, the arthacaryāsamgrahavastu is not practised before the stage of irreversibility. The most likely explanation is that the arthacaryāsamgrahavastu is seen to link up with the samānärthatāsamgrahavastu at which the bodhisattva is expected to display personal achievements for others to emulate. For these to be perfect, he would naturally make his personal advance an objective of the previous samgrahavastu.

923. R, folio $696.2-4$.

924. $B b h$, pp. $217-230$.

925. $B b h$, pp. $217.5-221.7 ; M s l$, p. 116.2-9.

926. $B b h$, pp. 222.20-223.7, 225.4-20.

927. R, folio 695.5. 
According to the $B b h$, progress in the samānārthatāsamgrahavastu falls into four phases. ${ }^{928}$ At first, the bodhisattva does not show his capabilities to the full as he does not wish to boast about them. Then, having become more confident, he modestly begins to explain them to beings, always looking for the most appropriate means. Next, in order to instruct in the accumulation of merit, he encourages to the maxims of his own conduct. Finally, now facing a well-disposed audience, he censures heterodox practices and warns his listeners not to swerve from the Buddhist path. His attitude during these phases does not change. He guides sentient beings to roots of virtue; he adheres to the Vinaya and acts in accordance with the Dharma, hoping that others will emulate his conduct.

These concerns also dominate the Bdp's understanding of the samānärthatāsamgrahavastu. Committed to the liberation of beings, the bodhisattva promotes only those aspirations that he himself considers to be of highest quality. For this purpose he generates the thought of all-knowing with the firm intention to pass it on as soon as he himself acquired it. ${ }^{929}$ As in the $B b h$, the rationale is twofold, that is, to establish beings in the Dharma and to fulfil for himself the buddha-qualities. ${ }^{930}$

The one issue in which the $B d p$ differs markedly from the views of the $B b h$, and indeed most other works I have consulted, is the spiritual status of the persons to whom he addresses the samgrahavastu. For the bodhisattva of the $B d p$, these are invariably mendicants (yācanaka) who have renounced worldly concerns and subscribe to a life of renunciation. Accordingly, giving means for him pleasing mendicants; friendly speech is paying respects to mendicants; rendering service means attaining the goal of the mendicants and to pursue a common goal is pursuing a goal similar to theirs. ${ }^{931}$ For the $B d p$, the practice of the samgrahavastu is therefore confined in scope.

Several reasons could have led to this attitude. First, there is the possibility that the $B d p$ was composed at a time when the path was not yet fully open to the laity. If this could be proved, it would lend further support to my hypothesis that we are dealing in the $B d p$ with Mahāyāna text of very early origin. Then, it might reflect historical circumstances where the bodhisattva-himself a recluse or wandering ascetic-would shun the distraction of worldly life and mix only with like-minded practitioners. Alternatively, it is not inconceivable that

928. Bbh, pp. 226.15-227.2.

929. R, folio 696.7 .

930. $\mathrm{R}$, folio 697.7 .

931. $\mathrm{R}$, folio 695.6-7. 
the mendicant audience was simply a device to raise the status of the bodhisattva. For a bodhisattva to be in the company of bhiksus and ascetics would surely have added to his prestige, at a time when lay participation was on the increase.

Whatever the reasons for this limitation, it is clear from later literature that it was not destined to last. The vast majority of Mahāyāna sūtras, including many of the śästras leave no doubt that the path with all its practices-if not expressively pursued by monks and laymen alike-was unanimously understood to embrace all categories of sentient beings in its final objective of universal liberation. 


\section{Conclusion}

The foregoing analysis of the $B d p$ 's practices and doctrines now provides sufficient data for us to establish the approximate position of the $B d p$ in Mahăyāna literature. Comparison with other texts has shown that its treatment of the bodhisattva ideal bears all the hallmarks of an early date of composition. Evidence of its antiquity is found in practically all areas of discussion, including the nature of the practices, the doctrinal frame in which they are developed, in the path structure and in the ideal itself.

First to the presentation of the practices. Repetitions in their discussion, the loose rambling style of presentation, the predominantly descriptive approach and a certain lack of organisation all suggest that the underlying structures of the practices were still fluid and had not yet been codified by the time the $B d p$ was composed. This is most evident in the treatment of the dāna-, kșānti- and vīryapāramitā but applies also to the bodhipākșika dharma. In each of these we find repetitions, variant classifications, interjections of unrelated thought and outlines of contents that are not adhered to. In later writings many of these structural 'anomalies' are corrected and brought into line with the current thinking on the bodhisattva. Immediate evidence of this process is contained in the $A k n$ whose editorial adjustments of the material of the $B d p$ clearly reflect discontent with some detail of its overall design. In addition, the $B d p$ gives little information on the interrelation between the various practices. Explanatory comments are generally restricted to the practices themselves and do not clarify the context where they occur. For instance, the $B d p$ goes to great lengths to enumerate the objects of generosity and to describe the hardship encountered during the training in patience. And yet, it gives little attention to the psychological processes underlying both dāna and ksānti. This is particularly evident in its discussions of the apramāna and dhyanna where there is virtually no information on the meditative experience itself. Here, as in most other chapters, the $B d p$ is mainly concerned with providing a description of the practices themselves and to illustrate their implications for the bodhisattva's spiritual progress. Hence, we learn a lot about the scope of their implementation and the benefits they bestow, but are left in ignorance about the psychological mechanisms of their functioning. We have seen that such emphasis on detailed descriptions and lengthy enumerations is particularly widespread among the earlier 
bodhisattva works.

The $B d p$ 's antiquity is also borne out by the nature of its practices, many of which show traits of early Buddhism. The exposition of the akusalakarmapatha in the Sila Chapter, the detailed discussion of the bodhipākșika dharma and its insistence on traditional moral discipline indicate that the $B d p$ originated at a time when early Buddhist maxims had still considerable influence on Mahāyāna thinking. In its exposition of silla, for example, the $B d p$ closely follows the prescriptive approach of the śrāvaka Vinaya and does not allow for adjustments in moral observance even if the bodhisattva's vow should require it. Furthermore, it identifies desire as the chief source of moral impurity. We have seen that in both respects significant shifts in interpretation occur in later literature. Further evidence is found in the $B d p$ 's conception of prajñā. Unlike later sources which tend to conceive of prajña $\bar{a}$ predominantly as dharmanairätmya, the $B d p$ emphasises the destruction of the belief in a self and realisation of dependent co-origination. Also its threefold division of wisdom, distinguishing śruta, yoniśo manasakära and pratipatti as the fundamental causes of prajī $\bar{a}$ is, in a variant form, already found in the earliest strands of Buddhist literature. The fact that the scheme in the $B d p$ shows some terminological divergencies indicates that it was conceived before the exact terms had been codified.

The description of the practices themselves is marked by a high degree of realism. That is to say, it is conceived in terms of real sacrifice, hardship and struggle. In all chapters, except for the eleventh, the impact of Mahāyāna ontology is very small and does not affect the implementation of the bodhisattva practice. Again, this is a common feature especially among the works belonging to the first waves of Mahāyāna sūtras.

Also of interest is the $B d p$ 's position on skilful means. References to the term upayakausalya occur at three places altogether. And yet, despite this lack of technical referral, there is an implicit employment of principle of skilful means throughout. In chapter eleven, for example, skilful means is closely associated with compassion and the welfare of others. Here, it becomes instrumental to both the bodhisattva's personal accomplishments and to the spiritual purification of sentient beings. In chapter ten, skilful means is placed at the very centre of the discussion and becomes the underlying force behind the bodhisattva's training in the abhijñă. Epitomised by the joint cultivation of 'means' (upāya) and 'knowledge' (jñāna), it allows the bodhisattva effective communication of his insights to this fellow beings. Upayya, in this context, stands above all for the practice of the abhijña which create the conditions through 
which he learns of people's spiritual requirements. Adaptation to other people's needs is, of course, the very foundation of the concept of upayyakausalya. And yet, there is no provision of a separate chapter of skilful nor is it treated in anywhere near the detail of the other päramitā. The conclusion must be that at the time of the $B d p$ 's composition upayyakauśalya had not yet received the status it was granted in later centuries when it became a pāramitā in its own right.

Training in the practices themselves proceeds within the narrow confines of the mendicant ideal and is only open to practitioners who have renounced all ties with society. Except for one brief section, the $B d p$ does not even contemplate the possibility of a lay path for bodhisattvas. On the contrary, the Buddha warns repeatedly of the blemish of worldly life and strongly urges that the mendicant life should be taken up. The dismissal of the lay ideal is not surprising if we recall that most of the discourse is set in a loose narrative of Sākyamuni's previous lives. Traditionally, his strivings have always been closely associated with the mendicant ideal and physical austerity.

Other indications for an early origin of the $B d p$ are found in the bodhisattva doctrine. The exposition of the cittotpäda, for instance, lacks several important elements that found their way into later discussions. It does not mention either adhyāsaya or gotra and is rather unclear about the relationship of the cittotpāda and ásaya. Also the distinctions between the various types of cittotpäda are rather vague. Although the Bdp speaks of ten different kinds of cittotpāda and indicates that these are generated successively, in content all ten are very similar and allocated only approximate places on the path. Since later treatises distinguish quite regularly between ten types of cittotpāda, it is fair to assume that the scheme in the $B d p$ must have been something of an 'embryo' for later developments.

This applies also to the $B d p$ 's treatment of the apramāna and pāramitā which contains many of the ingredients that, in later times, were brought together into a coherent doctrine. For instance, it proposes the pāramitā context for the practice of the apramāna and recognises three levels of training in maitri. It does not endorse the reward of a high rebirth, but distinguishes between a srāvaka and bodhisattva way of apramāna practice. In dāna the $B d p$ differentiates between external and internal gifts and associates the practice of giving with the generation of the thought of enlightenment. When discussing $k s+a n t i$, it discriminates between patience with regard to suffering, hostility and dharma. Also its thought on vigour is divided into three spheres, that is, armoured vigour, vigour in the accumulation of roots of 
virtue and vigour in benefiting sentient beings. In the context of dhyāna, the $B d p$ speaks of nine preparatory types of meditation and distinguishes between meditation of production (marked by the abhijñ $\bar{a}$ ) and meditation that is aimed at the welfare of beings. We have seen that it was exactly these divisions that became the cornerstone of the pāramitā practice in later works. The loose fashion in which the $B d p$ speaks of these divisions is evidence of its position at the beginning of the development of the päramitā doctrine. In the perfection of vigour and meditation, for example, no formal division is put forward, but the contents of their expositions allow us to identify three distinct categories of vìrya and dhyāna. For ksänti the $B d p$ proposes its own division. Although the individual types differ by name, in contents, they run in fact very close to the kșānti categories of later treatises. In addition, the dynamics of the practices invariably match the order of the more advanced schemes. First, the $B d p$ expounds the preparatory practices, followed by the practice proper aimed at the bodhisattva's personal advance and finally it introduces a shift in concern towards the welfare of beings.

There are, however, issues that later writers criticised. When these were of little significance, they were simply not adopted and fell into oblivion. This appears to have happened to the threefold division of upekșa, to the order of the abhijñ $\bar{a}$ and their division into ordinary and non-regressing abhijñā. More important matters were modified or supplemented with additional material. Examples of such changes are found in the $A k n$ 's samādhi list and in its eighty-four types of learning, both of which originated in the $B d p$.

Other adjustments affected the arrangement of the practices. We have seen that the $B d p$ does not possess any formalised, linear path structure. Progress to buddhahood is primarily conceived in terms of practices, beginning with training in the apramana and ending in mastery of the samgrahavastu. History has shown that this design did not win acceptance. The first changes occurred already in the $A k n$ that places the apramana well behind the pāramitā and brings the means of conversion forward into the middle of the path before the pratisamvid, pratisarana and bodhipākșika dharma. The Akn also altered the order of the seven sets of bodhipākșika dharma to comply with their traditional presentation. Quite clearly, these changes were deliberate editorial adjustments that did not occur by chance, but were meant to improve on the $B d p$ 's arrangement of practice.

These modifications are significant in two respects. First, they allow us to trace the development of the bodhisattva doctrine and highlight some of the concerns that led to changes in the perception of the training. Second, they are testimony of the communication 
existing between the various Buddhist circles in ancient India. Although we do not know for how long this exchange of ideas persisted, it must have continued for several centuries since we find elements of the $B d p$ 's path design in the $B b h$ and $M s l$. While it is not possible to establish that the parallels between the $B d p$ and $B b h / M s l$ are the result of direct borrowing, the fact that they occur in no other texts allows for few alternatives. This would mean then that the arrangement of practices in the $B d p$-although criticised in detail—was highly esteemed even two or three centuries after its composition. Rivalry with the daśabhümika plan probably never occurred, since the $B d p$ 's account of the training is not based on a set of codified career stages, but revolves around a concatenation of practices.

In summary, we can distinguish the following training-phases in the Bdp. First, having generated the thought of enlightenment, the bodhisattva subscribes to the preliminary aspects of the path. This involves the practice of the apramanna and schooling in the perfections of dāna, sìla, kșanti, vìrya and dhyāna. Coursing in the lower levels of their practice (that is, the preparatory level and the practice proper), the bodhisattva passes through the sambhäramārga, prayogamārga, darśanamārga and bhāvanāmārga. When he has reached the bhāvanāmārga, the bodhisattva begins to train in skill. In order to establish a sound psychological basis for the more advanced phases, he focuses at first on the destruction of the belief in a self. Next, the bodhisattva endeavours to acquire knowledge and merit to secure his personal progress. For this purpose he trains in the pratisamvid, pratisarana, punya and jñana. These practices liberate the bodhisattva from the obstructions of defilements and mistaken views, establish him in moral conduct and bestow the powers and faculties. Thus schooled, he is able to embark on the pursuit of the bodhipākșika dharma. He now devotes most of his attention to the practice of meditation through which he acquires proficiency in faith, vigour, recollection, wisdom, etc. On the basis of these attainments, the bodhisattva comprehends eventually the insubstantiality of dharma (dharmanairātmya). This insight is reached for the first time during the joint practice of samatha and vipaśyana and signals the high-point in his cognitive training.

In order to acquire mental stability the bodhisattva withdraws into seclusion. Referred to as 'solitary wandering', it establishes the bodhisattva in emotional independence and cuts him off from all worldly constraints. Moreover, as the penultimate phase of the training proper, it leads him directly to the seat of enlightenment, thus placing buddhahood within reach. The acquisition of wisdom occurs when the bodhisattva penetrates 'skill' in dependent co-origination 
and attains mastery over all dharma. It brings the bodhisattva 'face to face' with reality and creates the preconditions for universal liberation. The scope and nature of the liberation-process are summed up by the four practices that are included in the means of conversion. The bodhisattva bestows gifts, uses benign language, renders service and adopts unsurpassed conduct for others to emulate. When he has mastered all four samgrahavastu, he is only one birth away from buddhahood. Apart from the immense gnoseologic realisation, this achievement marks also the bodhisattva's return to the world. That is to say, he abandons his training in the ekayānamārga and resumes his duties towards humankind.

This leads us to the bodhisattva ideal. For the $B d p$, entry in the bodhisattva path is entirely in the hands of the practitioner and takes place independent of external forces. For this all important step to take place, the bodhisattva must acquire a high degree of moral purity and be equipped with a determined resolve towards enlightenment. In addition, he must possess personal initiative and self-responsibility as there is no outside support apart from the sustaining power of the buddhas. Although devotional elements such as teacher veneration occur in several passages in the $B d p$, buddha-worship itself plays no active role in the process of purification.

The $B d p$ 's position on the bodhisattva's relationship with sentient beings is ambiguous. On the one hand, it affirms repeatedly and with great eloquence that the overriding concern of all practices is universal liberation. However, this commitment is not borne out by the description of the practices. On balance, the $B d p$ gives notably more attention to their acquisition than to exploring how they could be used to liberate sentient beings. The discussion of the samgrahavastu covers less than five folios while the exposition of the perfections runs into hundreds of pages.

This kind of indifference is also found in its exposition of dāna where freedom from birth in the lower destinies is given among the benefits that accrue from perfect giving. The lower realms are clearly excluded as an outcome for more advanced bodhisattvas. Accordingly, hell figures only as a deterrent and is never promulgated as a particularly beneficial 'training ground'. Once bodhisattvas have attained the stage of the prediction their interaction with beings of the evil destinies abates and gods and men become the object of their attention.

Quite clearly, the $B d p$ 's vision of the bodhisattva contains a high degree of spiritual realism. It is primarily concerned with the practical aspects of the training and shows little interest in the more breathtaking prospect of universal liberation. The picture it draws of the bodhisattva 
is of a person who is wholly absorbed by his yearning for enlightenment. Aiming to show how this goal is realised, the $B d p$ goes to great lengths to explain the underlying processes of purification. In a sense, the spirit of the exposition is therefore not so far removed from descriptions of the srāvaka training. It speaks of the importance of moral integrity, it emphasises the need for a disciplined spiritual environment, it urges self-reliability and warns of complacency. Moreover, references to the srāvaka are generally amicable and free of antagonism. These factors alone would point to a period of composition when the two ideals had still very much in common.

Further weight is lent to this hypothesis by the fact that many of the $B d p$ 's propositions belong to the incipient phase of the bodhisattva doctrine; the early nature of the practices and their loose divisions, the formal exclusion of skilful means, the basic path structure and the ill-organised form of presentation, they all imply an early origin of the $B d p$. We have thus identified in the $B d p$ a text of fundamental importance in the evolution of the bodhisattva ideal. Looking back at the history of the $B d p$, we notice that we are not the first to do so. The composers of the countless texts referring to the $B d p$ for its exposition of the paramita, the compilers of the Ratnakutta collection who placed the $B d p$ at the centre of their bodhisattva works and last, but not least, Hsüan-tsang, all of these have come to the same conclusion many centuries ago. 


\section{Chapter Five}

\section{Translation of Chapter Eleven of the Bodhisattvapițakasutra}

\section{Introduction}

The original version of the $B d p$ in the Indic language in that it was composed is no longer extant. As so many other Mahāyāna sütras, it is preserved only in Chinese and Tibetan translations. For the present study, I utilised the following versions of the $B d p$.

1. The ninth-century Tibetan translation made by Surendrabodhi, Silendrabodhi and Dharmatāsilla, entitled: ḥphags pa byan chub sems dpahi sde snod ces bya ba theg pa chen pohi mdo (ārya-bodhisattvapițaka-näma-mahāyāna-sūtra).

In editing and translating chapter eleven, I used or consulted the following four editions of the Tibetan $h K a h-h g y u r$.
a. sTog Palace (R), Leh-1979, vol. 37, folio 590.1-695.1
b. sD-dge (D), vol. 42, folio 315.1-384.2
c. Peking (P), vol. 23, pp. 73.1.7-89.2.2
d. sNar-than $(\mathrm{N})$, vol. 3 (ga), folio 327.3-386.4

2. Tun-huang Manuscript: Bibliothèque Nationale (Lalou, 1950), Pelliot, item no. 977

3. Tun-huang Manuscript: India Office Library (La Vallée Poussin, 1962), item no. $380.109,635.32,705.2$

In addition, I utilised several works that either paraphrase passages of the $B d p$ or contain selected quotations. These are:

1. Akșayamatinirdeśasūtra: hphags pa blo gros mi zad pas bstan pa źes bya ba theg pa chen pohi mdo (P 34, pp. 35.2.3-74.2.2).

2. Akșayamatinirdeśatikīa: hphags pa blo gros mi zad pas bstan pahi rgya cher hgrel pa (P 104, pp. 137.1.1-273.3.7).

3. Arthaviniścayasūtra: Samtani, NH, 1971.

4. Arthaviniścayatịkā: Samtani, NH, 1971.

5. Sikṣāsamuccaya: Bendall, C, 1902. 
On several occasions, I was able to identify passages from the $B d p$ that are found in later Buddhist Sanskrit literature. For the most part these are not attributed to the $B d p$ but were taken from the $A k n$. While they show some minor divergencies from the Tibetan of the $B d p$, they do give us a fairly good impression how the original Sanskrit text might have looked like.

Having said this, it is important to bear in mind that the conventional usage of the notion of a 'Sanskrit original' is rather misleading, since the Indic versions themselves were often subject to interpolation, rearrangement or shortening. Whether this was also the case with the $B d p$ is impossible to tell, although we have no reason to assume that it was exempt from such alterations. Assuming that certain changes were made, the Tibetan of the $B d p$ reflects only the Sanskrit text that existed in India in the eighth/ninth century that was used by the Indo-Tibetan translation team as basis for their work. Whether they founded their translation on only one version or had access to several manuscripts we cannot tell.

As we are dealing in the Tibetan with a translation from the Sanskrit (which turns my translation into a translation of translation), it was important not to lose the Sanskrit referent out of sight. For this purpose, I endeavoured to gain as close an understanding of the underlying Sanskrit as possible. In order to communicate my understanding to the reader, I provided in the notes Sanskrit equivalents to Tibetan technical terms. In establishing these, I drew generally on the vocabulary of the Mahāvyutpatti. While the use of (reconstructed) Sanskrit terms is helpful to demarcate the context of the discussion and to provide translation markers, it has the potential to create a whole series of linguistic problems. Wishing to avoid a fully-fledged discussion of each reconstruction, I limited myself to those terms that occur with some frequency in Buddhist literature. Even then, they are to some degree tentative and should be used only with caution.

In the translation of the technical terms my overall objective was to be as consistent as possible. Whenever the context allowed I would use the same English word for a given Tibetan/Sanskrit term. While this worked fine in many instances, in others it did not. When in difficulties, I provided the Tibetan or Sanskrit term in order to draw attention to my 'non-standard' rendering. In these cases my interpretation is generally based on the available commentarial sources that indicate the particular meaning of a word.

The most important commentary for the study of the $B d p$ is the $A k n-t i k \bar{a}$. The textual parallels between the $B d p$ and $A k n$ allowed me to draw quite regularly for explication on the annotations in the $A k n-t i \bar{k} \bar{a}$. Whenever the explanations of the $A k n-t i k \bar{a}$ affected my translation, I indicated this in the notes. Other texts of importance are the Arthav and Siks since both contain quotations from the $A k n$.

With my English translation I hope to have produced an accurate and readable version of the meaning and contents of chapter eleven. In doing so, I found myself often confronted to chose between the literal meaning and that what I thought the text intended to say. The 
principle of guidance in those situations was to be as literal as possible so long as it was reconcilable with the syntactical requirements of the English language. At times, this generated a rather Tibetanised English. Whenever in doubt, I followed the literal reading of the Tibetan, hoping that future research will throw light on those passages that I failed to penetrate fully. Not wishing to temper with the wording of the Tibetan, I kept additions or interpolations in my translation to a bare minimum. Again, this did not always further its readability, but constitutes, I believe, a methodological requirement for every translation activity, especially if presented to an academic audience for scrutiny.

The division of the text into sections is not found in the Tibetan but was introduced by me in order to make it more manageable. In essence, the choice by which I divided the text and the wording of the section-headings reflects my understanding of the content and are thus interpretative. Apart from exposing the structure of the exposition, their value is primarily methodologic in that they facilitate references to my edition.

Finally, the in-text folio numbering to the $B d p$ in my translation and edition refers to the sTog Palace Edition. For reasons of legibility, I based the translation and edition on the large type of the sTog Palace manuscript. All other reference to the Tibetan canon, whether in the notes to my translation or elsewhere in this dissertation, relate invariably to the Peking Edition. 
Translation of Chapter Eleven

\section{English Translation of Chapter Eleven of the Bodhisattvapitakasūtra}

SECTION I

\subsection{Accumulation}

(590) O Sāriputra, what is the Perfection of Wisdom of a bodhisattva, mahāsattva who cultivates the bodhisattvacaryā whenever he applies himself to it? Concerning this, O Sāriputra, a bodhisattva listens diligently to the Dharma-enunciation of the Bodhisattvapitaka. He takes hold of it and retains it. He reads it and fully absorbs it. He also explains it to others and propounds it at length.

O Sāriputra, when a bodhisattva has diligently listened to the Dharma-enunciation of the Bodhisattvapitaka, when he has taken hold of it, retained it, read it, fully absorbed it, and when he has also explained it to others and propounded it at great length, he attains the following forms of wisdom. But that wisdom, what is its form and what is the method by which it is acquired ${ }^{1}$ Its form is learning ${ }^{2}$ and the method by which it is acquired is correct reflection.

1. hjug pa: praveśa (Böhtlingk; Roth, $p w$, pp. 1082-1083).

2. In the $A k n-t i k \bar{k}$, founded on the variant reading in the $A k n(34$, p. 50.4.6) we read:

"What is the form (äkāra) of wisdom? What is its mode of acquisition (praveśa)? Learning is the form and correct reflection is its mode of acquisition."

Vasubandhu explains that the form of wisdom is learning (śruta) and that learning constitutes the own-being (svabhäva) of wisdom, whereas discerning the marks of dharma indicates correct reflection. He qualifies this position by stating that the eighty-four types of learning originate in wisdom and says - with $\bar{a} k \bar{a} r a$ being likened to hetu - that the question 'What is the cause of wisdom?' corresponds to the question 'What is the form of wisdom?' (104, p. 181.3.2-6).

3. tshul bźin yid la byed pa: yoniśo manasakāra

As a general term indicating close mental examination, the meaning of yonisio manasakära is well-defined. According to the Kośa (ii, p. 154) it is "earnest application (äbhoga) of thought (cetas); submitting or applying the thought to its object". In the nikayya, it is depicted as the first sign heralding the acquisition of the äryāsțängamärga and to be preparing the attainment of the samyakprahäna (S V, p. 31). For the Mahäyāna, manasakāra became an essential ingredient to wisdom that was thought to arise on the basis of learning ( $M s l$, p. 7.3). Its role on the path grew steadily until it was proposed that "a single instant of seeing founded in wisdom-based correct reflection (yoniśomanasakäraprajñäpratyavekșanā) can eradicate innumerable defilements of action" (Kp, p. 106, § 71.8). Cf. Śrotabhümi, 109, p. 287.5.3-4.

Buddhist sources came to differ, however, on the exact scope of yoniśo manasakära. Depending on the context and viewpoint from which it is commented upon, we find a number of variant explanations. The Abhidh-sam (R), p. 7, defines manasakāra as earnest application of thought (cetasa äbhoga), intended to fix thought (cittadhärana) on the object (älambana). Discussing the means by which the bodhisattva enters into the first dhyāna (p. 112), the Abhidh-sam lists seven kinds of reflection, viz., (1) reflection penetrating the characteristics (laksanapratisamveda), (2) reflection adhering to determination (adhimoksika), (3) reflection adhering to the state of solitude (pravivikta), (4) reflection attracting contentment (ratisamgrahaka), (5) reflection that investigates (mìmämsaka), (6) reflection of accomplishing practice (prayoganiștha) and (7) reflection of the fruits of the accomplishment of practice (prayoganișthaphala). 
Translation of Chapter Eleven

\subsubsection{Seventy-Two Forms of Learning}

What are the forms of learning? They are zest ${ }^{4}$, intent ${ }^{5}$, determination, spiritual friend, lack of conceit, (591) reverence ${ }^{6}$, veneration ${ }^{7}$, congeniality, compliance in speech, reverend service, willingness to listen, paying respect, correct reflection, attentiveness, considering the sacred word as a jewel, considering it as a remedy, considering it as calming all ailment, a

Capable of manifesting three different degrees of intensity (intense-weak, intense-mediocre and intenseintense, p. 160), it is either innate (upapattiprätilambhika), arising from learning (śrutamayî), arising from reflection (cintämaȳi ) or arising from contemplation (bhävanämayi). According to the Kośa (ii, p. 328), the first three types of manasakära take place within the kāmadhātu, whereas the fourth can either operate in the rüpa or arüpyadhātu. See also Kośa (ii, p. 325) where-in a discussion of prerequisites for path-entry - we meet with three other types of manasakära, viz., reflection directed at specific characters (svalaksanamanasakära), reflection directed at common characters (sāmānyalakșanamanasakära) and reflection of earnest application (adhimuktimanasakära).

Edgerton's observation (p. 418, col. 1) that in its verbal form (manasi karoti) correct reflection appears often in conjunction with cintayati led Meadows (1986, p. 109) to infer that manasakara represents specifically the "method by which one acquires prajñā consisting in pondering (cintāmayīprajñă)". While a general association of cintā with manasakära is no doubt correct, the view of the Kośa linking manasakära on equal terms with learning, reflection and contemplation (and inborness) casts some doubt on her narrow interpretation. Furthermore, according to the Abhidharmasamuccayabhäsya (p. 81), the second type of manasakära, ädhimoksikamanasakära, transcends both learning (śruta) and reflection (cintā) to realise śamatha and vipaśyanä. The $A k n-t i k \bar{a}$ (p. 185.4.1-4), commenting on the parallel passage in the $A k n$, explains:

"Reflecting and contemplating in accordance with [the noble path and cessation] is correct reflection. By means of correct reflection one penetrates things in accordance with reality, thus it is called penetration (praveśa) through correct reflection. Concerning penetration into meaning (artha); the meaning is understood after one has discerned through the wisdom arising from contemplation (bhāvanā) the dharma that were discerned with the wisdom arising from reflection (cintā). Hence, [correct reflection] is to be known as wisdom concerned with reflection and contemplation."

In the $B d p$ itself, manasakāra figures at thirteenth place amongst the seventy-two kinds of learning. It is identified with the bodhisattva's keen wish that bad, unwholesome dharma that have hitherto not arisen are not produced ( $\mathrm{R}$, folio 672.1-3). It is said to prompt him to abandon those unwholesome dharma that have already arisen ( $\mathrm{R}$, folio $673.3-4)$ and it is accredited with the elimination of desire (räga) by way of contemplating impurity ( $R$, folio 673.5-6).

Note that the Patis (p. 195), when discussing breathing exercises, speaks of seventy-two kinds of knowledge through insight. However, as these are exclusively concerned with the three marks of existence and restricted in their operation to a meditative context, it shows no parallels to our list.

4. Taking zest (chanda) as example of all other forms of learning, Vasubandhu explains their role as follows. First, as the cause of both learning and wisdom, each of them leads to wisdom. Second, the forms of learning itself becomes the cause of chanda, etc., with which it forms jointly the basis to wisdom. Third, each of the types of learning represents also the own-being of wisdom (Akn-tīkā, p. 181.3.6-4.1):

"Zest is the keen wish to hear the Dharma. From the keen wish to hear, learning and insight occur but without the keen wish they do not. Hence, zest should be understood as the cause (hetu) through which wisdom arises. Again, zest arises from learning, but not from non-learning. Hence, learning becomes the cause from which zest arises. If the two are taken together, they are therefore the one cause [of wisdom]. Again, what is the own-being of wisdom? The form of zest means that the own-being of insight is zest. With regard to the following items, the form of resolve, etc., should be understood accordingly."

5. As part of its explanation of intent (āsaya), the $A k n-t i \bar{k} \bar{a}$ (p. 181.4.3-4) draws attention to a passage in the $B b h$ (p. 18.17-21). However, this passage deals with adhyaśaya and not with äsaya-a confusion that exemplifies the conceptual proximity of both terms (cf. Edgerton, pp. 17-18). A good definition of áśaya is found further below in the $B b h$ (p. 313.4-6), stating that the intent of the bodhisattva is based on faith and Dharma-discernment and manifests a resolute belief accompanied by certain knowledge and determination towards the Buddha's teachings.

6. Akn: bag yod pa (apramādya).

7. Akn: gus par byed pa (satkrtya). 
receptacle of recollection, knowledge arising from awakening, ${ }^{8}$ search for understanding, penetration of reason, insatiability through hearing the Buddha's doctrine, propagation of renunciation, erudition through restrain ${ }^{9}$, adherence to great learning, experiencing joy in devotion, bodily cheerfulness, joyful mind, untiring listening, pursuit of the own-being of things, pursuit of designations, pursuit of good conduct ${ }^{10}$, lack of desire for other vehicles, pursuit of the perfections, pursuit of the bodhisattvapitaka ${ }^{11}$, pursuit of the means of conversion, pursuit of skilful means, pursuit of the pure abodes, pursuit of the super-knowledge (592), pursuit of the bases of mindfulness, pursuit of the perfect efforts, pursuit of the bases of success, pursuit of dependent co-origination, pursuit of impermanence, suffering and non-self, pursuit of serenity, pursuit of emptiness, signlessness and wishlessness, pursuit of nonaccumulation of karmic formations, pursuit of the accumulation of roots of virtue, self-assertion, reflection on the Doctrine, contemplation of unsuitable associations, severing of all defilement, delight in skilfulness, adherence to noble ones and rejection of ignoble ones, pursuit of noble [qualities], faculties, bases of mindfulness, factors of enlightenment and the noble eightfold path, the Tathāgata's powers, assurances, great benevolence, compassion, sympathetic joy, equipoise $^{12}$, unique knowledge (593) and eighteen exclusive buddha-qualities.

8. Vasubandhu's commentary on this term runs as follows (Akn-tikiā, pp. 182.4.5-7):

"Awakening is wisdom arising from reflection. Also, wisdom arising from reflection has two different aspects, e.g., the assumption and non-assumption of composure. But he who is awakened since he is knowledgeable, that one is of knowledge arising from awakening. By means of the teaching of the knowledge arising from awakening, he acquires composed wisdom."

Now, the term rtogs pa ses pa (gatibodhana) is ambiguous as it may carry several meanings (Edgerton, pp. 208, 402). In his English rendering of the Sikṣāsamuccaya (1981, p. 185) Bendall translates gatibodhana-erroneously I think-as 'illuminating the destinies'. This interpretation was also adopted by Meadows (1986, p. 107), translating it as 'understanding the course', while Braarvig (1989, p. 254) follows Vasubandhu's understanding. Since gati may indeed mean 'awakening' (Edgerton, p. 208)-a meaning that brings it much closer to Vasubandhu's commentary of the term gatibodhana-Meadows and Bendall are probably misguided in their translation. In addition, to render gatibodhana as 'knowledge arising from awakening', being possibly an antecedent to the technical term cintämayīprajña fits the context in which it is cited in the $B d p$, while the translation 'illuminating the destinies' does not.

9. This is one of the few instances in which, in spite of a common Sanskrit source term, the Tibetan translations of the $A k n$ and $B d p$ do not correspond. While in the $B d p$ the Sanskrit term dāttājāneya is rendered as sbyin nas mi smod $p a$, we find in the $A k n$ the phrase dul zin can śes pa. Notwithstanding these discrepancies in wording, both phrases concur closely in their respective meanings. Vasubandhu's explanation of that term runs as follows ( $A k n-t i t k \bar{a}, \mathrm{pp}$. 183.2.1-183.3. 5):

"As regards restraint, he is restrained since he is endowed with improved meditative expedients and does not enter into the realm of the sense organs such as that of the eye, etc. He suppresses the defilements such as passion, etc. That is the cause. He who is restrained in that way is all-knowing. He is all-knowing, because he arrives at the place where he should be walking to all the time via the true path. That is the fruit. The true path is the union of knowledge and means, the noble eightfold path, that of the four noble truths and so forth. As regards the place to which he should be going, this is nirväna. Thus it is that the learned one who originates in learning, although he is marked by the characteristic of the fruit and cause [of] the noble path becomes erudite through restraint."

10. According to the $A k i-t i k a \overline{~(p . ~ 183.4 .1), ~ g o o d ~ c o n d u c t ~ i s ~ h e r e ~ u n d e r s t o o d ~ t o ~ a p p l y ~ t o ~ p r a c t i c e s ~ t h a t ~ a r e ~}$ included in the $\bar{a} r y \bar{a} s \underline{t} \bar{i} \operatorname{ngama} r g a$ since it is primarily these that liberate the practitioner from suffering.

11. Vasubandhu informs us in this context that the Bodhisattvapitaka is the vaipulya of the twelvefold division of scriptures. ( $A k n-t i k \bar{a}$, p. 184.2.7).

12. These four preceding items constitute, of course, the four immeasurables (apramana), (Mvy 1504-7). Note 


\subsubsection{Forty-One Methods of Acquiring Learning}

Thus, O Sāriputra, in whatever one is learned in that one becomes knowledgeable and being knowledgeable one performs good conduct. Why?

One who aspires to the Dharma-enunciation of the Bodhisattvapitaka, he will listen to it. On hearing it, he becomes knowledgeable and being knowledgeable, he performs good conduct. One who pursues with determination the Dharma-enunciation of the Bodhisattvapitaka, he will listen to it. .....$^{13}$

One who applies himself to the Dharma-enunciation of the Bodhisattvapitaka, he will listen to it. ... :

One who adheres to a virtuous friend, he will listen to it. ... .

One who is free from conceit, he will listen to it. ... .

One who is well-disposed towards the greatly learned, he will listen to it. ... .

One who honours the greatly learned, he will listen to it. ... .

One who persists in congeniality towards them, (594) he will listen to it. ... .

One who is compliant towards them, he will listen to it. ... .

One who pays respect to the greatly learned, he will listen to it. ... .

One who is willing to listen, he will listen to it. ... .

One who venerates the greatly learned, he will listen to it. ... .

One who reflects on great learning ${ }^{14}$, he will listen to it. ... .

One who considers the sacred word as a jewel, he will listen to it. ... .

One who considers the sacred word as ambrosia, he will listen to it. ... .

One who after hearing the sacred word thinks that it appeases desire, hatred and delusion, he will listen to it. ... .

One who after hearing the sacred word considers holding on to it, he will listen to it. ... .

One who penetrates the realisation of dharma, he will listen to it. ... .

that unlike the ten powers (bala), four assurances (vaisäradya) and four unique knowledge (pratisamvid), the apramāna are listed individually and not subsumed under their title.

13. Each of the following forty-one examples, specifying the acquisition of learning, concludes in the stock phrase $\mid$... de ni thos par hgyur ro | thos nas bar du ses so | ses nas nan tan byed do $\mid$

These I have translated as: "... will listen to it. On hearing it, he becomes knowledgeable (prajänati) and being knowledgeable, he performs good conduct (pratipadyate)."

In order to achieve a better English reading, I omitted these rather cumbersome, prolix and repetitive phrases. The omissions have been indicated by the insertion of three ellipsis points in the appropriate hiatus. Of the forty-one methods of acquisition of learning, only sixteen have been directly taken from the list of seventy-two forms of learning, that is a $k \bar{a} r a$ no. $2,3,4,5,6,7,8,9,10,11,12,13,15,20,22,27$. A further seven methods of acquisition have counterparts in spirit, though not in letter, in the list of learning. These are no. 16, 17, 18, 21, 22, 26, 28. None of the remaining nineteen methods of acquisition exhibits any immediate parallels to the forms of learning. More importantly, none of the $B d p$ 's forty-one methods of acquisition corresponds to the thirty-two methods of acquisition of correct reflection that are given in the $A k n$. Both lists seem to have been construed along differing lines and have little in common except for the context in which they appear and the shared purpose to represent a further stage in the cognitive process leading to wisdom $(A k n$, p. 51.1.6-2.7).

14. My translation of this phrase is based on a passage in the Abhidh-sam (R), p. 137, saying that application (ädhäna) is correct reflection (yoniśo manasakāra) that has great learning (bahuśruta) as object. 
One who wishes for understanding of the sacred word, he will listen to it. ... .

One who after hearing the sacred word experiences mental inspiration, (595) he will listen to it. ... .

One who is insatiable in hearing the sacred word, he will listen to it. ... .

One who after hearing a discourse on giving considers the act of renunciation, he will listen to it. ....

One who after hearing a discourse on moral conduct guards morality, he will listen to it. ... . One who after hearing a discourse on forbearance acts with patience, he will listen to it. ... . One who after hearing a discourse on vigour acts with flawless vigour, he will listen to it. .... One who after hearing a discourse on meditation acts with his mind free of inattention, he will listen to it. ... .

One who after hearing a discourse on wisdom exerts his mind to suppress the impurities, (596) he will listen to it. ... .

One who generates joy in great learning ${ }^{15}$, he will listen to it. ... .

One who attains bodily cheerfulness ${ }^{16}$ on listening to the Dharma, he will listen to it. ... .

One who rejoices on hearing the Dharma, he will listen to it.... .

One who on hearing of the Mahāyāna aspires to it, he will listen to it. ... .

One who produces a friendly disposition on hearing about the means of conversion, he will listen to it. ... .

One who embarks on mindfulness with regard to body, feeling, thought and dharma on listening to a discourse on the bases of mindfulness, he will listen to it. ... .

One who becomes shameful and embarrassed by non-virtues that have already been sown and arisen on listening to a discourse on the perfect efforts, he will listen to it. ... .

One who constantly retains in mind virtuous dharma that have already been sown and arisen, (597) he will listen to it. ... .

15. According to Edgerton the term man du thos pa (bahuśruta) carries several, albeit related, meanings. He gives 'sacred word' (p. 536, col. 1)-that is most often the Dharma-and 'great learning' (p. 399, col. 1) as the most frequently occurring ones. Monier-Williams (p. 726, col. 1) gives 'one who has studied much', 'very learned', 'being of deep erudition' as the principal meanings of the term bahuśruta. Already in the nikäya, great learning (bahussuta) assumed an important position and monks bearing this title were greatly revered. It occurs in the Vinaya (ii, p. 95), Majjhimanikāya (III, p. 11) and at two places in the Anguttaranikāya (II, p. 22; III, p. 114) where it is cited among the four things that bestow the rank of Elder on a monk:

"He has heard very much and memorised what he has heard. He retains in his mind what he has heard; the teachings are good at the beginning, in the middle and at the end in the sense that the meaning and letter are good. He follows the way of the brahmacariya in every respect and with great purity. To these teachings he has listened very often, he has borne them in mind, repeated them aloud, investigated them for their meaning and well understood them through right view."

The bahuśruta par excellence was, of course, Ānanda who was singled out in recognition of this quality as the person responsible for the preservation of the Doctrine (D II, pp. 144-46). Listed among important qualities (A I, pp. 24-25; for its place in an alternative list of seven see; D III, p. 252; M III, p. 23), it became a title that bestowed great prestige and covered the sutta, vinaya and mātikā (A II, pp. 147, 170).

16. I follow here Bendall (1981, p. 185) in translating the term lus sim pa (käyaudbilya) as 'bodily cheerfulness'. 
On listening to a discourse on the bases of success, one whose body, mind and determination become agile, he will listen to it. ... .

On listening to a discourse on meditation, one who establishes his mind in unfaltering reflection, he will listen to it. ....

On listening to a discourse on the immeasurables, one who becomes benevolent towards all sentient beings, greatly compassionate towards the poor, well disposed towards the Dharma and remains in the state of equipoise with regard to non-virtue, he will listen to it. ... .

On listening to a discourse on the faculties, one who applies his mind to the faculty of faith, vigour, mindfulness, meditation and wisdom, he will listen to it. ... .

On listening to a discourse on the factors of enlightenment, one who applies his mind in order to understand all the dharma perfectly, he will listen to it. ... .

On listening to a discourse on the path, one who applies his mind to the pursuit of nirvāna, (598) he will listen to it. ... .

One who directs his mind towards unsurpassed and perfect enlightenment on listening to the immeasurable teaching of the Buddha, studying the Tathāgata's powers, assurances, benevolence, compassion, joy, equipoise, unique knowledge and the eighteen exclusive buddhaqualities, such a person learns. On learning, he becomes knowledgeable and being knowledgeable, he performs good conduct.

$\mathrm{O}$ Sanriputra, these are the forty-one methods of acquiring the forms of learning. ${ }^{17} \mathrm{O}$

Sāriputra, it is in this manner that a bodhisattva courses in the Perfection of Wisdom.

\subsubsection{Good Conduct}

Furthermore, O Sāriputra, when a bodhisattva who courses in the Perfection of Wisdom has properly listened to the Dharma-enunciation of the Bodhisattvapitaka, when he has taken

17. In the $A k n$ (p. 51.1.6), the contents of this section is called "thirty-two methods of acquisition by means of correct reflection". For the $A \mathrm{kn}$, this ties well to the introductory passage of 'learning' where learning is identified as the form (or cause) of wisdom and correct reflection as the method of acquisition. Accordingly, Vasubandhu explains that "acquisition (praveśa) is either to persist in correct reflection or realise own-being and distinction by means of these [manifestations of] correct reflection" $(A k n-t \bar{k} k \bar{a}, \mathrm{p} .185 .4 .5-7)$. In view of the purely cognitive orientation of the $A k n$ 's thirty-two methods of acquisition this interpretation is appropriate $(A k n$, p. 51.1.5-2.7).

In spite of the fact that the list contained in the $B d p$ does not match the contents of that in the $A k n$, the same assumption can be made for the $B d p$ ' $s$ enumeration. While it is true that the cognitive element in the forty-one kinds of penetration is less evident, its presence, joined with bhāvanāmayīprajña a, is difficult to overlook in the phrase: "On hearing it, he becomes knowledgeable and being knowledgeable, he performs good conduct". The concept of knowledge implies no doubt the element of reflection and correct conduct could be interpreted to correspond to contemplation $(b h \bar{a} v a n \bar{a})$ of those insights that were revealed to the bodhisattva in the course of the foregoing cognitive process. In the $B d p$ we have therefore a catalogue of forces that promote the generation of wisdom, given in the order in which they influence each other. First, there is learning, divided into seventy-two kinds. Second, if combined with a wholesome mental disposition the forms of learning lead to knowledge of what has been learned. Third, comprehension then modifies the bodhisattva's practice and causes him to apply himself correctly to its cultivation. 
hold of it, retained it, read it, fully absorbed it, when he has also explained it to others and propounded it at great length, he performs good conduct ${ }^{18}$.

What is his good conduct with regard to dharma? Just as one complies with the instructions, he performs good conduct with regard to dharma.

Furthermore, performing good conduct with regard to dharma is non-apprehension any dharma. Why? If one apprehends dharma, one's conduct becomes misguided. As regards people who adhere to grasping dharma; (599) there is no place or occasion ${ }^{19}$ that arises from these dharma. They are unestablished. But even people who do not apprehend them because they are cleansed and are established in good conduct become insecure ${ }^{20}$ towards these dharma, how much more those who grasp dharma? Hence, non-apprehension of any dharma is good conduct.

Furthermore, one who is unobstructed with regard to dharma is of good conduct. One who lacks assertion, grasping and attachment towards dharma and realises that they are unarisen and unceasing is of good conduct. In addition, seeing the absence of increase and decrease in dharma is good conduct.

Furthermore, I have not explained much here. Just as it did not become perceptible in accordance with the explanation, in the same way all dharma are imperceptible, inapprehensible and have one characteristic. What is this characteristic? It is the lack of characteristic. The characteristic is without characteristic. This is due to two factors. Why? Binary reflection and right understanding ${ }^{21}$ themselves, I declare to be without characteristic. This is their characteristic, but it is a non-characteristic. Consequently, one who understands that all dharma are imperceptible, inapprehensible and without characteristic is of good conduct. Embark diligently on good conduct. Attain the vision that all dharma are pure. (600)

18. nan tan ñin por byed pa yin pa: pratipattisära (Mvy 1810) According to the Bhävanäkrama ( $M B T$, ii, p. $222 \S 21)$, good conduct of bodhisattvas is at all times aimed at the welfare of sentient beings. Based on perfect knowledge and exempt from despondency, agitation or meditative faults, a bodhisattva ponders on the illusory nature of the skandha, dhātu, āyatana, etc., without, however, to bring the realisation of their insubstantiality to conclusion. Wishing to establish beings in true vision of all dharma (sarvadharmayathäbhütadarśana), he observes the three areas of practice (adhisilla, adhicitta, adhiprajña $)$ in order to set an example and manifests vigour and purity in conduct of body, speech and mind. Judging by the number of references Edgerton cites in his entry of pratipatti, these elements constitute for most texts the cardinal aspects of good conduct (p. 364). Precise definitions, however, are rare largely because the concept of pratipatti itself is rather broad and ill-delineated, changing with context and doctrinal orientation.

19. The Tibetan gnas dan skabs could conceivably represent a misinterpretation of the Sanskrit term avasthita (gnas skabs; Abhisaml, p. 119) or avastha (Mvy 7588), in which case the translation 'condition' would be more appropriate. While this would make better sense, expressing that unestablished dharma do not produce any conditions that might perpetuate the causal chain, the Tibetan reading does not support this interpretation.

20. the tshom du gyur pa: samśayita (Edgerton, p. 542; Monier-Williams, p. 1117, col. 3).

21. kun brtags pa: parikalpita; yai dag par brtags pa: sampratipannã. 
Then, on that occasion, the lord composed these verses:

Whoever fares in truly good conduct

According to the Bodhisattvapitaka

Such a wise person does not cling to phenomena.

Thus, non-clinging emulates good conduct.

A man who obtains dharma does not profess emptiness.

The wise one does not take pride in empty dharma.

He has not attachment to empty dharma whatsoever.

Thus non-attachment resembles good conduct.

One does not grasp nor reject the dharma.

There is non-practice of grasping dharma.

Hence non-grasping is the characteristic of dharma.

It is this kind of emulation that is good conduct.

Why is the bodhisattva never attached to dharma?

His pristine cognition does not apprehend dharma.

He does not even attach himself to the non-grasping pristine cognition.

It is this kind of emulation that is good conduct.

The wise one should abide in the qualities of purification. ${ }^{22}$

He should apply himself to these dharma.

When he has persisted in good behaviour and comportment.

At that time, his introduction to the Doctrine ${ }^{23}$ becomes pure.

When he has purified his deportment,

He understands such teaching.

Then, he also perceives the resolve of the thought of enlightenment.

Truly, at that time, once he has perceived this resolve, the wise one explains such teaching.

After he has acquired knowledge of the absolute truth of this profound teaching,

22. sbyanis pahi yon tan: dhütaguna (Edgerton, p. 286, col. 1).

23. sgo: mukha ('entrance', 'ingress', 'introduction')

Cf. Edgerton, p. 433, col. 2; Monier Williams, p. 819, col. 3 ff. See also entries for dharmamukha (Edgerton, p. 280, col. 1) and dharmälokamukha (Edgerton, p. 281, col. 2) on which my translation is based. 
He will always abide in truth.

$\mathrm{He}$ is noble due to his infinite conduct and excellent qualities.

The great learning of this wise man is like an ocean.

Truly, as regards the meaning and words of this teaching (601),

Their limit is beyond comprehension.

Both, words and meaning are infinite.

One who fares in good conduct remains unperturbed.

O Sāriputra, it is in this manner that the bodhisattva courses in the Perfection of Wisdom.

\subsubsection{Vision}

Furthermore, O Sāriputra, after the bodhisattva who courses in the Perfection of Wisdom has properly listened to the Dharma-enunciation of the Bodhisattvapitaka and has taught it in great detail to others, he attains light as regards all dharma, because he has dispelled the impenetrable, shadowy darkness of clouding ignorance. This is the light of wisdom. ${ }^{24}$ Since he has attained this vision, he knows virtuous and non-virtuous dharma. For the sake of life, he never adheres to non-virtuous dharma. But, because he abandons non-virtuous dharma and comprehends the teachings that he has thus heard he is virtuous, mighty and calm ${ }^{25}$.

Then, on that occasion, the lord composed these verses:

Just like one who has entered into a house

That is dim and filled with darkness,

24. Ses rab kyi sian: prajñāloka

If prajñăloka. corresponds to jñänäloka, it would indicate the presence of the first nirvedhabhāgìya, viz., usmagata or 'heat'. Springing from the simultaneous pursuit of samatha and vipasyana, light of knowledge reveals to the srāvaka for the first time the meaning of the four noble truths in their sixteen aspects $(D P P$, p. 20). The evidence suggesting such identity of prajñ $\bar{a}$ - and jinannăloka is, however, rather thinly spread and not necessarily conclusive. Even if one accepts the identity of prajña and jñ̄ana as it is postulated by the Kosia (vi, p. 246), we have little material to go by. Most of the standard treatises do not contain any reference to prajinaloka. It is not found in the Mpps, Kosia, Abhidh-sam, Msl or Msg and appears unknown even to the $B b h$. Indeed, besides two highly ambiguous references in the $M v u$ (iii, p. 332.15), the only text in that I located the term prajñaloka is the $D b h$. Here, it appears on its own on the ninth stage, standing for the 'light of wisdom' that the bodhisattva continually discharges into samsāra to benefit beings (p. 71, R). Elsewhere in the $D b h$ (p. $62, \mathrm{~N}$ ), the bodhisattva applies himself on the seventh stage to all practices by means of the light of the attainment, wisdom and knowledge (samäpattiprajñajinänälokena). The most instructive reference yet to prajñāoka is found on the prabhäkaribhümi (Dbh, p. $32, \mathrm{H})$ where the bodhisattva - contemplating the nature of conditioned existence-realises that to perceive all things truly is impossible unless by unproduced wisdom whose light $(\bar{a} l o k a)$ is dependent for unfolding on 'skill ' in learning (śrutakauśalya). It appears, therefore, that for prajñaloka to become manifest, the bodhisattva is required to devote himself to learning (and teaching) - a proposition that tallies well with the context in which prajña $a k a$ is mentioned in the $B d p$.

25. dge ba thub pa źi ba: śubhamuniśäta. 
Does not see with his eyes even those shapes

That exist in that house,

In the same way, by some of those in whom

impurity has arisen,

Virtuous and non-virtuous dharma

Are not perceived unless they listen to the Bodhisattvapitaka.

Once they have listened to it, they distinguish dharma.

On listening to it, they relinquish sin.

Once they have listened to it, they renounce all harm.

On listening to it, they attain nirvāna. (602)

Since they desire to learn, their erudition increases.

By learning, their wisdom increases.

By wisdom, their intentions become pure.

Once they have attained pure intentions, they attain happiness.

Those who reach the goal have sharp minds.

At the time when they reach nirvana,

Being secure in the Doctrine and skilled in purity,

They attain great happiness.

As regards the Dharma-enunciation of the Bodhisattvapitaka;

Once they have listened to it, they abide in the essence of the Doctrine.

After they have realised it in the world,

They will cultivate enlightened conduct.

O Sāriputra, it is in this manner that the bodhisattva courses in the Perfection of Wisdom.

\subsection{Application}

Furthermore, O Săriputra, a bodhisattva who courses in the Perfection of Wisdom generates the notion of a virtuous friend towards a person who adheres to the Bodhisattvapitaka. Having done so he purifies him in this very Dharma-enunciation of the Bodhisattvapitaka. He purifies him completely. He generates in him a keen wish for this Bodhisattvapitaka. He causes him to strive and apply himself diligently. He causes him to retain it in his mind and 
to endeavour zealously to that $\mathrm{end}^{26}$. Since he has fully penetrated the four perfect efforts he attains freedom from obstruction concerning any dharma whatsoever. ${ }^{27}$

Then, at that time, the lord pronounced these verses:

A person who pronounces the Dharma

Is thought of as a virtuous friend.

Once he permanently fares in good conduct,

He applies himself to the Doctrine and studies it. (603)

He never reduces his determination.

His vigour is always unsurpassed.

His wisdom is irrevocably completely purified.

He constantly abides in pristine cognition.

He understands my Dharma.

Due to his faith, he lives in this world.

He understands it as the imperturbable Dharma

That was fully explained by the Buddha.

The wise ones are skilled in analysing words.

Being learned, they comprehend their meaning.

They practice perpetually wholesome conduct.

They renounce perpetually unwholesome conduct.

Their minds are always free of blemish.

They are truly free from despondency concerning any teaching.

Just as easily as a body, they attain swiftly

26. yaì dag par rab tu hjog par byed pa: samyakpradadhäti (cf. Edgerton, p. 370, col. 2).

27. According to the Abhidh-sam (R), p. 120, adopting the line of reasoning that prevails in the nikāya, the fruit of the cultivation (bhävanāphala) of the four correct efforts (samyakprahäna) consists chiefiy of the abandonment of dharma that are detriment (vipaksa) to skilful dharma and the growth of dharma that counteract (pratipaksa) unskilful dharma. Marking the stage of ușmagata, the practitioner succeeds in eliminating the coarse impediments and prepares for entry on the transcendental path (Kośa, vi, p. 287). In the $B d p$, by saying that the samyakprahāna contribute to the elimination of all hindrances (ävarana), no immediate connection to such a fruit of perfect effort is attested. Moreover, it is also left open whether the bodhisattva is freed from the kleśāvarana and jñeyāvarana-the standard division of the $B b h$ (pp. 3.13, 37.6) and $M s l$ (pp. 2.25-3.4)-or whether he is still subjected to one of them. The fact that the Bdp makes a point in saying that he is liberated from hindrances of all dharma, suggests perhaps the former. In this event, the attainment of the samyakprahäna would establish the bodhisattva on the transcendental path-a remarkable progress from the cultivation of the usmagata phase of the prayogamärga that tallies ill with other path-schemes (cf. Kośa, vi, p. 184; $M v s$ (N), pp. 53.13-54.19). The likelihood of imminent entry into the lokottara path is however strengthened by the content of the following section since this lays down the attainments of the darśanamärga that mark the first phase of the transcendental path. 
The mind of enlightenment, vigour and determination.

By listening to the Doctrine, their wisdom increases.

Because of realisation arising from pristine cognition, their recollection stays flawless.

Once they constantly persist in pristine cognition and recollection,

They fully understand virtuous and non-virtuous dharma.

On learning the highest teachings,

They attain the supreme powers of understanding, recollection and wisdom.

Having studied like myself for a long time,

They know the disposition of sentient beings.

Once they have listened to the Doctrine they acquire excellence.

On acquiring excellence, their pristine cognition having become pure,

They perceive the disposition of sentient beings.

For this reason they teach the Dharma in accordance with the disposition of sentient beings ${ }^{28}$.

O Sāriputra, it is in this manner that the bodhisattva courses in the Perfection of Wisdom. (604)

\subsection{Seeing}

\subsubsection{Right View}

Furthermore, O Sāriputra, the bodhisattva who courses in the Perfection of Wisdom, having thus purified his mind and cleansed his entry into the light of the Doctrine, studies in the following way. So far as the emergence of the noble, right view is concerned, it has two causes and two conditions. What are the two? These are other people's statements and correct inner reflection. ${ }^{29}$

He considers thus: "What are the statements of other people and what is correct inner reflection?" While he reflects correctly in this manner, he considers the following in his mind: "Those who cultivate yoga do not hear the Dharma-enunciation of the Bodhisattvapitaka.

28. The word sems can is not found in the Tibetan text. I assume that its presence is implied, since sems can is the object of the preceding verse to which this verse is contextually closely related.

29. The origin of this concept goes back to early Buddhism. It is found at several places in the nikāya and was adopted at a later stage by the Mahāyăna. "Statements of others (parataś ca ghoṣah) and inner correct reflection (adhyätman ca yoniśo manasakāra) are the causes of right view" (A I, p. 87; Kośa, ii, p. 245; iv, p. $100 ; M s g$, p. 65 ). 
After they have obtained gratification through meditation alone without hearing the noble Dharma and Vinaya, they fall into great conceit through the power of pride. They are not liberated from birth, old-age, disease, death, misery, lamentations, suffering, grief and agitation. They are not liberated from the mass of suffering."

Pondering these, the Tathägata proclaimed: "One who listens congenially to the statements of others becomes liberated from old-age-and-death."

The lord spoke again:

On hearing these teachings, bodhisattvas understand them.

On hearing them, they do not commit offences. (605)

On hearing them, they abandon harm.

On hearing them, they attain nirväna.

A listener who wishes to learn becomes exuberant,

Because it is by learning that wisdom increases.

His intentions are purified through wisdom.

When he reaches the goal, he gains happiness.

Those who reach the goal have sharp minds.

At that time, they reach nirvāna.

Those who are skilled in pure dharma are purified

And attain supreme happiness.

\subsubsection{Practice and Seeing}

O Sanriputra, it is in this manner that the bodhisattva should study carefully the Dharmaenunciation of the Bodhisattvapitaka as the noble Dharma and Vinaya. He should take hold of it and retain it. He should read it and fully absorb it. He should also explain it to others and propound it in great detail. O Śāriputra, those who do not hear this Dharma-enunciation of the Bodhisattvapitaka and do not engage in correct practice violate the noble path.

Pondering this, the Tathāgata proclaimed: "Correct inner reflection is liberation from oldage-and-death."

He studies in this way: "On contemplating the bodhisattva's correct practice, viz., what this practice is actually like, he learns that a bodhisattva, mahāsattva does not pursue any dharma; he learns that he does not pursue any practice. Correct practice is an expression for non-practice.

Furthermore, the bodhisattva who practises correctly does not send out sound or murmurs. (606) He does not construe a place from which sound emerges. But, investigating its starting- 
point and end-point, he thinks: "Sound emerges from and disappears into sound itself". He studies, thinking: "If one researches all sounds ever pronounced, by whom they were pronounced, for what purpose they were pronounced and in order to comprehend what they were pronounced, without apprehending sound as an aspect of the past, present or future, this is correct practice ${ }^{306}$.

How does the bodhisattva who practises correctly in this manner see correctly? He studies in this way. At the time when the bodhisattva sees that all dharma are suppressed by their nature, at that time he sees correctly. At the time when he sees that all dharma are appeased by their nature, at that time he sees correctly. At the time when he sees that all dharma are tranquil by their nature, at that time he sees correctly. At the time when he sees that all dharma are unattained ${ }^{31}$ by their nature, at that time he sees correctly. At the time when he sees that all dharma are unborn by their nature, at that time he sees correctly. (607) At the time when he sees that all dharma are unarisen by their nature, at that time he sees correctly. At the time when he sees that all dharma are absolutely unbecome by their nature, at that time he sees correctly. At the time when he sees that all dharma are in a state of nirvāna by their nature, at that time he sees correctly. Also investigating by whom they are seen, he realises that they are altogether unseen and unexamined. If he sees it in this way he is of correct vision.

Once again, he studies in this way. A bodhisattva who practises correctly has no doubt or uncertainty concerning any dharma whatsoever. He is free from obstruction concerning any dharma whatsoever. He who practises correctly will always be at the door to liberation concerning any dharma whatsoever. He who practises correctly does not exert himself to renounce any dharma whatsoever. He who practises correctly does not exert himself to contemplate any dharma whatsoever. He who sees rightly all dharma and looks at them in accordance with reality is of right view.

What is looking at all dharma in accordance with reality ${ }^{32}$ ? It is non-seeing. Non-seeing is an expression for unborn. Unborn is an expression for unarisen. What is unarisen? It is an expression for invisibility.

Pondering this, the Tathāgata proclaimed: "If one realises that all karmic formations are unborn, one penetrates the certainty of truth ${ }^{33}$. (608) Penetration of the certainty of truth is

30. The syntax of this paragraph is ambiguous and I am not certain that I have correctly interpreted the thought that stands behind it.

31. sñom pa ma źugs pa: asamāpanna (cf. Edgerton, p. 570, col. 1).

32. According to the $B b h$ (p. 294.14-20) to see dharma in accordance with reality involves four fields of cognition. These are (1) seeking out names (nāma), (2) seeking out things (vastu), (3) seeking out the manifestations of own-being (svabhävaprajñapti) and (4) seeking out manifestations of distinction (viśeșaprajñapti).

33. yan் dag pa ñid du nes pa: samyaktvaniyata

The term samyaktvaniyata has two related, though conceptually somewhat different, meanings. On the one hand, it represents one of three categories ( $r a \bar{s} s i)$ classifying the various people according to the degree of spiritual attainments. First, there is the category of beings that are 'permanently fixed in falsehood' 
right view."

He studies in this way, thinking: "Why is it called penetration of the certainty of truth? Because all dharma are completely uniform with the buddha-qualities; therefore it is penetration of the certainty of truth."

Hence, those who wish to penetrate the certainty of truth should listen carefully to this very Dharma-enunciation of the Bodhisattvapitaka. They should take hold of it and retain it. They should read it and fully absorb it. Indeed, they should apply themselves correctly to this very Dharma-enunciation of the Bodhisattvapitaka.

O Sāriputra, it is in this manner that the bodhisattva courses in the Perfection of Wisdom.

\subsubsection{Penetration and Speech}

Furthermore, O Sāriputra, when the bodhisattva who courses in the Perfection of Wisdom, having thus purified his mind and cleansed his entry into the light of the Doctrine, penetrates correctly he realises correct speech. What is correct penetration? What is correct speech?

A bodhisattva's correct penetration is as follows. He penetrates the basis of perfect mental quietude and the binary thinking of insight ${ }^{34}$. This is correct penetration. (609) Although he

(mithyattvaniyata). People belonging to this group are permanently unable to comprehend the teachings of the Buddha and excluded from the tathägatagotra. Having committed grave offences, they are always born in the lower destinies, unless they move up to the next rásit. The second type, 'persons settled permanently in truth' (samyaktvaniyata) will come in contact with the Doctrine and understand it whether it is preached by a buddha or not. Springing from a combination of cognition and past virtuous conduct, it is the domain of advanced practitioners (according to the Digha 'non-returners'; D III, p. 217). Having entered into the path, their progress to nirvanna is assured and rapid. Third, the Buddha identified a group of people that are undetermined (aniyata) in the sense that they will only understand the Doctrine after lenghty expositions $(M v u$, iii, pp. 318, 347). Numerically, this category is said to be largest of the three since it contains the majority of people. According to the Sukhāvativyunha (p. 44), the heaven of Amitäbha is inhabited only beings of the first category. References to these three types of räsi may be found in the $\mathrm{S}$ I, p. 196; II, p. 25; III, p. 225; Kathävatthu, p. 186; Nett, p. 96; Dhs, p. 186; Kośa, iii, p. 137; iv, pp. 177, 202; Lal, pp. 351.9, 400.2; Bbh, p. 404.23).

On the other hand, as far as the path is concerned, entry into the certainty of truth marks an important turning-point in the spiritual advance of the adept. Being the point of embarkation on the bhāvanamärga, samyaktvaniyata establishes the practitioner in the äryan-fold and guarantees liberation after no more than seven births (Abhidh-sam (R), p. 152). For the bodhisattva, the stages are as follows (Bbh, p. 290.11-23): First, he enters into the fold of bodhisattvas. Provided that he fulfils a number of spiritual conditions, he is certain to attain buddhahood in future. Second, there is the generation of the thought of enlightenment. At this point he cannot be turned away from buddhahood and is beyond conditions. The third stage is marked by the acquisition of the bodhisattva's special powers (vasita). Being the outcome of his dedication to the welfare of beings and his correct vision of reality, he has now attained the certainty of the prediction and traverses the final phase of the path (cf. Asta, p. 33.18 ff, p. $322.5 ;$; $i k s$, p. 270.4). For a sound discussion of a number of connotations associated with the term niyata/niyama in the various strands of Buddhist literature, see: $B b h$, Lexikalisches ..., pp. 28-31.

34. The association of binary thinking (vikalpa) and insight (vipaśyanā) indicates that we dealing here still with the preparatory phase of vipaśyanā. For, when brought to its highest point, vipaśyanā is no longer subject to recollection (smrti) and reflection (manasakära), but operates as non-discursive knowledge (nirvikalpajn̄ana) manifesting analytical investigation (of the reai) (bhütapratyavekșä) that is devoid of mental and verbal proliferation (prapañcopaśama). According to the Bhävanäkrama (MBT, iii, pp. 15-16), recollective attention and reflection figure only during the initial stages of vipaśyana development, while, at the pinnacle of its evolution, asmrti and amanasakära - springing from analytical investigation-become 
penetrates the body of solitude ${ }^{35}$, favourable dispositions, indestructibility, impermanence, the causes and conditions, dependent co-origination, the belief in a living being, a life-force and a person, the non-existence of the past, present and future, investigation into immutability, imperishability of causes and retribution, emptiness of causes as well as acquaintance ${ }^{36}$ with signlessness and wishlessness, he does not realise emptiness and wishlessness.

Although he acquires meditations and attainments, he is not reborn through the power of contemplation. Although he acquires the knowledge of the super-knowledge, he does not enter into the suppression of impurity. Although he penetrates the notion of no-birth, he does not enter into the state of perfection. Although he penetrates the notion of non-self of all sentient beings, he does not renounce great compassion. Although he penetrates the notion of the destruction of all beings, he [does not] realise the inconceivable state of existence. Although he longs for nirvāna, he does not to embark on realising the Dharma. Although he penetrates the purity of objects of sense pleasure and abides in equipoise, he does not dismiss the joy of the Doctrine. Although he abandons all discursive proliferation ${ }^{37},(610)$ he does not renounce skilful means ${ }^{38}$. O Sāriputra, this is correct penetration.

the hub of the yogin's vipasyana experience (MBT, iii, pp. 15-17). This division is also borne out by the vipasyana account in the Abhidh-sam (R), p. 126, where, at first, insight is characterised by examination (vicaya), discernment (pravicaya), judgment (prativitarka) and investigation (mimāmsä). Cf. Samdhis (ÉLa), p. 90.3-22.

35. The Srotabhümi $(109$, p. 286.5.2-3) distinguishes five objects from which the bodhisattva achieves freedom when abiding in the 'body of solitude'. These are bad conduct (dușcarita), desire (käma), utensils (parișkära), sexual intercourse (samsarga) and defilements (kleśa).

36. hdris pa: paricaya (cf. Monier-Williams, p. 593, col. 2).

37. rtog pa spros pa: prapañca

Prapañca is a difficult term of which Edgerton's translation as 'spreading out', 'activity', 'error of false statement' or 'false imagining' - although linguistically sound-is not quite adequate (Edgerton, p. 380, col. 2). He comes somewhat closer when, on the basis of Chinese translations, he proposes 'frivolous talk' as its meaning. According to Stcherbatsky, prapanca is the "expression of conceptually differentiated reality in words" (Nirvāna, 1975, p. 38*, pp. 137, 168, 216). The same line of thinking is taken up by Honda, when (citing Stcherbatsky as authority) he defines prapañca as "diffusion or diversification as function of craving, the expression of conceptual conceit and wrongly differentiated reality in words and view, or the expression of conceptually differentiated reality in words" $(1968$, p. 233).

Note also that, according to the Siddhi (p. 607), this type of abandonment does not take place before the bhävanämärga. Although not explicitly linked with a path scheme, indications to this effect are also found in the Bhävanākrama (MBT, iii, p. 17.10-11) and Ratnameghasütra (cited in $M B T$, iii, p. 7.16-18).

38. The role of upayakausalya is twofold. On the one hand, it brings about personal welfare for the bodhisattva and, on the other hand, it furthers the liberation of beings. Taking this division as foundation, the $B b h$ (pp. 261.6-272.8) distinguishes several aspects within each category. First, as regards the bodhisattva's own welfare-epitomising the acquisition of buddha-qualities-it involves compassionate attention to sentient beings, accurate knowledge of all conditioned dharma, thirst for knowledge of unsurpassed enlightenment, non-defiled passing through the round of rebirth and ardent vigour (p. 261.6-19). Second, skilful means in the service of others-accomplishing the ripening of beings-is dominated by the cultivation of the four means of conversion (samgrahavastu). Through their presence, manifesting six kinds of effect, the bodhisattva multiplies the otherwise negligible fruits that accrue from the small roots of virtue of beings; he occasions the acquisition of great roots of virtue with little effort; he averts obstacles that would prevent beings from embracing the Buddha's teachings; he causes beings who are yet undecided to embark on the path; he ripens those who have already embarked on the path and he liberates those who have already ripened ( $p$. 261.20-27).

The $M s l$ (p. 147.3-9) speaks of five different types of means. First, there is non-constructive knowledge (nirvikalpajñana) that occasions the acquisition of the buddha-qualities. Second, the means of conversion 
O Säriputra, what is correct speech? His speech is logical. Furthermore, O Säriputra, it is attentive. It consists of sound and is articulate. It is investigative, non-contradictory and amiable. It is imperturbable, inapprehensive and compliant. It is judicious and well-balanced. It is unborn and lacks all foundation of quarrel. It is dependable and devoid of acrimony. ${ }^{39}$

It is speech of suchness. It is speech of thusness, genuine thusness, unfailing thusness, truth and actuality. ${ }^{40}$ It is speech of the sameness of the three times. It cuts off the fetters and is independent of form, feeling, perception, karmic formations and consciousness.

It is independent of the element of the eye, form and visual consciousness. It is independent of the element of the ear, sound and auditory consciousness. It is independent of the element of the nose, scent and olfactory consciousness. It is independent of the element of the tongue, flavour and gustatory consciousness. (611) It is independent of the element of the body, touch and tactile consciousness. It is independent of the element of the mind, its objects and mental consciousness.

His speech relies on the spirit, foundation of being, pristine cognition and on sütras of precise meaning. ${ }^{41} \mathrm{O}$ Sāriputra, this is correct speech.

It is in this way that a bodhisattva who applies himself to correct penetration and sees correct speech does not realise seeing. He sees just like one who lacks vision and clear insight $^{42}$. When he sees in this way, he is of correct vision.

Again, O Säriputra, the bodhisattva who practises correctly will never become confused concerning any dharma whatsoever. A bodhisattva who practises correctly will always be at the door to liberation concerning any dharma whatsoever. He who practises correctly does not exert himself to renounce any dharma whatsoever. He who practises correctly does not

that assist sentient beings to mature. Third, the confession of faults, joy in the Buddha, invitation to the buddhas and transference (of merit) that speed up the attainment of enlightenment. Fourth, cultivation of meditations (samädhi) and formulae (dhäranī) that purify his conduct. Fifth, generation of unsupported (apratișthita) nirvāna that prevents the bodhisattva from interrupting his course in samsāra (ref. Lamotte).

39. Up to this point, the characterisation of correct speech shows many parallels to the discussion of the bodhisattva's 'unique knowledge of eloquence' (pratibhänapratisamvid) that is discussed at 2.5.4 in my translation of chapter eleven (folio 629.6-631.4). However, the cognitive element, associating correct speech with insight and thus turning the bodhisattva's speech into a mirror of his profound understanding of the nature of reality, is specific to correct speech and not touched upon in the discussion of the pratibhänapratisamvid.

40. The four preceding attributes are translations of the following technical terms ( $M v y 1709,1711,1716)$ that, but for the last, serve as synonyms for the absolute (paramārtha): (1) de bżin ñid: tathätä, (2) gzian ma yin pa de bźin ñid: ananyatathată, (3) ma log pa de bźin ñid: tathată, (4) ji lta ba bźin: yathāvat.

41. This sentence, qualifying the foundation of speech, contains a reference to the bodhisattva's four types of reliance, viz., reliance on the spirit (artha) as opposed to the letter (vyañjana); reliance on the foundation of being (dharmatā) as opposed to the person (pudgala); reliance on pristine cognition (jiñana) as opposed to discursive insight (vijñäna); and reliance on sütras of precise meaning (nïthärtha) as opposed to those of provisional meaning (neyartha). The exact nature and scope of the bodhisattva's four reliances is considered in great detail at 2.6 as one of the skills leading to 'discerning-wisdom'.

42. rnam par mthon pa: vidarśana (Mvy 1141)

On the conceptual closeness of vipaśyana and vidarsana, see: Abhidh-d, pp. 355-7 (n. 440); Kośa, vi, pp. 279-281. 
exert himself to contemplate any dharma whatsoever. He who sees rightly all dharma and looks at them in accordance with reality is of right view.

What is looking at all dharma in accordance with reality? It is non-seeing. What is non-seeing? It is an expression for unborn. What is unborn? It is an expression for invisibility. ${ }^{43}$ (612) Just as it was previously discussed at great length, in the same way it should be formulated. It is in this way that the bodhisattva courses in the Perfection of Wisdom.

Furthermore, O Sāriputra, the bodhisattva who courses in the Perfection of Wisdom studies in this way. "It is correct that all dharma are like the self." He realises that just as the self is non-self, so all dharma are non-self. He realises that just as the sentient being is non-self, so all dharma are non-self. When he looks at them in this way, he sees correctly.

Seeing correctly that the sphere of samsāra is endowed with the sphere of nirvāna; this is correct practice. ${ }^{44}$ Then, he realises that the own-being of all dharma is invariably that of impurity. Indeed, he does not take pride in either yoga or non-yoga. Through correct practice, he sees correctly. Correct practice is as manifold as all bases of sentient beings. Not seeing the bases of sentient beings and to be imperturbable concerning the basis of the Doctrine; this is correct practice of the bodhisattva. O Sarriputra, it is in this manner that the forms of learning, correct penetration, correct vision and those which are the result of accurate vision are called wisdom.

O Săriputra, it is in this manner that the bodhisattva courses in the Perfection of Wisdom. (613)

\subsection{Emancipation}

Furthermore, O Sāriputra, the bodhisattva who courses in the Perfection of Wisdom is by virtue of his wisdom not linked to any conditioned dharma ${ }^{45}$. That is to say, he is emancipated from $^{46}$ ignorance. Having become strengthened through emancipation from karmic formations, he is emancipated from old-age-and-death. Since he is emancipated from the belief in a self, he is emancipated from the sixty-two heretical views that are based on the belief in a self. ${ }^{47}$

43. This passage starting with "Again, O Śāriputra" up to "invisibility" is almost identical with a previous section on folio 607 starting with "Once again, he studies ..." (folio 607.3-608.2).

44. The thought of the identity of samsära and nirvāna is taken up in greater detail at 2.3, discussing the bodhisattva's 'skill' in elements (dhātu).

45. hdus byas la spyod pahi chos thams cad mi gnas pa

lit.: 'to be independent of all dharma that participate in the conditioned'.

46. Ihan cig tu mi gnas: sahänvasthāna.

47. The doctrinal foundations to most of the sixty-two heretical views (drstitigata) are either the views of existence or non-existence (bhaväbhavadrști $)$ or the views of eternity or annihilation (śáśvatocchedadrsți). Representing the beliefs in extremes (antagrāhadrsți) that run counter to the 'middle path' of the Buddhists, they are rejected in equal measure by early Buddhists and later Mahāyāna writers alike. For references in the nikāya, see: D I, pp. 52-59; S II, p. 17; S III, p. 135; fine expositions of the Mahāyāna position are 
$\mathrm{He}$ is emancipated from lofty and wretched thoughts. He is emancipated from the eight worldly conditions. $\mathrm{He}$ is emancipated from the twenty secondary defilements ${ }^{48}$ including self-conceit, grave conceit and perverted conceit. ${ }^{49} \mathrm{He}$ is emancipated from all defilements, including minor, mediocre and major ones. Having become ensnared by the impenetrable, obscuring, dark mist of delusion, he is emancipated from all lowly and wicked dharma. He is emancipated from the activity of all evil, including contentious and defiled activity, activity of the aggregates, activity of the lord of death and activity of the Evil One. ${ }^{50}$

$\mathrm{He}$ is emancipated from all heretical views concerning the self, including the belief in a

found at Kp, pp. 86-108; Asta, p. 66; Madh. vrtti, pp. 272.14, 445.3. Additional material has been collected together by May (1959, p. 213, n. 720) and Lamotte (1976, p. 57, n. 36) from whom these references stem.

48. According to the Siddhi (p. 362), the twenty secondary defilements include (1) anger (krodha), (2) spitefulness (upanäha), (3) hypocrisy (mrakșa), (4) malice (pradāsa), (5) jealousy (ïrsyātha), (6) avarice (mātsarya), (7) deception (māya ), (8) concealment (śäthya), (9) complacency (mada), (10) violence (vihimsa), (11) lack of self-esteem (ährikya), (12) indecency (anapatrāpya), (13) inertness (styāna), (14) agitation (auddhatya), (15) lack of confidence (äśraddhya), (16) idleness (kauśídya), (17) indolence (pramāda), (18) confused recollection (mușitasmrtitä), (19) inattentiveness (asamprajanya) and (20) distraction (viksepa).

Other lists that show comparable, but not identical, contents are found in the Kośa (v, pp. 88, 89-109), comprising twenty-one secondary defilements and in the Dhsgr (§69), listing twenty-four items.

49. ña rgyal: māna; che bahi ña rgyal: mahämäna; log bahi ña rgyal: mithyāmäna

According to the Kosia (v, pp. 26-27), conceit falls into seven categories. Of these, only the first (viz., mäna) and last (viz., mithyämäna) are cited in the Bdp. Māna refers to a general arrogance of mind leading to feelings of superiority. Mithyamazana, in contrast, is more specific and causes that one attributes to oneself spiritual qualities that one does not possess (Kosia, v, p. 27). I have not found a text where mahämäna figures among the various types of conceit as an independent type of conceit. As māna and mithyämäna constitute respectively the first and last limb in the list of seven, it likely that the $B d p$ made this selection in order to indicate the presence of all seven types without actually listing all of them ( $M v y$ 1945-52).

50. This, of course, is a reference to the four types of māra. Personifying the forces of evil, Buddhist texts distinguish (1) the 'evil of defilement' (klesamära), (2) the 'evil of aggregate' (skandhamāra), (3) the 'evil of death' (mrtyumāra) and (4) the 'Evil One' (devaputramära). This is the most common division (Mvu, iii, pp. 218.7, 273.2; Lal, p. 224.18-19; Madh, vptti, p. 49.10; Dhsgr § 80; Mppś, i, pp. 340-46), although we read elsewhere (Udāna-a, p. 216.11) also of other types of mära, viz., the 'evil of formation' (abhisamskāra-māra) and the 'evil of misdeed' (äpattimära). Already in the nikāya, the internal armies of Māra are identified with personal faults, such as desire, sadness, hunger, thirst, greed, etc., (Sn, vss. 436-449) and were named accordingly as Tanhă, Arati, Rāga, etc. (S I, p. 124; III, p. 286). On the moment of their destruction during the last existence of bodhisattvas, the $A k n-t i \bar{k} k \bar{a}$ says:

"The four kinds of mära are the devaputramāra, kleśamāra, skandhamāra and the mrtyumāra.

Among them, the devaputramära is vanquished by the meditation of benevolence

(maitrisamädhi) underneath the tree of enlightenment. The klesamara is vanquished at the

time of comprehension of enlightenment. The skandhamära is vanquished by the reversal of

the support of the storehouse consciousness (älayavijñanāśrayaparāurtti) at the time of com-

prehension of enlightenment. Shortening the formation of long life (âauh-samskära) in Vaisāli

three month prior to the parinirvāna, the mrtyumära is vanquished by obtaining power over life."

For further details on interpretations of māra and the contexts in which they appear, see: E. Windisch, Mära and Buddha, Leipzig, 1895; A. Wayman, 'Studies in Yama and Mära', IIJ, 1959, pp. 112-32; Mppś, ii, pp. 880-884, 906-908; Malalasekera, Proper Names, ii, pp. 611-620. A list of disguises of Māra is given in the Ratnaketudhärani , Dutt, vi, 1941-53, pp. 77.7-79.2. For further references to the notion of mâra in Buddhist literature, see: Lamotte, 1976, pp. 99-101. In the same volume (pp. 169-70), Lamotte provides an excellent list of material that discusses the term äsrayaparävrtti (e.g., Bbh, pp. 367-70; see also: $M s g$, pp. $\left.16^{*}, 48^{*}\right)$. On the circumstances accompanying the Buddha's abandonment of the long-life samskāra, see: Waldschmidt, 1950, ii, p. 218. 
self, a living being, a life-force, a feeder, a person, a human being and an individual. (614) $\mathrm{He}$ is emancipated from all continuity brought about by the traces, including the obstruction of action, impurity, dharma, heretical views, retribution and nescience. He is emancipated from reflection, binary thinking, marks, mental constructions [brought about through] seeing, hearing and recollection, discursive knowledge and all adventitious bonds ${ }^{51}$. He is emancipated from [the dichotomy of] avarice and generosity, morality and immorality, patience and malice, vigour and indolence, meditation and disquietude, wisdom and folly, furtherance and impediments of the perfections, knowledge and nescience.

He is emancipated from antitheses of all dharma, including truth, falsehood and perjury, virtue and depravity, reproach and approval, samsāra and nirvāna. He is emancipated from all multiplicity, including multiplicity of buddha-fields, buddhas, sentient beings and dharma. $\mathrm{He}$ is emancipated from conditioned reflection ${ }^{52}$ of all sentient beings, including nescience, knowledge, discursive insight, conventional truth and absolute truth. (615) He is emancipated from the bases of all reflection, thought and consciousness; including perseverance [to] formlessness, signlessness, causelessness and unconditioned wisdom. He is emancipated from these and other incalculable, conditioned dharma. It is in this way that the wisdom of a bodhisattva who courses in the Perfection of Wisdom is emancipated from all conditioned dharma.

O Săriputra, it is in this manner that the bodhisattva courses in the Perfection of Wisdom.

\section{SECTION II}

\section{Skill}

Furthermore, O Sāriputra, a bodhisattva who adheres to the Bodhisattvapitaka and courses in the Perfection of Wisdom is skilled in discerning the Perfection of Wisdom. He attains skill in all dharma.

What is discerning wisdom? It is tenfold, viz., skill in aggregates, skill in sensefields, skill in elements, skill in truth, skill in unique knowledge, skill in reliance, skill in discursive insight and direct knowledge, skill in the factors of enlightenment, skill in the path and skill in dependent co-origination..$^{53}(616)$ Investigation by means of these ten kinds of skill is discerning wisdom.

51. sgros h. hogs pa: äropita (cf. Monier-Williams, p. 151, col. 1).

52. mishan ma yid la byed pa: nimittamanasakāra (cf. Edgerton, p. 207, col. 2).

53. Skt.: skandha-, āyatana-, dhātu-, satya-, pratisamvid-, pratisarana-, vijīãna-, jñ̄āna-, bodhyañgāni-, mārgaand pratityasamutpädakauśalya. According to Vasubandhu, 'skill'-referring to the eight kinds of 'skill' in the $A k n$ - constitutes the sphere of wisdom ( $A k n-t i \bar{k} \bar{a}$, p. 193.5.7). 
Translation of Chapter Eleven

\section{$2.1 \quad$ Skill in Aggregates}

What then is skill in aggregates? ${ }^{54} \mathrm{He}$ expounds the aggregates by way of allegories. That is to say, he shows that they are like froth, a mirage, a water bubble, a plantain tree, an illusion, a dream, an echo, an illusory appearance and a reflected image.

Matter is like froth and froth too is without a self, a living being, a life-force, a person, a man, a human being or an individual. The own-being ${ }^{55}$ of froth is also the own-being of matter. Skill concerning this is skill in aggregates. ${ }^{56}$

Feeling is like a water bubble and a water bubble too is without a self, a living being, a life-force, a person, man, a human being or an individual. The own-being of a water bubble is also the own-being of feeling. Skill concerning this is skill in aggregates. ${ }^{57}$

Perception is like a mirage and a mirage too is without a self, a sentient being ... or an individual. The own-being of a mirage is also the own-being of perception. Skill concerning this is skill in aggregates. ${ }^{58}(617)$

54. Vasubandhu, in his commentary on the $A k n$, elucidates the meaning of 'skill' in aggregates on pages 193.5.8-195.5.1. The corresponding passage in the $A k n$ is found on page 52.2.8-4.6. According to the $A k n$, 'skill' in aggregates means that the bodhisattva is capable of explaining the nature and role of the aggregates by way of comparisons. This is also the only instance where both $B d p$ and $A k n$ cite an equally phrased, direct answer to the question that is posed at the beginning of each kind of 'skill'. After that, only the $A k n$ provides brief direct answers to the initial questions, whereas the $B d p$ does not re-refer to the question (for details, see: $A k n-t i k \bar{a}$, pp. 194.1.1-2.6, 194.2.6-195.3.6, 195.3.6-5.1).

55. According to the $M v y$, the Tibetan term ran bzin has two principal meanings, viz., (1) svabhāva meaning 'own-being' (Mvy 3390, 4458, 7498) and prakrti meaning chiefly 'nature' (Monier-Williams, p. 1276, col. $1 ;$ p. 654, col. 1 respectively). Both meanings do overlap of course and it is difficult to decide with certainty which of the two is intended in this passage. Although prakrti is listed as the first, and thus principal term, I believe that it is in this context more appropriate to translate the term ran bzin as 'own-being' since reference is taken to the very nature, character or indeed 'own-being' of the dharma in question. The term 'nature' has a broader, slightly more encompassing and hence rather vague connotation that, I think, is here out of place.

56. The $A k n-t i k \bar{a}$ comments (p. 194.3.1-3; cf. $A k n$, p. 52.2.8-3.1):

"That is to say, in the great ocean some people see froth possessing matter and colour like crystals. Believing that it possesses substance and own-being, they grasp for it with their hands, but it flies away and disintegrates, whereupon they think: 'Alas, this is only froth, this is worthless, vain and lacks own-being'."

57. In the words of the $A k n-t i k \bar{a}$ (p. 194.3.8-4.4; cf. $A k n$, p. 52.3.1-2):

"When rains falls into water, some people perceive the water bubbles as if they constitute various types of crystals or gems. Thinking that they possess substance and are suitable [to be worn as] adornments, [people] grasp for them with both hands in order to arrange them but they disintegrate. Even those that they did not reach for burst as soon as they arise. Realising that they are devoid of substance, they learn and exclaim: 'Alas, these are water bubbles, without a self and own-being. They are worthless and vain.' It is in this way that also the aggregate of feeling [whether pleasant, unpleasant, etc.] - lacking a self or own-being-is worthless and vain just like the water bubbles. If grasped with the eyes and hands of wisdom, examining them whether they are existent or non-existent, one realises that all of them bear the mark of suffering and perish by nature as soon as they have arisen."

58. To quote again from the $A k n-t i t k a ̈$ (p. 194.4.4-8; cf. $A k n$, p. 53.3.2-3):

"Perception is to grasp the distinguishing marks of objects. Objects are matter, sound, etc. Distinguishing marks are the [colours of] white, red, etc. To grasp is to decide 'this is white-not red'. The perception aggregate is like a mirage. Why? It lacks a self and is insignificant. That is to say, thirsty people who are tormented by the sun during the hot season see mirages such as fountains of water with their eyes. Believing them to be of water, they hurry to drink it. On discovering that it is not water, they exclaim: 'Alas, this is a mirage. It lacks a self and own-being. It is worthless and vain.' Likewise, with the eye of wisdom, 
Karmic formations are like a plantain tree and a plantain tree too is without a self, a living being, a life-force ... or an individual. The own-being of a plantain tree is also the own-being of karmic formations. Skill concerning this is skill in aggregates. ${ }^{59}$

Consciousness is like an illusion and an illusion too is without a self, a living being, a life-force, a person, a man, a human being, an individual or a being that arises and feels. The own-being of an illusion is also the own-being of consciousness. Skill concerning this is skill in aggregates. ${ }^{60}$

Furthermore, the aggregates are of this world and the world, too, bears the characteristic of destructibility. ${ }^{61}$ The own-being of the worlds is also the own-being of aggregates. But what is the own-being of the world? Its own-being is that of impermanence and suffering. ${ }^{62}$ This, too, is the own-being of aggregates. Skill concerning this is skill in aggregates.

It is in this manner that the bodhisattva who is skilled in aggregates courses in the Perfection of Wisdom.

bodhisattvas realise that perception is full of thought construction concerned with misunderstandings."

59. The $A k n-t i \bar{i} k \bar{a}$ explains (p. 194.5.1-6; cf. $A k n$, p. 52.3.3-4):

"Karmic formation create various kinds of wholesome, unwholesome and neutral [actions]. The sum total of karmic formations is great. Why is the aggregate of karmic formation is like a plantain tree? It lacks a core. People who wish for a hard tree and cut down a plantain tree, stripping it off its bark from top to bottom, see that there is no core when they examine it in this regard and exclaim: 'Alas, this has the core of a plantain tree; it is empty, without substance or own-being.' In this way, when contemplating on the presence of a core or essence in the aggregate of diverse karmic formations [concerned with wholesome, unwholesome and neutral actions], one realises-when looking at it with the eye of wisdom - that it is thought-only (cittamätrata), unborn, beyond being and non-being. Having thus contemplated with effort on the duality of existence and non-existence, one sees that it is just like a plantain tree beyond one or many, self or others, without a core, essence or a self."

60. In the words of the $A k n-t i k \bar{a}$ (pp. 194.5.7-195.1.4; cf. $A k n$, p. 52.3.4-5):

"Consciousness is perception of objects such as form, etc. It consists of eight types, viz., consciousness pertaining to the eye, etc. The consciousness aggregate is like an illusion. Why? It is insubstantial. A magician conjures up with his art of magic trickery various illusory forms of gods, men, demons and animals. But, even though they are perceived with the eye, if one examines them with the expectation that they might possess an own-being and a lasting existence, on realising that they lack own-being and perish all the sudden, one exclaims: 'Alas, this is only an illusion; it is empty and devoid of own-being.' In the same way, if one examines with the eye of wisdom the own and general own-being in the consciousness aggregate generated by the different traces of action, expecting it to possess own-being and lasting existence, one realises that it perishes each moment like an illusion and is empty of own-being."

61. hjig rten yan hjig pa: loko 'pi lugla (cf. Mvy 3061 which gives hjig pas na hjig rten for luyjata iti loka).

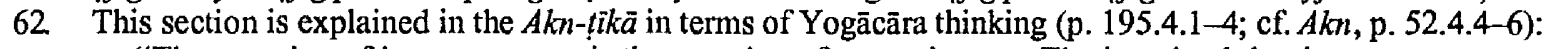

"The meaning of impermanence is the meaning of non-existence. The imagined that is empty of own-being as it is universally non-existent-bearing the character of being imagined like the horn of a hare-is impermanent. The sütra says that it is undergoing suffering by nature. The meaning of imagining the non-existent is the meaning of undergoing suffering by nature. Again, it bears the characteristic of dependence (paratantralaksana). To the degree to which one imagines object and subject through paratantra [vision], to that degree the own-being of suffering comes into being and becomes the cause of various types of suffering." 
Translation of Chapter Eleven

\section{$2.2 \quad$ Skill in Elements}

Next, what is skill in elements? ${ }^{63}$ That is to say, although it is true that the sphere of the Dharma $^{64}$ is the element of earth, it has not the characteristic of compactness. Although it is true that the sphere of the Dharma is the element of water, it has not the characteristic of moisture. (618) Although it is true that the sphere of the Dharma is the element of fire, it has not the characteristic of heat. Although it is true that the sphere of the Dharma is the element

63. Vasubandhu (pp. 193.5.1-196.4.5) explains that 'skill' in elements signifies 'skill' in pristine cognition that penetrates the elements of dharma - that is, the qualities and practices of a bodhisattva (p. 195.5.4) -with the element ( $d h \bar{a} t u)$ representing the cause and condition leading to the attainment of the individual buddha-qualities-- that is the dharma themselves (p. 195.5.5). Note also the usage of the term dhatu in the $A k n$ (pp. 52.4.6-53.2.3) that distinguishes carefully between khams and dbyins, a distinction that is not upheld in the Bdp. Theoretically, it is possible that chos kyi khams refers here to the twelfth dhatu or sixth kind of external object (visaya), viz., the class of non-sensuous objects. Contextual considerations render this explanation implausible, since they point to the 'sphere of the Doctrine' or Dharmadhatu-of which chos kyi khams is a highly unusual translation - and not to the series of elements (dhätu) that are represented in the composition of an individual stream of life (santäna). What is more, in the $A k n$ 's parallel reading the term chos kyi khams (except for one unambiguous reference to non-sensuous objects) is invariably replaced by the 'correct' rendering of chos kyi dbyins. This modification establishes beyond any doubt that, in the $A k n$, it is the Dharmadhatu and not the dharmadhätu that is referred to. All other occurrences of the term khams, whether in conjunction with nam mkhahi, hdod pahi or otherwise are preserved as they occur in the $B d p$. Thus, the $A k n$ puts forward what is in effect a (re)interpretation of the $B d p$ 's reading. As we have seen, this is a general feature of their relationship and does not pose much of a problem.

What is puzzles me is the mechanism by which this particular incongruity arose in the Tibetan, since their chronological order could not have been of any concern to the translators. They found presumably in both texts-assuming that they were translated from the Sanskrit which seems certain - the term dharmadhatu. And yet, they opted for a different term to translate the same word in the same sentence, passage and context, singling out chos kyi khams for the Bdp and chos kyi dbyins in the Akn. In the Akn, their choice might have been influenced by the explanation given in the $A k n-t i k \bar{a}$ (pp. 195.5.1-7), since it establishes quite clearly the Dharmadhätu and not non-sensuous objects as point of reference. But again, we cannot be certain that the commentary was at hand when the translators set about their task. In search for an explanation, I thought to find the key to this discrepancy in the terminologic revision (sgra gsar bcad) that took place in Tibet at the beginning of the ninth century. That is to say, I expected to learn that the $B d p$ had been translated before the Great Revision and was then left unrevised. This assumption proved ill-founded, since its translation was carried out by the very persons who played a major role in the Great Revision, namely Surendrabodhi, Sillendrabodhi and Dharmatāsîla (Simonsson, 1957, p. 241). Even if they translated the $B d p$ before receiving the royal command to undertake the general revision, they surely would have redrafted it afterwards. Moreover, already the first unrevised translation of the $A k n$ contains the terms chos kyi dbyins. I then discovered that Dharmatäsila had not only part in the translation of the $B d p$, but also revised the early translation the of $A k n$. It is probably safe to assume that he would have employed consistent terminology had he held the word dharmadhatu to refer to the same concept in both texts. Alternatively, he might have contributed to the translation of the $A k n$ after he had worked at the $B d p$ and neglected to go back to it for revision. In any event, it is quite unthinkable that he should have failed to notice the close parallelism that exists between the $A k n$ and $B d p$ while working at them. Today, it is impossible to say whether Dharmatāsila translated the $B d p$ before or after revising the old $A k n$ version, but given that an unrevised translation of the $A k n$ was already extant, one would expect him to turn first to the $B d p$. On the other hand, being a thorough and accomplished scholar, he might as well have given priority to correcting the old faulty translations before looking at new texts. To whatever view one chooses to subscribe, there seems to be no hard and fast evidence to support either of them. As far as the translation of the passage is concerned, it is probably safe to follow the reading of the $A k n$. First, it fits the context very well and it is confirmed by $A k n-t i k \bar{a}$. And yet, it fails to address the question that lies at the heart of the problem, that is, why such incongruence arose in the first place. Furthermore, it raises the methodological problem of basing the translation of a passage on a reading that is not found in the text itself, however close its affiliation to this text may be. Finally, it does not account for the highly unusual practice to employ the term chos kyi khams to render Dharmadhätu ('sphere of the Doctrine') into Tibetan.

64. For alternative meanings and translations of the term dharmadhätu, see: Ruegg (1962, p. 327) and Kosia (i, pp. 54-65, 100). 
of wind, it has not the characteristic of agitation.

Although it is true that the sphere of the Dharma is the element of visual consciousness, it has not the characteristic of seeing. Although it is true that the sphere of the Dharma is the element of auditory consciousness, it has not the characteristic of distinguishing sound. Although it is true that the sphere of the Dharma is the element of olfactory consciousness, it has not the characteristic of perceiving scent. Although it is true that the sphere of the Dharma is the element of gustatory consciousness, it has not the characteristic of savouring flavour. Although it is true that the sphere of the Dharma is the element of tactile consciousness, it has not the characteristic of contact. Although it is true that the sphere of the Dharma is the element of mental consciousness, it has not the characteristic of cognition.

The sphere of the self and the sphere of the Dharma are identical. The spheres of desire, form and non-form are identical. The spheres of nirvāna and samsāra are identical. ${ }^{65}$ Thus, the sphere of all dharma and the sphere of space are identical. Since they are identical with emptiness, they are uniform. Since they are identical with non-becoming, they are uniform. Because of penetrating the spheres of the conditioned and unconditioned, his teaching about them is infinite. ${ }^{66}(619)$ By means of that penetration, he investigates; this is skill in elements.

It is in this manner that the bodhisattva, mahassattva who is skilled in elements courses in the Perfection of Wisdom.

\subsection{Skill in Sensefields}

Next, what is the bodhisattva's skill in sensefields ${ }^{67}$ Concerning this, the bodhisattva perceives the eye in accordance with reality, thinking: "It is empty in itself and by itself, such is its own-being." This is the bodhisattva's skill in sensefields. Corresponding to the former, the bodhisattva perceives also the ear, nose, tongue, body and mind in accordance with reality, thinking: "They are empty in themselves and by themselves, such is their own-being." 68 Not encouraging those who gather various objects and items in their sensefields for the sake of accumulating virtue, he does not discriminate virtuous and non-virtuous dharma ${ }^{69}$. This is the bodhisattva's skill in sensefields.

Although he thus looks unperturbed at the eye and form, thinking: "This is the visual sensefield and that is the tactile sensefield", he does not realise [absolute] imperturbability.

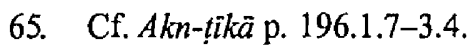

66. $A k n-t i \grave{k} \bar{a}$ p. $196.3 .4-4.3$.

67. $A k n-t i k \bar{a}$, pp. 196.4.5-197.5.6

In the $A \mathrm{kn}$, the corresponding passage is found on page 53.2.3-4.4. Here, the passage on sensefields is slightly longer than that of the $B d p$, interpolating an introductory section modelled on that of the preceding topic which runs as follows: "Even though the sensefield of the Dharma ..., it has not the characteristic of ...."

68. In my translation, I disregarded the Tibetan clause yid kyi since reference is clearly taken to all five remaining sense organs-not only to the mind ( $R$, folio 619.4).

69. $A k n-t i k \bar{a}$, p. 197.1.3-2.1 (lit.: ' ... he does not embark on two notions (viz., dual thinking) concerning ...'). 
This is the bodhisattva's skill in sensefields. Corresponding to the former, although he thus looks unperturbed at the ear and sound, nose and scent, tongue and taste, body and touch as well as at the mind and mental objects, he does not realise [absolute] imperturbability. (620) This is the bodhisattva's skill in sensefields.

The sensefields consist also of noble and ignoble sensefields. Now, while a noble sensefield causes appreciation of the path, an ignoble sensefield causes withdrawal from the path. ${ }^{70}$ This is to say, while the bodhisattva who persists in the path generates great compassion in support of sentient beings who have relinquished their zeal on the path, he himself never renounces the sensefields of the path. This is the bodhisattva's skill in sensefields.

It is in this manner that the bodhisattva who is skilled in sensefields courses in the Perfection of Wisdom.

\subsection{Skill in Truth}

What then is the bodhisattva's skill in truth ${ }^{71}$ The bodhisattva's skill in penetrating truth is fourfold. That is to say, it is knowledge of suffering, knowledge of its origin, knowledge of its cessation and knowledge of the path.

What is knowledge of suffering? Knowledge that the aggregates are unborn is knowledge of suffering. What is knowledge of its origin? Knowledge that thirst has been vanquished is knowledge of its origin. What is knowledge of its cessation? Knowledge that suffering is free from origination and destruction is knowledge of its cessation. What is knowledge of the path? Not drawing mistaken inferences ${ }^{72}$ concerning uniform dharma is knowledge of the path. (621) Even when he thus understands these four truths by means of wisdom, the bodhisattva does not realise them in order to develop sentient beings. This is skill in truth. ${ }^{73}$

70. Quoting a passage from the $M s l$ (p. 124.3-15), Vasubandhu cites ten kinds of ignoble paths. These are the paths of (1) beings that are set alight with desire for bliss and sense-pleasure, (2) beings that have fallen under the power of Māra, (3) beings that are afflicted by suffering, (4) beings that are enveloped by obstruction, (5) beings that follow a path leading to the evil destinies, (6) beings that are tied by great fetters, (7) beings that long for indulgence in food, (8) beings that lose their way, (9) beings that follow a wrong path and $(10)$ beings that are of little strength. On the basis of his infinite compassion, the bodhisattva's does not forsake these wretched sentient beings but extends his sympathy to them ( $A k n-t \bar{i} k \bar{a}$, p. 197.4.1-5.5).

71. In the $A k n$, the corresponding passage is found on pages 53.4.4-54.2.8. Judging by the great attention Vasubandhu devotes to this section in the $A k n-t i k j a$, , he must have considered 'skill' in truth as central to the training in prajina $\bar{a}$ (pp. 197.5.6-203.4.8).

72. sgro mi h̆dogs pa: adhyäropa (cf. Monier-Williams, p. 23, col. 2).

73. Akn-tikiä, pp. 198.5.6-199.1.3:

"To comprehend the own characteristic is wisdom, but to understand the general characteristic is pristine cognition. Here, however, the quoted wisdom is just wisdom and pristine cognition is to understand the notion of emptiness just as it is explained above; this is included (parigrhita) in wisdom. For the sake of sentient beings [the bodhisattva] does not realise [wisdom and pristine cognition] but, according to the sütra, ripens sentient beings. Although the bodhisattva understands the four noble truths, he does not realise nirvanna, but being totally at ease like the srāvaka he ripens sentient beings with great compassion and numerous means for their benefit. This then is included in means. Knowledge of the four truths as expounded above is included in wisdom and means; this is the bodhisattva's 'skill' in truth." 
Furthermore, skill in truth is threefold. These are the conventional truth, absolute truth and the truth of characteristic. Now, conventional truth is just worldly convention and is expressed by letters, language and symbols. This is the conventional truth. What then is the absolute truth? The mind itself does not wander, how much less letters? This is the absolute truth. What then is the truth of characteristic? That is to say, all characteristics are of one characteristic and one characteristic is also a non-characteristic. The bodhisattva does not tire of explaining the conventional truth. He does not lapse into realising absolute truth. He discerns the truth of the characteristic by way of the non-characteristic. This is the bodhisattva's skill in truth.

Furthermore, truth is one, not two. This is the truth of cessation. He does not draw mistaken inferences concerning the one truth, but establishes in truth sentient beings who have lapsed into mistaken inferences. This is the bodhisattva's skill in truth.

Furthermore, the five aggregates are suffering. (622) That the five aggregates bear the characteristic of suffering, this is the noble truth of suffering. Knowledge that the characteristic of suffering bears the characteristic of emptiness, this is the noble truth of suffering. That heretical views arising from thirst are the cause for the proclivity to the five aggregates, this is the noble truth of the origin of suffering. ${ }^{74}$ That heretical views are also the cause of thirst-without drawing mistaken inferences concerning them, holding on to them or asserting them - this is the noble truth of the origin of suffering. That due to complete exhaustion the five aggregates are in a state of cessation-that they have not arisen in the past, do not exist in the present and will not perish in the future-this is the noble truth of cessation. To attain, following persistence in the path, besides knowledge of suffering, its origin and cessation also consecutive knowledge ${ }^{75}$ is the noble truth of the path that leads to the cessation of suffering. Reflection on knowledge of truth causes erroneously projecting sentient beings to discern it; this is skill in truth of bodhisattvas.

Furthermore, all feelings are suffering. Knowledge of feeling through discernment and understanding; this is the noble truth of suffering. The cause by which feeling is known as it is when it arises, the cause of its perception, this is the noble truth of suffering. Renouncing feeling and prompting [others] to experience non-feeling, investigating its cessation, but not realising the cessation of feeling, this is the noble truth of the bodhisattva's cessation of suffering. (623) The feeling by which one is attracted to the path is like a ferry; there is

74. The structure of this sentence is unclear. I follow in my translation the interpretation given in the $A k n-t i k \bar{a}$ (p. 201.3.5-7).

75. rjes las rtogs pa: anvayajñäna

According to the Kos'a, 'consecutive knowledge' is a type of understanding that-being a non-propositional form of knowledge - arises in the practitioner after he has experienced and accepted the validity of the four noble truths in the three spheres of existence (Kośa, vi, p. 184). As a consequent knowledge bearing on the subject (grähaka), it is one of the four factors that are brought in relation with each of the four truths (äryasatya). Arising in response to the gradual comprehension of each of these four truths, it represents three of the fifteen events making up the darsanamärga, while the appearance of consecutive knowledge in response to the experience of the last truth—-the path-belongs already to the bhävanämärga. 
neither a requirement for feeling nor is feeling a requirement of the path, this is the noble truth of the path that leads to the bodhisattva's cessation of suffering. After he has understood them in this way, realising that the four truths are uniform, his vision is never fully purified; this is the bodhisattva's skill in truth.

Furthermore, birth is suffering. Knowledge that arises from careful investigation in no-birth, this is knowledge of suffering. Birth arises through the condition of becoming. Knowledge that things existing perish is knowledge of its origin of suffering. Knowledge that everything born is unborn and that-there being absolutely no cessation in the unborn-it is unceasing, this is knowledge of its cessation and exhaustion. This kind of considering, evaluating, pursuing, discriminating and penetrating knowledge is knowledge of the path. ${ }^{76}$ Although he is placed in this knowledge of truth, [the bodhisattva] does not persist in this knowledge of truth; this is the bodhisattva's skill in truth.

It is in this manner that the bodhisattva who is skilled in truth courses in the Perfection of Wisdom.

\subsection{Skill in Unique Knowledge}

Next, what is the bodhisattva's skill in unique knowledge $?^{77}$ The unique knowledge of the bodhisattva is fourfold. (624) What are the four? These are the unique knowledge of the own-being of things, the unique knowledge of designations, the unique knowledge of languages and the unique knowledge of eloquence.

\subsubsection{Skill in the Unique Knowledge of the Own-being of Things}

What is the unique knowledge of the own-being of things? ${ }^{78}$ It is knowledge that the

76. The $A k n-t i t k \bar{a}$ (p. 203.2.3-4.3), quoting the $M s l$ (p. 58.8-13), distinguishes eleven types of penetration. These are (1) sudden, adventitious penetration (agantukatvaprativedhata), (2) penetration into the aspects of reckoning (samkhyänanimittaprativedhata), (3) penetration into the inconceivability of objects (arthānupalambhaprativedhata), (4) penetration into the inconceivability of reality (upalambhänupalambhaprativedhata), (5) penetration into the sphere of the Dharma (dharmadhattuprativedhata), (6) penetration into the insubstantiality of a person (pudgalanairätmyaprativedhata), (7) penetration into the insubstantiality of dharma (dharmnairātmyaprativedhata), (8) penetration into inferior intent (hīnassayaprativedhata), (9) penetration into the most exalted intent (udäramahätmyäsayaprativedhata), $(10)$ penetration into differentiation according to the accomplished Dharma (yathädhigamadharmavyavasthänaprativedhata); and (11) penetration into dharma arrangement (vyavasthapitadharmaprativedhata).

77. Vasubandhu's annotation of the corresponding passage in the $A k n$ is found on pp. 240.2.7-244.5.4. In the $A k n$ (and thus also in the $A k n-t i k \bar{a}$ ) the bodhisattva's unique knowledge (pratisamvid) is not being dealt with in the section on 'skill', but figures as an independent aksaya.

78. The term artha carries several meanings, with 'purport', 'aim' and 'meaning' being probably the most frequent ones. In the present context, however, none of these renderings seems appropriate. As Lamotte has shown, the most accurate translation of the term artha here is 'thing' or 'object', referring to the 'own-being' (svalaksana) or 'chose désignée' (bhäșitärtha) of the item in question (Mppś, pp. 1614, 1616, n. 1). This interpretation is supported by the $A k n-t \bar{t} k \vec{a}$ (p. 240.3.3-4), stating that "in order to instruct in knowledge of the characteristic (laksana), it is asked what is the unique knowledge of the own-being of things?" For further evidence of this position, see: Bbh, p. 258.8-10, Msl, pp. 138.21-139.1, Aloka, p. 455 . 25 ff; Kośa, vii, pp. 89-94; Abhidh-d, pp. 393.1-94.1; and for the nikāya: A I, p. 24; II, p. 160; III, pp. 113,120 . For references to the pratisamvid in the āgama and Chinese translations of Sarvāstivāda Abhidharma 
teachings of the Buddha are statements of absolute truth ${ }^{79}$. It is knowledge of the causes, conditions and circumstances of non-duality. It is knowledge of the infinitude of interconnections. It is knowledge of the basis of spiritual fruition. It is knowledge of the pure sphere of the Dharma. It is knowledge in conformity with thusness. It is knowledge of the unclassifiability ${ }^{80}$ of nirvāna.

It is knowledge arising from ${ }^{81}$ the realisation of emptiness. It is knowledge arising from the understanding of signlessness. It is knowledge that wishlessness is wishlessness. It is knowledge that the non-accumulation of karmic formations is a non-accumulation of karmic formations. It is knowledge penetrating sameness. ${ }^{82}$

It is knowledge penetrating the non-existence of the living being and self. It is secure knowledge that the life-force comes to an end and that the non-existence of the person is the absolute truth. It is knowledge that the past is determined, that the future is without limit and that the present is everywhere. It is knowledge that the aggregates are an illusion, that the elements resemble venomous serpents and that the sensefields are defined as emptiness. ${ }^{83}$

It is knowledge that diseases abate, that there is no agitation in the beyond and that there is no substance ${ }^{84}$ to objects. It is knowledge that mindfulness is the basis of spiritual fruition. It is knowledge that comprehension is absorption, that understanding is realisation and that truth is awakening. It is knowledge that suffering is non-existent, that its origin is a nonaccumulation of karmic formations, that its cessation is signless and that the path is salvation.

It is knowledge that the Doctrine consists of versatile statements. It is knowledge that the faculties penetrate and that the powers are invincible. It is knowledge that perfect mental quietude is the basis of spiritual fruition and that insight is true vision. It is knowledge that illusions are fabricated, that mirages are deceptive and that dreams are untrue vision. It is knowledge that echoes occur only in certain circumstances and that miraculous appearances are subject to change.

It is knowledge that diversity of characteristic is one-characteristic, that unity is separation.

works, see: $A m r t$ (B), p. 214.

In the Tibetan, the following specification of the nature and scope of the bodhisattva's unique knowledge of things assumes the form of a long enumeration. In order to achieve a better English reading, I have treated each of the fifty-one items of that specification as an individual clause.

79. Here, the Bdp agrees with the Mpps which gives also the absolute truth (paramärtha) as the object of the arthapratisamvid (Mppś, iii, p. 1616). Other texts, however, most notably the Kośa, Vibh and Nyāyānusāra, give artha as its object while, for the Aloka, it is dharmalaksana (Mppś, iii, p. 1616, n. 3).

80. mi gnas pa: aniśrita (cf. Edgerton, p. 25, col. 2).

81. rjes su rtogs pa śes pa: anvayajñāna (Mvy 1224, 1228, 1232, 1236).

82. tsul gcig. ekarūpa

$A k n-t \underline{i k a}$, pp. 240.5.8-241.1.1:

"That is, [the bodhisattva] realises that the characteristics of all dharma are of one characteristics, that their nature is of one characteristic."

83. nes pa rtog pa: nirüpana a (cf. Monier-Williams, p. 554, col. 1).

84. yul med pa: avișaya (cf. Monier-Williams, p. 110, col. 2). 
It is knowledge that purification does not lead to future rebirth ${ }^{85}$. When concerned with the Srāvakayāna, it is knowledge understanding in conformity with statements. When concerned with the Pratyekabuddhayāna, it is knowledge understanding causal dependence and unsurpassed knowledge of solitude. When concerned with the Mahāyāna, it is knowledge of all kinds of accumulation of roots of virtue. This is the bodhisattva's unique knowledge of the own-being of things. (626)

Furthermore, as regards the unique knowledge of the own-being of things; it is to rely on the spirit conforming to reliance on the spirit of every dharma-foundation of all dharma. Why? All dharma being without exception empty, emptiness is the own-being concerned. All dharma being without exception signless, signlessness is the own-being concerned. All dharma being without exception wishless, wishlessness is the own-being concerned. All dharma being without exception non-manifest ${ }^{86}$, non-manifestation is the own-being concerned. All dharma being without exception devoid of a living being, a life-force or a person, personlessness is the own-being concerned. ${ }^{87}$

Such understanding of dharma is the unique knowledge of the own-being of things. The teaching of the own-being of things is an unestablished and inexhaustible teaching. This unique knowledge is a teaching of the awakened $\operatorname{truth}^{88}$. It is conferred by the lord buddhas and gives lasting pleasure. It is genuine, authentic and factual; it is well-realised ${ }^{89}$ through wisdom and altogether beyond reproach. This is the bodhisattva's unique knowledge of the own-being of things.

\subsubsection{Skill in the Unique Knowledge of Designations}

Next, what is the unique knowledge of designations $?^{90}$ It is knowledge penetrating dharma

85. mtshams sbyor ba med pa: apratisamdhi (cf. Edgerton, p. 372, col. 1).

86. rnam par pye ba: vicita (cf. Monier-Williams, p. 959, col. 1).

87. According to the Mpps, reliance on dharmata as opposed to pudgala and the resultant recognition of the own-being of dharma pertains to the sphere of the dharmapratisamvid (Mpps, iii, p. 1621).

88. rtogs pahi don: adhigamärtha (cf. Edgerton, p. 12, col. 2).

89. sin tu rtogs pa: supratividdha (cf. Edgerton, p. 600 , col. 1).

90. In my translation of the term dharmapratisamvid I follow once again Lamotte (Mpps, iii, pp. 1614, 1617, n. 1), who cites several passages that liken it to 'knowledge of instruction' (desanā) (Vibhanga), 'knowledge of enunciation' (paryāya) (Äloka) or 'knowledge of names' (näman) (Nyāyānusāra). The dharmapratisamvid is hence primarily a knowledge that assists the bodhisattva to understand the designations (bhäșitärtha), names (nāman), phrases (pada) or syllables (vyañjana) that are employed to designate any kind of object. In practice, however, the scope of the dharmapratisamvid is much more limited. That is to say, it is only concerned with the word of the Buddha ( $V i b h$, p. 294.22-24). In the words of the $A b h i d h-d$ (p. 393.5-6):

"The pratisamvid is the indestructible knowledge concerning the categories of names, etc., that are contained in the twelve branches [of the Dharma]. It relates to matters of expression and pertains to discussion."

In the $B b h$ (p. 258.4-8) no such detail is found as the dharmapratisamvid is only taken to address, rather generally, the characteristics of dharma (dharmalaksana). The text is similarly unhelpful with regard to the objects of the other pratisamvid (p. 258.8-24).

According to the $A k n-t \bar{i} k \bar{a}$ (p. 242.3.5-8; cf. $A k n$, pp. 62.5.4-63.2.4), the difference between artha and dharma is one of voice:

"While it is true that between artha and dharma there is no difference, artha should be 
that pertain to virtue and non-virtue, reproach and approval, impurity and purity, (627) worldliness and supra-worldliness, conditioning and non-conditioning, contamination and the fortune of purification ${ }^{91}$, samsāra and nirvāna. It is knowledge of the sameness of the sphere of the Dharma, knowledge of the sameness of enlightenment and knowledge of the sameness of the elements. This is [the bodhisattva's] unique knowledge of designations.

Furthermore, as regards the unique knowledge of designations; ${ }^{92}$ it is knowledge of the thoughts of those who act with desire, fictitious desire, severe desire, slight desire, unarisen desire, constant and infinite desire as well as with presently conditioned desire.

It is knowledge of sentient beings who act with desire. That is to say, it is knowledge of those who, while being externally free from desire crave internally; of those who, while being internally free from desire crave externally; of those who are internally as well as externally free from desire; of those who crave internally and externally; of those who, while being free from desire for sound crave for form; of those who, while being free from desire for form crave for sound; (628) of those who crave for both form and sound; of those who do not crave for either sound or form; of those who, while craving for form are free from desire for scent; of those who, while craving for scent are free from desire for touch; of those who, while craving for touch are free from desire for flavour and of those who, while craving for flavour are free from desire for form or scent.

By means of this acumen, there being twenty-one thousand modes of desire, twenty-one thousand modes of hatred, twenty-one thousand modes of delusion and twenty-one thousand modes of conduct that partake uniformly in desire, hatred and delusion ${ }^{93}$, it is knowledge of the thoughts of eighty-four thousand modes of conduct. ${ }^{94}$

It is knowledge of appropriate instructions and knowledge of instructions that are neither too long nor too short. It is knowledge of sentient beings who transcend desire and knowledge of those who are superior receptacles. It is knowledge of instructions that are efficacious. This is the unique knowledge of designations.

perceived as the object that should be instructed in and understood, but dharma should be perceived as the agent that instructs and prompts understanding. Again, dharma are conditioned and unconditioned things, etc., that are cited by name, while artha is the meaning of them that should be discerned and examined. Again, knowledge of artha is accurate cognition (aviparitādhigāma) of the characteristics of all dharma while knowledge of dharma is knowledge of the names of these dharma."

91. mam par byan் bahi cha daǹ ḥthun pa: vyavadānabhägin (cf. Edgerton, p. 515, col. 2).

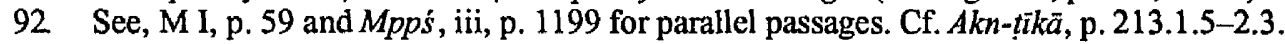

93. In the fourth item, 'partaking in the three uniformly', our text deviates from elsewhere well-established patterns. Most texts, like the Kośa (i, p. 47; ii, p. 297), cite 'pride' (lobhā) as the fourth member of the root-defilements of räga, moha and dvesa.

94. The notion that the dharma-aggregate of the Buddha consists of 84.000 units covering the mental conduct of all beings is, of course, an ancient one. It is found, for instance, in the Saddhp (p. 254.11), Kośa (i, pp. 46-47), $R g v$ (p. 232) and is cited in the $M s g$ (p. 229). The division into the 21000 varieties of desire, hatred, delusion and pride is less frequent as it is only found in the Kos a (i, p. 47). Note that according to the Mpps (iii, p. 1623) knowledge of the dispositions of sentient beings falls within the scope of the pratibhānapratisamvid - not the dharmapratisamvid. 


\subsubsection{Skill in the Unique Knowledge of Languages}

Next, what is the unique knowledge of languages? ${ }^{95}$ Penetrating all languages non-verbally, he explains the Doctrine to people by way of the language of gods, nāga, yaksa, gandharva, mahoraga, southern mahoraga, kinnara and ancestors as well as by way of sounds and melodies. This is the unique knowledge of languages. (629)

It is in this way that he should discern, acquire and retain the practices. It is in this way that he should model his practice to the letter.

The bodhisattva knows the appellation of words that are in the singular, dual or plural. He knows words that are of feminine, masculine or neuter gender. He knows contracted and expanded words. He knows abusive and laudatory words. He knows words of the past, present and future. He knows how to infer by means of one letter. He knows how to infer by means of many letters. This is the unique knowledge of languages.

Again, as regards the unique knowledge of languages; it is free of error, neither repetitive nor hasty. He is well-acquainted ${ }^{96}$ with texts that clarify the meaning of practices. By all means, this knowledge is of insightful cognition, profound, versatile and prompts delight in samsāra. It is embellished with conventional and absolute truth. It is subject to self-induced cognition. It is conferred by the Buddha and gives pleasure to all sentient beings. This is the bodhisattva's unique knowledge of languages.

\subsubsection{Skill in the Unique Knowledge of Eloquence}

Next, what is the bodhisattva's unique knowledge of eloquence $?^{97}$ It is articulate speech that teaches instructions free-speakingly. It is speech that is fluent, (630) eloquent, spirited and dynamic. It is impeccable and non-evasive. It is completely flawless, non-contradictory,

95. For the Mahāyāna, the object of the niruktipratisamvid is primarily knowledge of languages. This departure from the early conceptions according to which it covers chiefly grammar (Kośabhäsya, p. 419.17-18) mirrors a revised understanding of the training requirements that sprang from the bodhisattva's pledge to universal liberation ( $A k n-t i \grave{k} \bar{a}$, p. $243.3 .3-4$; cf. $A k n$, p. 63.2.4-3.5):

"In order to instruct in knowledge of language conventions (vyavahärajña), it is asked what is the unique knowledge of languages?"

For further evidence of this interpretation see: $B b h$ (p. 258.11-13) and $M s l$ (p. 139.1).

96. yons su byan ba: paricita (Mvy 2412).

97. $A k n-t i k \bar{a}$, p. $243.5 .4-5$; cf. $A k m$, p. 63.3.5-4.8:

"In order to instruct in knowledge of expression (abhiläpajña), it is asked what is the unique knowledge of eloquence?"

Once again, this interpretation is also attested in the $B b h$ (p. 258.14-17) and $M s l$ (p. 139.1-2). The reasons for the bodhisattva's eloquence are explained in the $S g s$ (p. 188):

"Pourquoi le bodhisattva est-il doué d'éloquence (pratibhänasampanna)? Le devaputra - Le bodhisattva parle sans utiliser la notion du soi (ätmasamjinâa), sans utiliser la notion d'autrui (parasamjina) et sans utiliser la notion de dharma: il est donc 'doué d'éloquence'. Lorsqu'il prêche la Loi, les phonèmes (aksara) sont inépuisables (akșaya), et les dharma aussi sont inépuisables. Parlant ainsi, il ne parle pas de dualité (dvaya): il est donc 'doué d'éloquence'. Kulaputra, si le bodhisattva ne rejette pas le caractère de magie (māyälakșana) inhérent aux dharma et ne rejette pas le caractére d'écho (pratiśrutkālaksana) inhérent aux sons (svara), il est 'doué d'éloquence'." 
non-contentious and preoccupied with the Doctrine. It is patient, profound and versatile. It is eloquent in conventional and absolute truth. It is eloquent attending to all forms of giving, morality, patience, vigour, meditation and wisdom. It is eloquent in mindfulness, right efforts, bases of success, faculties, powers, factors of enlightenment, path, perfect mental quietude and insight. ${ }^{98}$ It is eloquent in that it knows all entrances into contemplation, liberation, meditation, attainment and truth. It is eloquent in all vehicles as well as in the mental activity of all sentient beings.

It is eloquent in that it is of resourceful, congenial and orderly speech. It consists of subtle, smooth, taintless, emancipated, nonpartisan, honourable, articulate, fitting, impeccable, renown, sympathetic and laudatory speech. It is speech that is praised by all noble ones. Its sound reverberates with knowledge of infinite buddha-fields. (631) Its pure sound resembles melodies. It is the one sound that induces awakening. By means of this buddha-bestowed eloquent, [the bodhisattva] teaches the Doctrine to humans and other living beings. Also this liberating Dharma-discourse of his brings to a halt suffering in those who practice it. This is the bodhisattva's unique knowledge of eloquence. This is bodhisattva's skill in eloquence.

It is in this manner that the bodhisattva who is skilled in eloquence courses in the Perfection of Wisdom.

\subsection{Skill in Reliance}

Next, what is the bodhisattva's skill in reliance? ${ }^{99}$ The reliances of bodhisattvas are four. What are the four? They rely on the spirit rather than on the letter. They rely on direct

98. This is the only instance in the $B d p$ where the bodhipasksika dharma are listed in their entirety. All other references to their categories, including their detailed discussion as one of the bodhisattva's skills under 2.7 .2 and 2.8-10, fail to mention the 'four bases of success' ( $r d d h i p a \overline{d a}$ ).

99. For a commentary on the terms and concepts that are involved in this section, see: $A k n-t i k \bar{a}$ (1) spirit/letter. pp. 244.5.8-246.3.8, (2) direct knowledge/discursive insight: pp. 246.3.8-247.2.5, (3) sütras of precise/provisional meaning: p. 247.2.6-5.3 and (4) foundation of being/person: pp. 247.5.6-248.4.7.

The translations of the Sanskrit terms included in this category has not been agreed upon. Compare, for instance, those of Wayman (1974, p. 103), viz., 'meaning/letter', 'doctrines/personalities', 'knowledge/perception' and 'final meaning/provisional meaning' with those of La Vallée Poussin (Kośa, ii, p. 246). In my translation, I was guided by the terminology that is employed by Lamotte in his article: "La critique d'interpretation dans le bouddhisme' (Annuaire de l'Institut de Philologie et Histoire Orientales et Slaves, 9, 1949).

The concept of the four reliances is no doubt an ancient one. It is already found in several of the early suttas. For brief, often archaic statements on individual aspects of the four pratisarana, see for instance: D III, pp. 127-129; M I, p. 265; II, p. 240; A I, p. 60; Mahävagga I, p. 23. 4; Nett, p. 21. Other early commentarial references to the pratisarana are found in the Dipavamsa (ed. Oldenburg, p. 36), in the introduction to the commentary on the Kathāvatthu (JPTS, 1889, p. 3), Vism (pp. 473, 499) and Atthasālini (p. 91; ref. La Vallée Poussin).

In many of these early works comparatively little importance is being attached to their attributes. Their rise to one of the major sets of practices in the spiritual training of the religious seems to have taken place in the later scholastic or analytic period of Buddhist thought. In particular, Asanga has made major contributions to the process of defining the exact scope and application of the pratisarana. In both the MsI (p. 138.1-14) and $B b h$ (pp. 256.23-58.3), for instance, we have detailed passages where their significance is analysed with considerable scholastic exactitude. I have incorporated this material into my discussion of the pratisarana in chapter four. 
knowledge rather than on discursive insight. They rely on sütras of precise meaning rather than on sütras of provisional meaning. They rely on the foundation of being rather than on persons.

\subsubsection{Skill in Reliance on the Spirit and not on the Letter}

What is the spirit? What is the letter? The letter penetrates the activity of mundane dharma. The spirit realises supramundane dharma. The letter instructs in generosity, benignity, discipline and bravery. The spirit perceives benignity, tranquillity, non-arising and non-decaying. (632) The letter proclaims the teachings ${ }^{100}$ of samsāra. The spirit relies on inconceivability. The letter proclaims the qualities of nirvāna. The spirit does not discriminate dharma that by their nature are in nirvan $a^{101}$. The letter preaches according to the differentiation of the vehicles. The spirit is knowledge that arises from realising dharma-sameness. The letter instructs not to abandon any sentient being. The spirit purifies the three spheres of giving ${ }^{102}{ }^{103}$

The letter-disciplining body, speech and mind-instructs in achieving all attainments of learning and purity. The spirit-not apprehending body, speech and mind-purifies the nonaccumulation of karmic formations. The letter, suppressing malice, anger, pride and self-conceit instructs in patience and bravery. The spirit achieves the conviction of the non-arising of dharma. The letter instructs in vigour concerning all roots of virtue ${ }^{104}$. The spirit is vigour independent of apprehension or renunciation. The letter instructs in contemplation, liberation, meditation and attainment. The spirit is knowledge of entering the attainment of cessation. ${ }^{105}$

The letter, being the receptacle of all that has been heard, is the root of wisdom. The spirit is the ineffable meaning. The letter instructs in the practice of the thirty-seven bodhipākșika dharma. ${ }^{106}$ The spirit realises the fruit of the practice ${ }^{107}$ of the thirty-seven bodhipäkșika

100. Cf. Pelliot, 977, 1a.3 which has rgyus meaning 'knowledge', 'intelligence'; 'history', 'tale' instead of yons su bśad pa.

101. ran bźin gyis yons su mya nan las hdas pa: prakrtiparinirvrta (cf. Edgerton, p. 356, col. 2).

102 hkhor gsum: trimandalapariśuddha (Mvy 2537; cf. Edgerton, p. 258, col. 1).

103. Pelliot, 977,1 a. $2-4$ :

"The spirit penetrates the meaning of the supramundane. The letter penetrates the activity of mundane dharma. The spirit perceives benignity, tranquillity, non-arising and non-decaying. The letter preaches generosity, benignity, diligence and great joy. Furthermore, the letter is proclaimed through causes of samisära. The spirit looks at the inconceivable. The letter proclaims praise of the qualities of nirvāna. The spirit does not discriminate dharma that by nature are in nirvāna."

104. I follow here the Pelliot reading.

105. Pelliot, 977, folio 1a.5-1b.1:

"The letter--disciplining body, speech and mind-instructs in achieving all attainments of learning and purity. The spirit--when seeing body, speech and mind-purifies the accumulation of karmic formations. Furthermore, the letter heals the defilement of malice, anger, pride and self-conceit and instructs in patience and joy. The spirit achieves the conviction of the non-arising of dharma. Furthermore, the letter instructs in vigour concerning all roots of virtue. The spirit is free from discrimination and discernment. It is vigour that is independent."

106. Pelliot, 977,1 b. $2-3$ :

"The letter generates the practice of the thirty-seven bodhipākșika dharma." 
dharma. The letter instructs in suffering, its origin and the path. The spirit realises its cessation. The letter instructs in ignorance, etc., up to old-age-and-death. The spirit realises the cessation of ignorance, etc., up to the cessation of old-age-and-death. The letter instructs in the accumulation of perfect mental quietude and insight. The spirit realises knowledge and deliverance.

The letter explains the Doctrine to those who act with desire, hatred or delusion or who partake uniformly in all three. The spirit is the unperturbed liberation of the mind. The letter points to all dharma that cause obstruction. The spirit is the unobstructed pristine cognition and liberation. The letter displays the incalculable, excellent qualities of the three jewels. The spirit accomplishes the imperturbable state of being and the unconditioned qualities of the Sangha. ${ }^{108}(634)$

The letter instructs in learning and attainments that are accomplished by the bodhisattva, starting with the first production of the thought of enlightenment, the point of departure, up to the seat of enlightenment. ${ }^{109}$ The spirit is perfect enlightenment arising from pristine cognition of all-knowing since is endowed with a single moment of thought. In brief, that which instructs in up to eighty-four thousand dharma-aggregates is the letter. The ineffable meaning of all sounds, letters and syllables is the spirit. ${ }^{110}$

107. nan tan du byed pa: pratipatti (cf. Edgerton, p. 364, col. 2).

108. Pelliot, 977, 1.b3-4:

"Furthermore, the letter explains the Doctrine to those who partake uniformly in desire, hatred or delusion. The spirit is the unperturbed liberation. Furthermore, the letter points to all obstructing dharma. The spirit is the unobstructed pristine cognition and liberation. Furthermore, the letter analyses the colour of the qualities of the three jewels."

109. byan chub kyi sñin po: bodhimanda

The Tibetan rendering of the term bodhimanda is explained in the $\overline{A l o k a}$ (p. 206.7):

"The bodhimanda, used as a seat, is a spot so named because the manda, that is the quintessence of bodhi, is present there."

There exist two types of interpretation of the concept of bodhimanda. First, when understood as a seat, it refers to the seat underneath the Bodhi-tree under which all buddhas are held to attain enlightenment (Saddhp, p. 316.3-4). As a physical entity, the seat of enlightenment became soon subject to a cult. Already during Mauryan times, the tree of enlightenment received royal attention and became a sanctuary that was enclosed by brick walls and regularly worshipped (Bloch, Inscriptions d'Aśoka, p. 112, Divya, p. 404.2). By the seventh century the cult of the bodhimanda had progressed to assume cosmic dimensions. Hsüan-tsang (Beal, 1981, ii, pp. 115-6) saw in the enclosure surrounding the Bodhi-tree a 'diamond seat' (vajrāsana) of which he was told that it would appear at the beginning of a Bhadrakalpa and stood, immovably, at the exact centre of the trichiliomegachiliocosm. Second, as a spiritual concept, the term bodhimanda stands for the presence of the Dharma as it is preserved in the sutras or as it is embodied by the dharmakāya of all buddhas. As such it is non-spatial and may be found in any location where the presence of the Dharma is manifest. To this effect, we read in the Saddhp (p. 391.6-13, trsl. Kern):

"And wherever on earth, son of good family, this Dharma-enunciation shall be made known, read, written, meditated, expounded, studied or collected into a volume, be it in a monastery or at home ... in that place one should erect a stüpa in dedication to the Tathāgata; for such a spot must be regarded as a bodhimanda."

The same thought is also expressed in the $V k n$ (p. 99, trsl. Lamotte) when Vimalakirti announces that all bodhisattvas "whether they go somewhere or return from it, whether they advance or stop ... come always from the seat of enlightenment." For these and further references to the development of the concept of bodhimanda, see: Lamotte, 1976, p. 94, n. 105.

110. Pelliot, 977, 1b.6-7:

"The spirit is perfect enlightenment arising from pristine cognition of all-knowing composed 
Next, what are sutras whose meaning is provisional? Texts that propound the letter should be absorbed meticulously just as they are preached. These are sutras of provisional meaning.

What are sütras whose meaning is precise? Texts that propound the spirit should be absorbed meticulously just as they are preached. These are sütras of precise meaning. ${ }^{111}$

Why does one rely on the foundation of being rather than on persons? Since the provisional meaning is that of persons, one does not rely on these. Rather, since the precise meaning corresponds to the foundation of being, one relies on it.

These are the bodhisattva's four reliances. ${ }^{112}$ It is in this manner that the bodhisattva, mahäsattva who is skilled in reliance courses in the Perfection of Wisdom. ${ }^{113}$

Next, what is the bodhisattva's skill in the letter? ${ }^{14}$ (635) Concerning this, the bodhisattva who is skilled in two dharma courses in the Perfection of Wisdom. What are the two

of a single moment of thought. In brief, that which preaches all eighty-four thousand dharmaaggregates is the letter. That which is truly ineffable through any sound or letter is the spirit."

111. Pelliot, 977, folio 1b.7-2a.1:

"Next, what are sütras whose meaning is provisional? Sayings that should be absorbed meticulously just as they are preached, these are sütras of provisional meaning. What are sütras whose meaning is precise? Sayings should be understood in detail just as they are preached, these are sütras of precise meaning."

112 This is evidently not the case, as the pair jñāna/vijñana has not yet been treated. For a discussion of this incongruity, see note 114 . In the $A k n$, this confusion has been redressed.

113. Pelliot, 977, 2a.1-2a.2:

"How does one rely on the foundation of being rather than on persons? That which is the provisional meaning is the meaning of the person. Through that there is no liberation. That which is the precise meaning corresponds to the foundation of being. Through that there is liberation."

114. The sequence in which the material is presented is quite evidently out of order. This irregularity appears in all blockprint editions consulted by me, that is, the sDe-dge, sNar-than, Peking and sTog-Palace $b K a h$-hgyur and, to a lesser extent, also in the Pelliot manuscript. Although it is true that one cannot speak of a universal agreement as to the sequence in which the four pairs of pratisarana should be cited (compare, for instance, the sequence proposed in $M v y$ 1545-49 and Kośa, ii, pp. 246-8), the actual order in which the pairs are discussed corresponds invariably to that put forward in the respective subject listings. To my knowledge, the $B d p$ is the only text in which this is not the case. What is more, in the $B d p$ the pairs nithärtha/neyärtha and dharmatälpudgala are dealt with twice. The sequence runs as follows:

1. Artha/vyañjana (R, folio 631.6-634.4; Pelliot: la.2-2a.7)

2. Nïthärtha/neyārtha (R, folio 634.4-5; Pelliot: 2a.7-2b.1)

3. Dharmatälpudgala (R, folio 634.5-6; Pelliot: 2b.1-2b.2)

Interpolation

- Stockphrase: 'It is in this manner that ... .' This phrase concludes elsewhere major sections in the $B d p$.

- Re-introduction of the theme, linking the discussion of jinana/vijñäna to 'skill' in the letter. This connects not only the discussion of the pair jinanna/vijñana to the previously interrupted exposition, but leads also to the sequence found in the subject heading ( $\mathrm{R}$, folio 631.3-6, viz., arthalvyañjana; jñäna/vijñāna; nïthärtha/neyārtha; dharmatälpudgala)

- Coursing in the Perfection of Wisdom is acted out by 'skill' in two dharma, that is, jñāna and vijñäna.

End of Interpolation

4. Iñānalvijñäna ( $\mathrm{R}$, folio 634.7-636.5; Pelliot: 2b.2-3a.1)

5. Nithärtha/neyārtha ( $R$, folio 636.6-638.1; Pelliot: 3a.2-3b.1)

6. Dharmatälpudgala (R, folio 638.1-639.4; Pelliot: 3b.1-3b.7)

The whole interpolation is absent in the Pelliot manuscript. Here, the discussion of the pair dharmata/pudgala is immediately followed by an exposition of jüānalvijñāna. 
dharma? He is skilled in discursive insight and direct knowledge. ${ }^{115}$

\subsubsection{Reliance on Direct Knowledge and not on Discursive Insight}

What is discursive insight? What is direct knowledge? As regards discursive insight; there are four abodes of discursive insight. What are the four? Matter in which discursive insight rests and is firmly rooted is its abode. Feeling, perception and karmic formations in which discursive insight rests and is firmly rooted are its abodes. This is discursive insight.

What is direct knowledge? Cognition that persists in the five appropriating aggregates and knows the aggregate of consciousness, this is direct knowledge. ${ }^{116}$ Perception of the element of earth, fire, water or wind is discursive insight. Cognition that does not attend to the four elements, but perceives the pure sphere of the Dharma, this is direct knowledge.

Furthermore, as regards discursive insight; perception of form, sound, scent, flavour, touch or mental objects through the respective consciousness is discursive insight. Tranquillity in internal sensefields, imperturbability in external sensefields and non-apprehension ${ }^{117}$ of any dharma whatsoever by relying on direct knowledge, this is direct knowledge. ${ }^{118}$

Furthermore, as regards discursive insight; knowledge that is born from false mental constructions and imagination is discursive insight. Imperturbability and refrain from grasping, asserting, construing and discerning, this is direct knowledge.

Furthermore, discursive insight persists in the sphere of conditioned dharma but does not wander in the unconditioned. Perception of the unconditioned, this is direct knowledge.

Furthermore, discursive insight attends to the notions of birth and decay. Independence of the unborn and unceasing, this is direct knowledge. ${ }^{119}$

\subsubsection{Reliance on Sütras of Precise and not on Sütras of Provisional Meaning}

Next, what are the sütras whose meaning is precise? What are the sütras whose meaning is

115. This paragraph is missing in the Pelliot manuscript.

In the $A k n-t \bar{k} k \bar{a}$, this subcategory is explained on pages 246.3.7-247.2.5. For a discussion of the terms vijñänaljñäna, see: Wayman, 1980, p. 251-267.

116. Pelliot, 977 , folio 2a.3-4:

"What is direct knowledge? Cognition that does not persist in the five appropriating aggregates and knows the aggregate of pristine cognition, this is direct knowledge."

117. gźog par mi byed pa: samnidhāpayate (cf. Edgerton, p. 58, col. 2).

118. Pelliot, 977, folio 2a.5-6:

"Furthermore, as regards discursive insight; [absorption of external objects through consciousness], starting with absorption of form through the eye and ending with absorption of mental objects through mentation, this is discursive insight. Tranquillity concerning internal sensefields, inactivity concerning external sensefields and non-apprehension of any dharma whatsoever for the sake of proceeding to pristine cognition, this is direct knowledge."

119. Pelliot, 977, folio 2a.7-2b.1:

"Furthermore, discursive insight penetrates conditioned dharma. Discursive insight does not participate in the unconditioned. Knowledge through the unconditioned, this is direct knowledge. Furthermore, discursive insight attends to the notions of birth and origination. Non-attending to the unborn and unceasing, this is direct knowledge." 
provisional? Sütras that introduce to the path are of provisional meaning. Sütras that introduce to its fruit are of precise meaning. ${ }^{120}$ Sütras that cause to accomplish the conventional truth are of provisional meaning. Sütras that preach the absolute truth are of precise meaning. ${ }^{121}$

Furthermore, sütras that introduce to action and duties are of provisional meaning. ${ }^{122}$ (637) Sütras that are taught in order to bring action and impurity to a final halt are of precise meaning.

Furthermore, sütras that are taught in order to explain impurity are of provisional meaning. Sütras that are taught for the sake of complete purification are of precise meaning. Sütras that cause weariness with samsāra are of provisional meaning. Sütras that do not partake in the duality of samsāra and nirvāna are of precise meaning. Sütras that are taught with manifold words and letters are of provisional meaning. Sütras that are profound, hard to fathom and difficult to understand are of precise meaning. Sütras that delight the hearts of sentient beings with many words are of provisional meaning. Sütras that cause sentient beings to gain confidence with few syllables and words are of precise meaning. ${ }^{123}$

Furthermore, sütras that proclaim with various words a self, a living being, a life-force, a person, a man, a human being, an individual or a being that arises and feels saying that there is an owner when there is no such owner ${ }^{124}$ are of provisional meaning. Sütras that instruct in

120. This section contains a good example of the doctrinal advance of the $A k n$ over the $B d p$. Preserved in the Sanskrit of the Madh. vrtti (p. 43.4-6), the $A k n$ reads:

"Sütras that have been expounded in order to teach the path of penetration (märgävatāra) are of provisional meaning. Sütras that have been expounded in order to teach the fruit of penetration (phalävatära) are of precise meaning."

It continues:

"All sütras that instruct in emptiness, signlessness, wishlessness, non-accumulation (anabhisamskkāra), non-birth (ajāta), non-origination (anutpäda), non-becoming (abhava), non-self, the absence of life-force, person and a master (svämin), such texts are of precise meaning" (Madh. vrtti, p. 43.6-9).

A corresponding section is found in the $B d p$ at $637.5-638.1$.

121. Pelliot (977, folio $2 \mathrm{~b} .1-3)$ has:

"Sütras that preach the conventional truth are of provisional meaning. Sütras that preach the absolute truth are of precise meaning."

According to the Mpps (ii, p. 539), sūtras are of provisional meaning if they contain the following sayings: "Among all omniscient, the Buddha is the foremost; among all texts, the sutras are the foremost; among all beings, monks are the foremost."

These Lamotte identifies as the three agraprajñapti proclaiming the superiority of the triratna (A II, p. 34; III, p. 35; Itv, p. 87). In addition, nittärtha sütras explain that "one acquires great merit through generosity, that morality allows for rebirth among the gods". Neyārtha sūtras, in contrast, are held to teach that a master of the Doctrine (dharmäcärya) gains the following five advantages (anusiamsā): (1) great merit, (2) affection from human beings, (3) beauty, (4) renown and (5) eventual arrival at nirvāna. These, of course, are exactly the benefits that are said elsewhere (A III, p. 41) to accrue to persons who engage in generosity.

122. Pelliot, 977, folio 2b.3-3:

"Furthermore, sütras that introduce to action are of provisional meaning."

123. Pelliot, 977 , folio $2 \mathrm{~b} .3-6$ :

"Furthermore, sūtras that are taught in order to cleanse impurity are of provisional meaning.

... Furthermore, sütras that delight the minds of sentient beings with many classifications are of provisional meaning. Those which are straightforward for the mind in [showing] few classifications and words are of precise meaning."

124. bdag po med pa bdag po yod pa: asvāmikasvämika (cf. Monier-Williams, p. 124, col. 1). 
emptiness, signlessness and wishlessness, in non-birth, non-arising and non-becoming, in the non-existence of a living being or person as well as in the gateways to liberation from the three times are of precise meaning. ${ }^{125}(638)$

\subsubsection{Reliance on the Foundation of Being and not on the Person}

Next, what is the foundation of being? ${ }^{126}$ What is the person? One who attends to the belief of the existence of a person and pursues religious practice, this is the person. ${ }^{127}$ The Dharmacontinuance of one who acquires the belief of the existence of a person, this Dharma-sphere is the foundation of being.

Furthermore, as regards the person; in order to convert sentient beings the Tathāgata explains everything with the help of conventional methods in terms of persons, saying: "The unique person who is born in this world and appears for the sake of the benefit and well-being of many sentient beings, who feels compassion for the world and accomplishes the welfare, benefit and happiness of hosts of beings among gods and men, viz., the Tathāgata, Arhant, Samyak Sambuddha as well as lay persons, virtuous lay persons, faithful persons, Dharmaobserving persons, persons of the eighth rank $^{128}$, stream-enterers, once-returners, non-returners, arhants, pratyekabuddhas and bodhisattvas, [all] these are persons." Now, those who become attached to such [appellations] have nothing to rely on. ${ }^{129}$ In order to establish beings in understanding, the lord said that rather than to rely on the notion of the person they should rely on the foundation of being. (639)

Next, what is the foundation of being? All dharma bear the characteristics of unbecome, unmade, unproduced and unaccomplished; of changeability, fluctuation, rootlessness and complete sameness, viz., sameness in equality, non-equality and in both equality and nonequality; of non-discrimination, non-undertaking, certainty and lack of own-being. This is the

125. Pelliot, 977 , folio $2 \mathrm{~b} .6-7$ :

"Furthermore, those which explain the assembly of a self, a living being, a being that feeis and a person are of provisional meaning."

126. Pelliot, 977 , folio 3a.1-1:

"Next, what is the foundation of being?"

127. The structure of this sentence is ambiguous. I follow here the interpretation of the parallel passage in the $A k n$ (p. 64.4.7-8) as proposed by Vasubandhu in the $A k n-t \bar{l} k \bar{a}$ (pp. 247.5.3-248.1.1).

128. äryāștamaka

The term astamaka is problematic. Given in the Pāli as atthamaka, it is interpreted by the PED and CPD as a reference to that person among the ariya-puggala who has reached the eighth stage, that is to say, he is a person who has just entered on the lowest stage of the srāvaka-path (sotäpattiphala-sacchikiryāya pațipanno; Puggalapañinati, p. 73). While such a definition is quite acceptable, difficulties arise since there appears to be no reference to a seventh, sixth, etc., person. In the Nett (pp. 49-50; ref. Gethin), the term atthamaka serves to define the anāgamin. On the basis of these findings, but somewhat evading the problem, Naanamoli suggests to consider the meaning of atthamaka as corresponding with that of patipannaka ('one who has entered on the path') - an assumption that is probably correct in essence as the practice of atthamaka refers in the Netti (pp. 95-6) to a person practising on the transcendental path. La Vallée Poussin comes to a similar conclusion (1907, p. 266, n. 2). The Mvy (1143) speaks of a aștamakabhümi, being the third of the seven bhümi of the śrāvaka (cf. Edgerton, p. 81).

129. rton pa ma yin pa: apratisarana 
foundation of being.

Those who rely on the foundation of being never rely on elements. Hence, because they rely on all dharma by means of penetrating the door to Dharma-observance, [they know that] the totality of dharma is such foundation of being. ${ }^{130}$

These are the four reliances of bodhisattvas. This is the bodhisattva's skill in reliance. It is in this manner that the bodhisattva who is skilled in reliance courses in the Perfection of Wisdom. ${ }^{131}$

\subsection{Skill in Accumulation}

\subsubsection{Skill in the Accumulation of Merit}

Next, what is the bodhisattva's skill in accumulation? The accumulation of the bodhisattva is twofold. What are the two? These are the accumulation of merit and the accumulation of pristine cognition.

What is his accumulation of merit? It contains the bases of meritorious work that arise from generosity, moral conduct and contemplation. ${ }^{132}(640)$ It contains the bases of meritorious

130. Lit: 'the totality of dharma is such foundation of being.' Pelliot, 977, folio 3a.4-7:

"What is the foundation of being? Existence has the foundation of the unmade, unproduced, unestablished and unsupported. All dharma bear the characteristics of complete sameness, viz., non-equality and equality, of non-discrimination, non-undertaking, non-originating and lack of own-being. This is the foundation of being. The dharma of those who rely on the foundation of being do not reappear. Hence, having relied on all dharma by means of entering into the door of Dharma-observance, they seize them. All dharma are such a foundation."

131 This paragraph, starting with 'These are' up to 'of Wisdom' is missing in the Pelliot manuscript.

132 bsod nams bya bahi dnos po: punyakriyāvastu

In the suttas of the Pali tradition, we find three kinds of bases of merit, viz., the basis of meritorious work arising from generosity, arising from morality and meditation (dāna-, silar, and bhävanāmayakriyävatthu). Brief references to these three are found in D III, p. 218 and Ittv., p. 51. In the Anguttaranikaya IV, p. 241, the Buddha expounds the various fruits that accrue to practitioners of the three bases of meritorious work, in particular, the sublime spheres of rebirth.

The most instructive explanation of their role and functioning is found in the Kos a (iv, pp. 231-33). Distinguishing, like the Päli, meritorious action arising from generosity, morality and meditation (danna-, síla-, bhävanāpunyakriyāvastu), it characterises each of the three as merit (punya), action (kriya) and basis (vastu). Dāna, síla and bhävanā themselves are the bases of meritorious action (punyakriyā), because in process of their realisation the practitioner undertakes the preparation for merit.

Generosity, consisting of vocal and physical action is that which produces the action. But it is not so much the object that is given that matters and determines the resulting merit, than the reason why a certain thing has been granted. Hence, volition (cetanā) or the collection of thought and mentation (cittacaittakaläpa) is crucially important to the accumulation of merit of which dāna, sila and bhāvanāa are merely objects (vastu) or bases (adhișthāna). Depending on cetanā, generosity can either display a pure or impure disposition. Founding its views on the eight factors of the Sarigitisutta (D III, pp. 258-60), the Mpps (v, p. 2249) distinguishes sixteen types of impure giving, including generosity out of desire for retribution, out of hope for heavenly rebirth, fame, etc. Pure generosity, in contrast, is always motivated by the desire to purify one's thought and to adorn the spirit, and leads to nirvāna.

Morality as a basis of meritorious work is like generosity manifested in vocal and physical action. According to the Mppś, its scope of application is limited to the pañcasilla consisting in abstention from killing, theft, lying, adultery and intoxication. Capable of showing three degrees of accomplishment (low, mediocre and high) and qualified by the motivation and circumstances surrounding moral violations, the amount of merit it produces varies with the integrity of the practitioner (A IV, pp. 241-43). 
work that are furnished with a calm, benevolent disposition, compassionate conduct, exertion for all roots of virtue and the elimination of one's own and other peoples' sins.

It contains the bases of meritorious work that are furnished with gratitude ${ }^{133}$ towards all sentient beings of all times for their roots of virtue, viz.; towards all learned ones and unlearned ones, towards all pratyekabuddhas and those who have produced the thought of enlightenment for the first time, towards all who have embarked on virtuous conduct, towards all irreversible bodhisattvas, towards those who are separated from buddhahood by just one birth $^{134}$ and towards the buddhas of the past, present and future. It contains the bases of meritorious work furnished with the request of the Doctrine from all buddhas and noble ones. It contains the bases of meritorious work that are furnished with the transformation of all virtue into enlightenment.

He generates the thought of enlightenment in sentient beings who have not generated the thought of enlightenment. He teaches the Path of the Perfections to those who have generated the thought of enlightenment. He provides the poor with riches and dispenses medicine to the ill. He pays homage to the worthy ones. He is patient and congenial with the weak. He does not conceal his sins but eliminates evil. (641) He shows all forms of reverence and worship to those lord buddhas who dwell in the world and to those who have passed into nirvanna. He venerates his instructors and preceptors just as the teaching. He is diligent in seeking the Doctrine like a priceless jewel. He delights in the Dharma-pronouncement and even goes one hundred miles to hear them. He is not satisfied with hearing to the Doctrine, but explains it without aiming at worldly rewards. He honours his father and mother. He observes and stands by his deeds. He refrains from wickedness and is insatiable for accumulating merit. ${ }^{135}$

Since he constrained his body, speech and mind with vows, he is free from physical, verbal

Meditation as the basis of meritorious work-according to the Ittv (pp. 19-22) the highest and most productive of all three types - is above all concerned with the generation of benevolent thought (maitricitta). Convinced of the prevalence of hatred (dvesa) and distraction (viksepa) in the kämadhätu, the Mppś (v, pp. 2255-7) argues that maitri is the most urgent object of meditation that generates more merit than any of the other apramāna.

Finally, concluding the discussion of the punyakriyāvastu, the Mpps (v, pp. 2258-60) adds detail by highlighting the role that is played by material gifts and the gift of the Dharma as bases of merit. According to the Kośavyäkhya (pp. 352.31-354.31), citing a passage from the Madhyamagama (T 26, k. 2 , p. 427 c $25-428$ c 25), merit consisting of material gifts (aupadhikapunya)-being sevenfold-is greatest if it is aimed at establishing and sustaining a monastic establishment. Immaterial bases of merit (anaupadhikapunyavastu), in contrast, concern primarily instructions and religious service but are as fruitful in terms of merit as material gifts.

In the $M v y$ (1699-1704) the number of bases of meritorious work is increased to five (dāna-, sila-, bhāvanä-, aupadhika-, and gunyapunyakriyāvastu.), the last of which I have not been able to trace in any of the texts I consulted for this thesis.

133. rjes su yi rañ ba: anumodhanā (cf. Edgerton, p. 32, col. 2).

134. skye ba gcig gis thogs pa: ekajatipratibaddha.

135. Pelliot, 977 , folio 3b.5-4a.1:

"Bodhisattvas generate the thought of enlightenment for those who have generated the thought of enlightenment. ... They conceal their sins and eliminate sin. ... They are not satisfied with hearing to the Doctrine, but explain the stainless Doctrine. ... They know, recollect and feel their deeds." 
or mental hypocrisy. He attains pure merit by building a Tathāgata-stūpa. He accomplishes the marks of a great person by gathering endless offerings. He accomplishes the eighty secondary marks by accumulating numerous stores of roots of virtue. His body is adorned with freedom from conceit. His speech is adorned with freedom from all offensive speech. His mind is adorned with freedom from intellectual impediments. ${ }^{136}$

$\mathrm{He}$ is an embellishment of the buddha-field through the miracles of the super-knowledge. He is an embellishment of the Dharma-characteristic by virtue of his purified pristine cognition. $\mathrm{He}$ is an embellishment of the great retinue by renouncing slander, despondency and dissentsowing words. (642) $\mathrm{He}$ is an embellishment of the imperturbable Doctrine by retaining the Doctrine. His Dharma-discourse does not intimidate since he applauds when he is pleased, saying: "Well done!". He explains in a fruitful manner by listening to the Doctrine with devotion and casting sin and ignorance aside. He is an embellishment of the Bodhi-tree by offering meditation-groves to the Buddha. He is an embellishment of the seat of enlightenment by virtue of retaining the thought of enlightenment - the factor that precedes all roots of virtue.

His life and death are pure since he does not generate actions and impurities. His hand is blessed since he gives away all his jewels and precious objects. His wealth is inexhaustible through the attainment of an inexhaustible resolution. ${ }^{137}$ Since he does not contract his eye-brows angrily, sentient beings gain faith as soon as they see him and greet with a smiling face ${ }^{138}$. He is an embellishment of sameness by directing light-rays at all sentient beings. ${ }^{139}$ Since he does not despise the ill-instructed, he emits much light. By virtue of accumulating moral merit, his birth is pure. Because he does not abuse lowly people, the womb is completely pure at his birth. ${ }^{140}$

By virtue of the complete purity of his tenfold virtuous activity ${ }^{141}$, he is born as god or man.

136. Pelliot, 977 , folio $4 a .2-3$ :

"His body is adorned with emanations by accomplishing the marks [of a great person], by gathering endless offerings, by accomplishing the eighty secondary marks and by accumulating numerous stores of roots of virtue."

137. According to Vasubandhu's commentary on the Dbh (Dasa-bh, p. 219), the accumulation of merit is the first of four blessings (guna) that pertain to bodhisattvas who have progressed to the seventh stage with a set of ten superior practices and is held to generate great wealth:

"Superiority in wealth and personality is obtained according to requirement. Superiority of wealth and personality depends on the accumulation of merit."

138. bźin hịdzum pas gson por smra ba: smitīmukhapūrväbhibhāsantạtā (cf. Edgerton, p. 614, col. 1).

139. I adopted here the argument found in Pelliot, 977, folio 4a.7.

140. Pelliot, 977, 4a.7-7:

"He attains sameness by uniformly [directing] light-rays at all sentient beings. Since he exerts himself for the ill-instructed, he emits adorned emanations. By virtue of accumulating moral merit, his birth is pure. On account of his prediction, the womb is completely pure at his birth."

141. Here, the tenfold virtuous conduct of the bodhisattva refers, in all probability, to abstention from of the traditional ten akuśalakarmapatha, viz., killing, theft, sexual misconduct, falsehood, slander, harsh and frivolous talk, covetousness, animosity and wrong views. This conclusion is, however, not completely safe as Buddhism developed several other enumerations of dharma consisting of ten kinds of virtue. There is, for instance, a group of ten pārājika dharma in the Brahmajālasütra, containing besides the pañcaśila (6) 
He has conquered desire for worldly objects ${ }^{142}$ by contemplating all precepts. ${ }^{143}$ Since he readily shares his knowledge ${ }^{144}$ he masters the Doctrine. Due to his pure resolve, he appears in all worlds. He has faith in the magnificent Doctrine since he is not intend on the limited practice of the layman-observing-two-of-the-pañcasilla ${ }^{145}$. (643) Since he does not give up the mind of all-knowing, he retains all of his merit. He acquires the seven riches of the universal monarch ${ }^{146}$ since he is motivated by faith. Acting in accordance with ${ }^{147}$ his previous resolution, he does not deceive the worlds. He acquires all buddha-qualities by accomplishing virtuous dharma. This is the bodhisattva's skill in the accumulation of merit.

\subsubsection{Skill in the Accumulation of Pristine Cognition}

Next, what is the bodhisattva's skill in the accumulation of pristine cognition? Pristine cognition arises on the basis of causes. He contemplates all causes and conditions of pristine cognition in this way.

What are its causes and conditions? He endeavours zealously to procure the Doctrine. He adheres to friends who comply with pristine cognition. He relies on the pristine cognition of the Buddha rather than on that of srāvaka and pratyekabuddhas. Rather than assuming a

bringing other in disrepute, (7) avarice, (8) boastfulness at the cost of others, (9) malevolence and (10) calumny of the triratna (DeGroot, 1967, pp. 32-39).

Even the ten dușkaracarya of the bodhisattva might be included among the candidates, viz., the exploit of (1) promise (pratijiñ $\bar{a}$ ), (2) non-regression (avivartana), (3) not turning the back when facing misery (aparänmukhïbhāva), (4) dedication (abhimukhïbhäva), (5) purity in the face of constant exposure to samsāra (anupalepa), (6) commitment (adhimukti), (7) penetration (prativedha), (8) comprehension (avabodha), (9) non-abandoning and stainlessness (aparityäganihsamkleśa) and (10) effort (prayoga) in order to fulfil the tasks of a buddha (Msg, pp. 223-4). An alternative list of duskaracarya is given in the Lal (pp. 243-60; trsl. Foucaux, 1988, pp. 210-224).

For a full study of the duskaracaryā, see: J. Dutoit, 1905.

142. gdon mi za bar: avaśya; lit.: 'hoarfrost' (cf. Edgerton, p. 76, col. 1).

143. Pelliot, 977 , folio 4a.7-4b.3:

"By virtue of the complete purity of his tenfold virtuous activity, he is born as god or man. He attains certainty by holding steadfastly on to all precepts."

144. slob dpon kyi dpe mkhyud pa: ācäryamuști; lit.: "close-fistedness of a teacher to share things with his pupils' (cf. Edgerton, p. 89, col. 1).

145. ñi tshe bahi spyod pa: pradeśakāin (Mvy 1610)

The meaning of the term pradesakarin is ambiguous. If one were to follow the context in which it is presented in the $M v y$ where pradeśakārin appears among the twenty-eight types of religious austerity, it would appear to refer to some form of ascetic practice that is practised in a certain region or place (pradesa). This interpretation is not supported by the Kośa (iv, p. 73) and Mppś (ii, p. 821) that clearly associate the term pradeśakärin with a type of upāsaka adhering to a selection of the pañcasíla. In the $K o s i a$, this upāsaka is said to observe two of the five rules, while in the Mppś he may observe two or three of the pañcasila. As neither of these texts mentions which of the five rules the pradeśakärin chooses to observe, we learn little of the moral maxims pertaining to this class of upāsaka.

146. According to the $M v y$ (3621-28), these are a parasol (cakra-ratna), elephant (hasti-ratna), horse (aśva-ratna), jewel (mani-ratna), royal consort (stri-ratna), householder (grhapati-ratna) and an officer or minister (parinayaka-ratna). Compare the contents of this enumeration with a list of seven treasures (dhana) of the bodhisattva (Mvy 1565-72), viz., faith (śraddha), morality (silla), sense of shame (hri), fear of blame (apaträpya), learning (śruta), renunciation (tyāga) and wisdom (prajñă). The seven riches are well known from the nikāya where they occur, for instance, in D III, p. 163, p. 251 and in A IV, p. 4. The same list occurs in the $B d p$ on folio 337.5-338.3.

147. ñams su len pa byed pa: asthitikrtya (cf. Edgerton, p. 111, col. 2; p. 86, col. 2). 
proud attitude towards his superiors and teachers, he rejoices in them. When his virtuous friends have realised that he possesses a good resolve, they do not hesitate to instruct him in all discourses of pristine cognition. When they have realised that he is a receptacle, they instruct him constantly ${ }^{148}$ with great concentration in the Doctrine. After he has heard the Doctrine, he exerts himself in the accumulation of virtuous practice. Exertion in the accumulation of virtuous practice itself is exertion in the accumulation of pristine cognition.

What is exertion in the accumulation of virtuous practice? (644) He is content with little profit, little activity and few words. He sleeps neither at dawn nor at dusk and applies himself diligently to yoga. He contemplates the meaning of dependent co-origination and attempts subsequently to grasp it. His mind is unperturbed. He conquers sin. He knows when he is liberated from $\sin { }^{149} \mathrm{He}$ is free from grudge and manifestations of evil tendencies ${ }^{150}$. He performs good conduct and endeavours in virtuous practice. He is inclined to, and has a propensity for, virtuous practice. He applies himself to it as if his head and clothes were constantly alight. ${ }^{151}$

He persists in his search for pristine cognition. He is vigilant and sustains his efforts. He gains distinction and withdraws into seclusion ${ }^{152}$. He takes delight in solitude and contemplates the bliss of quietude. He cherishes the [four practice of] the noble lineage. He does not turn away from purification. He takes delight in the great joy of the Doctrine and aspires to it. He does not heed the esoteric formulae of the materialists. He is impeccably mindful in his search for supramundane dharma. When contemplating, his mind his well-focused on the meaning. ${ }^{153}$ His understanding operates in accordance with the path. He exercises constraint

148. bar chad med pa: nirantara (cf. Monier-Williams, p. 539, col. 2).

149. ltun ba las hbyun bar śes pa;

The meaning of this sentence is ambiguous since it does not indicate the scope of the attainment. That is to say, it is not clear whether it refers to the sixth abhijiñ conferring 'knowledge of the destruction of defilements' (äsravaksayajñäna), or whether it is simply an expression of the bodhisattva's control over the process of purification. The wording of the Tibetan suggests that it has a more general meaning since, according to Mvy (209), äsravaksayajñana has its equivalent in zag pa zad pa ses pa. On the other hand, the concept of 'knowledge of the purification of sin' runs arguably rather close to that of assravaksayajñana and might overlap. Since 'knowledge of the destruction of defilements' is a highly technical concept-its application being practically restricted to the attainment of arhantship or buddhahood-the taking of a more cautious approach, pointing to vague parallels only, is perhaps appropriate.

150. kun nas ldan pa med pa: paryutthāna (cf. Edgerton, p. 335, col. 2).

151. Pelliot, 977 , folio 4 b.7-5a.1:

"Contemplating the meaning of exertion, he removes afterwards the defilement of indolence-the ruin of the mind. ... He is not covered by it. He is not encircled by it. Being endowed with good conduct, he endeavours in virtuous practice. ... In this way, he persists in his search for pristine cognition."

152 hdu hdzis dben pa: samsarga

lit.: 'to be solitary as to commingling' (cf. Monier-Williams, p. 1119, col. 3).

Pelliot, 977, folio 5a.2:

"He is vigilant and does not long for honour. He does not gain distinction but withdraws into seclusion."

153. This last phrase is essentially a paraphrase of the Tibetan clause. The literal translation would run as follows: "When contemplating, he complies with understanding the meaning." See also: Pelliot, 977, folio 5a.3. 
with regard to sense-pleasure. ${ }^{154}$

He penetrates pristine cognition by way of its conditions. ${ }^{155} \mathrm{He}$ is an embellishment of modesty and chastity. He treads the path of the Buddha. He removes nescience, ignorance and the mist of delusion. ${ }^{156}$ (645) His eye of wisdom is stainless. He is fully purified. His understanding is excellent. He reveres his superiors. His mind is extremely versatile. He acquires direct knowledge ${ }^{157}$. In his attainments, he does not depend on others and he does not boast with them. He discerns alien attainments. ${ }^{158} \mathrm{He}$ undertakes wholesome actions ${ }^{159}$. He does not refute the ripening of deeds, though he knows that deeds are perfectly pure. This is the bodhisattva, mahāsattva's accumulation of pristine cognition.

Furthermore, his accumulation of pristine cognition is acquired through four kinds of giving.

(1) He gives bark of the birch tree, pencils, ink and books to reciters of the Doctrine.

(2) He gives various cushions to them.

(3) He gives all kinds of goods, shows respect and composes verses for them.

(4) He shows sincere gratitude to reciters of the Doctrine for bringing together all teachings.

These four kinds of giving augment his accumulation of pristine cognition. There are four kinds of guard that augment his accumulation of pristine cognition. What are the four?

(1) He guards the body of the reciters of the Doctrine.

(2) He guards their welfare. ${ }^{160}$

(3) He guards them when they enter into his region and district.

(4) He guards propitious objects.

These four kinds of guard augment his accumulation of pristine cognition. There are four kinds of support ${ }^{161}$ that augment his accumulation of pristine cognition. What are the four?

154. Pelliot, 977 , folio $5 \mathrm{a} .2-3$ :

"He adheres to the vow."

155. I follow here Pelliot, 977 , folio 5a.3 which reads: rkyen gyis ye ses chud pa.

156. Pelliot, 977, folio 5a.3:

"Disapproving of nescience, he does not cleanse the mist of ignorance and delusion."

157. minon sum tu ses pa: pratyaksajñāna (cf. Edgerton, p. 374, col. 1).

158. Pelliot, 977 , folio 5a.3-4:

"He does not (sic) discern alien attainments."

159. legs par bya bahi las byed pa: sukrtakarmakärin (cf. Monier-Williams, p. 1220, col. 2).

160. Omitted in Pelliot, 977, folio 5a.7.

161. ne par rton pa: upasthambana (cf. Edgerton, p. 143, col. 2)

The Mahâvastu (ii, p. 280.16-17) cites five kinds of support that enable the bodhisattva to display his noble, fearless smile (äryasmitta). These are zeal (chanda), vigour (virya), recollection (smrti), meditation (samādhi) and wisdom (prajña $)$. According to the Dbh (Daśa-bh, p. 15), the bodhisattva depends for 
(1) It is support of the teachings of the reciters of the Doctrine. (646)

(2) It is support of pristine cognition.

(3) It is support of worldly possessions.

(4) It is support of enlightenment. ${ }^{162}$

These four kinds of support augment his accumulation of pristine cognition. There are five powers that augment his accumulation of pristine cognition. What are the five?

(1) It is the power of faith in order to pay homage.

(2) It is the power of vigour in order to attain learning.

(3) It is the power of mindfulness as not to forget the thought of enlightenment.

(4) It is the power of meditation in order to gain faith in dharma-sameness.

(5) It is the power of wisdom for the sake of the power of learning.

These five powers augment his accumulation of pristine cognition. ${ }^{163}$ There are four kinds of moral conduct that augment his accumulation of pristine cognition. What are the four?

(1) It is moral conduct that is assured in the Doctrine.

(2) It is moral conduct that pursues the Doctrine.

(3) It is moral conduct that has faith in the Doctrine.

(4) It is moral conduct that transforms into enlightenment.

These four kinds of moral conduct augment his accumulation of pristine cognition. ${ }^{164}$ There

accomplishing the cittotpāda on (1) support of true instructions of the path of the stages, (2) support of instructions in the purifying impact of the six perfections and (3) support of generosity.

In the Abhidh-sam (R), p. 162, in contrast, support (upasthamba) is cited as one of eleven aspects in which the training of the bodhisattva differs from that the sravvaka, specifically with regard to the duration of the training and the ensuing need for an accumulation of virtue. See, also Kośa (ii, p. 314) where upasthambahetu is interpreted as the 'cause of maintenance' since the mahäbhüta are the cause of the continuation of the bhautika (cf. Edgerton, ärambana, p. 103, col. 1).

Judging by the ill co-ordination of these references and the lack of common ground, it is doubtful whether the Mahãyanna ever developed a theory of the bodhisattva's support. In the eyes of many, this might have seemed quite superfluous with Mahāyāna writers readily adopting the four types of reliance (pratisarana) from early Buddhism.

162. Pelliot, 977, folio 5b.1:

"It is support of intelligence (buddhi)."

163. These five kinds of power (bala) correspond to the five bala of the thirty-seven bodhipäksika dharma, viz., śraddhä, virya, smrti, samädhi and prajñă. They are treated in greater detail in section 2.10 .5 (R, folio 677.2-679.5).

164. Compare these types of moral conduct with those proposed by later exegetical writers (Bbh, p. 138.21-23), distinguishing morality of the vow (samvarasilla), morality involving the accumulation of virtue (kusaladharmasamgrăhakaśila) and morality involving efforts directed at the welfare of sentient beings (sattvārthakriyāsíla). 
are four kinds of patience that augment his accumulation of pristine cognition. What are the four?

(1) Since he exerts himself diligently to attain the Doctrine, he bears patience with the words of those who speak evil and utter slander.

(2) Since he exerts himself diligently to attain the Doctrine, he endures patiently wind, warmth, cold, heat, thirst and hunger.

(3) Since he exerts himself diligently to attain the Doctrine, he complies patiently with his instructors and preceptors.

(4) Since he exerts himself diligently to attain the Doctrine, he is patient towards the empty, signless and wishless nature of dharma.

These four kinds of patience augment his accumulation of pristine cognition. ${ }^{165}$ (647) There are four kinds of vigour that augment his accumulation of pristine cognition. What are the four?

(1) It is vigour in learning.

(2) It is vigour in retaining.

(3) It is vigour in teaching.

(4) It is vigour in application.

These four kinds of vigour augment his accumulation of pristine cognition. There are four factors of contemplation that augment his accumulation of pristine cognition. What are the four?

(1) He takes delight in seclusion

(2) And in solitude.

(3) He seeks pristine cognition and the super-knowledge.

(4) He enters the pristine cognition of the Buddha.

These four factors of contemplation augment his accumulation of pristine cognition. There

165. Of all classifications of bodhisattva practices presented in this section, it is the scheme of patience that bears closest resemblance to the divisions of later scholasticism $(B b h$, p. 189.7-11). That is to say, the first type corresponds to the category of parāpakäramarșanakșänti, representing patience supporting injury and verbal abuse at the hand of other. The second type runs parallel to the bodhisattva's willingness to put up with painful sensations caused the four elements (duhkhädhivāsanäksänti), while the fourth type, 'patience towards the empty, signless and wishless nature of dharma' is close to the bodhisattva's 'conviction of the non-arising of dharma' (anutpattikadharmaksanti) that is the highest development of patience contemplating dharma (dharmanidhyānaksänti). It is only the third type of patience, bearing with instructors and preceptors, that is not accounted for as an independent category in later writings. 
are four wisdom-manifesting dharma that augment his accumulation of pristine cognition. What are the four?

(1) He refutes the notion of nihilism.

(2) He impugns the notion of permanence.

(3) He does not challenge dependent co-origination. ${ }^{166}$

(4) He rejoices in the belief of the non-existence of the self.

These four wisdom-manifesting dharma augment his accumulation of pristine cognition. There are four dharma that augment his accumulation of pristine cognition of means. ${ }^{167}$ What are the four?

(1) He complies with the world.

(2) He complies with the sütras.

(3) He complies with the Doctrine.

(4) He complies with pristine cognition.

These four dharma become his accumulation of pristine cognition of means. There are four dharma that cause him to penetrate the pristine cognition of the accumulation of paths. (648) What are the four?

(1) It is the path of the pāramitā.

(2) It is the path of the bodhipäksika dharma.

(3) It is the Noble Eightfold Path.

(4) It is the path that leads to pristine cognition of all-knowing.

These four dharma cause him to penetrate the pristine cognition of the accumulation of paths. There are four kinds of insatiability that augment his accumulation of pristine cognition. What are the four?

(1) He is insatiable for learning.

(2) He is insatiable for instructions.

(3) He is insatiable for investigation.

(4) He is insatiable for pristine cognition.

166. Pelliot, 977 , folio 5 b.6:

"Assembling causes and conditions, he does not challenge origination."

167. Cf. Pelliot, $977,5 b .7$ which reads thabs dan ye ses kyi tshogs. 
These four kinds of insatiability augment his accumulation of pristine cognition.

Furthermore, as regards his accumulation of pristine cognition; complying with all sentient beings and with all buddha-fields, the accumulation of pristine cognition should be seen as arising from giving. The accumulation of pristine cognition should be seen as arising from morality, patience, vigour, meditation, wisdom, benevolence, compassion, joy and equipoise. Why? Because all undertakings of the bodhisattva are dependent on, as well as motivated and supported by, pristine cognition. By persisting in pristine cognition, the holder of pristine cognition becomes a universal support. Moreover, none of the evil ones obtains an occasion to harm him. He acquires not only the sustaining power of the Buddha, but he is also established in the pristine cognition of all-knowing. ${ }^{168}(649)$

These two are the bodhisattva's accumulations of merit and pristine cognition. A bodhisattva, mahäsattva who is skilled in these two kinds of accumulation courses in the Perfection of Wisdom. ${ }^{169}$

\subsection{Skill in Bases of Mindfulness}

Next, what is skill in the bases of mindfulness of bodhisattvas? They generate the four bases of mindfulness of bodhisattvas. What are the four? They generate the basis of mindfulness considering the body as body. They generate the basis of mindfulness considering feeling as feeling. They generate the basis of mindfulness considering thought as thought. They generate the basis of mindfulness considering dharma as dharma. ${ }^{170}$

\subsubsection{Skill in the Basis of Mindfulness concerning the Body}

What is the generation of the basis of mindfulness considering the body as body? $O$

168. Pelliot, 977, folio 6a.2-4:

"Furthermore, as regards his accumulation of pristine cognition; complying with all sentient beings and with all buddha-fields, also giving should be seen as the accumulation of pristine cognition. Also morality, patience, vigour, meditation, wisdom, benevolence, compassion, joy and equipoise should be seen as the accumulation of pristine cognition. ... Having persisted in pristine cognition, he gathers all sentient beings [around him]. None of the evil ones obtains an occasion to harm him and he is established in the pristine cognition of all-knowing."

169. This paragraph is missing in the Pelliot manuscript. The section that follows in Pelliot 977 on 'skill in accumulation' appears in all block-print editions of the $B d p$ at the very end of chapter eleven. In my edition, it corresponds to section 3.1 and 3.2 ( $R$ folio 686.4-690.1).

170. On the relationship between the smrtyupasthäna and prajñă, the commentary on the Arthaviniścayasütra remarks (Arthav-t (S), pp. 210.6-211.3):

"When considering the body, feeling, thought and dharma, the bodhisattva acquires a thought that is exempt from misconception (viparyāsa). He considers the body as body; that is to say, he considers it in accordance with reality; this is the sense of 'considering'. This is valid in equal measure with regard to mindfulness concerning feeling, thought and dharma. Because they take as object a personal series, a series of others and both (svaparobhayasantatyalamba$n a t v a \bar{t} t$, the bases of mindfulness have individually as own-being (svabhāva) the threefold science (traividya); that is to say, their own-being consists of wisdom springing from learning, reflection and contemplation." 
Săriputra, a bodhisattva who dwells, considering the body as body contemplates the origin, present condition and future destiny of the body:

"Alas, this body is arisen from delusion ${ }^{171}$. It is born from causes and conditions. It is motionless, inactive, non-self and without proprietor. For instance, by reason of dharma that are neither a self nor of a self, neither permanent, steadfast or abiding this body that resembles grass, bricks, wood, ass or a mirage and consists of the aggregates, sensefields and elements is empty just like the grass, tree branches, plants or forests, that too emerge from causes and conditions and are without a self or proprietor. Rather than developing a sense of owner-ship for my body, I should patiently put up with the fact that the own-being of my body is insubstantial.

What is substantial? The body of the Tathāgata is substantial. The Tathāgata's body is the body of the Doctrine. It is the vajra-body. It is imperishable and firm. ${ }^{172}$ I shall accomplish this most distinguished body of all three worlds. Though indeed this body of mine has produced sin through many offences, notwithstanding, it will become the Tathāgata's impeccable body."

Once he has duly realised thus through his powers of investigation, he guards his body-the abode of the mahäbhüta-carefully and thinks: "May this body of mine perish [complying with] every requirement whatsoever of sentient beings. May this body of mine that has arisen from the mahäbhüta become the subsistence of sentient beings through the assorted doors, bases, enunciations and enjoyments, just like the four external mahābhüta, viz., the element of earth, water, fire and wind support sentient beings through the various doors, bases, (651) enumerations, favours and enjoyments."

Although it is true that he has discerned the body to be impermanent, he truly does not weary of death and birth. Although it is true that he has discerned the body to be suffering, physical suffering does not distress him. Although it is true that he has discerned the body to be non-self, he does not weary of developing sentient beings. Although it is true that he has discerned the body to be calm, he does not enter into indifference through a calm body. Although it is true that he has discerned the body to be empty and solitary, he does not enter into nirvāna. ${ }^{173}$

When he dwells, considering the body as a body he does not consider it to be substantial or

171. phyin ci log: viparyāsa (cf. Monier-Williams, p. 974, col. 2).

172. The Rcd (p. 236.3.3-5) employs the same argument in its description of the bodhisattva's mindfulness concerning the body:

"By means of this defiled body I shall attain unassisted the body of the Tathāgata; the body of the Dharma, the body of merit and pristine cognition, the vajra-body, the blissful and non-afflicted body; a body that exalts in innumerable deeds in the triple world, a body that, when seen in its shape, appeases all sentient beings."

Descriptions of the Tathăgata's body in these terms are by no means uncommon and found in several other sūtras. See, for instance: Mahāyāna Mahäparinirvānasūtra (T 374, k.3, p. 382c27; ref. Lamotte).

173. Very similar thought is expressed in $B b h$, p. $259.15-22$. 
real. When he dwells, considering the body internally he does not permit the arising of internal, consequential defilements. When he dwells, considering the body externally he is emancipated from external, consequential defilements.

Since his body is without defilements, the bodhisattva is rich in pure physical activity. After he has purified his body, he attains a body that is adorned with the eighty secondary marks. After his body has been adorned, he converts gods and men. This is the bodhisattva's generation of the basis of mindfulness considering the body as body. (652)

\subsubsection{Skill in the Basis of Mindfulness concerning Feeling}

Again, how does the bodhisattva generate the basis of mindfulness considering feeling as feeling? ${ }^{174}$ Concerning this, the bodhisattva thinks: "Whatever I feel, it is all suffering." Even though he experiences pleasant sensations, because he realises feeling that is awakened ${ }^{175}$ by pristine cognition, wisdom and means he is not inclined towards the propensity of desire. Although affected by painful sensation, he produces great compassion for all those who are born in the evil destinies, but he is not inclined towards the propensity of hatred. Even though he is affected by feelings that are neither pleasant nor painful, he is not inclined towards the propensity of delusion. He experiences every sensation-whether it be pleasant, painful, unpleasant or painless - through a recollection subsequent to that feeling and sees their origin. In order to fully understand and appease the feelings of all sentient beings, he penetrates these himself, thinking:

"Since sentient beings do not know the origins of their feelings, they rejoice in pleasant sensations. They become angry at painful sensations. At sensations that are neither pleasant nor painful, they are confused. But me, my sensations being awakened by wisdom and pristine cognition, I have carefully purified all feelings. (653) By virtue of my accomplishments that I attained through skilful means and great compassion, I shall teach the Doctrine in order to bring all feelings of sentient beings to a final halt."

Why is it called feeling? An awakened feeling leads to happiness. A feeling that is not awakened leads to suffering. What then are awakened feelings? Concerning this, although there is no self, sentient being, life-force or person that produces feeling, feeling is attachment; feeling is appropriation; feeling is grasping; feeling is delusion; feeling is binary thinking; feeling is inclination to false doctrines. Feeling is the notion of the eye up to the notion of the mind, this is feeling. Feeling is the notion of form up to the notion of mental objects, this is

174. The $A k n-t i \bar{k} \bar{a}$ explains (p. 256.2.2-5; cf. $A k n$, p. 67.2.1-4.4):

"What is [the bodhisattva's] feeling? Persisting in mindfulness concerning feeling, he achieves transcendence beyond the three kinds of suffering and experiences an unstained, pure and peaceful feeling. Thus, it is asked how do bodhisattvas generate the basis of mindfulness considering feeling as feeling? Feeling is understood by bodhisattvas and should be contemplated. That feelings are pleasant or unpleasant is stated elsewhere."

175. rtogs pahi tshor ba. adhigamavedanā. 
feeling. Any sensation that emerges from the condition of touch in conjunction with the eye-whether it be pleasant, painful, unpleasant or painless - this is feeling. Corresponding to the former, any sensation that is linked with external or internal dharma and emerges from the condition of touch in conjunction with mental processes-whether it be pleasant, painful, unpleasant or painless - this is feeling. (654)

Furthermore, by way of enumeration feeling is one, viz., knowledge by a single moment of thought ${ }^{176}$; feeling is twofold, viz., internal and external; feeling is threefold, viz., knowledge of the past, present and future; feeling is fourfold, viz., knowledge of the four elements; feeling is fivefold, viz., reflection on the five aggregates; feeling is sixfold, viz., mistaken imagining of the six sensefields; feeling is sevenfold, viz., the seven states of consciousness ${ }^{177}$; feeling is eightfold, viz., the eight mistaken modes of practice ${ }^{178}$; feeling is ninefold, viz., the nine abodes of sentient beings ${ }^{179}$; feeling is tenfold, viz., the path of tenfold virtuous activity. ${ }^{180}$ Corresponding to the former, all this is feeling. To the degree that there exists mental construing and reflection, everything will be felt. Hence, the feeling of incalculable sentient beings is infinite.

Now, the bodhisattva who dwells, considering feeling as feeling generates pristine cognition of the feelings of all sentient beings as they arise, persist and disappear. He who knows feeling with regard to the virtuous and non-virtuous feelings of all sentient beings has generated

\section{6. sems gcig pus rnam par rig pa}

It appears that this statement is an indirect reference to the sixteen moments $(k s a n a)$ of thought that mark the practitioner's gradual cognition of the four noble truths (Kośa, vi, pp. 178-193). Rejecting the notion of gradual advance as postulated by the Sarvāstivāda (Kośa, vi, pp. 185-9), the Bdp follows the view of the Mahāsanghika and early Mahīsāsaka (Masuda, 1929, pp. 21, 59) suggesting that comprehension of the four noble truths occurs simultaneously and is not subject to measured progress. Since the reasoning on which this theory rests is very complex, I shall mention only one explanation for this proposition. According to the Aloka (ii.12, p. 171) intuition of the darsanamārga as a single-moment intuition (ekaksanäähisamaya) takes place because of the emergence of pure knowledge (anäsravjñäna). This knowledge makes known the nature of all modes and has within its scope the totality of all factors (sarvadharmavisaya). Being fully comprehensive, it allows only for the presence of one thought-moment. An excellent account of the psychological intricacies that are involved in the controversy between those who propose that comprehension (abhisamaya) takes place on the basis of a gradual progress and those maintaining that it is subject to simultaneous/instantaneous attainment has been produced by Ruegg, 1989, pp. 150-182.

177. According to the Kośa (iii, pp. 16, 21-22), the seven bases of consciousness are (1) beings diverse in body and mentation (nānātvakāyasamjñā), (2) beings diverse in body but identical in mentation (nānākāyayaiksamjiñā), (3) beings of identical body but diverse mentation (ekatvakāyanänätvasamjñāa), (4) beings of identical body and mentation (ekatvakäyaikatvasamjña $)$, (5) beings belonging to the infinitude of space (äkäśänantyāyatana), (6) being belonging to the infinitude of consciousness (vijñānānantyāyatana) and (7) beings belonging to the infinitude of nothingness (äkincanyayatana). References in the nikāya are found in D II, p. 68; III, p. 253 and in A IV, p. 39. The same list is also found in the Mvy (2289-95).

178. log par nes pahi sbyor ba: samniyojana (lit.: 'to put into effect or employment').

179. These nine abodes of beings (sattvāuāsa) consist of the seven basis of consciousness (vijñannasthiti), of the abode of beings beyond perception (asamjñisattva) and of the sphere of neither perception or non-perception (naivasamijñanäsamjiñäyatana). For canonical references, see: D III, pp. 263, 263; A IV, p. 401, (cf. Amrrt (B), p. 219).

180. Canonical sources speak of two, three, five, six, eighteen, thirty-six and one hundred and eight kinds of feeling (S IV, pp. 231-32). The most common variety is that which distinguishes between pleasant (sukha), unpleasant (dukkha) and neither pleasant nor unpleasant (adukkhäsukha) feelings (cf. Mppś, iii, p. 1174). 
the bodhisattva's basis of mindfulness considering feeling as feeling.

\subsubsection{Skill in the Basis of Mindfulness concerning Thought}

Next, what is the bodhisattva's basis of mindfulness considering thought as thought? ${ }^{181}$ (655) The bodhisattva is mindful of the thought of enlightenment; he guards it, secures it and does not turn his attention away from it. ${ }^{182} \mathrm{He}$ looks at it in this way:

"Once a thought has arisen, it disintegrates. It is induced. Since it is fickle, it does not persist internally and it does not perish outwardly. The thought of enlightenment that I produced at first has disappeared. It does not exist. It changed. It is not found in any place. Since it is not found anywhere, I am not able to retain it. The thoughts that produced my roots of virtue have also disappeared. They do not exist. They changed. They are not found in any region or quarter.

Even the thoughts that transform [roots of virtue] into enlightenment do not bear any characteristic of own-being. Thought is not discerned by thought. Thought is not seen by thought. If thought is not known by thought, what then is the thought by which I shall attain supreme and perfect enlightenment? The thought of enlightenment is not tied to the thought of roots of virtue. The thought of roots of virtue, too, is not tied to the thought of the transformation into enlightenment. The thought of the transformation into enlightenment, too, is not tied to either the thought of enlightenment or to the thought of roots of virtue."183

If he ruminates thus, he does not become terrified, frightened or fearful but thinks again:

"Truly, in the profound law of dependent co-origination the causes and retribution are imperishable. (656) Yet, even though the foundation of thought has such own-being all dharma are dependent on causes and conditions; they are motionless, inactive and non-self. Because. I act just as I wish, I shall apply myself diligently to creation ${ }^{184}$ and not weaken this foundation of thought."

What is the foundation of thought? What is creation? ${ }^{185}$ Thought is like an illusion. There is

181. On the basis of mindfulness concerning thought, the $A k n-t i k \bar{a}$ comments (p. 257.4.6-5.1; cf. $A k n$, pp. 67.4.4-68.2.5):

"What is an established (pratisthita) bodhisattva? He traverses the basis of mindfulness concerning thought as thought. He transcends all states of consciousness and accomplishes the infinite bodhisattva-meditation. Thus, it is asked what is the bodhisattva's basis of mindfulness considering thought as thought? That which is to be cultivated by the bodhisattva is the thought of enlightenment."

182 Akn-tịkä, p. 257.5.1-4:

"Unlike the practice of recollection concerned with the impermanence of one's own thought of srāvaka and pratyekabuddhas, bodhisattvas do not forget through mindfulness and unfailing memory the first thought of enlightenment."

183. We find the same argument-investigating the nature of thought and reconciling its apparent transitoriness with role of the thought of enlightenment-in the Rcd's discussion of the mindfulness concerning thought (pp. 237.4.7-38.2.1).

184. Cf. $A k n$ (p. 67.5.5) which has rnam par sgrub pa (vithapanā) for the Bdp's sgrub pa. Both texts agree on the second member of the pair, that is, sems kyi chos ñid (cittadharmatä).

185. Compare this section on cittadharmatā and vithapanā with Bdp's thirty-two pairs of mental vigour 
nobody whosoever that causes its obstruction. This is the foundation of thought. To transform all possessions after one has renounced them into the pledge that effectuates the buddha-field is creation. Thought is like a dream and bears the characteristic of calm. This is the foundation of thought. Gathering the accumulation of the vow and transforming it swiftly into intuitive knowledge of all methods is creation. Since thought disintegrates like an illusion, decay is the foundation of thought. To transform the power of patience and bravery in order to accomplish the pledge of enlightenment is creation. Since thought is solitary like the reflected image of the moon in water, solitude is the foundation of thought.

To transform all undertakings of vigour in order to accomplish all buddha-qualities is creation. (657). Thought is inapprehensible and imperceptible. This is the foundation of thought. To transform all contemplations, liberations, meditations and composures of mind into buddha-meditation is creation. Thought is beyond form. It is inobservable, intraceable and not verifiable. This is the foundation of thought. To transform knowledge of all instructions in the various wordings as requested in order to accomplish buddha-knowledge is creation. Thought arises towards various objects. This is the foundation of thought. To produce ${ }^{186} \mathrm{a}$ disposition for the roots of virtue is creation. Thought does not arise in the absence of its cause. This is the foundation of thought. To produce the mental conditions of the bodhipakssika dharma is creation. Thought does not arise in the absence of an object. This is the foundation of thought. To produce the mental conditions of the buddha-sphere is creation.

O Sanriputra, it is in this manner that the bodhisattva generates the basis of mindfulness considering thought as thought.

When he dwells, considering thought as thought he converges with thought for the sake of acquiring the super-knowledge. After he has acquired the super-knowledge, the bodhisattva perceives the thoughts of all sentient beings by means of a single thought. (658) Truly, once he has perceived them he explains the teaching of such own-being. Furthermore, when the bodhisattva dwells, considering thought as thought he converges with thought for the sake of attaining great compassion. By virtue of the attainment of great compassion, he does not weary of developing all sentient beings.

When he dwells, considering thought as thought, he does not sustain thought for the sake of achieving the cessation and final end of thought. Rather, he generates thought through the fetters of the stream of existence. Even though knowledge of the recollection of thought persists by means of dharma that settle him in certainty of the unarisen and unbecome, he does not descend on to the level of srāvaka and pratyekabuddha. And until he has accomplished all buddha-qualities he perpetuates the succession of thought. It is by virtue of wisdom that is endowed with a single moment of thought that he acquires supreme and perfect enlightenment.

(cittavirya) that distinguish between activity (pravrtti) and stillness (sthiti) of the mind ( $\mathrm{R}$, folio 474.2-76.5). 186. ñer bar sbyor ba: upasaṃhära (cf. Edgerton, p. 142, col. 2). 
O Sāriputra, it is in this manner that the bodhisattva generates the basis of mindfulness considering thought as thought.

\subsubsection{Skill in the Basis of Mindfulness concerning Dharma}

O Sāriputra, how does the bodhisattva generate the basis of mindfulness considering dharma as dharma ? $^{187} \mathrm{O}$ Sanriputra, concerning this, bodhisattvas who look at dharma with the eye of noble wisdom are not confounded until they reach the seat of enlightenment. (659)

When they dwell, considering dharma as dharma they do not see dharma of even the size of an atom that are exempt from emptiness, signlessness or wishlessness, the unborn, unarisen, non-accumulated or beingless. They do not perceive dharma of even the size of an atom that are exempt from dependent co-origination. When the bodhisattva dwells, considering dharma as dharma he perceives their foundation of being, but he does not perceive them incorrectly. ${ }^{188}$

What is the foundation of being? The truth of the non-existence of a self, a sentient being, a life-force or a person, this is the foundation of being.

What is incorrect? Belief in a self, a sentient being, a life-force or a person, the belief in nihilism or permanence and belief in origination or destruction, this is incorrect.

Again, O Sāriputra, all dharma are truth. All dharma are error. Why? Because of understanding emptiness, signlessness and wishlessness, all dharma are truth. (660) Because of mistaken inclinations to consider dharma as a self or of a self, all dharma are error. ${ }^{189}$

Now, when the bodhisattva dwells, considering dharma as reality he sees not even a dharma of the size of an atom amongst all dharma that is not a buddha-quality and becomes transformed into enlightenment, buddhahood, the path, liberation or deliverance. ${ }^{190}$ After he has realised that all dharma exist he acquires a great compassion called 'Unobstructed' 191 .

187. On the basis of mindfulness concerning dharma, the $A k n-t i k \bar{k}$ says (p. $259.2 .8-3.2$; cf. $A k n$, p. $68.2 .5-5.1$ ): "What is a purified bodhisattva? He persists in the basis of mindfulness concerning dharma. He transcends possession (paryavasthäna) of hindrances, fetters, ties, latent defilements and impurities and attains mastery over all dharma. Thus, it is asked ...."

188. According to a brief discussion of the Vaisesika understanding of dharma and adharma in the Kosia (iv, p. 7), dharma corresponds to merit and adharma to demerit. Elsewhere (Kosa, iv, p. 155; iii, p. 207), the meaning of adharma is given as stain or passion ( $r \bar{a} g a)$.

189. Philosophically, this interpretation of the nature of dharma and adharma evolves from the postulate of the sameness of all dharma (sarvadharmasamatä). Fundamentally, it rests on the proposition that "this indifferentiation (anānārthatâ) is a mark of reality because of the sole flavour of emptiness (śūnyatāyaikarasatvatt)" (Madh. vrtti, p. 375.7). On the moral level, suggesting that both dharma and adharma are causes of birth and destruction of all types of phenomena, the $B d p$ seems to follow the view of the Sarvāstivāda Abhidharma, postulating moral neutrality for dharma (Kosia, iv, p. 7).

190. $A k n-t i k \bar{a}$, p. $259.4 .7-5.4$ (cf. $A k n$, p. 68.3.5-6):

"Therefore, [because of universal emptiness, non-existence and non-apprehension] the bodhisattva who considers dharma does not see any dharma that is not a buddha-quality, deliverance, the path, liberation or the way leading out [of the triple world]."

191. ñon mons pa med pa: anāvarana (cf. Edgerton, p. 23)

In the $S i k s$ (p. 236.8), quoting the $A k n$, a samādhi bearing this name is found. This samādhi recurs in the Aloka (Obemiller (DDP), p. 36) where it signals-if accompanied by the anvayajñāna concerned with subjects (grähaka) -acquisition of the fourth nirvedhabhaggiya, that is, the laukikägradharma. It therefore constitutes the last psychic experience of laukika status and-being traditionally associated with the 
Recognising that even the defilements of all sentient beings show no trace of impurity, he considers them to be contrived.

Why? Thus penetrating true meaning, bodhisattvas are enlightened because they themselves are awakened by the insight that there is neither an accumulation of impurity nor a substance to the aggregates. The own-being of impurity is also the seat of enlightenment. The seat of enlightenment is also the own-being of impurity. Although bodhisattvas are mindful of this, they do not achieve even a little. They do not advance or secure [anyone]. ${ }^{192}$ (661) They realise that intransitoriness ${ }^{193}$ is the foundation of being. Hence, the sphere of the Doctrine is intransitory. The place where the sphere of the Doctrine is situated, there is also the sphere of sentient beings. The place where the sphere of sentient beings is situated, there is also the sphere of space. Hence, all dharma are identical with space.

When the bodhisattva dwells, considering dharma as dharma he relies on the teaching of the Buddha. Even though considering all dharma, he delights in the teaching of the Buddha. Although it is true that he is aware of destruction, he does not realise unconditioned destruction. Although it is true that he is aware of no-birth, he does not give way to the conclusions of no-birth but reappears in order to look after sentient beings.

This basis of mindfulness establishes him in mindfulness of all dharma. However numerous the dharma and dharma-designations of the srāvaka, pratyekabuddhas or buddhas are, he is established in their impeccable, unfailing recollection that is not darkened until the end of time.

This basis of mindfulness considering dharma as dharma is an infinite teaching because it does not belong to the sphere of ordinary conduct, but is included ${ }^{194}$ in all teachings of the Buddha and because it (662) appeases the minds of all sentient beings, suppresses all evil and is spontaneous awakening. O Säriputra, it is in this manner that the bodhisattva generates the basis of mindfulness considering dharma as dharma. These are the four bases of mindfulness.

O Săriputra, it is in this manner that the bodhisattva who is skilled in the four bases of mindfulness courses in the Perfection of Wisdom.

\subsection{Skill in the Factors of Enlightenment}

Next, what is the skill in the factors of enlightenment of bodhisattvas? ${ }^{195}$ The factors of

attainment in bala-allows the bodhisattva to pass into the darśanamārga. As the darśanamārga itself is taken up by the cultivation of the seven bodhyanga - the next set of practices in the $B d p$-it is probably safe to see in this reference (and, in particular, in the modification of the $A k n$, turning anāvarana from a type of compassion to a form of meditation) a further indication of a consciously perceived path-structure in the $B d p$.

192 I take the Tibetan terms ñe bar hjog pa to stand for upasthāpayanti; rab tu hjog pa for prasthäpayanti and hjog pa for sthäpayanti.

193. gnas pa ñid: sthititä (Mvy 1720).

194. yan dag par hdus pa: samavasarana (cf. Monier-Williams, p. 1157, col. 3).

195. According to the $A k n-t \bar{i} k \bar{a}$ (p. 266.1.3), the factors of enlightenment make up the path of seeing (darśanamārga): "The title to summarise these seven factors is darśanamārga." 
enlightenment of bodhisattvas are seven. What are the seven? These are the factor of enlightenment of mindfulness, the factor of enlightenment of Dharma-discernment, the factor of enlightenment of vigour, the factor of enlightenment of joy, the factor of enlightenment of tranquillity, the factor of enlightenment of meditation and the factor of enlightenment of equipoise. $O$ Săriputra, these are the seven factors of enlightenment of bodhisattvas.

What is the factor of enlightenment of mindfulness? ${ }^{196}$ It is recollection by which they consider the Doctrine mindfully, by which they examine and investigate it thoroughly, (663) by which they research, analyse and distinguish it. By that recollection they are led to the characteristic of the own-being of dharma. Again, what is knowledge of the characteristic of the own-being of dharma? It is recollection and realisation that all dharma are empty of own-characteristic. This is the factor of enlightenment of mindfulness.

What is the factor of enlightenment of Dharma-discernment? ${ }^{197}$ It is knowledge discerning the eighty-four thousand dharma-aggregates. It is discerning the Dharma just as it should be discerned, viz., discerning its teachings that are of precise meaning in terms of precise meaning, teachings that are of provisional meaning in terms of provisional meaning, teachings that are of conventional truth in terms of conventional truth, teachings that are of absolute truth in terms of absolute truth, symbolic teachings in terms of symbols and investigative ${ }^{198}$ teachings in terms of investigation. This is the factor of enlightenment of Dharma-discernment.

What is the factor of enlightenment of vigour? It is exertion to attain joy of Dharmadiscernment, purification, meditation, equipoise and the receptacle of pristine cognition; it is exertion to attain perseverance, power, valour, irreversible aspiration, strength, resolute ardour and intuitive perception of the path. (664) This is the factor of enlightenment of vigour.

What is the factor of enlightenment of joy? It is delight, joy and supreme pleasure in the Doctrine leading to fearlessness and courage. It is fearless delight that purifies not only the body and mind, but removes also impurity. This is the factor of enlightenment of joy.

What is the factor of enlightenment of tranquillity? It is pacifying body, mind and defilements, freedom from obstruction and one-pointedness while in meditation. This is the factor of

On the factors themselves, Vasubandhu comments (Akn-tikkā, p. 266.1.3-5; cf. $A k n$, p. 70.2.3-4.4): "As regards the factors of enlightenment; enlightenment is knowledge of destruction and non-origination. It has the own-being of lack of thought-construction. These seven factors, mindfulness, etc., are its causes or associates (sahāya); hence they are called factors."

Note that according to the Abhidh-sam (R), p. 118, the sahāya are associates to the factors of enlightenment and not the factors themselves (ref. Braavrig).

196. $A k n-t i k \bar{a}$, p. 266.1.6-7:

"A bodhisattva who is linked with mindfulness acquires certainty that he will reach truth and attains the factor of enlightenment of mindfulness."

197. $A k n-t i \bar{k} \bar{a}$, p. $266.2-3$ :

"A bodhisattva who is linked with discernment progresses in the factor of enlightenment of Dharma-discernment."

An identical formula is used in the commentary to introduce the remaining five factors of enlightenment. 198. rnam par gtan pa la bab pa: nirnaya (cf. Monier-Williams, p. 555, col. 1). 
enlightenment of tranquillity. ${ }^{199}$

What is the factor of enlightenment of meditation? $?^{200}$ It is a composed mind by means of which knowledge and realisation of the Doctrine becomes-not a distracted mind. It is a composed mind by means of which awakening to dharma becomes-not a distracted mind. Apart from those who apply themselves to dharma-sameness and the Doctrine, no sentient beings understand this since they are ensnared by attachment. This is the factor of enlightenment of meditation. (665)

What is the factor of enlightenment of equipoise? It is thought that is quiescent because it is not seized by dharma taking part in pleasure or discomfort, that is not diverted by worldly dharma, but dwells in perfect rest. It is thought that is free from turbulence, discomposure and anxiety, that does not take up desire or hatred, but is in harmony with the noble path itself. This is the factor of enlightenment of equipoise.

O Säriputra, it is in this manner that bodhisattvas who are skilled in the seven factors of enlightenment course in the Perfection of Wisdom.

\subsection{Skill in the Path}

\subsubsection{Skill in the Noble Eightfold Path}

Next, what is the bodhisattva's skill in the path? The path of bodhisattvas is eightfold. What are the eight? These are right view, right resolve, right speech, right conduct, right livelihood, right effort, right mindfulness and right meditation. These are the eight limbs of the path of bodhisattvas. ${ }^{201}$

What is right view? (666) It is a view that is noble and transcends the mundane realm. It

199. In several places in the Samyuttanikāya (S V, pp. 66, 104, 111) a distinction is proposed between tranquillity of the body (käyapassadhi) and tranquillity of the mind (cittapassadhi). Following this differentiation, the $D h s$ (pp. 14-5, 66) defines kayyapassadhi in terms of calmness of the aggregates of feeling (vedanä), perception (sañna a) and formations (samkhära), while explaining cittapassadhi as calmness of the consciousness-aggregate (viññäna). By implication, it is then vedanā, saññā and samkhära that link the practitioner's physical and nental experience and might be taken to bridge the attainment in joy and tranquillity -with the former pertaining to the body and the latter to the mind (Waldschmidt, 1956, p. 292, 30.27).

200. $A k n-t i \hat{i} \bar{a}$, p. 267.1.1-2:

"Meditation by means of which thusness is known through one's own [effort] and then realised; this is the factor of enlightenment of meditation."

201. Vasubandhu indicates in the $A k n-t i \bar{k} \bar{a}$ that the eightfold path constitutes the bhävanāmārga (p. 267.3.5-6):

"Out of these, the summarising title (pindärtha) 'path of cultivation' is taught by means of the noble eightfold path while its 'practice' is taught by means of perfect mental quietude and insight."

The eightfold path itself is defined as follows ( $A k n-t i \bar{k} \bar{a}$, p. 267.3.8-4.2; cf. $A k n$, pp. 70.4.4-71.2.1):

"The path is pristine cognition by means of which the ārya attain unsurpassed enlightenment.

The eight [factors], viz., right view, etc., are called limbs since they are associates of the pristine cognition of the path. They are right because they have turned away from mistaken views of the world." 
does not arise from the belief in a self, a sentient being, a life-force or a person; it does not arise from the belief in nihilism or permanence, origination or destruction. It does not arise from heretical views, starting with that which distinguishes virtue and non-virtue and ending with the view of [permanent] nirvāna; this is right view. ${ }^{202}$

What is right resolve? A resolve through which impurities such as desire, hatred and delusion, etc., prevail does not suffice. Rather, it is a resolve through which morality, contemplation, wisdom, deliverance and the knowledge and vision of deliverance come into being ${ }^{203}$; this is right resolve. ${ }^{204}$

What is right speech? It is right speech through which neither oneself nor others are distressed. It is rich in utterances of beneficial application ${ }^{205}$. It is through this speech that one penetrates path-uniformity; this is right speech. ${ }^{206}$

What is right conduct? Concerning unwholesome action; a bodhisattva does not perform action of the kind that produces evil retribution. (667) Concerning wholesome action; he performs action of the kind that produces wholesome retribution. Concerning wholesome/unwholesome action; he does not perform action of the kind that produces wholesome/unwholesome retribution. Concerning action that is neither wholesome nor unwholesome; he performs action of the kind that leads to the exhaustion of action since it produces no retribution. Hence, confidence in one's doings and diligent exertion to right action, this is right conduct. ${ }^{207}$

What is right livelihood? It is to live without abandoning the noble lineage ${ }^{208}$ or the virtues

$202 A k n-t i k \bar{a}$, p. 267.4.2-3:

"A bodhisattva who transcends binary thinking acquires right view on the path of contemplation."

203. Akn-tikiā, p. 267.5.1-2:

"Right resolve does not construct objects that generate klesa, it does not generate the origination of klesa."

204. $A k n-t i k \bar{a}$, p. 267.4.7-8:

"A bodhisattva who professes good resolve attains right resolve on the bhāvanāmārga."

205. rjes su sbyor ba: anuyoga (cf. Edgerton, p. 32, col. 2).

206. $A k n-t i k \bar{a}$, p. 267.5.1-2:

"A disciplined bodhisattva who is attracted to the bhāvanāmārga by right speech acquires moral conduct that was approved by the arya."

207. $A k n-t i \vec{i} \bar{a}$, p. 267.5.6-7:

"A composed bodhisattva who is attracted to the bhāvanāmärga by right conduct acquires moral conduct that was approved by the arya."

208. hphags pahi rigs: āryavamśa

To define right livelihood in terms of the äryavamśa is significant, since it throws some light on the $B d p$ 's position regarding the bodhisattva's sphere of conduct. The āryavamsia, literally 'lineage of noble ones' describes a set of ascetic disciplines that are held conducive to liberation. Their purpose is to lead to contentment and the eradication of desire. Although its practice is technically known as 'lineage', it is by virtue of one's way of life rather than birth that membership is attained. Unlike the notion of gotra to which one belongs by birth (for exceptions to this rule, see: $B b h, \mathrm{pp} .1-11$ ), the äryavamsa-although notionally parallel to gotra-is a matter of personal decision.

Its frequent occurrences in the nikãya suggest that the âryavamśa gained high esteem from relatively early on. Detailed discussions of the practices that belong to the äryavamsia are found, for instance, at M I, p. 2 and A II. 27, 28 (ref. Schuster). The practices that are included in the àryavamsia are (1) contentment with robes made of rags (civara $\overline{\text { ) }}$, (2) contentment with alms-food consisting of scraps (pindiyalopa), (3) contentment with roots of trees (rukkhamüla) as lodging and (4) contentment with strong-smelling urine (pütimutta) as medicine.

Besides the more explicit references, the four practices appear in number of other places in the early 
of mendicant life $\mathrm{e}^{209}$. It is to live without joking, hypocrisy or violent retaliation and to be easily satisfied with food and medicine ${ }^{210}$. It is to live without assuming negligence in one's training or to envy other persons' property, but to be content with one's own belongings. It is to live beyond reproach as it was prescribed by the noble one; this is right livelihood. ${ }^{211}$

suttas. First, all but the last practice are included in the dhutāinga (Vism, pp. 24, 30-36, 40). Second, among the practices that Devadatta wished to make obligatory for all monks, we note that it was mainly the concerns of the first three aryavamśa practices that stood at the centre of his aspirations (Vin, iii, x.1.1, Cullavagga, vii.3).

That the äryavamsia continued to enjoy high esteem is shown by Buddhaghoșa's (Vism, pp. 93-94) recommendation of four texts that should be used by monks as guides to their practice. These include besides the Ariyavamsasutta, the Rathavinitasutta (M I, p. 24), Malakasutta (Sn, iii.11) and Tuvatakasutta ( $S n$, iv. 14), all of which are concerned with issues of discipline and contentment. Similar concerns are also expressed in the seven suttas that are cited by Aśoka in his Bhäbrä edict as works that monks, nuns and lay-persons should study in detail (Warder, 1980, pp. 255-57). Finally, mirroring the ideal of practitioners who elected the disciplinarian vigour of seclusion, the arryavamsia correspond to the four types of requisites that a pratyekabuddha is allowed to possess, viz., robes, almsfood, a place to rest and medicine (Kloppenberg, 1974, p. 26). All of this suggests that the ascetic ideal that is epitomised by the four arryavams a practices-always voluntary and free from the extremes of self-mortification-enjoyed broad support among the Buddhist community during the first centuries of Buddhism.

Not surprisingly, this concern for discipline, moderation and self-control did not wane in the course of time, but maintained much of its appeal for later generations of Buddhists. In scholastic writings, the four ăryavamiśa are treated in the Kośa (iv, pp. 146-8), Mppś and the Sarvāstivāda Dharmaskandha (chpt. vi). Among the early sūtras of the Mahāyāna, they are given prominent treatment in the $U g$ (pp. 268.1.6-69.3.1), $R p$ (p. 13.17-18, p. 14.7-8) and $K p$ (pp. 13-14, 174, 179-181; §6, 123, 126). In particular, the Ug stands out for its detailed discussion. Here, they dominate practically the whole of section seven and stand at the heart of the bodhisattva's training in solitude and contentment. Two aspects of its discussion are especially noteworthy. First, there is the fact that the $U g$ 's presentation of the four practices corresponds almost verbatim to that of A II.28, pp. 26-7. This reinforces the assumption that the aryavamśa acquired great renown already in ancient times for it to enjoy the use of stockphrase in its description. Second, we note a tendency in the $U g, K p$ and $R p$ to make the arryavamsia specifically the domain of the pravrajita bodhisattva. All three texts make it obvious that they consider it elemental to the proper conduct of recluse bodhisattvas. In them the aryavamsia epitomise the basic mental disposition that is conducive to a proper attitude in training, but are nowhere near the actual attainment of bodhi. In the $K p$ their mastery is also open to those of inferior understanding and is little more than preparatory to meditation practice.

Undoubtedly, this attitude reflects the Buddha's thinking when he decreed that their practice should not be made obligatory since he thought that they were of benefit only to those who already possessed a disposition of asceticism. It appears, therefore, that the interpretation of the arryavamśa had changed little since the early days. During the incipient Mahāyana, the role of the äryavamśa is associated only with a minority of practitioners - the pravrajita bodhisattva - and is valued as a preliminary practice to meditation that instilled discipline, quietude and contentment in the adept. It is only with the rise of scholasticism, that this general appreciation became refined, leading to the detailed accounts in the Kośa and Vism.

The $B d p$ 's position on the äryavamśa does not match fully either of these strands. On the one hand, to inciude them in right livelihood would seem to assign the arryavamsia practices to the general model of Buddhist conduct and not specifically to the pravrajita environment. On the other hand, their positioning as the first practice of right livelihood suggests that they enjoyed a certain preeminence over the other factors (e.g., absence of hypocrisy, violence, jest). This prominence appears strengthened through the practices that follow after the reference to the arryavamsia. Most of them speak of moderation, contentment and moral integrity as the ideal life-style of wandering mendicants. By implication their inclusion in the general category of right livelihood would seem to point to the modest, reclusive life epitomised by the arryavamisa as the model training for the $B d p$ 's bodhisattva to follow.

209. sbyans pahi yon tan: dhütaguna (cf. Edgerton, p. 286, col. 1).

210. dgan sla ba: suposa; gso sla ba: subhara (cf. Edgerton, p. 600, col. 1; p. 601, col. 1).

211. $A k n-t i \bar{i} \bar{a}, \mathrm{p} .268 .1 .2-3$ :

"A peaceful bodhisattva who is attracted to the bhāvanāmārga by right effort acquires moral conduct that was approved by the arrya."

Most other works on the bodhipakssika include in the exposition of right livelihood as brief account of the five mistaken forms of livelihood (mithyajiviva). These include (1) hypocrisy in order to obtain alms 
What is right effort? Effort that preaches mistaken conduct, effort that leads to the propensities of defilements ${ }^{212}$ of desire, hatred and delusion-this is not intended. Rather, it is effort that-introducing to the noble path and truth-accords with the effort that establishes in the path leading to nirvāna; this is right effort. ${ }^{213}(668)$

What is right mindfulness? It is mindfulness that is well-composed, self-possessed, sincere and truthful; it is mindfulness that investigates the faults and defects of samsāra and guides the bodhisattva on the path to nirvāna; it is mindfulness that causes recollection and is not oblivious of the noble path; this is right mindfulness. ${ }^{214}$

What is right meditation? It is composure towards reality and all dharma. When one dwells in this [type of] meditation, one penetrates reality. If one dwells in this [type of] bodhisattvameditation in order to liberate all sentient beings and penetrates reality, that is right meditation. ${ }^{215}$

(kuhanā), (2) boasting (lapanā), (3) divination (naimittikatā), (4) extraction of gifts from the laity (naispeșikatā) and (5) unceasing concern for profit (läbhena läbham niścikirșatä). In the nikāya, they are found in D I, pp. 8, 67; M III, p. 75; A III, p. 111; for Sanskrit references, see: Kośavyākhyā, p. 420; Bbh, pp. 168.21-169.2; Abhidh-d, p. 309.9-11 and Siks, p. 183.15. A fine summary of the significance of the five terms is given in the Abhidh-d (p. 310.1-5):

"The five mistaken forms of livelihood constitute particular thoughts. Hypocrisy is to resort to manifold posturing in order to demonstrate qualities that one does not possess. Boasting is to show off one's qualities out of own interest. Divination is to interpret signs either favourably or unfavourably [for one's own benefit] with the pretext to pay service [to others]. Extortion is to extract favour through threats. Unceasing concern for profit is to strive for new gains by virtue of previously obtained profit."

The best analysis of the five types of mistaken livelihood in European languages is probably that by Wogihara $\left(B b h\right.$, pp. $\left.21-26^{*}\right)$. For other references of their occurrence in Buddhist literature, particularly in exegetical material, see: $M p p s$, iii, pp. 1182-3.

212. ñon monis pa bag la ñal ba: kleśánuśaya (cf. Edgerton, p. 198, col. 1)

The exact relationship between the kleśa and anuśaya is frequently glossed over in Buddhist literature. In many texts both terms are used as near-synonyms and are only inadequately distinguished. Even in scholastic works, their differences are not always made clear. According to the Dhsgr (\$ 67) and Siddhi (p. 343), the kleśa are sixfold, viz., desire (räga), aversion (pratighā), conceit (māna), ignorance (avidya), mistaken views (kudrști) and doubt (vicikitsā). In the Kośa (v, p. 2) these six factors (replacing the last two with $d r s \underline{t} i$ and vimati respectively) are said to characterise the anuśaya.

In the Sarvāstiväda Abhidharma (Jñänaprasthāna, T 26, p. 943a27; ref. La Vallée Poussin), this list of anuśaya is extended to include ten kinds of anusaya by subdividing the kudrst ti into the (1) belief in a self (satkāyadrștí), (2) false views (mithyādrșțî), (3) belief in the extremes (antagrähadrștí), (4) the esteeming of views (drstiparämarśa) and (5) the esteeming of moral and ascetic practices (sillavrataparāmarśa). Creating further subdivisions and addressing specific viewpoints, the basic list of six has been variously expanded with the highest number of anuśaya amounting to ninety-eight (Kośa, v, p. 13).

A key passage in the Kośa (v, p. 6) explains that the anuśaya are not different from the kleśa but constitute kleśa in a state of sleep. They are said to be the opposite of paryavasthana (active defilement) that is, kleśa in an awakened state. Because the anuśaya are non-manifested they are in a latent state, bearing the characteristics of a seed belonging to a person who engendered the previous klesia. While the anuśaya are the cause of the kleśa, they are not solely responsible since the kleśa depend for arising on the presence of dharma as objects and on incorrect preparation. In the words of the Kosa $(\mathrm{v}, \mathrm{p} .72)$ :

"Kleśa arise from the non-abandoning of the anuśaya, from the presence of their object and from erroneous judgement."

213. $A k n-t i \bar{k} \bar{a}$, p. 268.1.6-7:

"A bodhisattva who has gone forth to mendicant life acquires right livelihood on the bhāvanāmārga."

214. Akn-tikka, p. 268.2.1-2:

"A bodhisattva who is full of joy acquires the ability to retain words and meanings on the bhāvanāmārga."

215. As this sentence differs from the preceding one only by qualifying meditation as bodhisattva-meditation, it 
After the bodhisattva has intuitively grasped the inexhaustible path of the lord buddhas of all times he preaches, explains and fully elucidates it. This is right meditation. ${ }^{216}$

These are the eight limbs of the path of bodhisattvas. This is the bodhisattva's skill in the path.

\subsubsection{Skill in Perfect Mental Quietude and Insight}

Furthermore, as regards their skill in the path; the path of bodhisattvas is twofold. What are the two? (669) These are perfect mental quietude and insight. This is the twofold path.

What is perfect mental quietude? It is composure, serenity and stillness. It is imperturbability, restraint with regard to senses and congeniality. It is freedom from conceit, arrogance and folly. It is resoluteness, watchfulness and self-possession. It is non-delusion of mind, joy in solitude, quietude and seclusion. It is reflection on physical seclusion, mental quietude and the door to solitude. It is ease of mind and modesty. It is purity of life, excellence of practice and guarded conduct. It senses timeliness. It is contentment with food and medicine. It is analytical investigation ${ }^{217}$. It is mental poise and patient endurance of the words of those who speak evil. It is generating the thought of enlightenment at the door to yoga. It is taking pleasure in deep absorption and contemplating the branches of meditation. That is to say, it producing benevolence, acquiring compassion, persisting in sympathetic joy, assuming equipoise and attaining successively all eight [types of] meditation. This is perfect mental quietude. ${ }^{218}$

Again, the accumulation of perfect mental quietude is infinite. Guidance to that accumulation is perfect mental quietude.

What is insight? (670) It is the path of contemplation ${ }^{219}$ connected to wisdom. It is knowledge

appears that the $B d p$ intends to point to a difference between the srāvaka-meditation and the bodhisattvameditation. That is to say, the srāvaka is concerned with his own liberation and may pass from the state of meditation into nirvāna, but the bodhisattva's motivation of his meditative practice is the goal of universal liberation.

216. Akn-tikiā, p. 268.2.6-7:

"A bodhisattva who is of great power attains the accomplishment of his intended aims on the bhāvanāmārga."

An Italian translation of the parallel passage in the $A k n$ (as preserved in the Arthav) was composed by Alfonsa Ferrari, 1944, pp. 603-4. I have reproduced the Sanskrit of that passage in the notes to my edition. Note, however, that her transiation is based on the Tibetan, since in 1944 the Sanskrit text of the Arthav was not yet available.

217. so sor rtog pa: pratyaveksāa

For a definition of pratyaveksă , see: $M B T$, iii, pp. 3, 5, 14-15, Bbh, p. 109.18-22.

218. According to the $B b h$ (p. 260.15-23), samatha falls into four categories. First, there is samatha that is knowledge indicating the absolute truth (paramārthikasämketikajñäna). Second, there is samatha that-being the fruit of the first type-is effortless perception of discursive proliferation (prapañca). Third, samatha is characterised as penetration of the ineffability of things and their signlessness. Fourth, by cleansing the mind of all discrimination, samatha leads to the essentially uniform single flavour of all dharma (sarvadharmasamata). By means of these four aspects of samatha, its practice accomplishes the pristine cognition of enlightenment. Other, less specific, classifications of samatha are found in the Samdhis (ELa), p. 93.1-10.

219. sgom pahi lam: bhāvanāmārga

At first sight, this reference to the path of cultivation (bhävanāmārga) is surprising. According to the Siddhi (p. 569) vipaśyanā constitutes the central vision of the darśanamärga and plays a decisive role in 
seeing the imperturbability of dharma. It is knowledge seeing that there is no sentient being, life-force or person and that the aggregates are illusory. It is knowledge seeing that the elements are like the sphere of the Doctrine. It is knowledge seeing that the sensefields are like an empty city and that the eye scrutinises discursively. It is knowledge seeing that dependent co-origination is non-contradictory and that it is beyond the heretical view stipulating the existence of a sentient being. It is knowledge seeing that causes and effects ripen. It is knowledge seeing the manifestation of the fruit-attainment. It is knowledge seeing that penetrating reality is attainment.

Again, as regards insight; it is accurate seeing of dharma. It is seeing the suchness of dharma. It is seeing the unfailing thusness of dharma. It is seeing the emptiness, signlessness and wishlessness of dharma.

Again, as regards insight; it does not consist of seeing through causes or the absence of causes. It does not consist of seeing through causes that arise, abide and perish or that are mentally construed; and although it is insight, one sees not even a little. ${ }^{220}(671)$

Furthermore, as regards insight; it is seeing by seeing and non-seeing by seeing. When one sees in this manner, then one sees rightly. When one sees rightly, one acquires skill in insight. Now, concerning the insight of bodhisattvas; they neither fall into karma-producing activity nor attend to accumulating roots of virtue; this is the insight of bodhisattvas. ${ }^{221}$

the establishing of 'seeing'. Indeed, most texts agree that the practice of vipasyana belongs to the darśana$m \bar{r} r g a$ and not to the bhāvanāmārga (examples, see: Ruegg, 1989, pp. 186-88). It could, however, be argued that bhāvanämärga constitutes essentially a refined renewal of the 'non-constructive gnosis' (nirvikalpajñāna) first intuited during the darśanamārga (Siddhi, p. 606). Judging by the characterisation of vipaśyana in the $B d p$, it is probable that it is this parallelism that is played at, since the content-affirming cognition of the emptiness, sameness and ultimate non-existence of dharma-corresponds to the definition of the bhävanamärga as "intuition dominated by supreme wisdom that is engaged in pondering, investigation and contemplation of the unreality of the separate elements of existence, their non-substantiality and relativity" (DPP, pp. 41-42). In the $B b h$ (pp. 109.7-110.4) both samatha and vipasyana play a part in the cultivation (bhāvana $)$ of balagotra, leading to the elimination of evil dispositions and purification of the vision of knowledge. This might explain why we find in several texts (e.g., $A k n-t i k \bar{a}$, p. 267.3.5-6, Abhidh-sam (R), p. 126) that the cultivation of samatha and vipasyana is placed at the end of the bhävanāmärga, indicating the final consummation of non-constructive gnosis.

220. The syntax of this passage is ambiguous and I am not certain whether my translation represents its chain of reasoning accurately. The commentary on the $A k n$ is of little help here, since the crucial portion is not found in the root text ( $A k n$, p. 71.3.5-8; $A k n-t i k \bar{a}$, pp. 268.4.1-269.5.6). However, some light is shed on the meaning of this passage by a paragraph in the Samdhis (ÉLa) (pp. 90.21-91.17) that discusses the ways in which thought perceived during meditation differs from ordinary thought.

221. Like śamatha, also vipaśyana displays four levels of operation. First, at the lowest level, vipaśyanā encompasses all four aspects of samatha. Second, vipaśyanā removes the remaining mistaken mental assumptions (samāropa) concerning dharma. Third, vipaśyanā eradicates all blame and contradiction (apavāda) and fourth, through infinite methods of differentiation vipaśyanā penetrates dharma analysis (Bbh, pp. 260.23-261.5).

Compare these four types of vipasyana with the three types that are proposed in the Samdhis (ELa) (p. 92.14-29). Here, we learn that vipaśyanā may either spring from notions (nimittamayĩ), striving (prayeșanāmayj) or from analytical investigation (pratyavekssanämayĩ). The first is concerned with images that carry reflection (vikalpabimba) perceived during meditation. The second addresses dharma that the bodhisattva penetrated only partially through wisdom. The third type of vipaśyana investigates accurately the Dharma in order to reach the bliss of enlightenment. Further material on the various divisions and aspects of samatha and vipaśyana is found in the Abhidh-sam (R), p. 126. 
It is in this way that the bodhisattva who is skilled in perfect mental quietude and insight courses in the Perfection of Wisdom.

\subsubsection{Skill in Perfect Efforts}

Furthermore, as regards skill in the path; the path of bodhisattvas is fourfold. What are the four?

They generate the keen wish that bad, unwholesome dharma that have hitherto not arisen are not produced. They strive and apply themselves diligently, they control their mind and endeavour zealously to that end.

They generate the keen wish that bad, unwholesome dharma that have already arisen are abandoned. They strive and apply themselves diligently, they control their mind and endeavour zealously to that end.

They generate the keen wish that virtuous dharma that have hitherto not arisen are produced. They strive and apply themselves diligently, they control their mind and endeavour zealously to that end.

They generate the keen wish that virtuous dharma that have already arisen persist, reappear, (672) prevail and endure. They strive and apply themselves diligently, they control their mind and endeavour zealously to that end. ${ }^{222}$

'He generates the keen wish that bad, unwholesome dharma that have hitherto not arisen are not produced' is an expression for correct reflection. 'He strives and applies himself diligently to that end' is an expression for not abandoning this correct reflection. 'He controls the mind and endeavours zealously to that end' is an expression for correct, careful investigation. Why? Because correct practices do not manifest unwholesome dharma.

What are unwholesome dharma? Unwholesome dharma are the detriment of moral conduct, meditation and wisdom. What is the detriment of moral conduct? Dharma that corrupt moral conduct and some others that impair it, (673) viz., dharma that are detrimental to the moralityaggregate, these are the detriment of moral conduct.

What is the detriment of meditation? Dharma that corrupt religious practice and some others that distract the mind, viz., dharma that are detrimental to the meditation-aggregate, these are the detriment of meditation.

222. Playing at the ambiguity of the word-formation of prahānalpradhāna, Vasubandhu comments (Akn-tikka, p. 260.5.4-6):

"It is fitting to call 'bad, unwholesome dharma that have hitherto not arisen are not produced" and 'those that have already arisen should be abandoned' perfect abandoning (samyakprahāna). But how can 'so that virtuous dharma that have hitherto not arisen are produced' and 'those that have arisen should endure' be called perfect abandoning? To designate the two in this way appears illogical, but there is no inconsistency here since 'perfect abandoning' is taken to mean to abandon the detriment (vipaksaprahāna), to produce and make the virtuous dharma endure and to abandon the detriment that takes place in order to produce and make endure [virtuous dharma]." 
What is the detriment of wisdom? Dharma that corrupt vision and some others that obscure his vision overwhelmingly, viz., dharma that are detrimental to the wisdom-aggregate, these are the detriment of wisdom. These are bad, unwholesome dharma.

Due to correct reflection he generates the keen wish that such bad, unwholesome dharma are abandoned. He strives and applies himself diligently, he controls his mind and endeavours zealously to that end. Hence, these unwholesome dharma do not accumulate in his mind and do not prevail in any region or quarter.

He perceives that these unwholesome dharma that-wandering in the mind-have arisen from conditions and obstructions, viz., from desire by way of the disposition of affection, from hatred by way of the disposition of anger and from delusion by way of the disposition of ignorance. Then, the disposition of correct reflection acts to appease desire by way of contemplating ${ }^{223}$ impurity, to appease hatred by way of contemplating benevolence and to appease delusion by way of contemplating dependent co-origination. ${ }^{224}$ Pacification of these impurities is abandoning after having qualified them. ${ }^{225}$ One who abandons does not apprehend anything. (674) Since he is aware that all dharma are uniform, because of that, he abandons correctly. This is the second right effort.

Again, the expression 'he generates the keen wish that virtuous dharma that have hitherto not arisen are produced. He strives and applies himself diligently, he controls his mind and endeavours zealously to that end' has an infinite basis. Why? Because the virtuous dharma that should be accomplished by the mahāsattva, bodhisattva are incalculable. Here, 'keen wish' is the foundation of all roots of virtue. 'Acquisition of diligence' is the foundation of all roots of virtue. 'Perseverance ${ }^{226}$ in controlling the mind' is the foundation of all roots of virtue. ${ }^{227}$ This is the third right effort.

Again, 'he generates the keen wish that all virtuous dharma that have already arisen persist, prevail and endure. He strives and applies himself diligently, he controls his mind and endeavours zealously to that end' is an expression for the roots of virtue that have been transformed into enlightenment.

Why? Roots of virtue that have been transformed into enlightenment endure until he has

223. The 'word 'contemplating' (tib.: sgom pa) is not found in the Tibetan text, but is to be supplied on contextual grounds.

224. Compare this proposition with the view expressed in the Siddhi (pp. 359, 351) that defilements of speculation (parikalpitaklesia) can be abandoned through seeing (darśana) because they are coarse and hence easily abandoned while innate defilements (sahajakleśa) because they are difficult to abandon are eliminated through contemplation (bhāvanāa).

225. tha sñad du btags pahi phyir (lit.: 'after having named them')

The idea behind this thought appears to be that the bodhisattva cannot proceed to eradicate unwholesome dharma until he has positively identified them.

226. ñam su len par byed pa: ästhitikriyā (cf. Edgerton, p. 111, col. 2).

227. Most other works do not elaborate the differences between the two poles of the samyakprahanna. For instance, in the $K p$ (p. 139; $\S 95$ ) the four perfect efforts are collectively the remedy (cikitsā) that prompts the abandonment of non-virtuous dharma and leads to the fulfilment (pāripüri) of all virtuous dharma. 
settled on the seat of enlightenment. Why? Because a thought thus produced is not dependent on the triple world. (675) Roots of virtue that depend on the triple world perish. Why? Because a thought thus produced is dependent on the triple world. All roots of virtue that are transformed into all-knowing are independent of the triple world and do not perish. This is the fourth right effort. ${ }^{228}$

It is in this manner that the bodhisattva who is skilled in the fourfold path courses in the Perfection of Wisdom.

\subsubsection{Skill in Faculties}

Furthermore, as regards skill in the path; the path of the bodhisattva is fivefold. What are the five? These are the faculty of faith, the faculty of vigour, the faculty of recollection, the faculty of meditation and the faculty of wisdom. ${ }^{229}$

What is the faculty of faith? It is faith through which he gains confidence in four dharma. ${ }^{230}$ What are the four?

\section{(1) While in samsära, he has faith in worldly right view ${ }^{231}$. He relies on the ripening}

228. For the $A k n-t i \bar{k} k \bar{a}$, the attainment of the four efforts mirrors the bodhisattva's progress in vigour. To begin with, during the first perfect effort, the bodhisattva exerts himself to produce the antidote to unwholesome dharma, viz., vigour (p. 260.5.7). Second, in order to abandon those bad dharma that have already arisen, he appeases them (p. 262.1.2-3). Third, now in possession of vigour, the bodhisattva promotes the becoming of wholesome dharma (p. 262.2.7-8). Fourth, being established in vigour, he consolidates those wholesome dharma that have already arisen (p. 262.3.6-7).

229. An Italian translation largely paralieling our 'skill' in faculties (as cited in the Arthav from the $A k n$, but made on the basis of the Tibetan) was composed by A. Ferrari (op. cit., pp. 601-2). I have reproduced the Sanskrit of that passage in the notes to my edition of chapter eleven.

230. The section of 'skill' in faculties is one of the few passages of the $B d p$ that are extant in the Sanskrit. It is found in the Siks citing from the $A k n$ (pp. 316.13-317.13). An abbreviated Sanskrit version of the parallel passage in the $A k n$ is also found in the Arthav (S), pp. 31.6-33.2 and in its commentary (Arthav-t (S), pp. 223-25).

According to the $A k n-t i k \bar{a}$ (p. 263.5.4-5):

"A bodhisattva who posseses supreme faith progresses in the faculty of faith. Supramundane

faith is superior to mundane faith, it is distinguished, greater and unsurpassed."

231. laukika samyagd!stit: 'worldly right view'

According to the commentary on the Arthav, faith in worldly right view refers to the bodhisattva's belief in the existence of the other world (paraloka) and pertains to laukika consciousness (Arthav-t $(S)$, pp. 223-25). Merely concerned with the bodhisattva's receptivity to, and knowledge of, the structure of samsāra, it is to be distinguished from the samyagdrști of the āryāstāngamārga (Kośa, vi, p. 290). The Sarvāstivāda understood laukika samyagdrsți as 'prajñā associated with (samprayukta) mental perception (manovijinana)' that allows for vision of dharma. Wholesome by nature, but impure (säsrava) it is not the right view of the arhant which is always pure (Kośa, ii, p. 81). This would establish the indriya in the $B d p$ as pertaining to the laukika consciousness-a possibility that is acknowledged by the Sarvāstivāda (Bareau, 1955 , p. 143).

The issue of the feasibility of 'worldly right view' is hotly debated and the Sarvāstivāda view remained by no means unchallenged. Criticism came, for instance, from the Theravāda tradition, arguing that there exists neither a laukika right view nor a laukika faculty of faith (op. cit., p. 66). For them, all mundane qualities - be it faith, vigour, mindfulness, meditation or wisdom - exist, by definition, outside the way to deliverance. As such, they are clearly distinct from the indriya, because they do not fulfil the purpose of the indriya, namely, the abandonment of delusion and extermination of desire that can only be achieved through pure wisdom and pure faith (op. cit., p. 67). The $A k n-t i t k \bar{a}$ (p. 264.1.2-5), defines 'worldly right view' as perception of the conduct of ignorant laymen, as knowledge of the ripening of deeds in retribution 
of deeds and refrains from sinful actions for the sake of life.

(2) He has faith in the bodhisattva training and, once embarked on this training, does not long for another vehicle.

(3) He has faith in the precise meaning of the absolute truth, in the profound law of dependent co-origination, in investigation concerning the sentient being and in the notion that all dharma bear the characteristics of emptiness and signlessness. (676) He does not harbour inclinations towards any heretical belief. ${ }^{232}$

(4) He has faith in all buddha-qualities, in the powers and assurances. After he has heard of them, he becomes convinced and gathers these qualities trustingly. This is the faculty of faith.

What is the faculty of vigour? He produces dharma in that he has faith through the faculty of vigour; this is the faculty of vigour. He retains dharma that he gathered with vigour through the faculty of recollection; this is the faculty of recollection. He focuses his thought by means of the faculty of meditation on dharma that he retained through the faculty of recollection; this is the faculty of meditation. He examines by means of the faculty of wisdom dharma on which he focused his thought through the faculty of meditation; knowledge of these dharma is the faculty of wisdom.

It is in this way that his five faculties are connected with each other and cause him to accomplish all buddha-qualities. They cause him also to attain the stage of prediction. For instance, just like those who possess the five transcendental super-knowledge do not predict a foetus in the womb until he has attained male or female faculties, (677) in the same way also the lord buddhas do not predict bodhisattvas until they have attained these five faculties. ${ }^{233}$

and as knowledge of existence of the triratna. The issue of the laukika/lokottara distinction does not figure in the $A k n-t i k \bar{a}$ 's explanation of the passage on the s'raddhendriya beyond the statement that worldly observance of sraddha , etc., contains the preconditions for the indriya to become a transcendental practice (pp. 263.5.4-6, 264.3.4).

232. lta bar byas pa: drstikrta (cf. Edgerton, p. 269, col. 2).

233. This allusion to the prediction of buddhahood refers no doubt to the fourth and last prediction of the bodhisattva. Being public and made in the presence of the person concerned (sammukhapudgalavyäkarana), it is only conferred after the bodhisattva has developed the spiritual indriya (that, according to Kumārajiva, are of lokottara rank) and observes constantly the brahmacarya ideal, when he has attained the conviction of the non-arising of dharma (anutpattikadharmakșänti) and resides on the acaläbhümi (Sgs, pp. 212-13; $M s l$, p. 166.9-17; Bbh, p. 290.6-7).

The preceding three vyākarana are explained as follows: The first prediction (anutpāditabodhicittotpādavyākarana) is conferred on a person who abides in the lineage of the buddhas (gotrastha) but has not yet generated the thought of enlightenment. He is endowed with weak faculties (tiksnendriya) but of honest aspiration (udärādhimuktika). Such a person is identified in the five destinies by the Buddha through his great sight (apratihatabuddhacakșus) and prophesied to generate the bodhicitta in due course. The second prediction is conferred on a bodhisattva who has already generated the thought of enlightenment (upāditacittavyäkarana). It is conferred on those who have developed their roots of virtue, who have planted and cultivated the seed of enlightenment, who possess acute faculties, who accomplish superior conduct (krtacary $\vec{a})$ and show compassion towards beings. At this stage, their attainments are already irreversible (avaivartika) and free from the eight unfavourable conditions of birth (astakssana). The third prediction (asamakșavyäkarana or rohavyäkarana) is secret in the sense that it is only known to the 
This is his fivefold path. It is in this way that the bodhisattva who is skilled in the fivefold path courses in the Perfection of Wisdom.

\subsubsection{Skill in Powers}

Furthermore, O Sāriputra, what is the bodhisattva's skill in the fivefold path? The five limbs are the power of faith, the power of vigour, the power of recollection, the power of meditation and the power of wisdom. ${ }^{234}$

What is his power of faith? It is faith, confidence and devotion that is invincible. Even if Māra were to assume the appearance of the Buddha and approached [the bodhisattva], someone who has faith in the pristine cognition of the Doctrine would tell them apart, saying: "These teachings are not the Doctrine of the Buddha." Even if he deters him and dissuades him from his resolution, by persisting in thorough investigation the mahäbhüta are completely transformed. However, this does not happen to a bodhisattva who trusts the power of faith. Thus, Māra cannot separate him from the bodhisattva's power of faith.

What is the bodhisattva's power of vigour? Whatever vigour they acquire and however many virtuous dharma they practice, although they attain a degree of firm power in these, the worldings including the gods are not able to repulse, describe or generate the degree of his power unless they are liberated in his place ${ }^{235}$. (678) This is the bodhisattva's power of vigour.

What is the bodhisattva's power of recollection? In whatever state or dharma his mind is established through the bases of mindfulness, no defilements whatsoever can perturb or distract him from them. Through the force of the power of recollection he overcomes all defilements. His recollection is truly invincible. This is the bodhisattva's power of recollection.

What is the bodhisattva's power of contemplation? He practises with composure in the midst of all bustle of worldly affairs. When he reflects on all sounds of worldly paths, the thicket of sound does not become an impediment to his first contemplation. ${ }^{236}$ Although he

assembly, but not to the bodhisattva concerned. The reason usually given in support of this secrecy is that, if conferred personally, the bodhisattva might forfeit his vigour in anticipation of what is by now certain buddhahood. On the other hand, the buddha's address to the assembly is meant to provide inspiration to the audience, to sustain their interest and to remove all remaining doubt of the feasibility of the goal ( $\dot{S g s}$, pp. 202-213).

234. The difference between the practice of the indriya and bala is that (Akn-tikäa, p. 264.4.3-6):

"When treated as faculties [the bodhisattvas] attain only mastery in realising and fulfilling the practices in which one should have faith, etc., but they are not such that they overcome their antitheses. When treated as powers, however, faith, etc., provided that they are cultivated and purified, gather force and become a bala in order to overcome its antitheses, viz., distrust, etc."

This explanation runs very close to the reasoning that is given in the Abhidh-sam (R), p. 123, where we learn that the pañcabala are called power because they eliminate the danger posed by their antitheses and because of their distinction.

235. The last subclause represents only an approximate translation of the Tibetan phrase gnas der ma bsgral gyi bar $d u(\mathrm{R}$, folio 678.1). A more literal rendering would be: "unless they are removed from that place".

236. The allegory likening sound to a thicket is also found in the Kathāvatthu (pp. 202, 572-3; ref. Braavrig). 
discriminates when pursuing virtuous investigation, it does not become an impediment to his second contemplation. Although delight and happiness arise in him and persist, it does not become an impediment to his third contemplation. Although he is not indifferent for the sake of developing sentient beings and to uphold the holy Doctrine, it does not become an impediment to his fourth contemplation. (679) When he dwells in these four contemplations, he is invincible by virtue of his contemplation and liberation. He does not renounce the state of contemplation and is not reborn by reason of the power of contemplation. This is the bodhisattva's power of contemplation.

What is the bodhisattva's power of wisdom. It is pristine cognition that is unconquerable by mundane and supramundane dharma. As soon as the bodhisattva is born in this world, he accomplishes without a teacher all excellent practices, formidable actions and arduous attainments in every manual skill. Indeed, it is by means of these supramundane dharma that he delivers the worlds. Gods or men cannot defeat these dharma since they originate in the bodhisattva's power of wisdom and pristine cognition. This is the bodhisattva's power of wisdom. This is the other fivefold path.

It is in this manner that the bodhisattva who is skilled in these five limbs courses in the Perfection of Wisdom.

\subsubsection{Skill in Solitary Wandering}

Furthermore, in brief, the path of bodhisattvas is solitary ${ }^{237}$. That is to say, it is a path that is traversed alone. The bodhisattva is unaccompanied and on his own. (680) Being without companion, he puts on his armour with the resolution that upholds the force of his diligent power for the sake of unsurpassed and perfect enlightenment. He is self-sufficient and does not dependent on others. ${ }^{238} \mathrm{He}$ practises all by himself. He excels by virtue of his own power. Having put on a hardened armour, he reflects:

"I shall achieve that which no other sentient being has achieved. I shall achieve that which no other noble one or newly-set-out bodhisattva has achieved. Generosity is not my companion, but I am a companion of giving. ${ }^{239}$ Moral conduct, patience, vigour, meditation and wisdom are not my companions, but I am their companion. I am not to be raised by the perfections, but the perfections are to be raised by me. Corresponding to the former, I shall meticulously

237. mgo gcig pa: ekāmśa (cf. Edgerton, p. 153, col. 2).

According to the $A k n-t i \bar{k} k \bar{a}$ (pp. 271.4.4-272.2.1), the bodhisattva who pursues solitary wandering approaches enlightenment. He practices his training effortlessly and is distinguished by four traits:

"A bodhisattva who practices without effort is of four kinds. First, he is unable to dispense (aviksipa). Second, he has attained patience (kșāntipräpta). Third, he persists in equality (samatâvihärin) and, fourth, he is free from hindrances (nirāvarana)."

238. $A k n-t i \grave{i} k \bar{a}$, p. 272.1.1:

"A bodhisattva who is unable to dispense, strives to attain mundane and supramundane qualities only for himself."

239. $A k n-t \bar{t} k \bar{a}$, p. 272.1.3:

"A bodhisattva who has attained patience, purifies the perfections by himself." 
understand all roots of virtue, that is, I shall not be raised by any roots of virtue, but all roots of virtue shall be raised by me. ${ }^{240}$ Once I took a seat on the vajra-throne without recourse to such dharma $a^{241}$ and defeated Māra with his host single-handedly, I shall acquire supreme and perfect enlightenment by means of wisdom that is furnished with just one moment of thought."242 (681)

Earnest and determined practice ${ }^{243}$ to that end, this is the bodhisattva's solitary wandering along the path. It is in this manner that one who is skilled in the bodhisattva's solitary wandering along the path courses in the Perfection of Wisdom. This is the bodhisattva's skill in the path.

It is in this manner that the bodhisattva who is skilled in the path courses in the Perfection of Wisdom.

\subsection{Skill in Dependent Co-origination}

Next, what is the bodhisattva's skill in dependent co-origination? After the bodhisattva has thus retreated into solitude and become absorbed in meditation, he ponders:

"What is the origin of this whole mass of suffering?" Then, he reflects: "Because superficial reflection ${ }^{244}$ has arisen, ignorance arises. Because ignorance has arisen, karmic formations arise. Because karmic formations have arisen, consciousness arises. Because consciousness has arisen, name-and-form arise. Because name-and-form have arisen, the six internal sensefields arise. Because the six internal sensefields have arisen, contact arises. Because contact has arisen, feeling arises. Because feeling has arisen, thirst arises. Because thirst has arisen, grasping arises. Because grasping has arisen, becoming arises. (682) Because becoming has arisen, birth arises. Because birth has arisen, old-age-and-death arises. Because old-age-anddeath has arisen, suffering, lamentations, misery, grief and despair arise."

And again, he reflects: "I know that just as all these dharma that emerge from causes of virtue, non-virtue, stillness and nirvāna are still, inactive and non-self and arise from conditions-sentient beings establishing by cause of action faculties that are the cause of correct

240. Akn-tịkä, p. 272.1.4-5:

"A bodhisattva who persists in sameness attains the four means of conversion, dharma that ripen sentient beings."

In the $S g s$ (pp. 129-31), the Buddha addresses a brief discourse on the identity and non-reality of the Tathāgata to a Brahmā god called Samatāvihārin. Arguing from the empty and illusory nature of dharma, he shows that all dharma are in fact same-an attribute that he then applies to the Tathagata. Having comprehended the gist of this teaching, Samatāvihārin, advancing to the eighth stage, gains at the end the 'conviction of the non-arising of dharma'.

241. According to the $A k n-t i k \bar{a}$ (p. 272.1.7-8), dharma should here be taken to include mundane and supramundane qualities (guna), the six perfections and four means of conversion.

$242 A k n-t i k \bar{a}$, p. 272.1.6:

"A bodhisattva who is without hindrances overcomes the hindrances so that he attains supreme enlightenment by himself."

243. nes par rtog pahi bsam pahi sbyor pa: avakalpanāśayaprayoga.

244. tshul bzin ma yin pa: ayoniśa (cf. Edgerton, p. 64, col. 2)

Cf. $S b h$, Wayman, 1961, p. 170. 
knowledge and by cause of fruition of correct knowledge superior practice ${ }^{245}$-in the same way arise the assembled causes for the acquired and non-acquired dharma." This is the bodhisattva's skill in dependent co-origination.

Then, he reflects: "But, what is cessation? Because superficial reflection has ceased, ignorance ceases. Only when by reason of the cessation of ignorance karmic formations have come to a final halt, only then ceases this whole mass of suffering."

It in this way that knowledge with regard to this [causal flow] becomes skill in dependent co-origination.

Then, he reflects: "But, all dharma are subject to causes, conditions and their combination. What is subject to causes, conditions and their combination is not the basis of a self, a life-force or a person. (683) It is without reckoning whatsoever."

Such reflection is skill in dependent co-origination. It is in this manner that, as conditions for his enlightened disposition, the bodhisattva raises all buddha-qualities and discerns that these conditions are truly exhausted and ceasing; but, for the sake of looking after sentient beings he attains also non-cessation and non-exhaustion. This is the bodhisattva's skill in dependent co-origination.

\subsection{Skill in all Dharma}

What then is the bodhisattva's skill in all dharma? As regards the sum total of dharma; it comprises conditioned and unconditioned dharma. Thus, the bodhisattva should be skilled in the conditioned and unconditioned.

What is skill in the conditioned? His predispositions of body, speech and mind are pure. He transforms the virtuous [predispositions] ${ }^{246}$ of body, speech and mind into all-knowing by reason of discerning them as unconditioned enlightenment; this is skill in the unconditioned.

245. The meaning of this sentence is rather obscure. If one were to go by sense only, it would appear that the Tibetan have misinterpreted this passage, translating a bahuvrhi compound as a tatpurușa compound (private communication with David Ruegg).

Vasubandhu's comments on this section run as follows ( $A k n-t i k k \bar{a}$, p. 206.2.6-3.3; cf. $A k n$, p. 54.3.5-7):

"If [the bodhisattva] knows that dharma are not only exhausted but also arise from the cause of unceasing action, thinking: 'Sentient beings who act in correct knowledge that penetrates the cause of faculties and think: 'This is the origin of the cause of faculties, this is the origin of the cause of action', are established in the cause of spiritual fruition. Because the faculties themselves are the cause that prompts and establishes virtue, non-virtue, samsära and nirvāna, it is the cause of faculties. In this way, dharma emerge from the cause of faculties, but the bodhisattva] perceives that the agent, etc., is not the object acts in correct knowledge that penetrates action-the cause of faculties. Although they are all virtue, non-virtue, samsāra and nirväna and emerge from the cause of faculties and action, virtue, etc., are established as action and faculties - the cause of spiritual fruition.' This is 'skill' in dependent co-origination. It is in this way that 'skill' [seeing] that birth is the origin of causes because it turns into a force that is able to produce fruits after having gathered causes and conditions perceives spiritual fruition as birth."

Other examples that correlate the indriya with pramāna are found in the Lankāv (pp. 133.9, 151.6, $190.4-6,242.9)$.

246. $A k n-t i \grave{k} \bar{a}$, p. $218.2 .5-3.1$. 
Furthermore, as regards skill in the conditioned; (684) it is gathering the five perfections that lead to the perfection of wisdom, viz., the perfection of giving, morality, patience, vigour and meditation. Again, due to knowledge of the unconditioned, he does not depreciate the perfection of wisdom with the five perfections; but, aspiring to skill in the entire accumulation of perfections and to unstained enlightenment, he transforms them into all-knowing; this is skill in the unconditioned.

Furthermore, as regards skill in the conditioned; it is attracting sentient beings by means of all-penetrating light-rays that are directed at all of them and through the four means of conversion. Because he is free from conceit, not believing in a self, he is skilled in the means of conversion; and since he aspires to unconditioned enlightenment, he transforms them into all-knowing; this is skill in the unconditioned.

Furthermore, as regards skill in the conditioned; he does not cut off the fetters of the stream of existence, but rids himself of the impurities of the stream of existence; he continues practices that are connected to enlightenment without taking up the practice of laymen who observe only one of the pañcasilla ${ }^{247}$; this is the skill in the conditioned.

Knowing that he should be acquainted with the teachings of emptiness, signlessness and wishlessness, he is manifestly skilled in them; (685) and although he settles in enlightenment without depending on others, he does not realise the unconditioned; this is skill in the unconditioned.

Furthermore, to be unaffected by the impurities of worldly conduct in spite of acting in the triple world, this is skill in the conditioned. Not to fall into the sphere of deliverance, in spite of knowing pristine cognition that liberates from the triple world; this is skill in unconditioned.

As regards skill in all dharma; it is an expression for 'all-knowing'. Since the attainment of realisation that arises from pristine cognition of all-knowing does not lead to liberation if it lacks wisdom or skill, on account of that, he is skilled in all dharma. It is in this manner that the bodhisattva who is skilled in all dharma courses in the Perfection of Wisdom. ${ }^{248}$

O Sāriputra, it is in this way that a bodhisattva, mahāsattva who persists in the Bodhisattvapitaka and courses in the Perfection of Wisdom and-being skilled in discerning wisdom-is truly proficient in these ten kinds of skill courses in the Perfection of Wisdom.

247. sbyor ba phyogs gcig pa: ekadeśaprayoga Cf. Mvy 1609 which gives sna gcig spyod pa for ekadeśakāin (Kośa, iv, p. 73; Mppś, ii, p. 821).

248. Cf. $A k n-t i \grave{k} \bar{a}$, p. 218.2.1-5.7. 
SECTION III

\subsection{Wisdom}

What is wisdom? What is the meaning of perfection? Wisdom is comprehensive knowledge of virtuous and non-virtuous dharma. (686) Wisdom is realisation of dharma that are conducive to the four states of penetration ${ }^{249}$. Wisdom is correct knowledge because it leads to the realisation of the noble Doctrine. Accurate discernment of dharma leads to correct knowledge. Wisdom is discernment of all heretical views, manifestations of vices, impediments and obstructions. Wisdom is separation from prayers concerned with wishes, yearning or desires. Wisdom is the source of happiness ${ }^{250}$ by virtue of complete purification. Wisdom is the source of delight because it does not cut the connection to joy in the Doctrine. Wisdom is support because it realises complete pristine cognition. Wisdom is the basis of all bodhipa $\bar{k}$ șika dharma. Wisdom bears the characteristic of attainment, because it realises spiritual fruition in accordance with the vehicles. Wisdom bears the characteristic of perfectly knowing naturally illuminating pristine cognition. Wisdom is deliverance because it ferries across all rivers. Wisdom is guidance to true reality. Wisdom is the receptacle of all virtuous dharma. ${ }^{251}$

249. nes par hybyed pahi cha dañ hthun pa: nirvedhabhāgìya

The four states of penetration are 'heat' (usmagata), 'summit' (mürdhan), 'patience' (kșänti) and 'highest mundane dharma' (laukikāgradharma). In the Sarvāstivāda scheme of the srāvaka-training, the nirvedhabhägìa constitute the four major practices of the prayogamārga. Being states conducive to enlightenment, they mark the practitioner's meditative progress particularly in respect to the understanding of the four noble truths. During the 'heat phase', representing a state of complete perfect mental quietude (samatha)

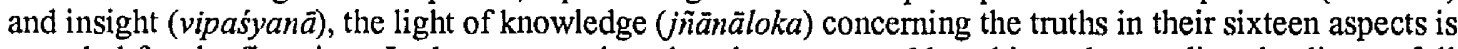
revealed for the first time. In due course, the other three states add to this understanding, leading to full intuition (abhisamaya) of the truths at the first moment of the darsanamärga. For the bodhisattva, the experience of the nirvedhabhägiya is similar in order but different in contents. Having entered the 'usmagata phase', he sees with the clear light of intuition the unreality of external phenomena. Springing from the meditation on emptiness practised before the sambhäramärga, his attainment is still weak but is called 'heat' because it is "like the heat that precedes the fire of direct knowledge of the truth on the dar'sanamärga" (Aloka, Minaev, pp. 41a.16-41b.1; ref. Obermiller). The 'mürdhan phase' consolidates the attainments of the 'usmagata phase', effectively preventing that the bodhisattva's accumulation of roots of virtue is brought to a standstill by kleśa. At the ' $k$ șanti phase', the bodhisattva is fully awakened to the unreality of worldly phenomena. Now he begins to focus his mind on the unreality of the subject of experience, leading to a "meditative state that is characterised by the origination, for the first time, of the clear light of knowledge, revealing the unreality of subjective elements" (Äloka, op. cit., p. 48a.5, ref. Obermiller). It bears the name ksantiti because it establishes the bodhisattva in the 'conviction of the non-arising of dharma', leading to liberation from rebirth in the evil destinies. Subsequent to the ' $k$ santi phase', having shed all distinctions of the subject/object dichotomy, the bodhisattva passes into the unperturbable meditation (ānantaryasamādhi) from where he attains direct knowledge of reality. Entitled 'phase of highest mundane virtues' (laukikägradharma), he is still an ordinary being and well below the rank of the arhant. Hence, the bodhisattva does not intuit as yet the Dharmadhätu and his knowledge of it is largely based on faith. Most path-schemes do not allocate the four nirvedhabhagiya to any of the stages proper, but associate it to the preliminary efforts of the adhimukticaryäbhümi (Msl, p. 27.7-11, p. 93.6-23; Kosa, vi, pp. 169-177; Amrt (B), pp. 156-159).

For references to the nirvedhabhăgìya in Pāli sources, see: D III, pp. 251, 277; S V, p. 345; A III, p. 427; Nett, pp. 21, 48, $143 \mathrm{ff}, 153 \mathrm{ff}$ and Vism, pp. 15, 88. Note, however, that while the term nibbedhabhagiya itself is canonical, the list of the four items is not. Most of these Pâli references are taken up by Rahula in his discussion of the nirvedhabhägiya in śrāvaka sources (Rahula, 1980, pp. 105-6, n. 4).

250. sim par byed pa: prahlädankärin (cf. Monier-Williams, p. 701, col. 3).

251. Pelliot, 977, folio 6a.4-6b.2: 
Wisdom is the source of purification of all propensities of impurity. Wisdom is the supreme attainment, the crown of all dharma. (687) Wisdom is excellence in the much needed realisation arising spontaneously from pristine cognition. Wisdom is separation from causation since it is not stained by the triple world. Wisdom is obtained by all noble ones. Wisdom is elimination of prayers since it abandons all reflection on the marks. Wisdom is detrimental to indolence since it is wholly separated from the darkness of delusion. ${ }^{252}$

Wisdom is the practice of all those who are established on the stage of meditation. Wisdom is guidance to those who persist in the path to pristine cognition of all-knowing. Wisdom is a source of light since it suppresses the dark cloud of mist formed by the air of ignorance. Wisdom gives perfect sight to those who delight in its sight accordingly. Wisdom is free from impurity because it transcends the sphere of the eye and the sphere of form. Wisdom is absolute truth since it issues from truth. Wisdom is imperturbable because it is fully tamed. Wisdom is the light at the gates to pristine cognition. Wisdom, unfolding in all directions, is inexhaustible.

Wisdom is not contradicted because it is seen as the entrance to dependent co-origination. Wisdom is the path of liberation, since it prompts severing of all fetters of grasping. Wisdom is unstained since it is emancipated from all sinful dharma. ${ }^{253}(688)$

O Săriputra, thus the scope and application of the bodhisattva's wisdom and pristine cognition

"O Saariputra, as regards wisdom; realisation of all virtuous practices is. wisdom that realises because it realises all dharma. It is correct knowledge because it knows all dharma in accordance with reality. It is wisdom arising from awakening because it is not defiled by any sinful dharma that lead to heretical beliefs. It is separation from desire because it purifies constantly all wishes, yearnings or desires. It is the source of contentment since it appeases constantly all suffering. It is the source of happiness because it does not cut the connection to joy in the Doctrine. It is reliance because it realises understanding of the meaning. It is establishing because it establishes all bodhipäksika dharma. It bears the characteristic of attainment, because it attains spiritual fruition in accordance with the vehicles. It bears the characteristic of wisdom of perfect knowledge because it realises the bright nature of pristine cognition. It is deliverance with compassion because it ferries across the streams of all rivers. It is comprehension because it comprehends that all dharma are truly unborn. It is agitation because it kindles all virtuous dharma."

252 Pelliot, 977, folio 6b.2-5:

"[Wisdom] is the source of purification, because it is separated from reflection of the defilements of the propensities of disease. It is unsurpassed because it proceeds to the crown of all dharma. It is contentment because it realises teachings through spontaneously arisen pristine cognition. It is separation from causes since it is not stained by the triple world. It is attainment because it is attained by all noble ones. It is elimination of prayers because it removes all reflection on the marks. It is non-self because it is wholly separated from the darkness of delusion."

253. Pelliot, 977 , folio 6 b.5-7a.3:

"[Wisdom] is practice because it accomplishes the deeds of all those who are established on the stage of meditation. It is travelling because it abides in all noble paths of pristine cognition. ... It is the source of vision because it guides everyone in accordance with that vision. It is freedom from impurity because it transcends the path of intrigues through the eye of wisdom. It is absolute truth because it understands the great noble truth. ... It is splendour because it becomes the gate of pristine cognition. It is inexhaustible knowledge because it illuminates all that which is moving. It is non-cessation because it sees constantly and extensively. ... It is separation from abodes because it is emancipated from all impure, defiled dharma." 
are truly as manifold as the mental activity of all sentient beings. The exploring of the bodhisattva's wisdom and pristine cognition is truly as manifold as the aspiration of all sentient beings. ${ }^{254}$ The doors that lead to the bodhisattva's wisdom are truly as manifold as the doors to the impurities of all sentient beings. The basis of his persistence ${ }^{255}$ in wisdom is truly as manifold as the knowledge of śāvaka, pratyekabuddhas and fully accomplished buddhas. ${ }^{256} \mathrm{~A}$ bodhisattva should study this by all means. This is the wisdom of the bodhisattva. ${ }^{257}$

\subsection{Perfection}

Next, what is the meaning of 'perfection'? What is wisdom is also the meaning of 'perfection'. Comprehensive knowledge of virtuous [and non-virtuous] dharma is the meaning of 'perfection'. Corresponding to the former, one should examine also the wording of all perfections accordingly. ${ }^{258}$

Furthermore, the meaning of excellently accomplishing the bodhisattva-training is the meaning of 'perfection'. Furthermore, the meaning of accomplishing pristine cognition of allknowing is the meaning of 'perfection'. The meaning of withdrawing from conditioned and unconditioned dharma is the meaning of 'perfection'. (689) The meaning of realising the faults of samsāra is the meaning of 'perfection'. The meaning of showing the inexhaustible Dharma-depository of knowledge is the meaning of 'perfection'. The meaning of accomplishing unstained liberation is the meaning of 'perfection'. The meaning of realising the uniformity of giving, morality, patience, vigour, meditation and wisdom is the meaning of 'perfection'. The meaning of ascertaining is the meaning of 'perfection'. ${ }^{259}$

254. Cf. Pelliot, 977, folio 7a.4 which has sems can thams cad kyi mos pa instead of sems can thams cad kyi bsam $p a$, thus clarifying the meaning of bsam $p a$.

255. Cf. Pelliot, 977, folio 7b.6, which has śes rab gyi spyod pa instead of ses rab la gnas pa.

256. Cf. $A k n-t i \bar{k} a \bar{a}, \mathrm{pp} .218 .5 .7-222.5 .7$.

257. Pelliot, 977 , folio 7a.3-7:

"O Sarriputra, in this way I have instructed you briefly the characteristics of wisdom. As regards the wisdom of bodhisattva, mahäsattvas, it should furthermore be known to be infinite and without limit. Why? The scope and application of the wisdom and pristine cognition of bodhisattvas, mahäsattvas are truly as manifold as the mental activity of all sentient beings. The activity of the wisdom and pristine cognition of bodhisattvas, mahäsattvas should be known to be truly as manifold as the aspiration of all sentient beings. The magnificent gates to the wisdom of the bodhisattvas, mahäsattvas should be known to be truly as manifold as the gates to the impurities of all sentient beings. The basis of the activity of wisdom should be known to be truly as manifold as the knowledge of srāvaka, pratyekabuddhas and fully accomplished buddhas. O Sãriputra, concerning all bases of wisdom; the bodhisattva, mahäsattva should study these attainments with vigour. This is the seizure of wisdom of bodhisattvas, mahāsattvas."

258. This paragraph is missing in the Pelliot manuscript.

259. Pelliot, 977 , folio 7a.7-7b.6:

"Furthermore, O Śāiputra, that is the meaning of the perfection of bodhisattvas, mahāsattvas? O Sāriputra, all knowledge that the joy of all virtuous dharma turns into the perfection, this should be known as the meaning of 'perfection'. Again, O Sarriputra, corresponding to the former, the accumulation of wisdom should be known as the meaning of 'perfection's. Furthermore, all meanings of the excellent accomplishment of the conduct of bodhisattvas should be known as the meaning of 'perfection'. The meaning of nonattachment to any of the dharma of the past, present and future should be known as the meaning of 'perfection'. The meaning of constantly realising the incalculable great non-reality of samsära should be 
The meaning of penetrating the sphere of all sentient beings is the meaning of 'perfection'. The meaning of attaining the conviction of the non-arising of dharma is the meaning of 'perfection'. The meaning of accomplishing the stage of irreversibility is the meaning of 'perfection'. The meaning of acquiring the buddha-field is the meaning of 'perfection'. The meaning of developing sentient beings is the meaning of 'perfection'. The meaning of [going to] the seat of enlightenment is the meaning of 'perfection'. The meaning of defeating all evil ones is the meaning of 'perfection'. The meaning of accomplishing all buddha-qualities is the meaning of 'perfection'. Furthermore, the meaning of being firmly planted in the Dharmaenunciation of the Bodhisattvapitaka is the meaning of 'perfection'. ${ }^{260}(690)$

\section{SECTION IV}

O Sāriputra, if one studies the Dharma-enunciation of the Bodhisattvapitaka one accomplishes all perfections. O Saanriputra, hence, a son or daughter of good family who persists in the Mahāyāna should retain the Dharma-enunciation of the Bodhisattvapitaka. He should take hold of it and read it. He should explain it also to others and propound it at great length.

Why? O Sāriputra, when he has listened to the Dharma-enunciation of the Bodhisattvapitaka, when he has taken hold of it, retained it, read it, fully absorbed it and when he has explained it also to others and propounded it at great length he obtains ten excellent blessings. What are the ten?

(1) When he is reborn in another existence, he is skilled in all arts

(2) And crafts.

(3) He is of high lineage and well-respected.

(4) He is renown for his great powers.

(5) His words are valued.

(6) He possesses great wealth.

known as the meaning of 'perfection'. Knowledge of the meaning of non-absorbing or non-realising any dharma whatsoever should be known as the meaning of 'perfection'. Understanding the meaning of the absolutely inexhaustible Dharma-depository should be known as the meaning of 'perfection'. The meaning of accomplishing the unstained liberation should be known as the meaning of 'perfection'.... The meaning of 'skill' in supreme discernment should be known as the meaning of 'perfection'."

260. Pelliot, 977 , folio $7 \mathrm{~b} .6-8 \mathrm{a} .3$ :

"The meaning of going to all spheres of sentient beings is the meaning of 'perfection'. The meaning of attaining the conviction of the non-arising of dharma is the meaning of 'perfection'. Accomplishing the end of irreversibility is the meaning of 'perfection'. The meaning of purifying the buddha-field is the meaning of 'perfection'.... The meaning of taking a seat on the throne of enlightenment after having come to the seat of enlightenment is the meaning of 'perfection'. The meaning of defeating the host of Māra is the meaning of 'perfection'.... Furthermore, the meaning of firmly abiding in the Dharma-enunciation of the Bodhisattvapitaka is the meaning of 'perfection'." 
(7) He is exalted among gods and men.

(8) He becomes an universal monarch.

(9) He becomes Brahmā.

(10) He is never separated from the thought of enlightenment.

He obtains these ten excellent blessings. Furthermore, he obtains ten other excellent blessings. What are the ten?

(1) He is not drawn into the disputes of the ascetics. (691)

(2) He does not hold the belief of the existence of a self.

(3) He does not hold the belief of the existence of a sentient being.

(4) He does not hold the belief of the existence of a life-force.

(5) He does not hold the belief of the existence of a person.

(6) He does not hold the belief of nihilism.

(7) He does not hold the belief of permanence.

(8) He does not hold the view that all things exist.

(9) When he goes forth to mendicant life, he accomplishes joyfully the production of the thought of enlightenment.

(10) He understands swiftly the words that he has heard.

He obtains these ten excellent blessings. Furthermore, he obtains ten other excellent blessings. What are the ten?

(1) He acquires recollection.

(2) He acquires intellect.

(3) He acquires spiritual realisation.

(4) He acquires aspiration.

(5) He acquires wisdom.

(6) He obtains the favourable condition of birth ${ }^{261}$.

(7) He recollects his former lives.

(8) His desire is small by nature and restrained; hence, he is not afflicted by the torment of desire.

(9) His hatred is small by nature and restrained; hence, he is not afflicted by the

261. These are the opposites of the conditions of birth that are unfavourable to the religious life (asamaya brahmacaryāuāsāya), viz., birth in the destiny of the hellbound (narakā), animals (tiryañca), hungry ghosts (preta), gods of long life (drghāyuso devā); possession of defect faculties (indriyavaikalya), false views (mithyādarśana) and life in periods when Tathāgata do not appear (tathăgatānām anutpāda). References in the nikāya are found in D III, pp. 263-64, 287; A IV, pp. 225, 227; for Sanskrit sources, see: $M v u$, ii, p. 363.3; Lal, p. 412.14; Siks, p. 2.4; Gv, p. 116.16; Dhsgr, § 34 (ref. Lamotte). 
torment of hatred.

(10) His delusion is small by nature and restrained; hence, he is not afflicted by the torment of delusion.

He obtains these ten excellent blessings. Furthermore, he obtains ten other excellent blessings. (692) What are the ten?

(1) He attains marvellous wisdom.

(2) He attains astute wisdom.

(3) He attains acute wisdom.

(4) He attains sharp wisdom.

(5) He attains awesome wisdom.

(6) He attains profound wisdom.

(7) He attains discerning wisdom.

(8) He attains unproduced wisdom.

(9) After he has met the Tathāgata, he praises him with melodies of verse.

(10) On posing well-contemplated questions to the Tathāgata, he receives answers.

He obtains these ten excellent blessings. Furthermore, he obtains ten other excellent blessings. What are the ten?

(1) He gives pleasure to all virtuous friends.

(2) He loosens all fetters of evil.

(3) He defeats all evil ones.

(4) He rebukes all impure ones.

(5) $\mathrm{He}$ is aggravated about actions that appertain to any karmic formation.

(6) He shuns all paths that lead to the evil destinies.

(7) He sees the path that leads to nirväna.

(8) He bestows offerings that deliver from the whole round of rebirth.

(9) He complies with the methods of all bodhisattvas. (693)

(10) He complies with the pronouncements of all lord buddhas.

He obtains these ten excellent blessings.

O Săriputra, when he has listened to the Dharma-enunciation of the Bodhisattvapitaka, when he has taken hold of it, retained it, read it, fully absorbed it and when he has explained it also to others and propounded it at great length he obtains all of these excellent qualities. 
Then, in order to elucidate in great detail this very meaning, the lord composed these verses:

Those who retain this king of sütras,

These wise ones attain infinite wisdom.

They become not only skilled in practices and their meanings,

But excel also in parts of speech and accomplish the letter.

Every monk who retains this king of sütras,

Once joy and delight have arisen in him,

Explains the Doctrine in this way

And bestows unceasingly the gift of the Doctrine.

After sentient beings have heard much about the Doctrine,

They say: "Alas, when will he who explains the Great Attainment

Instruct us in such a Doctrine?

When will we take hold of such a sütra?"

Chiefs who are endowed with such wisdom

Do not become dismayed about dharma.

By means of their recollection and wisdom

They teach sayings of noble and unsurpassed pristine cognition. (694)

Those who retain this king of sütras,

Noble, eminent and praised, confer it unceasingly

And prompt others to seek the well-taught sayings of the Doctrine.

Since they have learned it, they are exalted in perpetuity.

After they have learned it, they cause others to grasp its meaning.

He who is endowed with wisdom does not pursue the letter.

By investigating the meaning his understanding increases.

His pristine cognition is infinite in perpetuity.

Also the meaning of infinite pristine cognition is untold.

He who is of infinite reflection is skilled in absolute truth.

Apply yourself to his attainments,

For his are the attainments of learning. 
His desire and hatred are small.

His delusion is very small.

Also his mind attains purity.

For his are the attainments of learning.

After he has obtained wealth he does not become self-conceited,

But reflects on its purpose, thinking: "Is there substantiality in this wealth?"

After he has realised that wealth is insubstantial,

He disregards it and goes forth to mendicant life.

He withdraws from worldly life and abides in solitude.

Being always free from indolence,

$\mathrm{He}$ is not satisfied by listening to teachings.

When he confers the Doctrine he is free from avarice.

Since he went and posed questions

To the protector of the world,

Because of that, his pristine cognition increases.

Now, there is no abating in his virtue.

O Sarriputra, this is the Perfection of Wisdom of bodhisattvas. A bodhisattva who applies himself diligently to it pursues the bodhisattva conduct; this is diligent application to the Perfection of Wisdom. 


\begin{tabular}{|c|c|c|c|}
\hline no. & Akşayamatinirdesa & Akn in Siksāsamuccaya & Bodhisattvapiţaka \\
\hline 1 & hdun pa & chanda $(1)^{\ddagger}$ & hdun pa \\
\hline 2 & bsam pa & āśaya (2) & bsam pa \\
\hline 3 & hlag pahi bsam pa & adhyäsaya* & sbyor ba \\
\hline 4 & sbyor ba & prayoga (3) & dge bahi bśes gñen \\
\hline 5 & dge bahi bses gñen & nirmāna $(5)$ & ǹa rgyal med pa \\
\hline 6 & na rgyal med pa & pramāna $(6)^{1}$ & rab tu hdud pa \\
\hline 7 & bag yod pa & kalyānamitra (4) & ri mor byed pa \\
\hline 8 & gus par byed pa & gaurava (7) & hthun pa \\
\hline 9 & hthun pa hdzin pa & pradaksina (8) & bkah blo bde ba \\
\hline 10 & bkah blo bde ba & suvacana (9) & bsñen bkur byed pa \\
\hline 11 & bsñen bkur byed pa & paryupāsana (10) & rna ba blags te ñan pa \\
\hline 12 & rna ba blags te ñan pa & avahitaśrotra (11) & bkur sti byed pa \\
\hline 13 & yid la byed pa & manasakāra (13) & yid la byed pa \\
\hline 14 & mam par mi g.yen pa & aviksepa (14) & mi g.yen pa \\
\hline 15 & gnas & vasthāna* & rin po cher hdu ses pa \\
\hline 16 & rin po cher hdu ses pa & ratnasamjūña (15) & sman du hdu ses pa \\
\hline 17 & sman du ḥdu ses pa & bhaiṣajyasamjñ̃ā (16) & $\begin{array}{l}\text { nad thams cad rab tu źi bar } \\
\text { byed pahi hdu ses pa }\end{array}$ \\
\hline 18 & $\begin{array}{l}\text { ñon mons pahi nad thams } \\
\text { cad źi bar byed pa }\end{array}$ & sarvavyādhiśamana (17) ${ }^{2}$ & dran pahi snod \\
\hline 19 & dran pahi snod & smrtibhojana (18) & rtogs pa ses pa \\
\hline 20 & rtogs pa ses pa & gatibodhana (19) & blo gros hdod pa \\
\hline 21 & blo gros hdod pa & matirocana $(20)$ & blo la hjug pa \\
\hline 22 & blo la hjug pa & buddhipraveśa (21) & $\begin{array}{l}\text { sañs rgyas kyi chos thos } \\
\text { pas mi sgoms pa nan pa }\end{array}$ \\
\hline 23 & $\begin{array}{l}\text { sans rgyas kyi chos thos } \\
\text { pas mi sgoms pa ñan pa }\end{array}$ & $\begin{array}{l}\text { atrptabuddhadharma } \\
\text { Sravana (22) }\end{array}$ & gtoń pa spel pa \\
\hline 24 & gton pa spel pa & tyāgavrhana (23) & byin nas mi smod pa \\
\hline 25 & dul źin cań ses pa & dāntājāneya (24) & man du thos pa sten pa \\
\hline 26 & man du thos pa brten pa & bahuśrutasevana (25) & $\begin{array}{l}\text { gus par dgah ba myon bar } \\
\text { byed pa }\end{array}$ \\
\hline 27 & $\begin{array}{l}\text { sti stan du byas te dgah ba } \\
\text { myon par byed }\end{array}$ & $\begin{array}{l}\text { satkrtyaprityanubhavana } \\
(26)\end{array}$ & lus sim pa \\
\hline 28 & lus bde pa & kāyaudbiya (27) & sems rans pa \\
\hline 29 & sems rab tu dgah & cittaprahlādana (28) & mi skyor bar ñan pa \\
\hline 30 & mi skyor bar ñan pa & aparikheda śravana (29) & don ñan pa \\
\hline 31 & don ñan pa & dharma śravana (31) & chos ñan pa \\
\hline 32 & chos ñan pa & (artha sravana) ${ }^{3}$ & nan tan ñan pa \\
\hline 33 & nan $\tan$ ñan pa & pratipatti sravana (32) & $\begin{array}{l}\text { theg pa gźan la hidod pa } \\
\text { med pa ñan pa }\end{array}$ \\
\hline 34 & gźan gis bstan pa ñan pa & paradeśanā śravana* & pha rol tu phyin pa ñan pa \\
\hline 35 & chos mthos pa ñan pa & śruta śravana* & $\begin{array}{l}\text { byan chub sems dpahi sde } \\
\text { snod ñan pa }\end{array}$ \\
\hline 36 & mñon par śes pa ñan pa & abhijñã śravana (39) & bsdu bahi dnos ñan pa \\
\hline 37 & $\begin{array}{l}\text { theg pa gzan la hodod pa } \\
\text { med pa ñan pa }\end{array}$ & $\begin{array}{l}\text { anyayānāsprhana śravana } \\
\text { (33) }\end{array}$ & thabs mkhas pa ñan pa \\
\hline
\end{tabular}




\begin{tabular}{|c|c|c|c|}
\hline 38 & pha rol tu phyin pa ñan pa & $\begin{array}{l}\text { prajñāpāramitā śravaṇa } \\
\text { (34) }\end{array}$ & tshans pahi gnas pa ñan pa \\
\hline 39 & $\begin{array}{l}\text { byan chub sems dpahi sde } \\
\text { snod ñan pa }\end{array}$ & $\begin{array}{l}\text { bodhisattvapițaka } \\
\text { sravana }(35)\end{array}$ & mñon par śes pa ñan pa \\
\hline 40 & bsdu bahi dños ñan pa & $\begin{array}{l}\text { samgrahavastu śravana } \\
(36)\end{array}$ & $\begin{array}{l}\text { dran pa ñe bar gźags pa } \\
\text { ñan pa }\end{array}$ \\
\hline 41 & thabs mkhas pa ñan pa & $\begin{array}{l}\text { upāyakausalya śravana } \\
(37)\end{array}$ & $\begin{array}{l}\text { yan dag par spoń ba ñan } \\
\text { pa }\end{array}$ \\
\hline 42 & tshańs paḥi gnas pa ñan pa & brahmavihāra sravana (38) & $\begin{array}{l}\text { rdzu hphrul gyi rkan pa } \\
\text { ñan pa }\end{array}$ \\
\hline 43 & $\begin{array}{l}\text { dran pa dan śes pa bźin } \\
\text { ñan pa }\end{array}$ & $\begin{array}{l}\text { smrtisamprajanya śravaṇa } \\
(40)^{4}\end{array}$ & $\begin{array}{l}\text { rten cin habrel par ḥbyun ba } \\
\text { ñan pa }\end{array}$ \\
\hline 44 & skye ba la mkhas pahi ñan & utpādakauśalya śravana* & mi rtag pa ñan pa \\
\hline 45 & $\begin{array}{l}\text { mi skye ba la mkhas pa } \\
\text { ñan pa }\end{array}$ & $\begin{array}{l}\text { anutpãdakauśalya } \\
\text { śravana* }\end{array}$ & sdud bsnal ba ñan pa \\
\hline 46 & mi sdug pa & aśubha* & bdag med pa ñan pa \\
\hline 47 & byams pa & maitryāh śravana* & źi ba ñan pa \\
\hline 48 & rten cin ḥbrel bar ḥbyun pa & $\begin{array}{l}\text { pratityasamutpāda śravaṇa } \\
(43)\end{array}$ & stoń pa ñid ñan pa \\
\hline 49 & mi rtag pa ñan pa & anitya sravana (44) & mtshan ma med pa ñan pa \\
\hline 50 & sdud bsnal ba ñan pa & duhkha sravana (45) & smon pa med pa ñan pa \\
\hline 51 & bdag med pa ñan pa & anātma śravaṇa (46) & $\begin{array}{l}\text { mñon par hdu mi byed pa } \\
\text { ñan pa }\end{array}$ \\
\hline 52 & źi ba ñan pa & sānta sravana (47) & $\begin{array}{l}\text { dge bahi rtsa ba mñon par } \\
\text { hdu byed pa ñan pa }\end{array}$ \\
\hline 53 & ston pa ñid ñan pa & sūnyatā sravana (48) & rañ dbań du gyur pa \\
\hline 54 & mtshan ma med pa ñan pa & animitta śravana $(50)$ & chos ñam par hdu ses pa \\
\hline 55 & smon pa med pa ñan pa & apranihita śravana (49) & $\begin{array}{l}\text { kun tu hdre ba mi hthun } \\
\text { pahi phyags su hdu ses pa }\end{array}$ \\
\hline 56 & $\begin{array}{l}\text { mñon par hadu mi byed pa } \\
\text { ñan pa }\end{array}$ & $\begin{array}{l}\text { anabhisaṃskāra śravaṇa } \\
(51)\end{array}$ & $\begin{array}{l}\text { ñon mons pa thams cad } \\
\text { tshar gcod pa }\end{array}$ \\
\hline 57 & $\begin{array}{l}\text { dge bahi mnon par hadu } \\
\text { byed pa }\end{array}$ & $\begin{array}{l}\text { kuśalābhisamskāra } \\
\text { śravana (52) }\end{array}$ & $\begin{array}{l}\text { mkhas pa la mnon par } \\
\text { bgah ba }\end{array}$ \\
\hline 58 & $\begin{array}{l}\text { bden pas byin gyis brlabs } \\
\text { pa }\end{array}$ & satyādhișțhāna (53) & hphags pa sten pa \\
\hline 59 & chud mi gzon pa & avipraṇāśa* & $\begin{array}{l}\text { hphags pa ma yin pa yońs } \\
\text { su spon pa }\end{array}$ \\
\hline 60 & ran gi kha na las pa & svādhina* & hphags pa ñan pa \\
\hline 61 & ran gi sems srun pa & svacittāraksana* & dbaǹ pa ñan pa \\
\hline 62 & brtson hgrus mi gtod pa & viryasyāsramsana & $\begin{array}{l}\text { rjes su dran pa sgom pa } \\
\text { ñan pa }\end{array}$ \\
\hline 63 & sñon moǹs pahi gñen po & dharmanidhyapti* & $\begin{array}{l}\text { byan chub kyi yan lag ñan } \\
\text { pa }\end{array}$ \\
\hline 64 & chos la nes par sems pa & kleśavipakșa (56) & $\begin{array}{l}\text { hphags pahi lam yan lag } \\
\text { brgyud pa ñan pa }\end{array}$ \\
\hline 65 & rañ gi phyogs sruñ pa & svapakșaparīkarșaṇa* & $\begin{array}{l}\text { de bźin gśegs pahi stobs } \\
\text { ñan pa }\end{array}$ \\
\hline
\end{tabular}




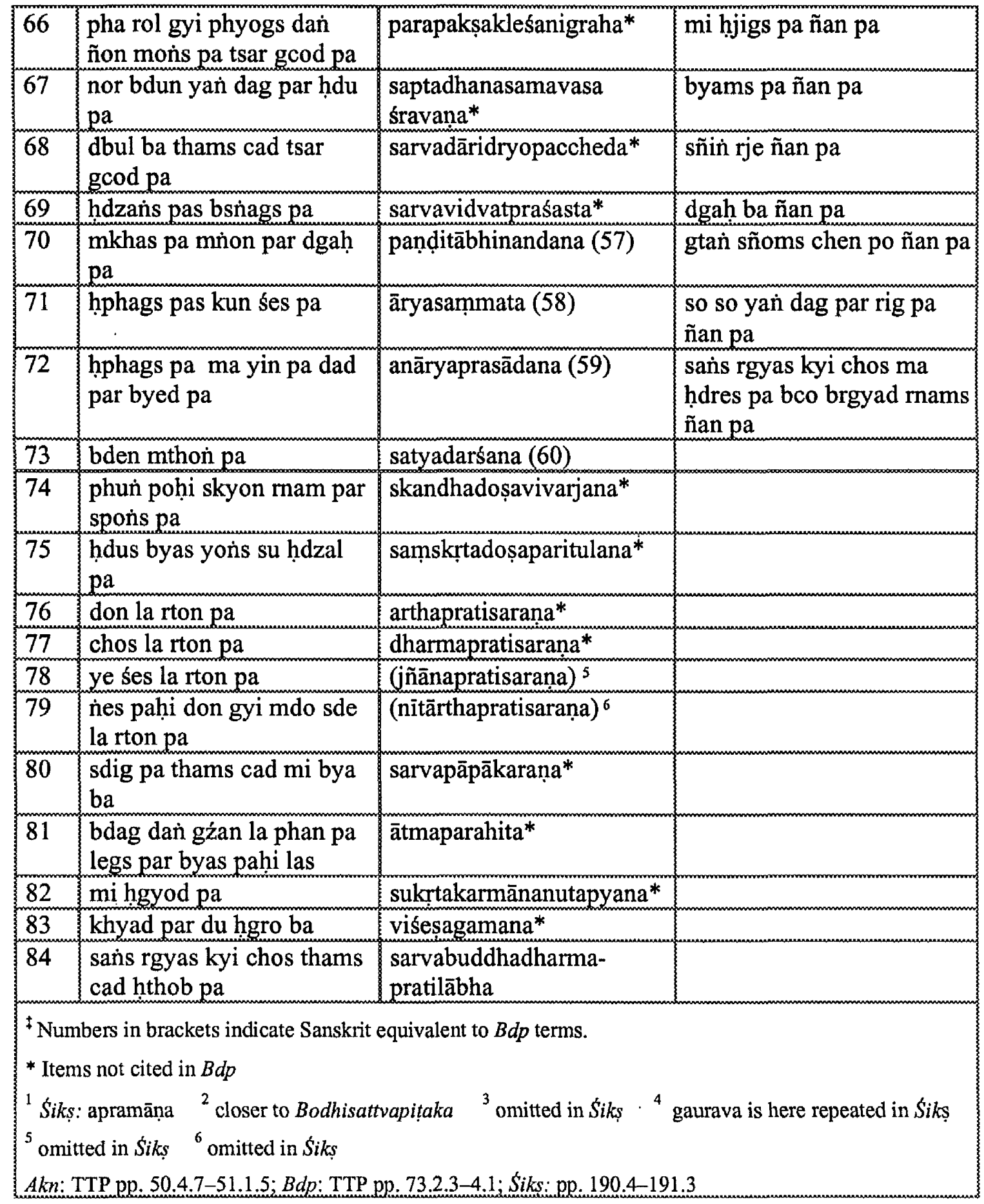




\begin{tabular}{|c|c|c|c|}
\hline no. & Aksayamatinirdesa & Akșayamatinirdeśa (Skt) ${ }^{\ddagger}$ & Bodhisattvapitaka \\
\hline 1 & glog gi sgron mas bgryan & vidyutpradīpālamkāra $(M v y$ 546) & rnam par snan (3) \\
\hline 2 & zla bahi hod & *candraprabha & mdzad zi ba \\
\hline 3 & $\begin{array}{l}\text { dge bkod rnam snañ de } \\
\text { bźin sems }\end{array}$ & $\begin{array}{l}\text { subhavyūhapratibhāsa (Mvy } \\
556)\end{array}$ & zla ḥod (2) \\
\hline 4 & mi khyab & *acintya & rnam pa bkod pa (3?) \\
\hline 5 & hphags par snañ & udgataprabha (Mvy 511, 568) & $\begin{array}{l}\text { de ñid glog gis rab tu } \\
\text { brgyan pa }\end{array}$ \\
\hline 6 & dri ma med pa & vimala $(D b h$, p. 82.10) & mnon par hphags (56) \\
\hline 7 & $\begin{array}{l}\text { chos rnams kun la dbañ } \\
\text { byed }\end{array}$ & *sarvadharmavasavarartin & de bźin sems dpah (3?) \\
\hline 8 & yon $\tan$ hod & *gunaprabha & dri ma med (6) \\
\hline 9 & myan nan med & *aśoka & snan ldan \\
\hline 10 & brtul źugs grub pa & *siddhavrata & yon $\tan$ hod $(8)$ \\
\hline 11 & grags pa brten & *drdhakīti & grub hod \\
\hline 12 & kun nas hphags pa & samudgata $(M v y 512)$ & mya nan med $(9)$ \\
\hline 13 & chos kyi sgron ma & *dharmapradipa & $\begin{array}{l}\text { chos rnams thams cad la ni } \\
\text { dban sgyur (7) }\end{array}$ \\
\hline 14 & chos dpal lhun po che & *dharmaśrimahāmeru & chos sgron (13) \\
\hline 15 & chos kyi dbañ phyug & *dharmeśvara & de bźin chos dpah \\
\hline 16 & chos śes dban byed & *dharmajñãnavaśavartin & chos kyi dbań phyug (15) \\
\hline 17 & chos kyi phun po & *dharmaskandha & ri rab dpah (14) \\
\hline 18 & mam par hthor ba & vikirana ( $M v y 569)$ & $\begin{array}{l}\text { dam pahi chos kyi ye śes } \\
\text { dban byed (16) }\end{array}$ \\
\hline 19 & $\begin{array}{l}\text { chos rnams hdzin pa } \\
\text { rnam par dag pa }\end{array}$ & $\begin{array}{l}\text { dharmadharaviśuddhi }(K v, \mathrm{pp} \text {. } \\
51.14,83.12)\end{array}$ & $\begin{array}{l}\text { dam chos kun hidzin sin tu } \\
\text { rnam dag (19) }\end{array}$ \\
\hline 20 & $\begin{array}{l}\text { pha rol sems kyi spyod } \\
\text { pa spyod pa }\end{array}$ & *paracittacaritacaryā & $\begin{array}{l}\text { gźan gyi sems la rnam } \\
\text { dpyod (21) }\end{array}$ \\
\hline 21 & $\begin{array}{l}\text { rgyal mtsan rtse mohi } \\
\text { dpun rgyan }\end{array}$ & dhvajāgrakeyūra (Mvy 530) & dam chos kyi mchog \\
\hline 22 & ñon mońs sel & *klešāpaha & hod zer \\
\hline 23 & $\begin{array}{l}\text { bdud bźihi stobs tnams } \\
\text { rab tu hjoms pa }\end{array}$ & *caturmārabalapramardin & $\begin{array}{l}\text { rgyal mtsan rtse mo dpun } \\
\text { rgyan (21) }\end{array}$ \\
\hline 24 & $\begin{array}{l}\text { stobs bcu hphags pa } \\
\text { stobs dan idan pa }\end{array}$ & *daśabalodgatabalin & ñon mon̉s sel (22) \\
\hline 25 & $\begin{array}{l}\text { chags med chags pa sin } \\
\text { du gcod pa }\end{array}$ & *asangasangātyantasamuccheda & $\begin{array}{l}\text { bdun kyi stobs rnams } \\
\text { hjoms pa (23) }\end{array}$ \\
\hline 26 & lag na sgron ma & *hastadipa & $\begin{array}{l}\text { stobs bcu dań stobs las } \\
\text { mnion hphags }(24)\end{array}$ \\
\hline 27 & Sin du sgra bsgrags & *atyantaśabdita & kun bcad chags med \\
\hline 28 & sa hdzin & *nimimdhara & lag na sgron ma (26) \\
\hline 29 & brtan pa hdi dañ rañ bźin & *drdhasvabhāva & bdud sbyin bsgrags pa \\
\hline 30 & Ihun po sgron ma & *merupradipa & sa hdzin (28) \\
\hline 31 & mi pham rgyal ba & *ajitamjaya & legs par gnas pa (71?) \\
\hline 32 & śes rab bkyed & *prajñotpāda & ri rab sgron $(30)$ \\
\hline 33 & ye śes tal la & jñānolka (Mvy 744$)$ & rgyal ba mi hpham (31) \\
\hline 34 & bsam gtan hbyun gnas & *dhyānākara & ye ses sgron (80?) \\
\hline 35 & mthah yas dban byed & *anantavaśavartin & de bźin mig gtsań \\
\hline
\end{tabular}




\begin{tabular}{|c|c|c|c|}
\hline 36 & $\begin{array}{l}\text { sems rnams las su run } \\
\text { par byed pa }\end{array}$ & * cittakarmaṇyatākāra & $\begin{array}{l}\text { rgyal thams cad dran pa } \\
(45)\end{array}$ \\
\hline 37 & $\begin{array}{l}\text { byed dan byas dan tshor } \\
\text { byan med }\end{array}$ & *akārakakṛtakavedaka & $\begin{array}{l}\text { chos dran yon tan ye ses } \\
\text { hjug (46?) }\end{array}$ \\
\hline 38 & chu yi zla ba & *udakacandra & ston par hjug (51) \\
\hline 39 & ñi mahi dbyañs dag & *sūryaghoșa & de bźin mtsan me (52) \\
\hline 40 & tin hdzin mi gton & samādhyanutsarga & smon med (53) \\
\hline 41 & bdud rnams hjoms pa & *jārapramardaka & de bźin źi bahi sa \\
\hline 42 & $\begin{array}{l}\text { rnam pa sna tshogs hidu } \\
\text { ses med pa }\end{array}$ & *avicitrasamjūin & ḥdu śes sna tsogs bral (42) \\
\hline 43 & stag śin du dul ba & *suvinītahastivyāghra & rab dul klu dbań stag (43) \\
\hline 44 & glañ po śin du dul ba & *sudāntahastivyāghra & hkhyil ba \\
\hline 45 & $\begin{array}{l}\text { rgyal ba kun gyi rjes su } \\
\text { dran pa }\end{array}$ & *sarvajinānusmṛti & rnam par Idog pa \\
\hline 46 & $\begin{array}{l}\text { chos dran dge hdun ye } \\
\text { ses dban byed }\end{array}$ & $\begin{array}{l}\text { *dharmānusmrrti- } \\
\text { samghajñānavaśavartin }\end{array}$ & hjums pa med pa (49?) \\
\hline 47 & mi ldog pa & avivarta (Mvy 553) & stobs \\
\hline 48 & ldog pa med pa & avinivartaniya (Mvy 740$)$ & mig dag (49?) \\
\hline 49 & mig mi hdzums & *animisa & rdo rje hdra (55) \\
\hline 50 & bdag med rab dge & *nairātmyaprasuddhi & rdo rje sa \\
\hline 51 & $\begin{array}{l}\text { rtag tu ston pahi rnam } \\
\text { par hjug pa }\end{array}$ & *nityaśūnyākārapraveśa & mnon hphags (56) \\
\hline 52 & rtag tu mtsan med & *nityānimitta & mi hjum lhun po lha bu \\
\hline 53 & rtag tu mi smon & *nityāpranihita & kun nas glon hkhyil (58) \\
\hline 54 & $\begin{array}{l}\text { gnas par bsam gtan byed } \\
\text { pa mi chags }\end{array}$ & *samsthitāsaktadhyāyin & rnam pa dag sgra (59?) \\
\hline 55 & $\begin{array}{l}\text { rdo rje lta buhi tin ne } \\
\text { hdzin }\end{array}$ & vajropamasamādhi (Mvy 560) & ñes rtogs $(60$ \\
\hline 56 & mnion par hphags & *abhyudgata & ñon moǹs bral ba (61) \\
\hline 57 & nes par bcom pa & *nirghäta & nam mkhah hdra (62) \\
\hline 58 & kun nas hkhyil & *samāvarta & nam mkhahi bar skabs \\
\hline 59 & rnam par dag pa & *viśuddha & $\begin{array}{l}\text { yon tan thams cad gus par } \\
\text { len pa (64?) }\end{array}$ \\
\hline 60 & nes par sems & *nidhyapti & $\begin{array}{l}\text { blo gros dran rtogs blo } \\
\text { hphel (65?) }\end{array}$ \\
\hline 61 & ñon mons bral ba & *apagatakleśa & stobs mi zad \\
\hline 62 & $\begin{array}{l}\text { yañs pa nam mkhah lta } \\
\text { bu }\end{array}$ & akāsasamavipula (Dbh, p. 82.13) & nes tsig bstan pa \\
\hline 63 & gzuñ ba hjug pa & *avatārana & mthah yas mi zad \\
\hline 64 & yon tan hjug pa & * gunāvatāra & legs byas byas pa (71) \\
\hline 65 & $\begin{array}{l}\text { dran rtogs bla gros ses } \\
\text { rab bsgrub pa }\end{array}$ & *smṛtigatimatiprajñāsādhaka & chud mi za ba (70) \\
\hline 66 & $\begin{array}{l}\text { spobs pa dag ni mi zad } \\
\text { byed pa }\end{array}$ & *pratibhānākșayakārin & lha ba \\
\hline 67 & sgra ston pa & *śabdaśâsana & hgro ba tsim byed (72) \\
\hline 68 & bden pa mthon ba & *satyadarśana & $\begin{array}{l}\text { byams pa mnon hphags } \\
\text { (76) }\end{array}$ \\
\hline 69 & hdzin pa & *dhātrana & sñin rje yańs pahi rtsa (77) \\
\hline 70 & chud mi za & *avipranāsa & dgah la hdug pa \\
\hline
\end{tabular}


Appendix II: Samādhi Lists in the Bdp and the Akn

Appendix ii

\begin{tabular}{|c|c|c|c|}
\hline 71 & legs byas sbyin & *sukṛtadāna & $\begin{array}{l}\text { mchog tu dgah la hadug pa } \\
(78)\end{array}$ \\
\hline 72 & hgro ba tsim par byed & *jagatsamptarpana & $\begin{array}{l}\text { btan sñoms gñis la chags } \\
\text { grol (79) }\end{array}$ \\
\hline 73 & bltar mi mthon & *adrșya & $\begin{array}{l}\text { chos don chos kyi hod zer } \\
(80)\end{array}$ \\
\hline 74 & rab tu rtogs & *prativedha & hgrug med (21) \\
\hline 75 & dgah mgu skyed pa & *susthityutpāda & ye ses sgron (82?) \\
\hline 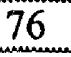 & byams pa hphags pa & *maitryudgata & ye ses mtso \\
\hline 77 & $\begin{array}{l}\text { sñin rje chen pohi rtsa ba } \\
\text { bsam dag pa }\end{array}$ & *mahākaruṇāmūlaśuddhāsaya & $\begin{array}{l}\text { rnam grol sñin po higro } \\
\text { tsim byed ( } 83)\end{array}$ \\
\hline 78 & $\begin{array}{l}\text { dgah rnam par dag la } \\
\text { hjug pa }\end{array}$ & *muditākārapraveśa & rdo rje rgyal mtsan (85) \\
\hline 79 & $\begin{array}{l}\text { btan sñoms gñis la chags } \\
\text { las grol ba }\end{array}$ & *dvayasañgavimuktopekșā & padma dam pa (87) \\
\hline 80 & $\begin{array}{l}\text { chos don chos byed ye } \\
\text { ses tal la }\end{array}$ & $\begin{array}{l}\text { *dharmārthadharma- } \\
\text { kāryajñānolka }\end{array}$ & chos kyis rgyal \\
\hline 81 & mi hgrugs pa & *avikopita & mi g.yo (69) \\
\hline 82 & ye ses rgya mtso & *jūānasāgara & Ses rab rtsibs \\
\hline 83 & $\begin{array}{l}\text { hgro ba tsim byed rnam } \\
\text { par dul ba }\end{array}$ & *vinitajagatsamtarpana & źi ba \\
\hline 84 & $\begin{array}{l}\text { rnam par grol bahi ye śes } \\
\text { dban byed }\end{array}$ & *vimuktijñänavaśavartin & sañs rgyas mtso \\
\hline 85 & rdo rjehi rgyal mtsan & *vajradhvaja & hod zer mthah yas \\
\hline 86 & sñin pohi padma & *hrdayakamala & $\begin{array}{l}\text { rnam grol sbyin pa ye ses } \\
\text { (96 }\end{array}$ \\
\hline 87 & padma ḩdas & *atikrāntakamala & $\begin{array}{l}\text { de bźin gśegs kyi rgyan } \\
(97)\end{array}$ \\
\hline 88 & hjig rten chos bral & *lokadharmavirahita & bkod pa chen po \\
\hline 89 & mi g.yo ba & aniñjya (Mvy 554) & źin bkod snañ na \\
\hline 90 & rdo rje lta bu & vajropama $(M v y 516)$ & $\begin{array}{l}\text { sems can bsam ba yons } \\
\text { ran dgah }(100)\end{array}$ \\
\hline 91 & dpah bar hgro & sūramgama (Mvy 506) & $\begin{array}{l}\text { rdzogs pahi byan chub lam } \\
\text { la rtag mthun (103) }\end{array}$ \\
\hline 92 & sañs rgyas dgoñs & *buddhābhiprāya & $\begin{array}{l}\text { pha rol phyin pa rgyan } \\
\text { bkod mchog gtsug (104) }\end{array}$ \\
\hline 93 & de bźin mi ḥgrugs & *aprakampya & $\begin{array}{l}\text { byan chub yan lag me tog } \\
\text { sbyin }(105)\end{array}$ \\
\hline 94 & gzi brjid can & tejovatī (Mvy 549) & $\begin{array}{l}\text { mam grol sñin po bdun } \\
\text { rtsi sbyin (106?) }\end{array}$ \\
\hline 95 & gzi brjid hod zer & *tejoraśmi & $\begin{array}{l}\text { rluñ dañ rluń bźin hagro ba } \\
\text { mi dmigs }(108)\end{array}$ \\
\hline 96 & $\begin{array}{l}\text { mam par grol bahi ye ses } \\
\text { mchog sbyin }\end{array}$ & *vimuktijñānavarada & $\begin{array}{l}\text { rgya mtso śugs ḥdzin } \\
(110)\end{array}$ \\
\hline 97 & $\begin{array}{l}\text { sañs rgyas rgyan mams } \\
\text { sin tu bkod pa }\end{array}$ & *buddhālaṃkārātyantavyūha & rin chen mdzod ldan (109) \\
\hline 98 & kun tu snañ & samantāloka (Mvy 562) & $\begin{array}{l}\text { brag dan ri hathab rgyal po } \\
\text { (111) }\end{array}$ \\
\hline 99 & sañs rgyas źin dag & *visuddhabuddhaksetra & rdzu hphrul yañs (112) \\
\hline
\end{tabular}


Appendix II: Samādhi Lists in the Bdp and the Akn

\begin{tabular}{|c|c|c|c|}
\hline 100 & $\begin{array}{l}\text { sems can bsam pa rab tu } \\
\text { hjug pa }\end{array}$ & *sattvāśayapraveśa & sin tu don hadzin (112) \\
\hline 101 & mgu byed & *ārādhana & sañs rgyas yul ston (113) \\
\hline 102 & Sin tu mgu & *atyantārādhana & \\
\hline 103 & $\begin{array}{l}\text { byan chub lam gyi rjes su } \\
\text { hthun pa }\end{array}$ & *bodhipathānulomika & \\
\hline 104 & $\begin{array}{l}\text { pha rol phyin bgryan } \\
\text { gtsug na rin po che }\end{array}$ & *pāramitālaṃkāracūụamaṇi & \\
\hline 105 & $\begin{array}{l}\text { byan chub lam na lag me } \\
\text { tog sbyin pa }\end{array}$ & *bodhyangapuṣpadāna & \\
\hline 106 & $\begin{array}{l}\text { mam par grol bahi hibras } \\
\text { bu sbyin pa }\end{array}$ & *vimuktiphaladāna & \\
\hline 107 & mi hchi dbyañs & *amrtasvara & \\
\hline 108 & $\begin{array}{l}\text { dmigs med rlun bźin } \\
\text { hgro }\end{array}$ & *yathāvāyvanālambanagamana & \\
\hline 109 & rin chen mthah & ratnakoti $(M v y$ 564) & \\
\hline 110 & rgya mtsoh sugs hdzin & *arnavavegadhārin & \\
\hline 111 & $\begin{array}{l}\text { ri dan brag rnams rdob } \\
\text { par byed pa }\end{array}$ & *girisailāsphalana & \\
\hline 112 & $\begin{array}{l}\text { rdzu hphrul don chen yan } \\
\text { dag bkyed pa }\end{array}$ & *maharddhyarthasamutpāda & \\
\hline 113 & $\begin{array}{l}\text { sañs rgyas dpag med pa } \\
\text { mthon ba }\end{array}$ & *aprameyabuddhadarśana & \\
\hline 114 & thos pa thams cad hdzin & *sarvaśrutadhāra & \\
\hline 115 & mi g.yen & *aviksipta & \\
\hline 116 & g.yel ba med pa & *atandrita & \\
\hline 117 & $\begin{array}{l}\text { skad cig gcig la ye ses } \\
\text { sbyin pa }\end{array}$ & *ekakșaṇajñānadātṛ & \\
\hline 118 & $\begin{array}{l}\text { yon tan mthah yas rgya } \\
\text { mtso rnam par dag }\end{array}$ & *anantaguṇaviśuddhārṇava & \\
\hline $\begin{array}{l}{ }^{\ddagger} \mathrm{Rec} \\
\ddagger \mathrm{Nu} \\
{ }^{*} \mathrm{Con} \\
\text { Akn:" }\end{array}$ & $\begin{array}{l}\text { nstructed by Braavrig (1989; pp. } \\
\text { nbers in brackets indicate locatio } \\
\text { ectural reconstructions } \\
\text { TP pp. } 50.2 .2-4.2 ; B d p: \text { TTP: } p \text { p }\end{array}$ & $\begin{array}{l}146-48) \\
\text { on of } B d p \text { samãdhi in the } A k n \text { samādhi } \\
\text { p. } 72.4 .5-73.1 .3\end{array}$ & \\
\hline
\end{tabular}




\title{
Appendix III
}

\section{The Mahāratnakūta Collection}

A Bibliographical Guide ${ }^{1}$

\begin{abstract}
Sanskrit Title: ${ }^{2}$
ārya-Mahāratnakūṭa-dharma-paryāya ${ }^{3}$

Chinese Title: Ta pao chi ching, forming the Pao chi pu (Ratnakūta Section) of the 'ching' (sütra division of the Chinese Ta ts'ang ching). ${ }^{4}$

Tibetan Title: hphags pa dkon mchog brtsegs pa chen pohi chos kyi mam grans ston phrag brgya $\mathrm{pa}^{5}$
\end{abstract}

\section{Trisamvaranirdeśaparivarta}

Chinese Title: $\quad$ 1. San Lü'i hui [T. 310.1 $]^{6}$

2. Ta fang kuang san chieh ching [T. 311]

Tibetan Title: $\quad$ sdom pa gsum bstan pahi lehu źes bya ba theg pa chen pohi mdo [TTP 760.1; TTD 45]

\section{Anantamukhapariśodhananirdeśa}

Chinese Title: $\quad$ Wu pien chuang yen hui $[\mathrm{T} 310.2]^{8}$

Tibetan Title: $\quad$ hphags pa sgo mthah yas pa rman par spyon ba bstan pahi lehu źes bya ba theg pa chen pohi mdo [TTP 760.2; TTD 46]

\section{Tathägatācintyaguhyanirdeśa}

Chinese Title:

1. Mi chi chin kang li shih hui ching [T 310.3$]^{9}$

1. The bibliographical data listed here have been taken from the following catalogues: Demiéville, $\mathbf{P}$. et al. (1978); Lancaster, L. (1979); Nanjio, B. (1883); Skorupski, T (1985).

2. As reconstructed from the Tibetan versions.

3. Hereafter, the pre/suffixes (ārya-... -nāma-mahāyāna-sūtra) will be omitted.

4. Taishō Shinshü Daizōkyö, no. 310.1-49, vol. 11, pp. 1a 1-659a 27 (120 chüan).

5. Tibetan Tripitaka Peking Edition (ed. by D.T. Suzuki, Tokyo; 1956), no. 760.1-49, vol. 22-24. Tibetan Tripitaka sDe-dge Edition. Berkeley: East Asiatic Library, University of California; no. 45-93, vol. $39-44$.

6. Trsl. by Bodhinuci (572-727AD) (3 chüan), [T 2154-570b:15].

Bodhiruci, born a Brahmin, was of South Indian origin. He became a Buddhist in $631 \mathrm{AD}$ and arrived in China in $693 \mathrm{AD}$ where he died in $727 \mathrm{AD}$. His original name was Dharmaruci II. He also translated the Sukhävativyūhasütra and a number of works on tantric ritual [Bagchi, ii, pp. $540 \mathrm{ff}$ ].

7. Trsl. by Dharmaksema between 414 and $426 \mathrm{AD}$ [T 2154-520c:17].

8. Trsl. by Bodhinuci (chüan 4-7).

9. Trsl. by Dharmarakșa I. He was born of an Indo-Scythian family in Tun-huang in $233 \mathrm{AD}$ and worked at 
2. Ju lai pu ssu i pi ta ch'eng ching [T 312 $]^{1}$

Tibetan Title: $\quad$ ḥphags pa de bźin gśegs pahi gsañ ba bsam gyis mi khyab pa bstan źes bya ba theg pa chen pohi mdo [TTP 760.3; TTD 47]

English (part. trsl.): Bendall; Rouse (1981), pp. 8, 125, 157, 225, 251, 283, 314 (quot.). Obermiller (1931), i, pp. 15, 29, 84, 91, 94; ii, p. 101 (quot.).

German (part. trsl.): Winternitz (1930), pp. 37, 45.

\section{Svapnanirdeśa}

Chinese Title:

Ching chü t'ien tzu hui [T 310.4 $]^{2}$

Tibetan Title:

hphags pa rmi lam bstan pa ses bya ba theg pa chen pohi mdo

[TTP 760.4; TTD. no. 48]

\section{Amitäbhavyūha}

Chinese Title:

no coresponding translation. ${ }^{3}$

Tibetan Title:

hphags pa hod dpag med kyi bkod pa źes bya ba theg pa cben pohi

English (trsl.): mdo [TTP 760.4; TTD 49]

Beal (1882), pp. 378-383 (part.).

Chang (1983), pp. 339-363.

Müller (1883).

German (part. trsl.): Winternitz (1930), pp. 21-30.

Edition: $\quad$ Müller; Takakusu (1932).

\section{Akșobhyatathāgatasyavyūha}

Chinese Title: $\quad$ 1. Pu tung ju lai hui $[\mathrm{T} 310.6]^{4}$

2. A ch'u fo kuo ching [T 313]

Tibetan Title: $\quad$ ḥphags pa de bźin gsegs pa mi ḥkhrugs pahi bkod pa źes bya ba theg pa chen pohi mdo [TTP 760.6; TTD 50]

Ch'ang-an from $265 \mathrm{AD}$ to $300 / 10 / 13 \mathrm{AD}$ (chüan 8-14), [T 2154 493b:16].

1. Trsl. by Dharmarakșa II between 1018 and 1058 AD (20 chüan), [Ono. vol. 12, p. 184a].

2. Trsl. by Dharmarakșa I between 265 and $313 \mathrm{AD}$ (chüan15-16) [T 2154-496c:20].

3. No Sanskrit original appears to be extant. If the original version of the Amitäbhavyūha corresponds to the Large Sukhāvatīvyüha [extant in Sanskrit and various Chinese translations], then the translation of Bodhiruci $[T .:$ No.310.5] is the most relevant here. No corresponding Mongolian and Tibetan versions of the Large Sukhävatīvyūha appear to have been preserved.Large Sukhävatīvyüha:

a) Wu liang shou ju lai hui [T.: 310.5]

b) Wu liang ch'ing ching p'ing teng chiao ching [T 61].

Trsl. by Lokakșema between 147 AD and 186 AD in Loyang [T 2153-389a; 18].

4. Trsl. by Bodhiruci (chüan 19-20).

5 Trsl. by Lokakṣema between 147 and $186 \mathrm{AD}$ in Loyang (2 chüan), [T 2151-384c: 8; T 2146-115c: 2]. $\mathrm{K}$ 'ai -yüan gives $147 \mathrm{AD}$ for the date of translation [T 2154-478c: 5]. 
English (trsl.): $\quad$ Chang (1983), pp. 315-338.

French (trsl.): $\quad$ Dantinne (1983).

\section{Varmavyūhanirdeśa}

Chinese Title: $\quad$ Pei chia chuang yen hui [T 310.7 $]^{1}$

Tibetan Title: $\quad$ ḥphags pa go chahi bkod pa bstan pa źes bya ba theg pa chen pohi mdo [TTP 760.7; TTD 51]

\section{Dharmadhātuprakrtyasaṃbhedanirdeśa}

Chinese Title: $\quad$ Fa chiai t'i hsing wu fen pieh hui [T 310.8 $]^{2}$

Tibetan Title: $\quad$ ḥphags pa chos kyi dbyiǹs kyi ran bźin dbyer med pa bstan pa źes bya ba theg pa chen pohi mdo [TTP 760.8; TTD 52]

\section{Daśadharmaka}

Chinese Title: $\quad$ 1. Ta ch'eng shih fa hui [T 310.9$]^{3}$

2. Ta ch'eng shih fa ching [T 314 $]^{4}$

Tibetan Title: $\quad$ hiphags pa chos bcu pa źes bya ba theg pa chen pohi mdo [TTP 760.9; TTD 53]

English (part. trsl.) Bendall; Rouse (1981), pp. 5, 8, 114 (quot.).

\section{Samantamukhaparivarta}

Chinese Title: $\quad$ 1. Wen shu shih li p'u men hui [T 310.10 $]^{5}$

2. P'u men p'in ching [T 315$]^{6}$

Tibetan Title: $\quad$ ḥphags pa kun nas sgohi lehu źes bya ba theg pa chen pohi mdo [TTP 760.10; TTD 54]

English (trsl.): $\quad$ Chang (1983), pp. 134-148.

1. Trsl. by Bodhiruci (chüan 21-25).

2. Trsl. by Mandrasena in $503 \mathrm{AD}$ (chüan 26-27). He arrived in Nan-ching/Nanking in the same year from Fu-nan (Lower Cambodia) [T 2154-537b: 12].

3. Trsl. by Buddhasānta in $539 \mathrm{AD}$ (chüan 28). Native of North India; in China from 508 to $539 \mathrm{AD}$ (Loyang) [T 2154-542a: 26].

4. Trsl. by Sanghabhadra between 506 and $520 \mathrm{AD}$ [T 2151-364b: 24].

5. Trsl. by Bodhiruci (chüan 29).

6. Trsl. by Dharmarakșa I in $287 \mathrm{AD}$ [T 2154-493b: 22]. 


\section{Raśmisamantamuktanirdeśa}

Chinese Title: $\quad$ Ch'u hsien kuang ming hui [T 310.11 $]^{1}$

Tibetan Title: $\quad$ hphags pa hod źer kun du bkye ba bstan pa źer bya ba theg pa chen pohi mdo [TTP 760.11; TTD 55]

English (trsl.): $\quad$ Chang (1983), pp. 191-222.

\section{Bodhisattvapitaka}

Chinese Title: $\quad$ 1. Ta p'u sa ts'ang hui [T 310.12 $]^{2}$

2. Ta ch'eng p'u sa ts'ang cheng fa ching [T 316 $]^{3}$

Tibetan Title: $\quad$ hphags pa byan chub sems dpahi sde snod ces bya ba theg pa chen pohi mdo [TTP 760.12; TTD 56]

English (part. trsl.): Pedersen (1976).

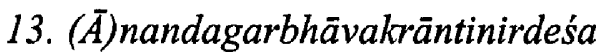

Chinese Title: $\quad$ 1. Fo wei a nan shuo ch'u t'ai hui [T 310.13$]^{4}$

2. Pao t'ai ching [T 317]

Tibetan Title: $\quad$ hphags pa dgah bo mnal na gnas pa bstan pa theg pa chen pohi mdo [TTP 760.14; TTD 57]

\section{4. Äyuṣmannandagarbhāvakrāntinirdeśa}

Chinese Title: $\quad$ Fo shuo ju t'ai ts'ang hui [T 310.14 $]^{6}$

Tibetan Title: $\quad$ ḥphags pa tshe dan ldan pa dgah bo mnal du ḥjug pa bstan pa źes bya ba theg pa chen pohi mdo [TTP 760.13; TTD 58]

German (trsl.): $\quad$ Huebotter (1932)

1. Trsl. by Bodhiruci (chüan 30-34).

2. Trsl. by Hsüan-tsang in $645 \mathrm{AD}(556 / 600 / 602-664 \mathrm{AD})$, who travelled to Central Asia and India from 629 to $644 / 645 \mathrm{AD}$ [T 2154-555c: 5].

3. Alternative title: P'u sa tsang cheng fa ching; trsl. by Dharmarakșa II between 1018 and 1058 AD [Ono. vol. 12, p. 184a].

4. Trsl. by Bodhiruci (chüan 55).

5. Trsl. by Dharmarakșa I in $281 \mathrm{AD}$ [T 2157-790c: 15] or $303 \mathrm{AD}$ [T 2149-234b: 10].

6. Alternative title: Fo wei nan t'u shuo chu chia ju t'ai ching; trsl. by I-ching (I-tsing) in $710 \mathrm{AD}$, who travelled abroad from 671 to 695/98 AD. He died in $713 \mathrm{AD}$ (chüan 55). 


\section{Mañjuśríbuddhakṣetragunavyüha}

Chinese Title: $\quad$ 1. Wen shu shih li shou chi hui [T 310.15] ${ }^{1}$

2. Wen shu shih li fo t'u yen ching [T 318 $]^{2}$

3. Ta sheng wen shu shih li p'u sa fo ch'a kung te chuang yen ching [T 319] $]^{3}$

Tibetan Title: $\quad$ hphags pa hjam dpal gyi sans rgyas kyi źin gi yon tan bkod pa źes bya ba theg pa chen pohi mdo [TTP 760.15; TTD 59]

English (trsl.): $\quad$ Bendall; Rouse (1981), pp. 4, 14, 15, 170 (quot.). Chang (1983), pp. 164-190.

French (part. trsl.): Lamotte (1960), pp. 20-23.

\section{Pitāputrasamāgama}

Chinese Titie: $\quad$ 1. P'u sa ch'ien shih hui $[\mathrm{T} 310.16]^{4}$

2. Fu tzu ho chi ching [T 320$]^{5}$

Tibetan Title: $\quad$ hphags pa yab dań sras mjal ba źes bya ba theg pa chen pohi mdo [TTP 760.16; TTD 60]

English (part. trsl.): Bendall; Rouse (1981), pp. 177, 226 (quot.).

Conze (1954), pp. 164-165.

Obermiller (1931), i, p. 134 (quot.).

\section{Pürnapariprcchā}

Chinese Title:

Fu lou na hui [T 310.17 $]^{6}$

Tibetan Title:

hphags pa gañ pos źus pa źes bya ba theg pa chen pohi mdo [TTP 760.18; TTD 61]

\section{Räștrapālaparipṛchā}

Chinese Title:

1. Hu kuo p'u sa hui [T 310.18]

1. Trsl. by Sikṣānanda between 695 and 707 AD in Loyang. Native of Khotan (chüan 58-60), [T 2154-566a: 22f.].

2. Trsl. by Dharmarakșa I in $290 \mathrm{AD}$ in Loyang (2 chüan), [T 2148-289a: 4; T 2151-790c:18].

3. Trsl. by Amoghavajra between 720 and 774 AD in Loyang (3 chüan), [T 2157-881a: 17; T 2157-980a: 8].

4. Trsl. by Narendrayaśas in 568 AD. Arrival in China from Uḍdiyāna (North India) in 556 AD [T 2154-543c: 10].

5. Trsl. by Jih-ch'eng and Dharmarakșa II between 1058 and $1072 \mathrm{AD}$ [Ono. vol. 12, p. 184b].

6. Alternative titles: Fu lou na wen ching, P'u sa ts'ang ching; trsl. by Kumārajiva in 405 AD [T 2154-512: 15].

7. Trsl. by Jñānagupta towards the end of the sixth century AD. Native of Gandhära (523-600 AD), [T 
2. Hu kuo tsun che so wen ta ch'eng ching [T 321] $]^{1}$

Tibetan Title: $\quad$ 1. ḥphags pa yul ḥkhor skyon gis źus pa źes bya ba theg pa chen pohi mdo [TTP 760.17; TTD 62]

2. hạphags pa yul ḥkhor skyon gis źus pa źes bya ba theg pa chen pohi mdo [TTP 833; TTD 166]

English (trsl.): $\quad$ Ensink (1952).

Edition: $\quad$ Finot (1910)

\section{Ugrapariprcchā}

Chinese Title: $\quad$ 1. Yü chieh chang che hui [T 310.19] ${ }^{2}$

2. Fa ching ching [Dharmādarśasütra, $T$ 322] ${ }^{3}$

3. Yü chieh lo yüeh wen p'u sa-hsing ching [T 323] $]^{4}$

Tibetan Title: $\quad$ ḥphags pa khyim bdag drag sul can gyis źus pa zes bya ba theg pa chen pohi mdo [TTP 760.19; TTD 63]

English (trsl.): $\quad$ Bendall; Rouse (1981), pp. 11, 21, 39, 83, 119, 130, 133, 141, 144, $149,176,187,188,190,191,194,245,248,263,282$ (quot.).

Schuster (1976).

\section{Vidyutprāptapariprcch $\bar{a}$}

Chinese Title: $\quad$ Wu chin fu ts'ang hui [T 310.20] $]^{5}$

Tibetan Title: $\quad$ hphags pa glog thob kyis źus pa źes bya ba theg pa chen pohi mdo [TTP 760.20; TTD 64]

English (trsl.): $\quad$ Chang (1983), pp. 149-163.

\section{Bhadramāyākāravyākaraṇa}

Chinese Title: $\quad$ 1. Shou huan shih po t'o lo chi hui [T 310.21]

2. Huan shih jen hsien ching [T 324]

Tibetan Title: $\quad$ hphags pa sgyu ma mkhan bźan po lun bstan pa źes bya ba theg pa

2154-550b: 19].

1. Trsi. by Dānapāla in $994 \mathrm{AD}$ (4 chüan), [Ta-chung-lu, vol. 8 p.23 b: $26 \mathrm{~b}$ ].

2. Trsl. by Sanghavarman from Sogdia in 252 AD (chüan 82), [T 2154 487a: 3]. According to Schuster (citing Hirawaka, A.) by Dharmamitra I a Kaśmirian who stayed in China from 424 to 442 AD.

3. Trsl. by An Hsüan (a Parthian layman) and Yen Fo-t'iao (the first known Chinese Buddhist monk from An Hui) in $181 \mathrm{AD}$ (1 chüan), [T 2151-350a: 14].

4. Trsl. by Dharmarakșa I between 266 and 300/10/13 AD (1 chüan), [T 2151-353a: 26].

5. Trsl. by Bodhiruci (chüan 83-84).

6. Trsl. by Bodhiruci (chüan 85 ).

7. Trsl. by Dharmarakșa I (1 chüan), [T 2151-353a: 26 f.]. 
chen pohi mdo [TTP 760.21; TTD 65]

English (trsl:): $\quad$ Chang (1983), pp. 3-26.

Edition: Régamey (1938).

\section{Mahāprätihāryopadeśa}

Chinese Title: $\quad$ Ta shen pien hui [T 310.22 $]^{1}$

Tibetan Title: $\quad$ hphags pa cho hphrul chen po bstan pa źes bya ba theg pa chen pohi mdo [TTP 760.22; TTD 66] ${ }^{2}$

\section{Maitreyamahāsimhanā̄da}

Chinese Title: $\quad$ Mo ho chia she hui [T 310.23]

Tibetan Title: $\quad$ ḥphags pa byams pahi sen geḥi sgra chen po źes bya ba theg pa chen pohi mdo [TTP 760.23; TTD 67]

English (part. trsl.): Obermiller (1931), i, p. 12 (quot.).

\section{Vinayaviniścaya-Upālipariprcchā}

Chinese Title: $\quad$ 1. Yu po li hui [T 310.24$]^{3}$

2. Chüeh ting p'i ni ching [T 325] $]^{4}$

3. San shih wu fo ming li ch'an wen [T 326]

4. Yu po li wen fo ching [T 1466$]^{6}$

Tibetan Title: $\quad$ hphags pa hadul ba rnam par gtan la dbab ne bar ḥkhor gyis źus pa źes bya ba theg pa chen pohi mdo [TTP 760.24; TTD 68]

English (trsl.): $\quad$ Bendall; Rouse (1981), pp. 161, 165, 173, 264 (quot.). Chang (1983), pp. 262-279.

French (trsl.): $\quad$ Python (1973).

Edition: Python (1973).

1. Trsl. by Bodhiruci (chüan $86-89$ ).

2 TTP, TTD: Mahāprātihāryanirdeśa.

3. Trsl. by Bodhiruci (chüan 90 ).

4. Translator unknown (Chin Dynasty $266 \mathrm{AD}$ to $420 \mathrm{AD}$ in Tun-huang). The text mentions Tun-huang San-ts'ang as the translator, who is often identified with Dharmarakșa I (1 chüan), [T 2145-12a: 21].

5. Trsl. by Gunavarman during the Liu Sung Dynasty.

6. Trsl. by Amoghavajra between 720 and $774 \mathrm{AD}$ in Loyang. Completely different version which in many respects is remnisent to extracts of the Theravāda Vinaya. No corresponding Tibetan translation is known to exist (ed. by H. Bechert, Göttingen 1984) (1 chüan), [T 2157-881a: 17]. 


\section{Adhyāśayasamcodana}

Chinese Title: $\quad$ 1. Fa sheng chih le hui $[\mathrm{T} 310.25]^{1}$

2. Fa chio ching hsin ching [T 327 $]^{2}$

Tibetan Title: $\quad$ ḥphags pa lhag pahi bsam pa bskul ba źes bya ba theg pa chen pohi mdo [TTP 760.25; TTD 69]

English (part. trsl.): Bendall; Rouse (1981), pp. 17, 100, 105-114, 310 (quot.).

\section{Subāhupariprcchā}

Chinese Title:

1. Shan pei p'u sa hui [T 310.26$]^{3}$

2. Su p'o hu t'ung tzu ch'ing wen ching [T 895 $]^{4}$

3. Miao pei p'u sa so wen ching [T: no. 896 $]^{5}$

Tibetan Title: $\quad$ ḥphags pa lag bźans gis źus pa źes bya ba theg pa chen pohi mdo [TTP 760.26; TTD 70]

\section{Sūratapariprcchā}

Chinese Title:

Tibetan Title:

English (trsl.):
1. Shan shun p'u sa hui [T 310.27$]^{6}$

2. Hsü lai ching [T 329]

ḥphags pa nes pa źus pa źes bya ba theg pa chen poḥi mdo [TTP 760.27; TTD 71]

Chang (1983), pp. 243-255.

\section{Viradatta(grhapati)pariprcchā}

Chinese Title: $\quad$ 1. Ch'üan shou chang che hui [T 310.28 $]^{8}$

2. P'u sa hsiu hsing ching [T 330 $]^{9}$

3. Wu wei shou so wen ta ch'eng ching [T 331 $]^{10}$

Tibetan Title: $\quad$ ḥphags pa khyim bdag dpas byin gyis źus pa źes bya ba theg pa chen pohi mdo [TTP 760.28; TTD 72]

English (part. trsl.): Bendall; Rouse (1981), pp. 37, 217 (quot.).

1. Trsl. by Bodhiruci (chüan 91-92).

2. Trsl. by Jñānagupta in $595 \mathrm{AD}$ (2 chüan), [T 2151-366a: 3].

3. Trsl. by Kumärajīiva between $402 \mathrm{AD}$ and $412 \mathrm{AD}$ (chüan 93-94), [T 2154-514c: 26].

4. Trsl. by Subhakarasimha in $726 \mathrm{AD}$ (3 chüan), [T 2157-874c: 3].

5. Trsl. by Fa-t'ien between 973 and $988 \mathrm{AD}$ (4 chüan), [T 2035-398b: 23; Ta-chung-lu vol. 6, p. 16b-17b].

6. Trsl. by Bodhiruci (chüan 95).

7. Trsl. by Chih-shih-lun in 373 AD [T 2157-815c: 26].

8. Trsl. by Bodhiruci (chüan 96).

9. Trsl. by Po Fa-tzu between 290 and $306 \mathrm{AD}$ (1 chüan), [T 2153-399c: 25].

10. Trsl. by Dānapāla in $983 \mathrm{AD}$ (3 chüan), [T 2035-398b: 25]. 
German (part. trsl.): Winternitz (1930), pp. 45-46.

\section{Udayanavatsarājapariprcchā}

Chinese Title: $\quad$ 1. Yu t'o yen wang hui [T 310.29 $]^{1}$

2. Yu t'ien wang ching [T 332 $]^{2}$

3. Ta ch'eng jih tzu wang so wen ching [T 333] $]^{3}$

Tibetan Title: $\quad$ hphags pa bad sahi rgyal po ḥchar byed kyis źus pa źes bya bahi lehu [TTP 760.29;TTD 73]

English (part. trsl.): Bendall; Rouse (1981), p. 85 (quot.).

Obermiller (1931), ii, p. 169 (quot.).

\section{Sumatidarikāpariprcchā}

Chinese Title: $\quad$ 1. Miao hui t'ung nü hui [T 310.30 $]^{4}$

2. Hsü mo t'i p'u sa ching [T 334$]^{5}$

3. Hsü mo t'i ching [T 336 $]^{6}$

Tibetan Title: $\quad$ hphags pa bu mo blo gros bźan mos źus pa źes bya ba theg pa chen pohi mdo [TTP 760.30; TTD 74]

English (trsl.): $\quad$ Chang (1983), pp. 256-261.

\section{Gangottarapariprcchā}

Chinese Title: $\quad$ Heng ho shang yu p'o i hui [T 310.31]

Tibetan Title: $\quad$ ḥphags pa gan gahi mchog gis źus pa źes bya ba theg pa chen pohi mdo [TTP 760.31; TTD 75]

English (trsl.): $\quad$ Chang (1983), pp. 37-40.

\section{Aśokadattävyäkarana}

Chinese Title: $\quad$ 1. Wu wei te p'u sa hui [T 310.32 $]^{8}$

2. A sheh shih wang nü a sha ta p'u sa ching [T 337 $]^{9}$

1. Trsl. by Bodhiruci (chüan 97).

2. Trsl. by Fa-chü between $290 \mathrm{AD}$ and $306 \mathrm{AD}$ (1 chüan), [T 2151-355a: 15].

3. Trsl. by Fa-t'ien in $984 \mathrm{AD}$ (1 chüan), [Ta-chung-lu, vol. 4, p. 1a: 3b].

4. Trsl. by Bodhiruci (chüan 98 a).

5. Trsl. by Dharmarakșa I between 265 and $313 \mathrm{AD}$ (1 chüan), [T 2151-353a: 26].

6. Trsl. by Bodhiruci in $693 \mathrm{AD}$ (1 chüan).

7. Trsl. by Bodhiruci (chüan $98 \mathrm{~b}$ ).

8. Trsl. by Buddhasañnta in $539 \mathrm{AD}$ (chüan 99), [T 2154-542a: 28].

9. Trsl. by Dharmarakșa I in $317 \mathrm{AD}$ (1 chüan), [T 2154-493c: 9]. 
Tibetan Title: $\quad$ ḥphags pa mya nan med kyis byin pa lun bstan pa źes bya ba theg pa chen pohi mdo [TTP 760.32; TTD 76]

English (trsl.): $\quad$ Chang (1983), pp. 115-133.

\section{Vimaladattāpariprcchā}

Chinese Title: $\quad$ 1. Wu kou shih p'u sa (fen pieh) ying pien hui [T 310.33]

2. Li kou shih nü ching [T 338 $]^{2}$

3. Te wu kou nü ching [T 339 $]^{3}$

Tibetan Title: $\quad$ ḥphags pa dri ma med kyis byin pas źus pa źes bya ba theg pa chen pohi mdo [TTP 760.33; TTD 77]

English (trsl.): $\quad$ Chang (1983), pp. 73-99.

\section{Gunaratnasaṃkusumitapariprcchā}

Chinese Title: $\quad$ Kung te pao hua fu p'u sa hui [T 310.34 $]^{4}$

Tibetan Title: $\quad$ 1. ḥphags pa yon tan rin chen med tog kun tu rgyas pas źus pa źes bya ba theg pa chen pohi mdo [TTP 760..34; TTD 78]

2. hphags pa sans rgyas bcu pa źes bya ba theg pa chen pohi mdo

[TTP 938; TTD 272]

\section{Acintyabuddhavișayānirdeśa}

Chinese Title: $\quad$ 1. Shan te t'ien tzu hui [T 310.35]

2. Wen shu shih li so shuo pu ssu i fo ching chieh ching [T 340]

Tibetan Title: $\quad$ hphags pa sans rgyas kyi yul bsam gyis mi khab pa bstan pa źes bya ba theg pa chen pohi mdo [TTP 760.35; TTD 79]

English (trsl.): $\quad$ Chang (1983), pp. 27-37.

\section{Susthitamati(devaputra)pariprcchā}

Chinese Title: $\quad$ 1. Shan chu i t'ien tzu hui [T 310.36] $]^{7}$

1. Trsl. by Nieh Tao Chen and Dharmarakșa I between 280 and $312 \mathrm{AD}$ at Ch'ang-an (chüan 100), [T 2154-501a: 2].

2. Trsl. by Dharmarakșa I in 289 AD (1 chüan), [T 2154-493c: 11].

3. Trsl. by Gautama Prajñāruci in $541 \mathrm{AD}$ (1 chüan), [T 2157-840c: 24; T 2157-841b: 5].

4. Trsl. by Bodhiruci (chüan 101a).

5. Trsl. by Bodhiruci (chüan 101b).

6. Trsl. by Bodhiruci in $693 \mathrm{AD}$ (2 chüan), [T 2153-380a: 8].

7. Trsl. hy Dharmagupta between 605 and 617 AD. Arrival from South India (Lata) in Ch'ang-an in 590 AD 
Tibetan Title:

2. Shen shan chu i t'ien tzu so we
3. Ju huan san mei ching [T 342$]^{2}$

ḥphags pa lhahi bu blo gros rab gnas kyis źus pa źes bya ba theg pa

English (trsl.): chen pohi mdo [TTP 760.37; TTD 80]

Chang (1983), pp. 41-72.

\section{Simhapariprcchä}

Chinese Title: $\quad$ 1. A she shih wang tzu hui [T 310.37$]^{3}$

2. T'ai tzu shua hu ching [T 343$]^{4}$

3. T'ai tzu ho hsiu ching [T 344]

Tibetan Title: $\quad$ hphags pa sen ges źus pa źes bya ba theg pa chen pohi mdo [TTP 760.37; TTD 81]

English (part. trsl.): Bendall; Rouse (1981), pp. 5, 53 (quot.).

\section{Upāyakausalyaparivarta}

Chinese Title: $\quad$ 1. Ta ch'eng fang pien hui $[\mathrm{T} 310.38]^{6}$.

2. Hui shang p'u sa wen ta shan ch'üan ching [T 345 $]^{7}$

3. Ta fang kuang shan ch'iao fang pien ching [T 346$]^{8}$

Tibetan Title: $\quad$ 1. hphags pa sañs rgyas thams cad kyi gsan chen thabs la mkhas pa byan chub sems dpah ye ses dam pas źus pahi leḥu źes bya ba theg pa chen pohi mdo [TTP 760.38; TTD 82 $]^{9}$

2. h.phags pa thabs mkhas pa źes bya ba theg pa chen pohi mdo [TTP 927; TTD 261]

English (trsl.): $\quad$ Bendall; Rouse (1981), pp. 70, 161, 163, 164, 165 (quot.). Chang (1983), pp. 427-468.

Obermiller (1931), i, p. 134 (quot.).

Tatz, M. (1981).

German (part. trsl.): Winternitz (1930), p. 40.

(chüan 102-105), [T 2154-552b: 22].

1. Trsl. by Prajñăruci in 541 AD (3 chüan), [T 2149-269c: 24].

2. Trsl. by Dharmarakșa I (3 chüan; var. 4), [T 2151-353a: 26].

3. Trsl. by Bodhiruci (chüan 106a).

4. Trsl. by Dharmarakșa I (1 chüan), [T 2151-353a: 26f ].

5. Translator unknown. Listed in the Hsi-chin-lu as having been translated between 265 and 316 AD (1 chüan), [T 2154-587b: 23].

6. Trsl. by Nandi (from Western China) in $420 \mathrm{AD}$ at Lo-yang (chüan 106b-108), [T 2154-509a: 6].

7. Trsl. hy Dharmarakșa I in 285 AD (2 chüan), [T 2145-8a: 12].

8. Trsl. by Dānapāla in $1005 \mathrm{AD}$ (4 chüan), [Ta-chung-lu. vol. 13, p.1a-4a].

9 Title as listed in Tibetan bKah-hgyur. Arya-sarvabuddhamahārahasyopāyakausalyajñānottarabodhisattvapariprcchāparivarta-näma-māhāyāna-sūtra (D, P, R). 


\section{Bhadrapālaśreșthipariprcchā}

Chinese Title: $\quad$ 1. Hsien hu chang che hui $[\mathrm{T} 310.39]^{1}$

2. Ta ch'eng hsien shih ching [T 347 $]^{2}$

Tibetan Title: $\quad$ hphags pa tshon dpon bźan skyon gis źus pa źes bya ba theg pa chen pohi mdo [TTP 760.39; TTD.: 83]

English (trsl.): $\quad$ Chang (1983), pp. 223-242.

\section{Dārikāvimalaśraddhāpariprcchā}

Chinese Title: $\quad$ Ching hsin t'ung nü hui [T 310.40 $]^{3}$

Tibetan Title: $\quad$ Bu mo rnam dag dad pas źus pa źes bya ba theg pa chen pohi mdo [TTP 760.40; TTD 84]

\section{Maitreyapariprcchädharmāṣța}

Chinese Title: $\quad$ 1. Mi le p'u sa wen pa fa hui [T 310.41$]^{4}$

2. Ta ch'eng fang teng yao hui $[\mathrm{T} 348]^{5}$

Tibetan Title: $\quad$ 1. hphags pa byams pas źus pa brgyad pa źes bya ba theg pa chen pohi mdo [TTP 760.41/2; TTD 85/6]

2. hphags pa byams pas źus pa źes bya ba theg pa chen pohi mdo [TTP 816; TTD 149]

\section{Maitreyapariprcchā}

Chinese Title: $\quad$ 1. Mi le p'u sa wen hui [T 310.42]

2. Mi le p'u sa so wen pen yüan ching [T 349] ${ }^{7}$

Tibetan Title: $\quad$ 1. hphags pa byams pas źus pahi lehu źes bya ba theg pa chen pohi mdo [TTP 760.42/41; TTD 86/85]

2. hphags pa byams pas źus pahi lehu źes bya ba theg pa chen pohi mdo [TTP 816; TTD 149]

1. Alternative title: I shih ching; trsl. by Jñănagupta (from Gandhāra) in 591 AD (chüan 109-110), [T 2154-548b: 8].

2. Trsl. by Divākara in $680 \mathrm{AD}$ (2 chüan), [T 2153-397a: 7; Ono.: $630 \mathrm{AD}$ ].

3. Trsl. by Bodhiruci (chüan 111a).

4. Trsl. by Bodhiruci (chüan 111b).

5. Trsl. by An Shih-Kao between 148 and 170 AD (1 chüan), [T 2151-349a: 12].

6. Trsl. by Bodhiruci (chüan 111c).

7. Trsl. by Dharmarakṣa I in $303 \mathrm{AD}$ (1 chüan), [T 2157-791a: 10]. 
43. Kāśyapaparivarta

Chinese Title: $\quad$ 1. P'u ming p'u sa hui [T 310.43$]^{1}$

2. I jih me ni pao ching [T 350 $]^{2}$

3. Mo ho yen pao yen ching [T 351$]^{3}$

4. Ta chia she wen ta pao chi cheng fa ching [T 352 $]^{4}$

Tibetan Title: $\quad$ ḥphags pa hod sruns kyi lehu źes bya ba theg pa chen pohi mdo [TTP 760.43; TTD 87]

English (trsl.): $\quad$ Bendall; Rouse (1981), p. 52, n. 1; pp. 53, 54, 55, 144, 147, 190, 235 (quot.).

Chang (1983) pp. 387-414.

German (trsl.): $\quad$ Weller (1965).

Winternitz (1930), pp. 36-37.

Edition: $\quad$ Stael Holstein (1926).

Vorob'jev- Desjatovski (RO; 21).

44. Ratnarāási

Chinese Title: $\quad$ Pao liang chü hui $[\mathrm{T} 310.44]^{5}$

Tibetan Title: $\quad$ hphags pa rin po chehi phun po źes bya ba theg pa chen pohi mdo [TTP 760.45; TTD. no. 88]

English (trsl.): $\quad$ Bendall; Rouse (1981), pp. 56, 127, 129, 134, 135, 194, 278

(quot.).

Chang (1983), pp. 280-314.

Edition: Hoernle (1916), pp. 116-121.

\section{Aksayamatipariprcchā}

Chinese Title: $\quad$ Wu chin hui p'u sa hui [T 310.45]

Tibetan Title: $\quad$ ḥphags pa blo gros mi sad pas źus pa źes bya ba theg pa chen pohi mdo [TTP 760.44; TTD 89]

English (trsl.): $\quad$ Bendall; Rouse (1981), pp. 12, 24, 36, 37, 115, 118, 156, 163, 185, 204, 219, 221, 248, 254, 260, 261, 264, 283 (quot.). Chang (1983), pp. 415-426.

German (part. trsl.): Winternitz (1930), p. 48.

1. Alternative title: $\mathrm{Ku}$ ta pao shi ching; translator unknown (chüan 112).

2. Trsl. by Lokakșema in $179 \mathrm{AD}$ (1 chüan), [T 2149-223c: 18].

3. Translator unknown; Ch'in Dynasty (265-420 AD); (1 chüan), [T 2153-382b: 17].

4. Trsl. by Dānapāla in $985 \mathrm{AD}$ ( 5 chüan), [Ta-chung-lu. vol.4, p.23a: $25 \mathrm{~b}]$.

5. Alternative title: Pao liang ching; trsl. by Tao-Kung between 401 and $412 \mathrm{AD}$ at Ch'ang-an (chüan 113-114).

6. Trsl. by Bodhiruci (chüan 115a). 


\section{Saptaśatikaprajñ̄āpāramitā}

Chinese Title: $\quad$ 1. Wen shu shuo pan jo hui $[\mathrm{T} 310.46]^{1}$

2. Ta pan jo po lo mi to ching (chapter 7) $\left[\mathrm{T} \mathrm{220.7]^{2 }}\right.$

3. Wen shu shih li so shuo mo ho pan jo polo mi ching [T 232 $]^{3}$ hphags pa ses rab kyi pha rol tu phyin pa bdun brgya pa źes bya ba theg pa chen pohi mdo [TTP 760.46; TTD 90]

English (trsl.): $\quad$ Chang (1983), pp. 100-114.

Edition: $\quad$ Tucci (1923).

\section{Ratnacūdapariprcchā}

Chinese Title: $\quad$ Pao chi p'u sa hui [T 310.47]

Tibetan Title: $\quad$ hphags pa gtsug na rin po ches źus pa źes bya ba theg pa chen pohi mdo [TTP 760.47; TTD 91]

English (part. trsl.): $\quad$ Bendall; Rouse (1981), pp. 115, 120, 217, 219, 222, 222, 249, 284 (quot.).

Obermiller (1931), ii, p. 115 (quot.).

\section{Srìmālādevisimhanāda}

Chinese Title: $\quad$ 1. Sheng man fu jen hui [T 310.48$]^{6}$

2. Sheng man shih tzu hou $i$ cheng ta fang pien fang kuang ching [T 353] $]^{7}$

Tibetan Title: $\quad$ ḥphags pa lha mo dpal ḥphren gi sen gehi sgra źes bya ba theg pa chen pohi mdo [TTP 760.48; TTD 92]

English (trsl.): $\quad$ Bendall; Rouse (1981), p. 44 (quot.). Chang (1983), pp. 363-386.

Wayman (1974).

1. Trsl. by Mandrasena in 503 AD (chüan 115b-116), [T 2154-537b: 12].

2. Trsl. by Hsüan-tsang between 659 and $663 \mathrm{AD}$ (2 chüan), [T 2154-555b: 28; T 2149-282b: 10 ].

3. Trsl. by Mandrasena in 503 AD (1 chüan), [T 2154-537: 12].

4. Trsl. by Sanghabhara between 509 and 520 AD at Lo-yang (2 chüan), [T 2151-364b: 24].

5. Trsl. by Dharmarakșa I in 290 AD (chüan 117-118), [T 2154-493b: 21].

6. Trsl. by Bodhiruci (chüan 119).

7. Trsl. by Gunabhadra in 436 AD (1 chüan), [T 2154-528a: 15]. A translation made by Dharmakșema in 433 $\mathrm{AD}$ was no longer extant by the time of the Yüan Dynasty. (See: Wayman, 1974, pp. 9-13). 
49. (Rsi) vyāsapariprcchā

Chinese Title: $\quad$ 1. Kuang po hsien jen hui [T 310.49 $]^{1}$

2. P'i yeh p'o wen ching [T 354]

Tibetan Title: $\quad$ ḥphags pa drañ sron rgyas pas źus pa źes bya ba theg pa chen pohi mdo [TTP 760.49; TTD 93]

1. Trsl. by Bodhiruci (chüan 120).

2. Trsl. by Gautama Prajñāruci in $542 \mathrm{AD}$ (2 chüan), [T 2157-841a: 1]. 


\section{Appendix IV}

\section{Tibetan Text of Chapter Eleven of the Bodhisattvapițakasūtra}

\section{SECTION I}

\section{1}

(590) Sã rihi bu de la byañ chub sems dpaḥ chen po gan la brtson na $\left.\right|^{1}$ byan chub sems dpaḥi spyad pa spyod par hgyur bahi byan chub sems dpaḥ sems dpaḥ chen poḥi ses rab kyi pha rol tu phyin pa gan źe na | śā riḥi bu ḥdi la byań chub sems dpaḥ byañ chub sems dpaḥi sde snod kyi chos kyi rnam grans rab tu ñan par byed $\left.\right|^{2}$ hadzin par byed | hachan bar byed | klog par byed | kun chub par byed | gźan dag $^{3}$ la yan ḥchad cin rgya cher yan dag par rab tu ston par byed de $\|$

sã rihi bu de la byan chub sems dpas ${ }^{4}$ byan chub sems dpahi sde snod kyi chos kyi mam gran̉s śin tu mñan | blaǹs | bzun | bklags | gźan dag ${ }^{5}$ la yan̉ bśad cin rgya cher yan dag par rab tu bstan na | śes rab kyi rnam pa hidi dag hthob par hgyur ro || śes rab de yan rnam pa $\operatorname{gan}^{6}$ | hyjug pa gan źe na | de la ses rab $^{7}$ thos pa ni rnam paho $\|$ tshul bźin yid la byed pa ni hjug paho $\|$

\subsection{1}

thos pa yañ ${ }^{8}$ rnam pa gañ źe na | ḥdi lta $s^{9}{ }^{9} \mid$ ḥdun ${ }^{10}$ pahi rnam pa dan | bsam pahi rnam

1. In my edition of chapter eleven, $I$ have adopted the punctuation and Arabic page/folio numbering as it is found in the modern reprint of the sTog Palace Kanjur (Leh-1979). Whenever it seemed appropriate to point to the inclusion of additional sad in other editions of the canon, I have indicated thus in the footnote section. Round brackets serve to indicate conjectural insertions, while square brackets indicate deletions. Whenever available, I reproduced in the footnote section the reading of the Tun-huang manuscript (Pelliot 977) of the $B d p$. Since it is independent of the various blockprint versions, I decided to treat the Tunhuang manuscript as a variant in its own right. Thus I have not edited the text, but faithfully recorded its readings. Like many Tun-huang works, it contains a fair amount of non-standard spellings, such as 'sa ri bu' for 'sā ri bu', 'myed' for 'med' or 'yin ba' for 'yin pa', etc. In order to keep the manuscript portions on the same page as the text of the sTog Palace reading, I have broken it up by paragraphs to match those to the main body of the text.

2. P add: len pa byed.

3. D N gźan dag.

4. $\mathrm{N}$ dpah.

5. $\mathrm{N}$ gźan dag.

6. D dan.

7. D N add: kyi; R add: kyis.

8. N gan.

9. I provide here the Sanskrit equivalents of the 72 technical terms that are given in the Tibetan:

1. ḥdun pa: chanda; 2 . bsam pa: āśaya; 3 . sbyor pa: prayoga; 4. dge bahi bśes gñen: kalyänamitra; 5 . na rgyal med pa: nirmānaa; 6 , rab ḥdud pa: praṇama; 7. ri mor byed pa: mänanā; 8 . ḥthun pa: anukula; 9 . bkah 
pa dan் | sbyor baḥi rnam pa dań | dge baḥi bśes gñen gyi rnam pa dan | na rgyal med paḥi rnam pa dan | rab tu (591) ḥdud pahi rnam pa dan | ri mor byed pahi rnam pa dan | ḥthun ${ }^{1}$ paḥi rnam pa dan் | bkaḥ blo bde baḥi rnam pa dan | bsñen bkur byed pahi rnam pa dań | rna blags te $^{2}$ ñan paḥi rnam pa dan | bkur sti byed pahi rnam pa daǹ | yid la byed paḥi mam pa dañ | mi g.yeń bahị mam pa dań | rin po cher ${ }^{3}$ ḥdu śes pahi rnam pa dan | sman du ḥdu śes pahi rnam pa dan | nad thams cad rab tu źi bar byed paḥi ḥdus ses kyi mam pa dan | dran pahi snod kyi mam pa dan் | rtogs pa śes pahi rnam pa dan | blo gros ḥdod pahi rnam pa dan் / blo la hjug pahi rnam pa dan் / sańs rgyas kyi chos thos pas mi noms pahi rnam pa dan | gton ba spel baḥi rnam pa dan் | byin nas mi smod pahi mam pa dan | man du thos pa sten ${ }^{4}$ pahi rnam pa dan் | gus par dgaḥ ba myon̉ bar byed paḥi rnam pa dan் | lus sim paḥi rnam pa dan் | sems rañs paḥi rnam pa dan் | mi skyor ba ñan paḥi rnam pa dań | don ñan paḥi rnam pa dan் / chos ñan paḥi rnam pa dan | nan tan ñan pahi rnam pa dan் | theg pa gźan (dag) la ḥdod pa med par

blo bde ba: suvacas; 10 . bsñen bkur byed pa: paryupāsana; 11. ma ba blags te ñan pa: avahitaśruta; 12 . bkur sti byed pa: satkära; 13. yid la byed pa: manasakāra; 14. mi g.yeñ pa: atandrita; 15 . rin po cher hdu ses: ratnasamjñnā; 16. sman du ḥdu śes pa: bhaișajyasamjñãa; 17. nad thams cad rab tu źir bar byed pahi ḥdu śs pa: sarvavyãdhisamana; 18. dran pahi snod: smrtibhojana; 19. rtogs pa ses pa: gatibodhana; 20. blo gros hdod pa: matirocana; 21 . blo la hjug pa: buddhipraveśa; 22 . sañs rgyas kyi chos thos pas mi sgoms pa: atṛptabuddhadharmaśravana; 23. gton pa spel pa: tyagavṛhaṇa; 24. sbyin nas mi smod pa: dāntājāneya; 25. mań du thos pa sten pa: bahuśrutasevanā; 26 . gus par dgah ba myon bar byed pa: *gauravanandānubhavati; 27. lus sim pa: kāyaudbilya; 28. sems rańs pa: cittaprahīàdana; 29. mi skyö bar ñan pa: aparikhedaśravana; 30. don ñan pa: arthaśravana; 31. chos ñan pa: dharmaśravaṇa; 32. nan tan ñan pa: pratipattiśravana; 33. theg pa gźan la ḥdod pa med pa ñan pa: *parayānānarthika; 34. pha rol tu phyin pa ñan pa: prajñ̄āpāramitāśravana; 35 . byañ chub sems dpahi sde snod ñan pa: bodhisattvapițakasravana; 36 . bsdu bahi dnos nan pa: samgrahavastuśravaṇa; 37 . thabs mkhas pa ñan pa: upāyakauśalyaśravana; 38 . tshañs pahi gnas pa ñan pa: brahmavihāraśravana; 39 . mñon par śes pa ñan pa: abhijñāśravaṇa; 40 . dran pa ñe bar gźags pa ñan pa: smṛtisamprajanyaśravaṇa; 41. yaǹ dag par spon ba ñan pa: samyakprahāṇaśravaṇa; 42. rdzu ḥphrul gyi rkañ pa ñan pa: ṛddhipādaśravaṇa; 43. rten cin ḥbrel par ḥbyun ba ñan pa: pratītyasamutpãdaśravaṇa; 44. mi rtag pa ñan pa: anityaśravaṇa; 45 . sdud bsgnal ba ñan pa: duhkhaśravaṇa; 46 . bdag med pa ñan pa: anātmaśravaṇa; 47. źi ba ñan pa: šāntaśravaṇa; 48. ston pa n̂id ñan pa: śūnyatāśravana; 49. mtshan ma med pa ñan pa: apranihitaśravaṇa; 50 . smon pa med pa ñan pa: animittaśravana; 51 . mnon par hdu mi byed pa ñan pa: anabhisamskāraśravaṇa; 52 . dge bahi rtsa ba mnon par hudu byed pa ñan pa: kuśaläbhisamskāraśravana; 53. raǹ dbañ du gyur pa: *svādișthāna; 54. chos ñam par hụdu šes pa: *dharmanidhyapti; 55 . kun tu ḥdre ba mi mthun pahi phyags su hạu ses pa: *samsargapratipakșasamjñ̄a; 56. ñon mons pa thams cad tshar gcod pa: *sarvakleśanigrahasthāna; 57 . mkhas pa la mñon par bgah ba: paṇđitābhinanđana; 58. hphags pa sten pa: āryasammata; 59 . ḥphags pa ma yin pa yons su spoñ pa: anāryapraśādana; 60. ḥphags pa ñan pa: satyadarśanaśravana; 61. dbań pa ñan pa: indriyaśravana; 62 . rjes su dran pa sgom pa fian pa: *anusmṛtibhāvanāśravaṇa; 63 . byan̉ chub kyi yan lag ñan pa: bodhyangāniśravana; 64 . ḥphags pahi lam yan lag brgyad pa fian pa: āryāșțāngamārgaśravaṇa; 65. de bźin gśegs paḥi stobs ñan pa: tathāgatabalāniśravaṇa; 66. mi ḥjigs pa ñan pa: vaišāradyaśravaṇa; 67. byams pa ñan pa: maitríśravaṇa; 68 . sñin pa fian pa: karuṇāśravaṇa; 69. dgah ba ñan pa: muditāśravana; 70. gtañ sñoms chen po ñan pa: upekșāsravana; 71. so so yań dag par rig pa ñan pa: pratisamvicchravana; 72. sañs rgyas kyi chos ma hạres pa bco brgyad rnams ñan pa: āvenikabuddhadharmaśravaṇa (Sikṣ: pp. 190-191; Akn: pp. 50.4.7-51.1.5; see also Appendix i).

10. $P$ mos.

1. R mthun (throughout the text).

2. R ma ba blags te te.

3. P dkon mchog.

4. N bstan. 
ñan ${ }^{1}$ paḥi rnam pa dan | pha rol tu phyin pa ñan pạ̣i rnam pa dan | byan chub sems dpaḥi sde snod ñan pahi rnam pa dan் | bsdu bahi dnos po ñan pahi rnam pa dañ | thabs mkhas pa ñan paḥi rnam pa dan் | tshańs paḥi gnas pa ñan paḥi rnam pa dan் | mnon par śes pa ñan pahi rnam pa (592) dań $\mid$

dran pa ñe bar bźag pa ñan paḥi rnam pa dan் | yañ dag par spon̉ ba ñan paḥi rnam pa dan் | rdzu ḥphrul gyi rkań pa ñan pahi mam pa dan் | rten cin ḥbrel par ḥbyuń ba ñan pahi rnam pa dañ / mi rtag pa ñan pahi rnam pa dan் | sdug bsnal ba ñan pahi rnam pa dan் / bdag med pa ñan pahi rnam pa dań | źi ba ñan paḥi rnam pa dan் | ston̉ pa ñid ñan pahi rnam pa dañ | mtshan ma med pa ñan paḥi rnam pa dañ | smon pa med pa ñan pahi rnam pa dan் / mñon par ḥdu mi byed pa ñan paḥi rnam pa dan் / dge baḥi rtsa ba mn்on par ḥdu byed pa ñan paḥi mam pa dan | rañ dbañ du gyur paḥi rnam $\mathrm{pa}^{3}$ dan $\mid \operatorname{chos}^{4}$ ñan par ḥdu śes pahi rnam pa dan | kun tu ḥdre ba mi ḥthun paḥi phyogs su ḥdu śes pahi rnam pa dañ | ñon mońs pa thams cad tshar gcod pahi rnam pa dan் | mkhas pa la mñon par dgaḥ baḥi rnam pa dan் | ḥphags pa sten ${ }^{5}$ pahi rnam pa dan | ḥphags pa ma yin pa yoǹs su spoń ${ }^{6}$ bahi rnam pa dan் | ḥphags pa ñan pahi rnam pa dań | dbañ po ñan pahi rnam pa dań | rjes su dran pa sgom pa ñan pahi rnam pa dań | byañ chub kyi yan lag ñan paḥi rnam pa dan் | ḥphags paḥi lam yan lag brgyad pa ñan paḥi rnam pa dan | de bźin gśegs paḥi stobs dan | mi hjigs pa dan | byams pa dañ | sñin rje dań | dgaḥ ba dan | btan sñoms chen po dan̉ | (593) so so yaǹ dag par rig pa dan் | sañs rgyas kyi chos ma hidres pa bcu brgyad mams ñan pahi mam pa ste $\mid$

\section{1 .2}

śā rihi bu de ltar gan na thos pa de ni ${ }^{7}$ śes paho \| gań na śes pa de ni nan tan no \| de cihi phyir źe na | gan byan chub sems dpahi sde snod kyi chos kyi rnam grańs la mos pa de ni thos par h.gyur ro \| thos nas rab tu śes so || śes nas nan tan byed do \|

gań byan chub sems dpahi sde snod kyi chos kyi rnam grańs la bsam pa yod pa de ni thos par hgyur ro || thos nas rab tu śes so \| ses nas nan tan byed do || gan byań chub sems dpahi sde snod kyi chos kyi rnam grańs la sbyor ba yod pa de ni thos par hgyur ro || thos nas rab tu śes so || śes nas nan tan byed do \| gan dge bahi bśes gñen la rten $^{8}$ par byed pa de ni thos par

1. P om: par nan.

2. P sdug bsnal.

3. P bdag la rag las pahi rnam pa, for D N R ran dban du gyur pahi mam pa.

4. N kun tu chos.

5. D N R bsten; P bstan.

6. D R spań.

7. D R na; $N$ om: pa de ni.

8. D P sten; $\mathrm{N}$ brten. 
hgyur ro || thos nas rab tu ses so || ses nas nan tan byed do || gan na rgyal med pa de ni thos par hgyur ro || thos nas rab tu ses so || ses nas nan tan byed do \| gan man du thos pa (de) la rab tu hadud pa de ni thos par hygur ro || thos nas rab tu ses so || śes nas nan tan byed do || gan man du thos pa de ${ }^{1}$ la ri mor byed pa de ni thos par hygur ro \| thos nas rab tu ses so \| ses nas nan tan byed do \| gan ḥthun par hạdzin pa de ni thos par hgyur ro \| thos nas rab tu ses so $\|$ ses nas nan (594) tan byed do \| gañ bkah blo bde ba de ni thos par hgyur ro \| thos nas rab tu Śes so \| śes nas nan tan byed do \|

gan man du thos pa (de) la bsñen bkur byed pa de ni thos par hgyur ro $\|$ thos nas rab tu ses so \| Ses nas nan tan byed do \| gan ma ba blags te ñan pa de ni thos par hygur ro \| thos nas rab tu ses so || śes nas nan tan byed do || gan man du thos pa (de) la bkur sti ${ }^{2}$ byed pa de ni thos par hygyur ro || thos nas rab tu śes so \| ses nas nan tan byed do || gan ḥchad pa dan | gan man du thos pa (de la) $)^{3}$ yid la byed pa de ni thos par hyyur ro \| thos nas rab tu śes so \| ses nas nan tan byed do $\|$ gan mañ du thos pa (de) la ${ }^{4}$ rin po cher ${ }^{5}$ hdu ses pa de ni thos par hgyur ro || thos nas rab tu ses so || ses nas nan tan byed do || gan man du thos pa (de) la rtsir ${ }^{6}$ hadu ses pa de ni thos par hgyur ro || thos nas rab tu ses so || ses nas nan tan byed do || gan man du thos pa thos nas ḥdod chags dan | źe sdan dan | gti mug rab tu źi bar ḥdu śes pa de ni thos par hgyur ro || thos nas rab tu ses so || ses nas nan tan byed do || gan man du thos pa thos nas ${ }^{7}$ ḥdzin par ḥdu śes pa de ni thos par hgyur ro || thos nas rab tu śes so || śes nas nan tan byed do || gań chos mams rtogs par khon du chud pa de ni thos par hgyur ro || thos nas rab tu ses so || śes nas nan tan byed do || gań mañ du thos par blo gros hadod pa de ni thos par hygur ro || thos nas rab tu śes so $\|$ śes nas nan tan byed do \| gan mañ du thos pa thos nas | blo rnam par mi ${ }^{8}$ g.yo ba de ni thos par hgyur ro || (595) thos nas rab tu ses so || ses nas nan tan byed do \| gan thos pas mi noms pa de ni thos par hgyur ro \| thos nas rab tu ses so $\|$ ses nas nan tan byed do II

gan sbyin pahi gtam thos nas gton bar rtog $\mathrm{pa}^{9}$ de ni thos par hgyur ro || gan tshul khrims kyi gtam thos nas tshul khrims srun ${ }^{10}$ ba de ni thos par hgyur ro $\|$ thos nas rab tu śes so $\|$ ses

1. N om: de.

2. N bsti.

3. D P R thos par, N pa.

4. D N R om: la.

5. P dkon mchog du.

6. P sman du.

7. DR na.

8. D P R om: mi.

9. N sbyin pa gton bar byed pa.

10. $\mathrm{N}$ bsrun. 
nas nan tan byed do \| gan̉ bzod pahi gtam thos nas bzod par byed pa de ni thos par hygur ro \| thos nas rab tu śes so || Ses nas nan tan byed do || gan brtson hgrus kyi gtam thos nas brtson hgrus ma ñams par byed pa de ni thos par hgyur ro \| thos nas rab tu ses so || ses nas nan tan byed do || gan bsam gtan gyi gtam thos nas sems mi g.yen bar byed pa de ni thos par hgyur ro || thos nas rab tu śes so || śes nas nan tan byed do || gan ses rab kyi gtam thos nas zag pa zad pa la ${ }^{1}$ sems gźol bar byed pa de ni thos par (596) hgyur ro \| thos nas rab tu śes so \| ses nas nan $\tan$ byed do $\|$

gan man du thos pa (de la) ${ }^{2}$ dgah ba skye ba de ni thos par hgyur ro \| thos nas rab tu śes so || ses nas nan tan byed do || gan chos thos nas lus sim par byed pa de ni thos par hgyur ro \| thos nas rab tu śes so \| śes nas nan tan byed do \| gañ chos thos nas rańs par byed pa de ni thos par hygur ro \| thos nas rab tu śes so || śes nas nan tan byed do \|

gan theg pa chen po thos nas mos par hygur ba de ni thos par hygur ro \| thos nas rab tu śes so || śes nas nan tan byed do || gan bsdu bahi dnos po thos nas gan bsdu bar sems skyed ${ }^{3}$ pa de ni thos par hygyur ro \| thos nas rab tu śes so || śes nas nan tan byed do || gan dran pa ñe bar bźag pahi gtam thos nas | dran pa lus la źugs pa ${ }^{4}$ dan $\mid$ dran pa tshor ba la źugs pa dan் | dran pa sems la źugs pa dan் | dran pa chos la źugs pa de ni thos par hgyur ro || thos nas rab tu ses so || ses nas nan tan byed do || gan yan் dag par spon bahi gtam thos nas mi dge ba skyes sin byun ba dag $1 a^{5}$ khrel źin no tsha bar hygur ba de ni thos par hgyur ro \|l thos nas rab tu ses so \| ses nas nan tan byed do \|

gan dge bahi chos skyes śin byun ba la mi gton bar blo hjug pa (597) de ni thos par hgyur ro \| thos nas rab tu śes so \| Śes nas nan tan byed do \|

gan rdzu ḥphrul gyi rkan pahi gtam thos nas lus yan̉ ba dan | sems yan ba dan் | ḥdun pa yań ba skye ba de ni thos par hgyur ro \| thos nas rab tu śes so \| śes nas nan tan byed do \| gan bsam gtan gyi gtam thos nas nes $\operatorname{par}^{7}$ rtog pa la sems gton ${ }^{8}$ ba de ni thos par hyur ro $\|$ thos nas rab tu śes so $\|$ śes nas nan tan byed do \| gan tshad med pahi gtam thos nas sems can thams cad la byams pa dan $\mid$ hphon $s^{9}$ par gyur pa rnams la sñin rje che ba ${ }^{10} \mid$ chos la dgah ba

1. N las.

2. D N P R thos par.

3. N bskyes.

4. P son ba (also in the following three instances).

5. $P$ gis.

6. P sred pa.

7. P om: nes par.

8. P gźol.

9. D N phons; P des.

10. D om: che; $\mathrm{N}$ chen po. 
dan | mi dge ba la btañ sñoms pa de ni thos par hgyur ro || thos nas rab tu śes so || śes nas nan tan byed do || gan dban poḥi gtam thos nas dad pạ̣i dbań po dan | brtson ḥgrus kyi dbañ po dan | dran pahi dbań po dan | tin ṅe hạdzin gyi dbañ po dan | ses rab kyi dban po la sems hjug ${ }^{1}$ par byed pa de ni thos par hgyur ro \| thos nas rab tu ses so \| ses nas nan tan byed do \| gan byan chub kyi yan lag gi gtam thos nas chos thams cad khon du chud par bya bahi phyir sems ḥjug par byed pa de ni thos par hgyur ro || thos nas rab tu śes so || ses nas nan tan byed do \| gan lam gyi gtam thos nas mya nan las (598) hạh bar hgro ba la sems hijug pa de ni thos par hgyur ro \| thos nas rab tu ses so \| ses nas nan tan byed do \|

gan de bźin gśegs pahi stobs dan் | mi hjigs pa dan | byams pa dan | sñin rje dan | dgaḥ ba dan் | btań sñoms chen po dan் | so so yan dag par rig pa dan | sañs rgyas kyi chos ma hạdres pa bcu brgyad yañ dag par bslab pa $^{2}$ sańs rgyas kyi chos tshad med pa thos nas bla na med pa yan dag par rdzogs pahi byan chub tu sems hjug ste | de thos par hgyur ro || thos nas rab tu śes so || śes nas nan tan byed do $\|$

sā riḥi bu ḥdi ni $^{3}$ thos pahi rnam pa la hjug pa rnam pa bźi bcu rtsa gcig ces bya ste | sā rihi bu de ltar na byan chub sems dpah ${ }^{4}$ ses rab kyi pha rol tu phyin pa la ${ }^{5}$ spyod do $\|$

\section{1 .3}

sâ rihi bu gźan yañ byan chub sems dpah ses rab kyi pha rol tu phyin pa la spyod pa | byan chub sems dpahi sde snod kyi chos kyi rnam grańs sin tu mñan | blańs | bzun | bklags | kun chub par byas | gźan la yan் ${ }^{6}$ bśad cin rgya cher yan dag par rab tu bstan na nan tan sñin por byed pa yin no || chos mams la nan tan byed pa gań źe na | gan ji ltar bstan pa bźin du gnas pa ste | de ni chos la nan tan byed paho ${ }^{8}||$

gźan yan chos la nan tan byed pa de ni gań chos thams cad mi len paho \| de cihi phyir źe na | chos rnams len na ${ }^{10}$ yan log paḥi nan tan du hgyur te | gañ zag (599) gan chos len par gnas pa de ${ }^{11}$ ni chos de dag las ḥbyun bar ḥgyur baḥi gnas dan skabs med de / de ni gnas med

1. P gźol (also in the next three occurrences of the term 'hjug').

2. P dag dan, for D N R yan dag par bslab pa.

3. P gźan, for D N R hdi ni.

4. N dpahi.

5. P om: la (also in all further instances of this regularly reoccuring stock phrase).

6. Nom: yan.

7. N P nas.

8. N R do.

9. D N P om: de

10. Nom: na.

11. D P R om: de. 
paḥo || gan zag mi len par spyod pa rnams kyan bsal ${ }^{1}$ bahi phyir | chos hidi dag la nan tan du bźag $^{2}$ pa the tshom du hgyur na | chos len par spyod pa rnams lta smos kyan ci dgos te / de bas na chos thams cad mi len pa ni ${ }^{3}$ nan tan no $\|$

gźan yaǹ gań chos rnams la mi sgrib pa de ni nan tan źes byaho \| gań chos rnams la rlom sems $^{4}$ med pa dan் | gań chos rnam mi len pa dan் | mi rlom pa dan் | mi skye ba dan | mi hgog pa de ni nan tan źes byaho $\|$

gźan yañ ${ }^{5}$ chos rnams la bsnan ${ }^{6}$ pa med pa dan் | bsal ba med pa de ni nan tan źes byaḥo || gźan yań gań du cun zad kyañ ma bśad | ji ltar bśad pa bźin du mi snań ba de lta bu ni chos thams cad mi snań $b^{7} \mid$ mi blan ba $\mid$ mtshan ñid gcig paho || mtshan ñid gañ źe na | ḥdi lta ste | mtshan ñid med paho || mtshan ñid ces bya $b a^{8}$ ni mtshan ñid med pa ste $\mid$ de ni gñi ga las ḥgyur ro || de ciḥi phyir źe na | kun brtags pa ḥam | yan̉ dag par brtags pa de ñid mtshan $\tilde{n ̃ i d}^{9}$ med par bśad pa yin no || ḥdi ni mtshan ñid do | ḥdi ni mtshan ñid ma yin paḥo źes | ḥdi lta ste $\mid$ chos thams cad la mtshan ñid med pa $\mid$ mi snañ ba $\mid$ blan ba med par rtogs pa de ni nan tan źes byaḥo || nan tan la brtson par gyis sig | chos thams cad mi sgrib par snan ba thob par gyis sig $\|$ (600)

de nas dehi tshe bcom ldan ḥdas kyis tshigs su bcad pa ḥdi dag gsuns so $\|$

gan źig byan chub sems dpahi sde snod la \|

sin tu nes par nan tan gnas byed pa $\|$

mkhas pa de ni chos la hadzin ${ }^{10}$ mi byed $\|$

mi ḥdzin pas na nan tan de hadraho $\|$

mis ni chos rñed ston par mi byed do $\|^{11}$

chos lahana de ni ston par rlom sems $\operatorname{med}^{12} \|$

stoń pahi chos la rlom sems ${ }^{13}$ gañ yañ med $\|$

1. P bstsal (also in all subsequent occurrences of the word 'sel ba').

2. N gźag.

3. N len pahi.

4. D N R rlom sems; P sñems pa.

5. P add: kyan.

6. D P bstan.

7. N om: mi snañ ba.

8 Nom: ba.

9. P om: mtshan ñid.

10. $\mathbf{P}$ len (also in the next line).

11. $P$ chos rñed ston pa fid du mi byed min.

12. P ston pa sñems mi byed.

13. P sñems pa (also in the following three occurrences of the word 'rlom sems'). 
rlom sems med phyir nan tan de hadrahọ $\|$

chos la len pa med cin ḥdor ba med \|

chos ni chos la len par byed pa med $\|$

len pa med phyir hadi ni chos kyi mtshan \|

hadi hạdra ba ni nan tan źes byaḥo $\|$

gañ phyir chos la nams kyan de mi chags \|

de la de yi ye ses blañs mi hgyur \|

ye śes ma blańs de lahan rlom sems med $\|$

ḥdi hadra ba ni nan tan źes byaho \|

mkhas $\mathrm{pa}^{3}$ sbyañs pahi ${ }^{4}$ yon tan gnas par gyis \|

chos hidi dag la sin tu brtson par gyis \|

cho ga spyod pa dag la gnas gyur na $\|$

dehi tshe de yi sgo ni dag par ḥgyur \|

sgo dag na ni chos ḥdi ḥdra ba śes \|

de na sems la bsam pahana śes par hygur \|

mkhas pas de tshe bsam pa śes nas ni $\|$

ḥdi ḥdra ba yi chos kyan ḥchad par ḥgyur \|

zab mohi chos la don dam mkhas ${ }^{5}$ gyur nas \|

rtag tu don la mam par gdon $\mathrm{mi}^{\mathrm{za}^{6}}$

spyod pa mthah yas yon tan rnams kyis hiphags \|

mkhas pa man du thos pa rgya $\mathrm{mtsho}^{7}$ ḥdra $\|$

1. D N de.

2. D P R la; $N$ lahan.

3. D N pas.

4. P nan tan.

5. P bstsal.

6. N add: ba.

7. P add: mi mams. 
de yi don dañ tshig hibru' dag la yañ || (601)

mthạ ma rtogs par run ba ma yin źin $\|^{2}$

don kyan mthạ yas tshig ḥbru mthạ yas te $\|$

nan tan sñin por byed pa mi ḥkhrugs hgyur $\|$

saa rihi bu de ltar na byan chub sems dpạ̣ śes rab kyi pha rol tu phyin pa la spyod do $^{3} \|$

\section{1 .4}

sá rihị bu gźan yañ byań chub sems dpah śes rab kyi pha rol tu phyin pa la ${ }^{4}$ spyod pa ${ }^{5}$ | byan chub sems dpaḥi sde snod kyi chos kyi rnam grans sin tu ñan pa nas / gźan la rgya cher bstan paḥi bar du byas nas ma rig pahi mun pa mun nag mun pa rab rib stug po bsal ${ }^{6}$ bahi phyir | chos thams cad la snan ba thob ste | ses rab kyi snan baho || de snan ba ${ }^{7}$ thob pas dge ba dań mi dge baḥi chos mams rab tu śes te / de srog gi phyir yan mi dge bahi chos la mi gnas te | de mi dge bahi chos mams span bahi phyir |ji ltar thos pahi chos rnams rtogs pas na | dge ba thub pa źi ba źes byaho \|

de nas bcom ldan ḥdas kyis dehi tshe tshigs su bcad pa ḥdi dag gsuñs so \|

ji ltar mun pas khyab bsgribs $\mathrm{pa}^{8} \|$

khyim du źugs par gyur na ni \|

yod par gyur pahi gzugs ${ }^{9}$ rnams kyan் $\|$

mig gis mthon bar mi hgyur ro $\|$

de bźin du ni ḥdi la yañ $\|$

la ${ }^{10}$ laḥi mi dag skyes gyur kyañ $\|$

dge ba dań ni sdig pahi chos $\|$

1. P yi ge (also in all subsequent occurrences of the term 'tshig hbru').

2. P mthah ma khon du chud par mi nus te.

3. P paho (also in all subsequent ocurrences of this stock-phrase).

4. D P R om: la.

5. P add: na (also in all subsequent occurrences of this stock phrase).

6. R gsal.

7. D N add: de.

8. $\mathrm{P}$ pahi; $\mathrm{N}$ pas.

9. $N$ gzug.

10. D rtal. 
ma thos par ni śes mi hgyur ${ }^{1} \|$

thos nas chos rnams mam par śes $\|$

thos nas sdig pa $\operatorname{sten}^{2}$ mi byed $\|$

thos nas gnod pa spon bar (602) byed \|

thos nas mya naan hadas pa hịthob \|

thos par hdod pas thos pa hiphel \|

thos pas ses rab hphel bar hgyur ||

ses rab kyis ${ }^{3}$ ni don rnams sbyon $\|$

don thob nas ni bde hathob hygur $\|\left.\right|^{4}$

don thob de ni yid $\mathrm{rno}^{5}$ ste $\|$

tshe hadi la ni mya naan hadas \|

chos la sbyor źin gtsan la mkhas \|

sin tu bde ba hthob par hgyur \|

byań chub sems dpahi sde snod ni $\|$

thos nas chos ñid gnas par hygur ${ }^{6} \|$

hjig rten $\mathrm{la}^{7}$ ni snań gyur nas $\|$

byan chub kyi ni ${ }^{8}$ spyad pa spyod $\|$

saa rihi bu de ltar na byan chub sems dpạ ses rab kyi pha rol tu phyin pa la spyod do \|

\section{2}

sā rihi bu gźan yan byan chub sems dpaḥ śes rab kyi pha rol tu phyin pa la spyod pa / byan chub sems dpahi sde snod ${ }^{9}$ ḥdzin pahi gan zag la dge baḥi bśes gñen du hạdu śes bskyed nas |

1. $\mathrm{R}$ nus.

2. N bstan; R bsten.

3. P byan chub śes rab kyis; $N$ śes rab kyi.

4. N om: entire last line of verse.

5. P gźuns.

6. P thos nas chos nid la gnas te.

7. P gyi.

8. P byan chub sems dpahi.

9. P add: kyi mam grañs. 
byan chub sems dpahi sde snod kyi chos kyi mam grañs ḥdi ñid la sin tu byan bar byed | rnam par dag par byed do \| byan chub sems dpaḥi sde snod hạdịi don gyi phyir ḥdun pa skyed | hbad par byed | brtson hgrus rtsom par byed | sems la rab tu hidzin par byed | yan dag par rab tu hyjog $\operatorname{par}^{1}$ byed de / de yan dag par spon ba bźi la rab tu źugs pas | chos thams cad la sgrib pa med pa hithob po \|

de nas dehi tshe bcom ldan ḥdas kyis tshigs su bcad pa ḥdi dag gsuns so \|

chos smra ba ni gan yin pa $\|^{2}$

de la dge bahi (603) bśes su sems $\|^{3}$

rtag par nan tan gnas gyur nas $\|$

chos la nan tan byas te ñan $\|$

rtag par ḥdun pa ḥbri mi byed ॥

rtag par brtson hgrus sin tu hphags \|

rtag $\operatorname{par}^{4}$ śes rab rnam par sbyon \|

ye śes la ni rtag tu gnas $\|$

de ni bdag ñid ${ }^{5}$ chos ses te $\|$

dad pahi phyir ni hgro mi byed \|

sañs rgyas kyis ni gan bsad $\mathrm{pa}^{6} \|$

mi g.yo ba yi chos ses so ॥

mkhas pa de dag tshig rnams ḥbyed la ${ }^{7}$ mkhas \|

bslabs pa don la khon du chud par byed \|

de dag dkar pohị phyogs ni rtag par sbyon் \|

nag pohi phyogs ni rtag tu spyoñ bar byed $\|$

de yi sems la nams kyañ ñams pa med $\|$

1. P smon par, for D N R rab tu hjog par.

2. P gan dag chos ni smra ba la.

3. P dge bahi bśes gñen du hadi sems.

4. N rnam rtag.

5. P dan.

6. P pahi.

7. P gi rnam pa, for D N R mams ḥbyed la. 
de ni chos rnams gañ laḥañ źum pa $\operatorname{med}^{1} \|$ lus yañ de bźin sems dan brtson hgrus dan் \| ḥdun pa yañ bahan ${ }^{3}$ myur du ḥthob par hgyur \|

chos thos nas ni ses rab hphel bar hgyur \| ye ses rnam par rtogs nas dran mi ñams $\|$ dran dañ ye śes la ni rtag gnas nas \| dge dan mi dgehi chos ni rab tu ses \|

bla na med pahi chos rnams bslabs nas ni $\|$ rtogs dan dran pa śes rab stobs mchog thob $\|$ ji ltar bdag ñid ${ }^{4}$ yun rin bslabs pa bźin \| des ni sems can mams kyi bsam pa śes \|

chos bslabs nas ni khyad par hthob hgyur te $\|$ khyad par thob cin ye ses dag gyur nas $\|$ de ni sems can rnams kyi bsam pa śes $\|$ de phyir bsam pa bźin du chos ston to $\|$

śā rihi bu de ltar na byan chub (604) sems dpạ̣ ses rab kyi pha rol tu phyin pa la spyod do $\|$ bam po bcu bdun pa $\|^{5}$

\section{3}

\subsection{1}

sāa rihi bu gźan yan byan chub sems dpaḥ ses rab kyi pha rol tu phyin la spyod pa de ltar blo sbyans pa dan் | de ltar chos snan் bahi sgo sin tu yons su dag pas hịi ltar slob ste | ḥphags pahi yañ dag par lta ba ḥbyun̉ ba (de) ni rgyu gñis dan | rkyen gñis te | gñis gan źe na | gźan

1. P mi hgyur.

2. P yań ba; $R$ kyan.

3. P yod pa, for D N R yan bahan.

4. $\mathrm{P}$ gis.

5. D P om: bam po bcu bdun pa. 
gyi sgra dan் | bdag ñid ${ }^{1}$ tshul bźin yid la byed paho ||

de ḥdi sñam du sems te | gźan gyi sgra de gan | bdag ñid tshul bźin ${ }^{2}$ yid la byed pa de gan źe na | de de ltar tshul bźin yid la byed pa na | ḥdi sñam du sems par ḥgyur te | rnal ḥbyor spyod pa gań dag byan chub sems dpahi sde snod kyi chos kyi rnam grañs hadi ma thos | ḥphags pahi chos ḥdul ba ma thos par | tin ne hidzin tsam gyis dgạ ba rñed $^{3}$ nas | na rgyal gyi dbañ gyis che bahi na rgyal du lhun ba de dag ni skye ba dań | rga ba dan | na ba dań | ḥchi ba dan் | mya nan dan | smre snags ḥdon pa dan் / sdug bsñal ba dan | yid mi bde ba ${ }^{4}$ dan் | hakhrug pa las yons su mi thar | sdug bsnal gyi phun po las yons su mi thar te | de dag la de bźin gśegs pas dgońs nas ḥdi skad gsuns so $\|$ pha rol la rjes su hithun pa thos pa ni rga ba dan ḥchi ba las rnam par grol bahọo

yaǹ bcom ldan hadas kyis gsuns so ${ }^{5} \|$

chos rnams thos nas mam par ses $\|$

thos nas (605) sdig pa mi byed do $\|$

thos nas gnod pa spon bar hgyur \|

thos nas mya nan hadas pa hithob \|

thos hidod ${ }^{6}$ thos pa hphel bar hygur ॥

thos pas ses rab hphel bar hgyur \|

śes rab kyis ni don rnams sbyon \|

don rñed nas ni bde ḥthob hgyur \|

don rñed de ni yid rno ste $\|$

tshe hạdi la ni mya nan hadas \|

chos gtsan mkhas pa gtsañ $\mathrm{ba}^{7}$ dan் $\|$

mchog $^{8}$ tu bde ba hithob par hgyur \|

1. P la (also in the next phrase).

2. N add: du.

3. P tshor.

4. P yi mug pa, for D N R yid mi bde ba.

5. D N P R pa.

6. P pas.

7. D gtsan ma.

8. $P$ sin. 


\subsection{2}

śā rihi bu de ltar byan chub sems dpạ̣ byan chub sems dpahi sde snod kyi chos kyi rnam grans ḥphags pahi chos ḥdul ba sin tu mñan par bya | blan bar bya | gzun bar bya | bklag par bya | kun chub par bya | gźan la yan rgya cher yan dag par rab tu bstan par byaho ||

śā riḥi bu gan byan chub sems dpaḥi sde snod kyi chos kyi rnam grańs ḥdi mi ñan pa dan | tshul bźin du sbyor bar mi byed pa de dag ni ḥphags paḥi lam las yons su nams $\operatorname{par}^{2}$ hgyur te | de la dgons nas de bźin gśegs pa ḥdi skad du | bdag ñid tshul bźin yid la byed pa (de) ni rga ba dañ ${ }^{3}$ ḥchi ba las grol baḥo \| źes gsuń no $\|$

de ḥdi ltar slob ste | byan chub sems dpaḥi tshul bźin sbyor ba ni gan ji ltar na byan chub sems dpah tshul bźin sbyor ba yin sñam nas | de ḥdi ltar slob ste | byan chub sems dpaḥ sems dpah chen po ni chos gan lahana sbyor bar mi byed | rab tu sbyor bar mi byed do || tshul bźin du sbyor ba źes bya ba de ni mi sbyor bahi tshig bla dags so \|

gźan yan byan chub (606) sems dpạ̣ tshul bźin du sbyor ba ni sgra ḥbyin par mi byed | zlos pa ḥbyin par mi byed / gañ nas sgra ḩbyun ba de yań mi dmigs | sgra de ñid gañ nas byuñ ${ }^{5}$ gan̉ du ḥgag ces sñon gyi mthah dan phyi mahi mthạ̣ la rtog par byed do \| gań smras ba dan | gaǹ smra ba dan் | gaǹ smra bar hgyur ba dan் | gañ gi ${ }^{6}$ smras ba dan் | gań gi smra ba dan் | gań gi smra bar hgyur ba dan் | gañ ${ }^{7}$ spoń bahi phyir smras ba dan | gań spon baḥi phyir smra ba dan் | gañ spon̉ bahị phyir smra bar ḩgyur ba dan | gan khon du chud par bya baḥi phyir smras ba dan | gaǹ khon du chud par bya bahi phyir smra ba dań / gań khon du chud par bya bahi phyir smra bar hgyur ba de thams cad yońs su btsal na ḥdas pahi mam pa dan | ma hono pahi rnam pa dan | da ltar byun bahi rnam par mi dmigs pa de ni | deḥi tshul bźin du ${ }^{8}$ sbyor baho \| źes de de ltar slob bo \|

byan chub sems dpạ̣ de ltar tshul bźin du sbyor bas ji ltar na ${ }^{9}$ tshul bźin du mthon źe na | de ḥdi ltar slob ste / gañ gi tshe na byań chub sems dpaḥ chos thams cad ran bźin gyis ḥgags par mthon ba dehi tshe tshul bźin mthon no $\|$ gan̉ gi tshe chos thams cad ran̉ bźin gyis ñe bar

\footnotetext{
1. D R dpas.

2. P bribar.

3. D add: na ba dan.

4. N om: na.

5. N hibyun.

6. D N gan gis (also in the following two clauses).

7. $\mathrm{P}$ gan gi (also in the following two clauses).

8. N add: du.

9. N om: na.
} 
źi bar ${ }^{1}$ mthon ba dehi tshe tshul bźin mthon no $\|$ gań gi tshe chos thams cad rnam par źi bar mthon ba dehi tshe tshul bźin mthon no $\|$ gan gi tshe chos thams cad rañ bźin gyis sñoms par ma źugs par mthon ba dehi tshe tshul bźin mthon no $\|$ (607) gañ gi tshe chos thams cad ma skyes par mthon ba dehi tshe tshul bźin mthon no \| gan gi tshe chos thams cad ma byun bar mthon ba dehi tshe tshul bźin mthon no \| gan gi tshe chos thams cad sin tu yan dag par ma byun bar mthon ba dehi tshe tshul bźin mthon no \|l gan gi tshe chos thams cad mya ñan las ḥdas par mthon ba dehi tshe tshul bźin mthon no $\|$ de gan gis mthon ba de la yań rtog ste | ci nas kyaǹ mi mthon ba dań mi rtog pa de ltar mthon ste | de ltar mthon na tshul bźin mthon̉ ba źes byaho \||

yan hadi ltar slob ste | byan chub sems dpah tshul bźin du sbyor ba ni | chos gan la yan the tshom dan rmońs pa med do || tshul bźin du sbyor ba ni chos gań la yan sgrib pa med do \| tshul bźin du sbyor ba ni chos gan la yañ ${ }^{2}$ thar pahi sgor mi hgyur ba med do \|l tshul bźin du sbyor ba ni chos gañ la $^{3}$ yan spañ bar bya bahi phyir hibad ba med do $\|$ tshul bźin du sbyor ba ni chos gań la yań rtogs par bya bahi phyir habad ba med do \| gan chos ${ }^{4}$ thams cad yan dag par mthon ba dan | ji lta ba bźin du mthon ba de ni yañ dag par lta baḥo ||

chos thams cad ji lta ba bźin du mthon ba gań źe na | ḥdi lta ste | ma mthon baho || ma mthon ba źes bya ba de ni ma skyes pahi tshig bla dgas so \| ma skyes ${ }^{5}$ pa źes bya ba de ni yan் dag par ma byun baḥi tshig bla dgas so || yañ dag par ma byuñ ba źes bya ba gań źe na | de ni mi snan bahi tshig bla dgas te | (608) de bźin gśegs pas de la dgońs nas ḥdu byed thams cad mi skye bar mthon na yañ dag pa ñid du nes $\mathrm{pa}^{6}$ la ḥjug ste | ḥ̣i lta ste | yañ dag pa ñid du nes pa la hjug pa de ni yaǹ dag par lta bahọo $\|$ źes de skad gsuń noo

de ḥdi sñam du sems te | de cihi phyir źe na | yan dag pa ñid du nes pa la hjug źes bya źes do $^{8}||$ ḥdi ltar slob ste | chos thams cad gañ dan mñam pa sańs rgyas kyi chos de dañ mñam ste | de bas na yan dag pa ñid du nes pa la ḥjug paḥo ${ }^{9}||$

de lta bas na yan dag pa ñid du nes pa la hjug par ḥdod pa rnams kyis / byañ chub sems dpahi sde snod kyi chos kyi mam grañs ḥdi ñid sin tu mñan par bya / blan bar bya / gzun bar bya | bklag par bya | kun chub par byaho || byan chub sems dpahi sde snod kyi chos kyi rnam

1. N om: źi bar; P om: ñe bar.

2. D P R add: gan.

3. D R om: la.

4. N chos gañ chos.

5. N skyed.

6. P skyon med pa, for D N R ñid du nes pa (also in all subsequent occurrences of the term 'nid du nes pa').

7. D N om: źe.

8. P add: de ltar rtog pa las; $\mathrm{N}$ add: la.

9. N om: de bas na yan dag pa ñid du nes pa la hijug paho. 
gran̉s ḥdi ñid lahạan tshul bźin du sbyor bar bya ste | śă riḥi bu de ltar na byañ chub sems dpạ̣ ses rab kyi pha rol tu phyin pa la spyod do $\|$

\subsection{3}

sā riḥi bu gźan yañ byan chub sems dpah ses rab kyi pha rol tu phyin pa la spyod pa ${ }^{1}$ de ltar blo sin tu yońs su sbyańs pa dan $/$ de ltar chos ${ }^{2}$ snan bahi sgo śin tu yoǹs su dag pas tshul bźin du hjug pa la brtson na | tshul bźin gyi tshig mthon no ||

de la tshul bźin du hjug pa gań tshul bźin gyi tshig gań źe na | de ltar byan̉ chub sems dpahi tshul bźin du hjug pa ni | hidi lta ste | źi gnas kyi gnas ${ }^{3}$ la hjug pa dan | lhag mthon rnam par rtog pa la hjug $\mathrm{pa}^{4}$ ni (609) tshul bźin du hjug paho \| lus dben par ḥjug pa dan் | sems yid du ḥon bar hjug pa dan் / chad pa ma yin par hjug pa dan் / rtag pa ma yin par ḥjug pa dan் | rgyu dań rkyen la hjug pa dan | rten cin ḥbrel par ḥbyun ba la hijug pa dan | sems can med pa dań srog med pa dan் / gañ zag med pa la ḥjug pa dan | ma ḥoǹs ma phyin mi gnas pa la hijug pa

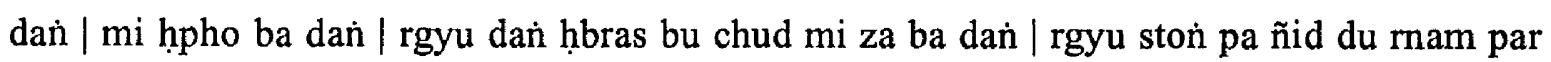
ḩbyed $\mathrm{pa}^{5}$ la hjug pa dan $/$ mtshan ma med par ḥdris par bya ba la hjug pa dan் | smon pa med par rab tu śes pa la hjug kyañ stoń pa ñid dan் / mtshan ma med pa dañ ${ }^{6}$ smon pa med pa len par hjug pa ma yin pa dan |

tin ne ḥdzin dañ sñoms par ḥjug $\mathrm{pa}^{7}$ len pa la ḩjug kyan | tin ne ḥdzin gyi dbañ gis skye ba la mi hjug pa dan் / mnon par śes pahi ye ses len pa la hjug kyan் / zag pa zad pa la mi hjug pa dan் | mi skye bar rtog pa la hyjug kyan | nes par gyur bar hygro ba ${ }^{8}$ la mi hijug pa dan | sems can thams cad $^{9}$ bdag med par rtog par hyjug kyan் | sñin rje chen po gton ba la mi hjug pa dan | skye ba thams cad hjig par mthon ba la hjug kyan ${ }^{10} \mid$ srid pa bsam gyis mi khyab pa len pa la (mi) hjug pa dan | mya nan hạdas bar ḥdod pa la hjug kyan / chos mnon du bya ba la mi hjug pa dan் / ḥdod paḥi yon tan gyi dgạ̣ ba btañ sñoms pa ${ }^{11}$ la ḥjug kyan | chos kyi dgah ba ḥdor

1. P add: na.

2. N om: chos.

3. P byin gyi rlabs (also in the next occurrence of the term 'gnas pa' (adhișthāna)).

4. N om: hjug pa.

5. P rab tu rtogs pa

In P, 'rab tu rtogs pa' regularly substitutes the D N R compound 'rnam par hbyed pa' (pravicaya).

6. N P R om: mtshan ma med pa dan.

7. $\quad$ P bźag pa; $\mathrm{N}$ hjug pa la.

8. P skyon med pa las hadah pa, for D N R nes par gyur bar hgro ba.

9. P add: kyi.

10. N R dan.

11. $\mathrm{N}$ dgah bar btań sñoms; $\mathrm{P}$ dgah bar ñes sñoms pa. 
ba la mi hjug pa dan | (610) rtog pa spros pa thams cad gton ba la hjug kyan் thabs mkhas pa gton ba la mi ḥjug pa ste | śā riḥi bu de ni tshul bźin du ḥjug pa źes byaḥo ||

sā rihi bu de la ${ }^{1}$ tshul bźin gyi tshig ces bya ba gan źe na | rigs paḥi tshig de ni tshul bźin gyi tshig go | śā rihi bu gźan yan tshul bźin gyi tshig de ni tshul gyi² tshig go | de ni sgoḥi tshig go | de ni khahi tshig go | de ni rgyuhi tshig go | de ni rab tu rnam par habyed pahi tshig go | de ni mi hygal bahi tshig go | de ni mi rtsod pahi tshig go / de ni btan sñoms kyi tshig go | mi len pahi tshig dan $\mid$ mi ḥdor baḥi tshig dan $\mid$ mi spros pahi tshig dan $\mid$ mi bsnan pahi tshig dan் | ma bri baḥi tshig dan | mi skye baḥi tshig dań | rtsod baḥi gźi med paḥi tshig ${ }^{3}$ dan $\mid$ mi $\operatorname{ldog}$ pahi tshig dan $\mid$ gñen po med pahi tshig dan |

de kho nahi tshig dan | de bźin kho naḥi tshig dan | ma log pa de bźin ñid kyi tshig dan | gźan ma yin pa de bźin ñid kyi tshig dan | de bźin ñid kyi tshig dan | ji lta ba bźin gyi tshig dan | dus gsum mñam pahi tshig ${ }^{4}$ dañ | yoǹs su chad pahi tshig dan் | gzugs rnam par śes pahi gnas med pahi tshig dan | tshor ba dan | ḥdu śes dan் | hạdu byed dan | rnam par śes pa gnas med paḥi tshig go|

de ni mig dan | gzugs dan் | mig gi mam par śes paḥi khams gnas med paḥi tshig go | de ni rna ba dan் | sgra dan | rna baḥi rnam par śes pahi khams gnas med pahi tshig go | de ni sna dan் | dri dan் | snahi mam par śes pahi khams gnas med pahi tshig go | de ni ltse dan | (611) ro dań | ltseḥi rnam par śes pahi khams gnas med paḥi tshig go | de ni lus dan | reg dañ $\mid$ lus kyi rnam par ses pahi khams gnas med pahi tshig go | de ni yid dan | chos dan் | yid kyi rnam par śes paḥi khams gnas med pahi tshig go / de ni don la rton paḥi tshig go / de ni chos la rton pahi tshig go / de ni ye śes la rton paḥi tshig go | de ni nes paḥi don gyi mdo sde la rton paḥi tshig ste | śā rihi bu de ni tshul bźin gyi tshig go ||

de ltar byan chub sems dpạ̣ tshul bźin du hjug pa la brtson pa | tshul bźin gyi tshig mthon ba (de) ni gań gis mthon ba de ñid mi mthon ste $\mid$ ji $\operatorname{ltar}^{6}$ mi mthon $\mid$ mam par mi mthon ba ${ }^{7}$ de ltar mthon no $\|$ de ltar mthon na tshul bźin mthon ba źes byaho $\|$

sā rihi bu gźan ${ }^{8}$ yan byañ chub sems dpah tshul bźin du sbyor ba ni chos gañ la yan rmońs par mi hgyur ro \| byan chub sems dpạ̣ tshul bźin du sbyor ba ni chos gan yañ ${ }^{9}$ thar pahi

1. D P om: de la.

2. P rigs pahi, for $\mathrm{D} \mathrm{N} R$ tshul gyi.

3. D N R rtsod bahi gźi med pahi tshig; P mi ḥthab pahi tshig.

4. $\quad \mathrm{P}$ dus gsum mñam pahi tshig, for $\mathrm{D}$ dus gsum mñam pa ñid kyi tshig.

5. P om: reg dan.

6. P add: mi rtog.

7. P om: rnam par mi mthon ba.

8. D N R om: gźan.

9. D P add: gan. 
sgor mi ḥgyur ba med do \| tshul bźin du sbyor ba ni chos gań yan spoń bahị phyir ḥbad pa med do || tshul bźin du sbyor ba ni chos gan yan rtogs par bya bahi phyir ḩbad pa med do \| gań chos thams cad yan dag par ${ }^{1}$ mthon ba dañ $\mid$ ji lta ba bźin du$^{2}$ mthon ba de ni yañ dag par lta baho \|

chos thams cad ji lta ba bźin du mthon ba gan źe na | hại lta ste | mi mthon baho || mi mthon ba gań źe na | de ni ma skyes baḥi tshig bla dags so || ma skyes pa źes bya ba gan źe na | de ni (612) mi snañ bahi bar gyi tshig bla dags te | rgya cher ji ltar snar bzlas ${ }^{3}$ pa de ltar de bźin du bzlas par bya ste / de ltar na byan chub sems dpah ses rab kyi pha rol tu phyin pa la spyod do \|

sā rihi bu gźan yan byañ chub sems dpaḥ ses rab kyi pha rol tu phyin pa la spyod pa ḥdi Itar slob ste | chos thams cad ni bdag bźin du tshul bźin te ${ }^{4}||$ ji ltar bdag la bdag med pa de bźin du chos thams cad bdag med par mthon no $\|$ ji ltar sems can bdag med pa de bźin du | chos thams cad bdag med par mthon ste | de ltar mthon na tshul bźin du mthon no ||

gań tshul bźin ḥkhor baḥi khams mthon ba [de tshul bźin] ${ }^{6}$ | mya nan las hạdas paḥi khams dań Idan par mthon ba ste / de ni tshul bźin du sbyor ba źes byaho $\|$ de ni chos thams cad kyi ran̉ bźin la ñon mońs pahi ran̉ bźin du bye brag med pa dań ldan par mthon no ${ }^{7} \|$ rnal ḥbyor daǹ rnal ḩbyor ma yin par yañ ${ }^{8} \mathrm{mi}$ sñems so $\|$ tshul bźin du$^{9}$ sbyor bas tshul bźin mthon ste | tshul bźin gyi sbyor ba ji sñed pa sems can gyi gnas thams cad kyan de sñed do || sems can gyi gnas ${ }^{10}$ kyan் mi mthon ${ }^{11}$ | chos kyi gnas kyan hakhrug par mi byed pa de ni byan chub sems dpahi tshul bźin sbyor ba ste $\mid$

śã riḥi bu de ltar na mam pa ḥdi dan | thos pa ḥdi dan | tshul bźin du ḥjug pa ḥdi dan | tshul bźin mthon ba ḥdi dan / ji lta ba bźin du mthon baḥi rgyu ḥthun pa ḥdi dan hạdi dag ni ses rab ces bya byaho $0^{12}$ | sã rihi bu de ltar na byan (613) chub sems dpah śes rab kyi pha rol tu phyin pa la spyod do $\|$

1. P pahi.

2. D N R om: du.

3. R hdas.

4. P bdag tshul bźin du byed paho

5. N P add: de.

6. P gan tshul bźin byed pa las hkhor bahi khams mthon ba de tshul bźin byed pa ni.

7. P dan ldan par khyad par med par mthon no, for $D$ N R du bye brag med pa dan ldan pa(r) mthon no.

8. N om: yan.

9. N P R om: du.

10. $\mathrm{P}$ byin gi rlabs (also in the next phrase).

11. P gton.

12. D N R ste. 
sā riḥi bu gźan yan byan chub sems dpaḥ ses rab kyi pha rol tu phyin pa la spyod pa | ḥdus byas la spyod pahi chos thams cad la ses rab kyis mi gnas pa yin te ${ }^{1} \mid$ hdi lta ste | ma rig pa dan lhan cig tu mi gnas | hadu byed mams dan lhan cig tu mi gnas pa nas rgyas par byas te ${ }^{2} \mid$ rga șịi bar dan lhan cig tu mi gnas | bdag tu lta ba dan lhan cig tu mi gnas pa nas ${ }^{3}$ | bdag tu lta bahi rtsa ba las byun bahi lta ba rnam pa ${ }^{4}$ drug bcu rtsa gñis dan lhan cig tu mi gnas | mtho bar sems pa dañ lhan cig tu mi gnas | dmah bar sems pa dan lhan cig tu mi gnas | hjig rten gyi chos brgyad rnams dan lhan cig tu mi gnas | na rgyal $^{5}$ dan | che bahì na rgyal dañ | log paḥi na rgyal nas | ñe baḥi ñon moǹs pa ñi suhịi bar dañ lhan cig tu mi gnas | chen po dañ | ḩbrin po dan் | phra mo nas | ñon mońs pa thams cad kyi bar dan lhan cig tu mi gnas | gti mug gi mun pa rab rib kyi lin thog sgrib pa dan chod par byed pa kun tu dkris te hag pa nas ${ }^{6} \mid$ dmah bahi chos thams cad kyi bar dan lhan cig tu mi gnas | rtsod pahi rñog pa dañ | ñon mońs pa dan் | phun po dan் | lhahi bu dan | hchi bdag gi bdud nas | bdud thams cad kyi las kyi bar dan lhan cig tu mi gnas |

bdag dan | sems can dan $\mid$ srog dan | gso dan் | gan zag dan | sed bu dan | śed las skyes pa (614) nas | bdag du lha ba thams cad kyi bar dan lhan cig tu mi gnas | las kyi sgrib pa dan | ñon mońs paḥi sgrib pa dan் | chos kyi sgrib pa dañ ${ }^{8}$ l ta baḥi sgrib pa dan | mam par smin pahi sgrib pa dañ | mi śes pahi sgrib pa nas | bag chags kyi mtshams sbyor ba thams cad kyi bar dan் lhan cig tu mi gnas | kun tu rtog pa dan் | rnam par rtog pa dan் | mtshan ma dan் | dmigs pa dan் | mthon ba dan் | thos pa dan | dran pa dan் | rnam par rig pa dan $\mid$ mdud pahi sgro ḥdogs pa thams cad dan lhan cig tu mi gnas | ser sna dan | gton ba dan | tshul khrims dan | hạchal paḥi tshul khrims ${ }^{10}$ dań | bzod pa dan | gnod sems dań | brtson ḩgrus dań | le lo dań | bsam gtan dañ | g.yen ba dañ | ses rab dañ | ḥchal pahi ses rab nas | pha rol tu phyin pahi

1. P hdus byas kyi spyod pa thams cad la śes rab dan gnas pa yin te, for D N R hudus byas la spyod pahi chos thams cad la śes rab kyis mi gnas pa yin te.

2. P rgya cher, for D N R rgyas par byas te.

3. P om: nas.

4. D N R lta bar gyur pa.

5. D N R na rgyal; $P$ na (also in all subsequent occurrences of the term 'na rgyal').

6. $\quad \mathrm{N}$ tog gis bsgrib pa; $\mathrm{P}$ gti mug gi mun pa rab rib stug po sgrib pa sgrib par byed pa, for D $\mathrm{R}$ gti mug gi mun pa rab rib kyi lin $t(h) o g(b) s g r i b$ pa dañ chod par byed pa kun tu dkris te hadug pa nas.

7. $P$ nus nan pahi rñog pa; $R$ rtson pahi tñog pa.

8. P om: chos kyi sgrib pa dan.

9. P rnam par ses pa.

10. P tshul khrims nan pa, for $\mathrm{D} N \mathrm{R}$ ḥchal pahi tshul khrims. 
phyogs ${ }^{1}$ dan | mi ḥthun pahi phyogs dan | śes pa dañ | mi śes pahi bar thams cad dan lhan cig tu mi gnas |

nes pa dan | ma nes pa dan | log par nes pa dan | dge ba dan | mi dge ba dan | kha na ma tho ba dań / kha na ma tho ba med pa dan | ḥkhor ba dan mya nan las has pa nas / chos thams cad kyi gñen pohi bar dañ lhan cig tu mi gnas | źin sna tshogs dan | sańs rgyas sna tshogs dan | sems can sna tshogs dan | chos sna tshogs nas | sna tshogs thams cad ${ }^{2}$ kyi bar dan lhan cig tu mi gnas | mi ses pa dań | ses pa dan | mam par ses pa dan | kun rdzob dan | (615) don dam pa nas | sems can thams cad kyi mtshan ma yid la byed dag dan lhan cig tu mi gnas | śes rab mi rgyu ba dan / lus med pa dan் | mtshan ñid med pa dan | mtshan ma med pa dan | hadus ma byas $\mathrm{pa}^{3}$ nas | yid la byed pa thams cad dan் | sems dan rnam par ses pahi gnas dag gi bar ${ }^{4}$ dań lhan cig tu mi gnas te / de dag dan gźan yan ḥdus byas la spyod pahi chos dpag du med pa dag dan lhan cig tu mi gnas so $\|$

de ltar na byañ chub sems dpah ses rab kyi pha rol tu phyin pa la spyod pahị śses rab de ni hidus byas kyi spyod pa thams cad dan lhan cig tu mi gnas te | sā rihi bu de ltar na byan chub sems dpah ses rab kyi pha rol tu phyin pa la spyod do $\|$

\section{SECTION II}

2.

śā rihi bu gźan yañ byañ chub sems dpaḥ byan chub sems dpaḥi sde snod la gnas pa | śes rab kyi pha rol tu phyin pa la spyod pa na ${ }^{6} \mid$ ses rab kyi pha rol tu phyin pa rnam par hbyed mkhas pa yin te | chos thams cad la mkhas pa rjes su ḥthob po ||

de la śes rab rnam par ḥbyed pa gan źe na | ḥdi lta ste | phun po la mkhas pa dan் | khams la mkhas pa dan | skye mched la mkhas pa dan | bden pa la mkhas pa dan | so so yan dag par rig pa la mkhas pa dan் | rton pa $^{7}$ la mkhas pa dan் | rnam par ses pa dań ye ses la mkhas pa dan் | byań chub kyi yan lag la mkhas pa dan | lam la mkhas pa dan | rten cin ḥbrel par (616) ḥbyun ba la mkhas pa dań bcu ste $\mid$ mkhas pa rnam pa bcu po hidi dag gi ${ }^{8}$ mam par ḥbyed pa gan

1. P gĩen po.

2. P om: thams cad.

3. N om: pa.

4. P om: gi bar.

5. D P R add: gan.

6. D N R om: na.

7. P rten pa (in $\mathbf{P}$, 'rton pa' is frequently substituted by 'rten pa').

8. D R gyi; P gań. 
yin pa de ni śes rab rnam par ḥbyed pa źes byaḥo $\|$

\section{1}

de la phun po la mkhas pa gań źe na / gan̉ ḥdi phun po mams kyi dper bya ba bstan pa ${ }^{1}$ ḥdi lta ste $\mid \mathrm{dbu}^{2}$ ba rdos ba lta bur bstan pa dan | smig rgyu lta bur bstan pa dan் | chu bur lta bur bstan pa dan | chu $\sin ^{3}$ lta bur bstan pa dan | sgyu ma lta bur bstan pa dan | rmi lam lta bur bstan pa dan | brag cha lta bur bstan pa dan் | mig yor lta bur bstan pa dan | gzugs brñan lta bur bstan paho $\|$

gzugs ni chuhi dbu ba lta bu ste | dbu ba la yaǹ bdag med | sems can med | srog med | gan zag med | skyes bu med | sed $b^{4}$ med | sed las skyes ${ }^{5}$ med do || dbu bahi ran bźin gan yin pa gzugs kyan dehi ran bźin ${ }^{6}$ te | gan de la mkhas pa de ni phuń po la mkhas pa źes byaho ||

tshor ba ni chuhi chu bur lta bu ste | chu bur la yan bdag med | sems can med | srog med | gań zag med | sed bu med | sed las skyes med | skye ba po $\operatorname{med}^{7} \mid$ skyes bu med de $^{8}||$ chu bur gyi ran bźin gañ yin pa tshor ba yañ dehi ran bźin yin te / gañ de la mkhas pa de ni phun po la mkhas pa źes byaho \|

ḩdu śes ni smig rgyu lta bu ste | smig rgyu la yan bdag med | sems can med pa nas $\mid$ skyes buhi bar du med do || smig rgyuhi ran̉ bźin gan̉ yin pa ḥdu śes kyan deḥi ran̉ bźin yin te | gan de la mkhas pa de ni (617) phuñ po la mkhas pa źes byaho $\|$

ḥdu byed rnams ni chu sin lta bu ste / chu śin la yan bdag med | sems can med | srog med pa nas | skyes buhi bar du med do $^{10} \|$ chu sin gi ran bźin gan yin pa hadu byed dag kyañ dehi ran bźin yin te | gañ de la mkhas pa de ni phun po la mkhas pa źes byaho ||

rnam par śes pa ni sgyu ma lta bu ste | sgyu ma la yań bdag med | sems can med | srog med | gan zag med | sed bu med | sed las skyes med | skyes bu med | byed pa po med | tshor ba po med do $^{11}$ || sgyu mahi ran bźin gan yin pa mam par ses pahan dehi rań bźin yin te | gań de la mkhas pa de ni phun po la mkhas pa źes byahọ $\|$

1. P dpe hjog cin hịchad pa.

2. N lbu.

3. P add: skyes (also in all further occurrences of the term 'chu sin').

4. P sed can (also in all further occurrences of the term 'sed bu').

5. N skyes pa (also in all subsequent occurrences of the term 'sed las skyes').

6. D add: yin.

7. P om: skye ba po med.

8. Nom: skyes bu med de.

9. $\quad \mathrm{N}$ hadi.

10. D N P R med pa ste.

11. D N P R med pa ste. 
gźan yan phun po rnams źes ${ }^{1}$ bya ba (de) ni ḥjig rten yin te | ḥjig rten yan ḥjig paḥi mtshan ñid do \|l. hjig rten rnams kyi ran bźin gan yin pa phun po mams kyañ deḥi rañ bźin yin no || yan̉ hjig rten gyi ran̉ bźin gań yin źe na | ḥdi lta ste / mi rtag paḥi rañ bźin dan | sdug bsnal gyi ran bźin te | phun poḥañ dehi ran bźin no || gan̉ de la mkhas pa de ni phun po la mkhas pa źes byaho \|

de ltar na byan chub sems dpah phun po la mkhas pa ses rab kyi pha rol tu phyin pa la spyod do $\|$

\section{2}

de la khams la mkhas pa gań źe na | ḥdi lta ste | chos kyi khams de ni saḥi khams mod kyi | chos kyi khams sra bahi mtshan ñid ma yin no || chos kyi khams (618) (de) ni chuhi khams mod kyi | chos kyi khams rlan pahi mtshan ñid ma yin no || chos kyi khams (de) ni mehi khams mod kyi | chos kyi khams tsha baḥi mtshan ñid ma yin no \| chos kyi khams (de) ni rlun gi khams mod kyi | chos kyi khams g.yo baḥi mtshan ñid ma yin no $\|$

chos kyi khams (de) ni mig gi rnam par śes paḥi khams mod kyi | chos kyi khams mthon bahi mtshan ñid ma yin no $\|$ chos kyi khams (de) ni rna bahi rnam par ses pạ̣i khams mod kyi | chos kyi khams sgra rtogs pahi mtshan ñid ma yin no || chos kyi khams (de) ni snahi rnam par ses paḥi khams mod kyi | chos kyi khams dri snom paḥi mtshan ñid ma yin no || chos kyi khams (de) ni ltsehi rnam par śes pahi khams mod kyi | chos kyi khams ro myon bahi mtshan ñid ma yin no $\|$ chos kyi khams (de) ni lus kyi rnam par ses pahi khams mod kyi | chos kyi khams reg pahi mtshan ñid ma yin no || chos kyi khams (de) ni yid kyi rnam par śes pahi khams mod kyi | chos kyi khams rnam par sgom pahi mtshan ñid ma yin no $\|$

chos kyi khams dan bdag gi khams de ni mtshuns so || ḥdod pahi khams dan | gzugs kyi khams dan | gzugs med pahi khams de (ni) mtshuns so || ḥkhor baḥi khams dan mya nan las hadas pahi khams de (ni) mtshuns so $\|$ de ltar chos thams cad kyi khams dan nam mkhahi khams de (ni) mtshuñs te / ston pa ñid dan mtshuns pas mthuñ ${ }^{3} \mid$ mi hgyur ba dan mtshuns pas mtshuńs te / ḥdus byas kyi khams su hjug pa dan | ḥdus ma byas kyi khams su hjug pahi (619) phyir | de la bśad pa dpag du med do \| gan khams la ḥjug pa des rab tu rnam par ḥbyed pa $^{4}$ de ni mkhas pa źes byaho $\|$

de lta na khams la mkhas pahi byan chub sems dpah sems dpaḥ chen po ses rab kyi pha rol

1. N śes (in N, all initial ' $z$ ' turn into ' $s$ ' when preceded by a final ' $s$ ').

2. D P R om: de.

3. D P R mthuns par.

4. $\quad$ P stsogs par byed pa; $R$ rab tu libyed pa. 
tu phyin pa la spyod do $\|$

\section{3}

de la byań chub sems dpahi skye mched la mkhas pa gan źe na / ḥdi la mig bdag dań bdag gis ston pa te | byañ chub sems dpạ̣ mig gi ran bźin ni ${ }^{1}$ ḥdi lta buḥo || źes yan dag pa ji lta ba bźin du rab tu śes te | de ni byan chub sems dpahi skye mched la mkhas paho ||

gon ma bźin du sbyar te | de bźin du rna ba dan | sna dan | ltse dan | lus dan | yid bdag dan bdag gis stoñ pa de | byañ chub sems dpạ̣ yid kyi ran̉ bźin ni ḥdi lta buho || źes yan dag pa ji lta ba bźin du rab tu śes te $\mid$ dge ba ${ }^{2}$ sogs pahi phyir gaǹ skyed mched la kun sogs pa dan $\mid$ sna tshogs sogs pa de dag sogs par mi byed cin | dge ba dan mi dge baḥi chos mams la hadu śes gñis su mi hjug ste ${ }^{3}$ de ni byan chub sems dpahi skye mched la mkhas paho $\|$

hadi ni mig gi skye mched do || hadi ni gzugs kyi skye. mched do || źes ${ }^{4}$ de ltar mig dan gzugs rnams la ḥdod chags med par mthon yan | ḥdod chags med pa mnon du mi byed pa de ni byañ chub sems dpaḥi skye mched la mkhas paho || rna ba dań sgra | sna dañ dri | ltse dan ro | lus dan reg | yid dań chos | gon ma bźin du sbyar te | de ltar byan chub sems dpah yid dañ chos (620) kyi bar du hodod chags med par mthon mod kyi | hidod chags med pa mnon du mi byed pa | de ni byan chub sems dpahi ${ }^{5}$ skye mohed la mkhas paho ||

skye mched ces bya ba de (ni) yan ḥphags pahi skye mched dan | ḥphags pa ma yin pahi skye mched do || de la ḥphags pahi skye mched ni gan lam sdud par byed paho || ḥphags pa ma yin pahi skye mched ni gan lam gton bar byed $\mathrm{pa}^{6} \mid$ hidi lta ste | byan chub sems dpah lam la gnas pa ni sems can lam la brtson pa bor źin gnas $\mathrm{pa}^{7}$ la sñin rje chen po ḥthob cin | lam gyi $^{8}$ skye mched kyan mi gton ba ste / de ni byan chub sems dpahi skye mched la mkhas paho $\|^{9}$

de ltar na byan chub sems dpahii ${ }^{10}$ skye mched la mkhas pa ses rab kyi pha rol tu phyin pa la spyod do $\|$

\footnotetext{
1. D P R om: ni.

2. P add: las.

3. P om: hidu śes gniis su mi hjug ste.

4. P add: hidu śes gñis su mi hjug ste.

5. P dpah.

6. P add: ste.

7. P om: la brtson pa bor źin gnas pa.

8. $\mathrm{R} \mathrm{mi}$

9. D add: de ltar na byań chub sems dpahi skye mched kyań mi gton ba ste / de ni byań chub sems dpahi skye mched la mkhas paho.

10. P R dpah.
} 


\section{4}

de la byañ chub sems dpahi bden pa la mkhas pa gań źe na | byañ chub sems dpahi bden pa la hyjug pa mkhas pa ni rnam par bźi ste | ḥdi lta ste | sdug bsnal ses pa dan் | kun ḥbyun ba śes pa dañ | hogog pa śes pa dañ | lam śes paḥo ||

de la sdug bsnal śes pa gań źe na $/ \operatorname{gan}^{1}$ phun po rnams la mi skye bar ses pa de ni sdug bsnal śes pa źes byaho || de la kun ḥbyun ba ses pa gań źe na | gañ sred pa hjoms pa ${ }^{2}$ (śes pa) de ni kun ḥbyun ba śes pa źes byaḥo || de la ḥgog pa ses pa gań źe na | gañ mi ḥbyuñ (ba) mi hjig par śes pa de ni ḥgog pa śes pa źes byaho \| de la lam ses pa gań źe na | (621) gan mñam pa ñid ${ }^{3}$ thob pahi chos mams la sgro mi ḥdogs pa de ni lam ses pa źes byaho \| gan gi tshe byan chub sems dpas bden pa ḥdi bźi de ltar śes rab kyis śes kyan sems can yońs su smin par bya bahi phyir mñon du mi byed pa de ni bden pa la mkhas pa źes byaho $\|$

gźan yan bden pa la mkhas pa (ni) rnam pa gsum ste | ḥdi lta ste | kun rdzob kyi bden pa dań | don dam pahi bden pa dan | mtshan ñid kyi bden paho $\mid$

de la kun rdzob kyi bden pa (gań źe na) ${ }^{4}$ hjig rten gyi tha sñad ji sñed pa dan | yi ge dan | sgra dan் | brdar bstan $\mathrm{pa}^{5}$ ste | de ni kun rdzob kyi bden pa źes byaho || de la don dam pahi bden pa gań źe na / gan̉ la sems kyi rgyu ba yañ med $\mathrm{na}^{6}$ yi $\mathrm{ge}^{7}$ lta ci smos te / de ni don dam paḥi bden pa źes byaho || de la mtshan ñid kyi bden pa gań źe na | ḥdi lta ste | mtshan ñid thams cad mtshan ñid gcig la | mtshan ñid gcig pa ni $^{8}$ mtshan ñid med paho || de la byan chub sems dpah kun rdzob kyi bden pa ḥchad pas mi skyo \| don dam pahi bden pa mnon du byed par mi ltun் | mtshan ñid kyi bden pa mtshan ñid med pas rtogs par byed $\mathrm{pa}^{9}$ de ni byan் chub sems dpaḥi bden pa la mkhas pa źes byạ̣o $\|$

gźan yan bden pa ni gcig bu | gñis ma yin $\mathrm{pa}^{10}$ ste | ḥdi lta ste | ḥgog paḥi dben paho || de la dben pa geig bu la gań sgro mi ḥdogs pa dan | sems can sgro hadogs par lhun ba rnams la bden pa sbyor bar byed pa de ni byan chub sems dpahi bden pa la mkhas pa źes byaho $\|$

gźan yan̉ phuñ po lna (622) rnams ni sdug bsñal ba ste / gañ phuñ po lna rnams kyi sdug bsnal gyi mtshan ñid de ni sdug bsñal (gyi ḥphags paḥi bden pa) źes byaho || gan sdug bsnal

1. N om: gañ.

2. R add: źes bya ba.

3. P gnis.

4. D N P R ni.

5. P kun rtog pa hchad pa, for D N R brdar bstan pa.

6. P gan sems de ñid kyañ rab tu mi rgyun, for D N R gañ la sems kyi rgyu ba yañ med na.

7. P add: dag.

8. P han.

9. P rtog pa, for D N R rtogs par byed pa.

10. P gñis po med pa, for D N R gñis ma yin pa. 
gyi mtshan ñid kyi ston pa ñid kyi mtshan ñid rtogs pa de ni sdug bsnal ḥphags pạ̣i bden pa źes byaho $\|$ gań phun po lnaa rnams kyi bag la ñal rgyu sred pa las byun bahi lta ba de ni kun ḥbyun baḥi bden pa źes byaḥo ${ }^{1} \|$ gan sred paḥi rgyu lta ba de la yań sgro mi ḥdogs (pa) mi len (pa) mi sñems pa de ni kun ḩbyun ba ḥhags pahi bden pa źes byaho \| gañ phuń po lña ${ }^{2}$ rnams sin tu zad pahi phyir hgog pa snon gyi mthar ma byun ba / phyi mahi mthar mi ḥpho ba | da lta byun bar mi gnas pa de ni hggog pa ḥphags pạ̣i bden pa źes byaho || gan lam la brten nas ${ }^{3}$ sdug bsnal ses pa dan | kun ḩbyun ba śes pa dan் | hgog pa śes pa la yan reg par byed la | rjes las rtogs pahi śes pa yan thob par byed pa de ni sdug bsnal hgog par hgyur bahi lam ḥphags pahi bden pa źes byaḥo || gan̉ bden pa śes pa de la rnam par rtog pa dan் | sems can yońs su brtag pa la rtog par byed pa de ni byañ chub sems dpạ̣i bden pa la mkhas pa źes byaho \|

gźan yań tshor ba thams cad (ni) sdug bsnal ba ste | de la tshor bar ${ }^{4}$ mam par ḥbyed ${ }^{5}$ pa dań | blos rig pa ñid de ni | sdug bsnal ḥphags paḥi bden pa źes byaho || rgyu gan gis kun ḥbyun bar śes paḥi rgyu de ji lta ba yan dag par rab tu ses pa de ni kun ḥbyun ba ḥphags pahi bden pa źes byaḥo || gan tshor ba gton źin ma tshor ba tshor bar byed pa dan் | hgog pa la yan் so sor rtog (623) la | tshor ba hgog pa yan mnon du mi byed pa de ni byan chub sems dpahi sdug bsñal ḥgog pa ḥphags paḥi bden pa źes byaḥo \| tshor ba gan gis gziñs dan ḥdra baḥi lam de sdud par byed la | tshor bar dgos pa yan ma yin | lam gyi dgos pa yaǹ ma yin pa de ni byan chub sems dpaḥi sdug bsnal ḥgog par hgro bahi lam ḥphags pahi bden pa źes byaho || de ltar rtogs nas bden pa de ${ }^{6}$ bźi la mñam par mthon źin | mthon ba śin tu dag pa yan ma yin pa de ni byañ chub sems dpahi bden pa la mkhas pa źes byaho $\|$

gźan yan skye ba (ni) sdug bsnal ba ste | gan mi skye ba la so sor rtog pa śes pa de ni sdug bsñal ses pa źes byaḥo || srid pạ̣i rkyen gyis skye ba ste / gan srid pa hjig par śes pa de ni kun ḩbyun ba śes pa źes byaḥo \| skye ba thams cad gañ gis mi skye bar śes $1 a^{7}$ | de la hagog pa gañ yan̉ med cin | gan mi hgog par śes pa de ni zad pa ḥgog pahi ${ }^{8}$ śes pa źes byaho || gan de ltar tshor ba ${ }^{9}$ dan் | hjal ba dan் | yońs su tshol ba dan | rnam par rtog pa dan | hjug pahi śes pa de ni lam śes pa źes bya ste / gan̉ bden pahi śes pa de la gźog par byed kyan | bden paḥi śes

1. P R bden paho.

2. D P R om: lna.

3. $\quad P$ gań lam rtogs nas.

4. D N R add: bya ba; Akn (p. 54.1.8) om: bya ba.

5. P rdzogs.

6. P add: dag.

7. $\mathrm{N}$ pa.

8. P par.

9. D R bar. 
pa de la mi gnas $\mathrm{pa}^{1}$ de ni byañ chub sems dpahi bden pa la mkhas pa ste

de ltar na byan chub sems dpạ̣ bden pa la mkhas pa ses rab kyi pha rol tu phyin pa la spyod do $\|$

\section{5}

de la byañ chub sems dpahii ${ }^{2}$ so so yan dag par rig pa la mkhas pa gań źe na | (624) byañ chub sems dpahi so so yaǹ dag par rig pa ni bźi po ḥdi dag (yin te) | bźi gañ źe na | ḥdi lta ste | don so so yań dag par rig pa dan | chos so so yan dag par rig pa dan | nes paḥi tshig so so yan̉ dag par rig pa dan் | spobs pa so so yaǹ dag par rig paho \|

\subsection{1}

de la don so so yan dag par rig pa gan źe na | gan chos mams la don dam pahi tshig tu śes pa dan் | gñis su med paḥi rgyu śes pa dan | rkyen śes pa dan | hadus pa śes pa dan | mthah ${ }^{3}$ med pahi rjes su hgro ba śes pa dan | rten $\mathrm{pa}^{4}$ la hjug pa ses pa dan் / chos kyi dbyins dbyer med pa śes pa dan் | de bźin ñid kyi ${ }^{5}$ rjes su hjug pa ses pa dan | yań dag pahi mthah mi gnas pa śes pa dań | ston pa ñid rjes su rtogs pa śes pa dan் / mtshan ma med pa rtogs pa śes pa dan | smon pa med pa la smon pa med par śes pa dan் | mñon par hadu mi byed pa la mñon par hadu mi byed par ses pa dan $\mid$ tshul geig tu hyjug pa ses pa dan $\mid$ sems can med pa hijug pa ses pa dan | bdag med par hjug pa śes pa dań | srog med par byed pa gcig pa ${ }^{6}$ śes pa dan் | gañ zag med $\operatorname{par}^{7}$ don dam par śes pa dan் / ḥdas pahị dus la ma chags par śes pa dan் / ma ḥoǹs bahi dus la mthah med par ses pa dan் | da ltar byun baḥi dus la thams cad du śes pa dan | phun po rnams la sgyu mar śes pa dan / khams rnams la sbrul gdug pa lta bur ${ }^{8}$ ses pa dan / skye mched rnams la ston pa ñid du (625) nes par rtog par śes pa dań | nañ (du) źi bar ${ }^{9}$ śes pa dan | phyi rol tu mi rgyu bar ${ }^{10}$ ses pa dan | yul la yul med par śes pa dan | dran pa la gnas su śes pa dañ | rtogs pa la khon du chud par ses pa dan | blo gros la ${ }^{11}$ mñon sum du śes pa dan $\mid$ bden pa la rab tu rtogs par ses pa dan | sdug bsñal la mi ḥbyun bar śes pa dan் | kun ḥbyun ba la mnon par

1. $\quad$ P gnas par byed pa, for D N R gnas pa.

2. N dpah.

3. P hgog pa.

4. Prten cin hibrel pa; $\mathrm{N}$ brten (also in the next occurence of the term 'rten pa').

5. D kyis.

6. R om: gcig pa.

7. NP pa.

8. D N dan mtshuns par.

9. DN P R ba.

10. D N P R ba.

11. P om: la. 
ḥdu mi byed par ses pa dan | hgog pa la mtshan ñid med par śes pa dań | lam la sgrol bar śes pa dan $\mid$

chos la tshig rab tu tha dad par ses pa dañ | dbañ po mams la hjug par ses pa dañ | stobs rnams la mi rdzi ${ }^{1}$ bar śes pa dan | źi gnas la gnas su śes pa dan | lhag mthon la snañ bar śes pa dan | sgyu ma la bsgrub par ses pa dan | smig rgyu la ḥkhrul ${ }^{2}$ bar ses pa dan | rmi lam la mi bden pa mthon bar śes pa dan $/$ brag cha la rkyen la hjug par ses pa ${ }^{3}$ dan $\mid$ mig yor la ḥpho bar śes pa dan $\mid$ mtshan ñid sna tshogs la mtshan ñid gcig tu śes pa dan $\mid$ ḥdu ba la ḥbral bar śs pa dan | rab tu sbyans pa la phyir ${ }^{4}$ mtshams sbyor ba med par śes pa dan | ñan thos kyi theg pa la sgrahi rjes su hgro bar hjug par ses pa dan | ran sañs rgyas kyi theg pa la rten pa la hyjug pa ses śin dben pa $1 a^{6}$ mchog tu ses pa dan | theg pa chen po la dge baḥi rtsa baḥi tshogs bsags pa thams cad ses pa ste $\mid$ de ni byan chub sems dpahi don so so (626) yan dag par rig pa źes byaḥo $\|$

gźan yañ don ${ }^{7}$ so so yañ dag par rig pa ni gañ don la rton pa ste | chos thams cad kyi chos ñid kun gyi don la rton pa ñid kyi rjes su ḥbran bahọo ${ }^{8}||$ de ciḥi phyir źe na | chos thams cad ma lus par' ston pa ste | ston pahi don gan yin pa de ni don no || chos thams cad ma lus par mtshan ma med pa ste | mtshan ma med pahi don gan yin pa de ni don no $\|$ chos thams cad ma lus par smon pa med pa ste | smon pa med pahi don gan yin pa de ni don no || chos thams cad ma lus par rnam par phye ba ste | rnam par phye bahi don gan yin pa de ni don no $\|$ chos thams cad ma lus par sems can med | srog med | gan zag med pa ste | gan zag med pahi don gan yin pa de ni don no $\|$ gan de lta buhi chos rnams rtogs pa de ni don ${ }^{10}$ so so yan dag par rig pa źes bya ste | gan don ston pa de ni gnas med pa ston paho || de ni mi ${ }^{11} \mathrm{zad}$ pa ston paho || so so yañ dag par rig pa ni rtogs pahi don ston pa yin te / sañs rgyas bcom ldan hadas rnams kyis gnañ ba $\mid$ rjes su yi ${ }^{12}$ ran ba | yan dag pa | de kho na $\mid$ gźan ma yin pa $\mid$ śes rab kyis sin tu rtogs pa | thams cad tu kha na ma tho ba med pa de ni byan chub sems dpahi don so so yan dag par rig pa źes byaḥo \|

1. P mi thoms pa; R mi brdzi pa.

2. D hạkhrug.

3. P rten ciñ ḥbrel pa śes pa, for D N R rkyen la hjug par ses pa.

4. P sbyans pa la slar, for D N R rab tu sbyans pa la phyir.

5. P rjes us rtogs pa hjug pa, for D N R rjes su hgro bar hjug pa(r).

6. D P om: la.

7. D P R om: don.

8. N hbran no; $P$ chos thams cad kyi chos so | chog gi don la rten pa ñid la rten paho.

9. $\quad$ P kun (also in the following five instances of the phrase ' $m a$ lus par').

10. P R om: don.

11. P om: mi.

12. $\mathrm{N}$ yid. 


\section{5 .2}

de la chos so so yan dag par rig pa gań źe na | gan dge ba dan | mi dge ba dan | kha na ma tho ba dan் bcas pa dan் | kha na ma tho ba med pa dan் | zag pa dań bcas pa dan் | (627) zag pa med pa dan் | hijig rten pa dan | hijig rten las ḥdas pa dan | ḥdus byas dan் | ḥdus ma byas dañ | kun nas ${ }^{1}$ ñon moǹs pa dan் | rnam par byan̉ baḥi cha dan̉ ḥthun pa dan் | ḥkhor ba dan mya nan las ḥdas par ñe bar ḥgro baḥi chos rnams la ḥjug pa śes pa dan | chos kyi dbyiñs mñam pa ñid ses pa dan் | byań chub ${ }^{2}$ mñam pa ñid śes pa dan $\mid$ khams mñam pa ñid śes pa ste | de ni chos so so yan dag par rig pa źes byaho \|

gźan yan chos so so yan dag par rig pa ni | gan hadod chags spyod pa rnams la sems ${ }^{3}$ hjug $\mathrm{pa}^{4}$ dan் | bcos pahii ${ }^{5}$ hdod chags spyod pa mams dan | ḥdod chags brtan par spyod pa rnams dan | ḥdod chags chun du spyod pa mams dan / mam par mi ldan bahi hạdod chags spyod pa rnams dan | mthah mar ${ }^{6}$ rtag tu med paḥi ḥdod chags spyod pa rnams dan | da ltar byun ba la rkyen gyis hodod chags spyod pa mams la hjug pa ste |

sems can gań dag nan du hodod chags $1 a^{7} \mid$ phyi rol tu hodod chags med pa dan | phyi rol tu ḥdod chags la | nan du ḥdod chags med pa dan | nan duhan ḥdod chags med | phyi rol tuhañ

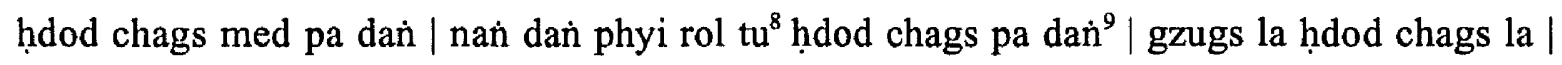
sgra la ḥdod chags med pa dan் | sgra la ḥdod chags la | gzugs la ḥdod chags med pa dan | gzugs dan் sgra la họdod chags pa dan | (628) gzugs dan sgra la họdod chags med pa dañ ${ }^{10} \mid$ gźugs la họdod chags la $^{11}$ | dri la ḥdod chags med pa dan | dri la ḥdod chags la | reg la ḥdod chags med pa dan | reg la ḥdod chags la | ro la ḥdod chags med pa dan | ro la hidod chags la | gzugs la hodod chags med pa dan | dri la hodod chags med pa de ni hadod chags spyod pa rnams kyi hjug pa ste |

hjug pa dehi sgos ḥdod chags spyod pa mams la ñi khri chig stón | źe sdañ spyod pa rnams la ñi khri chig ston் / gti mug spyod pa rnams la ñi khri chig ston / cha mñam par spyod pa rnams la ñi khri chig ston ste / gań de dag gi spyod pa brgyad khri bźi stoń gi sems hjug pa

1. P om: kun nas.

2. N add: kyi.

3. P spyod pahi sems, for D N R spyod pa rnams la sems.

4. D P R add: śes pa.

5. P sgyu mahi.

6. D P R ma.

7. P kyi (also in the seven following occurrences of the term 'la' of the present context).

8. P add: yan.

9. N om: nan dan் phyi rol tu hdod chags pa dañ; $R$ add: nań dani phyi rol tu hadod chags med pa dan.

10. R om: gzugs dan sgra la hạdod chags med pa dan.

11. D gźugs la ḥdod chags la; $\mathrm{N}$ dan. 
ses pa dan் | ji ltar rigs par bstan ${ }^{1}$ pa ses pa dan | mi mań mi ñun bar bstan pa ses pa dan | ḥdod pa las yan dag par ḥdạ bar śes pa dan் | snod kyi khyad par ses pa dań / habras bu yod par bstan pa śes pa | de ni chos so so yan̉ dag par rig pa źes byahọo

\subsection{3}

de la nes pahi tshig so so yań dag par rig pa gan źe na | gan skad thams cad la skad med par hjug pa śes pa dan / Thahi skad dan | kluhi skad dan் | gnod sbyin gyi skad dan | dri zahi skad dań | mi hạam ciḥi skad dań | lto ḥphye chen poḥi skad dań | mi dań mi ma yin pahi skad dan் | ḥgro ba snaar skyes pahi sems can rnams kyi skad dan | sgra dan dbyañs ${ }^{2}$ rnams las skad des de dag la chos hehad pa ste | de ni nes paḥi tshig so so yan dag par rig pa źes byaho \| (629)

de ltar chos de dag brtag par byaho || de ltar chos de dag bsdu bar byaho || de ltar chos de dag rjes su rgyun chags par byaho \| de ltar chos de dag yi ge rnams kyis sbrel bar byaho \| de tshig gcig gi bla dags ses | tshig gñis pahi bla dags śes | tshig mań poḥi bla dags śes | bud med kyi tshig śes | skyes pahi tshig ses | ma nin gi tshig ses | bsdus bahi tshig ses | rgyas pahi tshig śes | smad pahi tshig śes | stod paḥi tshig śes ${ }^{3}$ | ḥdas pahi tshig śes | ma hono bahi tshig ses | da ltar byun baḥi tshig śes | yi ge gcig gis sgro btags pa śes | yi ge man pos sgro btags pa śes | de ni nes pahi tshig so so yañ dag par rig pa źes byaho $\|$

yan̉ deḥi nes paḥi tshig so so yan dag par rig pa ni ḥkhrul ba ma yin | zlos pa ma yin | brtags pa ma yin | don gsal bahi yi ge ${ }^{4}$ yons su byan̉ ba ste / ci nas kyañ hạhor yan dag par dgah ba sna tshogs pa zab pa | zab par snan ba / kun rdzob dan don dam pas brgyan pa bdag gis ${ }^{6}$ sems mthon baḥi śes pa la rag lus pa | sañs rgyas kyis gnañ ba | sems can thams cad dgạ̣ bar byed pa ste | de ni byan chub sems dpaḥi nes paḥi tshig so so yañ dag par rig pa źes byaḥo \|

\subsection{4}

de la byan chub sems dpahi spobs pa so so yan dag par rig pa gań źe na / gan̉ tshig bzañ $\mathrm{ba}^{7}$ | mi gnas par lun̉ bstan pa ston (630) pa | rgyun mi hachad pa | spobs pa myur ba $\mid$ spobs pa mgyogs sin myur ba $\mid$ spobs pa ma $^{8}$ rmońs pa | spobs pa ji ltar dris pa bźin pa| spobs pa

1. P hchad (also in the next two occurrences of the term 'bstan').

2. N dbyins.

3. D Rbstod pahi tshig śes; P om: bstod pahi tshig ses.

4. N R ye śes.

5. $P$ dam pahi rgyan.

6. N P R gi.

7. $\mathrm{P}$ gañ mdzes pahi tshig.

8. Nom: ma. 
yoǹs su ma ñams pa | spobs pa mi hyal ba | spobs pa rtsod pa med pa | spobs pa chos la rab tu dgah ba ${ }^{1}$ | spobs pa bzod pa la gnas pa | spobs pa zab pa | spobs pa sna tshogs | kun rdzob dan don dam pa la spobs pa | sbyin pa dan | tshul khrims dan் | bzod pa dan் | brtson ḥgrus dan் | bsam gtan dañ | śes rab thams cad la gnas paḥi spobs pa | dran pa ñe bar bźag pa dan | yan dag par spon் ba dan் | rdzu hphrul gyi rkañ pa dan் | dbań po dan | stobs dan் | byañ chub kyi yan lag dan் | lam dan் | źi gnas dan் | lhag mthon la spobs pa | bsam gtan dan் | rnam par thar pa

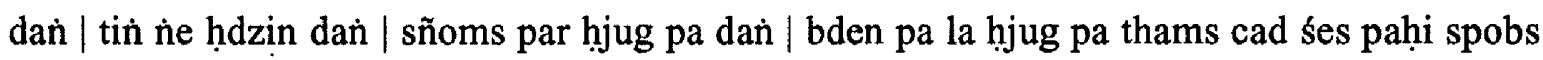
pa | theg pa thams cad la spobs pa | sems can thams cad kyi sems kyi ${ }^{2}$ spyod pa la spobs pa |

tshig mi lkug pahi spobs $\mathrm{pa}^{3} \mid$ tshig mi rtsub paḥi spobs pa | tshig mi ḥchal baḥi spobs pa | tshig rtsub mo ma yin pahi spobs pa $\mid$ tshig mñen ${ }^{4}$ pahi spobs pa $\mid$ tshig dag pa $\mid$ tshig grol ba | tshig ma chags pa $\mid$ tshig btsun pa $\mid$ tshig hbrel ba $\mid$ tshig ldan pa $\mid$ tshig ma ñams pa | tshig sñan ba | tshig hjam pa | tshig ma smad pa | tshig ḥphags pa thams cad kyis bstod pa ste / źin mthah yas pahi rnam par ses pahi rjes su (631) son baḥi sgra / tshañs paḥi sgra skad kyi dbyañs dan hạra ba / rtogs par byed pahi sgra gcig pa | sañs rgyas kyis gnan baḥi spobs pas sems can gźan dań gań zag gźan dag la chos ston ${ }^{5}$ to $\|$ dehi chos bstan pa de yan habyun bar byed pa / de byed pahi sdug bsñal yan dag par zad par ${ }^{6}$ hgyur ba ste / de ni byan chub sems dpahi spobs pa so so yan dag par rig pa źes byaho $\|$ de ni byan chub sems dpahi spobs pa la mkhas pa ste |

de ltar na byan chub sems dpah ${ }^{7}$ spobs pa la mkhas pa ses rab kyi pha rol tu phyin pa la spyod do $\|^{8}$

\section{6}

de la byan chub sems dpahi rton pa la mkhas pa gañ ${ }^{9}$ źe na | byan chub sems dpah mams kyi rton pa ḥdi bźi dag ${ }^{10}$ ste / bźi gań źe na | ḥdi lta ste | don la rton ${ }^{11}$ gyi | tshig ḥbru la ma yin pa dañ | ye ses la rton gyi | rnam par śes pa la ma yin pa dan $\mid$ ṅes pahi don gyi ${ }^{12}$ mdo sde

1. P spobs pa chos dan hgrogs na bde ba.

2. D N R dan.

3. P tshig lug bźin du mi lkug pahi spobs pa.

4. $\mathrm{N}$ gnien.

5. P hchad (also in the next phrase for 'bstan').

6. N om: zad par.

7. D N dpahi.

8. D add: bam po bcu brgyad pa; $P$ add: hphags pa byan chub sems dpahi snod sde ces bya ba theg pa chen pohi bam po bcu brgyad pa.

9. D P R om: gan.

10. D N R om: dag.

11. N ston.

12. $\mathrm{N}$ gyis. 
rnams la rton gyi | drań bahi don mams la ma yin pa dan | chos ñid la rton gyi | gañ zag la ma yin paho $\|^{1}$

\subsection{1}

de la don gan | tshig ḥbru gan źe na | tshig ḥbru źes bya ba ni gan hjig rten gyi chos kyi bya ba la ḥjug paḥo || don źes bya ba ni gan hjig rten las ḥdas pahi chos rtogs paḥo \|t tshig (632) ḥbru źes bya ba ni sbyin pa dan | dul ba dan் | sdom pa dan் | des pa bstan ${ }^{2}$ paḥo || don źes bya ba ni dul ba dań | źi gnas dan் | gsar ${ }^{3}$ pa ma yin pa dañ | sñin ma yin par śes paḥo || tshig ḥbru źes bya ba ni ḥkhor ba yons su bśad pa sgrogs paḥo ${ }^{4} \|$ don źes bya ba ni mi dmigs pa la rton $^{5}$ paho $\|$ tshig ḥbru źes bya ba ni mya nan las ḥdas paḥi yon tan yońs su sgrogs paho \| don źes bya ba ni chos rań bźin gyis yońs su mya nan las has pa rnams la rnam par mi rtog paho \| tshig hbru źes bya ba ni theg pa ji ltar rnam par bźag ${ }^{6}$ pa bźin du hachad paho \| don źes bya ba ni chos tshul gcig pa rtogs par śes paho $\|$ tshig ḥbru źes bya ba ni sems can thams cad mi gton bar bstan paḥo $\|$ don źes bya ba ni ḥkhor gsum yońs su dag paho $\|^{7}$

tshig ḥbru źes bya ba ni lus dan | nag dan | yid sdom źin bslab pa dan் | sbyañs baḥi yon tan thams cad yan dag par len par bstan paho || don źes bya ba ni lus dan | nag dań | yid mi dmigs śn mñon par hadu mi byed pa yoǹs su dag paḥo $\|$ tshig ḥbru źes bya ba ni gnod sems kyi ${ }^{8}$ tha ba dan் | khro ba dan | na rgyal dan | rgyags pa dan் | dregs pa hjom źin bzod pa dan des pa bstan pạ̣o || don źes bya ba ni mi skye bahi chos la bzod pa thob paḥo || tshig ḥbru źes bya ba ni dge bahi rtsa ba la brtson hgrus rtsom pa thams cad bstan paho \| don źes bya ba ni mi

1. Pelliot, 977, folio 1a.1-2

de la byan chub sems dpahi so sor rton pa la mkhas pa gan źe na | de ni rnam pa bźi ste | don la rton gyi tshig ḥbru la ma yin ba dań | ye ses la rton gyi rnam par śes pa la ma yin ba dan | nes pahi don gyi mdo sde la rton gyi dran bahi don gyi mdo sde la ma yin ba dan | chos la rton gyi gan zag la ma yin ba dan bźiho $\|$.

2. $\mathrm{N}$ brtan (also in the next occurence of the phrase 'des pa bstan paho'); $\mathrm{P}$ hchad (also in the following thirteen occurrences of the word 'bstan pa').

3. D N sar.

4. P tshig ḥbru źes bya ba ni ḥkhor baḥi dam ḥchạ̣ ba yons su sgrogs paho, for D N R tshig ḥbru źes bya ba ni ḥkhor ba yons su bśad/bcad pa sgrogs paho.

5. P rtog.

6. D P R gźag.

7. Pelliot, 977 , folio 1a.2-5 de la don ni gan | tshig ḥbru ni gan źe na | de la don ces bya ba ni hjig rten las hadas pahi don so sor chud paho || tshig ḥbru źes bya ba ni gan hjig rten gyi chos gyi bya ba la gźug paho | don ces bya ba ni dul ba dan żi gnas dan | gsar rñin myed par śes paho || tshig ḥbru źes bya ba ni sbyin ba dań đnul ba dan myi gyel ba dan | sin tu dgah ba bśad paḥo || gźan yan tshig ḥbru źes bya ba ni ḥkhor baḥi rgyus rab tu bgrags paho | don ces bya ba ni myi dmyigs pa la ltas paho \| tshig hbru źes bya ba ni mya nan las hadas pahi yon tan bsnags pa yon்s su bsgrags paho || don ces bya ba ni ran bźin gyis mya nan las hadas pahi chos la mams la rtog pa myed pahọo || gźan yan tshig ḥbru źes bya ba ni ci ltar theg pa mam par gźag pa bsad paho || don ces bya ba ni tshul gcig gyi chos so sor chud bar śes paho \| gźan yan tshig ḥbru źes bya ba ni sems can thams cad yons su myi gtañ bar bśad paho | don ces bya ba ni khor sum yoñs su dag paho $\|$.

8. $P$ dan. 
len (pa) mi gton ba la ${ }^{1}$ gnas pahi brtson ḥgrus so \| tshig ḥbru źes bya ba ni bsam gtan dañ | rnam par thar pa dan | tin ṅe ḥdzin dan் | sñoms par ḥjug pa ${ }^{2}$ bstan paho || don źes bya ba ni ḥgog pahi sñoms par hijug $\mathrm{pa}^{3}$ (633) ses paḥo $\|^{4}$

tshig ḥbru źes bya ba ni thos pa thams cad ḥdzin pa śes rab kyi rtsa baho ${ }^{5} \|$ don źes bya ba ni brjod du med pahi don to \| tshig ḩbru źes bya ba ni gan byan chub kyi phyogs kyi chos ${ }^{6}$ sum cu rtsa bdun gyi chos mams rab tu bstan paho \| don źes bya ba ni gan̉ byañ chub kyi phyogs kyi chos gsum bcu rtsa bdun gyi chos rnams nan tan du byed pahi ḥbras bu mnon sum du byed paḥo || tshig ḥbru źes bya ba ni sdug bsnal ${ }^{7}$ dan | kun ḥbyun ba dan | lam rab tu bstan paḥo || don źes bya ba ni ḥgog pa mñon sum du byed paḥo || tshig ḥbru źes bya ba ni ma rig pa la sogs ${ }^{8}$ te | rga śịi bar du bstan paho $\|$ don źes bya ba ni ma rig pa ḥgog pa nas | rga śịi bar du ḥgog paḥo \|l tshig ḥbru źes bya ba ni źi gnas dan lhag mthon gi tshogs bstan paho $\|$ don źes bya ba ni rig pa dañ rnam par grol ba śes paho $\|^{9}$

tshig ḥbru źes bya ba ni gań ḥdod chags dañ | źe sdań dań | gti mug dañ | cha mñam par spyod pa rnams la chos bstan paḥo \| don źes bya ba ni sems kyi rnam par grol ba mi ḥkhrugs paḥo || tshig ḥbru źes bya ba ni sgrib par byed paḥi chos thams cad rab tu bstan paho \| don źes bya ba ni sgrib pa med pạ̣i ye śes rnam par thar paho \| tshig ḥbru źes bya ba ni dkon mchog gsum gyi yon tan bsñags pa mthah med pa yan dag par rab tu bstan paho \| don źes bya ba ni gan chos ḥdod chags (634) med pa dan | ḥdus ma byas pahi dge hadun gyi yon tan bsgrub paho ${ }^{10} \|^{11}$

1. N om: la.

2. P bźag pa.

3. P bźag pa.

4. Pelliot, 977 , folio 1a.5-1b.1

tshig hbru ni lus dan nag yid kyi sdom ba ste | bslab pa dan sbyanis pahi yon tan thams cad gzun ba bśad paho \| don ces bya ba ni lus dan nag yid mthon bar ḥdu byed pa yin bar yons su dag paho \|l gźan yan tshig ḥbru źes bya ba ni gnod sems kyi dri ma (...) khon khro ba dan rgyags pa dań / dregs pa kun bcos śin bzod pa la śin tu dgah ba bśad paḥo || don ces bya ba ni myi skye bahi chos la bzod pa so sor rñed paho \| gźan yan tshig habru źes bya ba ni dge bahị rtsa ba thams cad la brtson hgrus bsad paho \|l don ces bya ba ni rnam par myi rtog cin rtog pa myed de | myi gnas pahi brtson higrus so \|.

5. P rtsa ba śes rab tu ḥgyur baho, for D N R śes rab kyi rtsa baho.

6. P om: kyi chos (also in the next occurence of the phrase 'phyogs kyi chos').

7. N sdug bsnal pa.

8. P las stsogs.

9. Pelliot, 977 , folio $1 \mathrm{~b} .1-1 \mathrm{~b} .3$

gźan yan tshig ḥbru źes bya ba ni thos pa thams cad hdzin pa ses rab kyi rtsa baho \|l don ces bya ba ni brjod du myed pahi don to $\|$ gźan yan tshig habru źes bya ba ni byan cub kyi phyogs sum cu rtsa btun gyi chos rab tu skye baho \|l don ces bya ba ni gan byan chub kyi phyogs kyi chos mams kyi nan tan gyi hbras bu mnion du byed paho \| gźan yan tshig ḥbru źes bya ba ni sdug bsnal dan kun hbyun dan lam rab tu dbye baḥo || don ces bya ba ni hgog pa mnion tu byed paho \| gźan yan tshig ḥbru źes bya ba ni ma rig pa thog mar hgro bas na śi bahi bar duho kun bye paho \| don ces bya ba ni ma rig pa hgags pas rga sihi bar du hgag paho \| gźan yan tshig ḥbru źes bya ba ni źi gnas dan lhag mthon gyi tshogs bśad paḥo \|l don ces bya ba ni rig pa rnam par grol ba ses paholl.

10. D yon tan sgrub paho; $N R$ yon tan bsgrub paho; $P$ yon tan no. 
tshig ḥbru źes bya ba ni gan̉ byañ chub sems dpaḥi thog ma sems bskyed nas | byan chub kyi sñin pohi bar $\mathrm{du}^{1}$ bslab ${ }^{2}$ pa dan yon tan rtsom pa bstan paho \| don źes bya ba ni sems kyi skad cig gcig dan் ldan pas ${ }^{3}$ | thams cad mkhyen pahi ye śes mnon par rdzogs par byan chub paḩo || mdor na chos kyi phun po brgyad khri bźi stoń gi bar du bstan pa de ni tshig ḥbru źes byaḥo || sgra dan் | yi ge dan் | gań sgra dan yi ge thams cad kyis brjod du myed pa de ni don ces byaho ${ }^{4} \|^{5}$

de la dran̉ bahi don gyi mdo sde gan dag yin ${ }^{6}$ źe na / gan tshig ḥbru bśad pa ji ltar bstan pa bźin du rgya cher khon du chud par bya ste | hạdi dag ni drañ bahi don gyi mdo sde dag go ||

nes pahi don gyi mdo sde gan dag yin źe na | don gań bśad pa ji ltar bstan pa bźin du rgya cher khon du chud par bya ste | hidi dag ni nes pahi don gyi mdo sde dag go $\|^{8}$

de ji ltar na chos la rton gyi | gan zag la ma yin źe na | gan dran bahi don de ni gan zag gi don yin pas de la mi rton gyi | gan nes pahi don de ni chos ñid ji lta ba bźin pas de la rton pa ste | hadi dag ni byan chub sems dpahi rton pa bźi paho || de ltar na byan chub sems dpaḥ sems dpah chen po rton ${ }^{9}$ pa la mkhas pa śes rab kyi pha rol tu phyin pa la spyod do $\|^{10}$ bam po bcu brgyad $\mathrm{pa}^{11} \|$

de la byan chub sems dpạ̣ rnams kyi tshig ḥbru (635) la mkhas pa gan źe na $\mid$ ḥdi la byan

11. Pelliot, 977 , folio $1 \mathrm{~b} .3-1 \mathrm{~b} .5$

gźan yan tshig ḩbru źes bya ba ni hadod chags że sdañ gti mug cha mñam ba spyod pa la chos hichad paho \|l don ces bya ba ni hkhrug pa myed pahi rnam par grol baho || gźan yan tshig ḥbru źes bya ba ni bsgribs pa thams cad la chos hehad paho \| don ces bya ba ni bsgribs pa myed pahi ye śes rnam par thar paho \|l gźan yan tshig hbru źes bya ba ni dkon mchog gsum gyi yon tan kha dog rab tu phye baho $\|$ don ces bya ba ni hidod chags myed pahi chos ñid de $\|$ dge hạdun gyi yon tan hadus ma byas sgrub paho $\|$.

1. $\quad$ P kyi.

2. $\mathrm{N}$ bslabs.

3. P sems skad cig tu sbyor bas.

4. I follow here Pelliot, 1b.7; P sgra dań yi ge thams cad kyi habru ... \|, for D N R sgra dan | yi ge dan | tshig hbru thams cad ....

5. Pelliot, 977 , folio $1 \mathrm{~b} .5-7$

gźan yan tshig ḥbru źes bya ba ni gan byań chub sems dpạ̣ thog ma sems bskyed pa nas sñin po byan cub kyi bar du bslab pahi yon tan brtsam ba bśad paho $\|$ don ces bya ba ni sems skad cig ma gcig gyis sbyor ba thams cad mkhyen pahi ye ses mñon bar byan chub paho $\|$ mdor na ci tsam tu chos kyi phun po brgyad khri bźi ston bśad pa ni tshig ḥbru źes byaho / gan sgra dan yi ge thams cad kyis brjod du myed pa de ni don ces byaho $\|$.

6. D N R om: dag yin.

7. D N R om: dag yin.

8. Pelliot, 977, folio 1b.7-2a.1 de la dran baḥi don gyi mdo gan źe na gañ gsuńs pa hbyed pa ji ltar bśad pa bźin rgyas par chud par bya ba ste | de ni drań bahii don gyi mdoḥo źes byaḥo || de la nes pahi don gyi mó gan źe na | gañ gsuñs pa gañ ji Itar don bśad pa bźin du rgyas par šes par byaho \| de ni ñes pahi don gyi mdo źes byaho \|.

9. D ston.

10. Pelliot, 977 , folio 2a.1-2a.2

de la ji ltar na chos la rton gyi gan zag la ma yin (...) źe na | gań dran bahi don pa de gan zag gyi don te | de las habyun ba ma yin no | gañ nes pahi don de chos ñid ji lta ba bźin te des hạbyun no $\|$.

11. D P om: 'bam po bcu brgyad pa'. 
chub sems dpah ${ }^{1}$ chos gñis la mkhas pa ses rab kyi pha rol tu phyin pa la spyod do $\|$ chos gñis gań źe na | hạdi lta ste | rnam par śes pa la mkhas pa dań | ye śes la mkhas pa yin no $\|^{2}$

\subsection{2}

de la rnam par ses pa gan | ye ses gañ źe na | mam par śes pa źes bya ba ni | hִdi lta ste | rnam par ses paḥi gnas pa bźiḥo ${ }^{3}$ || bźi gań źe na | gzugs la źugs ${ }^{4}$ pahi rnam par śes pa yońs su gnas śin gnas pa dan | tshor ba la źugs pa dan | ḥdu śes la źugs pa dan் | ḥdu byed la źugs pahi mam par śes pa yons su gnas śin gnas pa ste | de ni rnam par śes pa źes byaho $\|^{5}$

de la ye śes gań źe na | gañ len pahi phuñ po lna ${ }^{6}$ rnams la gnas pa | rnam par śes pahi phun po yońs su śes pa de ni ye śes źes byaho || gan̉ saḥi khams rnam par śes pa dan | chuhi khams dań | mehi khams dan் | rluñ gi khams rnam par śes pa de ni rnam par śes pa źes byaho |l gan̉ yań ye śes khams bźi la mi gnas pa | chos kyi dbyiǹs tha mi dad pa ses pa de ni ye śes źes byaho $\|^{7}$

gźan yań rnam par śes pa źes bya ba ni gań mig gi rnam par ses pas śes par bya baḥi gzugs rnams $^{8}$ ses pa dan | rna bahi mam par ses pas śes par bya bahi sgra mams dan | snahi rnam par śes pas śes par bya bahi dri mams dan் | ltsehi rnam par (636) ses pas śes par bya bahi ro rnams | lus kyi rnam par śes pas śes par bya baḥi reg rnams dan / yid kyi rnam par śes pas śes par bya bahi chos rnams ses pa de ni mam par śes pa źes byaho \| gañ yań nań gi skye mched rnams la ñe bar źi źin | phyi rol gyi skye mched rnams la rgyu ba med pa ye śes la rton pas ${ }^{9}$ | gań yaǹ chos gźog par mi byed pa de ni ye śes źes byaḥo $\|^{10}$

1. D dpahi.

2. This paragraph is missing in the Pelliot manuscript.

3. P bzi dag ste.

4. P su son, for D N R la źugs (also in the following three occurrences of the phrase 'la źugs').

5. Pelliot, 977 , folio 2a.1-2a.3

de la ji ltar na ye śes la rton gyi rnam par śes pa la ma yin źe na | de la rnam par śes pa źes bya ba ni rnam par śes pa gnas pa bźi ste | bźi gañ źe na | gzugs la ñe bar son bahi mam par śes pa kun tu gnas pas gnas so || de bźin du tshor ba dan | hadu ses dan | hadu byed la son bahi mam par śes pa kun tu gnas pas gnas te | de ni rnam par śes pa źes byaho $\|$.

6. Akn bźi.

7. Pelliot, 977, folio 2a.3-2a.5 de la ye śes gań źe na | gan len pahi lna phun la myi gnas sin ye śes kyi phun po yons su śes pa de ni ye ses ses byaho || gan sahi khams rnam par rig pa dań | de bźin du chu dan mye dañ rlun gi khams rnam par rig pa de ni mam par śes pa źes byaho $\|$ gañ khams bźi la myi gnas pahi ye ses chos kyi dbyiñs ma bye bar śes pa de ni ye ses źes byahọo $\|$.

8. D P add: la.

9. P mi rgyul ye śes la hjug pahi phyir, for D N R rgyu ba med pa ye ses la rton pas.

10. Pelliot, 977 , folio $2 a .5-2 a .6$

gźan yaǹ mam par śes pa źes bya ba ni myig gis (...) rnam par ses pahi gzugs rnam par chud pa nas yid kyi mam par rig pahi chos mams chud pahi bar de ni rnam par śes pa źes byaho \|l gan nan gyi ḥdu mched źi źin phyihi hadu mched la rab tu myi spyod de / ye ses la so sor ḥbyun bahi phyir chos gan la yan myi hjog pa de ni ye śes źes byaho $\|$. 
gźan yan rnam par śes pa źes bya ba ni dmigs pa las rnam par śes pa skye ba dan | yoǹs su rtog' pa las mam par śes pa skye ba ste | de ni rnam par śes pa źes byaho || gan yaǹ mi hadzin pa | mi sñems pa $\mid$ mi dmigs pa | rnam par mi rig pa | mi ḥkhrugs pa de ni ye śes źes byaho || gźan yan hadus byas la spyod pahi chos rnams la rnam par śes pa ${ }^{2}$ gnas kyi | ḥdus ma byas la mam par śes pa rgyu ba med de | gañ yan̉ ḥdus ma byas ses pa de ni ye śes so ||

gźan yan skye ba dan hjig pa la gnas pa ni rnam par śes paho \| gań yañ ${ }^{3}$ mi skye (ba) ${ }^{4} \mathrm{mi}$ hgag (ba) mi gnas pa de ni ye ses źes byaho $\|^{5}$

\section{6 .3}

de la nes pahi don gyi mdo sde gañ | dran bahi don gyi mdo sde gan źe na / mdo sde gan dag lam la hjug par byed pa de dag ni dran baḥi don źes byaho $\|$ mdo sde gan dag ḥbras bu la hjug par byed pa de dag ni nes pahi don źes byaḥo \| mdo sde gañ dag kun rdzob sgrub par byed pa de dag ni dran̉ bahi don źes byaho $\|$ mdo sde gan dag don dam par bstan ${ }^{6}$ pa de dag ni nes paḥi don źes byahọo $\|^{7}$

gźan yań mdo sde gañ dag las kyi ${ }^{8}$ bya ba (637) la hjug pa de dag ni drań baḥi don źes byaho \| mdo sde gañ dag las dañ ñon mońs pa zad par bstan pa de dag ni nes pahi don źes byaho $\|^{9}$

gźan yan̉ mdo sde gan̉ dag kun nas ñon mońs pa yoǹs su bśad pahi phyir bstan pa de dag ni dran bahị don to $\|$ mdo sde gan dag rnam par byan ba rnam par dag pahi phyir bstan pa de dag ni nes pahi don to $\|$ mdo sde gan dag ḥkhor bas skyo bar byed pa de dag ni drañ bahi don to $\|$ mdo sde gan dag ḥkhor ba dan mya nan las ḥdas pa gñis su mi hijug pa de dag ni nes pahi

1. N rtogs.

2. N add: la.

3. R N om: yan.

4. cf. Pelliot, 977, folio 2b.1 and Akn (p. 64.3.5).

5. Pelliot, 977 , folio 2a.6-2b.1

gźan yan rnam par śes pa źes bya ba ni dmyigs pa las rnam par śes pa skyes pa dan | yoñs su rtog pa las rnam par śes pa skyes pa de ni rnam par śes pa źes byaho || gan myi hadzin | myi bsñems | myi dmyigs | rnam par chud pa myed cin myi skur de ni ye ses źes byaho \|l gźan yan hadus byas kyi spyod pahi chos la rnam par śes pa hjug go \|t hdus ma byas la mam pa śes pa spyod pa myed do \|l gan hadus ma byas śes pa de ni ye śes so || gźan yan skye ba dan | hgyur ba la so sor gnas pa rnam par śes paho || gań ma skyes myi hgog pa | so sor myi gnas pa de ye ses źes byaho ||.

6. P ston (also in the following six occurrences of the term 'bstan').

7. Pelliot, 977 , folio $2 b .1-3$

de la nes pahi don gyi mdo sde ni gan / drań bahi don gyi mdo sde gañ źe na / móo sde gań gis lam la gjud pa de ni bkri bahi don ces byaho \| mdo gan gis dag habras bu gjud pa de ni nes pahi don ces byaḥo \| gźan yañ mao sde gan gis kun rdzob bśad pa de ni dran bahi don ces byaho $\|$ mdo sde gań las (...) don dam pa bśad pa de ni nes pahi don ces byaho $\|$.

8. Akn (p. 64.3.7) dan.

9. Pelliot, 977, folio $2 \mathrm{~b} .3-3$ gźan yan mdo sde gañ gis bya ba la gjud pa de ni dran bahi don ces byaḥo || gan gis las dan ñon moñs pa zad pahi phyir bśad pa de ni nes pahi don ces byaho \|. 
don to $\|$ mdo sde gan dag yi ge dan tshig sna tshogs su bstan pa de dag ni dran bahi don to $\|$ mdo sde gañ dag zab pa | blta dkaḥ ba / rtogs par dkah ba de dag ni nes pahi don to || mdo sde gan̉ dag tshig ḥbru mań ba ${ }^{1}$ sems can rnams kyi sems rańs ${ }^{2}$ par byed pa de dag ni dran̉ bahi don to $\|$ mdo sde gan dag tshig dan tshig ḥbru ñun la nes par rtogs $\operatorname{par}^{3}$ byed pa de dag ni nes pahi don to $\|^{4}$

gźan yan̉ mdo sde gan dag bdag dan | sems can dań | srog dan் | skyes bu dan் | gań zag dan் | śed bu dañ | sed las skyes dan | byed pa po dan | tshor ba pohi sgra sna tshogs bdag po med pa bdag po yod pa bźin du bstan pa de dag ni drañ bahi don to || mdo sde gañ dag ston pa ñid dań | mtshan ma med pa dan் | smon pa med pa dan் | mi ḥbyun ba dań | ma skyes ba dan | yan் dag par mi ḩbyun ba dan் | sems can med pa dan் | gań zag med pa dan் | dus gsum (638) las rnam par thar pahi sgo bstan pa de dag ni nes pahi don to $\|^{6}$

\section{6 .4}

de la chos gan | gañ zag gan źe na | gañ gañ zag tu lta ba la gnas te | $\operatorname{chos}^{8}$ la rtsom pa de ni gañ zag ces byaḥo \| gan gań zag tu lta ba rtsom pa dehi chos gnas pa chos kyi dbyiǹs de ni chos źes byahọo $\|^{10}$

gźan yaǹ gań zag ni so sohi skye bohi gañ zag dañ | so sohi skye bo dge bahi gañ zag dan | dad pahi rjes su ḥbran bahii ${ }^{11}$ gań zag dań | chos kyi rjes su ḥbran baḥi gañ zag dan | brgyad

1. Akn (p. 64.4.3) add: żin.

2. P rins.

3. P sems rtog par; $R$ nes par rtog par.

4. Pelliot, 977 , folio $2 \mathrm{~b} .3-6$

gźan yań mdo sde gan gis ñon mons pa yoǹs su bsal bahi phyir bśad pa de ni dran bahi don ces byaho gan gis las byan ba rnam par dag pa bsad pa de ni nes pahi don ces byaho || mdo sde gan gis ḥkhor ba la skyo bar byed pa de ni dran bahi don ces byaho \| gan gis ḥkhor ba dan mya nan las has pa gñis su myed par gjud pa de ni nes pahi don ces byaho $\|$ gźan yañ mdo sde gań las mam par bkra bahi tshigs dan hubyed ba bśad pa de ni dran baḥi don ces byaḥo || gan las zab mo blta dkaḥ ba chud dkaḥ ba bśad pa de ni nes pahi don ces byaho \| gźan yan mdo sde gan las hbyed pa mañ po sems can rnams kyi sems tshim bar byed pa de ni dran bahi don ces byaho $\|$ gan las tshig (...) dan habyed pa ñun ba la sems la rtog pa myed pa de ni nes pahi don ces byaho $\|$.

5. N źes byaho.

6. Pelliot, 977 , folio $2 \mathrm{~b} .6-3 \mathrm{a} .1$

gźan yan gan las bdag dan sems can dan | ḥtsho ba dan | gañ zag las btsogs (conjectural reading) pa bśad pa de ni dran bahi don ces byaho || gan las ston pa dan mtshan ma myed pa dan | smon pa myed pa dan | ma skyes pa dań | sgra myed pa dan | ma byun ba dan | sems can myed pa dan | gañ zag myed pa dan | dus gsum las rnam par thar pahi sgo de ni nes pahi don ces byaho $\|$.

7. N om: gan.

8. D N R add: kha cig.

9. $\mathrm{N}$ gnas pahi dbyiñs de ni chos śes paho, for D P R gnas pa chos kyi dbyiñs de ni chos źes byaho.

10. Pelliot, 977 , folio 3a.1-1 de la chos ni gañ | gan zag ni gań źe na | gan gañ zag tu lta ba la gnas te | gañ chos la brtsom ba de ni gan zag ces byaho || gañ zag tu lta ba rtsom ba deḥi chos (la) gnas pa dañ | chos kyi dbyiñs de ni chos śes byaho $\|$.

11. P hjug pahi (also in the next clause). 
paḥi gan̉ zag dan | rgyun du źugs pahi gan̉ zag dan | lan cig phyir ḥon bahi gań zag dañ | phyir mi ḥon bahi gań zag dan | dgra bcom pahi gan̉ zag dan் | ran sańs rgyas kyi gan̉ zag dan் | byañ chub sems dpahi gań zag dan் | skye bo man po la phan pa dań | skye bo mań po la bde ba dan | hjig rten la thugs ${ }^{1}$ brtse ba dan | lha dan mihi skye bo phal po chehi don dañ | phan pa dan | bde baḥi phyir gañ zag gcig hjig rten du skye źin ḥbyun bar ${ }^{2}$ ḥgyur ba | ḥdi lta ste | de bźin gśegs pa dgra bcom pa yan dag par rdzogs pahi sañs rgyas te / gañ zag gi sgra de thams cad de bźin gśegs pas kun rdzob kyi gnas kyis sems can mams gzud ${ }^{3}$ pahi phyir bstan paho \| de la gań mñon par chags pa de dag ni rton pa ma yin pa ${ }^{4}$ źes byaho $\|$ de dag rtog ${ }^{5}$ pa la dgod pahi phyir chos ñid la rton par byahi gañ zag la ma yin no || źes | (639) bcom ldan hạdas kyis gsuns te $\left.\right|^{6}$

de la chos ñid gań źe na $\mid$ ḥdi lta ste $\mid$ mi ḥgyur ba $\mid$ sgro ma btags pa $\mid$ mi byed pa $\mid$ rnam par mi byed pa $\mid$ mi gnas pa $\mid$ gnas med $\mathrm{pa}^{7} \mid$ rtsa ba med pa | thams cad du mñam pa | mñam pa la mñam pa $\mid$ mi mñam pa la mñam pa $\mid$ mñam pa dań mi mñam pa la mñam pa $\mid$ rnam par mi rtog pa $\mid$ mi rtsom pa $\mid$ nes par hgyur ba $^{8} \mid$ thob pa $\mid$ chos thams cad la sin tu no bo nid med pahi mtshan ñid de ni chos ñid ces bya ste / gañ dag chos ñid la rton par byed pa de dag $^{10}$ ni khams gan lahan rton par mi byed do $\|$ de bas na chos kyi tshul gyi sgo la hjug pa hadis chos thams cad la rton pahi phyir chos thams cad de lta buhi chos ñid yin no ${ }^{11} \|^{12}$

1. P om: thugs.

2. D N skye ba(r) habyun bar.

3. P gźag.

4. Nom: pa.

5. N rton.

6. Pelliot, 977, folio 3a.1-3a.4

gźan yan gañ zag ni ma rabs so || gań zag ni ma rabs dge baḥo || dad pas rjes su ḥbran bahọo || chos kyi rjes su habran baho || gan zag ni brgyad paho || rgyun tu źugs paḥo || lan cig phyir hạon bahọo || phyir myi họ baho || sgra bcom baho || ran sans rgyas so || byan chub sems dpaho || higro ba mań po la phan bahi phyir bde bahi phyir | hjig rten las brtse baḥi phyir| lha dan myi dan hgro bahi hadus pa chen po la phan ba dan bde bahi phyir gan zag gcig hjig rten du skye bas skyeho / de ni de bźin gśegs pa dgra bcom ba yan dag par rdzogs pahi sañs rgyas so | gan zag gi sgra de thams cad ni de bźin gśegs pas kun rdzob kyi rims kyis sems can gzuñ bahi don tu bśad paho || de la mñon bar chags pa de ni so sor myi habyun ba źes byaho || so sor rton pa de dag la gźag pahi phyir bcom ldan hadas kyis gsuns pa | chos ñid la so sor rton par kyahi (conjectural reading) gan zag la ma yin no $\|$.

7. P mi hdug pa.

8. D P R nes par gyur pa.

9. N add: de.

10. $\mathrm{N}$ om: dag.

11. P de lta ba dan hadra bar hgyur te, for D N R de lta buhi chos ñid yin no.

12. Pelliot, 977 , folio $3 a .4-7$

de la chos ñid gan źe na | de ni hgyur ba myed pa bskyed pa dań | rnam par myi bya ba dań | myi gnas pa dan | so sor myi gnas pahi rtsa baho || thams cad tu mñam ba dan | myi mñam ba dan mñam ba | mam par rtog pa myed pa | rtsom ba myed pa | myi hgyur ba thob pa | chos thams cad sin tu no bo ñid myed pahi mtshan fid ste | de ni chos ñid ces byaho || gan chos de la so sor rton pa ni chos gań gi phyir yan myi hbyun no || de bas na dehi chos kyi sgor hjug pas chos thams cad la rton pa nas bzun ste | chos thams cad de ltar buhi no bo ñid yin no \|z źes gsuńs so \|. 
de dag ni byan chub sems dpạ̣ rnams kyi rton pa bźi (dag) źes bya ste | de ni byan chub sems dpahi rton pa la mkhas pa źes byaḥo \| de ltar na byan chub sems dpạ̣ rton pa la mkhas pa ses rab kyi pha rol tu phyin pa la spyod do $\|^{1}$

\section{7}

de la byan chub sems dpahi tshogs la mkhas pa gań źa na | byan chub sems dpah rnams kyi tshogs ni ḥdi gñis te | gñis gan źe na | ḥdi lta ste | bsod nams kyi tshogs dan | ye śes kyi tshogs so $\|^{2}$

\subsection{1}

de la bsod nams kyi tshogs gan źe na / sbyin pa las byun baḥi bsod nams ${ }^{3}$ bya bahi dnos po dań | tshul khrims las byun bahi bsod nams bya baḥi dños po dań / sgom pa las byun bahi bsod (640) nams bya bahi dnos po dan் / byams pahi sems la sñoms par hyjug pa dañ / sñin rjehi sbyor ba dan | dge bahi rtsa ba thams cad la brtson ${ }^{4}$ pa dan | bdag dan pha rol gyi sdig pa ḩchags pa dan் | dus gsum du gtogs pahi sems can thams cad dan | slob pa thams cad ${ }^{5}$ dan | mi slob pa thams cad dan | ran sans rgyas thams cad dan / sems dan po ${ }^{6}$ bskyed pa rnams dan | spyod pa la źugs pa thams cad dan் | phyir mi ldog pa mams dan | skye ba ${ }^{7}$ gcig gis thogs pahi byan chub sems dpah rnams kyi sems bskyed pa la rjes su yi ran ba dan / hadas pa dan் | ma byon pa dan | da ltar byun bahi sańs rgyas bcom ldan ḥdas mams kyi dge bahi rtsa $\mathrm{ba}^{8}$ thams cad kyi rjes su yi ran ba dan ldan pạ̣i bsod nams bya bahi dnos po dan / sańs rgyas thams cad dan் / hphags pa thams cad la $\operatorname{chos}^{9}$ gsol ba hdebs $\mathrm{pa}^{10}$ dan ldan pahi bsod nams bya bahi dnos po dan $\mid$ dge ba thams cad byañ chub tu bsno ba dañ ldan pahi bsod nams bya bahi dnos po dan $\left.\right|^{11}$

1. The last paragraph is missing in the Pelliot manuscript.

2. Pelliot, folio 3a.7-7

de la byań chub sems dpahi tshogs la mkhas pa gan źe na | byan chub sems dpahi tshogs ni rnam pa gñis te | de ni bsod nams dan | ye ses kyi tshogs so ||.

3. P sbyin pahi bsod nams (also in all following instances of the same context).

4. N rtsom.

5. N thin.

6. P thog mar.

7. P tshe.

8. D N P 'dge ba' only.

9. $\mathrm{N}$ add: ston par.

10. P om: hdebs pa.

11. Pelliot, folio $3 \mathrm{~b} \cdot 1-4$ de la bsod nam gyi tshogs gan źe na | sbyin ba las bsod nams byahi dnos po dan $\mid$ de bźin du tshul khrims dan | bsgom na las bsod nams bya bahi dnos po dań | byams pahi sems sñoms par sgrub pa | sñin rjehi sbyor ba dan | dge bahi thams cad kyi rtsa ba rtsom ba | bdag dan pha rol gyi sdig hchags pa | dus gsum gyis bsdus pa | sems can thams cad dan | bslob pa dan | myi slob pa thams cad dan | ran sañs rgyas thams 
sems can byan chub tu sems ma bskyed pa rnams byan chub tu sems skyed pa dan / byan chub tu sems bskyed pa $^{1}$ rnams la pha rol tu phyin pahi lam ston pa dan | dbul po rnams la lons spyod kyis sdud pa dan | nad pa rnams la sman² sbyin pa dan | gus par bsñen bkur byed

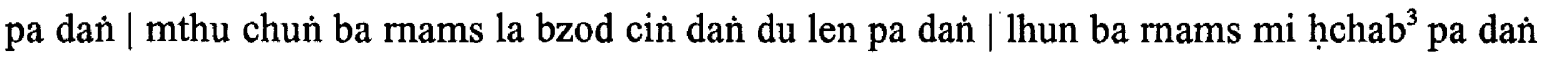
| sdig pa ḥchags pa dan | sañs (641) rgyas bcom ldan ḥdas rnams ${ }^{4}$ bźugs pa dan yońs su mya naan las ḥdas pa rnams la bsñen bkur dan ri mo thams cad byed pa dan | slob dpon dan mkhan po rnams la ston pa bźin du ri mo byed pa dan | chos la rin po che rin than med pa bźin du yons su tshol bahi brtson hgrus dan | chos smra ba la dgaḥ źin dpag tshad brgyar yan soń ste | chos ñan pas chog mi śes pa dan | zañ ziñ med par chos ḥchad pa dan | pha dan ma la rim gro ${ }^{6}$ byed pa dan | byas pa gzo ba dan | byas pa ses pa dan | hgyod pa med pa dan | bsod nams (bya baḥi dnos po) bsags pas chog mi śes pa dan் $\left.\right|^{7}$

lus bsdams pahi lus $1 a^{8}$ tshul ḥchos pa med pa dan் $\mid$ nag bsdams pahi nag la tshul ḥchos pa med pa dan் | yid bsdams pahi yid la tshul ḥchos pa med pa dan | de bźin gśegs pahi mchod rten btsugs paḥi phyir tshañs paḥi bsod nams yońs su ḥdzin pa dan | mchod sbyin gtan pa med pa bsags ${ }^{9}$ pas mtshan ñid ${ }^{10}$ yońs su rdzogs pa dan | dge bahi rtsa bahi tshogs sna tshogs bsags pas dpe byad bzań po yońs su rdzogs pa dan | ńa rgyal med pas lus brgyan pa dan | nag gi ñes pa thams cad spańs pas nag brgyan pa dan | blo thogs pa med pas sems brgyan pa dan $\left.\right|^{11}$

cad dan | thog ma sems bskyed pa rnams dan | spyad pa rdzogs pa mams dan | phyir myi ldog pa rnams dan | skye ba gcig gis thogs pahi byan chub sems dpah mams kyi sems bskyed pahi rjes su yi ran no || hadas pa dan | ma hons pa dan / da ltar gyi sañs rgyas bcom ldan has mams kyi dge ba thams cad kyi rjes su yi ran ba dan | Itan gcig son bahi bsod nams byahi dnos poho || sans rgyas thams cad dan | haphags pahi thams cad la chos gsol ba dan Itan gcig son bahi bsod nams byahi dnos poho $\|$ dge ba thams cad byan chub tu brjod pa dañ ltan cig son bahi bsod nams bya bahi dnos poho $\|$.

1. N om: dan / byan chub tu sems bskyed pa.

2. N add: gyi.

3. P ḥchags.

4. P R om: rnams.

5. P gus pa (also in the following two instances of the term 'ri mo').

6. P bsinen bkur.

7. Pelliot, 977 , folio $3 \mathrm{~b} .5-4 \mathrm{a} .1$

byan chub tu sems bskyed pa rnams byan cub sems dpah rnams kyis sems bskyed paho $\|$ byan chub tu sems bskyed pahi rnams la pha rol tu phyin pahi lam ston paho \| dbul po mams lons spyod kyis bsus paho || na ba rnams la sman rab tu byin te rim hgro dan bkur sti byed paho $\|$ mthu chun ba rnams la bzod chin źi baho | ltun ba so sor g.yogs baho || sdig bśegs paho | sañs rgyas bcom ldan hidas bźugs pa dan | mya nan las hdas pa thams cad la ri mo bkur sti byed paho || slob dpon dan mkhan po la ston par ri mo byed paho | chos la rin than myed pahi rin po che tshol baḥi brtson hygrus so $\|$ chos ḥchad pa la dgah ste dpag tshad brgyar kyan mñan pas myi ñoms pa | ma hdres pahi chos hchad pa | pha ma la rim hgro byed pa | byas pa śes pa | byas pa dran ba $\mid$ byas pa tshor ba $\mid$ hgyod pa myed pa | bsod nams bstsags pas myi noms pa $\mid$.

8. D N R lus bsdams sin.

9. $\mathrm{N}$ bstsags (also in the next occurence of the term 'bsags').

10. D N R mtshan.

11. Pelliot, 977 , folio $4 a .1-3$ lus bsdams pas sgyu myed pa | nag bsdams pas nag la sgyu myed pa | yid bsdams pas yid la sgyu myed pa | 
mnon par ses pa sprul pas sańs rgyas kyi źin gi $\operatorname{rgyan}^{1}$ dan $/$ ye śes yons su dag pas chos kyi mtshan ñid kyi rgyan dan் | phra ma dan | źe gcod pa dan் | dbye baḥi tshig yońs su spańs pas (642) ḥkhor man poḥi rgyan dan | chos ḥdzin pas ḥdod chags med pahi chos kyi ${ }^{3}$ rgyan dan | rab tu dgah nas legs so źes ${ }^{4}$ bya ba byin pas chos kyi gtam mi hijigs par byed pa dan | sgrib pa dań sgrib par byed $\mathrm{pa}^{5}$ rnam par spańs śin gus par chos ñan pas ḩbras bu yod par chos hichad pa dan / sańs rgyas rnams la dkah thub kyi nags tshal phul bas byan chub kyi sin gi rgyan dan் / dge baḥi rtsa ba thams cad snon du ḥgro źin byan chub kyi sems mi gton bas byaǹ chub kyi sñin poḥi rgyan dań $\left.\right|^{6}$

las dañ ñon mons pa mi dmigs pas tshe dan si ḥpho yoǹs su dag pa dan் | rin po che phańs pahi dnos po thams cad yons su gton bas rin po chehi lag $\mathrm{pa}^{7}$ dan $\mid \mathrm{mi}$ zad pahi smon lam thob pas lons spyod mi zad pa dan | khro gñer med pas mthon ma thag tu sems can rnams dad cin bźin ḥdzum pas gson por smra ba dan் | sems can thams cad la ḥod zer sñoms pas ${ }^{8}$ mñam pa ñid kyi rgyan thob pa dan | ma lobs pa la mi brñas pas ${ }^{9}$ hod mań po gton ba ${ }^{10}$ dan $\mid$ tshul khrims kyi bsod nams bsags pas skye ba yońs su dag pa dan் | ltun ba la mi rtsod pas mnal yoǹs su dag pa dañ $\left.\right|^{11}$

dge ba bcuhi las yoǹs su dag pas lha dan mir skye ba dan $\mid$ rjes su bstan pa ${ }^{12}$ thams cad la

de bźin gśegs pahi mchod rten so sor gźag pahi phyir tshans pahi bsod nams yon s (...) | mtshan yons su rdzogs pa $\mid$ phanis pa myed pas sdud pa bskyed pa | dpe byad bzan po yońs su rdzogs pa $\mid$ mam par bkra bahi dge bahi ttsi ba tshogs ba bstags pas sprul pas lus brgyan pa | nag gyi nes pa thams cad mam par spans pas nag brgyan pa / thogs pa myed pahi blos sems brgyan pa |.

1. Akn (p. 65.2.8-3.3) gives 'rgyan du hgyur ba dan' in this and in the following five instances of the phrase 'rgyan dan'.

2. N kyis.

3. N kyis.

4. P R om: źes.

5. D N R chod pa.

6. Pelliot, 977 , folio 4a.3-5

mnion bar šes pas rnam par sprul pahi phyir sañs rgyas kyi źin brgyan pa | ye ses yońs su dag pas chos kyi mtshan brgyan pa | phra ma dan gla ma źid (conjectural reading) dbye bahị tshig yons su spañs pas hkhor gyi lus brgyan pa | chos hdzin pas hadod chags myed pahi chos kyis rab tu brgyan to | rab tu dge ba dge bar sbyin nas chos kyi gtam myi hjigs pa | sgrib pa dan bsgribs pa mam par spañs pahi phyir bkur sti byas te | chos nan pas hbras bu yod pahi chos hechad paho \| sans rgyas rnams la dkah thub kyi nags tshal phul bas byan chub kyi sin gis brgyan to $\|$ dge ba thams cad thogs par hgro bas byan chub kyi sems myi gton bahi phyir byan chub kyi snim po brgyan to $\|$.

7. DN R lag na rin po che.

8. $\mathrm{N}$ pa.

9. P zil gyis mi gnon pas, for D N R mi brñas pas.

10. D mthon ba.

11. Pelliot, 977 , folio $4 a .5-7$

las dan ñon mons par myi dmyigs pas tshe dan śi hphos yońs su dag paho | rin po che bzañ pohi dnos po thams cad yons su btan bas rin po chehi lag paho | myi zad pahi smon lam thob pahi phyir lons spyod myi zad paho || bźin ba ḥdzum źin gsoñ por smra ste khro gñer myed pahi phyir mthon ma thag tu sems can rnams dad paho | sems can thams cad la ḥod sñoms pahi phyir sñoms pa ñid so sor thob paho || ma lobs pa la phyis brtsan bas hod kyis rgyan gton baho || tshul khrims kyi bsod nams bstsags pas skye ba yons su dag paho || lun bstan pahi phyir mnaha yońs su dag pahọo |.

12. P bstan par bya ba, for D N R rjes su bstan pa. 
rab tu rtog pas gdon mi za bar gnon pa dan | chos la slob dpon gyi dpe mkhyud med pas chos kyi dbań phyug dañ ${ }^{1}$ | lhag pahi bsam pa yons su dag pas hjig rten thams cad la mnon sum pa dan | ñi tshe bahi spyod pa mi (643) hdod pas rgya chen pohi chos la dad pa dan | thams cad mkhyen paḥi sems mi ḥdor bas bsod nams thams cad yon்s su ḥdzin pa dan் | dad pa snon du ḩgro bas nor bdun yoǹs su rdzogs pa dan | snon dam bcas pa ñams su len par byed pas ${ }^{2}$ hjig rten thams cad mi slu ba dan | dge bahi chos yoǹs su rdzogs pas sańs rgyas kyi chos thams cad yońs su rdzogs pa ste | de ni byan chub sems dpahi bsod nams kyi tshogs la mkhas pa źes byahọo $\|^{3}$

\subsection{2}

de la byan chub sems dpahi ye ses kyi tshogs la mkhas pa gan źe na | rgyu gan gis ye śes skye ba ste | de ltar rgyu dan rkyen $^{4}$ gan gis ye ses rtogs paho ||

de la rgyu gań | rkyen gan źe na | chos tshol ba la rab tu ḥdun pa dan | ye śes kyi rjes su son bahi bśes gñen bsten pa dan | sańs rgyas kyi ye ses la rton gyi | ñan thos dañ ran saǹs rgyas kyi ye śes la mi rton pa dań | de dag la na rgyal mi byed pa | bla ma la dgah ba dañ | ston pa la dgah ba dan | deḥi dge baḥi bśes gñen de dag gis ḥdi ni bsam pa dañ ldan bar śes nas | ye śes kyi gtam gañ yań mi ston pa med pa dan / snod du ses nas bar chad med par sems rtse gcig tu chos ston pa dan் | des chos de thos nas chos kyi tshogs la brtson par $^{5}$ byed de / gan chos kyi tshogs la brtson par byed pa de ñid dehi ye śes kyi tshogs la brtson pa yin no $\|^{6}$

de la chos kyi tshogs la brtson (644) pa gań źe na | ḥdi lta ste | don ñun ba dan | bya ba ñun

1. P chos la slob dpon gyis mi hachab pas chos la dban phyug dan, for D N R chos la slob dpon gyi dpe mkhyud med pas chos kyi dban phyug dan.

2. D N ñams su lon par byed pas; $P$ sgrol bas.

3. Pelliot, 977 , folio $4 \mathrm{a} .7-4 \mathrm{~b} .3$

dge ba bcuhi las yons su dag pas tha dan myir skyeho \| bstan pa thams cad la yid ches pas bsgrims pa gdon myi za baho || chos la mkhan po myi ḥchab pas chos la dban paho | lhag pahi bsam pa yon's su dag pas hjig rten thams cad kyi bla yin no | thi tse pahi spyod lam mos pas rgya chen pahi chos la dad paho || thams cad mkhyen pahi sems myi hador bas bsod nams thams cad yoñs su hạzin paho $\|$ dad pa thog mar hgro bas nor btun yons su rdzogs paho | snon dam bcas pa las bsgal pahi phyir hjig rten thams cad myi bslu baho || dge bahi chos yons su rdzogs pas sañs rgyas kyi chos thams cad yons su rdzogs paho \|l de ni byan chub sems dpahi bsod nams kyi tshogs la mkhas pa źes byaho $\|$.

4. D P R add: gan dan.

5. P rnal hbyor (also in the following three occurrences of 'brtson par': 1. D R P rnal hbyor, 2. P rnal hbyor, 3. P rnal hbyor pa).

6. Pelliot, 977 , folio $4 \mathrm{~b} .3-6$

de la byan chub sems dpahi ye ses kyi tshogs la mkhas pa gan źe na | rgyu gan gis ye śes bskyed pa ste / de ltar rgyu dan rkyen gan gis ye ses chud paho || de la rgyu dan rkyen gan źe na || chos tshol ba la rab tu mos $\mathrm{pa} \mid$ ye śes kyi rjes su son bahị bśes ñen bsten pa | sans rgyas kyi ye śes la rton te | ñan thos dan ran sańs rgyas kyi ye ses la myi rton paho | de dag la na myed pa | bla ma la rans pa | mkhan po la rans pa | de dag dge bahi bśes ñen gyis bsam ba phun sum tshogs par rig nas ye śes kyi gtam gan yan myi ston pa myed do || snod tu rig nas htshams myed par hbad de | de la chos hechad do || des dehi chos thos nas chos kyi tshogs la brtson par byed do | gan chos kyi tshogs la rtson ba de ñid ye ses kyi tshogs la brtson baho ||. 
ba dan் | sgra ñun ba dan | srod dan tho rañs la mi ñal źin rnal ḥbyor la brtson pa dan | ḥbrel pahi don la yons su rtog pa dan | phyir źin yońs su tshol ba dan | sems la rñog pa med pa dan | sgrib pa gnon pa dań | ltuñ ba las ḥbyun bar ses pa dan | hgyod pa med pa dan் | kun nas ldan ba med pa dań / nan tan sñin por byed pa dan | chos la gźol ba dań | chos la ḥbab pa dan் | chos la bab pa dañ ${ }^{1}$ | chos la brtul ba dan | rtag par mgo dan lus ${ }^{2}$ la me ḥbar ba lta bu dan $\left.\right|^{3}$

ye śes tshol ba de ñid la gnas pa dan் | mi lhod pa dan | brtson hgrus mi gton ba dan் | khyad par du ḥgro ba dan் | ḥdu ḥdzi las dben pa dan | gcig pur ${ }^{4}$ dgaḥ ba dan | dgon paḥi bde ba yid la byed pa dan் | ḥphags pahi rigs la dgah ba dan | sbyañs pa las mi hygyur ba dan | chos kyi kun dgah (ba) la dgah źin mos $\mathrm{pa}^{5}$ dan / hyjig rten rgyan phan pạ̣i gsañ tshig la ri mo ${ }^{6} \mathrm{mi}$ byed pa dan | hjig rten las ḥdas pahi chos tshol ba la dran pa mi ñams pa dan் | rtogs pa la don rtogs pahi rjes su ḥgro ba dan | blo gros la lam gyi rjes su ḥthun par byed pa dan / mos pa la sdom pa dan $\left.\right|^{7}$

rkyen la ye ses kyi rjes su rig $\mathrm{pa}^{8}$ dan் $\mid$ khrel yod pa dañ ${ }^{9} \mid$ no tsha ses pahi $\operatorname{rgyan}^{10}$ dan $\mid$ saǹs rgyas kyi ḥgros kyi rjes su hgro ba dan் | mi ses pa sel ba dan் | ma rig pa dań gti mug gi lin tog (645) sel ba dań | ses rab kyi mig rnam par dag pa dan் | rab tu mam par dag pa dan | blo rgya che ba dan | bla ma źum pa dan் | blo rab tu tha dad pa dan | mñon sum du śes pa dan | gźan (dag) la rag ma lus pahi yon tan dan | rañ gi yon tan gyis mi sñems pa dan | pha rol gyi yon tan la rtog $\mathrm{pa}^{11}$ dan் | legs par bya bahi las ${ }^{12}$ byed pa dan் | las kyi rnam par smin pa la $\mathrm{mi}^{13}$ hgal bar byed $\mathrm{pa}^{14}$ dan | las yons su dag par śes $\mathrm{pa}^{15}$ ste / de ni byan chub sems dpah

1. R om: chos la bab pa dan.

2. D P R gos.

3. Pelliot, 977 , folio $4 \mathrm{~b} .6-5 \mathrm{a} .1$

de la chos kyi tshogs la brtson ba gañ źe na / de ni don ñun ba | bya ba ñun ba / sgra ñun ba | nam gyi cha stod dan cha smad la myi ñal bar brtson ba dan ldan ba | brtson bahi don la yons su rtog pa phyi phyir yons su hjig pa sems ma sñoms pahi (conjectural reading) bsgrib pa mam par sel ba / lhun ba las hbyun bar ses pa | ḥgyod ba myed pa | yoǹs su bskor pa myed pa / nan tan gyi sñin po can chos la gźol ba | chos la ḥbab pa | chos la bab pa | chos la sgrim ba | rtag par mgo dan gos la mye ḥbar bả bźin du ye śes tshol bahi de ñid la gnas pa $\mid$.

4. $\quad \mathrm{PR}$ bu; $\mathrm{N}$ pu.

5. P chos la kun dgạ̣ źin dgaḥ bas dgaḥ ba, for D N R chos (kyi) kun dgạ (ba) la dgah źin mos pa.

6. N ri mor.

7. Pelliot, 977 , folio 5a.1-3

myi lhod pa bkur ba myi hodod pa | khyad bar du myi hgro ba | hdu hodzi dan tha dad pa | gcig pur dgah ba | dgon pahi sgor yid la byed pa | ḥphags pahi rigs la dgah ba | sbyans pa las myi hgyur ba / chos la kun dgaḥ źin dgal bas dgah ba / hjig rten pa (phyal bahi) snags la bkur sti myi byed pa | hjig rten las has pahi chos tshol bahi dran ba myi ñams ba | rig pahi don gyi hgros su hgro ba | blo hgros lam tu mthun ba | sdom ba brtan pal.

8. P ye ses su rtogs pa.

9. P om: khrel yod pa dan.

10. P no tsha ba dad mdzes pahi rgyan.

11. P mi rtog pa.

12. D R legs par bya baḥi las bya bahi las; $P$ bthad por byed pahi.

13. N om: mi. 
sems dpaḥ chen poḥi ye śes kyi tshogs źes byahọo $\|^{1}$

gźan yaǹ ye śes kyi tshogs ni sbyin ba rnam $\operatorname{par}^{2}$ bźi ste |

(1) chos smra ba là gro ga dan் | smyu gu dan் | snag tsha dan் / glegs bam sbyin pa dan |

(2) chos smra ba la chos kyi stan sna tshogs sbyin pa dan!

(3) chos smra ba la rñed pa dañ / bkur sti dan | tshigs su bcad pa thams cad sbyin pa dan |

(4) chos smra ba la chos kun bsdu bahi phyir g.yo med par legs so || źes bya ba sbyin pa ste |

sbyin pa bźi po de dag [ni] ye ses kyi tshogs sogs ${ }^{3}$ par hgyur ro \| kun srun ba bźi ${ }^{4}$ mams ye śes kyi tshogs sogs par ḥgyur te | bźi gan źe na |

(1) chos smra ba mams kyi lus [kun] $]^{5}$ srun ba ${ }^{6}$ dan |

(2) dge ba srun ba dan

(3) yul dań ljons su hijug pa la srun ba dań

(4) phan pahi dnos po [kun $]^{7}$ srun ba ste |

$[\mathrm{kun}]^{8}$ srun ba bźi po de dag (ye ses kyi tshogs sogs par hgyur ro) ${ }^{9} \|$ ñe bar rton pa ${ }^{10}$ bźi ye śes kyi tshogs (sogs par) ${ }^{11}$ ḥgyur te | bźi gañ źe na |

(1) chos smra ba rnams kyi chos ñe bar (646) rton pa dan |

(2) ye ses ñe bar rton pa dań

(3) zañ ziñ ñe bar rton pa dań

(4) byań chub ñe bar rton paho $\|^{12}$

14. P byed pa mi gton ba, for D N R mi higal bar byed pa.

15. $\mathrm{R}$ byed pa.

1. Pelliot, 977 , folio 5a.3-5

rkyen gyis ye śes chud pa | no tsha dan khrel yod pahi rgyan | sañs rgyas kyi hgro bahi rjes su hgro ba | myi ses pa hador bab ma rig pa dan gti mug kyi bris (conjectural reading) ma sel ba | śes rab kyi myig rnam par dag pa | rab tu rnam par dag pahi blohi rgya che ba $\mid$ blo ma hikhums pa $\mid$ blo rab tu tha dad pa $\mid$ mnion sum du ses pa | pha rol gyi kha na ma las pahi yon tan mnon bar myi bsñems | pha rol gyi yon tan la myi rtog pa | bzan por byas pahi las byed pa | las kyi rnam par smin pa la myi htshab pa | las yoñs su dag par śes pa de ni | byan chub sems dpahii ye śes kyi tshogs śes byaho \|.

2. D N P om: rnam par.

3. N stsogs (but for one, also in all further occurrences of the word 'sogs' in this tretrad section); this applies also to the parallel passage in the Akn (p. 66.1.3-3.6).

4. N add: po.

5. Akn (p. 66.1.3) om: kun.

6. $\mathrm{R}$ yons su srun ba (also in the next three clauses).

7. Akn (p. 66.1.4) om.

8. Akn (p. 66.1.4) om: kun.

9. Given in Akn (p. 66.1.4).

10. $\mathrm{N}$ ñe bar brtan pa; $P$ rton pa (also throughout this stanza).

11. Given in Akn (p. 66.1.4) as 'stsogs par'.

12. Pelliot, 977, folio 5a.6-5b.1 
(ñe bar rton pa bźi po de dag ye śes kyi tshogs sogs par ḩgyur ro $\|)^{1}$ stobs lna ye śes kyi tshogs (sogs par) ${ }^{2}$ hgyur te | lna gań źes na | hidi lta ste |

(1) mos pahi phyir dad pahi stobs dan $\mid$

(2) thos pa tshol bahi phyir brtson hgrus kyi stobs dan |

(3) byan chub kyi sems ${ }^{3}$ mi brjed paḥi phyir dran paḥi stobs dan |

(4) mñam pa ñid kyi chos la nes par rtogs pahi phyir tin ṅe hạdzin gyi stobs dan |

(5) thos pahi stobs kyi phyir ses rab kyi stobs ste |

stobs lna po de dag ye śes kyi tshogs su (sogs par) ${ }^{4}$ hgyur ro \| tshul khrims bźi ye ses kyi tshogs sogs ${ }^{5}$ par hgyur te | bźi gań źe na | hidi lta ste |

(1) chos la nes pahi ${ }^{6}$ tshul khrims dan |

(2) chos ḥtshol bahi tshul khrims dan |

(3) chos la nes par rtogs pahi tshul khrims dan |

(4) byan chub tu bsno bahi tshul khrims te |

tshul khrims bźi po de dag ye ses kyi tshogs sogs par ḥgyur ro \| bzod pa bźi ye śes kyi tshogs sogs par hgyur te | bźi gan źe na | ḥdi lta ste |

(1) chos tshol ba la mnon par brtson pas nan du smra ba dan | nan du brjod pahi tshig (mams) ${ }^{7}$ bzod pa dan $\mid$

(2) chos tshol ba la minon par brtson pas rlun dan் | tsha ba dan் | gran் ba dan் | dro ba dan் | skom pa dan | bkres pa bzod pa dan |

(3) chos tshol ba la mnon par brtson pas | slob dpon dan mkhan pohi rjes su hjug pa dan |

gźan yan ye ses kyi tshogs mam pa bźi ste | chos ḥchad pa la ḥgro ba dań | ga la ma dań snag tsa dan | glegs bam byin ba dan / chos ḥchad pa la mam par bkra bahi stan sbyin ba dan / chos ḥchad pa la brten pa dan | bku sti dan | tshigs su bcad pa thams cad sbyin ba dan | chos hechad pa la chos kun bsdu bahi phyir dgeho źes bya ba sbyin ba dan bźi ni ye śes kyi tshogs bstsogs par hgyur ro || gźan yañ kun tu bsrun ba bźi ye ses kyi tshogs su ḥgyur te | bźi gañ źe na | chos ḥchad pahi lus kun bsrun ba dañ | yul dañ ljons su źugs la kun tu bsrun ba dañ | phan bahi dños po kun tu bsrun ba dañ bźiho \| gźan yañ brtan ba bźi ye śes kyi tshogs su hgyur te | bźi gan źe na | chos ḥchad pa la chos brtan ba dan | ye śes brtan ba dañ | zan źin kun brtan ba daǹ | blo brtan paho || (R folio 645.3-646.1).

1. Given in Akn (p. 66.1.6).

2. Given in Akn (p. 66.1.6) as 'stsogs par'.

3. P add: kun.

4. Given in Akn (p. 66.1.8) as 'stsogs par'.

5. N bsags.

6. P bde bar gnas pahi, for $D N R$ nes pahi.

7. P nan par honons pahi tshig mams, for $\mathrm{D} \mathrm{N} \mathrm{R} \mathrm{nan} \mathrm{du} \mathrm{brjod} \mathrm{pahi} \mathrm{tshig.}$ 
(4) chos tshol ba la mnion par brtson pas | stoń pa ñid [pa] dan் | mtshan ma med pa dan் | smon pa med pahi chos bzod pa ste |

bzod pa bźi po de dag (647) ye śes kyi tshogs sogs par hgyur ro \| brtson hgrus bźi ye ses kyi tshogs sogs par hgyur te | bźi gan źe na | hidi lta ste |

(1) thos pahi brtson ḥgrus dan்

(2) hadzin pahi ${ }^{1}$ brtson higrus dań

(3) bstan pahi ${ }^{2}$ brtson higrus dan |

(4) nan tan gyi brtson higrus te।

brtson hgrus bźi po de dag ye śes kyi tshogs sogs par hgyur ro $\|^{3}$ bsam gtan gyi yan lag bźi ${ }^{4}$ ye ses kyi tshogs [kyi] sogs par hgyur te | bźi gañ źe na | hại lta ste |

(1) dben pa dàn

(2) gcig bur dgạ̣ ba dan |

(3) ye śes dañ $\mid$ mnon par śes pa tshol ba dan $\mid$

(4) sańs rgyas kyi ye ses la hjug pa ste |

bsam gtan gyi yan lag bźi po de dag ye śes kyi tshogs sogs par ḥgyur ro || śes rab snań bahi chos ḥdi bźi ye śes kyi tshogs sogs par ḥgyur te | bźi gañ źe na | ḥdi lta ste |

(1) chad pa la mi gnas pa dan |

(2) rtag pa la mi hijug pa dan |

(3) rten cin ḥbrel par ḥbyun ba dań mi ḥgal ba dań |

1. D N R gzuns kyi (Akn hdzin pahi).

2. D R brtan pahi; P hachad pahi (Akn bstan pahi).

3. - Pelliot, 977 , folio 5 b.1-5

gźan yan stobs lna ye śes kyi tshogs su hgyur te lna gan źe na | lhag par grol bas dad pahi stobs dan | thos pa tshol bas brtson hgrus kyi stobs dan | byan cub kyi sems kun tu ma stor bas dran bahi bstobs dan | mñam ba ñid kyi chos la rtog pas ti ñe hadzin gyi stobs dan | thos pahi stobs kyi phyir ses rab kyi stobs so || gźan yan tshul khrims bźi ye śes kyi tshogs su hgyur te | chos la dgah bahi tshul khrims dan | chos tshol bahi tshul khrims dan | chos rtog pahi tshul khrims dan | byan chub tu bsños pahi tshul khrims dan || gźan yan bzod pa bźihi ye śes kyi tshogs su hgyur te | chos tshol ba la mñon bar brtson bas nan tu smra ba dan skya skyoli tshig (conjectural reading) bzod pa dan / chos tshol ba la mnon bar brtson bas gran ba dan dro ba dañ skom ba dań | bkris ba bzod pa dan | chos tshol ba la mnion bar brtson bas slob dpon dan mkhan pohi rjes su hgyur ba dan $\mid$ chos tshol ba la mnon bar brtson bas ston pa ñid dan mtshan ma myed pa dan smon pa myed pahi chos bzod pahọo || gźan yan brtson hgrus bźi ye ses kyi tshogs su hgyur te | thos pahi brtson hgrus dañ | gzun bahi brtson hgrus dan | bśad pahị brtson ḥgrus dan | nan tan gyi brtson hgrus so || ( $R$ folio 646.1-647.2).

4. Akn add: byan chub sems dpahịi. 
(4) bdag med pa la mos pa' ste |

ses rab snan bahi chos bźi po de dag ye śes kyi tshogs sogs par hayur ro || chos ḥdi bźi thabs kyi ye ses kyi ${ }^{2}$ tshogs (sogs par) ${ }^{3}$ hgyur te | bźi gañ źe na | ḥdi lta ste |

(1) hjig rten pahi rjes su hjug pa dan்

(2) mdo sdehii ${ }^{4}$ rjes su hjug pa dan்

(3) chos kyi rjes su hjug pa dan |

(4) ye śes kyi rjes su hjug pa ste।

chos bźi po de dag thabs kyi ye śes kyi tshogs (sogs par) ${ }^{5}$ hgyur ro ${ }^{6}$ || chos hại bźi lam gyi ye ses kyi tshogs ${ }^{7}$ (648) la hjug par hgyur te | bźi gañ źe na | ḥdi lta ste |

(1) pha rol tu phyin pahi lam dan 1

(2) byan chub kyi phyogs kyi lam dan |

(3) yan lag brgyad pahi lam dan $\left.\right|^{8}$

(4) thams cad mkhyen pahi ye ses su ḥgro baḥi lam ste |

chos bźi po de dag lam gyi ye śes kyi tshogs ${ }^{9}$ la ḥjug par hgyur ro ${ }^{10} \|$ mi noms pa ḥdi bźi ye ses kyi tshogs sogs par hgyur te | bźi gañ źe na | ḥdi lta ste |

(1) thos pas mi noms pa dan்

(2) bstan pas mi noms pa dan

(3) dpyod pas mi noms pa daǹ $\mid$

(4) ye ses kyis mi noms pa ste |

mi noms pa bźi po de dag ye śes kyi tshogs sogs par ḥyur ro $\|^{11}$

1. Given in Akn (p. 66.3.1) as 'bzod pa'.

2. N thabs kyi; Akn (p. 66.3.1-2) has: thabs bźi po de dag byan chub sems dpah mams kyi ye śes kyi tshogs stsogs par hgyur ro.

3. Given in Akn (p. 66.3.2) as 'stsogs par'.

4. Akn (p. 66.3.2) replaces 'mdo sde' with 'sems can'.

5. Given in Akn (p. 66.3.5) as 'stsogs par'.

6. Akn (p. 66.3.3) has 'thabs bźi po de dag byan chub sems dpah mams kyi ye ses kyi tshogs stsogs par hgyur ro'.

7. DN P R lam gyi tshogs kyi ye ses.

8. Akn (p. 66.3.4) has 'sahi lam dan' for 'yan lag brgyad pahi lam dan' (D N P R).

9. D N P R lam gyi tshogs kyi ye śes.

10. Akn (p. 66.3.4-5) has 'tshogs stsogs par hgyur ro', for 'tshogs la hjug par ḥgyur ro' (D N P R).

11. Pelliot, 977 , folio 5 b.5-6a.2 gźan yan bsam gtan bźi ye śes kyi tshogs su hgyur te | dben ba dań | dag pa (conjectural reading) | gcig pur 
gźan yań ye śes kyi tshogs ni gan sems can thams cad kyi rjes su hgro ba dan / źin thams cad kyi rjes su hgro ba ste | sbyin pa las kyañ ye śes kyi tshogs su bltaho || tshul khrims dan |

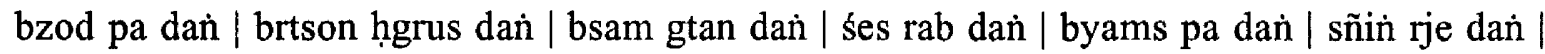
dgaḥ ba dan | btañ ${ }^{1}$ sñoms las kyañ ye śes kyi tshogs su bltaho ||

de ciḥi phyir źe na | ji tsam du byan chub sems dpahi rtsom pa de thams cad ye ses las rag las $\mathrm{pa}^{2} \mid$ ye śes snon du hgro ba | ye śes la rton pa ste | de ye śes la gnas pas ${ }^{3}$ ye śes can thams cad kyi rton par hgyur te ${ }^{4}$ | bdud thams cad kyis kyan de la glags mi rñed do || sańs rgyas kyi byin gyi rlabs kyan hathob | thams cad (649) mkhyen pahi ye ses la yan hjog par byed do $\|^{6}$

de gñis ni byan chub sems dpaḥi bsod nams kyi tshogs dañ ye ses kyi tshogs te | byan chub sems dpah sems dpạ chen po tshogs rnam par gñis de ${ }^{7}$ la mkhas pa śes rab kyi pha rol tu phyin pa la spyod do $\|^{8}$

\section{8}

de la byan chub sems dpah rnams kyi dran pa ñe bar bźag pa la mkhas pa gan źe na | ḥdi bźi ni byan chub sems dpaḥ rnams kyi dran pa ñe bar bźag pa sgom pa ste | bźi gan źe na | ḥdi lta ste | lus la lus kyi rjes su lta ba dran pa ñe bar bźag pa sgom pa dan | tshor ba la tshor bahi rjes su lta ba dran pa ñe bar bźag pa sgom pa dan | sems la sems kyi rjes su lta ba dran pa ñe

dgah ba dan | ye śes kyi mnion bar śes pa tshol ba dan | sańs rgyas kyi ye śes la hjug paho || śes rab kyi snan bahi chos bźi ye ses kyi tshogs su hgyur te / chad pa la so sor myi gnas pa dan | rtag pa la myi hjugs pa dan | rkyen dan hadu ba tshogs te ḥbyun ba ma bgags pa dan | bdag myed pa la dad paho || chos hại bźi thabs dan ye ses kyi tshogs su hgyur te | hjig rten gyi rjes su hjug pa dan | mdo sdehi ries su hjug pa dan | chos kyi rjes su hjug pa dan | ye śes kyi rjes us hjug paho || chos hadi lam gyi tshogs kyi ye ses la hjug par hgyur te | pha rol tu phyin pahi lam dan | byan chub kyi phyogs kyi lam dan | yan lag brgyad kyi lam dan | thams cad mkhyen pahi ye śes kyi rjes su hgro bahi lam mo || myi no(m)s pa bźis ye ses kyi tshogs su hgyur te | thos pas myi noms pa dań | bśad pas myi noms pa dan | dpyod pas myi noms pa dań | ye śes kyis myi nooms paho $\|$ ( $\mathrm{R}$ folio 647.2-648.4).

1. P R gtan.

2. D N R ye śes kyi khar las pa.

3. $\mathrm{N}$ gnas pa.

4. P ye ses thams cad mkhyen pahi ye śes la rten par hgyur żin.

5. D N R gźog.

6. Pelliot, 977 , folio 6a.2-4

gźan yan ye śes kyi tshogs ni sems can thams cad kyi rjes su hgrọ ba dañ | żin tham cad kyi rjes su hgro ba ste | sbyin ba yan ye ses kyi tshogs su bltaho || tshul khrims dan | bzod pa dan | brtson hgrus dan | bsam gtan đan | ses rab dań | byams pa dań | sñin rje dan | dgah ba dan | btan sñoms kyan ye śes kyi tshogs su bltaho || de jihi phyir źe na |ji tsam tu byan chub sems dpahi brtson ba de thams cad ye ses kyi khar las so || ye śes thog mar hgroho || ye ses la so sor rton to | de ye ses la gnas nas sems can thams cad so sor hikhor bar hgyur ro || bdud thams cad kyis de la glags myi rñyed de | thams cad mkhyen pahi ye ses su hjog go |f źes gsuns so $\|$.

7. D N P R rnam pa de gñis.

8. As in the previous instances, this connecting phrase is here missing in the Pelliot manuscript. Moreover, the next sentences do not correspond to those in the following section of the blockprint editions but are found in a much later part defining wisdom (cf. R folio 685.7), thus effectively jumping almost a third of the entire chapter. 
bar bźag pa sgom pa dan | chos la chos kyi rjes su lta ba dran pa ñe bar bźag pa sgom paḥo ||

\section{8 .1}

de la lus la lus kyi rjes su lta ba dran pa ñe bar bźag pa sgom pa gań źe na | sā rihi bu ḥdi la byan chub sems dpạ̣ lus la lus kyi rjes su lta źin gnas pa de lus kyi snon gyi mthạ la yan so sor rtog | lus kyi phyi mahi mthạ̣ la yan so sor rtog | lus kyi da ltar byun ba la yan so sor rtog ste | kye maḥo lus ḥdi ni phyin ci log las byun ba ste | rgyu dan rkyen las skyes ba | g.yo ba med pa | byed pa med pa | bdag po med pa | yoñs su ḩdzin pa med pa | hdi lta ste | dper na phyi rol gyi rtswa dan் | śin gel ba dan் | sman dan | nags tshal dag rgyu dan rkyen las byun źin (650) bdag po med $\mathrm{pa}^{1}$ | yońs su hadzin pa med pa | de bźin du lus ḥdihan rtswa | rtsig pa dan | sin dan் | bon ba ${ }^{2}$ dañ | mig yor lta bu dañ ${ }^{3}$ phun po dan் | khams dañ | skye mched yons su

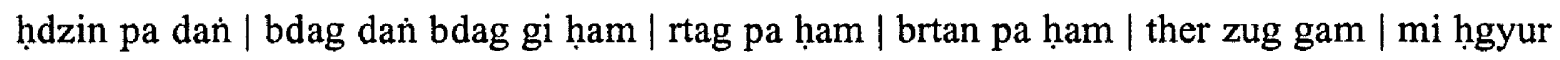
bahị chos kyis ston ste / lus de la na yir mi byaḥi | lus sñin po med pa des sñin po blañ bar byaho ${ }^{4} \|$

de la sñin po gań źe na | ḥdi lta ste | de bźin gśegs pahi skuho || de bźin gśegs pahi sku ni chos kyi sku | rdo rjeḥi sku | mi phyed pahi sku | sra bahii ${ }^{5}$ sku | hjig rten gsum po ${ }^{6}$ thams cad dan khyad źugs pahi sku bdag gis bsgrub par byaḥo || bdag gi lus ḥdi ñes pa du mahi skyon chags mod kyi | hon kyañ ñes pa thams cad dan bral bahi de bźin gśegs paḥi sku thob par byaho || źes de so sor rtog pahi mthus legs par mthon nas | ḥbyun ba chen pohi gnas kyi lus yońs su srun bar byed do || nahi lus ni sems can thams cad kyi ci ${ }^{7}$ dgos par zad paho \| hadi lta ste | dper na phyi rol gyi ḩbyun ba chen po bźi po sahi khams dan | chuhi khams dań | mehi khams dan் | rlun gyi khams sgo sna tshogs dan | dmigs pa sna tshogs dan | rnam grañs sna tshogs dan் | yo byad sna tshogs dan் | lons spyod ${ }^{8}$ sna tshogs kyis sems can rnams ñe bar ḥtsho ba de bźin du / bdag gi ḥbyun ba chen po bźi las gyur pahii (65I) lus ḥdi sgo sna tshogs dan் | dmigs pa sna tshogs dan | rnam grañs sna tshogs dan் | lońs spyod sna tshogs rnams kyis ${ }^{9}$ sems can rnams kyi ñe bar ḥtsho bar gyur cig | sñam mo ||

1. Nom: pa.

2. P gseg ma.

3. Nom: dan.

4. P de la sñin po med paho, for D N R des sñin po blań bar byaho.

5. P brtan pahi.

6. P R om: po.

7. $\mathrm{N}$ cir.

8. D N R yons su spyod pa (also in the next occurrences for the term 'lons spyod').

9. D P R mams kyis; $N$ kyi. 
de lus mi rtag pa ñid duhañ so sor rtog mod kyi | skye ba ${ }^{1}$ dan śi ḥphos kyan mi skyoho ${ }^{2}$ |l lus sdug bsñal ñid duhan ${ }^{3}$ so sor rtog mod kyi | lus kyi sdug bsnal bas kyan yońs su mi gduń no || lus bdag med pa ñid du yan so sor rtog mod kyi | sems can yons su smin par bya baḥi phyir ${ }^{4}$ yan mi skyoho || lus źi ba ñid duhạn so sor rtog mod kyi | lus źi bas ${ }^{5}$ btan sñoms su yan mi ltun no $\|$ lus ston pa ñid dan lus dben pa ñid duhañ ${ }^{6}$ so sor rtog mod kyi | dben paḥi mur yań mi ltun̉ no $\|$

de lus la lus kyi rjes su lta źin gnas pa na lus la rdzas dan sñin por rjes su mi mthon no (de) nañ gi lus la yan̉ lus kyi rjes su lta źin gnas pa na nan̉ gi rjes su son bahi ñon mońs pa rnams kyi go skabs mi ḥbyed do \| de phyi rol gyi lus la lus kyi rjes su lta źin gnas pa na phyi rol gyi rjes su son bahi ñon mons pa rnams dan lhan cig mi gnas so $\|$

de lus ñon mońs pa med pas lus kyi las yoǹs su dag pa ldan pa yin no $\|$ de lus yońs su dag nas mtshan (ñid) gyis yan dag par brgyan pahi sku hthob po $\|$ de lus mtshan ñid kyis ${ }^{7}$ brgyan par gyur nas tha dan mi rnams mnion du hạdu ${ }^{8}$ bar hgyur te $\mid$ de ni byan chub sems dpahi lus la lus kyi rjes su lta ba ${ }^{9}$ (652) dran pa ñe bar bźag pa sgom paho \|

\section{8 .2}

yan் ji ltar na byań chub sems dpah tshor ba la tshor bahi ${ }^{10}$ rjes su lta ba dran pa ñe bar bźag pa sgom pa yin źe na / ḥdi la byań chub sems dpah gañ ci $\operatorname{tshor}^{11}$ yań ruñ ${ }^{12}$ de thams cad sdug bsnal lo || źes de sñam du sems te | de ye śes kyis rtogs pa dañ | śes rab kyis rtogs pa dan | thabs kyis rtogs pahi tshor ba sin tu rtogs pas bde bar tshor ba tshor bar ${ }^{13}$ byed mod kyi | hadod chags kyi bag la ñal ba yan bag la ñal bar mi byed do $^{14} \|$ sdug bsnal bahi tshor bas reg nas kyan் nan son du skyes pa thams cad la sñin rje chen po skyed cin khon khro bahị ${ }^{15}$ bag la ñal yan̉ bag ${ }^{16}$ la ñal bar mi byed do $\|$ bde ba yan ma yin | sdug bsnal ba yaǹ ma yin pahi tshor

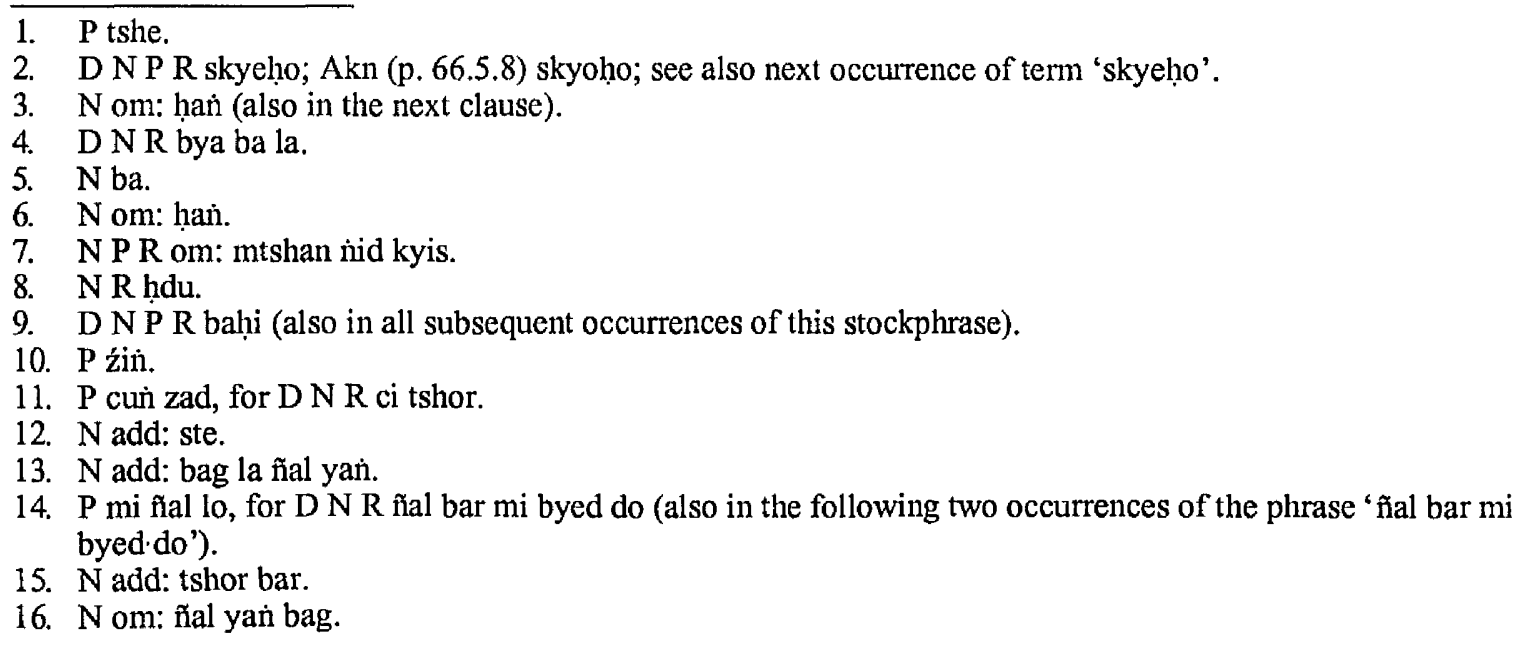


bas reg ${ }^{1}$ kyan் $\left.\right|^{2}$ ma rig paḥi bag la ñal yan bag la ñal bar mi byed do $\|^{3}$ de tshor bahi rjes su son bahi dran pas bde ba ḥam | sdug bsñal ba ḥam | bde ba yan ma yin | sdug bsnal ba yan ma yin pahi tshor ba gań tshor ba yan tshor ba de dag las ḩbyun bar lta ba yin no \| sems can thams cad kyi tshor ba yońs su śes sin źi bahi phyir yan hijug ste |

sems can ḥdi dag ni tshor ba las ḥbyun bar mi śes pas de dag bde baḥi tshor ba la dgah bar byed | sdug bsñal baḥi tshor ba la źe sdan bar byed | bde ba yañ ma yin | sdug bsnal ba yan ma yin pại tshor ba ${ }^{4}$ la rmons par byed kyir ${ }^{5}$ bdag ni (653) ses rab dan ye ses kyis rjes su rtogs pahi tshor ba | tshor ba thams cad so sor sbyañs pa dan | thabs mkhas pa dan sñin rje chen pos yońs su bzun bahi rtsom pas | sems can de dag gi tshor ba thams cad rgyun gcod pahi phyir ${ }^{6}$ chos bstan paho $\|$

ciḥi phyir tshor ba źes bya (ba) źe na | rtogs paḥi tshor ba ni bde bar hygur ro \| ma rtogs pahi tshor ba ni sdug bsnal bar hgyur ro $\|$

de la rtogs paḥi tshor ba gań źe na | ḥdi la bdag gam | sems can nam | srog gam | gañ zag gañ du ${ }^{8}$ yan tshor bar byed pa med do ${ }^{9} \|$ chags pa ni tshor baho \| yońs su hadzin pa ni tshor baḥo || len pa ni tshor baḥo || phyin ci log ni tshor baḥo || rnam par rtog pa ni tshor baho \| lta baḥi bag la ñal ba ni tshor baḥo || mig tu ḥdu śes pa tshor ba yin pa nas | yid kyi ḥdu śes pahi bar du ni tshor baho $\|$ gzugs su ḥdu ses pa tshor ba yin pa nas | chos su ḥdu śes paḥi bar du ni tshor baḥo || gan mig gi ḥdus te reg paḥi rkyen las byun baḥi tshor ba bde ba ham | sdug bsñal ba hạ | bde ba yań ma yin | sdug bsñal ba yañ ma yin pahi bar du de ni tshor ba źes byaho ||

gon ma bźin du nań dan phyiḥi chos rnams la sbyar te | yid kyi bar du ḥdus te reg paḥi rkyen las byun bahi tshor ba bde ba ham / sdug bsnal ba ḥam / bde ba yañ ma yin / sdug bsnal ba yan ma yin pahi bar du ni tshor źes byaho $\|(654)$

gźan yań rnam grañs kyis tshor ba gcig ste ${ }^{10} \mid$ de ni sems gcig pus ${ }^{11}$ mam par rig paho $\|$

1. P add: nas.

2. P bde ba yan med | sdug bsnal yan med pahi tshor ba med kyi mdo / de.

3. dușkhayā vedanayā spṛșțah sarvapāpākṣanopopananeșu sattveșu mahākaruṇām utpādayati || pe || api tu khalu punar abhiniveśo vedanā parigraho vedanopādānam vedanopalambho vedanā viparyāso vedanā vikalpo vedanetyādi \| (Akn as cited in Sikș, p. 233.6-8).

$4 \quad \mathrm{~N}$ ma yin pa, for D P R ma yin pahi tshor ba.

5. N P kyis.

6. N om: phyir; $P$ so sor sbyan bahi phyir; $R$ rgyun bcad pahi phyir.

7. P tshor bas ma rtogs pa ni, for $D N R$ rtogs pahi tshor ba (also in the two following occurrences of the phrase 'rtogs pahi tshor ba').

8. D N R om: du.

9. P rtogs par byed pa med paho, for D N R tshor bar byed pa med do.

10. P ni hdi lta ste (also in the next six phrases of this paragraph in which the numerical structure of feeling (tshor ba) is introduced).

11. P puhi. 
tshor ba gñis te | (de ni) ${ }^{1}$ phyi dan nan giho $\|$ tshor ba gsum ste | (de ni) ${ }^{2}$ ḥdas pa rnam par rig pa dan | ma họons ba rnam par rig pa dañ | da ltar byun ba rnam par rig paho || tshor ba bźi ste | de ni khams bźi mam par rig paho || tshor ba lna ste $^{3} \mid$ de ni phuń po lna yid la byed paho || tshor ba drug ste | de ni skye mched drug yońs su rtog paho || tshor ba bdun te | de ni rnam par śes pa gnas pa bdun no $\|$ tshor ba brgyad de | de ni log par nes pahi sbyor ba brgyad do || tshor ba dgu ste | de ni sems can gyi gnas dguho || tshor ba bcu ste | de ni ${ }^{4}$ dge ba bcuhi las kyi $\operatorname{lam}^{5} \mathrm{mo} \|$

gon ma bźin du sbyar te | thams cad ni tshor ba ste | dmigs pa ji sñed pa dan | yid la byed pa ji sñed pa de thams cad tshor bar byaho ${ }^{6} \|$ de bas na sems can tshad med pahi ${ }^{7}$ tshor ba tshad med pa źes byaho ${ }^{8} \|$

de la byan chub sems dpaḥ tshor ba la tshor bahi rjes su lta źin gnas pas | sems can thams cad kyi tshor ba skye ba dan் | hjig pa dan் | gnas pa la ye śes bskyed par bya ste / gañ sems can thams cad kyi dge ba dan mi dge bahi tshor ba la tshor ba śes pa de ni byan chub sems dpaḥi tshor ba la tshor baḥi rjes su lta ba dran pa ñe bar bźag paho \|

\section{8 .3}

de la byan chub sems dpahi sems la sems kyi (655) rjes su lta ba dran pa ñe bar bźag pa gan źe na | byań chub sems dpaḥ dehi ${ }^{10}$ mi brjed pa dań | sba ba dañ | kun bsruń ba dañ | mi g.yen baḥo || de ḥdi ltar so sor rtog pa ste | sems ni skyes nas hijig cin źu ste mi gnas pas ${ }^{11} \mid$ nañ na yañ mi gnas | phyi rol tu yan mi hpho ste / gan bdag gis thog mar sems bskyed pa de yañ zad $\mid$ med $^{12} \mid$ rnam par gyur te | yul na mi gnas | phyogs na mi gnas pas de rñed par mi nus te $\mid$ sems gan gis dge bahi rtsa ba bsgrubs pa de dag kyan zad $\mid$ med $\mid$ rnam par gyur te ${ }^{13} \mid$ yul na mi gnas | phyogs na mi gnas so ||

gañ yan byañ chub tu bsños pahi sems de yan no bo ñid kyis mtshan ñid med pa ste / sems

1. Akn (p. 67.3.7-4.3) upholds parallel phrasing throughout this passage, using the term 'gan hdi' instead of 'de ni'.

2. See previous note.

3. R tshor ba lina gan źe na.

4. Akn (p. 67.4.1) add: mi.

5. P add: rnams.

6. P yin par rig par bya ste, for $\mathrm{D}$ tshor bar bya baho.

7. $\mathrm{N}$ pas.

8. P de bas na sems can dpag tu med pa mams kyi tshor ba dpag tu med pa źes byaho.

9. D N R add: gan.

10. Akn (p. 67.4.5) add: byañ chub kyi sems.

11. $\mathrm{N}$ nas.

12. N om: med.

13. P med par gyur te, for D N R med | rnam par hgyur. 
kyis sems rab tu mi śes te ${ }^{1}$ | sems kyis sems mi mthon | sems kyis sems mi tshor na / gan gis bdag bla na med pa yań dag par rdzogs pahi byań chub mnon par rdzogs par ḥtshan rgya ${ }^{2}$ paḥi sems de gan yin | gan byan chub kyi sems de ni dge baḥi rtsa bahi sems dan mi hgrogs ${ }^{3}$ | gan dge baḥi rtsa baḥi sems de yan̉ bsnoo baḥi sems dan mi ḥgrogs | gan bsño baḥi sems de yan̉ byan chub kyi sems dan | dge bahi rtsa baḥi sems dan mi ḥgrogs so || źes de | de ltar so sor rtog pa na ${ }^{4}$ mi skrag mi dnana dnan bar mi ḥgyur gyi $i^{5}$ de yań ḥdi sñam du sems te |

rten cin ḥbrel par (656) ḥbyun ba zab mo rgyu dan ḥbras bu chud mi za baho || gal te sems kyi chos ñid de lta bu sems kyi ran bźin ñid yin yan chos thams cad rgyu dan rkyen la rag las pa | g.yo ba med pa | byed pa med pa | bdag po med pa |ji ltar ḥdod pa de bźin du hgrub kyis | bdag gis sgrub ${ }^{6}$ pa la brtson par byaho $\|$ sems kyi chos ñid de mi hibri bar byaho $\|$

de la sems kyi chos ñid gań | sgrub pa gań źe na | sems ni sgyu ma dan ḥdra ba ste | de la sbyin $^{8}$ par byed pa yañ su yañ ${ }^{9}$ med de | de ni sems kyi chos ñid de / gan yan bdog pa thams cad yoṅs su btań nas sańs rgyas kyi źin rnam par sgrub pahi rgyan du ${ }^{10}$ sno bar byed pa de ni sgrub par byed paḥo \| sems rmi lam dan ḥdra ba rab tu źi baḥi mtshan ñid de ni sems kyi chos ñid de | gañ yaǹ tshul khrims sdom pahi tshogs sogs so $\| \operatorname{chog}^{11}$ de thams cad myur bahi mñon par śes par sno ba de ni sgrub paho $\|$ sems smig rgyu lta bu sin tu zad pas zad par gyur $\mathrm{pa}^{12}$ de ni sems kyi chos ñid de / gań yań bzod pahi stobs dan | des pa ${ }^{13}$ byañ chub kyi rgyan bsgrub pahi phyir sno ba de ni deḥi sgrub paho \| sems chu zla lta bu sin tu dben pas dben pa de ni sems kyi chos ñid de / gañ yan brtson hgrus rtsom pa thams cad sañs rgyas kyi chos thams cad yons su rdzogs par bya bahi phyir sno ba (657) de ni dehi sgrub paho \| sems gzun du med pa mi mthon ba de ni sems kyi chos ñid de / gań yań bsam gtan dan் / rnam par thar pa daǹ | tin ne hadzin dañ | mñam par gźag pa thams cad sańs rgyas kyi tin ne ḥdzin du sno ba de ni dehi sgrub paho $\|$

sems gzugs med pa $\mid$ mi mthon ba $\mid$ mi thogs $\left.\mathrm{pa}^{14}\right|^{15}$ mam par mi rig pa de ni sems kyi

1. D P R om: te.

$2 . \quad P$ sanis rgyas.

3. P ldan (also in the following two occurrences of the word 'hgrogs').

4. N dan.

5. P mi hjigs mi skrag / skrag par mi hgyur gyi, for D N R mi skrag mi dnan dnana bar mi hgyur gyi.

6. D N R bsgrub.

7. P sbyor bar.

8. N D sgrib.

9. N om: yan.

10. P gyis.

11. R chos.

12. P sin tu zad cin med pa.

13. P hgrogs na bde ba.

14. D mi thos pa.

15. $\mathrm{R}$ add: mam par mi thogs pa. 
chos ñid de | gan yan dris pahi tshig tha dad pa bstan pa thams cad ses pa | sañs rgyas kyi ye śes yoǹs su rdzogs par sño ba de ni dehi sgrub paho \| dmigs pa sna tshogs la sems skye ba de ni sems kyi chos ñid de | gan yan dge bahi rtsa ba la dmigs pahi sems ñe bar sbyor ba ${ }^{1}$ de ni dehi sgrub paho || rgyu med pa las sems mi skye ba de ni sems kyi chos ñid de | gan yan byan chub kyi phyogs kyi chos kyi rgyuhi sems skyed pa de ni dehi sgrub paho || gan yul med par sems mi skye ba de ni sems kyi chos ñid de | gan yan sańs rgyas kyi yul gyi rgyuhi sems ñe bar sbyor ba de ni dehi sgrub paho \|

śā rihị bu de ltar na byan chub sems dpah sems la sems kyi rjes su lta ba ${ }^{2}$ dran pa ñe bar bźag pa sgom paho || de sems la sems kyi rjes su lta źin gnas pa na | mnon par śes pa thob paḥi phyir sems sin tu ḥbrel par byed de | de (658) mnon par ses pa thob nas sems gcig gis sems can thams cad kyi sems rab tu śes te | śes nas kyan dehi ran bźin gyi ${ }^{3}$ chos ḥchad do $\|$

gźan yan byan chub sems dpah (sems la) ${ }^{4}$ sems kyi rjes su lta źin gnas pa na / sñin rje chen po thob pahi phyir sems ñe bar ḥbrel par byed de | sñin rje chen po thob pas sems can thams cad yońs su smin par bya bahi phyir ${ }^{5}$ yoǹs su mi skyoho ${ }^{6} \|$ sems la sems kyi rjes su Ita źin gnas pa na | sems zad pa dań sems hgog par bya bahi phyir sems gnas par mi byed kyi | ḥkhor bahi rgyun gyi kun tu? sbyor ba rnams kyis sems mnon par sgrub ste | sems kyi dran pa śes pa de ma skyes pa dan mi skye ba nes par gyur pa la źugs pahi chos rnams kyis gnas te | ñan thos dań rañ sańs rgyas kyi sar yań mi ltun no || sańs rgyas kyi chos thams cad yońs su rdzogs par ma gyur kyi bar du | sems kyi rgyud de rgyun chags par byed de / sems kyi skad cig gcig dan̉ ldan pahi śes rab kyis bla na med pa yan dag par rdzogs pahi byañ chub mnon par rdzogs par ḥtshan rgya ste | sā rihi bu de ltar na byan chub sems dpạ̣ sems la sems kyi rjes su lta $b^{8}{ }^{8}$ dran pa ñe bar bźag pa sgom mo\|

\section{8 .4}

sāa riḥi bu ji ltar na byañ chub sems dpah chos la chos kyi rjes su lta ba dran pa ñe bar bźag pa sgom pa yin źe na | śā riḥi bu ḥdi la byan chub sems dpas ḥphags pạ̣i śes rab kyi mig gis chos gan (659) mthon ba de dag byan chub kyi sñin pohi bar du bar ma dor ${ }^{9}$ rmons par mi

1. P bsñen par byed pa (also in the next occurence of the phrase 'ñe bar sbyor ba').

2. D N P R źin.

3. P no bo ñid du, for $\mathrm{D} N \mathrm{R}$ ran bźin gyi.

4. Given in Akn (p. 68.2.1).

5. D N R bya ba la.

6. N skyeho.

7. $\quad \mathbf{P}$ ḥkhor ba dan ḥbrel cin; $\mathrm{R}$ ḥkhor baḥi rgyun gyi kun nas.

8. D N P R źin.

9. P sñin po tshun chad kyi bar du, for D N R sñin pohi bar du bar ma dor. 
h.gyur te | de chos la chos kyi rjes su lta źin gnas pa na | gañ stoń pa ñid du ma gtogs pa dañ | mtshan ma med par ma gtogs pa dan் | smon pa med par ma gtogs pa dan் | mi skye bar ma gtogs pa dan் | ma skyes par ma gtogs pa dan | mñon par ḥdu mi byed par ma gtogs pa dan் | dños po med par ma gtogs pahi chos rdul tsam ${ }^{1}$ yan mi mthon no $\|$

gan rten cin ḥbrel par ḥbyun bar ma gtogs pahi chos rdul tsam yan yań dag par rjes su mi mthon no || byan chub sems dpạ̣ de chos la chos kyi rjes su lta źin gnas pa na | chos ñid yañ dag par rjes su mthon gi / chos ma yin pa mi mthon no $\|$

de la chos gan źe na | ḥdi lta ste | bdag med pạ̣i don dañ | sems can med pahi don dań | srog med pahi don dań | gañ zag med pahi don te | de ni chos źes byaho ||

de la chos ma yin pa gań źe na | ḥdi lta ste | bdag du lta ba dan | sems can du lta ba dan | srog tu lta ba dan் | gañ zag tu lta ba dan | chad par lta ba dan | rtag par lta ba dan | habyun bar lta ba dan் | hjig par lta ba dan | de ni chos ma yin pa źes byaho ||

yan sã rihi bu chos thams cad chos so $\|$ chos thams cad ${ }^{2}$ chos ma yin paho \| de cihi phyir (660) źe na | ston் pa ñid dan் | mtshan ma med pa dan | smon pa med pa śes paḥi phyir chos thams cad chos so $\|$ bdag dan bdag gir lta bahi bag la ñal bahi phyir chos thams cad chos ma yin paho $\|$

de la byan chub sems dpa ${ }^{3}$ chos la chos rjes su lta źin gnas pa na | chos de dag la gan yañ sańs rgyas kyi chos ma yin pa gan las byan chub tu mi ḥgyur ba dan ${ }^{4}$ | gañ las sañs rgyas su mi ḥgyur ba dan் | gañ las lam du mi ḥgyur ba dan் | gan̉ las thar par mi ḥgyur ba dan | gañ las ḥbyun bar mi hgyur bahi chos rdul tsam yañ mi mthon ste / de chos thams cad ḥbyun bar śes nas sgrib pa med pa źes bya baḥi sñin rje chen po ḥthob ste / sems can thams cad kyi kun nas ñon mońs $\mathrm{pa}^{5}$ yañ de dag ñon moṅs pa dan bcas pa ma yin gyi | de dag ñon mońs pa med paho źes bcos mar ḥdu śes skyed do $\|^{6}$

de cihi phyir źe na | de ltar de dag ni nes pahi don la yaǹ dag par hjug pa ste | ñon mons pa rnams la bsags pa ḥam | phun pohi dnos po ${ }^{7}$ med de | de dag ñid rjes su rtogs pahi phyir

1. P phra rab tsam (also in all subsequent occurrences of the phrase 'rdul tsam').

2. N add: ni.

3. N dpahi.

4. P om: ba dan (also in the next three occurrences of the phrase 'mi hygur ba dan').

5. D P add: la.

6. yathā tāvad atrāha | dharme dharmānudarśi viharan bodhisattvo na kañcid dharmam samanupaśyati | yato na buddhadharmā yato na bodhị | yato na mārgo | yato na niḥsaraṇaṃ | sa sarvadharmāniḥ̂saraṇam iti | viditva 'nāvaraṇam nāma mahākaruṇāsamādhim samāpadyate | sa sarvadharmeșu sarvakleśeșu ca kṛtrim asaṃjñām pratilabhate | niḥkleśã ete đ̛harmã | na ete saklešăh | tat kasya hetoh | tathā hy ete nītārthe samavasaranti nāsti kleśānām saṃcayo | na rāśībhāvạ̣| na rāgabhāvo na dveșabhāvo na mohabhāva | eșām eva klesānām avabodhād bodhị | yat svabhāvaś ca kleśās tat svabhāvā bodhir ity evaṃ smịtim upasthāpayati iti || (Akn as cited in Sikș, p. 236.6-13).

7 Nom: hị dnos po. 
byañ chub po \| ñon mon̉s pahi ran bźin gan yin pa byan chub kyi rań bźin yan de yin no \| byan chub kyi ran bźin gań yin pa ñon mońs pahi ran bźin yan de yin te / de ltar dran pa ñe bar bźag ${ }^{1}$ kyan் | cuñ zad kyañ ñe bar hjog pa med | rab tu ḥjog pa med | (661) mi ḥjog pa med de | chos ñid de gnas pa ñid du rab tu ses so || de bas na chos kyi dbyiñs de ni gnas pa ñid ces byaḥo || chos kyi dbyins gnas ${ }^{2}$ gan la gnas pa | sems can gyi khams kyan gnas de la gnas so || sems can gyi khams gnas gañ la gnas pa | nam mkhahi khams kyañ gnas de la gnas te | de bas na chos thams cad nam mkhah dan mtshuñs źes byaho ||

byan chub sems dpạ de chos la chos kyi rjes su lta źin gnas pa na sañs rgyas kyi chos la rton pa yin / chos thams cad sańs rgyas kyi chos su mos par byed de / de zad pa śes pa yan bskyed mod kyi | hadus ma byas pahi zad pa yan mnon du mi byed / mi skye ba śes pa yan mnon par bsgrub [pa] mod kyi | sems can la lta baḥi phyir yań skye la | mi skye baḥi mthah de yan̉ mi gton no $\|$ dran pa ñe bar bźag paḥo źes bya ba ni chos thams cad dran pa de la bźag par byed cin | ñan thos sam | ran sańs rgyas sam | sańs rgyas kyi chos ji sñed chos su btags ${ }^{3}$ pa de dag thams cad ma lus par dran pa de la bźag ste | dran pa de yań brjed ${ }^{4}$ par mi byed \ phyi mahi mthahi bar du rmons par mi byed do $\|$

chos la chos kyi rjes su lta ba dran pa ñe bar bźag paho źes bya ba de ni bstan pa dpag tu med pa ste | kun tu spyod yul ma yin pa | sańs rgyas kyi chos thams cad la (662) yan dag par h̆du $\mathrm{ba}^{5}$ | sems can thams cad kyi sems tshim par byed pa | bdud thams cad hadul ba / ran byun ba rtogs pahi phyir te |

sã rihi bu de ltar na byan chub sems dpạ̣ chos la chos kyi rjes su lta ba dran pa ñe bar bźag pa sgom mo || de dag ni dran pa ñe bar bźag pa bźi źes byaḥo \|

sā rihi bu de ltar na byañ chub sems dpaḥ dran pa ñe bar bźag pa bźi po de dag la mkhas pa ses rab kyi pha rol tu phyin pa la spyod do $\|$

\section{9}

de la byañ chub sems dpaḥ rnams kyi byan chub kyi yan lag la mkhas pa gan źe na | byañ chub sems dpah rnams kyi byan chub kyi yan lag ḥdi bdun te | bdun gań źe na | ḥdi lta ste | dran pa yan் dag byan chub kyi yan lag dan / chos rnam par ḩbyed pa yan dag byan chub kyi yan lag dan் | brtson ḥgrus yań dag byań chub kyi yan lag dan் | dgạ ba yań dag byan chub

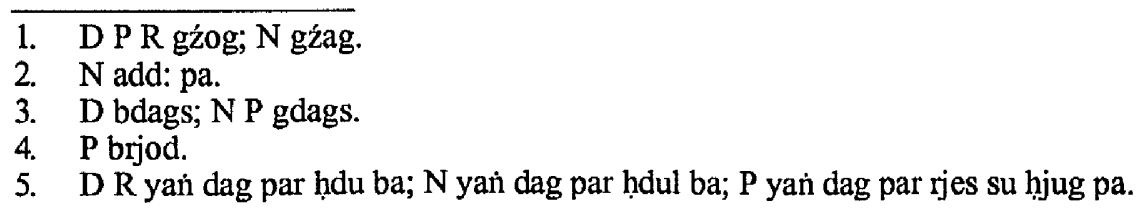


kyi yan lag dań | sin tu sbyañs pa yan dag byañ chub kyi yan lag dan | tin ne hadzin yañ dag byan chub kyi yan lag dan | btan sñoms yan̉ dag byan̉ chub kyi yan lag ste | śā riḥi bu de dag ni byañ chub sems dpah rnams kyi byan chub kyi yan lag bdun no \|

de la dran pa yan dag byań chub kyi yan lag gan źe na | dran pa gan̉ gis chos rtog par byed | chos la so sor rtog par byed | chos la dpyod par byed | chos (663) yons su tshol bar byed cin | chos rnam par ḥbyed par byed pa dan | chos la rnam par rtog par byed de / de dran pa des gañ chos mams kyi no bo ñid kyi mtshan ñid de yañ rjes su rtogs so \| yaǹ chos rnams kyi no bo ñid kyi mtshan ñid śes pa gañ źe na / chos thams cad rañ gi mtshan ñid kyi ${ }^{1}$ ston pa ste | gan de ltar dran źin khon du chud pa de ni dran pa yan dag byań chub kyi yan lag ces byaho \|

de la chos mam par ḥbyed pa yan dag byań chub kyi yan lag gań źe na | gañ chos kyi phun po brgyad khri bźi ston rab tu rnam par ḥbyed pa śes pa ste / nes paḥi don kyañ nes paḥi don du | drań baḥi don kyań drań bahi don du | kun rdzob kyi don kyan kun rdzob kyi don du | don dam pạ̣i don kyan don dam paḥi don $\mathrm{du}^{2}$ | brdahi kyan brdahi | rnam par gtan la bab paḥi kyań rnam par gtan la bab pahi ${ }^{3}$ chos de dag ji ltar rab tu dbye bar bya ba de bźin du | de dag rnam par ḩbyed par byed de | de ni chos rnam par ḩbyed pa yaǹ dag byan chub kyi yan lag ces byaho $\|$

de la brtson ḥgrus yañ dag byañ chub kyi yan lag gañ źe na | gañ chos rnam par ḥbyed pa de ñid kyi dgah ba dan | śin tu sbyañs pa dan | tin ṅe hạdzin dań | btañ sñoms dañ | ye ses kyi bar du hạdzin pa dań | spro ba dan் | stobs dan் | rtul ba dan் | mi zlogs pahi mos pa dan | mthu dan் | brtson pa mi ḥdor ba dañ ${ }^{4}$ (664) lam mñon par rtogs pahi phyir ${ }^{5}$ brtson hgrus rtsom ${ }^{6}$ pa ste | de ni brtson hgrus yan dag byañ chub kyi yan lag ces byaho ||

de la dgạ̣ ba yañ dag byan chub kyi yan lag gań źe na | dgaḥ ba gan dan | chos la dgah ba gań dan் | chos la mchog tu dgaḥ ba gań gis sems mi źum źin dań ba ste / ma źum pahi dgah ba des gañ lus sam | sems kyan śin tu byan bar ${ }^{8}$ byed la | kun nas ñon mońs pa yan sel ba de ni dgah ba yaǹ dag byan chub kyi yan lag ces byaho $\|$

de la sin tu sbyañs pa yan dag byan chub kyi yan lag gañ źe na | gañ lus sin tu sbyañs pa

1. D N P kyis.

2. Akn $\mathrm{D}$ don dam pa yan don dam par; $\mathrm{P} R$ don dam pahi don kyan don dam pahi don du.

3. P mtshan ma yaǹ mtshan mar mam par gdon mi za ba dań | mam par gdon mi za bar, for $\mathrm{D} N \mathrm{~N}$ brdahan brdar I mam par gtan la bab pa yan mam par gtan la bab par.

4. P brtson hgrus mi gton ba dan.

5. D N R rtogs par bya ba la.

6. P om: rtsom.

7. P rab tu.

8. P spyod par, for D N R sin tu byan bar. 
dan | sems sin tu sbyañs pa dan் | ñon moñs pa sin tu sbyañs pa dan | sgrib $^{1}$ pa med pa dan | tin ne hạdzin du dmigs pa la sems ñe bar gźag pa ste / de ni śin tu sbyañs pa yan dag byañ chub kyi yan lag ces byaho \|

de la tin ne ḥdzin yan dag byan chub kyi yan lag gań źe na | gan̉ sems mñam par gźag pas $^{2}$ chos śes pa rtogs par hgyur gyi ${ }^{3}$ | sems mñam par ma gźag pas ni ma yin pa dan | sems mñam par gźag pas ${ }^{4}$ chos de dag mñon par rdzogs par ḥtshan rgyahi | sems mñam par ma bźag pas ma yin te | chos mñam pa ñid dan | chos la gźol ba ma gtogs par rjes su chags pahi kun nas dkris pas rtogs par mi byed $\mathrm{de}^{5} \mid$ de ni tin ne (665) hạdzin yan dag byan chub kyi yan lag ces byahọ \|

de la btañ sñoms yañ dag byañ chub kyi yan lag gan̉ źe na | gan̉ yid bde ba dañ | gañ ${ }^{6}$ yid mi bde bahi cha dan ḥthun pahi chos mams ${ }^{7}$ la sems mi ḥdzin pa daǹ $\mid$ ḥjig rten gyi chos kyis mi ḥphrogs pa dan $\mid$ mtho $^{8}$ dman du mi gnas pahi phyir rab tu mi g.yo (ro) || mi hkhrug | rab tu mi ḥkhrug | yan dag par mi ḥkhrug | chags par mi byed | źe sdań bar mi byed kyi | ḥphags paḥi lam de ñid dan ḥthun par byed pa ste / de ni btañ sñoms yan dag byan chub kyi yan lag ces byaho $\|$

sā rihị bu de ltar na byan chub sems dpaḥ rnams kyi ${ }^{9}$ byan chub kyi yan lag de bdun la mkhas pa ses rab kyi pha rol tu phyin pa la spyod do $\|^{10}$

\subsection{0}

2.10 .1

de la byan chub sems dpaḥ rnams kyi lam la mkhas pa gań źe na | byañ chub sems dpạ̣ rnams kyi lam ni ḥdi brgyad do || brgyad gań źe na | hidi lta ste | yañ dag paḥi lta ba dań | yañ dag paḥi rtog pa dan | yań dag paḥi nag dan | yan dag paḥi las kyi mthaḥ dań | yan dag paḥi

1. $\quad$ N sgribs; P R bsgribs.

2. R ma bźag pas, for D N P bźag pas.

3. D R N te.

4. R ma bźag pa.

5. P lta ba bag la ñal dan kun nas bskor ba de dag spañs kyan mñon par rdzogs par ḥtshan mi rgya ba, for $\mathrm{D}$ N R ries su chags pahi kun nas dkris pas rtogs par mi byed de.

6. D P R om: gan.

7. P yid mi bde ba stan pa la phan pahi chos.

8. N mthon.

9. D P R om: mams kyi.

10. P add: hphag pa byan chub sems dpahi sde snod ces bya theg pa chen pohi mdo \| bam po cu dgu pa; $D$ has 'bam po bcu dgu pa' only. 


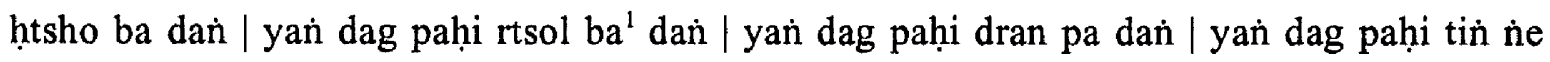
ḥdzin te | de dag ni byan chub sems dpaḥ mams kyi lam yan lag brgyad paho ||

de la yan் (666) dag paḥi lta ba gañ źe na | lta ba gan ḥphags pa hijig rten las hadas pa ste | bdag tu lta ba las lańs pa ma yin | sems can du lta ba las lańs pa ma yin | srog tu lta ba las lans pa ma yin | gan zag tu lta ba las lans pa ma yin | chad pa dan | rtag pa dan் | ḥbyun ba dañ | hjig par lta ba las lañs pa ma yin | dge ba dan mi dge bar lta ba.las lans pa ma yin pa nas | mya nan las ḥdas par lta baḥi bar las ${ }^{2}$ lans pa ma yin pa ste | de ni yaǹ dag paḥi lta ba źes byaḥo \|

de la yań dag pahi rtog pa gań źe na | rtog pa $^{3}$ gan̉ gis ḥdod chags dań | źe sdan் | gti mug la sogs paḥi ñon mońs pa gnas par ḥgyur baḥi rtog pa de ldan̉ bar mi byed ${ }^{4}$ kyi | rtog pa gan gis tshul khrims dan் | tin ne ḥdzin dań | ses rab dan | rnam par grol ba dañ | mam par grol bahi ye śes mthon ba ḥbyun bar ḥgyur ba de la rtog pa ste | de ni yañ dag pahi rtog pa źes byaho ||

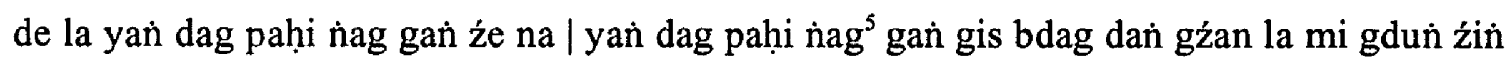
| de phan pahi rjes su sbyor bahi nag dan ldan pa yin te | nag des lam mñam pa la hijug pa (ste) | de ni yan dag pahi nag ces byaho ||

de la yaǹ dag pahi las kyi mthah gań źe na | gañ las (667) gnag la ${ }^{6}$ mam par smin pa gnag pa de lta bu mñon par ḥdu mi byed pa dan / gań las dkar la ${ }^{7}$ rnam par smin pa dkar ba de lta buhi las mnion par ḥdu byed pa dan் | gan las dkar gnag la rnam par smin pa dkar gnag tu h.gyur $b^{8}$ de lta buhi las mnon par ḥdu mi byed pa dan | gan las dkar gnag ma yin (pa) la rnam par smin par mi hgyur ba las zad par hgyur ba de lta buhi las mnon par ḥdu byed pa ste | de las bdag gir bya ba $1 a^{9}$ rton pa yan dag pahi las la brtson (pa ste / de ni) ${ }^{10}$ yan dag pahi las kyi mthạ źes byaho \|

de la yañ dag paḥi ḥtsho ba gań źe na | gan ḥ̣phags paḥi rigs dan | sbyañs paḥi yon tan mi gton ba dan $\mid$ kha gsag ${ }^{11}$ med pa dan $\mid$ tshul hehos pa med pa | thob kyis hjal ba ${ }^{12}$ med pa dan | dgań sla ba dan | gso sla ba dan | cho ga mi lhod pa dań | gźan gyi rñed pa la phrag dog med

1. P hibad pa.

2. Akn (p. 70.4.8) ḥdas par lta bahị bar las; D N R ḥdas par lta ba las; P hadas pahi bar lta ba las.

3. Nom: pa.

4. P higyur.

5. D R om: nag.

6. P po.

7. $\mathrm{P}$ po.

8. P om: tu hgyur ba.

9. P de ran gi las (...) byun ba las, for $\mathrm{D} \mathrm{N} \mathrm{R} \mathrm{de} \mathrm{las} \mathrm{bdag} \mathrm{gir} \mathrm{bya} \mathrm{ba} \mathrm{la.}$

10. D N P R pas.

11. $\mathrm{N}$ bsag.

12. P gźog slons, for D N R thob kyis hyjal ba. 
pa dan் | bdag gi rñed pas chog śes pa dan் | kha na ma tho ba med pa dañ | ḥphags pas gnan bahi ḥtsho ba ste | de ni yan dag pahi ḥtsho ba źes byaho ||

de la yaǹ dag paḥi rtsol ba gań źe na | rtsol ba gañ ${ }^{1}$ log par spyod par bśad pa hadod chags dañ | źe sdañ dañ | gti mug gi ${ }^{2}$ ñon moǹs pa bag la ñal bahi rtsol ba de mi ḥdod kyi $\mid$ rtsol ba gan̉ hphags pahi lam dan̉ bden pa la hyjug pa mya nan las ḥdas par ḥgro baḥi lam du hjug par $^{3}$ byed pahi rtsol ba deḥi rjes su ḥgro ba ste | de ni yan (668) dag pahi rtsol ba źes byaho ||

de la yan dag pahi dran pa gań źe na | dran pa gań śin tu ñe bar gźag ${ }^{4}$ pa dañ | tha mal pa ma yin pa dan் | draǹ ba dan் | gya gyu med pa dan் | ḥkhor bahi ñes pa dań skyon la lta ba dañ | mya nan las ḥdas pahi lam du ḥdren pahi dran pa dañ | dran par byed pa dañ | ḥphags paḥi lam mi brjed pa ste | de ni yaǹ dag pạ̣i dran pa źes byaho ||

de la yañ dag paḥi tinn ne ḥdzin gań źe na | yañ dag pa ñid du mñam pa / chos thams cad la mñam pa ste | tin ne hadzin de la rab tu gnas na yan dag pa ñid du hjug ste ${ }^{6}$ | gañ yań byań chub sems dpahi tin ne hadzin de la gnas na $^{7}$ sems can thams cad rab tu thar par bya bahi phyir | yaǹ dag pa ñid du ḥjug pa de ni yan dag paḥi tiǹ ne ḥdzin źes byaḥo || ḥdas pa dan் | ma byon pa daǹ | da ltar byun baḥi saǹs rgyas bcom ldan ḥdas rnams kyi lam $^{8}$ mi zad pa ḥdi byan chub sems dpas mnon par rtogs nas ḥchad pa dan | ston pa dan / yan dag par rab tu ston pa | de ni yañ dag paḥi tiǹ ne hudzin źes byaho $\|^{9}$

1. N om: gañ.

2. R gan;; $\mathrm{D}$ dan.

3. D R lam du hjug par; N lam du hjog par; P nan tan gton bar.

4. D N P R gźog.

5. P yan dag par (also in the next occurrence of the term 'yan dag da ñid du').

6. P yan dag pahi mi hgyur ba la hjug par byed de, for D N R yañ dag pa ñid du hjug ste.

7. $\mathrm{N}$ nas.

8 Akn (p. 71.1.6) 'tin ne hạdzin' for Bdp 'lam'.

9. tad yathā samyagdṛștị samyaksamkalpah samyagväk samyakkarmāntaḥ samyagäjĩvaḥ samyaksmṛtih samyaksamādhiśca || tatra katamā samyagdṛștịh | yã lokottarā nātmādrșțisamutthitānasattvanajivanapoșanapurușanapudgalanamanujanamānavadrșțisamutthitā nocchedas̄āśvatadrșțisamutthitā na bhavavibhavadrșțisamutthitā na kusalākuśalāvyākrtadrșțisamutthitā yā ca na saṃsāranirvāṇadrșțisamutthitā | iyamucyate samyagdṛ̦țịh || tatra katamaḥ samyaksaṃkalpaḥ | yaiḥ saṃkalpai rāgadveșamohaklešâṇ samuttișțhanti | tān saṃkalpān na samkalpayati | yaih samkalpaiḥ Silasamādhiprajñāivimuktijfānadarśanaskandha samuttișțhanti | tān saṃkalpān saṃkalpayati | ayamucyate samyaksamkalpah || tatra katamā samyagvāk | yayā vācā nātmānam na parāṃśca tāpayati nātmānam na parämśśca kleśayati nātmānam na parāmść upakaroti tayā āryayuktānukulyā vācā samādhipritivacanairyukto bhavati | iyamucyate samayagvãk || tatra katamaḥ samyakkarmāntaḥ | yatkarma kṛ̦ṇạ̣ kṛ̣ṇavipākam tatkarma nābhisaṃskaroti | yatkarma suklạ̣ suklavipākam tatkarmābhisaṃskaroti | yatkarma sulkakrṣnam vartate sulkakṛṣnavipākam vartate tatkarma nābhisaṃskaroti | yatkarma kṛṣnaśulkavipākaṃ kṛ̣̣nakṣayāya saṃvartate tatkarmābhisaṃskaroti | satkarmābhisaṃkaroti satkarmapratisaranakarmāntaḥ | iyamucyate samayakkarmāntạ̣ || tatra katamah samyagājivah | yadā āryavamśsena guṇasaṃlekhānutsarjanatā na kuhanatā na lapanatã na naiṣpeșikatā śuratācārașilatā paralābheșu na îrșyā àtmalābhasantușțị̣ anavadyatā āryānumatānavadyājivikā | ayamucyate samayagājiviạ̣ || tatra katamạ̣ samyagvyāyāmạ̣ | yo vyāyāmo mithyā yasmādrāgadveșamohā anuśerate taṃ vyāyāmaṃ necchati | yo vyāyāmah samyagāryamārgasatyāvatāro nirvāṇagāmi pratipadarpayati tạ̣ vyāyāmam samanugacchati | ayamucyate samayagvyāyāmaḥ || tatra katamã samyaksmṛtị̣ | yā supasthitā aprakampyā ṛjukā akuṭilā saṃsāradveșādinavadaršikā nirvāṇapathapraṇetrī smṛtiḥ 
de dag ni byan chub sems dpah mams kyi lam yan lag brgyad pa źes bya ste | de ni byan chub sems dpahi lam la mkhas paho $\|$ bam po bcu dgu pa $\|^{1}$

\subsection{0 .2}

gźan yan lam la mkhas pa ni byan chub sems dpah rnams kyi lam yan lag gñis pa ste | yan lag gñis gan źe na | ḥdi lta ste |źi (669) gnas dan | lhag mthon ste | de ni lam yan lag gñis pa źes byaho $\|$

de la źi gnas gañ źe na / gań sems kyi źi ba dań | rab tu źi ba.dan | ñe bar źi ba dań | mi

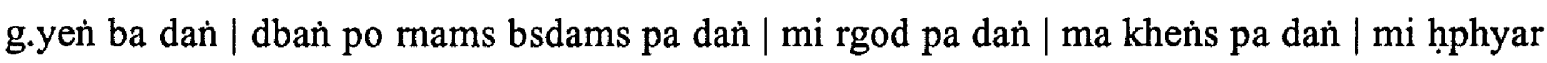
ba dan | mu cor mi smra ba dan | $\operatorname{des}^{2}$ pa dan | sbas pa dan | g.yo (ba) med pa dan | yid du ḥon ba dan் / gcig pur dgaḥ ba dan | ḥdu ḥdzi sel ba dan | dben par dgaḥ ba dan | lus dben pa dan | sems ma ḥkhrul ba ${ }^{3}$ dan் | dgon paḥi sgo yid la byed pa dan | chog ses pa dan | ḥdod pa ñun ba dan் | htsho ba yons su dag pa dan | cho ga phun sum tshogs pa dan | spyod lam sbas pa dan் | dus śes pa dan | tshod ses pa dan | drod ${ }^{4}$ ses pa dan | dgañ sla ba dan | gso sla ba dan | so sor rtog pa dan | mi mtho mi dmah ba dan | tshig nan pa smras pa bzod pa dan | rnal ḥbyor gyi sgor sems skyed pa dan | nan du yan dag ḥjog la mnon par dgaḥ ba dan / bsam gtan gyi yan lag yid la byed pa dan் | byams pa skyed pa dan | sñin rje mñon par sgrub pa dan | dgah ba la gnas pa dan் | btan sñoms sgom pa dan் | bsam gtan dan po nas | brgyad kyi bar du mthar gyis sñoms par hjug pa ste | de ni źi gnas źes byaho || yañ ${ }^{5}$ źi gnas kyi tshogs tshad med pa ste | tshogs de $1 a^{6}$ gań rjes su rtogs pa de ni źi gnas źes byaho \| (670)

de la lhag mthon gan źe na / gan śes rab kyi cha dan ḥ̂thun paḥi ${ }^{7}$ sgom pahi lam ste | chos rnams la g.yo ba med pa dań | sems can med pa dan் | srog med pa dan | gań zag med pa dan் | phun po rnams la sgyu maḥi phun por mthon baḥi ses pa dan / khams rnams la chos kyi khams su mthon bahi ses pa dan | skye mched mams la gron ston par mthon bahi śes pa dan | mig la rab tu rnam par phye bar mthon baḥi śes pa dan | rten cin ḥbrel par ḥbyun ba la mi hgal bar mthon bahị ses pa dań | sems can du lta ba dań bral bar mthon bahi śes pa dań | rgyu

spharaṇamāryamārgāsammoșaḥ | iyamucyate samayaksmṛtị̣ || tatra katamaḥ samyaksamādhị̣ | yạ̣ samyaktvena samādhị̣ | yasmin samādhau sthitaḥ sarvasattvapramokșāya samyak sthiratvam niyāmamavakrāmati | ayamucyate samayaksamādhih || ayamucyate āryāștāngo mārgaḥ || (Arthav (S), appendix, pp. 320-322)

1. D P om: 'bam po bcu dgu pa' at this place.

2. $P$ mñen.

3. P hikhrug pa.

4. P nid tshod.

5. N gan.

6. P las.

7. P cha la phan pahi, for D N R cha dan ḥthun pahi. 
dan ḥbras bu rnam par smin pa mthon bahi śes pa dan | ḥbras bu thob pa mnon sum du bya ba mthon baḥi śes pa dan | yañ dag pa ñid du hjug pa la hjug par byed $\mathrm{pa}^{1}$ mthon baḥi śes paho $\|$

yan̉ lhag mthon źes bya ba ni | ḥdi lta ste | chos rnams ji lta ba bźin tu mthon ba dan | chos rnams kyi ${ }^{2}$ de kho na ñid mthon ba dan | chos rnams kyi gźan ma yin pa ñid mthon ba dan | chos rnams kyi ston pa ñid mthon ba dan் / mtshan ma med pa mthon ba dan / smon pa med pa mthon baho || yan lhag mthon źes bya ba ni rgyus mthon ba med pa dan் | rgyu med par mthon ba med pa dan | skye ba dan | hjig pa dan | gnas pahi rgyus mthon ba med pa dan | dmigs pahi rgyus mthon ba med cin thag par mthoń (671) yań / cuń zad kyañ ${ }^{3}$ lhag par mi mthon baho \|

gźan yan் lhag mthon ni mthon bas kyan் mthon la $\mid$ mthoñ $^{4}$ ba yan் mi mthon ba ste | gañ gi tshe de ltar mthon ba dehi tshe yan் dag par mthon baho \| yan dag par mthon na lhag mthon la mkhas pa yan் rjes su hithob ste | de la byan chub sems dpahi lhag mthon ${ }^{5}$ la $\mid$ mnon par hdu byed par yan mi ltun źin | dge baḥi rtsa ba mñon par ḥdu byed pa la yan mi gnas te | de ni byan chub sems dpahi lhag mthon no $\|$

de Itar na byan chub sems dpaḥ źi gnas dan | lhag mthon la mkhas pa ses rab kyi pha rol tu phyin pa la spyod do $\|$

\subsection{0 .3}

gźan yan lam la mkhas pa ni byan chub sems dpah rnams kyi lam rnam pa bźi ste | rnam pa bźi gań źe na | ḥdi lta ste | sdig pa mi dge bahi chos ma skyes pa rnams mi skyed paḥi phyir ḥdun pa skyed ${ }^{6}$ | ḥbad bar byed | brtson hgrus rtsom | sems rab tu ḥdzin | yan dag par rab tu ḥjog go $\|^{7}$ sdig pa mi dge bahi $\operatorname{chos}^{8}$ skyes pa rnams spań bahi phyir ḥdun pa skyed | habad bar byed | brtson hyrus rtsom | sems rab tu hidzin | yan dag par rab tu hjog go || dge bahi chos ma skyes pa rnams bskyed pahi phyir ḥdun pa skyed | ḥbad bar byed | brtson ḥgrus rtsom | sems rab tu hạdzin | yan dag par rab tu (672) hyjog go \| dge bahi chos skyes pa rnams gnas pa

\footnotetext{
1. P yan dag pahi mi hgyur ba la hjug pa.

2. N om: kyi.

3. N om: kyan.

4. D N R blta.

5. N add: de ltar mthon.

6. P skye bar dad pa skyed, for D N R skyed pahi phyir hdun pa skye (also in all subsequent occurrences of this phrase, with 'pahi/bahi phyir hdun pa skyed' being invaribaly replaced by the phrase 'par/bar dad pa skyed').

7. P smon lam yan dag par rab tu hadebs pa dan, for D N R yan dag par rab tu hjog pa dan (also in the three subsequent occurrences of this phrase in this section).

8. D R om: chos.
} 
dañ | phyir źin ḥbyun̉ ba dan் | ñams par mi ḥgyur ba dań | chud mi za bar bya bahi phyir ḥdun pa skyed ${ }^{1}$ | ḥbad bar byed | brtson ḥgrus rtsom | sems rab tu ḥdzin | yan dag par rab tu hyjog paho \|

gań sdig pa mi dge baḥi chos ma skyes pa rnams mi skyed pahi phyir hdun pa skyed ces bya ba ni tshul bźin yid la byed pahi tshig bla dags so || ḥbad par byed | brtson higrus rtsom źes bya ba ni tshul bźin yid la byed pa de mi gton ba(hi tshig bla dags so) ${ }^{2} \|$ sems rab tu ḥdzin | yan dag par rab tu hjog ces bya ba ni tshul ${ }^{3}$ bźin la so sor rtog pahi tshig bla dags so || de ciḥi phyir źe na | tshul bźin la rab tu sbyor ba ni mi dge bahi chos mams mi ḥbyun bahị ${ }^{4}$ phyir ro $\|$

de la mi dge bahi chos rnams gan źe na | ḥdi lta ste | tshul khrims kyi mi ḥthun paḥi phyogs ${ }^{5}$ dan | tin ne hadzin gyi mi ḥthun paḥi phyogs dan | śes rab kyi mi ḥthun pahi phyogs so $\|$

de la tshul khrims kyi mi ḥthun pahi phyogs gan̉ źe na | ḥdi lta ste | tshul khrims ñams pa dan் | gañ gźan la $1 a^{6}$ tshul khrims ñams par hgyur baḥi chos mams (tshul khrims kyi phun poḥi mi ḥthun paḥi phyogs $)^{7}$ te | de ni tshul khrims kyi mi ḥthun pạ̣i phyogs źes byaḥo ||

de la tin ne ḥdzin gyi mi ḥthun pạ̣i phyogs gan źe na | gan̉ cho ga ñams pa dan | gan gźan la la sems g.yen̉ bar byed pahi chos tin ne ḥdzin gyi phun pohi mi ḥthun pahi phyogs te / de ni tìn (673) ne ḥdzin gyi mi ḥthun paḥi phyogs źes byaḥo $\|^{8}$

de la śes rab kyi mi ḥthun paḥi phyogs gañ źe na | ḥdi lta ste | lta ba ñams pa dan் | gan gźan la la lta ba kun nas ldan bahi $i^{9}$ sgrib par byed paḥi chos [gañ] | śes rab kyi phun pohi mi ḥthun paḥi phyogs de ni śes rab kyi mi ḥthun paḥi phyogs źes bya ste / de ni sdig pa mi dge bahi chos rnams źes byaho \|l

tshul bźin yid la byed pa gan gis sdig pa mi dge bahi chos de lta bu de dag span bahi phyir ḥdun pa skyed | ḥbad par byed | brtson hgrus rtsom | sems rab tu hadzin | yan dag par rab tu

1. P sgom pa mi brjed pa dan | ma stor bar dad pa skyed, for D N R phyir źin hbyun ba dañ | ñams par mi hgyur ba dan | chud mi za bar bya bahi phyir hadun pa skyed (also in partially corresponding passages below).

2 Akn (p. 68.5.6) reads 'yid la byed pahi tshig bla dags so'. Bdp reads 'yid la byed pa de mi gton baho'.

3. N add: yid.

4. P rgyu bar mi hgyur bahi, for D N R mi hibyun bahi.

5. P log pahi gñen po, for D N R mi hthun pahi phyogs (also in all subsequent occurrences of this phrase in this section).

6. P gan gźan yan la la (also in the following two occurrences of this phrase).

7. Given in Akn (p. 69.1.1); see also the following parallel phrases in the Bdp.

8. [pāpakānām akuśalānāṃ dharmaṇāṃ prahāṇāya chandaṃ janayatotyatra prastāve yāni cānyāni punah] kānicid anyāny api cittavikṣepakarāni yāni samādhiskandhasya vipakșāya samvartante | ayam ucyante samãdhivipakșah | yāvad ime ucyante pāpakā | akuśalā | dharmā iti || (Akn. as cited in Śikș, p. 117.13-16).

$9 \quad$ N R ba. 
hjog pa ste | de bas na mi dge bahi chos de dag sems la phun por gyur pa ma yin | yul na mi gnas | phyogs na mi gnas so ||

gan̉ yan̉ mi dge baḥi chos de rnams sems la rgyu ba sdug paḥi ${ }^{1}$ rnam pas ḥdod chags sam | khon khro baḥi rnam pas źe sdan nam / ma rig paḥi rnam pas gti mug gam | rgyu dañ sgrib pa gan dag las byun ba śes sin | de la tshul bźin yid la byed pahi rnam pa mi gtsan bas ḥdod chags źi bar byed | byams pas źe sdań źi bar byed | rten cin ḥbrel par ḥbyun bas gti mug źi bar byed de | gan kun nas ñon mońs pa de dag źi ba de ni tha sñad du btags pahi phyir spon ba źes byaho || gan̉ spon̉ ba (674) ni gañ yañ rñed par mi hgyur ro \| mñam pa ñid kyis ${ }^{2}$ chos thams cad mnon sum pas [na] dehi phyir ${ }^{3}$ yan dag par spon ba źes bya ste / de ni yan dag par spon̉ ba gñis pahọ $\|$

gan yañ dge bahi chos ma skyes pa rnams skyed pahi phyir ḥdun pa skyed | ḥbad par byed | brtson hgrus rtsom | sems rab tu ḥdzin | yan dag par rab tu hjog pa źes bya ba de ni gnas ${ }^{4}$ tshad med pa ste / de ciḥi phyir źe na | gan byan chub sems dpah sems dpaḥ chen pos yan dag par bsgrub par ${ }^{5}$ bya bahi dge bahi chos tshad med pahi phyir ro $\|$

de la ḥdun pa ni dge bahi rtsa ba thams cad kyi rtsa baho \| brtson ḥgrus yan dag par bsgrub pa ni dge bahi rtsa ba thams cad kyi rtsa baho \| sems rab tu ḥdzin pa ñams su len par byed $\mathrm{pa}^{6}$ de ni dge bahi rtsa ba thams cad kyi rtsa ba ste / de ni yan dag par spon ba gsum paho \|

gañ yań dge bahi chos skyes pa rnams gnas pa dañ | ñams par mi hgyur ba dan / chud mi za bar bya bahi phyir ḥdun pa skyed | ḥbad par byed | brtson higrus rtsom | sems rab tu ḥdzin | yan dag par rab tu hjog ces bya ba de ni dge bahi rtsa ba byan chub tu bsnoos pahi tshig bla dags so || de ciḥi phyir źe na | dge bahi rtsa ba byan chub tu bsños pa ni mthạ byan chub kyi sñin poḥi rab tu slar chud za bar mi ḥgyur ro || de cihi phyir źe na | de ltar khams gsum la mi gnas par sems skyed pahi phyir ro \|| (675) gan khams gsum la gnas pahi dge bahi rtsa ba de ni zad par ḥgyur ro \| de ciḥi phyir źe na | de ltar sems bskyed pa de ni khams gsum la ${ }^{7}$ gnas pahi phyir ro || gañ yañ dge bahi rtsa ba khams gsum la mi gnas pa thams cad mkhyen par bsños pa de ni zad par mi hgyur te ${ }^{8}$ | de ni yan dag par spon ba bźi paho $\|$

1. P rgyu ba gtsan pahi, for $D$ rgyu bahi sdug pahi.

2. N kyi.

3. D P add: phyir.

4. P tshig.

5. P bsdu bar, for D N R yan dag par bsgrub par (also in the next occurrence of the term 'yan dag par sgrub pa').

6. P sgrol ba, for D N nams su lon par byed pa (also in all subsequent occurrences of the term 'ñams su len par byed pa').

7. $\mathrm{N}$ om: gnas par sems skyed pahi phyir ro \| gan khams gsum la gnas pahi dge bahi rtsa ba de ni zad par hgyur ro || de ciḥi phyir źe na | de ltar sems bskyed pa de ni khams gsum la.

8. D N R de la zad pa gań yań med de. 
de ltar na byañ chub sems dpah lam yan lag bźi pa la mkhas pa ses rab kyi pha rol tu phyin pa la spyod do $\|$

\subsection{0 .4}

gźan yan lam la mkhas pa ni byań chub sems dpahi lam yan lag lna pa ste | lna gan źe na |

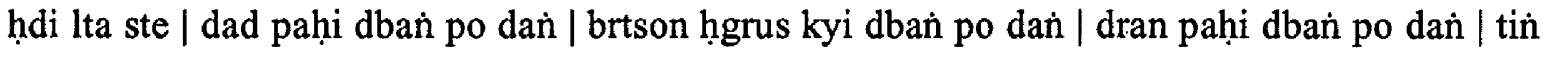
ne hạdzin gyi dbań po dan | śes rab kyi dbañ po ste |

de la dad pahi dbañ po gań źe na / dad pa gan gis chos bźi la dad par byed pa ste | bźi gañ źe na $\mid$

(1) ḩkhor ba na spyod pahi hyjig rten pahi ${ }^{1}$ yan dag par lta ba la mnon par dad de / de las kyi rnam par smin pa la rton pa yin te | srog gi phyir yan sdig pahi las mi byed pa dan |

(2) byan chub sems dpahi spyod pa la yan dad de / spyod pa la źugs pa de theg pa gźan la ḩdod par mi byed pa dan்

(3) don dam pa nes paḥi don dan / rten cin ḥbrel par ḥbyun ba zab mo dan் | sems can la rnam par dpyod $\mathrm{pa}^{2}$ dan் | ston pa ñid dan | mtshan (676) ma med pahi mtshan ñid kyi chos thams cad la dad de | lta bar byas pa $^{3}$ thams cad bag la nal bar mi byed pa dan |

(4) sańs rgyas kyi chos thams cad dan / stobs dan / mi hjigs pa mams la dad cin thos nas the tsom med $\mathrm{de}^{4}$ | nem nur med par chos de rnams sdud par byed pa de ni dad pahi dban po źes byaḥo $\|$

de la brtson ḥgrus kyi dban po gań źe na | chos gan la dad pa de brtson hgrus kyi dban pos skyed par byed pa ste | de ni brtson hyrus kyi dbañ po źes byaḥo || chos gan dag brtson harus kyis bsdus pa de dag dran pahi dbań pos chud mi za bar byed pa de ni dran paḥi dbań po źes byaho $\|$ chos gan dag dran pahi dbañ pos chud mi za bar byed paḥi chos de dag tín ne ḥdzin gyi dbañ pos rtse gcig tu byed pa de ni tin ne ḥdzin gyi dbań po źes byaho \| chos gan dag tin ne hạdzin gyi dbań pos rtse gcig tu byed pa de dag śes rab kyi dbań pos so sor rtog par byed de | gan̉ chos de dag śes pa de ni śes rab kyi dbań po źes byaḥo ||

de ltar na dbań po lna po de dag lhan gcig tu hbrel pa ste | sańs rgyas kyi chos thams cad yońs su rdzogs par byed do || lun bstan pahi sa yan thob par byed de | hịi lta ste | dper na phyi rol kyi mñon par śes pa lna dan ldan pa dag mnal na ḥdug pa / bud med dañ skyes pahi dban por ma gyur kyi bar du mnal na ḥdug pa la lun mi ston pa de (677) bźin du | sañs rgyas bcom

1. P kyi (Akn, p. 86.3.4, gyi)

2. N rnam par spyod pa; $P$ rtog.

3. D bya ba.

4. D P R med pa; $N$ med.

5. N om: dag.

6. DNPR pa. 
Idan has rnams ${ }^{1}$ kyan byañ chub sems dpah dbañ po lna po de dag dañ ${ }^{2}$ mi ldan gyi bar du lun mi ston te | de ni lam yan lag lna paho $\|^{3}$

de ltar na byań chub sems dpạ̣ lam yan lag lna pa la mkhas pa śes rab kyi pha rol tu phyin pa la spyod do $\|$

\subsection{0 .5}

gźan yan sā rihị bu byan chub sems dpaḥ lam yan lag lna la mkhas pa gan źe na | yan lag lna ni | ḥdi lta ste | dad pahi stobs dan | brtson ḥgrus kyi stobs dan | dran pahi stobs dan | tỉn ne hạdzin gyi stobs dan | śes rab kyi stobs so ||

de la dad paḥi stobs gań źe na | gań mos pa dad pa mgo gcig pa mi brdzi ba ste ${ }^{4}$ gal te deḥi drun du bdud sdig can sańs rgyas kyi gzugs su bsgyur te ḥons nas | chos kyi ye ses la dad pa gañ yan ruñ ba la la źig gis chos ḥdi dag ni sañs rgyas kyi chos ma yin no \|l źes ḥbral bar byed | họdun ${ }^{5}$ pa zlog par byed kyan | yoǹs su brtag pa bzuñ na ḥbyun ba chen po bźi rnams ni gźan du hgyur gyi | dad pahi stobs la mos pahii ${ }^{6}$ byan chub sems dpaḥ ni de lta bu ${ }^{7}$ ma yin no \|l de ltar byan chub sems dpahi stobs las ḥbral bar mi nus pa de ni dad pahi stobs so $\|$

de la byan chub sems dpahi brtson hgrus kyi stobs gań źe na / gan̉ brtson hgrus rtsom źin dge baḥi chos (678) gañ dañ gan la mñon par sbyor ba de dan de dag la brtan ${ }^{8}$ paḥi stobs kyi mthu thob kyan / gnas der ma bsgral gyi bar du stobs kyi mthu de la lha dan bcas pahi hjig

1. P om: rnams.

2. Nom: dan.

3. katamāni pañca | śraddhendriyạ̣ vīryendriyam smṛtīndriyaṃ samādhendriyam prajñendriyamiti | tatra katamā śraddhā | yathā śraddhayā caturo dharmān ābhiśraddadhāti | katamāmś caturah | samsārāvacarīm laukikim samyagdṛțtim sraddadhāti | sa karmavipākapratiśaraṇo bhavati | yad yat karma karișyāmi tasya tasya karmanạ phalavipākam pratyanubhavișyāmīti | sa jīvitahetor api pāpaṃ karma na karoti | bodhisattvacārikām abhiśraddadhāti | tat caryāpratipannaś cānyatra yāne spṛhāṃ notpādayati | paramārthanīārthạ̣ gambhīrapratītyasamutpāda

nairātmyaniḥsattvanirjīvaniḥpudgalavyavahärasūnyatānimittāpraṇihitalakṣaṇān sarvadharmān śrutvā śraddadhāti | sarvadṛștikṛtāni ca nonuśete sarvabuddhadharmān balavaiśāadyaprabhṛtịmśs ca śraddadhāti | sraddhāya ca vigatakathaṃkathastān buddhadharmān samudānayati | idamucyate śraddhendriyam || tatra katamad vīryendriyam | yān dharmān śraddhendriyeṇa śraddadhāti tān dharmān vīryendriyeṇa samudānayatīdam ucyate vīryendriyam || tatra katamat smṛtindriyaṃ | yān dharmān vīryendriyeṇa samudānayati tān dharmān smṛtindriyeṇa na vipraṇāśayati | idam ucyate smṛtindriyam | tatra katamat samādhīndriyạ̣ | yān dharmān smṛtindriyeṇa na vipraṇāśayati tān samādhīndriyeṇaikāgrīkarotīdam ucyate samādhìndriyam | tatra katamat prajñ்endriyam | yān dharmān samādhīndriyenaikāgrīkaroti tān prajñendriyeṇa pratyavekșate pratividhyati | yad eteșu dharmeșu pratyātmajñānam aparapratyayajñānam idam ucyate prajñendriyạ̣ || evam imāni pañcendriyāṇi sahitāny anuprabadhäni sarvabuddhadharmān paripūrayanti vyākaraṇabhumim cāpyayanti \|( Akn as cited in Sikṣ, pp. 316.13-317.13)

4. P phyogs gcig pa mi tshoms pa ste, for D N R mgo gcig pa mi brdzi ba ste (with 'mgo gcig pa' being below invaribaly rendered 'phyogs gcig pa').

5. $P$ dad.

6. P mos pahi stobs la gnas pahi, for D N R dad pahi stobs la mos pahi.

7. D N P om: bu.

8. R bstan. 
rten rnams kyis ${ }^{1}$ rnam par zlog pa ham | bstan pa ḥam ${ }^{2}$ | rnam par bslan bar mi nus te | de ni byan chub sems dpahi brtson hgrus kyi stobs źes byaho $\|$

de la byan chub sems dpaḥi dran pahi stobs gań źe na / chos gan dañ gan̉ la dran pa ñe bar bźag pas sems ñe bar bźag ${ }^{3}$ pa ste | de ni ñon mońs pa gań yan run ba dag gis gtor ba ham ${ }^{4}$ | g.yen் bar mi nus te | dran pahi stobs kyi mthu des ñon mońs pa thams cad ḥjom źin dran pa de yañ mi choms pa ste | de ni byañ chub sems dpahi dran pahi stobs źes byaho ||

de la byan chub sems dpaḥi tinn ne ḥdzin gyi stobs gań źe na / gan̉ ḥdu ḥdzi thams cad du ${ }^{6}$ dben par spyod pa ste | gan dag gi lam gyi sgra thams cad la yan rtog la | dehi bsam gtan dan pohi sgrahi tsher ma la sgrib par mi byed pa dan | dge bar rtog pa la yañ mam par rtog [pa] mod kyi | (dehi) bsam gtan gñis pa la yań sgrib par mi hgyur ba dan | de dgah ba dan bde ba skyes te gnas mod kyi | dehi bsam gtan gsum pa la sgrib par mi hygur ba dan் | de sems can yońs su smin par bya ba dan | dam paḥi chos yońs su gzun bar bya baḥi phyir btan sñoms pa yañ ma yin mod $\mathrm{kyi}^{7}$ | (dehi) bsam gtan (679) bźi pa la sgrib par ${ }^{8}$ mi hygyur ba ste | de bsam gtan de bźi la gnas na bsam gtan dan rnam par thar pas gźom ${ }^{9}$ par mi nus te / de tin ne hadzin gyi gnas kyan mi gton் la | tin ne hadzin gyi dban gis kyan mi skye ba ste / de ni byan chub sems dpahi tin ne hadzin gyi stobs so $\|$

de la byan chub sems dpaḥi ses rab kyi stobs gan źe na | gan hjig rten ${ }^{10}$ dan hjig rten las hadas pahi chos rnams kyis mi choms pahi ye śes te / byan chub sems dpah skyes ma thag tu bzoḥi gnas hjig rten na ji sñed spyod pa dam pa dan $\mid \mathrm{dkah}^{11}$ bar byed pa dan | rñed dkah ba de dag thams cad slob dpon med par mnon du hgyur te / gan hijig rten las hadas pa de ${ }^{12}$ dag kyan gan gis hjig rten dag sgrol bar byed de | de dag byan chub sems dpahi śes rab dań ye śes kyi stobs kyis ${ }^{13}$ byun ba | lha dañ mi rnams kyis ${ }^{14}$ mi choms pa ste / de ni byan chub sems dpahi śes rab kyi stobs so || hadi ni yan lag lna paḥi lam gźan no \|

de Itar na byań chub sems dpah (lam) ${ }^{15}$ yan lag lna la mkhas pa ses rab kyi pha rol tu

1. Nom: kyis.

2. R om: bstan pa ham.

3. N P R gźog.

4. D R gtor ba ham; $N$ bton ba ham; $P$ bsre bahi ma.

5. Akn, D N R bskyed pa.

6. D N om: du.

7. P yal bor gton pa yań ma yin., for D N R btan sñoms pa yan ma yin mod kyi.

8. D N R add: yan.

9. N gźog.

10. N add: pa.

11. N dgah.

12. D P R om: de.

13. $\mathrm{N}$ kyi.

14. N kyi.

15. Cf. concluding parallel phrases in the preceding passages on 'skill in the path'. 
phyin pa la spyod do $\|$

\subsection{0 .6}

gźan yan mdor bsdu na byan chub sems dpaḥ rnams kyi lam ni mgo gcig pa ste | ḥdi lta ste $^{1}$ | lam bgrod pa gcig paho || hidi lta ste | byan chub sems dpah gcig pu (680) gñis su med pa | bla na med pa yan dag par rdzogs paḥi byan chub tu grogs med par śin tu brtson pahi stobs kyi mthu yoṅs su gzun bahi bsam pas go cha bgos pa ste | gźan gyis ma bstan ${ }^{2}$ pa | gźan gyi ${ }^{3}$ drin mi ḥjog pa | bdag ñid ${ }^{4}$ byed pa | bdag gi stobs kyis yan dag par ḥphags pa ste | de ltar go cha sra bar ${ }^{5}$ bgos nas | gan sems can thams cad kyis ma thob ${ }^{6}$ pa de bdag gis thob par byaho || gan hịhags pa thams cad dan | gan theg.pa la gsar du źugs pahi byan chub sems dpah thams cad kyis ma thob pa de bdag gis thob par byaho \|

sbyin pa ni nahi grogs ma yin gyi $\mid$ na ni sbyin pahi grogs poho ${ }^{7}||$ tshul khrims dan | bzod pa dan் | brtson ḥgrus dan் | bsam gtan dan | śes rab ni nahi grogs ma yin gyi ${ }^{8}$ | na ni de dag gi grogs poho ${ }^{9}||$ na ni pha rol tu phyin pa rnams kyis bslan ${ }^{10}$ bar bya ba ma yin gyi | pha rol tu phyin pa rnams nas bslan bar byaho $\|$ gon ma bźin du sbyar te ${ }^{11} \mid$ dge bahi rtsa ba thams cad la rgyas par śes par byaḥo \| na ni dge bahi rtsa ba thams cad kyis bslan bar bya ba ma yin gyi | dge baḥi rtsa ba thams cad nas bslań bar byaho || źes de ltar buhi chos rnams la grogs med cin na gcig pu gñis su med par ${ }^{12}$ rdo rjehi gdan la ḥdug nas $\mid$ bdud stobs dan bcas pa btul te | (681) skad cig $^{13}$ gcig dan ldan pahi śes rab kyis bla na med pa yan dag par rdzogs pahi byan chub mnon par rdzogs par ḥtshan rgya bar byaho $\|^{14}$ źes | de la nes par rtog pahi ${ }^{15}$ bsam pahi

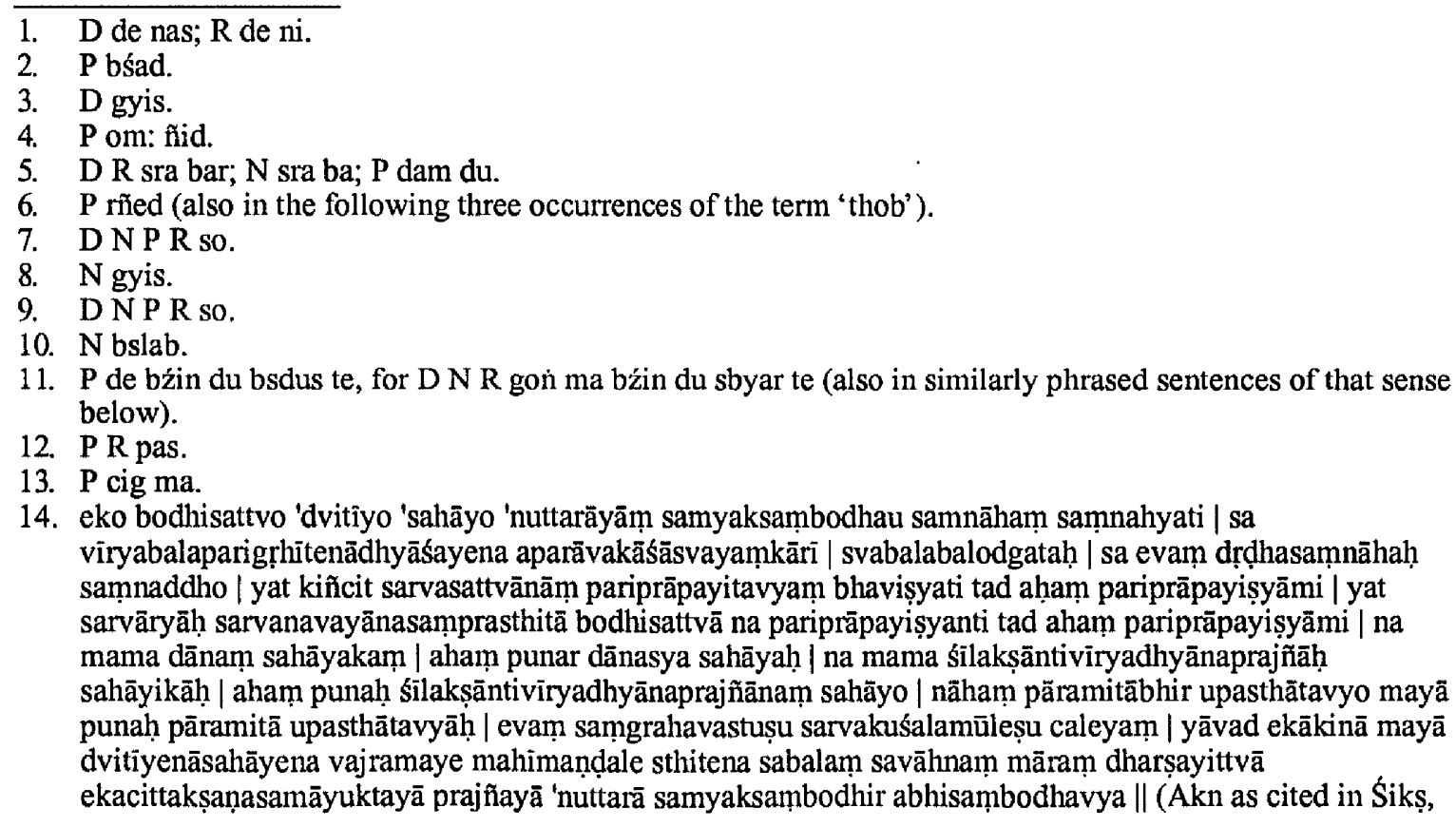


sbyor ba ${ }^{1}$ de ni byan chub sems dpaḥi lam² bgrod pa gcig pu źes bya ste / de ltar na byan chub sems dpahi lam bgrod pa gcig pu la mkhas pa śes rab kyi pha rol tu phyin pa la spyod do $\|$

de ni byan chub sems dpah rnams kyi lam la mkhas pa ste / de ltar na byan chub sems dpah $^{5}$ lam la mkhas pa ses rab kyi pha rol tu phyin pa la spyod do $\|$

\subsection{1}

de la byan chub sems dpaḥ rnams kyi rten cin ḥbrel par ḥbyun ba la mkhas pa gań źe na | ḥdi ltar byan chub sems dpah gcig pu dben par son ste | nan du yan dag par ${ }^{6}$ bźag nas hại ltar sems la rtog pa ste $^{7}$

sdug bsñal gyi phuñ po chen po ḥdi gan̉ las ḥbyun bar ḥgyur sñam pa dan் / de ḥ̣di ltar sems te | tshul bźin ma yin pa byun bahi phyir ma rig pa ḥbyun ${ }^{8} \mid$ ma rig pa byun bahi phyir ${ }^{9}$ hau byed ḥbyun / ḥdu byed byun bahi phyir mam par śes pa ḥbyun / mam par ses pa byun baḥi phyir min dan gzugs ḥbyun | min dan gzugs byun bahi phyir skye mched drug ḥbyun | skye mched drug byun bahi phyir reg pa ḥbyun | reg pa byun bahi phyir tshor ba ḥbyun | tshor ba byun bahi phyir sred pa ḩbyun | sred pa byun bahi phyir len pa ḩbyun | (682) len pa byun bahi phyir srid pa ḥbyun | srid pa byun bahi phyir skye ba ḥbyun | skye ba byun bahi phyir rga śi

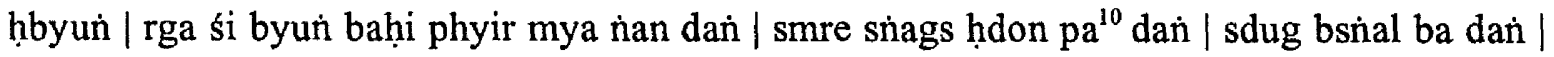
yid mi bde ba dan | ḥkhrug pa rnams ḥbyun bar ḥgyur ro || źes de sñam du sems so ${ }^{11} \|$

de yan̉ ḥdi sñam du sems par hygyur te ${ }^{12} \mid$ ji ltar mi g.yo ba dan $\mid$ mi byed pa dan $\mid$ bdag po med pa dan | dge bahị rgyu las byuń ba dan | mi dge baḥi rgyu las byun ba dan் | mi g.yo bahi rgyu las byun dan / mya nan las ḥdas pahi rgyu las byun bahi chos de dag thams cad rkyen las byun ba ste | gañ yan las kyi rgyu gan dag gis sems can gan dag gi dbań pohi rgyu tshad ma p. 278.4-14)

15. D P R pa.

1. P de ltar brtsam pahi sbyor ba rtog pa, for D N R de la nes par ttog pahi bsam pahi sbyor ba.

2. D R om: lam.

3. P lam phyogs gcig pu.

4. N add: bgrod.

5. D add: rnams kyi.

6. D P R om: par.

7. N skyes te.

8. P nañ du yan dag źugs pa sdug bsnal gyi phun po chen po hadi gań las hdu bar ḥgyur te źes de ltar sems kyi rtog pa skye ba las tshul bźin ma yin pa habyun ba las hgyur te, for D N R from nań du yan dag (pa) to rig pa hibyun.

9. $\mathrm{P}$ byun ba las (also in the following occurrences of the phrase 'byun bahi phyir' in this section).

10. P mya nan slos pa, for D N R smre snags hadon pa.

11. D N R sĩam mo.

12. D N R de yañ ltar sems te. 
dan் | lhag pahi cho gahi rgyu tshad mahi ḩbras buhi rgyu ḥgrub pa dan | de ltar zin pa dan mi zin pa la gan rgyu hadus pa byun ba de thams cad rab tu ses pa ste | de ni byan chub sems dpaḥi rten cin ḥbrel par ḥbyun ba la mkhas pa źes byaḥo \|

de yan ḥgag gań źe na | tshul bźin ma yin $\mathrm{pa}^{1}$ yid la byed pa ḥgags pahi phyir ma rig $^{2}$ pa hgag go || ma rig pa hgag ${ }^{3}$ pahi phyir hạdu byed hgag pa nas | sdug bsnal gyi phun po chen po ḥbạ̣ źig gi bar du hgag par hgyur ro || źes de sñam du sems te | de ltar gañ de la śes pa de ni rten cin ḥbrel par ḥbyun ba la mkhas pa źes byaḥo $\|$

de yan chos thams cad ni rgyu la rag las $\mid$ rkyen la $^{4}$ rag las $\mid$ hidus pa la rag las pa ste $\mid$ (683) gan rgyu dan $\mid$ rkyen dañ ${ }^{5}$ hạdus pa la rag las pa de ni bdag gi byin gyi rlabs ma yin | srog dan gañ zag gi byin gyi rlabs ma yin te | de la bgrań ba gań yan med do || źes de ltar (sñam du) sems te | gan de ltar sems pa de ni rten cin ḥbrel par ḩbyun ba la mkhas paho ||

de ltar na byań chub sems dpạ̣ sañs rgyas kyi chos thams cad byan chub kyi rnam pahi rkyen du slon bar byed la | rkyen de dag la yañ zad pa dan hgag par so sor rtog la | sems can la lta bahi phyir zad pa dan hgag pa ma yin pa yañ ${ }^{6}$ thob par byed pa de ni | byan chub sems dpahi rten cin ḥbrel par ḥbyun ba la mkhas paho \|

\subsection{2}

de la byan chub sems dpahi chos thams cad la mkhas pa gan źe na $\mid$ chos thams cad ces bya ba ni | hadi lta ste | ḥdus byas dañ ḥdus ma byas so || de la byan chub sems dpas hadus byas dan hidus ma byas la mkhas par bya ste

de la ḥdus byas la mkhas pa gań źe na | gan̉ lus kyi ḥdu byed dan | nag gi ḥdu byed dan | yid kyi ḥdu byed dag pa ste $^{7}||$ gan yañ ${ }^{8}$ lus dan | nag dan | yid kyi dge ba de dag hadus ma byas paḥi byan chub la so sor rtog paḥi phyir ${ }^{9}$ | thams cad mkhyen pa ñid du sno ba de ni ḩdus ma byas la mkhas paho $\|$

gźan yan hạdus byas la mkhas pa ni | hidi lta ste | (684) gan sbyin pahi pha rol tu phyin pa dan் | tshul khrims dan | bzod pa dan | brtson hgrus dan | bsam gtan dan | ses rab kyi pha rol tu

1. D pahi; P la.

2. $\quad \mathrm{N}$ rigs.

3. N P higags.

4. N las (also in the next clause).

5. N om: dań.

6. P mi zad pa yan hgag pa de yań, for D N R zad pa dan hgag pa ma yin pa yan.

7. D N R hdu byed do; Akn (p. 55.5.3) add: mnon par hdus byas ba de dag thams cad byan chub la rtog pas thams cad mkhyen pa ñid du yons su bsno ba ḥdi ni dehi hadus ma byas la mkhas pa źes byaho $\|$

8. D N gan la.

9. D N R yid kyi dge bahi hdu byed kyis hdus ma byas pahi byan chub la hdus ma byas par rtog pas, for $P$ yid kyi dge ba de dag hadus ma byas pahi byan chub la so sor rtog pahi phyir. 
phyin pahi ${ }^{1}$ dan | pha rol tu phyin pa lna rnams sdud paho \| gań.yan ḥdus ma byas paḥi śes pas S ses rab kyi pha rol tu phyin pa la pha rol tu phyin pa lna mams kyis smod par mi byed cin | pha rol tu phyin pahi tshogs thams cad la mkhas pa dañ | zag pa med pahi byan chub de la mos pas gan thams cad mkhyen pa ñid du bsno ba de ni dehi ${ }^{2}$ hdus ma $^{3}$ byas la mkhas paho $\|$

gźan yan hudus byas la mkhas pa ni (gan்) sems can thams cad la ḥod zer thogs pa med pa dan | bsdu ba bźis sems can ${ }^{4}$ sdud paho ${ }^{5}$ || gań yañ sñems pa med pahi phyir sems can la bdag med par hdzin pa dañ ${ }^{6}$ bsdu ba la mkhas sin | hdus ma byas pahi byan chub la mos nas | thams cad mkhyen pa ñid du bsno ba de ni dehi ḥdus ma byas la mkhas paho ||

gźan yan̉ ḥdus byas la mkhas pa ni gan̉ ḥkhor bahi rgyun gyi kun nas sbyor ba rnams yan dag par mi gcod la | ḥkhor bahi rgyun gyi ñon mońs pa rnams yañ dag par gcod pa dan / byan chub tu dmigs pahi sbyor ba rnams rgyun chags par byed $\mathrm{pa}^{8}$ dan $\mid$ sbyor ba phyogs gcig pa rnams mi sdud par spyod $\mathrm{pa}^{9}$ de ni ḥdus byas la mkhas pa źes byaho \| gan yañ ston pa ñid dan | mtshan ma med pa dan் | smon pa med pahi chos rnams la ḥdris par (685) bya ba ${ }^{10}$ ses śin mnon sum du mkhas pa dan / byan chub tu gźan gyi drin la mi hjog mod kyi ${ }^{11} \mid$ ḥdus ma byas kyan mnion sum du mi byed pa de ni ḥdus ma byas la mkhas paho $\|$

gźan yań khams gsum na spyod kyañ khams gsum na spyod pahi ñon mońs pa mams kyis mi gos ${ }^{12}$ pa de ni dehi ḥdus byas la mkhas paho $\|$ gan yan khams gsum las byun baḥi ye ses rab tu śes kyañ | habyun bahi khams su mi ltun ba de ni ḥdus ma byas la mkhas pahọo ${ }^{13}$ ||

gań chos thams cad la mkhas pa źes bya ba de ni thams cad mkhyen pa ñid kyi ${ }^{14}$ tshig bla dags so || gan thams cad mkhyen pa ñid kyi ye ses rtogs pa yoǹs su rdzogs pa de ni śes rab dan mkhas pa med na ḥbyun bar mi hgyur bas | deḥi phyir chos thams cad la mkhas pa źes bya ste / de ltar na byan chub sems dpah chos thams cad la mkhas pa ses rab kyi pha rol tu phyin pa la spyod do $\|$

1. DN R pa dan, for $\mathrm{P}$ pahi.

2. Nom: dehi.

3. Akn (p. 55.5.5) om: ma.

4. N add: rnams.

5. P bsdu pa filid dan.

6. DNR dag.

7. P hkhor bar hjug pahi sbyor ba, for D N R hikhor bahi rgyun gyi kun nas sbyor ba.

8. P kyi rjes su sbyor ba, for D N R rgyun chags par byed pa.

9. P sbyor ba.

10. P om: bya ba.

11. DNR cin.

12. P chags.

13. D P R mkhas pa źes byaho.

14. N mkhyen pahi. 
sā riḥi bu de ltar na byan chub sems dpah sems dpaḥ chen po byan chub sems dpahi sde snod la gnas pa | ses rab kyi pha rol tu phyin pa la spyod pa | ses rab rnam par hbyed pa la mkhas sin mkhas pa bcu po de dag la yaǹ mkhas pas śes rab kyi pha rol tu phyin pa la spyod do $\|$

\section{Section III}

\section{1}

de $\mathrm{la}^{1}$ śes rab ni gań | pha rol tu phyin pa rnams kyi don ni gań źe na | ses rab ces bya ba ni dge ba dan mi dge bahi chos (686) mams rab tu ses paho || ses rab ni nes par habyed pahi cha dan ḥthun pahi ${ }^{2}$ chos rnams kyi mñon sum mo $\|$ ḥphags pahi chos mnon sum du gyur pahi phyir tshad mar gyur pa ni śes rab bo \| chos yan dag pa ji lta ba bźin du rtogs pa ni ${ }^{3}$ tshad mar gyur paho || ses rab ni lta bar gyur pa thams cad dan் | kun nas ldań ba dan் | sgrib pa dan் | sgrib par byed paḥi chos rnams rab tu rtogs paho || ses rab ni ḥdod pa dan | $\operatorname{tshol}^{4}$ ba dañ | smon lam thams cad kyi smon lam dan bral baho || ses rab ni sin tu sbyañs pahi phyir

1. In $P$ (pp. 87.5.5-88.2.2), large parts of the section on the nature of wisdom ( $R$ folio 685.5-688.1) are cast in a slightly different order from that of D N and R. In meaning, however, they correspond closely to that of the other editions. In P, they run as follows:

de la śes rab ni gan / pha rol tu phyin pa rnams gyi don ni gan źe na | śes rab ces bya ba ni dge ba dan mi dge bahi chos rnam par rab tu śes paho \|l śes rab ni nes par rtogs pahi phyogs kyi chos mams kyi mnion sum mo \| hạhags pahi chos mnon sum du gyur pahi phyir tshad mar gyur pa ni ses rab po \| chos yan dag pa ji lta ba bźin du rtogs pa ni śes rab po \|l lta bar gyur pa thams cad dan kun nas ldań ba dan || sgrib pa dan sgrib par byed pahi chos rnams la smon pa dan bral ba ni ses rab po \| hodod pa tshol ba thams chad la smon par byed pa | sim par byed pa ni gduñ ba thams cad gton pahi phyir ses rab po || chos kyi dgah ba la dmigs śin mam par gcod pahi phyir dgah bar byed pa ni śes rab po \|l ye śes thams cad mñon sum du gyur pahi phyir rten pa ni ses rab po || byan chub kyi phyogs kyi chos thams cad kyi gnas ni ses rab po \| rñed pahi mtshan ñid ni śes rab po || theg pa ji lta ba bźin du ḥbras bu rtogs pahi phyir rab tu śes pahi mtshan ñid ni śes räb po || kluñ thams cad las sgrol bahi phyir | rań bźin śes pahi snan ba hjug pa ni śes rab po || yan dag par skyon med pahi bar du ḥdren pa ni śes rab po \|l dge bahi chos thams cad hạin pa ni ses rab po || ñon mons pa bag la ñal ba thams cad dan bar byed pa ni ses rab po \| chos thams cad kyi sbyi bo thob pahi rab mchog ni śes rab po \| ran byun bahi ye ses rtogs pahi phyir bzan ba ni śes rab po \| khams sum la ma chags pas rgyu ba dan bral ba ni śes rab po $\|$ hphags pa thams cad kyis śin tu bzun ba ni śes rab po $\|$ mtshan ma med par yons su rtog pa thams cad spans pas smon lam rnam par chad pa ni ses rab po || mun pa mun gnag thams cad dan bral bas bag med pahi gñen po ni ses rab po $\|$ mal habyor spyod kyis la gnas pa thams cad kyi sbyor ba ni śes rab po \|l thams cad mkhyen pahi ye śes kyi lam la gnas pa mams kyi rab tu hudren pa ni śes rab po || ma rig pahi klun gi mun pa rab rib kyi sprin hjom par byed pas snan bar byed pa ni ses rab po || mig la ji ltar mos pas rnams kyi mig thams cad sbyin par byed pa ni ses rab po || mig dan gzugs kyi lam las hdas pahi phyir zag pa med pa ni ses rab po || bden pa las hbyun bas don dam pahi ni ses rab po $\|$ sin tu dul bahi phyir mi hkhrugs pa ni śes rab po || ye śes kyi sgohi snan ba ni śes rab po || thams cad du rgyu bas mi zad pa ni ses rab po \| rten cin hbrel ba la hjug par mthon bahi phyir | hgal ba med pa ni śes rab po \|l len pahi hicin ba thams cad gcod par byed pas thar pahi lam ni ses rab po || sgrib par byed pahi chos thams cad dan than du mi gnas pas ma ḥdres pa ni śes rab po \|| (continuation: sã rihi bu ...).

2. P nes par rtogs pahi phyogs kyi.

3. D pahi phyir; P R pahi.

4. $\mathrm{N}$ tshor. 
sim par byed paho \|| śes rab ni chos kyi dgaḥ ba la dmigs pa rnam par mi gcod pahi phyir rab tu dgah bar byed paho $\|$ ses rab ni ye ses thams cad mnon sum du gyur pahi phyir rten $^{1}$ paho || śes rab ni byan chub kyi phyogs kyi chos thams cad kyi gnas so $\|$ ses rab ni theg pa ji lta ba bźin $d^{2}$ ḥbras bu rtogs pahi phyir thob pahi mtshan ñid do \|| śes rab ni ran bźin gyis ye ses snan ba rab tu śes pahi mtshan ñid do \| śes rab ni chu bo thams cad las grol bahi phyir rab tu sgrol baho || śes rab ni yan dag par gyur pa la ḥdren paho | śes rab ni dge bahi chos thams cad rab tu hạdzin paho $\|^{3}$

Ses rab ni ñon mons pahi bag la ñal thams cad dan bar byed paho \| śes rab ni (687) chos thams cad kyi spyi bo thob pahi mchog go \| śes rab ni ran habyun bahi ye ses rtogs par bya ba la ${ }^{4}$ dam paḥo \| ses rab ni khams gsum dan ma ḥđres pas rgyu dan bral baho \| śes rab ni ḥphags pa thams cad kyis ${ }^{6} \sin$ tu bzun baho \| śes rab ni mtshan mar yons su rtog pa thams cad spańs pas smon lam mam par chad paho || śes rab ni mun pa mun gnag dan bral bas bag med pahii gñen poho $\|^{7}$

ses rab ni rnal ḥbyor spyod pahi sa la gnas pa thams cad kyi sbyor baho \| śes rab ni thams cad mkhyen pahi ye ses kyi lam $\mathrm{la}^{8}$ gnas pa rnams kyi rab tu ḥdren paho \| śes rab ni ma rig pahi rlun gi mun par rab rib kyi sprin hjom par byed ${ }^{9}$ pas snañ bar byed paho \|| śes rab ni

1. N brten.

2. P tu, for D N R gyi.

3. Pelliot, 977 , folio $6 \mathrm{a} .4-6 \mathrm{~b} .2$

Sa ri bu de la ses rab źes bya ba ni | hadi lta ste | dge bahi chos thams cad rab tu rtogs pa gan yin ba de ni mnon sum mthon bahi ses rab yin te | chos thams cad jes su rtog pahi phyir ro || yan dag pahi tshad mi śes rab yin te | yan dag pa ci lta ba bźin du chos thams cad rab tu rtogs pahi phyir ro \| rab tu rtogs pahi śes rab yin te | lta bar son bahi kun nas dkris pahi chos thams cad gyis bsgrib par myi hgyur bahi phyir ro || smon pa dan bral bahi ses rab yin te / hdod pa dan tshol ba dan | smon pa thams cad gtan du bspans pahi phyir ro || tshim bar byed pahi śes rab yin te | yons su gdun ba thams cad gtan du źi bar byed pahi phyir ro || rab tu dgah bar byed pahi śes rab yin te | chos kyi dgạ ba la dmyigs ba rgyun chad pa myed pahi phyir ro || rton pahi śes rab yin te | don ses pa mams mnon sum du gyur pahi phyir ro || rnam par hjog pa śes rab yin te $\|$ byan chub kyi phyogs kyi chos thams cad mam par hjog pahi phyir ro \| thob pahi mtshan nid gyi ses rab yin te || theg pa ci lta ba bźin du ḩbras bu thob par byed pahi phyir ro \| rab tu śes pahi śes rab kyi mtshan ñid kyi śes rab yin te | ye ses kyi ran bźin śin tu gsal bar rtogs pahi phyir ro || sñin rjes sgrol bar byed pahi Ses rab yin te | chu bo thams cad lam sgrol bar byed pahi phyir ro \| gźol bar byed pahi Ses rab yin te | yan dag pahi chos skye ba myed pa la gźol bar byed pahi phyir ro || sgul bar byed pahi śes rab yin te | dge bahị chos thams cad rab tu bskyod par byed pahi phyir ro $\|$.

4 D P R om: la.

5. D rgyu ba.

6. N kyi.

7. Pelliot, 977 , folio $6 \mathrm{~b} .2-5$

dan bar byed pahi śs rab yin te | snun gyi bag la ñal gyi ñon mons pahi rtọg pa dan bral bahi phyir ro || mchog tu gyur pahi śes rab yin te | chos thams cad kyi spyi bor phyin pahi phyir ro || sin tu gya nom bahi ses rab yin te | ran byun bahi ye ses kyis chos rjes su rtogs pahi phyir ro || rgyu dan bral bahi śes rab yin te | khams gsum gyi chos dan ḥdres pa myed pahi phyir ro || yons su bzun bahi śes rab yin te | ḥphags pa thams cad kyis yons su bzun bahi phyir ro || smon pa mam par gcod pahi ses rab yin te | mtshan mahi rnam par rtog pa thams cad yons su bsal bahi phyir ro || bdag myed pahi śes rab yin te | gti mug gyi mun nag thams cad spans pahi phyir ro 1.

8. Nom: la.

9. D byas. 
mig la ji ltar mos pa rnams kyi mig thams cad sbyin par byed paho \|| śes rab ni mig dan gzugs kyi lam las ḥdas paḥi phyir zag pa med paḥo \| śes rab ni bden pa las byun bas ${ }^{1}$ don dam paḥo \| śes rab ni sin tu dul baḥi phyir mi ḥkhrugs paḥo || ses rab ni ye ses kyi sgoḥi snan baḥo \| ses rab ni thams cad du rgyu ba $^{2}$ mi zad paho $\|$

ses rab ni rten cin hibrel par (ḩbyun ba) la hjug par mthon bahi phyir hagal ba med paho \|l śes rab ni len pahi ḥchin ba thams cad gcod par byed pas thar pahi lam mo \| śes rab ni sgrib par byed pahi ${ }^{3}$ chos thams cad dan lhan cig tu (688) mi gnas pas ma hidres paho $\|^{4}$

śā rihi bu de lta bas na sems can thams cad kyi sems kyi spyod pa ji sñed pa byan chub sems dpah rnams kyi śes rab kyi las dan | ye śes kyi spyod pa yan de sñed do || sems can thams cad kyi bsam pa ji sñed pa byan chub sems dpah śes rab kyi dpyod ${ }^{7}$ pa dan | ye śes kyan de sñed do $\|$ sems can thams cad kyi ñon mons pahi sgo ji sñed pa byan chub sems dpaḥ śes rab la hjug pahi sgo yan் de sñed do || ñan thos dan | ran sańs rgyas dań | yan dag par rdzogs pahi sańs rgyas rnams kyi yońs su ses pa ji sñed pa śes rab la gnas paḥi gnas kyan de sñed do $\|$ byan chub sems dpas thams cad $1 a^{8}$ bslab par bya ste | de ni byań chub sems dpahi ses rab ces byaho $\|^{9}$

1. D ba.

2. $\mathrm{N}$ bahi.

3. D add: phyir.

4. Pelliot, 977 , folio 6 b.5-7a.3

sbyor bahi śes rab yin te | rnal ḥbyor spyod pahi sa la gnas pa thams cad las mnon bar grub bahi phyir ro || bsgrod par byed pahi śes rab yin te | hiphags pahi ye śes kyi lam thams cad la rab tu gnas pahi phyir ro || snañ bar byed pahi śes rab yin te / ma rig pahi rlun kyis rab rib gyi mun pa thams cad yońs su bsal bahi phyir ro || myig sbyin bar byed pahi ses rab yin te | myig bźin du thams cad rab tu hidren par byed pahi phyir ro || zag pa myed pahi ses rab yin te | ses rab kyi myig gis gya gyuhi lam las yan dag par hadas pahi phyir ro || don dam pahi ses rab yin te | hphags pa chen pohi bden ba rab tu rtogs pahi pbyir ro | tha dad pa myed pahi śes rab yin te | sin tu dul bar gyur pahi phyir ro || snañ bahi śes rab yin te | ye śes mams kyi sgor gyur pahi pbyir ro | zad myi ses pahi ses rab yin te | rjes su rgyu ba thams cad kun tu snari bar byed pahi pbyir ro | hagag pa myed pahi ses rab yin te | rtag par rgya cher mthon bahi phyir ro || rnam par grol bahi lam gyi śes rab yin te | hadzin pahi hachin ba thams cad gtan du spon bahi phyir ro || gnas dan bral bahi śes rab yin te | ñon mons pahi sgrib pahi chos thams cad dan ltan cig myi gnas pahi phyir ro \|.

5. D N R dan.

6. P dan (also in the next occurrence of the term 'śes rab kyi').

7. D R spyod.

8. N om: la.

9. Pelliot, 977, folio 7a.3-7

śa ri bu de ltar ye śes kyi mtshan ñid nas mdor bsdus nas bstan pa yin te / byan chub sems dpah sems dpah chen po rnams kyi ses rab ni gźan yań tshad myed dpag tu myed pa sñed yod par rig par byaho $\|$ de ciḷi phyir źe na sa ri bu hadi ltar sems can thams cad kyi sems kyi spyod pa ci sñed pa | byan chub sems dpah sems dpah chen po rnams kyi śes rab kyi lam dan | ye śes kyi spyod pa de sñed yod pas so | de bźin du sems can thams cad kyi mos pa ci sñed pa byan chub sems dpah sems dpah chen po mams kyi śes rab kyi spyod pa dan | ye śes kyan de sñed yod par rig par byaḥo || de bźin du sems cad kyi ñon mons paḥi sgra ci sñed pa byan chub sems dpah sems dpah chen po | mams kyi śes rab rgya chen pohi sgra yan de sñed yod par rig par byaho || de bżin du ñan thos dañ | rañ sańs rgyas dan | yan dag par rdzogs pahi sañs rgyas thams cad gyi yons su mkhyen pa ci sñed pa | byan chub sems dpah sems dpah chen po rnams kyi ses rab kyi spyod pahi gnas kyan de sñed yod par rig par byaho $\|$ sa ri bu de ltar śes rab kyi gnas thams cad la byan chub sems dpah sems dpah chen po mams kyis nan tan brtson hgrus kyis bslab par bya ste | hdi ni byan chub sems dpaḥ sems dpạ̣ chen po mams kyi śes rab kyi nom ba źes byaho \|l. 


\section{2}

de la pha rol tu phyin pahi don gañ źe na / śes rab gan yin pa pha rol tu phyin pahi don kyan de yin te | dge baḥi chos rnams rab tu śes pa de ni pha rol tu phyin pạ̣i don źes byaho || gon ma bźin du sbyar te / pha rol tu phyin pa thams cad kyi tshig ${ }^{1}$ kyan de bźin du dpyad par byaho ${ }^{2} \|^{3}$

gźan yan byan chub sems dpaḥi spyod paḥi khyad par yoǹs su rdzogs pạ̣i don ni pha rol tu phyin paḥi don to \| gźan yan thams cad mkhyen paḥi ye ses yons su rdzogs pahi don ni pha rol tu phyin pahi don to $\|$ ḥdus byas dan ḥdus ma byas (689) pahi chos la mnon par ma chags pahi don ni pha rol tu phyin pahi don to $\|$ ḥkhor bahi ñes pa khon du chud pahi don ni pha rol tu phyin pahi don to ${ }^{4}||$ zad mi ses pahi chos kyi mdzod ston pahi don ni pha rol tu phyin pahi don to II sgrib pa med pahi mam par thar pa yons su rdzogs pahi don ni pha rol tu phyin pahi don to || sbyin pa mñam pa ñid dań | tshul khrims dan் | bzod pa dan | brtson higrus dan | bsam gtan dan் | ses rab mñam pa ñid rtogs paḥi don ni pha rol tu phyin pahi don to || rnam par nes pahi don ni pha rol tu phyin pahi don to $\|^{5}$

sems can thams cad kyi khams $1 a^{6}$ hjug pahi don ni pha rol to phyin pahi don to $\|$ mi skye bahi chos la bzod pa yons su rdzogs pahi don ni pha rol tu phyin pahi don to || phyir mi ldog pahi sa yons su rdzogs pahi don ni pha rol tu phyin paḥi don to \| sańs rgyas kyi źin yońs su rdzogs pahi don ni pha rol tu phyin pahi don to $\|$ sems can yoṅs su smin pahi ${ }^{7}$ don ni pha rol tu phyin pahi don to || byan chub kyi sñin po yan dag par thob pahi don ni pha rol tu phyin

1. N om: kyi tshig.

2. P sbyar ro, for D N R dpyad par byaho.

3. This paragraph is missing in the Pelliot manuscript.

4. N om: hkhor bahi ñes pa khon du chud pahi don ni pha rol tu phyin pahi don to.

5. Pelliot, 977 , folio $7 \mathrm{a} .7-7 \mathrm{~b} .6$

gźan yan śa ri bu byan chub sems dpah sems dpah chen po mams kyi pha rol tu phyin pahi don gan źe na | sa ri bu hdi ltar ci tsam du dge bahi chos gya nom ba pha rol tu phyin par hgyur ba rab tu ses pa thams cad ni pha rol tu phyin pahi don ces bya bar rig par byaho \|| yań sa ri bu gon ma bźin du rgyas par sbyar te | śes rab kyi tshogs thams cad ni pha rol tu phyin pahi don yin bar rig par byaho | gżan yan byan chub sems dpah mams kyi spyod pahi khyad bar yons su rdzogs pahi don gan yin ba thams cad ni pha rol tu phyin pahi don yin bar rig par byaho | hadus byas dan | hdus ma byas kyi chos thams cad la mnon bar źen pa myed pahi don gan yin ba de ni pha rol tu phyin pahi don yin bar tig par byaho | hkhor bahi ñes dmyigs chen po tshad myed pa rtag tu rtog pahi don gan yin ba de ni pha rol tu phyin pahi don yin bar rig par byaho / chos thams cad khon tu ma chud cin ma rtogs pahi don rab tu ses pa gan yin ba de ni pha rol tu phyin pahi don yin bar rig par byaho / gan gyis mthar thug cin zad pa myed pahi chos kyi mdzod kyi don rab tu rtogs pa gan yin ba de ni pha rol tu phyin pahi don yin bar rig par byaho || bsgrib pa myed pahi rnam par thar pa yons su rdzogs pahi don gan yin ba de ni | pha rol tu phyin pahi don yin bar rig par byaho | sbyin ba dan tshul khrims dan் | bzod pa dań | brtson hgrus dan | bsam gtan dan | ses rab mñam ba ñid du rtogs pahi don gan yin ba de ni pha rol tu phyin pahi don yin bar rig par byaho / mchog tu rab tu mam par hbyed pa la mkhas pahi don gani yin ba de ni pha rol tu phyin pahi don yin bar rig par byaho $\mid$.

6. Pom: la.

7. D R smin par bya bahi. 
pahi don to || bdud thams cad rab tu hdul bahi don ni pha rol tu phyin pahi don to || sańs rgyas kyi chos thams cad yons su rdzogs pahi don ni pha rol tu phyin pahi don to \| gźan yan byan chub sems dpahi sde snod kyi chos kyi rnam grańs bźag par byed pahi don ni pha rol tu phyin (690) pahi don to $\|$

sā riḥi bu byañ chub sems dpạ̣i sde snod kyi chos kyi mam grańs bslabs na / pha rol tu phyin pa thams cad kyi pha rol tu son bar hyyur ro $\|^{2}$

\section{SeCTion IV}

sã rihi bu de bas na theg pa chen po la gnas pahi rigs kyi buham | rigs kyi bu mos byan chub sems dpahi sde snod kyi chos kyi rnam grańs ḥdi blan bar bya / gzun bar bya | bklag par bya | gźan la yañ bśad par bya | rgya cher rab tu bstan par byaho ||

de cihi phyir źe na | śā riḥi bu byan chub sems dpahi sde snod kyi chos kyi rnam grañ sin tu mñan | blańs | bzun | bklags | kun chub par byas | gźan la yan் bśad | rgya cher yañ dag par rab tu bstan na | yon tan bcu po ḥdi dag ḥthob par hgyur ro ${ }^{3}$ || bcu gan źe na | hidi lta ste |

(1) tshe rabs gźan du hphos nas ${ }^{4}$ bzohi gnas dan |

(2) las kyi gnas thams cad ${ }^{5}$ rtogs par khon du chud par hgyur|

(3) rigs mtho zini btsun ${ }^{6}$ par hygur |

(4) dban che bar grags par hgyur ${ }^{7}$

(5) tshig btsun par hgyur |

(6) lons spyod che bar hgyur |

(7) lha dan mi rnams la ḥphañs par hgyur |

1. D N P R gźog.

2. Pelliot, 977 , folio $7 \mathrm{~b} .6-8 \mathrm{a} .3$

sems can gyi khams thams cad kun tu hgro bahi don gan yin ba de ni pha rol tu phyin pahi don ces byaho | myi skye bahi chos kyi bzod pa yons su rdzogs pahi don gan yin ba de ni pha rol tu phyin pahi don ces byaho | phyir myi ldog pahi ma mthar yons su rdzogs pa gan yin ba de ni pha rol tu phyin pahi don ces byaho | sans rgyas kyi zin yons su sbyon bahi don gan yin ba de ni pha rol tu phyin pahi don ces byaho | sems can thams cad yońs su smyin bar byed pahi don gan yin ba de ni pha rol tu phyin pahi don ces byaho | byan chub kyi sñin por son nas byan chub kyi gdan la hadug pahi don gan yin ba de ni pha rol tu phyin pahi don ces byaho | bdud kyi dpun rnams rab tu btul bahi don gan yin ba de ni pha rol tu phyin pahi don ces byaho | sans rgyas kyi chos thams cad yons su rdzogs pahi don gan yin ba de ni pha rol tu phyin pahi don ces byaho | byan chub sems dpahi sde snod chos kyi rnam grans la yan dag par gnas pahi don gan yin ba ni pha rol tu phyin pahi don ces byaho $\|$.

3. N thob par hgyur ro (also in all subsequent occurrences of the phrase 'hthob par hgyur ro').

4. D add: kyan.

5. D N add: la.

6. N brtson.

7. P mthu che bar hgyu, for D N R dban che bar grags par hgyur. 
(8) ḥkhor los sgyur baḥi rgyal po ḥthob par ḥgyur |

(9) tshañs par hithob par hgyur|

(10) thams cad du byan chub kyi sems dañ mi ḥbral bar hgyur te |

yon tan gyi phan yon ${ }^{1}$ ḥdi ḥthob par ḥgyur ro \| de gźan yan' yon tan gyi phan yon bcu ḥthob par hgyur te | bcu gań źe na | ḥdi lta ste |

(1) gcer bu pahi $i^{2}$ rtsod pa dan |(691) hạdres ${ }^{3}$ pa ma yin par hygur ba dan |

(2) bdag du mi lta ba dañ ${ }^{4}$

(3) sems can du mi lta ba dan் |

(4) srog du mi lta ba dań

(5) gañ zag tu mi lta ba dañ |

(6) chad par mi lta ba dan்

(7) rtag par mi lta bar hgyur ba dan |

(8) dnos po thams cad la mi lta ba dan |

(9) rab tu ḥbyun ba la dgah bar sems skyed pa ḥthob pa dan |

(10) thos pahi tshig hbru myur du khon du chud par hgyur ba ste |

yon tan gyi phan yon bcu po de dag ḥthob par ḥgyur ro \| de gźan yañ yon tan gyi phan yon bcu hthob par hgyur te | bcu gan źe na | (hidi lta ste |)

(1) dran pa dan ldan par hgyur ba dan |

(2) blo gros dan் ldan par hygur ba dan்

(3) rtogs pa dan Idan par ḩgyur ba dan |

(4) mos $\mathrm{pa}^{5}$ dan ldan par hgyur ba dan

(5) ses rab dań ldan par ḩgyur ba dan்

(6) dal ba phun sum tshogs $\mathrm{pa}^{6}$ rñed par hgyur ba dan்

(7) tshe rabs dran par hgyur ba dan |

(8) ran bźin gyis ḥdod chags chun ste | hadod chags bdo ba ma yin ${ }^{7}$ la $\mid$ de sin tu hdod chags kyi gdun bas yoǹs su mi gdun ba dan $\mid$

(9) ran bźin gyis źe sdań chun ste | źe sdañ bdo ba ma yin la | de sin tu źe sdañ gi gduñ bas

1. P legs pa (also in all subseqent occurrences of the term 'phan yon').

2. P gcer bu can gyi.

3. $\quad \mathrm{N}$ hidren.

4. P om: ba dan (also in the following four occurrences of the phrase 'Ita ba dan').

5. P dgah ba.

6. P om: phun sum tshogs pa.

7. P mi drag, for D N R bdo ba ma yin (also in the next two occurrences of this term). 
yońs su mi gdun ba dan |

(10) rañ bźin gyis gti mug chun ste | gti mug gi bdo ba ma yin la | de sin tu gti mug gdun bas yońs su mi gdun bar mi higyur ba ste|

yon tan gyi phan yon bcu po de dag hthob par hgyur ro \| de gźan yan yon tan gyi phan yon bcu hthob (692) par hgyur te | bcu gan źe na | hidi lta ste |

(1) Ses rab no mtshar du hgyur |

(2) ses rab myur bar hgyur

(3) ses rab rno bar hgyur |

(4) ses rab mgyogs par hgyur |

(5) ses rab rgya che bar hgyur |

(6) ses rab zab par ḥyur |

(7) śes rab nes par ḥbyed par hgyur |

(8) ses rab ma chags par hgyur |

(9) de bźin gśegs pa mnon du mthon źin mthon nas tshigs su bcad pahi dbyañs kyis bstod pa dan |

(10) de bźin gśegs pa la tshul bźin du² źu ba yoǹs su źu źin tshul bźin du ${ }^{3}$ źu ba ${ }^{4}$ źus nas lan ldon par ḩgyur ba ste |

yon tan gyi phan yon bcu po de dag ḥthob par hgyur ro \| de gźan yan yon tan gyi phan yon bcu ḥthob par hgyur te | bcu gañ źe na | ḥdi lta ste |

(1) dge bahi bśes gñen thams cad ma ñes bar byas par ḥgyur ba dan |

(2) bdud kyi bcin ${ }^{5}$ ba thams cad lhod par byas par ${ }^{6}$ hgyur ba dan |

(3) des bdud thams cad tshar gcod par hgyur ba dan

(4) ñon mons pa thams cad smad par hyyur ba dan |

(5) hidu byed thams cad du gtogs pa las yid bskyod ${ }^{7}$ par hygur ba dan |

(6) hgro ba nan par hgro bahi lam thams cad la rgyab kyis phyogs par ${ }^{8}$ hgyur ba dan $\mid$

(7) mya nan las hadas ${ }^{9}$ par hgro bahi ${ }^{10}$ lam mñon du hgyur ba dan |

1. P om: rgya che bar.

2. D N P R gyi.

3. D P R gyi.

4. N add: la.

5. $\mathrm{N}$ bcins.

6. N om: byas par.

7. D P R bskyed.

8. P las skyo ba, for D N R la rgyab kyis phyogs par.

9. D N P hdah.

10. D hagyur bahi. 
(8) ḩkhor ba thams cad las sgrol bahi sbyin pa byin par ḩgyur ba dan |

(9) byan chub sems dpạ̣ thams cad kyi cho gahi rjes su źugs par hgyur ba dan | (693)

(10) sańs rgyas bcom ldan ḥdas thams cad kyi bkahi rjes su źugs par ḥyur ba ste |

yon tan gyi phan yon bcu po de dag ḥthob par ḥgyur ro || sāa riḥi bu byan chub sems dpaḥi sde snod kyi chos kyi mam grańs śin tu mñan ${ }^{1}$ | blańs | bzun | bklags | kun chub par byas | gźan la yań bśad cin rgya cher yań dag par rab tu bstan na / yon tan gyi phan yon hadi sñed ḥthob par h.gyur ro $\|$

de nas bcom ldan hadas kyis don de ñid rgyas par ${ }^{2}$ bstan pahi phyir | dehi tshe tshigs su bcad pa ḥdi dag gsuńs so \|

gan dag mdo sdehi rgyal po ḥdi ḥdzin pa \|

mkhas pa de dag śes rab mthah yas hgyur $\|^{3}$

chos dañ don rnams la yań mkhas par hgyur $\|^{4}$

tshig kyaǹ khyad par ḥphags śin yi ge rdzogs $\|^{5}$

gan źig mdo sdeḥi rgyal po ḥdi ḥdzin pa \|

de ni rab dgah sin tu mgu skyes nas $\|$

dge slon de ni ḥdir yan chos ḥchad de $\|^{6}$

rtag tu chos kyi sbyin pa byed par hgyur \|

sems can rnams ni man du chos thos nas $\|$ kye maho yon tan chen po ḥchad byed pa \| nam źig bdag cag ḥdi ḥdrahi chos ston cin \| mdo sde ḥdi ḥdra ḥdzin par ḥgyur źes zer $\|^{7}$

gan dag de ḩdra ses rab ldan mchog rnams \| chos rnams gañ la yań źum par mi hgyur te $\|^{8}$

1. $\mathrm{N}$ gñan.

2. $P$ sin tu.

3. P mkhas pa ses rab mthah yas bar yan hgyur.

4. P chos mams dan ni don rnams la hadi gsal.

5. P tshig la mkhas sin yi ge yons su rdzogs par hgyur.

6. P dge slon chos hidi hchad pa byed pa dan.

7. P mdo sde hadi ni hadzin par ḩgyur źes ḥdod.

8 P chos gan lahan śes rab źum par mi ḥgyur te. 
dran dan ye ses kyis ni ḥphags pa dan $\|$

bla na med pahi ye śes tshig ston ${ }^{1}$ hgyur $\|$ (694)

gan dag mdo sdehi rgyal po ḥdi ḥdzin pa $\|$

de ni ḥphags pas rtag bsnaggs rgyal bas gnan \|

chos tshig legs par bsad pa tshol bar byed \|

de ni thos pas rtag tu ḥphags par hgyur $\|^{2}$

thos nas don ni ñe bar ${ }^{3}$ hdzin par byed $\|$

Śes rab ldan pa ḥbru la mi sñegs te ${ }^{4} \|$

don la lta bas rtogs pa ḥphel bar ḥgur \|

de yi ye śes rtag tu tshad med do $\|$

ye ses mthah yas don kyan mthah yas te $\|$

sems dpaḥ ${ }^{5}$ thah yas dam pahi don la mkhas $^{6} \|$

de yi yon tan phyogs dañ phyogs su higro ${ }^{7} \|$

de yi thos pahi yon tan hidi dag go $\|$

de yi ḥdod chags chun la źe sdań chun $\|$

de yi gti mug sin tu rab tu chun $\|$

sems kyañ ${ }^{8}$ sin tu dag pa ${ }^{9}$ rñed par hgyur $\|$

de yi thos pahi yon tan hadi dag go \|

lons spyod rñed nas rgyags par mi hygyur te If

hadi la sñin po ci źes don la rtog \|

lońs spyod sñin po med par rab śes nas \|

de ni lons spyod mi lta rab tu ḥbyun $\|$

1. P hchad.

2. $\mathrm{P}$ thos nas rtag tu mnion par dgah bar hgyur.

3. P mion par.

4. D sñems te; $P$ rgyug ste.

5. N P R sems pa.

6. P gstsal.

7. N dgro.

8. P kyi.

9. D dgah ba. 
khyim nas ${ }^{1}$ byun ste dgon par gnas $\|$

rtag tu g.yel ba ${ }^{2}$ med pa dan $\|$

chos rnams thos pas mi noms te $\|^{3}$

chos sbyin pa la ser sna med \|

hjig rten mgon pohi druñ ñid du \|

soń ste źu ba źu byed pas $\|^{4}$

de phyir de yi ye ses ${ }^{5}$ hphel \|

de la dkar po ḩbri ba med $\|$

sā rihi bu de ni byañ chub sems dpah rnams kyi ses rab kyi pha rol tu phyin pa ste / byan chub sems dpah de la brtson pa byan chub sems dpaḥi spyad pa spyod do ${ }^{6} \|$ de ni ses rab kyi pha rol tu phyin pa la brtson pa źes byaho \|

1. D N R mnion par.

2. P sinom pa.

3. P chos rnams thos nas chog mi ses.

4. P son ste źu ba źus byas pas.

5. N ses rab.

6. P sã rihi bu de ni byan chub sems dpah mams kyi gan la brtson na / byan chub sems dpaḥ byañ chub sems dpahi spyad pa spyod par hgyur bahi śes rab kyi pha rol tu phyin pa ste, for D N R śā rihi bu de ni ... źes byaho. 


\section{List of Abbreviations}

A:

AAWG:

Abhidh-d:

Abhidh-h (A):

Abhidh-h (W):

Abhidh-sam (R):

Abhidh-sam:

Abhisaml:

Adsp (C):

Akn:

Akn-țikā:

Akv:

ALB:

AM:

Amrtar (B):

AOH:

Arthav (S):

As:

Așta:

Aloka:

Bbh:

BEFEO:

Bdp:

Bhadra-vy:

Bhadra-vy (R):

Bpm:

Bṛhad:

BRS:

BSHS:

BSHWR:

BSR:

BTI:

Bv:

Chānd:

CPD:

CSTCC:

$\mathrm{D}$ :

Daśa-bh:
Añguttaranikāya (Hardy, E)

Abhandlungen der Akademie der Wissenschaften, Göttingen

Abhidharmadipa (Jaini, P)

Le Coeur de la Loi Supreme: Abhidharmahridaya (Armelin, I)

The Essence of Metaphysics: Abhidharmahrdaya (Willemen, C)

Le Compendium de la Super-Doctrine d'Asanga:

Abhidharmasamuccaya (Rahula, W)

Abhidharmasamuccaya (Pradhan, P)

Abhisamayālamkāra (Conze, E)

Aștādaśasāhasrikā Prajñāpāramitā (Conze, E)

Akșayamatinirdeśa (TTP 842)

Akșayamatinirdeśa-țikā (TTP 5495)

Abhidharmakośa-vibhāșā (Haribhadra)

Adyar Library Bulletin, Madras

Asia Major

La Saveur de l'Immortel: La version chinoise de l'Amṛtarasa de

Ghoșaka (T 1553) (Broek, J)

Acta Orientalia, Hungarian Academy of Science

Arthaviniścaya Sütra (Samtani, NH)

Atthasālinī (Buddhaghoșa: Müller, M)

Aștasāhasrikā Prajñāpāramitā (Vaidya, PL)

Abhisamayālaṃkārāloka (Wogihara, U)

Bodhisattvabhümi (Wogihara, U)

Bulletin de l'École Française d'Extrême Orient

Bodhisattvapițaka (R 11.11)

Bhadramāyākāravyākaraṇa (TTP 760.21)

Bhadramāyākāravyākaraṇa (Régamey, C)

Bodhisattvaprātimokṣasūtra (TTP 915)

Bṛhadāranyaka Upanișad

Bihar Research Society

Buddhist Studies in Honour of Hammalaya Saddhatissa

Buddhist Studies in Honour of Walpola Rahula

Buddhist Studies Review

Buddhist Text Information

Buddhavamsa (Jayawickrama, NA)

Chāndogya Upanișad

A Critical Pali Dictionary (Copenhagen, 1924)

Ch'u San tsang Chi Chi of Seng-yu (T 2145)

Dīghanikāya (Rhys Davids, TW; Carpenter, J E)

Daśabhūmika-Sūtram (Rahder, J: Daśabhūmika Sūtra et

Bodhisattvabhümi) 
Dbh-v:

Dbh:

Dhs:

Dhsg:

Dhsgr:

Divya:

DPP:

Gv:

HIIB:

HJAS:

IBK:

IBS:

IHQ:

IIJ:

IT:

Itv:

JA:

JAOS:

Jātaka:

JABS:

JIH:

JIP:

JRAS:

Karuṇāp (Y):

$\mathrm{Kv}$ :

Kośa:

Kośabhāșya:

Kośavyākhyā:

$\mathrm{Kp}$ :

Lal:

Lañkāv:

Lkdh:

M:

Madh. vrtti:

MBT:

Mavbh:

MCB:

Mil:

Mmg:

$\mathrm{MN}$ :

Mpps:

Msg:
Daśabhūmikavibhāṣāśāstra (

Daśabhūmikasūtra (TTP 572)

Dhammasanganii (Müller, M)

Dharmasangitisūtra (TTP 904)

Dharmasamgraha (Müller, M; Wenzel, H)

Divyāvadāna (Cowell, EB; Neil, RA)

The Doctrine of Prajñāpāramitā as exposed in the Abhisamayālaṃkāra of Maitreya (Obermiller, E)

Gaṇdavyūha Sūtra (Suzuki, TD; Idzumi, H)

History of Indian Buddhism (Lamotte, E)

Harvard Journal of Asiatic Studies

Indogaku Bukkyūgaku Kenkyū (Journal of Indian and Buddhist Studies) Indological and Buddhist Studies: Volume in Honour of Professor J.W. de Jong on his Sixtieth Birthday. ed. Hercus et al. Canberra: Faculty of Asian Studies, Canberra, 1982

Indian Historical Quarterly

Indo-Iranian Journal

Indologica Taurinensia, Turin

Itivuttaka (Windisch, E)

Journal Asiatique

Journal of the American Oriental Society

Jātaka with Commentary (Fausböll, V)

Journal of the International Association of Buddhist Studies

Journal of Indian History

Journal of Indian Philosophy

Journal of the Royal Asiatic Society

Karuṇāpuṇụarīka (Yamada, I)

Kāraṇụavyūha (Samasrami, SV)

Abhidharmakośa (La Vallée Poussin, L)

Abhidharmakośabhāșya (Pradhan, P)

Sphuțārthā Abhidharmakośavyākhyā (Wogihara, U)

KāSyapaparivarta (Stael-Holstein, A)

Lalitavistara (Lefmann, S)

Lañkāvatära Sūtra (Nanjio, B)

Lokadharapariprcchā (TTP 841)

Majjhimanikāya (Trenckner, V; Chalmers, R)

Prasannapadā Madhyamakavṛtti (La Vallée Poussin, L)

Minor Buddhist Texts (Tucci, G)

Madhyamakāvatāra (La Vallée Poussin, L)

Mélanges Chinois et Bouddhiques

Milindapañha (Treckner, V)

Mahāmeghasūtra (TTP 898)

Monumenta Nipponica

Le Traité de la Grande Vertu de Sagesse: Mahāprajñāpāramitā Sāstra

(Lamotte, É)

La Somme du Grand Véhicule d'Asanga: Mahāyanasamgraha (Lamotte, 
É)

Msl: $\quad$ Mahāyānasūtrālaṃkāra (Lévi, S)

Mvs: $\quad$ Madhyāntavibhāga-bhāșya

Mvś (N): $\quad$ Madhyāntavibhāga-bhāșya (Nagao, G)

Mvu:

Mahāvastu (Sénart, E)

$\mathrm{N}:$

A Catalogue of the Chinese Translation of the Buddhist Tripitaka

(Nanjio, B)

NAWG: $\quad$ Nachrichten der Akademie der Wissenschaften in Göttingen

Nett:

Nettippakarana (Hardy, E)

Nidd:

Ono:

Mahāniddesa (La Vallée Poussin, L; Thomes, EJ)

Otani:

Ono Gemmyo, ed. Bussho kaisetsu daijiten

A Comparative Analytical Catalogue of the Kanjur Division of the

Tibetan Tripitaka at Otani University

Pañca:

Pañcaviṃśatisāhasrikā Prajñāpāramitā (Dutt, N)

Pațis:

Pațisambhidāmagga (Taylor, AC)

PED:

PEFEO:

Pali English Dictionary (Rhys Davids, TW; Stede, W)

PIT:

Pps

PraS:

Publication de l'École Française d'Extrême Orient

Publicazioni di Indologica Taurinensia

Pitāputrasamāgamasūtra (TTP 760.16)

Prbh: $\quad$ Pratyekabuddhabhūmi (Wayman, A)

Prṇ:

Ps:

PTS:

Pürṇapariprcchā (TTP 760.18)

pw:

$\mathrm{R}:$

Papañcasūdani (Buddhaghoșa: Woods, JH; Kosambhi, D; Horner, IB)

The Pali Text Society

Kleines Petersburg Wörterbuch (Böhtlingk; Roth)

Rcd:

sTog Palace Kanjur (Leh-1979)

Rgv:

Ratnacūọaparipṭcchā (TTP 760.47)

RO:

Ratnagotravibhāga (Takasaki, J)

Rp:

Rocznik Orientalistyczny

Rtm:

Rāșțrapālapariprccchā (Finot, L)

S:

Ratnameghasūtra

Saddhp:

Samādh:

Samyuttanikāya (Feer, L)

Saddharmapundarika (Kern, H.; Nanjio, B )

Satya (S):

Samādhiräjasūtra (Dutt, N)

Samdhis (ÉLa): $\quad$ L'Explication des Mystéres: Sampdhinirmocana Sūtra (Lamotte, É)

SBE:

Sgm:

Sacred Books of the East (Müller, M)

Siddhi:

Sāgaramatipariprcchā (TTP 819)

SII: $\quad$ Studien zur Indologie und Iranistik

Sn:

Suttanipāta (Andersen, D; Smith, H)

Sp:

Samantapāsādikā (Buddhaghoșa: Takakusu, J.; Nagai, G)

Sv:

Śbh:

Śbh (S):

Sumañgalavilāsinī (Buddhaghoșa: Rhys Davids, TW)

Śgs:

Śrāvakabhūmi

Srāvakabhūmi (Shukla, K)

La Concentration de la Marche Héroique: Súramgamasamādhisūtra 
Sikș:

Sms:

Śsp:

$\mathrm{T}$ :

Th:

To:

TP:

TSWS:

TTD:

TTP:

Ug:

Vibh-a:

Vibh:

Vism:

Vin:

Vkn:

Vup:

WZKSO:

ZDMG:
(Lamotte, É)

Śikṣāsamuccaya (Bendall, C)

Śrīmālādevisiṃhanāda (TTP 760.48)

Śatasāhasrikā Prajñāpāramitā (Ghosa, P)

Taishō Shinshū Daizōkyō Edition of the Chinese Buddhist Canon

(Takakusu, J; Watanable, K)

Theragāthā (Oldenberg, H)

A Complete Catalogue of the Tibetan Buddhist Canon (Ui, H)

T'oung Pao

Tibetan Sanskrit Works Series

Tibetan Tripitaka sDe-dge Edition

Tibetan Tripitaka Peking Edition (Suzuki, DT)

Ugrapariprechā (TTP 760.19)

Vibhanga Commentary (Buddhadatta, AP)

Vihbanga (Rhys Davids, CAF)

Visuddhimagga (Buddhaghoșa: Warren, HC; Kosambhi, D)

Vinayapitaka (Oldenberg, $\mathrm{H}$ )

The Teaching of Vimalakirti: Vimalakirtinirdesa Sūtra (Lamotte, É)

Vinayaviniścaya-Upālipariprịcchā (Python, P)

Wiener Zeitschrift für die Kunde Süd- und Ostasiens

Zeitschrift der Deutschen Morgenländischen Gesellschaft 


\section{Bibliography}

Adikāram, E. W. Early History of Buddhism in Ceylon. Migoda; 1946.

Agasse, J. M. "Le transfert de mérite dans le bouddhisme pāli classique". JA. 1978: pp. 311-332.

Ahmad, Zahiruddin. Sino-Tibetan Relations in the Seventeenth Century. Rome; 1970.

Anacker, Stephen. tr. ed. Seven Works of Vasubandhu. New Delhi: Motilal Banarsidass;1986.

Armelin, I. Le Coeur de la Loi Supreme. Paris; 1978.

Aronson, Harvey B. "Buddhist and Non-Buddhist approaches to the sublime attitudes (brahmavihāra)". BSHS; 1984: pp. 16-24.

- "Equanimity (upekkhā) in Theravāda Buddhism". Studies in Pāli and Buddhism. ed. A.K. Narain. New Delhi; 1979; pp. 1-18.

- Love, Compassion, Sympathetic Joy and Equanimity in Theravāda Buddhism. Ph.D. Madison: University of Wisconsin; 1975.

Bagchi, Chandra Prabodh. Le Canon Bouddhique en Chine: Les Traducteurs et les Traductions. 2 vols. Paris: Librairie Orientaliste Paul Geuthner; 1927, 1938.

Bailey, Harold W. Prolexis to the Book of Zambasta. Khotanese Texts, 6; Cambridge: Cambridge University Press; 1967.

Bareau, André. "Le Dīpaṃkarajātaka des Dharmaguptaka". Mélanges de Sinologie offerts à M. Paul Demiéville. Paris: Bibliothèque de l'Institut des Hautes Études Chinioses, 20; 1966: pp. 1-17.

_. Les sects bouddhiques de Petit Véhicle. Saigon: PEFEO, 38; 1955.

Barua, D. L., ed. Cariyāpițaka Commentary. London: PTS; 1979.

Bauman, M. Konkurriende Erklärungen zur Enstehung des Mahāyāna Buddhismus. Magister Arbeit. Universität Marburg; 1988.

Beal, Samuel. Buddhist Literature in China. London: Trübner \& Co.; 1882.

—. The Life of Hiuen-Tsiang by Shaman Hwui. London: Trübner \& Co.; 1973.

—. Si-yu-ki: Buddhist Records of the Western World. London: Trübner \& Co.; 1884 (rp. 1973).

- Travels of Fa-hian and Sung-Yun: Buddhist Pilgrims from China to India (400 AD and 
518 AD). London: Trübner \& Co,; 1869.

Bechert, Heinz. ed. Abkürzungsverzeichnis zur buddhistischen Literatur in Indien und Südostasien. Göttingen: Van den Hoeck \& Ruprecht; 1990.

—. "Buddhafeld und Verdienstübertragung: Mahāyāna-ideen im Theravāda Buddhismus Ceylons". Bulletin de la Classe des Lettres et des Sciences Morales et Politiques. Academie Royale de Belgique. 1976; 62(5): pp. 27-51.

- ed. Sanskrit-Wörterbuch der buddhistischen Texte aus den Turfan-Funden. 6 vols. Göttingen: Van den Hoeck \& Ruprecht; 1973.

- Die Sprache der ältesten buddhistischen Überlieferung. AAWG. Göttingen: Van den Hoeck \& Ruprecht; 1980.

Beck, Hermann. "Verzeichniss der Tibetischen Handschriften". Die Handschriftenverzeichnisse der Königlichen Bibliothek zu Berlin. Berlin. 1914; 24: pp. 16-25.

Bendall, Cecil. ed. Sikṣāsamuccaya. St. Petersburg: Bibliotheca Buddhica, 1; 1902.

Bendall, Cecil; La Vallée Poussin, Louis de. "Bodhisattvabhūmi: A. Text-Book of the Yogācãra School". Le Muséon. 1905-1911; 6, 7, 12: pp. 40-52, pp. 213-230 and pp. 155-191.

Bendall, Cecil; Rouse, W. H. D. Sikșāsamuccaya: A Compendium of Buddhist Doctrine. Delhi: Motilal Banarsidass; 1981.

Bloch, J. Les Inscriptions d'Aśoka. Paris; 1950.

Bode, M. The Legend of Ratthapāla. Paris: Mélanges Sylvain Lévi; 1911.

Bollée, W. B. ed. tr. Kuñāla-Jātaka. London: PTS; 1970.

Böthlingk; Roth. Sanskrit Wörterbuch. St. Petersburg; 1852.

Braavrig, Jens. The Akșayamatinirdeśasūtra. 2 vols. Ph.D.; University of Oslo; 1989.

Broek, J. van den, tr. La Saveur de l'Immortel: La version chinoise de l'Amrtarasa de Ghoșaka (T 1553). Louvain-la-Neuve: Publication de l'Institut Orientaliste de Louvain; 1977.

Bronkhorst, Johannes. "Dharma and Abhidharma". BSOAS. 1985; 48: pp. 305-320.

Brough, John. "Comments on Third Century Shan-shan and the History of Buddhism". BSOAS. 1965; 28: pp. 582-612.

Buddhadatta, A. P. ed. Vibhanga Commentary. London: PTS; 1923.

Buddhaghoșa. Atthasālinī. Müller, M., ed. London: Pali Text Society; 1979. 
—. Atthasālinī. Pe Maung Tin, tr. The Expositor. London: PTS; 1976.

-. Manorathapürañi. ed. Walleser, M. PTS, 1973.

—. Samantapāsāadikā. 7 vols. ed. Takakusu, J.; Nagai, G. London: PTS; 1924.

—. Sumañgalavilāsinī. 3 vols. ed. Rhys Davids, T. W.; Carpenter, J. E.; Stede, W. London: PTS; 1886.

—. Sāratthappakāsinī. 3 vols. ed. Woodward, F. L. London: PTS; 1921.

—. Visuddhimagga. ed. Warren, H.C; Kosambhi, Dh. Visuddhimagga. Cambridge, Mass.: Harvard Oriental Series, 41; 1950.

Bugault, Guy. La Notion de Prajñā. Paris: Publication de l'Institut de Civilisation Indienne; 1982.

Burgess, James. Report on the Buddhist Cave Temples and their Inscriptions. Calcutta: Archeological Survey of Western India, $4 ; 1883$.

Burgess, James. Report on the Elaura Cave Temples. Calcutta: Archeological Survey of Western India, 5; 1883.

Chang, Garma C. C. A Treasury of Mahāyāna Sūtras. London: The Pennsylvania State University Press; 1983.

Ch'en, Kenneth K. S. Buddhism in China: A Historical Survey. Princeton, NJ.: Princeton University Press; 1964.

—. The Chinese Transformation of Buddhism. Princeton, NJ.: Princeton University Press; 1973.

—. "The Question of Rāșțrapāla". HJAS. 1954; 47: pp. 274-281.

—_. "The Role of Buddhist Monasteries in T'ang Society". History of Religions. 1976; 15(3): pp. 209-230.

—. "The Tibetan Tripițaka". HJAS. 1945-47; 9: pp. 53-63.

Ch'eng, Lü: "Bodhiruci”. Encyclopaedia of Buddhism. vol. iii; ed. Malalasekera; Colombo: Ceylon Government Press; 1971: pp. 222-224.

Chi-tsang. (Chia-hsiang ta shih). Shêng-man ching pao-k'u. T 37.1 (no. 1744); Kyōshobu: pp. 1-90.

Chih-chih. May, Jacques M. tr. Traite sur la méditation bouddhique. Paris; 1951.

Collins, Steven. "Kalyāṇamitta and Kalyāṇamittatā". Journal of the Pali Text Society. 1986: pp. $51-72$. 
Conze, Edward. tr. Abhisamāyalaṃkāra. Rome: Serie Orientale Roma, 6; 1954.

—_. ed. Aștadaśasāhasrikā Prajñāpāramitā. Rome: Serie Orientale Roma, 24; 1962.

- The Large Sütra on Perfect Wisdom. Berkeley, Cal.: University of California Press; 1975.

- The Perfection of Wisdom in Eight Thousand Lines and its Verse Summery. Bolinas, Cal.: Four Season Foundations; 1975.

- Prajñāpāramitā Literature. Tokyo: The Reiyukai Library; 1978.

—. The Short Prajñāpāramitā Texts. London: Luzac \& Co.; 1973.

- Vajracchedikā Prajñāpāramitā. Rome: Serie Orientale Roma, 13; 1974.

Conze, Edward. et al. ed. Buddhist Texts Through The Ages. Oxford: Bruno Cassirer; 1954.

Cousins, L.S. "Buddhist Jhāna: Its nature and attainment according to the Pāli Sources". Religion, 3; 1973: pp. 115-31.

—. "Samatha-yāna and Vipassanā-yāna". BSHS. ed. Dhammapala et al.; Nugegoda; pp. $56-68$.

Cowell, E. B. tr. The Jātaka or Stories of the Buddha's Former Lives. London: PTS; 1981.

Cowell. E.B.; Neil, R.A. Divyāvadāna. Cambridge; 1886.

Cüppers, Ch. The IXth Chapter of the Samādhirājasūtra. Hamburg: Franz Steiner Verlag; 1990.

Dhammapala, G.; Gombrich, R.; Norman, K. R., eds. Buddhist Studies in Honour of Hammalaya Saddhatissa. Nugegoda; 1984.

Dantinne, J. La Splendeur de l'Inébranlabe (Akșobhyavyūha). Louvain-la-Neuve: Publication de l'Institut Orientaliste de Louvain; 1983.

Das, Chandra S. A Tibetan-English Dictionary with Sanskrit Synonyms. Calcutta; 1902.

Dayal, Har. The Bodhisattva Doctrine in Buddhist Sanskrit Literature. Delhi; 1932 (rp. New Delhi: Motilal Barnisardass; 1978).

Demiéville, Paul. "Le Chapitre de la Bodhisattvabhūmi sur la Perfection de Dhyāna". RO. 1957; 21: pp. 109-128.

- Le concile de Lhasa: Une controverse sur le quiétisme entre bouddhistes de l'Inde et de la Chine au VIIIe siècle de l'ère chrétienne. Paris: Bibliothéque de l'Institut des Hautes Études Chinoises, 7; 1987.

—. "L'origine des sectes bouddhiques d'après Paramārtha". $M C B .1932$; 1: pp. 14-64. 
—. "La Pénétration du Bouddhism dans la tradition philosophique chinoise". Cahiers d'Histoire Mondiale. 1956; 3(1): pp. 19-36.

—. "Recents travaux sur Touen-houang". TP. 1970; 56: pp. 16-95.

—. "Sur la mémoire des existence antérieures". BEFEO. 1927; 27: pp. 283-298.

—. "La Yogācārabhūmi de Sañgharakșa". BEFEO. 1950; 44: pp. 339-436.

Demiéville, Paul; Durt, H.; Seidel, A. Répertoire du Canon Bouddhique Sino-Japonnais Edition de Taishō Shinshū Daizōkō. Fascicule Annexe du Hōbōgirin, Paris: Adrien Maisonneuve; 1978.

Dutoit, J. Die Dușkaracaryā des Bodhisattva. Strassbourg; 1905.

Dutt, Nalinakșa. “The Bodhisattva Prātimokșa Sūtra: Vinayaviniścaya-Upāliparipṛcchā Sūtra”. IHQ. 1931; 7: pp. 259-286.

—. Gilgit Manuscripts. Calcutta; 1943-53 (Delhi: Sri Satguru Publications; rp. 1984).

—. ed. Pañcavimíáatisāhasrikā Prajñāpāramitā. London: Calcutta Oriental Series, 28; 1934.

Edgerton, Franklin. Buddhist Hybrid Sanskrit. 2 vols. New Haven: Yale University Press. 1953.

Eimer, Helmut. Skizzen des Erlösungsweges in Buddhistischen Begriffsreihen. Bonn: Religionswissenschaftliches Seminar der Universität Bonn; 1976; Arbeitsmaterialien zur Religionsgeschichte; Publ. by Hans Joachim Klimkeit.

- - "Some Results on Recent Kanjur Research". Archiv für Zentralasiatische Geschichtsforschung. 1983; Heft 1: pp. 5-26.

—_. "Zur Beurteilung der Textqualität der Kanjur-Handschrift aus dem Palast in Tog, Ladakh." IBS. 1982: pp. 121-136.

Emmerick, Ronald E. The Book of Zambasta: A Khotanese Poem on Buddhism. London: Oxford University Press; 1968.

Ensink, Jacob. The Question of Rāstrapāla. Zwolle, Netherlands; 1952.

Erdman, S. K. "A Synopsis of the Sūtra of Brahma's Net of the Bodhisattva Precepts". Maha Bodhi. 1958; 66: pp. 393-399.

Ergardt, J. T. Faith and Knowledge in Early Buddhism. Leiden; 1977.

Fachow, W. "Development of Tripițaka-Translations in China". ed. D.R. Bhandarkar, B.C. Law Commemoration Volume. Calcutta: 1945; pp. 66-74.

Fausböll, V. ed. Jātaka with Commentary. London: PTS; 1897. 
Feer, L. "Analyse du Kandjour: Recueil de Livres Sacres au Tibet". Annales du Musée Guimet. 1881; 2: pp. 131-555.

—. ed. Samyutta-Nikāya. London: PTS; 1884.

Fernando, C. M. tr. The Nikãyasamgraha. Colombo: Sri Lanka Government Press; 1908.

Ferrari, Alfonsa. "Arthaviniścaya". Atti della Reale Academia D'Italia-Memorie della Classe di Scienze Morali e Storiche, Serie Settima, 1944; 4 (13): pp. 536-625.

Finot, Louis. Rāṣtrapālapariprcchā: Sūtra du Mahāyāna. St. Pétersbourg: Bibliotheca Buddhica, 2; 1910.

Foucaux, P. E. tr. Le Lalitavistara. Paris: Les Deux Océans. 1988.

Frauwallner, Erich. “Abhidharma Studien III: Der Abhisamayvadah.” WZKS. 1971; 15: pp. $16-121$

—. Geschichte der Indischen Philosophie. Salzburg: Otto Müller Verlag; 1956.

—. "Landmarks in the History of Buddhist Logic". WZKSO. 1961; 5: pp. 125-148.

Freeman, Charlotte. "Saṃṿ̣ti, Vyavahāra and Paramārtha in the Akșayamatinirdeśa and its Commentary". T. Skorupski, ed. The Buddhist Forum. London: SOAS; 1991; 2: pp. $97-115$.

Gard, Richard A. "Ratnakūța". BTI. 1982; 19, 20, 22, 28: p. 19, pp. 1-11, pp. 5-8, pp. 5-11. Gethin, Rupert. The Path to Awakening. 2 vols. Ph.D.; Manchester University; 1987.

Ghosa, P. ed. Satasāhasrikā Prajñāpāramitā. Calcutta: Bibliotheca Indica; 1914.

Giles, Lionel. A Descriptive Catalogue of the Chinese Manuscripts from Tun-huang in the British Museum. London; 1957.

Gombrich, Richard F. "Notes on the Brahmanical Background to Buddhist Ethics". BSHS. 1984: pp. 91-102.

Gombrich, Richard F.; Cone, M. The Perfect Generosity of Prince Vessantara. Oxford: At the Clarendon Press; 1977.

Richard Gombrich et al., ed. Buddhist Studies in Honour of Walpola Rahula. London: Gordon Fraser; 1980.

Gomez, Luis O. "The Bodhisattva as Wonder-worker". L. Lancaster, ed. Prajñāpāramitā and Related Systems. Berkeley, Cal.: Berkeley Buddhist Studies Series, 1; 1977: pp. 221-262.

Grey, L. Concordance of Buddhist Birth Stories. London: PTS; 1990.

Groot, J. J. M. de. Le Code du Mahāyāna en Chine. Amsterdam; 1893. 
Guenther, Herbert von. The Jewel Ornament of Liberation by sGam-po-pa. London; 1959.

-. Philosophy and Psychology in the Abhidharma. Delhi: Motilal Banarsidass; 1957.

Hahn, Michael. Jñānaśrīmitras Vṛttamālāstuti. Wiesbaden: Otto Harrassowitz Verlag; 1971.

-. Lehrbuch der Klassischen Tibetischen Schriftsprache. Bonn: Indica et Tibetica, 10; 1985.

Hamm, F. R. "Die Verkörperung der Bodhisattva im Pāli-Jätaka”. ZDMG. 1968; 112: pp. 357-366.

Hara, M. "A Note on the Buddha's Birth Story". Indianisme et Bouddhisme: Mélanges offerts à Mgr Étienne Lamotte. Louvain-la-Neuve: Publication de 1'Institut Orientaliste de Louvain; 1980; pp. 143-159.

—. "Notes on two Sanskrit religious terms bhakti and śraddha". IIJ. 1964; 12: pp. 123-45.

—. "Review of H. Köhler: Srad-dhä in der vedischen und altbuddhistichen Literatur". IIJ. 1977; 19: pp. 105-8.

—. "Sraddhaviśeṣa". IT.1979; 7: pp. 262-73.

Hardy, E. ed. Añguttara-Nikāya. London: PTS; 1895.

—. ed. Nettippakarana. London: PTS; 1902.

Hare, E. M. tr. Woven Cadences . London: PTS; 1947.

Harrison, Paul. "Buddhānusmṛti in the Pratyutpanna-buddha-sammmukhāvasthita-samādhisūtra". JIP. 1978; 9: pp. 35-57.

- - Pratyutpanna-buddha-sammukhāvasthita-samādhi-sütra. 2 vols. Ph.D.; Canberra: Australian National University; 1979.

—. "Who gets to ride in the Great Vehicle?" JIABS; 10: pp. 67-89.

Hedinger, Jürg. Aspekte der Schulung in der Laufbahn eines Boddhisattvas. Wiesbaden: Otto Harrassowitz; 1984.

Heissig, W.; Tucci, G.: Die Religionen Tibets und der Mongolei. Stuttgart: Kohlhammer Verlag; 1970.

Heng Ching. Kșitigarbha Bodhisattva Pranidhāna Sütra. New York: The Institute for Advanced Studies of World Religions; 1973.

Hikata. A Historical Study of the Thoughts in Jatakas and Similar Stories. Tokyo; 1954.

- Suvikrāntavikrāmipariprcchā Prajñāpāramitā Sūtra: An introductory essay on Prajñāpāramitā Literature. Fukuoka, Japan; 1958. 
ed. Suvikrāntavikrāmi Pariprcchā Prajñāpāramitā Sūtra. Fukuoka; 1958.

Hirakawa, Akira. Index to the Abhidharmakośabhāṣyam. 3 vols. Tokyo; 1978.

—_. "Bōsatsuzō-kyō to Hōyaku-kyō". SK. 1971; 45-2(209): pp. 1-26.

- "The Rise of Mahāyāna Buddhism and its Relationship to the Worship of Stūpas". Memoirs of the Research Department of the Toyo Bunko. 1963; 22: pp. 57-106.

—_. "Stūpa Worship". Eliade, M., ed. The Encyclopedia of Religion. 1987; 14: pp. 92-96.

Hodge, Stephen. "Considerations on the Dating and Geographical Origins of the MahāVairocana Abhisambodhi-Sūtra". London: The Buddhist Forum; forthcoming.

Hoernle, Rudolf. Manuscript Remains of Buddhist Literature found in Eastern Turkestan. Oxford: At the Clarendon Press; 1970.

- "Three further Collections of Ancient Manuscripts from Central Asia." Journal of the Royal Asiatic Society of Bengal. 1897; 66.

Honda, M. "Daśabhūmika Sūtra". Sinor, D., ed. Studies in South, East and Central Asia. New Delhi: International Academy of Indian Culture; 1968: pp. 115-276.

Horner, I. B. ed. Buddhavamsa Commentary. London: PTS; 1976.

—. tr. Clarifier of the Sweet Meaning. London: PTS; 1978.

—. tr. Milinda's Questions. London: PTS; 1963.

- tr. The Minor Anthologies of the Pali Cannon. London: PTS; 1975.

Hübotter. "Die Sūtra über Empfängniss und Embryology". Mitteilungen der Deutschen Gesellschaft für Natur und Völkerkunde Ostasiens, 36. 1932: pp. 7-25.

Jaini, P. S., ed. Abhidharmadipa. Patna: TSWS, 4; 1959.

ed. Pañ̃̄āsa-Jātaka. London: PTS; 1981.

Jayawickrama, N. A. ed. Buddhavamsa and Cariyāpitaka. London: PTS; 1974.

Jones, J. J. tr. The Mahāvastu. 3 vols. London: PTS; 1949.

Jong, J. W. de. "Remarks on the Text of the Rāșțrapālapariprcchā". ALB. 1968; 31-32: pp. $1-7$.

Johnston, E. H. ed. Ratnagotravibhāga Mahāyānottaratantraśāstra. Patna: Bihar Research Society; 1950.

Joshi, C. V. ed. Pațisambhidāmagga Commentary. London: PTS; 1933.

Kajiyama, Yuichi. "Bhāvaviveka, Sthiramati and Dharmapāla". WZKSO. 1969; 12/13: pp. 193-203. 
—." On the Meaning of the Words Bodhisattva and Mahāsattva in Prajñāpāramitā Literature". Hercus et al., ed. IBS; 1982: pp. 253-270.

Katz, Nathan. Buddhist Images of Human Perfection. New Delhi: Motilal Barnasidass; 1982.

Kawamura, L. S. "The Akșayamatinirdeśasūtra and Mi phan's mkhas 'jug”. Steinkellner, E.; Tauscher, H., ed. Contributions on Tibetan and Buddhst Religion and Philosophy. Wien: Universität Wien; 1983; 2; pp. 131-147.

—. The Bodhisattva Doctrine in Buddhism. Calgary, Canada: Canadian Corporation for Studies in Religion, University of Calgary; 1981.

Kern, H. Lotus of the Good Law. New York: Dover Publications; 1963.

Kern, H.; Nanjio, B. Saddharmapundarika. St. Pétersbourg: Bibliotheca Buddhica, 10; 1908.

Kloppenberg, R. The Paccekabuddha: A Buddhist Ascetic. Leiden: Brill; 1974.

Köhler. Sraddha in der vedischen und altbuddhistichen Literatur. Universität Göttingen Dissertation (1948). Wiesbaden: Otto Harrassowitz; 1973.

Konow, St. ed. Daśasāhasrikā Prajñāāāramitāa. Oslo; 1941.

La Vallée Poussin, Louis de. tr. L'Abhidharmakośa de Vasubandhu. 6 vols. Bruxelles: MCB; 1923-31 (rp. 1971-80).

—. ed. Bodhicaryāvatārapañjïka. Calcutta: Bibliotheca Indica; 1914.

—. "Bodhisattva". Encyclopaedia of Religion and Ethics. 1909; 2: pp. 739-753.

—. "Le Bouddha et les Abhijñās". Le Muséon. 1931: pp. 335-342.

- Catalogue of the Tibetan Manuscripts from Tun-huang in the India Office Library. Oxford; 1962.

—. "Documents d'Abhidharma: les deux, les quartre, les trois vérités". $M C B .1937 ; 5:$ pp. 1159-189.

—. Dynasties et histoire de l'Inde depuis Kanishka jusqu'aux invasions musulmanes. Paris; 1935.

- "Faith and Reason in Buddhism". Transactions of the Third International Congress for the History of Religions. 1908; 2: pp. 32-43.

- Madhyamakāvatāra par Candrakirti. St. Petersburg: Biliotheca Buddhica, 9; 1907-12.

—. "Madhyamakāvatārabhāṣya". Le Muséon. 1907: pp. 249-317; pp. 271-358; pp. 235-328.

—. "Musīla et Nārada: Le chemin de Nirvāṇa". MCB. 1937; 5: pp. 189-223.

- Mülamadyamikakārikās de Nagārjuna, avec la Prasannapadā de Candrakīrti. St. 
Pétersbourg: Bibliotheca Buddhica, 4; 1913.

__. "Notes sur le moment ou Kșana des bouddhists". RO. 1931; 8: pp. 1-9.

_. Thèorie des Douze Causes. Grand: Université de Grand (Receuil, Fasc. 40); 1913.

—. tr. Vijñaptimātratāsiddhi. 2 vols. Paris: Librairie Orientaliste Paul Geuthner; 1929.

—. "Le Vinaya et la pureté d'intention". BCLS. 1929: pp. 201-217.

La Vallée Poussin, L. de; Thomes, E.J. eds. Mahāniddesa. London: PTS; 1916, 1917 (rp. 1978).

Lalou, Marcelle. "Chine et Tibét aux vii", viii et ixº siècles". Journal des Savants. 1965: pp. $636 \mathrm{ff}$.

—. Inventaire des Manuscrits tibétains de Touen-houang. Paris: Bibliothèque Nationale; 1950.

—. "Les plus anciennes rouleaux tibetains trouvés à Touen-huang". $R O .1957 ; 21$ : pp. $149-52$.

-. "Les Texts Bouddhiques au Temps du Roi Khri-sron்-lde-bcan" JA. 1953; 241: pp. 313-353.

—_. "La version Tibétaine du Ratnakūța". JA. 1927; 211: pp. 233-259.

Lamotte, Étienne. La Concentration de la Marche Héroïque: Süramgamasamādhi Sūtra. Bruxelles; 1965.

—. "La critique d'authenticité dans le Bouddhisme". India Antiqua. 1947: pp. 213-222.

_. "La critique d'interpretation dans le Bouddhisme". Annuaire de l'Institut de Philologies et d'Histoires Orientales et Slaves. 1949; 9: pp. 341-361.

- History of Buddhism from the Origins to the Saka Era. Louvain-la-Neuve: Publication de l'Institut Orientaliste de Louvain; 1988.

—. "Mañjuśrī". TP. 1960; 48: pp. 1-96.

- Samdhinirmocana Sūtra: L'explication des mystères. Louvain-la-Neuve: Institut Orientaliste Louvain; 1935.

_. La Somme du Grand Véhicule d'Asañga: Mahāyanasamgraha, 2 vols. Louvain-LaNeuve: Institut Orientaliste Louvain; 1973.

-. "Sur La Formation Du Mahāyāna". Asiatica (Festschrift für FriedrichWeller). Leipzig: Otto Harrassowitz; 1954.

The Teaching of Vimalakirti. London: PTS; 1976. 
—. Le Traité de la Grande Vertu de Sagesse de Nāgārjuna: Mahāprajñāaäramitā Sāstra. 5 vols. Louvain-la-Neuve: Institut Orientaliste Louvain;1944-1980.

- Der Verfasser des Upadeśa und seine Quellen. NAWG. Göttingen: Van den Hoeck \& Ruprecht; 1973.

Lancaster, Lewis R. An Analysis of the Aștasāhasrikā Prajñāpāramitāsūtra from the Chinese Translation. Ph.D.; Madison: University of Wisconsin; 1968.

—. The Korean Buddhist Canon: A Descriptive Catalogue. Berkeley, Cal.: University of California Press; 1979.

_. "The oldest Mahāyāna Sūtra: Its Significance for the Study of Buddhist Development". The Eastern Buddhist. 1975; 8, 2: pp. 30-41.

—. "Samādhi Names in Buddhist Texts". ed. A. Wijesekara, Malalasekra Commemoration Volume. Colombo: 1976; pp. 196-202.

- ed. Studies in Honour of Edward Conze: Prajñäpäramitā and Related Systems. Berkeley, Cal., Buddhist Studies Series, 1; 1977.

Law, B. C., tr. The Debates Commentary. London: PTS; 1940.

Lefmann, S. ed. Lalitavistara. Halle a.S.; 1902.

Legge, James. A Record of Buddhist Kingdoms, ... Account, ... Chinese Monk Fa-hien of his Travels in India and Ceylon (A.D. 399-414). London: 1886 (rp. 1965).

Lethcoe Nancy R. "The Bodhisattva Ideal in the Așța and Pañcaprajñāpāramitā Sūtras". L. Lancaster, ed. Prajñāpāramitā and Related Systems. Berkeley, Cal.: Berkeley Buddhist Studies Series, 1; 1977: pp. 263-282.

Leumann, E. Das nordarische (saktische) Lehrgedicht des Buddhismus. Abhandlungen für die Kunde des Morgenlandes, 20; 1936.

Leumann, E.; Watanabe, K. "Synopsis of the Contents of the Bodhisattvabhūmi". ZDMG. 1908; 62: p. 89-94.

Lévi, Sylvain. "Aśvaghoșa: le Sūtrālaṃkāra et ses Sources". JA. 1908; 12: pp. 57-184.

—_. "Les Seize Arhat protecteurs de la Loi". JA. 1916; 8: pp. 5-50, pp. 189-304.

—. ed. \& tr. Mahāyānasūtrālaṃkāra. 2 vols. Paris: Bibliothèque de l'École des Hautes Études-Sciences Historiques et Philologiques; 1907, 1911.

Lévi, Sylvain; J. Takakusu; P. Demiéville. ed. Hōbōgirin: Dictionare encyclopédique du bouddhisme d'après les sources chinoises et japonaises. 5 vols. Paris: Maison Franco- 
Japonaise; 1929.

Li Yung-hsi. The life of Hsüan-tsang. Peking: Chinese Buddhist Association, San Shih Buddhist Institute; 1959.

Li-kouang, Lin. L'Aide-Mémoire de la Vrai Loi (Saddharmasmrtyupasthānasūtra). Paris; 1949.

Liebenthal, Walter. "A Biography of Chu Tao-sheng”. MN. 1955; 11: pp. 64-96.

- Chao Lun: The Treatises of Seng-chao. Hongkong: Hongkong University Press; 1968.

—. "Chinese Buddhism during the fourth and fifth centuries". $M N .1955$; 9(1): pp. 44-83.

Link, Arthur E. "Biography of Shih Tao-an". TP. 1958; 46: pp. 1-48.

- "The Earliest Chinese Account of the Compilation of the Tripitaka". JAOS. 1961; 81(1, 2): pp. 87-103, pp. 281-299.

-. "Remarks on Shih Seng-yu's Ch'u San-tsang chi chi as a Source for Hui-chiao's Kao-seng-chuan as Evidenced in Two Versions of the Biography of Tao-an." Oriens. 1957; 10: pp. 292-95.

—. "Shih Seng-yu and his Writings". JAOS. 1960; 80: pp. 17-43.

Maas, Paul. Textual Criticism. Oxford: At the Clarendon Press; 1958.

Malalasekera, G. P. Dictionary of Pāli Proper Names. 2 vols. London: Murray \& Co.; 1938.

Masefield, Peter. Divine Revelation in Pali Buddhism. Colombo; 1986.

Masuda, J. tr. "Origins and Doctrines of Early Indian Buddhist Schools". AM. ; 1925; 2: pp. 1-78.

May, Jacques M. "Chōjō”. Hobogorin. 1970; 4: pp. 353-360.

—_. "La Philosophie bouddhique Idéaliste". Asiatische Studien (Études Asiatique), 1927; 25: pp. 279-301.

—. tr. Prasannapadā Madhyamakavִritti. Paris: Adrien Maisonneuve; 1959.

Meadows, Carol. Ārya-Süra's Compendium of the Perfections: Pāramitāsamāsa. Bonn: Indica et Tibetica, 8; 1986.

Mironov, N. D. "Buddhist Miscellanea". JRAS, 1927: pp. 241-252.

Mochizuki, Shinkō. Bukkyō Daijiten. Kyoto; 1931-36.

Monier-Williams, M. A Sanskrit-English Dictionary. Oxford: At the Clarendon Press; 1988.

Morris, R. ed. Buddhavamsa and Cariyäpițaka. London: PTS; 1882.

—. ed. Puggalapaññatti. London: PTS; 1883. 
Müller, Max. tr. Amitābhavyūha. London: SBE; 1883.

—. ed. Dhammasañgani. London: PTS; 1885.

Müller, M.; Takakusu, J. Sukhāvativyūha. Tokyo; 1932.

Müller, M.; Wenzel, H. Dharmasamgraha. Oxford: Anecdota Oxoniensia, Aryan Series, 1.5; 1885 .

Nagao, Gadjin,. ed. "The bodhisattva returns to this world". Kawamura, L. S., ed. The Bodhisattva Doctrine in Buddhism. Calgary: Canadian Corperation for Studies in Religion; 1981; SR-Supplement: pp. 61-79.

—. Index to the Mahāyāna-Sūtrālamkāra: Edition Sylvain Lévi. Tokyo: Nippon Gakujutsu Shinkō-kai; 1958.

—. Madhyāntavibhāga-Bhāṣya. Tokyo: Suzuki Research Foundation; 1964.

Nakamura, Hajime. ed. Bukkyō-go Daijiten: Dictionary of Buddhist terms. 3 vols. Tokyo: Shoseki Kabushiki Kaisha; 1975.

—. "Historical Studies of the Coming into Existence of Mahāyāna Sūtras". OkurayamaGaikuin-Kiyo (Bulletin of Okurayama Institute). 1956; 2: pp. 1-22.

Nanjio, B. ed. Lañkāvatāra Sütra. Kyoto: The Sanskrit Buddhist Texts Publishing Society; 1932.

- A Catalogue of the Chinese Translation of the Buddhist Tripitaka: The Sacred Canon of the Buddhists in China and Japan. Oxford: At the Clarendon Press; 1883 (rp. 1975).

Norman, K. R. tr. The Group of Discourses. London: PTS; 1984.

Ñāṇamoli, Bhikkhu. tr. The Guide. London: PTS; 1962.

—. tr. The Path of Discrimination. London: PTS; 1982.

- tr. The Path of Purification. London: PTS; 1956.

O’Brien, P. "A Chapter on Reality from the Madhyāntavibhāga-sāstra”. MN. 1953; 9, 10: pp. 277-303, pp. 227-269.

Obermiller, E. Analysis of the Abhisamayālamkāra. Calcutta: Oriental Series; 1943.

—. "The Doctrine of Prajñāpāramitā as exposed in the Abhisamayālaṃkāra of Maitreya". AOH. 1933; 9: pp. 1-33, pp. 34-54.

- tr. History of Buddhism. Chos-ḥbyun by Bu-ston. 2 vols. Heidelberg; 1931-32.

—. The Sublime Science of the Great Vehicle to Salvation. AOH. 1931; 9(part 2-4). 
Obermiller, E.; Stcherbatsky, Theodore. Abhisamayālañkara-Prajñāpāramitā-UpadeśaŚāstra. St. Petersburg: Bibliotheca Buddhica, 23; 1937.

Oldenberg, H. ed. Theragāthā. London: PTS; 1883.

-. ed. Vinayapitaka. 5 vols. London: PTS; 1983.

Ono, Gemmyo. Bussho Kaisetsu Daijiten. Tokyo: Daito Shuppansha; 1933-38.

Pagel, Ulrich. "The Bodhisattvapițaka and the Akșayamatinirdeśa". T. Skorupski, ed. The Buddhist Forum. London: SOAS; forthcoming.

Panglung, J.L. Die Erzählstoffe des Mülasarvāstivāda Vinaya. Tokyo: The Reiyukai Library; 1981.

Pedersen, Priscilla. The Dhyāna Chapter of the Bodhisattvapitaka Sütra. Ph.D. New York, D.C.: Columbia University; 1976.

Pradhan, P. ed. Abhidharmakośabhāṣya. Patna: TSWS, 8; 1967.

. ed. Abhidharmasamuccaya. Shantiniketan, India: Viśva Bharatī Studies, 12; 1950.

Przyluski, Jean. Le Concile de Rājagrha: Introduction à l'Histoire des Canons et des Sectes Bouddhiques. Paris: Libairie Orientaliste Paul Geuthner; 1926.

—. La Légende de l'Empereur Aśoka. Paris: Librairie Orientaliste Paul Geuthner; 1923.

—_. "Les Vidyārāja: Contribution à l'Histoire de la Magie dans les Sectes Mahāyānistes". BEFEO. 1923; 23: pp. 301-318.

—_. "La Voyage du Bouddha dans le Nord-Ouest de l'Inde". JA. 1914; 4: pp. 495-537.

Pye, Michael. Skillful Means: A Concept in Mahāyāna Buddhism. London: Duckworth; 1978.

Python, Pierre. ed. tr. Vinayaviniścaya-Upālipariprcchā. Paris: Adrien Maisonneuve; 1973.

Rahder, Johannes. "La carrière du sainte bouddhique". Bulletin de la Maison Franco-Japonaise. 1929: pp. 1-22.

—_. "Daśabhümika-Sūtram". Le Muséon. 1926; 39: pp. 125-250.

—. "Daśabūmika-Sūtram", (Seventh Stage). Acta Orientalia, Societates Orientales Batava Danica Norvegica. 1924; 3: pp. 215-256.

—. "The Gāthā Portion of the Daśabhūmika Sūtra". The Eastern Buddhist. 1931; 5(4): pp. 335-359.

—. Daśabhūmika Sūtra et Bodhisattvabhūmi. Paris: Libairie Orientaliste Paul Geuthner; 1926. 
- Glossary of the Sanskrit, Tibetan, Mongolian and Chinese versions of the Daśabhümika Sütra. Paris: Librairie Orientaliste Paul Geuthner; 1928.

Rahula, Walpola. Le Compendium de la Super-Doctrine d'Asanga: Abhidharmasamuccaya. Paris: PEFEO; 1980.

- History of Buddhism in Ceylon. Colombo; 1956.

—_. "L'Idéal du Bodhisattva dans le Theravāda et le Mahāyāna". JA. 1971; 259: pp. 63-70.

Ratnayaka, Shanta. "The Bodhisattva Ideal of the Theravāda". JIABS. 1985; 8(2): pp. 85-110. Régamey, Constantin. The Bhadramāyākäravyākaraṇa. Warsaw; 1938.

- Philosophy in the Samādhirājasūtra. Warsaw; 1938.

Renou, Louis; Filliozat, Jean, Demiéville, Paul. L'Inde Classique. 2 vols. PEFEO. 1953.

Rhys Davids, C. A. F. tr. Buddhist Psychological Ethics. London: PTS; 1974.

—. tr. Mahāsatipațthāna Sutta. London: PTS; 1910.

- ed. Vihbanga. London: PTS; 1904.

Rhys Davids, C. A. F.; Aung, S. Z. tr. Points of Controversy. London: PTS; 1915.

Rhys Davids, T. W.; Carpenter, J. E. ed. Digha-Nikāya. 3 vols. London: PTS; 1889.

—. ed. Sumañgalavilāsinī. 3 vols. London: PTS; 1968.

Rhys Davids, T. W.; W. Stede. The Pali Text Society's Pali-English Dictionary. London: Luzac \& Co.; 1925.

Robinson, R. H. "The Ethics of the Householder Bodhisattva". Bharati: Bulletin of the College of Indology. 1965; 9(2): pp. 25-55.

Rockwell, John. Samādhi and Patient Acceptance. MA Dissertation. Boulder Col.: The Naropa Institute; 1980.

Ruegg, David Seyfort. Buddha-nature, Mind and the Problem of Gradualism in a Comparative Perspective. London: SOAS; 1989.

- The Literature of the Madhyamaka School of Philosophy in India. Wiesbaden: Otto Harrassowitz; 1981.

—. "The Meaning of the Term Gotra". BSOAS. 1976; 39; pp. $341 \mathrm{ff}$.

—. "A Propos of a Recent Contribution to Tibetan and Buddhist Studies". JAOS. 1962; 82(3); pp. 320-331.

Saddhatissa, H. ed. Dasabodhisattuppattikathā. London: PTS; 1975.

—. tr. Birth Stories of the Ten Bodhisattvas. London: PTS; 1975. 
Sakaki. Mahāvyupatti. 2 vols. Kyoto; 1916-1925.

Sakurabe, Bunkyō. "Saizō-Daihōjaku-kyōno Kenkyū”. Otani Gekuhō. 1930; 11(3): pp. 134-175.

Samasrami, S.V. ed. Kāraṇdavyūha. Calcutta; 1873.

Samtani, N. H. ed. Arthaviniścaya Sütra. Patna: TSWS, 13; 1971.

Sasaki, G. H. "Khanti, Kānti, Kṣānti”. IBK. 1958; 7(1): p. 359-354.

Sastri, Aśoka Chatterjee. ed. tr. Satyasiddhiśāstra. 2 vols. Baroda: University of Baroda Press; 1978.

Schiefner, Anton. tr. Täranātha's Geschichte des Buddhismus in Indien. St. Petersburg; 1869.

Schmithausen, Lambert. Alayavijñana: On the Origin and Development of the a Central Concept of Yogācāra Philosophy. 2 vols. Tokyo: The Reiyukai Library; 1987.

—. "The Darśanamārga Section of the Abhidharmasamuccaya". E. Steinkeller; H. Tauscher. ed. Contributions on Tibetan and Buddhist Religion and Philosophy. Wien: 1983; pp. 259-274.

—. "Die letzten Seiten der Śāvakabhūmi". Hercus et al., ed. IBS; 1982: pp. 457-491.

—. "Zur Literaturgeschichte der älteren Yogācāra Schule". ZDMG. 1968; 2(Supplementum I): pp. 811-823.

- "On some aspects of descriptions or theories of 'liberating insight' and 'enlightenment' in early Buddhism". K Bruhn; A Wetzler, ed. Studien zum Jainismus und Buddhismus: Gedenkschrift für Ludwig Alsdorf. Wiesbaden: 1980; pp. 240-244.

- - "Textgeschichtliche Beobachtungen zum ersten Kapitel der Aṣțasāhasrikā Prajñāpāramitā". L. Lancaster, ed. Prajñāpāramitā and Related Systems. Berkeley, Cal.: Berkeley Buddhist Studies Series, 1; 1977: pp. 35-82.

—. "Die vier Konzentrationen der Aufmerksamkeit". Zeitschrift für Missionswissenschaft and Religionswissenschaft. 1976; 60: pp. 241-266.

Schopen, Gregory. "Edward Conze: The large Sūtra of Perfect Wisdom with the Division of the Abhisamayālamkāra". IIJ. 1977; 19: pp. 135-152.

- "The generalisation of an old yogic attainment in medieval Mahāyāna Sūtra literature: some notes on jatismara". JIABS. 1983; 6(1): pp. 109-147.

- "The inscription of the Kușān image of Amitābha and the character of the early 
Mahāyāna in India". JIABS. 1987; 10(2): pp. 99-134.

—. "Mahāyāna in Indian Inscriptions". IIJ. 1979; 21(1): pp. 1-19.

—. "The Phrase "sa prthivipradeśaś caityabhūto bhavet" in the Vajracchedikā: Notes on the Cult of the Book in Mahāyāna". IIJ. 1975; 17: pp. 147-181.

—. "Two Problems in the History of Indian Buddhism: The Layman/Monk Distinction and the Doctrine of the Transference of Merit". SII. 1985; 10: pp. 9-47.

—_. "Sukhāvatī as a Generalized Religious Goal in Sanskrit Mahāyāna Sūtra Literature". IIJ. 1977; 19: pp. 177-210.

Schuster, Nancy Joann. "The Bodhisattva Figure in the Ugrapariprcchā”. ed. Warder, A. K., New Paths in Buddhist Research. Durham, NC: The Acron Press; 1985: pp. 26-57.

—. The Ugrapariprcchā: the Mahāratnakūța Sūtra and Early Mahāyāna Buddhism. 2 vols. Ph.D. Toronto: University of Toronto; 1976.

Sénart, E. ed. Mahãvastu. 3 vols. Paris; 1897.

Shih, Robert. Biographies des Moines éminents (Kao Seng Tchouan) de Houei-kiao. Louvainla-Neuve: Bibliothèque du Muséon, 54; 1968.

Shukla, K. ed. Śrāvakabhūmi. Patna: TSWS, 19; 1973.

Simonsson, Nils. Indo-Tibetische Studien. Uppsala: Almsquist-Wiksells; 1957.

—. "Zur Indo-Tibetischen Textkritik". Orientalia Svecana. 1953; 2; pp. 129-152.

Skorupski, Tadeusz. A Catalogue of the sTog-Palace Kanjur. Tokyo: The Reiyukai Library; 1985.

—. ed. The Buddhist Heritage. Tring: The Institute of Buddhist Studies; 1989.

Smith, H. ed. Suttanipāta Commentary. London: PTS; 1918.

Stael-Holstein, A. von. A Commentary to the Kāśyapaparivarta. Peking; 1933.

—. The Kāśyapaparivarta: A Mahäyäna Sütra of the Ratnakūta Class. Shanghai; 1926.

Stanton-Pedersen, Priscilla. "Notes on the Ratnaküța Collection”. JIABS. 1980; 3(2): pp. $60-66$.

Stcherbatsky, Th. ed. Abhisamayālaṃkära. Leningrad: Bibliotheca Buddhica, 23; 1929.

—. ed. Nyāyabindu. St. Petersburg: Bibliotheca Buddhica, 7; 1918.

Suzuki, D.T. tr. The Lankavatara Sutra. London: Routledge \& Kegan Paul; 1978.

- The Tibetan Tripitaka Peking Edition. Tokyo: Tibetan Tripițaka Research Institute; 1956. 
Suzuki, D.T.; Idzumi, H. Gandavyūha Sūtra. Kyoto: The Sanskrit Buddhist Text Publishing Society; 1934.

Takasaki, Jikido. A Study on the Ratnagotravibhāga (Uttaratantra): Being a Treatise on the Tathāgatagarbha Theory of Mahāyāna Buddhism. Rome: Serie Orientale Roma, 33; 1966.

—_. "Bosatsuzō-kyō ni tsuite". IBK. 1974; 22(2): pp. 578-586.

Takakusu, J. "A Study of Paramārtha's Life of Vasubandhu, and the Date of Vasubandhu". JRAS. 1905: pp. 33-53.

Takakusu, J.; Watanabe, K. Taishō Shinshū Daizōkyō Tripitaka Collection. Tokyo; 1924-1933.

Tatz, Mark. Asanga's Chapter on Ethics with the Commentary of Tsong-kha-pa. Lewiston, N.Y.: The Edwin Mellen Press; 1986.

—_. "The Skill in Means Sutra". Shunyata. 1981; 3(1): pp. 24-39.

Taylor, A. C. ed. Kathāvatthu. London: PTS; 1894.

—. ed. Patisambhidāmagga. London: PTS; 1979

Thomas, E. J. "The Lalitavistara and Sarvāstivāda". IHQ. 1940; 40: pp. 239-245.

Trenckner, V. ed. Milindapañha. London: PTS; 1880.

Trenckner, V.; Chalmers, R. ed. Majjhima-Nikäya. 3 vols. London: PTS; 1902.

Tsukamoto, Zenryu. "The Early Stages in the Introduction of Buddhism into China". Cahiers d'Histoire Mondiale. 1960; 5: pp. 546-572.

Tucci, Giuseppe. ed. Minor Buddhist Texts. 3 vols. Rome: Serie Orientale Roma; 1956.

Ui, H. Index to the Bodhisattvabhūmi. Tokyo; 1961.

ed. Saptaśatikaprajñāpāramitā. Rome: Mémorie d. R. Academia dei Lincei; 1923.

Vaidya, P. L. ed. "Așțasāhasrikā Prajñāpāramitā". Mahāyāna-Sūtra-Saṃgraha. Darbhanga: Mithila Institute; 1960.

Vorob'jev-Desjatovski. "A Sanskrit Manuscript-fragment of the Kāśyapaparivarta”. RO. 21: pp. $491 \mathrm{ff}$.

Waldschmidt, Ernst. ed. tr. Das Mahāparinirvāṇa Sütra. 3 vols. Berlin; 1951.

- Bruchstücke Buddhistischer Sütras aus dem zentral asiatischen Sanskrit Kanon. Königlich Preussische Turfan Expedition Kleiner Sanskrit Texte, 4. Leipzig; 1932.

- Das Catusparisasūtra: Eine Kanonische Lehrschrift über die Begründung der buddhistischen Gemeinde. Berlin; 1952-62. 
- "The Rāșțapālasūtra in Sanskrit Remnants from Central Asia". Indianisme et Bouddhisme: Mélanges offerts à Mgr Étienne Lamotte. Louvain-la-Neuve: Publication de l'Institut Orientaliste de Louvain; 1980; pp. 359-374.

-. Sanskrit Handschriften aus den Turfanfunden. Wiesbaden; 1965.

Waley, A. The Real Tripitaka. London: George Allen and Unwin; 1952.

Warder, Anthony K. Indian Buddhism. New Delhi: Motilal Banarsidass; 1980.

—. "Original Buddhism and Mahāyāna". PIT. 1983; Collana di Letture(16): pp. 1-43.

Wayman, Alex. Analysis of the Srāvakabhūmi Manuscript of Asanga. Berkeley, Cal.: University of California Press; 1961.

—. "The Bodhisattva practice according to the Lam-Rin-Chen-Mo". The Tibet Society Newsletter. 1967; 1(2): pp. 85-100.

- Ethics of Tibet: The Bodhisattva Chapter of Tsong-kha-pa's Lam Rim Chem mo. Albany, N.Y.: State University of New York Press; 1991.

- "Nescience and Insight according to Asanga's Yogācārabhūmi". Richard Gombrich et al., ed. BSHWR. London: Gordon Fraser; 1980: pp. 251-267.

—. ed. "Pratyekabuddhabhümi". IBK. 1960; 8(1): pp. 379-75.

—. "A Report on the Srāvakabhūmi and its Author Asanga". BRS. 1956; 42(3, 4): pp. $1-14$.

—. "Studies in Yāma and Māra". IJJ. 1959; 3: pp. 44-73.

Wayman, Alex; Wayman, H. The Lion's Roar of Queen Srīmālā. New York: Columbia University Press; 1974.

Weller, Friedrich. "Zum Kāśyapaparivarta". Abhandlungen der Sächsischen Akademie der Wissenschaften zu Leipzig. 1965; 57: pp. 5-160.

Willemen, C. The Essence of Metaphysics. Bruxelles; 1975.

Williams, Paul. Mahāyāna Buddhism. London: Routledge; 1989.

Willis, Janice Dean. ed. tr. On Knowing Reality: The Tattvārtha Chapter of Asanga's Bodhisattvabhūmi. New Delhi: Motilal Banarsidass; 1979.

Windisch, E. ed. Itivuttaka. London: PTS; 1890.

Winternitz, Moritz. A History of Indian Literature. Calcutta; 1933.

-. Der Mahāyāna Buddhismus. Tübingen: Paul Siebeck Verlag; 1930.

Wogihara, Unrai. ed. Sphūṭārthā Abhidharmakośavyākhyā. Tokyo; 1932. 


\section{Errata Corrige}

p. 19.17

p. 21.15

p. 23.21

p. 26, n. 45

p. 33.7

p. 40.10

p. 49.13

p. 54 , n. 129

p. 54, in. 129

p. 56, n. 139

p. 56, n. 139

p. 56, n. 139

p. 63.23

p. 66.17

p. 71, n. 2

p. 90, n. 10

p. 90, n. 13

p. 94 , n. 25

p. 99.15

p. 99, n. 36

p. 103, n. 57

p. 108.17

p. 110 , n. 80

p. 117, n. 5

p. 118.6

p. 118.13

p. 121.11

p. 121.4

p. 125, n. 47

p. 126, n. 52

p. 128.15

p. 129.14

p. 130, n. 68

p. 138, n. 104

p. 141.6

p. 148 , n. 158

p. 149.1

p. 149.20

p. 151, n. 168

p. 157.22

p. 161, n. 212

p. 166.15

p. 169, n. 252

p. 175 , n. 283

p. 176, n. 287

p. 177, n. 295

p. 177 , n. 297 for: Sukhāvativyūha, read: Sukhāvatīvyūha (ibid., p. 50, n. 111)

for: Bodhisattvapițakasūtra, read: Bodhisattvapițaka

for: forth, read: fourth

for: additional, read: variant

for: chapters, read: discussions

for: Asanga while Aśvabhāsa, read: Asvabhāva while Asañga

for: bodhisattva, read: bodhisattvas

for: Rșivyasapariprechā, read: Rșivyāsapariprcchā

for: Śubhākarasiṃha's, read: Subhakarasimha's

for: $T$ 1526, read: $T 1521$

for: In the Chinese translation of the Suvikrāntavikrāmapariprcchā

Prajñāpāramitāsütra, read: In Seng-yu's catalogue

for: include it under, read: include its abstract. under

for: nineteen, read: twenty

for: Vimaladattaparipṛcchā, read: Vimaladattāpariprechā

for: Hsuan-tsang, read: Hsüan-tsang

for: Trisamvsranirdeśaparivarta, read: Trisampvaranirdeśaparivarta

for: Bdp, read: Ug

delete: and, of course, the Bdp

for: selected the pāramitā, read: selected pāramitā

for: twenty-one, read: twenty-three

for: Viradattag̣̣hapatiparipṛcchā, read: Vīradattag̣̣hapatiparipṛcchā (ibid., p.

107, n. 70 )

for: out the, read: out of the

for: pp. ix-x, read: pp. 5-15

for: Msl, read: cf. Msl

for: signals, read: signal

for: stage nine and ten, read: stage eight and nine

for: parārthālaṃbana, read: parārthālambana

for: calm nirvāna, read: that nirvāna is calm

for: Teviggasutta, read: Tevijjasutta

for: arūpyadhātu, read: ārūpyadhātu (ibid., p. 129 , n. $63 ;$ p. 136.11; p. 162, n. 213 ; p. 243.8; p. 315, n. 3)

for: giving?, read: giving.

for: friendliness, read: benevolence

for: are presented, read: is presented

for: are linked with, read: being linked with

for: to follow in, read: to follow

for: pp. 42.2 read: pp. 42.3 .2

for: manifest, read: manifesting

delete: (sarvadharmatā)

or: by absence of duality, gift, read: by absence of duality, his gift

for: śrāvakayāna, read: Śrāvakayāna

for: sādhāraṇāsādhāranaśikșaviśeșa, read: sādhāranāaādhāranaśikșāviśeșa

for: daśakusala, read: akuśalakarmapatha

for: holders of little worth, read: holders are of little worth

delete: (trsl. Conze)

for: cognitive abandonment, read: trusting abandonment

for: maintaining of mind, read: maintaining a mind

for: bhavișanti, read: bhavișyanti 
p. 180, n. 309 for: higher patience (sātyantakṣānti), read: absolute patience (atyantakṣānti)

p. 189.25 for: apakāramarșaṇakșānti, read: parāpakāramarșaṇakșānti

p. 195.14 delete: the bodhisattva's

p. 197.13 for: between kșānti and vïrya, read: between kṣānti and śruta, and kṣānti and vīrya

p. 197.14 for: it, read: the joint presence of kșānti and śruta

p. 214.9 for: ṛddhividhya, read: rddhividhyabhijñā

p. 219 , n. 518 for: willing to comply and, read: willing to

p. 221, n. 522 for: cetāna, read: cetanā

p. 224, n. 540 for: concentration agrees is, read: concentration is

p. 226.13

p. 231, n. 570

for: in first, read: in the first

for: Śrotabhūmi, read: Śrutamayībhūmi (ibid., p. 245.14 ; p. 247 , n. 655,688 , p. 266 , n. 750 ; p. 267 , n. 757 ; p. 291 , n. 884 ; p. 292 , n. 889 ; p. 314 , n. 3 ; p. 329, n. 35)

p. 233 , n. 584 for: This very thought is also, read: The opposite thought is

p. 234, n. 588 for: vidhyā, read: vidyā

p. 237.7 for: mürdhan, read: uṣmagata

p. 243.5 for: repeated meditation, read: repeated confrontation in meditation

p. 253.17 for: 'skill' prior, read: 'skill' in them prior

p. 256.6 for: Up, read: Ug

p. 262, n. 734 for: pity, read: compassion

p. 263.2 for: caturvidha, read: caturvidyā

p. 273.14 for: vyakaranabhūmi, read: vyākaranabhūmi

p. 279.7 for: many these, read: many of these

p. 281.19 for: images, read: reflection (ibid., p. 281.20)

p. 288, n. 872 for: p. 287 , read: pp. $159-78$

p. 294.17 for: other, read: bodhyanga and āryāșțāngamārga

p. 296.23 for: that unified, read: that is unified

p. 296, n. 909 for: ekāyana, read: ekayāna

p. 302.26 for: with Mahāyāna text, read: with a Mahāyāna text

p. 311.11 for: hKah-hgyur, read: bKah-hgyur

p. 315, n. 4 for: itself becomes, read: themselves become

for: insight, read: wisdom; for: resolve, read: intent

p. 315, n. 5 for: adhyasāâya, read: adhyāśaya

p. 316, n. 8 for: Braarvig, read: Braavrig

p. 317, n. 13 for: acquisition of correct reflection, read: acquisition by correct reflection

p. 318 , n. 15 for: brahmacariyā, read: brahmacariya

p. 324.21 for: any teaching, read: any teachings

p. 328 , n. 33 for: the heaven of Amitābha ... of the first category, read: the Pure Land of Amitābha ... of the second category

p. 330 , n. 40 for: ma log pa de bźin ñid: tathāta, read: ma log pa de bźin ñid: aviparyāsatathatā; for tathātā, read: tathatā

p. 351, n. 128 for: ațthamaka, read: atțhamaka

p. 353.17 for: passed into nirvāṇa, read: passed into parinirvāna

p. 355, n. 146 for: sraddha, read: śraddhā

p. 365, n. 181 for: thought as thought, read: thought

p. 383, n. 245 for: is not the object, read: not the object

p. 387, n. 257 for: briefly the characteristics, read: briefly in the characteristics

p. 387, n. 259 for: that is the meaning ...., read: what is the meaning ...?

p. 387, n. 259 for: great non-reality of saṃsāra, read: great punishment of saṃsära

p. 389.14 for: that all things exist, read: that all things are inherently existent

p. 501.29 for: May, Jacques M, read: Lounsberry, G.C. 